$9-1990$

\title{
Phase II Investigations at Prehistoric and Rock Art Sites, Justiceburg Reservoir, Garza and Kent Counties, Texas Volume I
}

Douglas K. Boyd

Prewitt and Associates, Inc.

James T. Abbott

Texas Department of Transportation

William A. Bryan

Prewitt and Associates, Inc.

Colin M. Garvey

Prewitt and Associates, Inc.

Steve A. Garvey

Prewitt and Associates, Inc.

See next page for additional authors

Follow this and additional works at: https://scholarworks.sfasu.edu/ita

Part of the American Material Culture Commons, Archaeological Anthropology Commons, Environmental Studies Commons, Other American Studies Commons, Other Arts and Humanities Commons, Other History of Art, Architecture, and Archaeology Commons, and the United States History Commons

Tell us how this article helped you.

This Article is brought to you for free and open access by the Center for Regional Heritage Research at SFA ScholarWorks. It has been accepted for inclusion in Index of Texas Archaeology: Open Access Gray Literature from the Lone Star State by an authorized editor of SFA ScholarWorks. For more information, please contact cdsscholarworks@sfasu.edu. 


\section{Phase II Investigations at Prehistoric and Rock Art Sites, Justiceburg Reservoir, Garza and Kent Counties, Texas Volume I}

Authors

Douglas K. Boyd, James T. Abbott, William A. Bryan, Colin M. Garvey, Steve A. Garvey, and Ross C. Fields

Creative Commons License

(c) (i) $(\Theta)$

This work is licensed under a Creative Commons Attribution-NonCommercial-No Derivative Works 4.0 International License. 


\section{PHASE II INVESTIGATIONS AT PREHISTORIC AND ROCK ART SITES, JUSTICEBURG RESERVOIR, GARZA AND KENT COUNTIES, TEXAS \\ VOLUME I
Prewitt and Associates, Ine. Consulting Archeoiegiais Austin, Texas 78752 (512) $459-3349$ 7701 N. Lamar, Suite 104}

by

Douglas K. Boyd James T. Abbott

William A. Bryan

Colin M. Garvey

Steve A. Tomka

and

Ross C. Fields

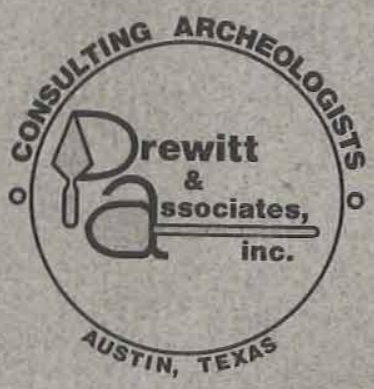


PHASE II INVESTIGATIONS AT PREHISTORIC AND ROCK ART SITES, JUSTICEBURG RESERVOIR, GARZA AND KENT COUNTIES, TEXAS

VOLUME I

by

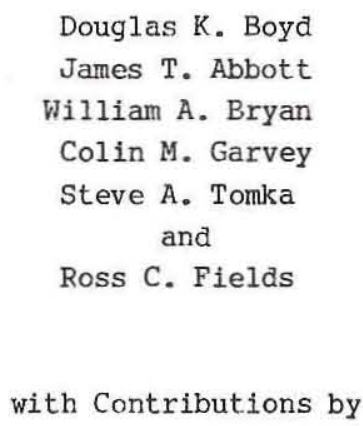

Richard W. Yerkes

CO-PRINCIPAL INVESTIGATORS: Eiton R. Prewitt and J. Michael Quigg

REPORTS OF INVESTIGATIONS NO. 71

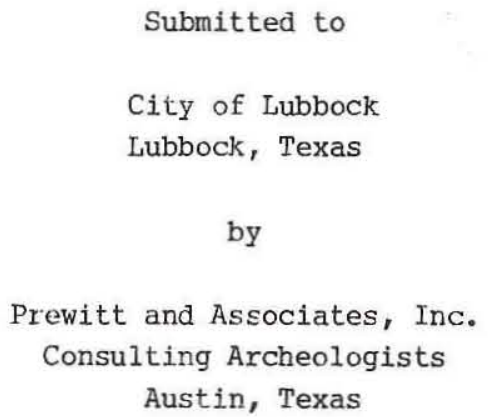




\section{VOLUME I}

CHAPTER 1: Introduction

CHAPTER 2: Environmental and Archeological Background

CHAPTER 3: Objectives and Methods

CHAPTER 4: Geomorphic and Geoarcheological Investigations

CHAPTER 5: Investigations at First-Priority Sites

CHAPTER 6: Investigations at Second-Priority Sites

CHAPTER 7: Investigations at Rock Art Sites

CHAPTER 8: Summary and Conclusions

CHAPTER 9: National Register Assessments

REFERENCES CITED

VOLUME II

APPENDIX A: Geomorphic Backhoe Trench Descriptions

APPENDIX B: Magnetometer Surveys at $41 \mathrm{GR} 323$ and $41 \mathrm{KT} 53$

APPENDIX C: Chronometric Dating

APPENDIX D: Artifact Analysis

APPENDIX E: Microwear Analysis of Selected Chipped Stone Tools

APPENDIX F: Mineralogical Analyses of Kaolinite and Pictograph Pigments

APPENDIX G: Organic Residue and Phytolith Analyses

APPENDIX H: Assessment of Pollen Preservation and Macrobotanical Analysis

APPENDIX I: Phytolith and Pollen Analyses: A Feasibility Study

APPENDIX J: Faunal Analysis

Series Technical Editor: Linda Nance Foster 


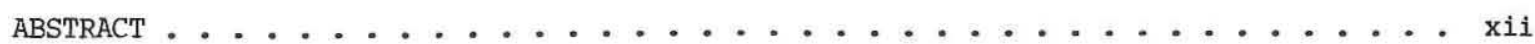
ACKNOWLEDGMENTS xiii

CHAPTER 1: INTRODUCTION

Douglas K. Boyd ............................... 1

CHAPTER 2: ENVIRONMENTAL AND ARCHEOLOGICAL BACKGROUND

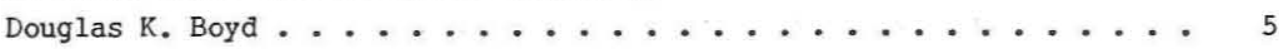

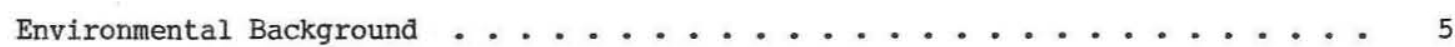

Previous Investigations ...................... 8

CHAPTER 3: OBJECTIVES AND METHODS

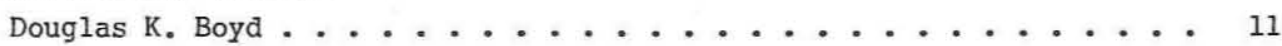

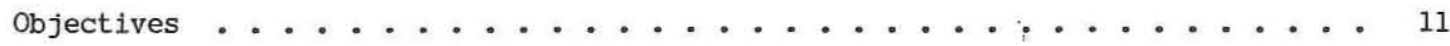

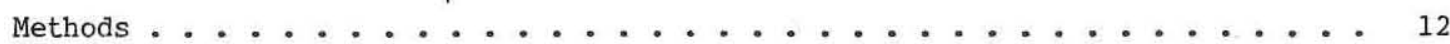

Archeological Site Testing . . . . . . . . . . . . . 12

Geoarcheological Investigations . . . . . . . . . . . 20

CHAPTER 4: GEOMORPHIC AND GEOARCHEOLOGICAL INVESTIGATIONS

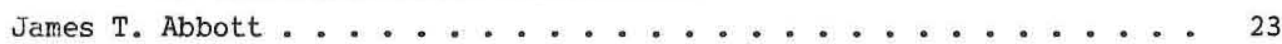

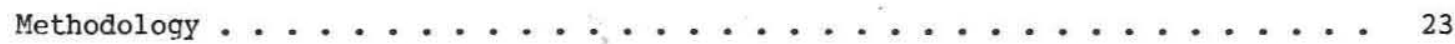

Physiography and Bedrock Geology . . . . . . . . . . . . . . 27

Geomorphology and Pedology . . . . . . . . . . . . . . . 29

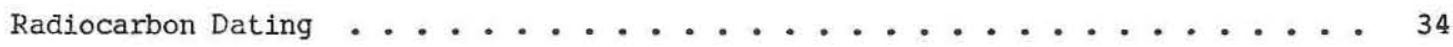

Sumary of Backhoe Trench Investigations ............... 34

The Upper Reservoir ...................... 34

The Canyon-confined Segment of the Reservoir . . . . . . . . . 38

Grape Creek, South Sage Creek, and the Lower Reservoir . . . . . . . . 44 44

The Uplands ..................... 51

Results of Subsurface Site Prospection ... . . . . . . . . . . 53

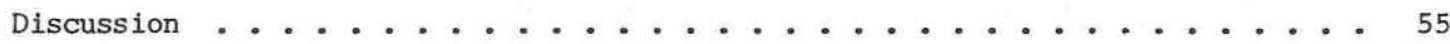

Geomorphic and $\mathrm{Climatic} \mathrm{Implications} \mathrm{.............} 55$

Archeological Implications . . . . . . . . . . . . . 58

Recommendations for Future Work ..................... 61

CHAPTER 5: INVESTIGATIONS AT FIRST-PRIORITY SITES

Douglas K. Boyd, William A. Bryan, and Colin M. Garvey . . . . . 63

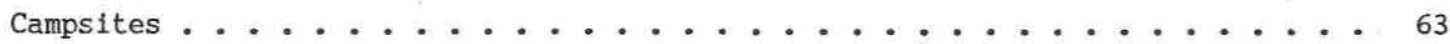

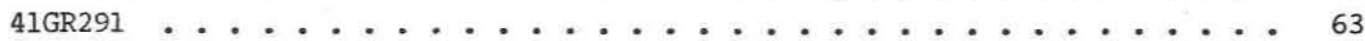

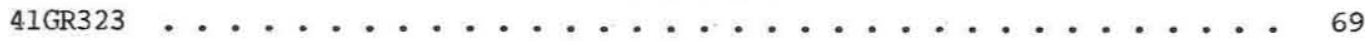

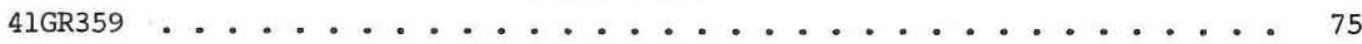

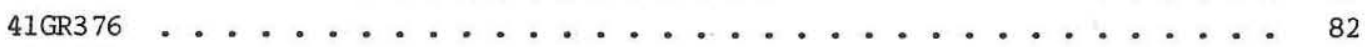

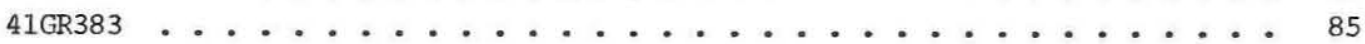




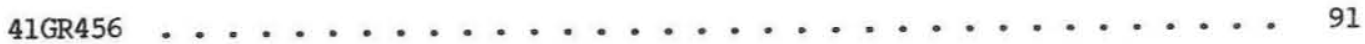

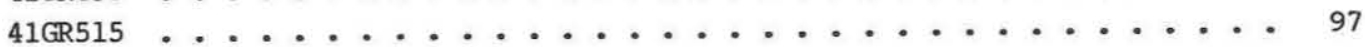

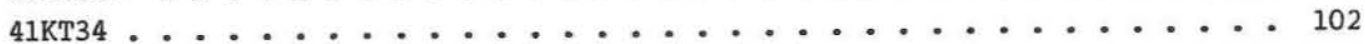

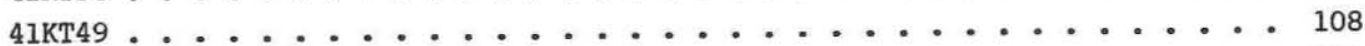

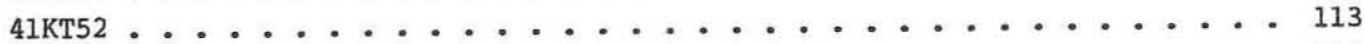

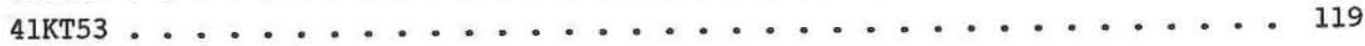

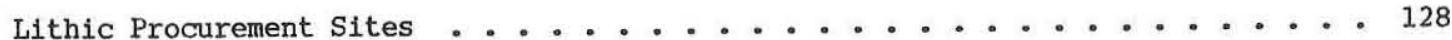

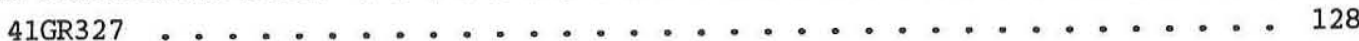

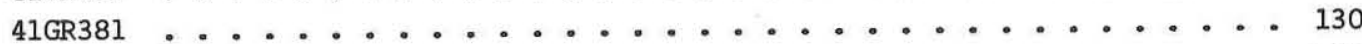

Discussion of Lithic Procurement Sites . . . . . . . . . . . 132

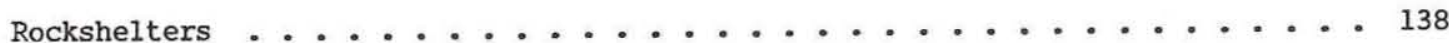

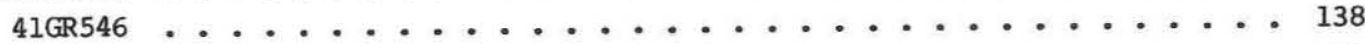

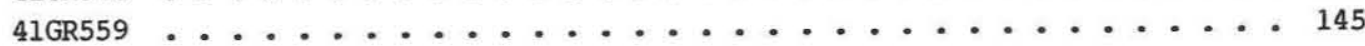

Faunal Localities . . . . . . . . . . . . . . . . . . 151

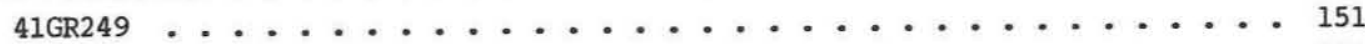

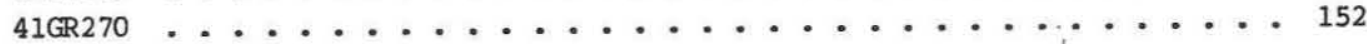

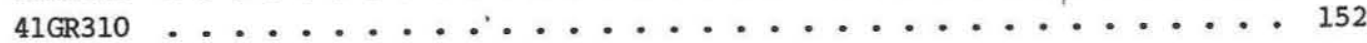

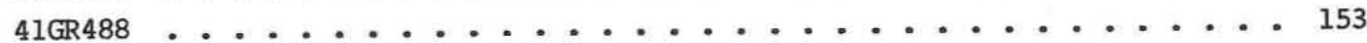

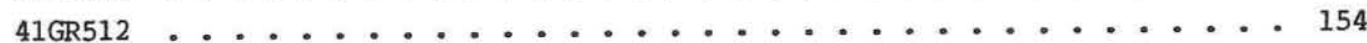

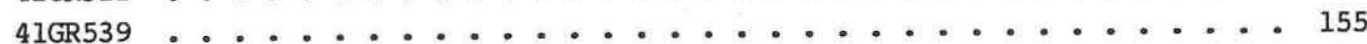

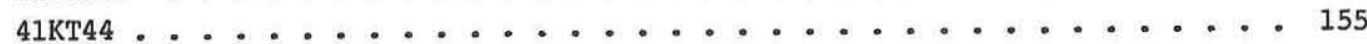

$41 \mathrm{KT69} \ldots \ldots \ldots 157$

CHAPTER 6: INVESTIGATIONS AT SECOND-PRIORITY SITES

Douglas K. Boyd and William A. Bryan ............ 159

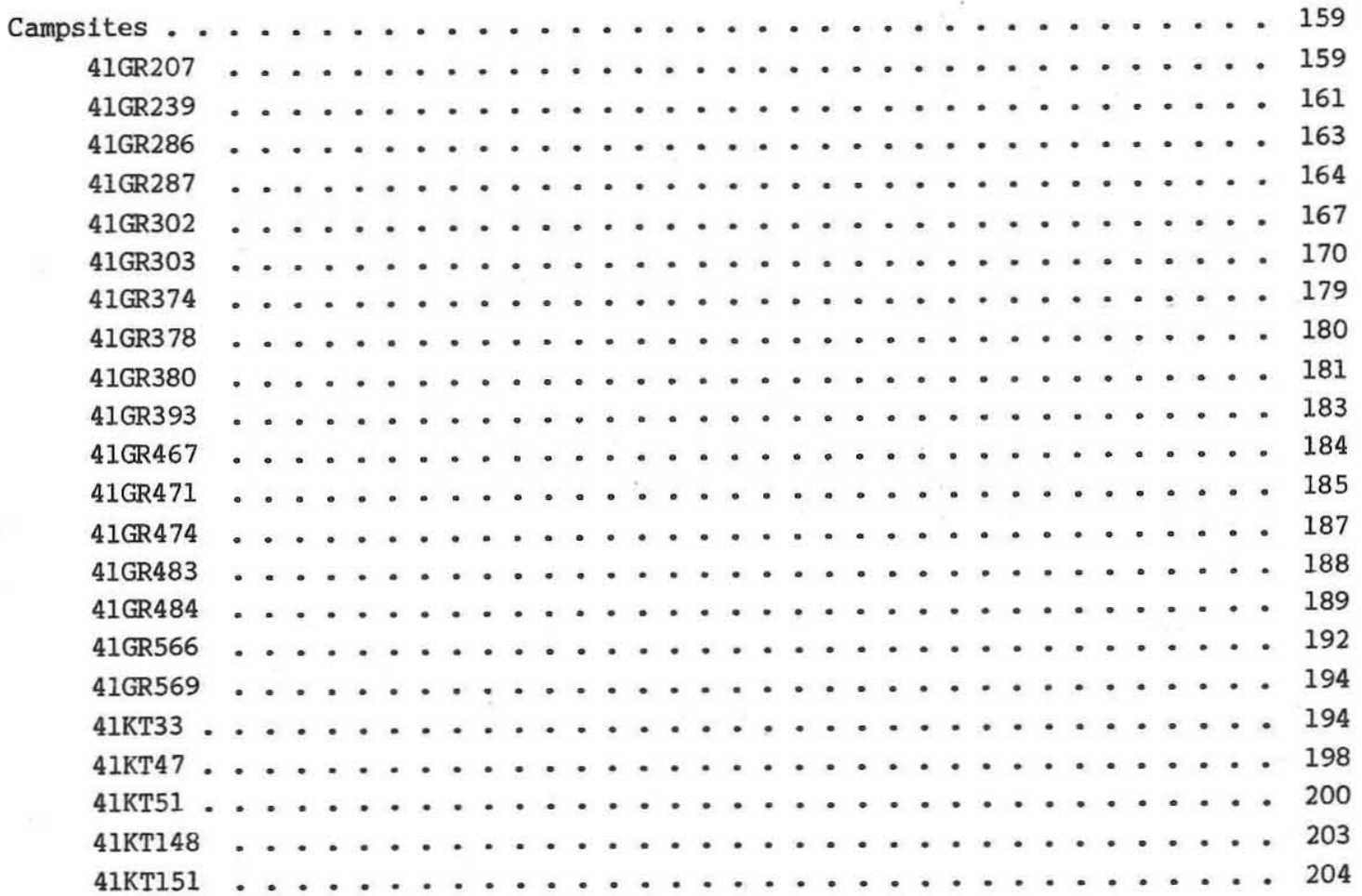


Lithic Procurement Sites ... . . . . . . . . . . . . 204

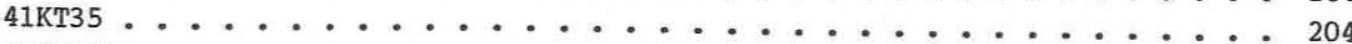

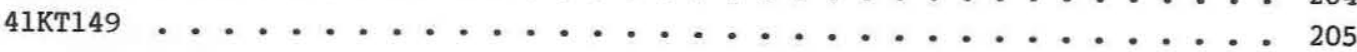

Lithic Scatters ... . . . . . . . . . . . . . . 205

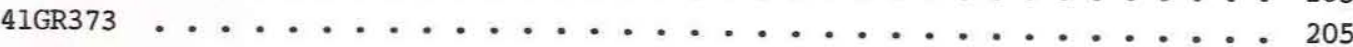

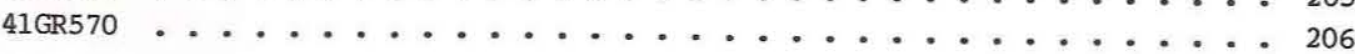

Isolated Finds ... . . . . . . . . . . . . . . . 206

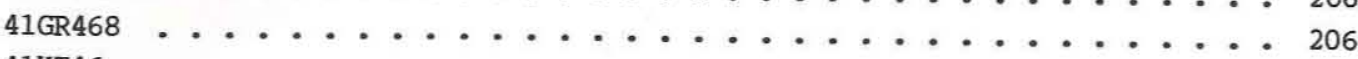

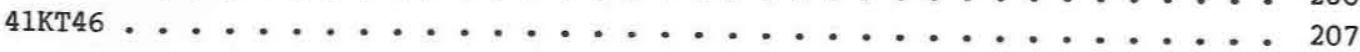

CHAPTER 7: INVESTIGATIONS AT ROCK ART SITES

Douglas K. Boyd and Colin M. Garvey ............. 209

Methods .......................... 209

Site Investigations . . . . . . . . . . . . . . . . 210

41 GR51 (Dorward Ranch Site) . . . . . . . . . . . . 210

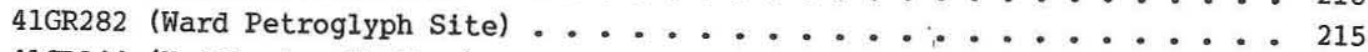

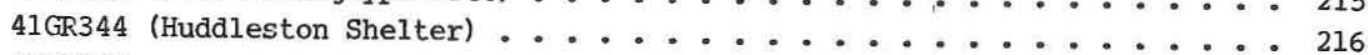

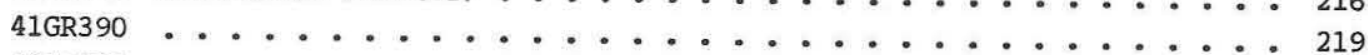

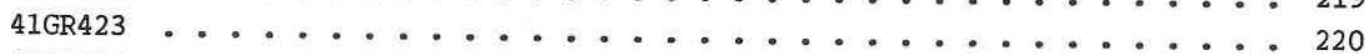

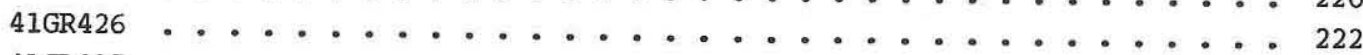

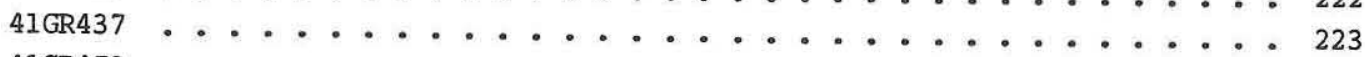

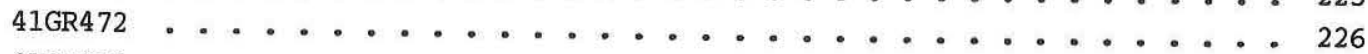

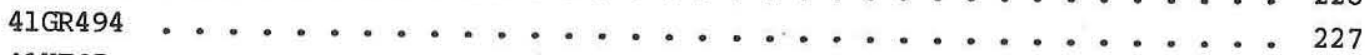

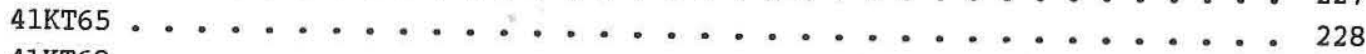

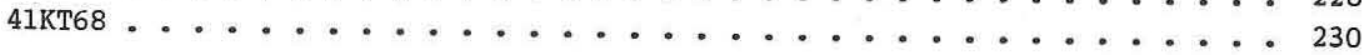

Summary ............................ 232

CHAPTER 8: SUMMARY AND CONCLUSIONS

Douglas K. Boyd and Steve A. Tomka ............. 235

Geoarcheological Investigations . . . . . . . . . . . . 235

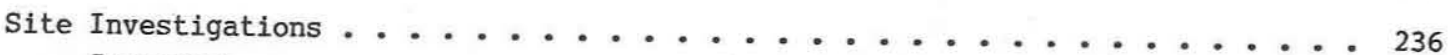

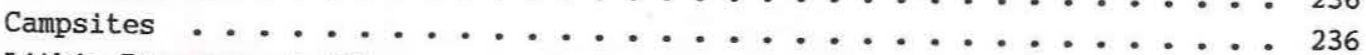

Lithic Procurement Sites . . . . . . . . . . . . . . . 242

Rockshelters ...................... 242

Faunal Localities ... . . . . . . . . . . . . . . . 244

Rock Art Sites . . . . . . . . . . . . . . . . 245

Assessment of Technical Studies . . . . . . . . . . . . . . . 245

Magnetometer Survey ... . . . . . . . . . . . . 245

Chronometric Dating ................................ 246

Paleoenvironmental Studies . . . . . . . . . . . . . . . . . 248

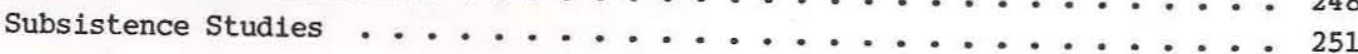

Prehistoric Chronology of Justiceburg Reservoir . . . . . . . . . . . 254

Paleoindian and Early to Middle Archaic Periods . . . . . . . . . . 256

Late Archaic Period ... . . . . . . . . . . . . . . . 257

Late Prehistoric I Period . . . . . . . . . . . . . . . . 258

Late Prehistoric II Period . . . . . . . . . . . . . . . . 260

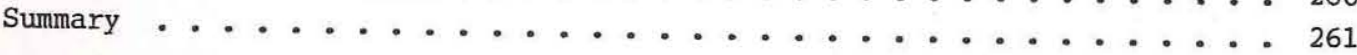


A Model of Late Holocene Human Adaptation for Justiceburg Reservoir . . . . . 261

Theoretical Background . . . . . . . . . . . . . . . 262

Late Archaic Period . . . . . . . . . . . . . . . 267

Late Prehistoric I Period ... . . . . . . . . . . . . 269

Late Prehistoric II Period . . . . . . . . . . . . . . 270

Summary ......................... 272

CHAPTER 9: NATIONAL REGISTER ASSESSMENTS

Douglas K. Boyd and Ross C. Fields . . . . . . . . . . 275

Assessment Criteria . . . . . . . . . . . . . . . 275

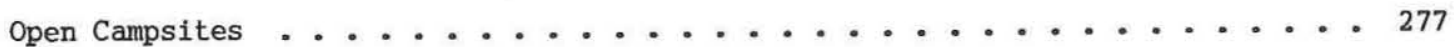

Lithic Procurement Sites . . . . . . . . . . . . . . . 282

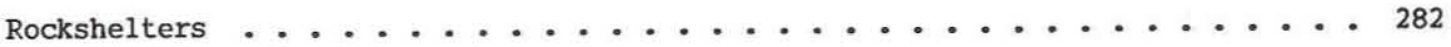

Faunal Localities . . . . . . . . . . . . . . . . . 283

Lithic Scatters and Isolated Finds . . . . . . . . . . . . 283

Rock Art Sites ..................... 283

Summary and Recommendations . . . . . . . . . . . . . 283

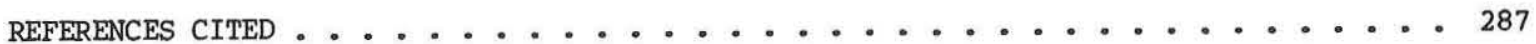




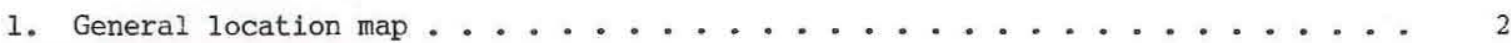

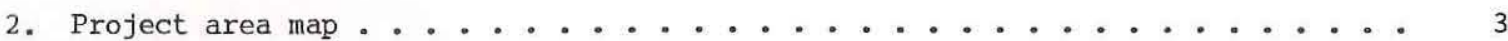

3. Generalized valley cross sections . . . . . . . . . . . . . . 6

4. Generalized landforms ... . . . . . . . . . . . . . . 7

5. Geomorphic map of the upper reservoir . . . . . . . . . . . . 35

6. Generalized cross section of the upper reservoir . . . . . . . . . 36

7. Representative profiles, upper reservoir . . . . . . . . . . . . 37

8. Geomorphic map of a segment of the central, canyon-confined reservoir . . . 40

9. Generalized cross section of the central, canyon-confined reservoir . . . . 41

10. Representative profiles, canyon-confined reservoir . . . . . . . . . 42

11. Representative profiles, canyon-confined reservoir . . . . . . . . . 43

12. Geomorphic map of central and lower Grape Creek, lower South Sage Creek, and the lower reservoir . . . . . . . . . . 45

13. Generalized cross section of the central Grape Creek valley . . . . . . . 46

14. Representative profiles, central Grape Creek valley . . . . . . . . . 47

15. Generalized cross section of the lower Grape Creek valiey . . . . . . . 48

16. Representative profiles, lower South Sage Creek valley and the lower reservoir ........................... 49

17. Generalized cross section of the lower reservoir . . . . . . . . . 50

18. Representative profiles, uplands above Grape Creek . . . . . . . . . . . 52

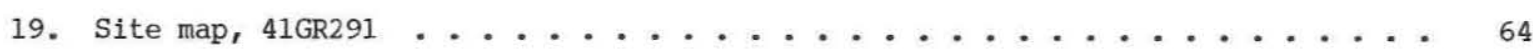

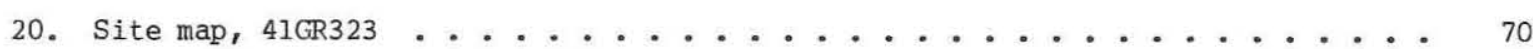

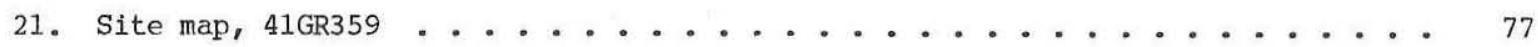

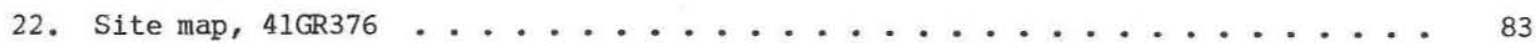

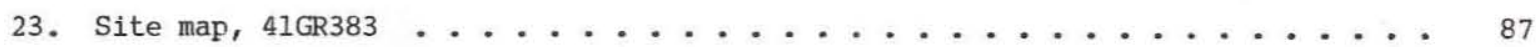

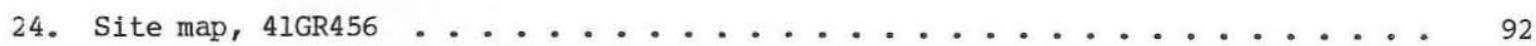

25. Pointed-oval bedrock mortars at $41 \mathrm{GR} 456$. . . . . . . . . . . . . 96

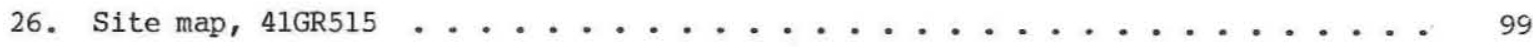

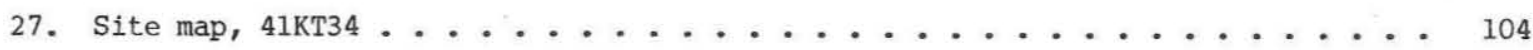

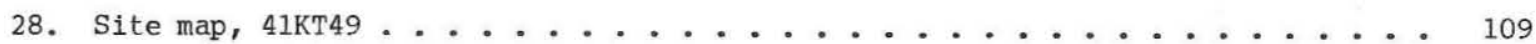

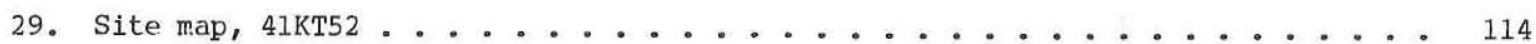

30. Stratigraphic profiles along Grape Creek cutbank and in Backhoe Trench 28, 41KT52 ............................ 116 
31. Photograph of Feature 1,41KT52 . . . . . . . . . . . . . . 117

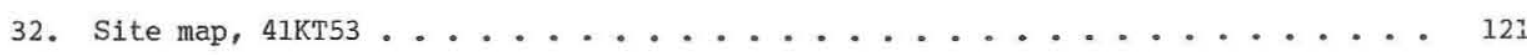

33. Plan and profile views of Feature 1, 41KT53 . . . . . . . . . . . 123

34. Photograph of Feature 3, 41KT53 . . . . . . . . . . . . . . 124

35. Plan and profile views of Feature 4, 41KT53 . . . . . . . . . . . . . 125

36. Site map, $41 \mathrm{GR} 327$. . . . . . . . . . . . . . . . . . . 129

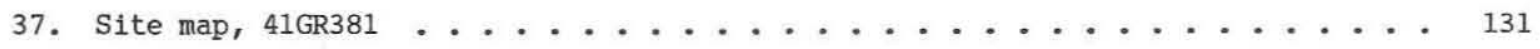

38. Site map, $41 \mathrm{GR} 546$. . . . . . . . . . . . . . . . . . . 142

39. Photograph of features at $41 \mathrm{GR} 546$. . . . . . . . . . . . . . 143

40. Site map, $41 \mathrm{GR} 559$. . . . . . . . . . . . . . . . . . 147

41. Photograph of bison bones exposed in test unit, 41KT44 . . . . . . . . 156

42. Generalized plan and profile views of Feature 1 and 2,

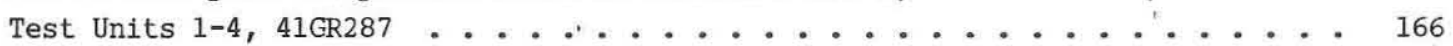

43. Site map, $41 \mathrm{GR} 303$. . . . . . . . . . . . . . . . . 172

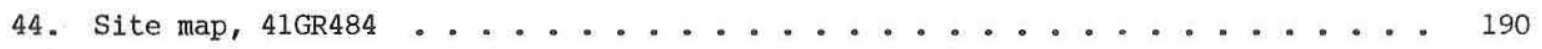

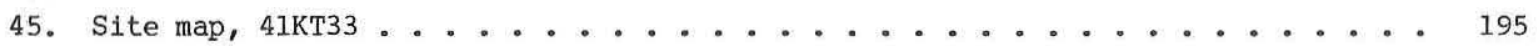

46. Site map, $41 \mathrm{KT} 51$. . . . . . . . . . . . . . . . . 201

47. Isolated petroglyph at 41 GR51 . . . . . . . . . . . . . . . 211

48. Petroglyphs at the Dorward Ranch Site, 4lGR51 . . . . . . . . . . . 213

49. Rock art at the Ward Petroglyph Site, 4lGR282 . . . . . . . . . . . 214

50. Rock art panel at Huddleston Shelter, 41GR344 . . . . . . . . . . 218

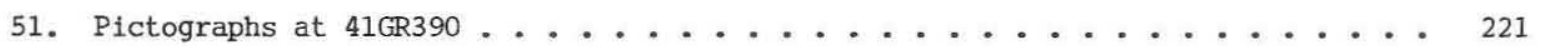

52. Painted petroglyphs at $41 \mathrm{GR} 423$. . . . . . . . . . . . . . . . . . . . 222

53. Photograph of pictograph handprint at 41 GR426 . . . . . . . . . . 224

54. Rock art at $41 \mathrm{GR} 437$. . . . . . . . . . . . . . . . . . 225

55. Petroglyphs at $41 \mathrm{GR} 472$. . . . . . . . . . . . . . . 227

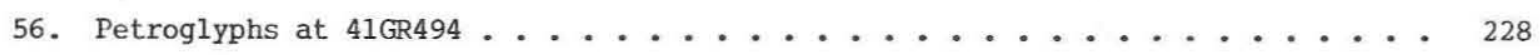

57. Photograph of rock art site $41 \mathrm{KT} 65$. . . . . . . . . . . . . . . 229

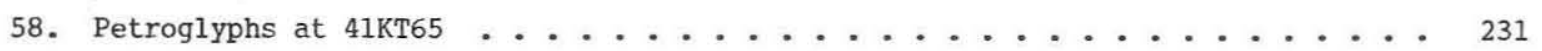

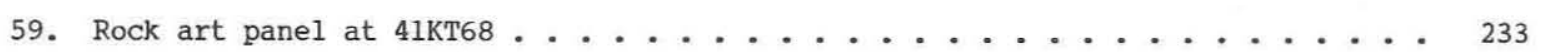

60. Stable carbon isotope data for humate and bison bone samples . . . . . . 250 
1. Summary of Phase I archeological sites . . . . . . . . . . . . . 10

2. Summary of sites investigated ................... 13

3. Field investigations at first-priority sites . . . . . . . . . . . 14

4. Field investigations at second-priority sites . . . . . . . . . . 16

5. Summary of backhoe testing by site . . . . . . . . . . . . . 18

6. Summary of backhoe trench data . . . . . . . . . . . . . . . 24

7. Sumary of excavations, 41GR291 . . . . . . . . . . . . . . 65

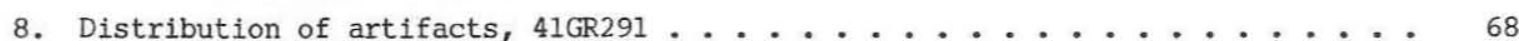

9. Summary of excavations, 41 GR323 . . . . . . . . . . . . . . 71

10. Distribution of artifacts, 41 GR323 ............................. 74

11. Summary of excavations, $41 \mathrm{GR} 359$. . . . . . . . . . . . . . 78

12. Distribution of artifacts, 41GR359 . . . . . . . . . . . . 80

13. Summary of excavations, 41GR376 . . . . . . . . . . . . . . . 84

14. Distribution of artifacts, 4lGR376 ...................... 85

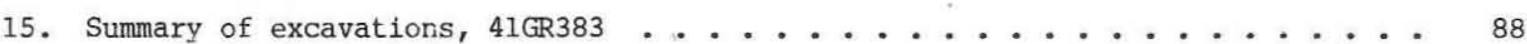

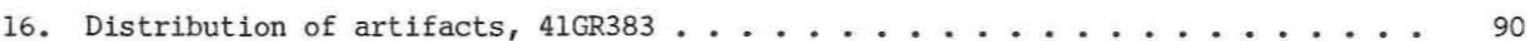

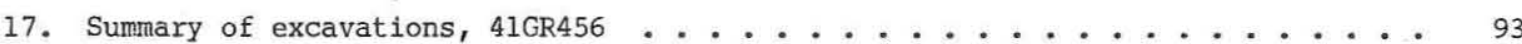

18. Distribution of artifacts, 41GR456 ......................... 97

19. Summary of excavations, $41 \mathrm{GR} 515$. . . . . . . . . . . . . . 100

20. Distribution of artifacts, 41GR515 . . . . . . . . . . . . 102

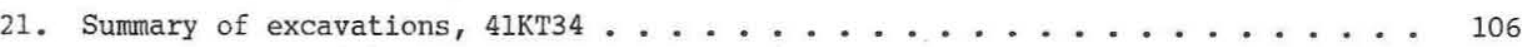

22. Distribution of artifacts, 41KT34 .......................... 107

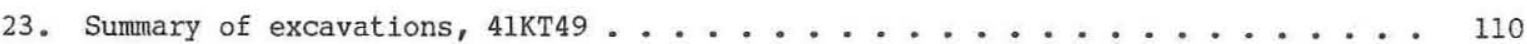

24. Distribution of artifacts, 41 KT 49 ............................ 112

25. Sumary of excavations, 41KT52 . . . . . . . . . . . . . . 115

26. Distribution of artifacts, 41 KT52 ........................... 119

27. Summary of excavations, 41KT53 . . . . . . . . . . . . . . 122

28. Distribution of artifacts, 41KT53 . . . . . . . . . . . . 127

29. Lithic material types represented in the Lingos gravels, Justiceburg Reservoir .................... . . 133

30. Comparison of Lingos and Seymour gravels by size . . . . . . . . . . 135

31. Comparison of Lingos and Seymour gravel lithology

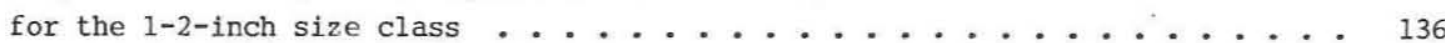


32. Comparison of Lingos and Seymour gravel lithology

for the over-2-inch size class ................. 137

33. Artifacts recovered from lithic procurement sites, 41 GR327 and 41 GR381 . . . . 139

34. Lithic material types represented in all lithic

reduction unit samples, $41 \mathrm{GR} 327$ and $41 \mathrm{GR} 381$. . . . . . . . . . . 140

35. Distribution of materials recovered, 41 GR546 . . . . . . . . . . . . 144

36. Summary of excavations, 41 GR559 . . . . . . . . . . . . . . 148

37. Distribution of materials recovered, 4lGR559 . . . . . . . . . . 150

38. Sumary of excavations, 41GR207 . . . . . . . . . . . . . . . . . . . . . . .

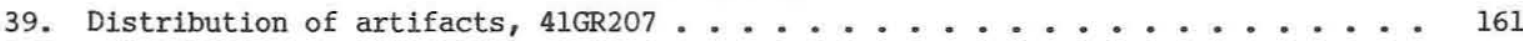

40. Summary of excavations, 4lGR239 . . . . . . . . . . . . . . . 162

41. Summary of excavations, 41GR287 . . . . . . . . . . . . . . . 165

42. Summary of excavations, 41GR302 ... . . . . . . . . . . . . . 168

43. Distribution of artifacts, 41GR302 . . . . . . . . . . . . . 170

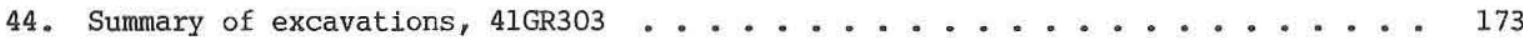

45. Distribution of artifacts, 41GR303 . . . . . . . . . . . 176

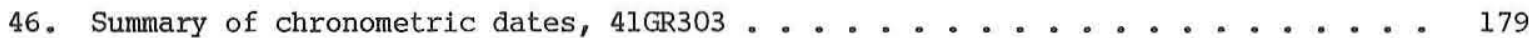

47. Sumary of excavations, 4lGR374 . . . . . . . . . . . . . . 180

48. Summary of excavations, 41GR378 . . . . . . . . . . . . . . 181

49. Summary of excavations, 41GR380 . . . . . . . . . . . . . . . 182

50. Distribution of artifacts, 41GR380 . . . . . . . . . . . . . 183

51. Summary of excavations, 4lGR467 . . . . . . . . . . . . . . 185

52. Sumnary of excavations, 41GR471 . . . . . . . . . . . . . . 186

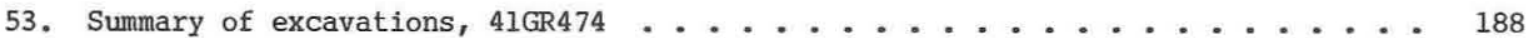

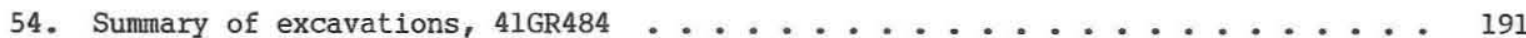

55. Distribution of artifacts, 41GR484 . . . . . . . . . . . . 193

56. Sumary of excavations, 41KT33 . . . . . . . . . . . . . . . 196

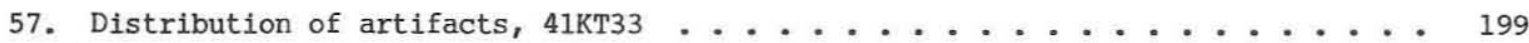

58. Summary of excavations, 41KT51 . . . . . . . . . . . . . 202

59. Distribution of artifacts, 41KT51 . . . . . . . . . . . . 203

60. Sumary of temporal assessments of prehistoric campsites . . . . . . . . 237

61. Subsurface features at prehistoric campsites .............. 238

62. Summary of artifacts recovered from prehistoric campsites . . . . . . . 239

63. Lithic material types represented among the chipped, ground, and battered stones at prehistoric campsites . . . . . . . . . . 240 
64. Summary of faunal localities

65. Noncultural sediment samples used for assessment of paleoenvironmental reconstruction potential

66. Pollen and phytolith analyses of archeological contexts . . . . . . . 252

67. Comparison of results of microwear and organic residue analyses . . . . . 255

68. Assessments of research potential and National Register eligibility . . . . 278

69. Chronological and topographic distribution of National Register-eligible prehistoric campsites . . . . . . . . . . 281

70. Sumary of National Register assessments . . . . . . . . . . . . . 284 
ABS'TRACT

Phase II cultural resources investigations at the proposed Justiceburg Reservoir in Garza and Kent counties, Texas, were conducted by Prewitt and Associates, Inc. in 19881989. This report documents the archeological work at 62 prehistoric and aboriginal rock art sites and the geoarcheological study conducted as part of the Phase II work. Investigations at 48 prehistoric sites, including open campsites, rockshelters, lithic procurement sites, faunal localities, and rock art sites, resulted in complete National Register assessments; 9 campsites, the 2 rockshelters, and 6 rock art sites are considered to be eligible for listing on the National Register of Historic Places. Less-intensive investigations at 14 prehistoric sites yielded insufficient data for full National Register assessments.

The geoarcheological study resulted in the formulation of a model of the geomorphic history of the project area. Of considerable importance is the recognition of a period of catastrophic flushing of alluvial sediments within the Double Mountain Fork valley during the middle Holocene, followed by late Holocene sedimentation and stabilization. This supports the concept of a dry middle Holocene Altithermal period and helps explain the biased archeological record in the project area. The prehistoric site investigations indicate that most of the archeological remains present at Justiceburg Reservoir date to the late Archaic and Late Prehistoric periods, a phenomenon noted in similar settings elsewhere in the Lower Plains. Of the open campsites assessed as eligible for listing on the National Register, four are classified as late Archaic (4500-2000 B.P.), two are classified as Late Prehistoric I (2000-1000 B.P.), and three are classified as Late Prehistoric II (1000 B.P. to evidence of European contact). The two investigated rockshelters contain evidence of Late Prehistoric I and II occupations. Due to the paucity of regional archeological data and the lack of a well-defined cultural chronology, only two of these sites can be assigned tentatively to recognized cultural complexes. Site 41 GR291 yielded ceramics and arrow points indicating a Palo Duro Complex occupation, Ca. A.D. 500, while ceramics and a distinctive hearth associated with the upper component at 41 KT53 suggest a Garza Complex occupation, ca. A.D. 1600-1700. No evidence of European contact was found at any of the habitation sites, but three of the rock art sites contain historic Plains Indian iconography.

The investigations at the prehistoric sites resulted in the formulation of a late Holocene cultural sequence for the project area. Analyses of the various classes of archeological evidence (e.g., artifacts, features, faunal remains) revealed broad cultural patterns that appear to reflect significant changes in subsistence strategies through time. It is suggested that these changes are related to late Holocene environmental conditions and corresponding shifts in the resource base. It is further suggested that bison were the most important resource controlling late Holocene human adaptations in the Texas Lower Plains. 
The second phase of the Justiceburg Reservoir cultural resources study ran smoothly thanks to the efforts of many individuals and organizations. The City of Lubbock, Texas, plays the key role in the planning and development of the proposed reservoir, and the City's Water Utility Department, directed by Samuel W. Wahl and his successor Dan Hawkins, has been extremely cooperative in fulfilling its responsibilities to the cultural resources. Mike Gilliland, Engineer Assistant, was especially helpful during our field investigations and worked diligently to attend to the many minor problems and details that arose. Mike's efforts are greatly appreciated by everyone on the field crew. The enthusiastic support of Mayor B. C. McMinn and the members of the Lubbock City Council, City Manager Larry Cunningham, and Deputy City Manager Bob Cass is gratefully acknowledged.

Freese and Nichols, Inc., Technical Representative for the City of Lubbock, was responsible for directly supervising the cultural resources study. This task was first performed by Susan Andrews and later by Barbara Nickerson; each deserves special recognition for her efforts. William, J. Mayer-Oakes of Texas Tech University served as an independent local advisor to the City of Lubbock.

The hospitality and cooperation of the people of Justiceburg, Post, and Snyder are appreciated by everyone who worked in the field. Our stay in Snyder was very pleasant thanks to the Reed and Chisum families, owners of the Townhouse Apartments. Dennis and Blanche Chisum and apartment manager Cinda Lucas were especially helpful and considerate; their extra efforts were above and beyond the call of duty. As always, Jennifer, Mary, and Riley Miller and the gang at the "Fort" made us feel welcome at our second home, Fort Justice. Avocational archeologist Emmett Shedd freely shared his knowledge of the region and also volunteered his time to assist in the fieldwork. Zoe Kirkpatrick arranged for special trips to rock art sites and also took time to share some of her vast knowledge of the region's flora with the field crew. The field investigations were also assisted by the cooperation of the individual landowners, on whose land the reservoir is to be built, who allowed us access to their property. Special thanks go to Mr. and Mrs. John Boren, who supported the investigation of rockshelters on their land.

My personal thanks go to all the people at Prewitt and Associates, Inc. who were involved in the Justiceburg Reservoir project. Co-Principal Investigators Elton R. Prewitt and J. Michael Quigg were involved in all aspects of the work and provided much needed guidance and assistance. The superb field crew consisted of Crew Chiefs Bill Bryan and Colin Garvey and Crewmembers Tom Ellzey, Tom Dureka, Steve Gaither, Dan Lauterbur, Greg Mason, Ann Mesrobian, Bob Stiba, and David Tucker; it was a pleasure to work with such a professional group. The expertise and hard work of Martha Freeman, Project Historian, and Jim Abbott, Project Geomorphologist, resulted in significant contributions to the history and prehistory of the region.

Laboratory work was supervised by Jeanine Seay. Steve Tomka analyzed the prehistoric stone artifacts and Quigg analyzed the faunal remains. Report preparation was supervised by Ross C. Fields. Typing was done by Linda Nance Foster and Jerrilyn McLerran, and editing was done by Foster, McLerran, and Fields. The fine illustrations were done by three individuals: Sandra Hannum did the majority, including the numerous maps and graphs, while the artifact illustrations are by Ellen Atha and the rock art reproductions are by Colin Garvey. 
This report is a compilation of the work of numerous people. While individual authors - are certainly responsible for their contributions, the final product is truly a team effort, and I express my gratitude to all of the people involved, especially the coauthors, consultants, and everyone at Prewitt and Associates, Inc.

Douglas K. Boyd

Project Archeologist 
CHAPTER 1

INTRODUCTION

by Douglas K. Boyd

This report describes Phase II cultural resources investigations at the proposed Justiceburg Reservoir in Garza and Kent counties, Texas. These investigations were conducted by Prewitt and Associates, Inc. of Austin, Texas, for the City of Lubbock, Texas, and are a continuation of efforts by the City to fulfill its obligation to deal with cultural resources that will be affected by the project. Because the proposed reservoir will be permitted by the U.S. Army Corps of Engineers, the investigations reported here were carried out under the provisions of Federal cultural resources laws and regulations; State laws and regulations also apply, however, since the project is being sponsored by a political subdivision of the State. The Phase II work focused on gathering data so that assessments of eligibility for listing on the National Register of Historic Places could be made and involved archeological, geoarcheological, and historical field investigations; fieldwork was conducted from August to November of 1988, and data analysis and report preparation continued through Summer 1989.

The proposed dam site is located on the Double Mountain Fork of the Brazos River, approximately $5 \mathrm{~km}$ ( 3 miles) upstream from its confluence with the North Fork of the Double Mountain Fork (Fig. 1). The proposed reservoir will inundate approximately 2,800 acres of land at the 2220-ft-msl conservation pool. The reservoir will impound water approximately $11 \mathrm{~km}$ ( 7 miles) upstream from the dam site, located at the Garza/Kent county line. At the 2257-ft-ms l maximum high water elevation (probable maximum flood), the reservoir will impound water upstream to the U.S. Highway 84 bridge at Justiceburg (Fig. 2).

The reservoir will serve as a water storage facility for the City of Lubbock. Longrange plans include a pipeline to transport water from the reservoir approximately $97 \mathrm{~km}$ (60 miles) northwest to the City. As part of the planning process, Phase I cultural resources investigations were conducted in 1987. This study identified and evaluated 375 cultural resources in the ca. 8,600-acre project area (Boyd et al. 1989). The Phase II investigations reported here are based on the Phase I site assessments and recommendations. Both phases of work were directly supervised by the technical representative for the City of Lubbock, Freese and Nichols, Inc., of Fort Worth.

The Phase II investigations are described in separate reports, one dealing with the geoarcheological study and the aboriginal site investigations and one dealing exclusively with the historical investigations (Freeman and Boyd 1990). The former encompasses a considerable amount of data and is divided into two volumes: Volume I presents background information, describes the investigations and their results, and synthesizes the prehistoric site data; Volume II contains appendixes which present a wide range of detailed information and constitute the supporting data for the geoarcheological and prehistoric archeological investigations.

Volume I consists of nine chapters. Chapter 2 presents environmental background information for the region and archeological background information for the project area. Chapter 3 discusses the objectives and methods of the Phase II investigations. Chapter 4 describes the geoarcheological investigations and proposes a geomorphic history of the 


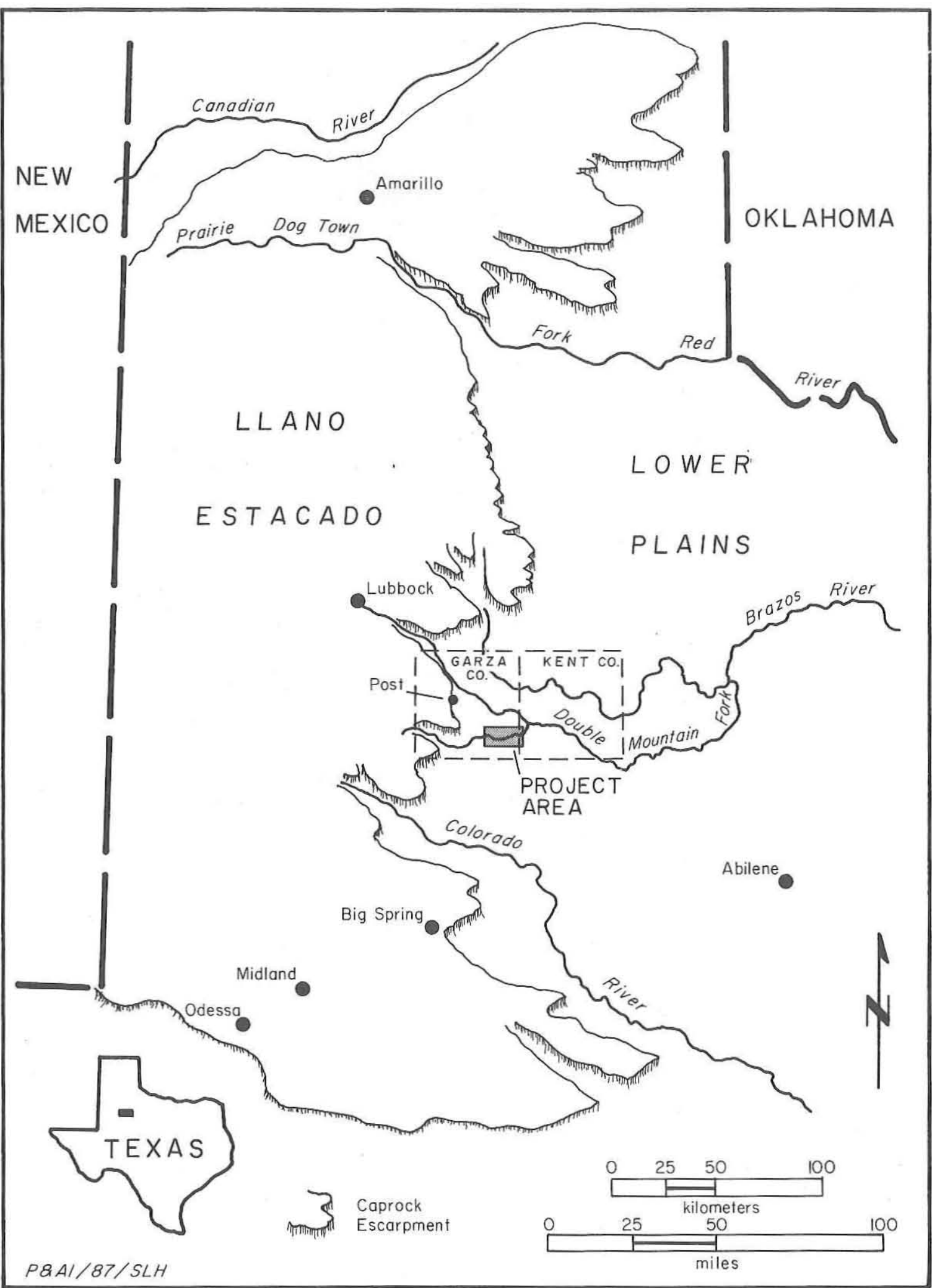

Figure 1. General location map. 


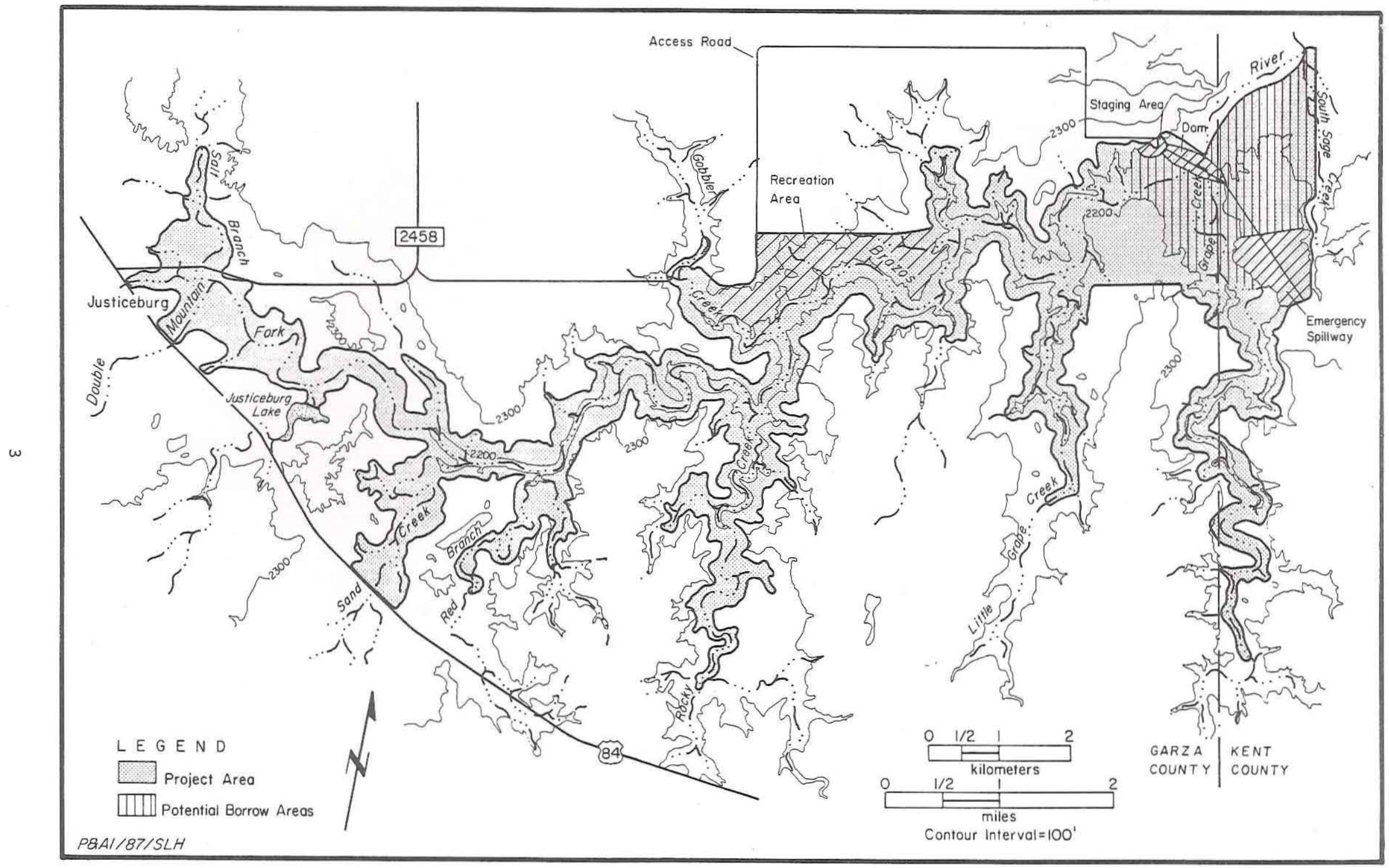

Figure 2. Project area map. 
project area. Chapter 5 presents the results of intensive investigations at 23 firstpriority prehistoric sites, while Chapter 6 details the limited to intensive archeological studies of 28 second-priority prehistoric sites. Chapter 7 describes the investigations at 11 aboriginal rock art sites. The geoarcheological and aboriginal site investigations are summarized in Chapter 8, culminating with a proposed cultural sequence for the project area and a model of late Holocene human adaptation for the Lower Plains. This chapter also evaluates the methods and results of the technical studies implemented during the Phase II investigations. The final section, Chapter 9, presents National Register assessments of the aboriginal resources and recommendations for future cultural resources studies.

Volume II consists of 10 appendixes presenting detailed data from a variety of studies. Appendix A describes the stratigraphic data from 77 backhoe tranches excavated during the geoarcheological investigations. Appendix B details the methods and results of magnetometer surveys conducted at two prehistoric sites to test the utility of this technique for locating subsurface cultural features. Appendix $C$ summarizes and evaluates the chronometric dates (i.e., radiocarbon and thermoluminescence assays) obtained to provide temporal control for defining the cultural sequence. The analysis of the prehistoric artifacts recovered is presented in Appendix D. Appendixes E-I present the results of several specialized studies performed by various consultants: (1) a microwear analysis of a selected sample of chipped stone tools conducted by Richard W. Yerkes of Ohio State University; (2) mineralogical analyses (X-ray diffraction) of pictograph pigments, an unusual artifact, and samples of source minerals performed by Steve W. Tweedy of the Bureau of Economic Geology at The University of Texas at Austin; (3) studies of organic residues and phytoliths by Michael L. Marchbanks; (4) an assessment of pollen preservation in selected sediment samples and identification of macrobotanical remains recovered from archeological contexts by John G. Jones of Texas A\&M University; and (5) pollen and phytolith analyses by Linda Scott Cummings of PaleoResearch Laboratories of Lakewood, Colorado. Volume II concludes with Appendix $J$, which describes the faunal remains recovered in the site testing. 


\title{
ENVIRONMENTAL AND ARCHEOLOGICAL BACKGROUND
}

\author{
by Douglas K. Boyd
}

This chapter consists of two sections. The first provides a summary of the environment of the region. A more detailed discussion of the environment is presented in Boyd (1989a). The second section describes the previous archeological investigations in the immediate vicinity of the project area. An extensive regional archeological background is presented in Boyd (1989b), and Freeman (1989a) discusses the regional historical background.

\section{Environmental Background}

The proposed Justiceburg Reservoir is located within the Lower Plains region of Texas (Brown et al. 1982), also referred to as the Rolling Plains (Lobeck 1948). The Lower Plains region is bordered on the north by the Canadian River in Oklahoma, on the east by the Western Cross Timbers region, on the south by the Edwards Plateau of Central Texas, and on the west by the Llano Estacado, the southernmost extension of the High Plains. The Llano Estacado is the dominant physiographic feature, and the Caprock Escarpment clearly marks the boundary between the Lower Plains and the High Plains. The project area is several kilometers east of the Carprock Escarpment.

The flat, featureless plain of the Llano Estacado provides a stark contrast to the undulating, eroded badland topography of the Lower Plains. The rolling landscape is the result of the erosion and retreat of the High Plains. During the last several hundred thousand years, the Caprock Escarpment has been retreating westward, exposing to erosion the underlying Triassic and Permian beds. The region is further dissected by wellentrenched rivers and tributary drainages which head on the Llano Estacado or at the Caprock Escarpment. Three river systems, the Red, Brazos, and Colorado, flow generally eastward through the Lower Plains region. The surface waters originate as rainfall or spring seeps from groundwater aquifers.

The Justiceburg Reservoir project area lies mostly within Triassic exposures consisting of alternating layers of mudstones, conglomerates, and sandstones. Where the Double Mountain Fork has cut down through the erosion-resistant sandstone layers, the topography is quite rugged. This segment of the valley, from the mouth of Sand Creek to just below the mouth of Little Grape Creek (see Fig. 2), is a steep-sided, narrow valley canyon (Fig. 3 , cross section $\left.A-A^{\prime}\right)$. The canyon rim and lower erosional remnants are capped by sandstone strata. The valley slope is near-vertical in places, and the canyon relief varies from 18.3-30.5 m (60-100 ft). The narrow canyon is less than $200 \mathrm{~m}$ wide at the bottom, and the river meanders back and forth within the valley, leaving only thin strips of alluvial floodplain between meanders.

The topography differs upstream and downstream from this canyon-confined segment of the river. The eastern end of the reservoir, near the mouth of Grape Creek, is also a steep-sided canyon, but the valley widens out considerably with an alluvial floodplain over 


\section{A}

\section{0 \\ 2080}

feet above

mean sea level

B

\section{C}

2300

feet above

mean sea level

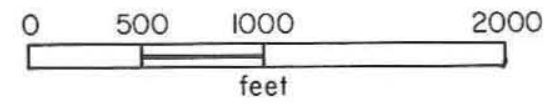

2000

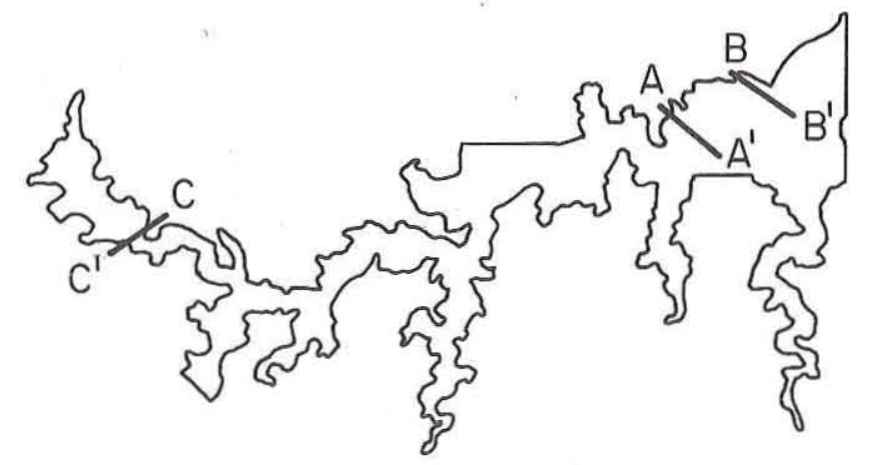

$P Q A / / 87 / S L H$

Figure 3. Generalized valley cross sections.

$1 \mathrm{~km}$ wide at this point (see Fig. 3, cross section B-B'). In the western end of the reservoir, near the community of Justiceburg, canyon-cutting is not pronounced because the river has not cut down through the erosion-resistant sandstone strata. The river channel is within a wide shallow valley which slopes gradually into the eroded upland (see Fig. 3 , cross section $\left(-C^{\prime}\right)$.

The rugged topography in the project area is characterized by a range of distinctive landforms (Fig. 4). The upland and upland margin settings are found all along the canyon rim. In some areas, the upland flat ends abruptly at the canyon rim with little or no eroded upland margin. In other areas, the eroding upland margin extends hundreds of meters 


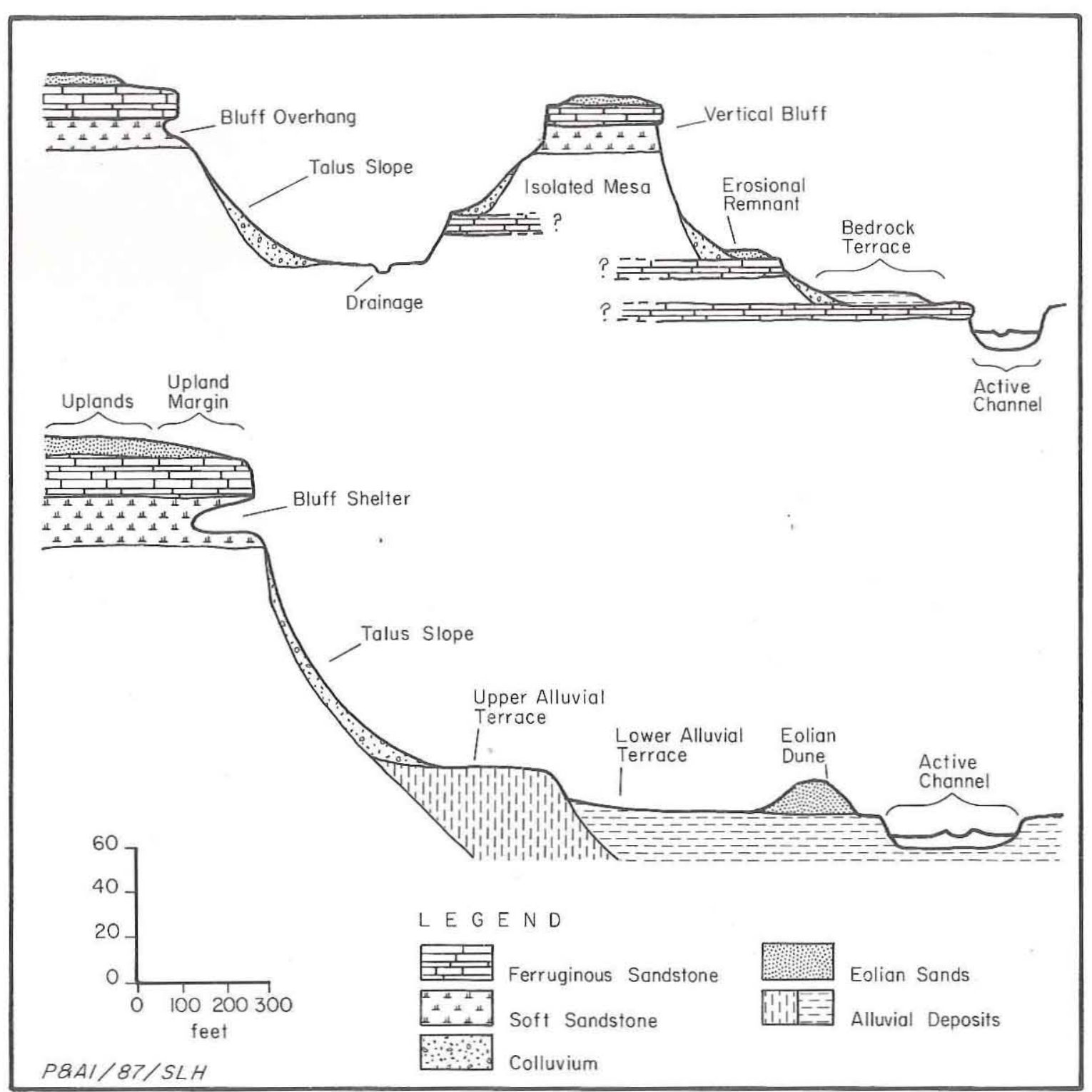

Figure 4. Generalized landforms.

back from the canyon rim. The canyon rim is marked by the uppermost, erosion-resistant sandstone ledge which usually forms a bluff several meters high. Erosion along the bluff has created numerous overhangs and shelters throughout the project area. The valley wall, the area between the upper bluff and the valley floor, may consist of talus slopes, isolated mesas, erosional remnants, bedrock benches, or any combination of these landforms. Talus slopes are composed of softer and more easily erodible mudstones and siltstones and are characteristically very steep. Talus slopes may be $20-30 \mathrm{~m}$ high, extending from the canyon rim to the valley floor, or they may cover only a few meters between exposed ledges of sandstone. In heavily eroded areas with numerous layers of erosion-resistant sandstone, the valley wall stairsteps, forming projecting erosional remnants, bedrock terraces, and 
isolated mesas. The valley wall landforms constitute a considerable portion of the project area, and the horizontal distance between the canyon rim and the valley floor may be hundreds of meters. The valley floor consists of the meandering channel of the Double Mountain Fork or its tributaries and the alluvial terraces and varies from a few meters to over 1,000 m wide. In some cases, upper and lower alluvial terraces can be distinguished, but usually only a single terrace is evident. A few eolian sand dunes have formed on the alluvial terraces at the upper end of the reservoir and occasional levees are evident along the river and stream channel margins.

The modern climate in the project area (from Scurry County data in Pass 1981:122) is mild, with short periods of extreme heat or cold. Temperatures average $14.4{ }^{\circ} \mathrm{C}\left(28^{\circ} \mathrm{F}\right)$ in the month of January and $35.5{ }^{\circ} \mathrm{C}\left(96{ }^{\circ} \mathrm{F}\right)$ in July, but extremes range from $-23.3{ }^{\circ} \mathrm{C}\left(-10^{\circ} \mathrm{F}\right)$ to $46.1{ }^{\circ} \mathrm{C}\left(115^{\circ} \mathrm{F}\right)$. The growing season averages 214 days. The average yearly rainfall is $49 \mathrm{~cm}$ (19.32 inches), with most occurring during the spring and summer months. Windspeed at Lubbock averages $20.5 \mathrm{kph}(12.8 \mathrm{mph}$ ), but a maximum windspeed of $142.4 \mathrm{kph}$ (89 mph) has been recorded (Pass 1981:111). The prevailing winds come from the south and southwest. Severe weather conditions, i.e., blizzards, droughts, and thunderstorms, are not uncommon.

The project area is within the Mesquite Plains district of the Kansan biotic province (Blair 1950). Vegetation in the region can be categorized generally into three floral assemblages occupying different topographic settings: (1) the juniper-mesquite/upland slope assemblage; (2) the mesquite-oldfield/terrace-floodplain assemblage; and (3) the saltcedar/riparian floral assemblage (Kenmotsu 1981:343-346). Lists of flora found in the region are presented in Kenmotsu (1981:343-346), Boyd (1989a:19-20), Etchieson et al. (1979:25-32), and Wulfkuhle (1986:40-44). The latter two provide data on human utilization of plants. Lists of regional fauna are presented in Wulfkuhle $(1986: 39,45-54)$ and Boyd (1989a:21) and include both modern and historic species.

Recent modification to plant and animal communities is apparent throughout the region, but little effort has been made to identify native species, particularly those that are no longer extant. Portions of the project area have undergone severe alterations, but some locations (portions of Grape and Little Grape creeks in particular) appear to be relatively undisturbed. If isolated pockets of unmodified native vegetation are present, then these areas may represent unique biotic communities within the region and warrant study.

\section{Previous Investigations}

Archeological work in the Justiceburg area was first done by members of the South Plains Archeological Society (SPAS), beginning in the 1950s. Emmett Shedd reported numerous prehistoric archeological sites in Garza County and in the project area between 1955 and 1960 and in the 1970s. Aaron Riggs, Jr. conducted a survey of Garza County rock art sites in the mid 1960s (Riggs 1965) and recorded the petroglyphs at Cowhead Mesa, the Verbena Site, and Dorward Ranch (41GR51); only the latter site is in the project area. He later recorded the petroglyhs at Yellowhouse Crossing Mesa (Riggs 1969). This site, also called the O.S. Ranch Petroglyphs, is a few kilometers north of the project area.

Riggs and Shedd directed the SPAS excavations at Reed Shelter (41GR54) in January 1966. The site yielded sparse Late Prehistoric cultural materials; bedrock mortar holes, petroglyphs inside the shelter, and a campsite and pictograph across the creek from the 
shelter (now site 41GR390) are also reported (Riggs 1966). These sites are in the project area.

Shedd (1968) reported a Late Prehistoric cairn-covered burial west of the project area in Garza County. Cockrum (1963) reported a multiple burial (actually two single and one double, cairn-covered interments) in northeastern Garza County. Kirkpatrick (1978) conducted a study of bedrock mortar holes which included four sites in the project area.

Archeological studies in conjunction with Justiceburg Reservoir began in 1973-1975. The South Plains Association of Governments (SPAG) initiated archeological surveys of selected areas within its 15-county jurisdiction (Campbell 1975a, 1975b, 1976, 1977; Campbell and Judd 1977a, 1977b; Judd 1977, 1978). These studies included a survey of the proposed Justiceburg Reservoir which reported 145 sites but recommended that only 1 site be tested and 12 sites be surface collected (Campbell 1975b:18-19). Local landowners, aware that the sites were more significant than the SPAG survey had indicated, funded another archeological study to reevaluate the archeological resources (Alexander 1982). Grand River Consultants, Inc. revisited and rerecorded nine sites and concluded that the SPAG data were questionable and thạt the resources warranted much more work than had been recommended. Alexander (1982:34) recommended "a thorough survey and documentation of the resources of the proposed reservoir. ..."

In 1987, the City of Lubbock contracted for Phase I cultural resources investigations with Prewitt and Associates, Inc. of Austin. The investigations consisted of a 100\% pedestrian survey, historic archival and informant research, and a preliminary geoarcheological study. The investigations and results are reported in Boyd et al. (1989).

The archeological survey recorded 330 archeological sites and 45 isolated finds, including 243 sites with prehistoric components, 30 sites with historic components, and 74 sites with rock art components (Table 1). Of the 243 prehistoric archeological sites, 48 components at 39 sites could be assigned a temporal affiliation (Boyd 1989c). These components included 4 middle Archaic, 10 late Archaic, 10 undefined Archaic, and 24 Late Prehistoric. Only six sites contained components that could be tentatively assigned a cultural affiliation. All are Late Prehistoric; three are assigned to the Palo Duro Complex (Willey and Hughes 1978), and three are assigned to the Garza Complex (Runkles 1964).

The 30 historic sites were attributed to one or more of the three economic/temporal categories defined for the region by Freeman (1989b). These are (1) buffalo hunting and ranching, 1875-1899; (2) permanent settlement attributed to the Four-Section Act of 1895, 1899-1909; and (3) railroad, town-building, and industrial (oil related) development, 19101945.

The 74 rock art sites include 54 sites with nonaboriginal, historic incriptions (Boyd 1989d). The inscriptions usually consist of names and dates and provide interesting biographic data. The earliest of these dates to 1849 , and numerous examples date to the late 1800 s and early 1900s. A number of inscriptions are attributed to regionally significant persons. Aboriginal rock art is found at 33 sites (Boyd 1989d); most contain only petroglyphs, but 5 sites have painted images. Three sites contain historic Indian elements; the remaining 30 sites are undated, but judging from the rapid weathering of the sandstone, these sites probably date within the last several hundred years. These 33 sites represent the highest density of aboriginal rock art sites yet recorded in northern Texas. 
TABLE 1

SUMMARY OF PHASE I ARCHEOLOGICAL SITES

Site Type

Number of Sites

PREHISTORIC

Lithic scatter

6

Faunal locality

Rockshelter

Lithic procurement

Campsite and lithic procurement/campsite

Total:

HISTORIC

Trash dump

Housesite/dugout

Cemetery

Railroad/resort complex

Campsite/grave

Unidentified

Total:

ROCK ART

Aboriginal

Mixed

Total:

The geoarcheological investigation by Blum (1989) defined the depositional environments and processes within the upland and riverine settings in the project area. In the riverine setting, the study defined only one locality (GM 2), near the mouth of Grape Creek, where Late Pleistocene to middle Holocene terrace sediments are preserved. All other alluvial terraces investigated date to the very late Holocene. The upland eolian sediments were found to be quite old and stable, with a minimum age of ca. 5,000 years. The study concluded that upland settings (and older terraces in the upper reservoir) may preserve prehistoric occupations of all ages but that the alluvial terraces in the canyonconfined valley, which constitute a large portion of the project area, are relatively young and should contain only late Archaic and Late Prehistoric archeological remains. The lack of preserved Late Pleistocene to middle Holocene sediments throughout most of the project area corresponds with the skewed inventory of archeological sites, which is heavily biased toward late Archaic and Late Prehistoric sites. 


\section{CHAPTER 3}

\section{OBJECTIVES AND METHODS}

by Douglas K. Boyd

This chapter consists of two sections. The first defines the objectives for the Phase II work. The second describes the methods used to accomplish these objectives.

\section{Objectives}

The ultimate objective of these investigations was to insure the proper consideration and treatment of cultural resources that will be affected by construction and operation of the reservoir. The Phase I investigations (Boyd et al. 1989), identified the cultural resources, defined the impacts to them, and evaluated these resources based on the criteria of eligibility for listing on the National Register of Historic Places. Of the 375 cultural resources recorded, 238 were considered to be potentially eligible for listing on the National Register. The primary objective of the Phase II investigations was National Register testing and assessment of a sample of 37 archeological sites (termed firstpriority sites) selected from the sites considered to be potentially eligible. These first-priority sites were selected and the level of testing effort was specified through consultation and agreement among the cultural resources personnel of the three managing entities: the U.S. Army Corps of Engineers, the Texas Historical Commission, and Freese and Nichols, Inc. Additionally, more-limited investigations were conducted at 30 sites (termed second-priority sites), concentrating mainly on investigating cultural remains discovered during mechanical subsurface testing (e.g., in the geoarcheological investigations) and on recording newly discovered sites or revisiting and reevaluating previously recorded sites. The specific objectives of the archeological site testing were as follows:

1. To determine the areal extent of each site to the degree practical.

2. To determine the stratigraphy and cultural chronology for each site whenever possible based on artifact analysis, correlative stratigraphic analysis, and chronometric dating.

3. To identify cultural features (e.g., pits, hearths, burials, structural remains) and special-use areas (e.g., areas within a site where tools were manufactured, food processed, and refuse disposed).

4. To gather baseline information to aid in the identification of subsistence strategies and seasonality based on paleoenvironmental data and cultural materials.

5. To establish the relationship between tested sites and other sites in the project area or region. 
The Phase II investigations had two major objectives in addition to site testing, one dealing with the historical resources of the project area, and one dealing with geoarcheological investigations. The former entailed archival research to gather the contextual data needed to evaluate the historical resources. The latter involved continued documentation of the sediments in the project area to better understand the depositional history and to evaluate the potential for buried archeological sites.

\section{Methods}

The three main areas of study--archeological site testing, historical research, and geoarcheological investigation--required different methods and techniques suited to the retrieval of data to meet different objectives. The investigation of different types of prehistoric and historic archeological sites also required different methodologies. The methods employed in investigating the prehistoric archeological sites and the rock art sites are detailed below. Also presented below is an overview of the geoarcheological investigations; a more-detailed discussion of this aspect of the project appears in Chapter 4. Finally, the approaches and methods used in the historic archival/informant research and site investigations are described in Freeman and Boyd (1990).

A total of 667 person-days were expended during the field investigations. Approximately $80 \%$ of the field effort was expended on the investigation of first-priority archeological sites, the geoarcheological investigations and subsurface mechanical testing, the historic archival/informant field research, the magnetometer pilot study, and field visits by consultants. The remaining $20 \%$ of the field effort was spent on second-priority site investigations.

\section{Archeological Site Testing}

The 37 first-priority sites consist of aboriginal rock art sites, historic sites, and prehistoric sites of four types: open campsites, lithic procurement sites, rockshelters, and faunal localities (Table 2). Investigations at the 34 first-priority aboriginal sites included, when appropriate, detailed mapping and recording of site setting, surface collection of individually mapped artifacts and/or selected block areas, backhoe trenches or exploratory trenches, mechanical auger tests, and hand-excavated test units (Table 3 ).

Second-priority site investigations mainly involved mechanical testing but also included tasks such as site revisits or recording of new sites (Table 4); of the 30 secondpriority sites, 28 are aboriginal and 2 are historic (see Table 2). Geomorphic backhoe trenches and archeological exploratory trenches were excavated at numerous second-priority sites, and additional investigations occurred when archeological materials were recovered. This additional work generally was limited to one or two hand-excavated test units, limited mapping, and occasional surface collecting. When significant finds were made, moreintensive investigations were conducted. Fifty-five test units were excavated at secondpriority aboriginal sites. 
TABLE 2

SUMMARY OF SITES INVESTIGATED

\begin{tabular}{lccc}
\hline Site Type & First Priority & Second Priority & Total \\
\hline & & & \\
Prehistoric & 11 & 22 & 33 \\
Campsites & 2 & 2 & 4 \\
Lithic procurement & 2 & 0 & 2 \\
Rockshelters & 8 & 2 & 2 \\
Faunal localities & 0 & 2 & 2 \\
Lithic scatters & 0 & 0 & 11 \\
Isolated finds & 11 & 2 & 5 \\
Aboriginal rock art & $\underline{3}$ & 30 & 67 \\
Historic & 37 & & 2 \\
Totals: & & & 2 \\
\hline
\end{tabular}

\section{FIELD METHODS}

\section{Mapping and Site Recording}

Mapping at first-priority sites was accomplished using a surveyor's transit or alidade and stadia rod. Permanent datum points were marked with 12 -inch sections of $1 / 2$-inchdiameter rebar; each site had at least one site datum, most required several. Site topography, natural and cultural features, and artifacts were mapped. All surface-collected artifacts and samples, mechanical excavations, and hand-excavated test units were mapped in relation to the datum points and topography. Vertical site profiles along a transect were mapped when appropriate. Notes on the site setting, vegetation, disturbances, or unusual characteristics were made. All sites were plotted on 1 inch $=500 \mathrm{ft}$ scale areal photographs.

Rockshelters and rock art sites required different methods. Plan view and crosssection drawings of each site were made using two or more 20-50-m tapes. In rockshelters or overhangs, two permanent site datum points, one inside the sheltered area and one on the blufftop above, were established when possible. Rock art sites required special photographic and graphic recording techniques, and a supplemental Rock Art Data Form was devised to standardize the observations and data recording. The methods used at the rock art sites are described in detail in Chapter 7.

Site mapping at second-priority sites was less intensive than at first-priority sites. At a few sites, detailed mapping was done using surveyor's equipment; at the majority of the sites, however, the excavations were mapped in relation to each other and to local landmarks (e.g., fencelines or roads). Trench excavations were triangulated with a Brunton compass to two or more prominent landmarks and plotted on 1 inch $=500 \mathrm{ft}$ scale areal photographs. Site mapping was done with a Brunton compass, taping and/or pacing distances. No detailed topographic mapping was done at these sites. 
TABLE 3

FIELD INVESTIGATIONS AT FIRST-PRIORITY SITES

Site

Description of Investigations

$\underline{\text { Prehistoric Campsites }}$

41GR291 Mapping, surface collection, 1 exploratory trench, 24 auger tests, 6 test units

41GR323

Mapping, surface collection, 11 auger tests, 10 test units

41GR359*

Mapping, surface collection, 3 shovel tests, 22 auger tests, 11 test units

$41 G R 376 *$

Mapping, surface collection, 5 test units

41 GR383

Mapping, surface collection, 11 auger tests, 8 test units

41GR456

Mapping, surface collection, bedrock mortar sample, 16 auger tests, 7 test units

41GR515 Mapping, surface collection, 3 backhoe trenches, 19 auger tests, 7 test units

4JKT34 Mapping, surface collection, 1 backhoe trench, 31 auger tests,

9 test units

41KT49*

Mapping, surface collection, 1 backhoe trench, 29 auger tests, 8 test units

$41 K T 52$

Mapping, 1 backhoe trench, 14 auger tests, 2 test units

41 KT53

Mapping, 4 backhoe trenches, 4 exploratory trenches, 13 test units

\section{$\underline{\text { Lithic Procurement Sites }}$}
41GR327**
Mapping, surface collection, lithic reduction sample, lithic material sample
$41 \mathrm{GR} 381 * *$
Mapping, surface collection, lithic reduction sample, lithic material sample

$\underline{\text { Rockshelters }}$

41GR546

Mapping, 1 test unit

41GR559

Mapping, 2 shovel tests, 3 test units

*Site also exhibits evidence of lithic procurement.

**Site also exhibits limited evidence of camp activities. 
Table 3 , continued

Site

Description of Investigations

Faunal Localities

41GR249

Mapping, 1 test unit

$41 \mathrm{GR} 270$

Mapping, 2 test units

41GR310

Mapping, 2 test units

41GR488

Mapping, 4 test units

41GR512

Mapping, 2 test units

41GR539

Mapping, 2 test units

$41 \mathrm{KT} 44$

Mapping, 4 test units

$41 \mathrm{KT} 69$

Mapping, 2 test units

Rock Art Sites

41GR51

Mapping, photographing and recording

41GR282

Mapping, photographing and recording, 1 shovel test

$41 \mathrm{GR} 344$

Mapping, photographing and recording

$41 \mathrm{GR} 390$

Mapping, photographing and recording

41GR423

Mapping, photographing and recording

$41 \mathrm{GR} 426$

Mapping, photographing and recording, pigment sample

4.1GR437

Mapping, photographing and recording, pigment sample

$41 \mathrm{GR} 472$

Mapping, photographing and recording, 4 shovel tests

41GR494

Mapping, photographing and recording

$41 \mathrm{KT} 65$

Mapping, photographing and recording

$41 \mathrm{KT} 68$

Mapping, photographing and recording

\section{Surface Collection}

Surface collections consisted of individual artifacts and recovery of artifacts from surface collection units. Functionally or temporally diagnostic artifacts were individually plotted and then collected. The latter surface collection technique, i.e., surface collection units, consisted of recovering all cultural materials from a specified area (e.g., a $2 \times 4-m$ block or a 5-m-diameter circle). These collections were generally made in areas with good erosional exposures and concentrations of lithic debitage and/or tools. All collected materials were bagged by provenience. 
TABLE 4

FIELD INVESTIGATIONS AT SECOND-PRIORITY SITES

Site

Description of Investigations

Prehistoric Campsites

41GR207

41GR239*

41GR286*

41GR287

41GR302

41GR303

41GR374

41GR378*

41GR380**

41GR393

41GR467

41GR4 71

41GR474

41GR483

41GR484

41GR566

41GR569

41KT33

41KT47

41KT51

41KT148

41KT15I
2 exploratory trenches, 3 test units, surface collection

2 exploratory trenches, 5 test units, surface collection

2 test units

2 exploratory trenches, 5 test units

2 exploratory trenches, 4 test units, surface collection

2 exploratory trenches, 5 test units, surface collection

2 exploratory trenches, 2 test units

2 exploratory trenches, 4 test units

2 exploratory trenches, 4 test units, surface collection

1 exploratory trench

3 backhoe trenches, 3 test units

1 backhoe trench, 2 test units, surface collection

7 backhoe trenches, surface collection

1 test unit (at 1987 backhoe trench location)

1 backhoe trench, 5 test units, limited mapping, surface collection

3 exploratory trenches

Newly recorded site located in 1 backhoe trench

3 backhoe trenches, 6 test units, mapping, surface collection

1 backhoe trench

1 backhoe trench, 3 test units, limited mapping, surface collection

Newly recorded site located by surface debris, 1 backhoe trench

Newly recorded site located in 1 backhoe trench

*Site also exhibits evidence of lithic procurement.

**Site type was considered to be lithic procurement during Phase I (Boyd et al. 1989); as a result of Phase II investigations, site classification has been changed to prehistoric campsite/lithic procurement. 
Table 4, continued

Site

Description of Investigations

Lithic Procurement Sites

41 KT35

1 backhoe trench

$41 K T 149$

Newly recorded site lccated by surface debris

\section{Lithic Scatters}

41GR373

1 exploratory trench

41GR570

Newly recorded site located by surface debris

Isolated Finds

41GR468

1 backhoe trench, 1 test unit

$41 \mathrm{KT} 46$

1 backhoe trench

Two types of special samples were collected from lithic procurement sites. At each site, lithic material samples were collected from a lxl-m unit, termed a Lithic Material Unit, within a shallow Quaternary gravel outcrop in an area where no modified lithics were present. All lithic materials from the surface of the unit to bedrock were collected to provide data comparable to other studies of Quaternary gravel sources in the region. Also, all materials, including unmodified flakes, were collected from specified $25-\mathrm{m}^{2}$ areas, termed Lithic Reduction Units, at each site where concentrations of lithic reduction materials were found. These samples were intended to provide complementary data on the natural lithic materials, raw material selection, and reduction strategies.

\section{Mechanical Testing}

On-site mechanical testing involved the use of a backhoe and a power auger. Backhoe testing involved excavation of either geomorphic backhoe trenches or archeological exploratory trenches (Table 5). Thirty-one of the 77 geomorphic backhoe trenches were located in previously known archeological sites, and excavation of two other trenches resulted in the recording of new prehistoric sites (41GR569 and 41KT151). Detailed stratigraphic data for the geomorphic trenches are provided in Appendix A.

The second aspect of the subsurface testing involved 28 exploratory trenches excavated in a variety of prehistoric sites regardless of site type or assessment, to provide both positive and negative archeological data. For example, exploratory trenches were occasionally excavated specifically to test the evaluation of relatively insignificant sites when the backhoe crossed such sites en route to other locations.

The geomorphic backhoe trench excavations were monitored by the Project Geomorphologist and an archeologist; backhoe trench profiles were photographed and recorded, and sediment samples were collected when appropriate deposits were encountered. The exploratory 
TABLE 5

SUMMARY OF BACKHOE TESTING BY SITE

\begin{tabular}{|c|c|c|c|}
\hline Site No. & & Backhoe Trench No. & Exploratory Trench No. \\
\hline $41 \mathrm{GR} 207$ & & - & 85,86 \\
\hline 41GR239 & & - & 88,89 \\
\hline 41GR287 & & - & 80,81 \\
\hline 41GR291 & & - & 82,83 (outside site) \\
\hline $41 \mathrm{GR} 302$ & & - & 78,79 \\
\hline $41 \mathrm{GR} 303$ & & - & 90 (outside site), 91,92 \\
\hline $41 \mathrm{GR} 373$ & & - & 87 \\
\hline 41GR3 74 & & - & 93,94 \\
\hline $41 \mathrm{GR} 378$ & & - & 95,96 \\
\hline 41GR380 & & - & 97,98 \\
\hline $41 \mathrm{GR} 393$ & t. & - & 84 \\
\hline $41 \mathrm{GR} 467$ & & $15,16,18$ & - \\
\hline $41 \mathrm{GR} 468$ & & 17 & - \\
\hline 41GR471 & & 12 & - \\
\hline 41GR4 74 & & $4,5,6,7,8,9,10$ & - \\
\hline 41GR484 & & 67 & - \\
\hline 41GR515 & & $19,20,21$ & - \\
\hline 41GR566 & & - & $99,100,101$ \\
\hline 41GR569 & & 1 & - \\
\hline 41KT33 & & $55,56,57$ & - \\
\hline $41 \mathrm{KT} 34$ & & 62 & - \\
\hline $41 \mathrm{KT} 35$ & & 54 & - \\
\hline $41 \mathrm{KT} 46$ & & 39 & - \\
\hline $41 \mathrm{KT} 47$ & & 38 & - \\
\hline $41 \mathrm{KT} 49$ & & 35 & - \\
\hline $41 \mathrm{KT} 51$ & & 31 & - \\
\hline $41 \mathrm{KT} 52$ & & 28 & - \\
\hline $41 \mathrm{KT} 53$ & & $25,26,27,32$ & $102,103,104,105$ \\
\hline $41 \mathrm{KT} 148$ & & 73 & - \\
\hline $41 \mathrm{KT} 151$ & & 30 & - \\
\hline
\end{tabular}

trench excavations were monitored and recorded by an archeologist. A sample of the fill from each trench was passed through a 1/4-inch screen, and cultural materials were collected by provenience. All on-site trenches are discussed in Chapters 5 and 6 . The backhoe trench and exploratory trench excavations and the subsequent hand excavation of test units account for the work at 26 of the 30 second-priority sites.

Subsurface on-site testing was also done using a gasoline-powered soil auger. The auger has a 12 -inch-diameter $(30-\mathrm{cm})$ bit and can dig to a maximum depth of $125 \mathrm{~cm}$. The auger was used to test large areas where the potential for shallowly buried cultural 
materials was high. All of the fill from each auger test was passed through a 1/4-inch screen, and all cultural materials were collected. The frequency of cultural materials recovered was calculated and used to define buried components and select areas for testing. Shovel testing was done only in circumstances where augering was not feasible.

\section{Test Unit Excavation}

Test unit locations were selected based on exposed artifacts or cultural features or cultural remains recovered in backhoe trenches, exploratory trenches, auger tests, or shovel tests. Some units were intended to sample cultural zones, while others were placed to test probable buried features. Test units were usually $1 \mathrm{xl} \mathrm{m}$ in size, but $1 \times 2-\mathrm{m}$ units were also used. All fill from the test units was passed through 1/4-inch screens, and all cultural materials were collected by provenience. Excavation levels varied in thickness, but arbitrary 10- cm levels were used most commonly. In sites with a considerable amount of overburden, levels $20 \mathrm{~cm}$ or more in thickness were used until the cultural zone was reached. In some cases, levels corresponding to natural stratigraphic zones were used.

During the excavations, various kinds of samples were collected from natural stratigraphic units and from cultural zones and features. Sampling from cultural features was considered especially important, and as many kinds of samples as possible were collected. Large bulk sediment samples were collected for humate radiocarbon dating or for flotation. Smaller sediment samples were collected for pollen or phytolith analysis. Organic materials such as charred wood, shells, and bones were collected for wood identification, faunal analysis, or radiocarbon dating. Burned rocks and stone tools were collected separately and were not cleaned so they could be used for organic residue, pollen, or phytolith analysis. Stone tools for use-wear analysis were also bagged separately to prevent damage to utilized edges. Burned rocks from features and ceramics were selected for thermoluminescence dating, and ceramics from excavated contexts were also bagged for organic residue analysis.

Magnetometer Pilot Study

Proton magnetometer surveys were run at two sites (41GR323 and 41KT53) as a pilot study to assess the utility of this technique in different site settings. These studies were intended to evaluate the feasibility and cost effectiveness of magnetic surveying as a possible mitigation tool. The methods and results are discussed in detail in Appendix $B$.

\section{Environmental Reconstruction}

The reconstruction of past environments is critical to interpretations of cultural adaptations but cannot be based solely on archeological data. In order to address paleoenvironmental research questions, sediment samples from dated noncultural contexts were analyzed specifically for paleoenvironmental data. Most of these samples were collected from backhoe trenches during the geomorphic testing. Comparisons of the carbon isotope, pollen, and phytolith data from these samples provide some insights into past environmental changes within the project area (see Chapter 8).

\section{Subsistence Studies}

Reconstructing prehistoric subsistence strategies is a complex task which requires a multidisciplinary approach and the application of specialized technical studies. Specific 
archeological excavation and sampling techniques were employed to maximize the recovery of such data, and various technical analyses were performed. The collection of different types of samples (as described above) from cultural contexts, particularly features, was a standard field practice primarily directed toward providing three classes of data. Small sediment samples were analyzed for pollen and phytoliths, large sediment samples were subjected to flotation recovery to provide faunal and macrobotanical data, and selected cultural materials (e.g., stone tools and burned rocks from features) were analyzed for organic residues and/or use-wear patterns. The evidence derived from these studies is particularly useful for interpreting subsistence and function (see Chapter 8).

\section{LABORATORY METHODS}

The initial laboratory processing of the cultural materials recovered consisted of five tasks: (1) assigning a unique lot number to each provenience at each site; (2) washing artifacts; (3) labeling artifacts with site and lot numbers; (4) cataloging all photographs and records; and (5) cataloging of all samples collected. All laboratory processing was done in accordance with the requirements of the Texas Archeological Research Laboratory of The University of Texas at Austin. 'One exception to the above order of processing was the stone tools for organic residue analysis. These specimens were cataloged without being washed and then submitted for extraction of the residue samples.

Bulk sediment samples from natural strata or cultural features were subjected to water flotation. The flotation device, modeled after that of Jackson (1981:347 351), consisted of a rectangular tank, a box with a fine screen (window screen) bottom for heavy fraction recovery, a tube for the flotation sample runoff, and a flotation sample recovery box. Matrix samples are placed in the heavy fraction box and submerged in the tank. Water jets spraying upward agitated the sample, and the light fraction floated down the tube and was collected in a fine mesh bag in the flotation recovery box. The heavy and light fractions were dried and hand sorted. Macrobotanical remains were submitted for species identification. Faunal remains and lithics recovered from flotation samples were added to the existing samples of these materials and analyzed in-house.

Artifacts were sorted and analyzed by material class and group, and the methods and results are presented in the appendixes to this report. Various technical studies were also performed by consultants. The methods and results are presented in appendixes also.

Chronometric dating of archeological features and sediments was particularly important. Thermoluminescence and radiocarbon samples were taken in the field and submitted to three institutions for assay: the TL Laboratory of Durham University, Durham, England; The Radiocarbon Laboratory of The University of Texas at Austin; and Geochron Laboratories Division of Kruger Enterprises, Cambriđge, Massachusetts.

Geoarcheological Investigations

The Phase II geoarcheological investigations expanded upon and revised the Phase I geoarcheological investigations (Blum 1989). The Phase II field efforts concentrated on subsurface mechanical testing with two main goals. The first was to acquire basic stratigraphic data for geomorphic interpretation. The second was to locate, define, and sample 
subsurface archeological materials. Subsurface mechanical testing was done with a backhoe, and hand-excavated $1 \times 1-m$ test units were employed to test archeological remains that were encountered.

The geomorphic aspect of the study involved the excavation of 77 trenches (designated Backhoe Trenches 1-77) and 20 test units. These trenches were excavated primarily to provide geomorphic data, but locations were intentionally selected to provide complementary archeological data whenever possible. Trenches were excavated to test for buried sites in specific areas, particularly the Grape Creek and South Sage Creek floodplains. Trenches were also excavated in or near known prehistoric sites, regardless of the site type or assessment, whenever appropriate geomorphic data could be obtained at that locale. An additional 28 trenches (designated Exploratory Trenches 78-105) were excavated in or near known sites, primarily to obtain archeological data. Second-priority site investigations, most of which were accomplished as part of the geoarcheological investigations, included 35 test units excavated to test archeological remains encountered in exploratory trenches and 21 test units excavated to test archeological remains encountered in backhoe trenches. The geoarcheological investigations and subsurface mechanical testing are described in detail in Chapter 4. 


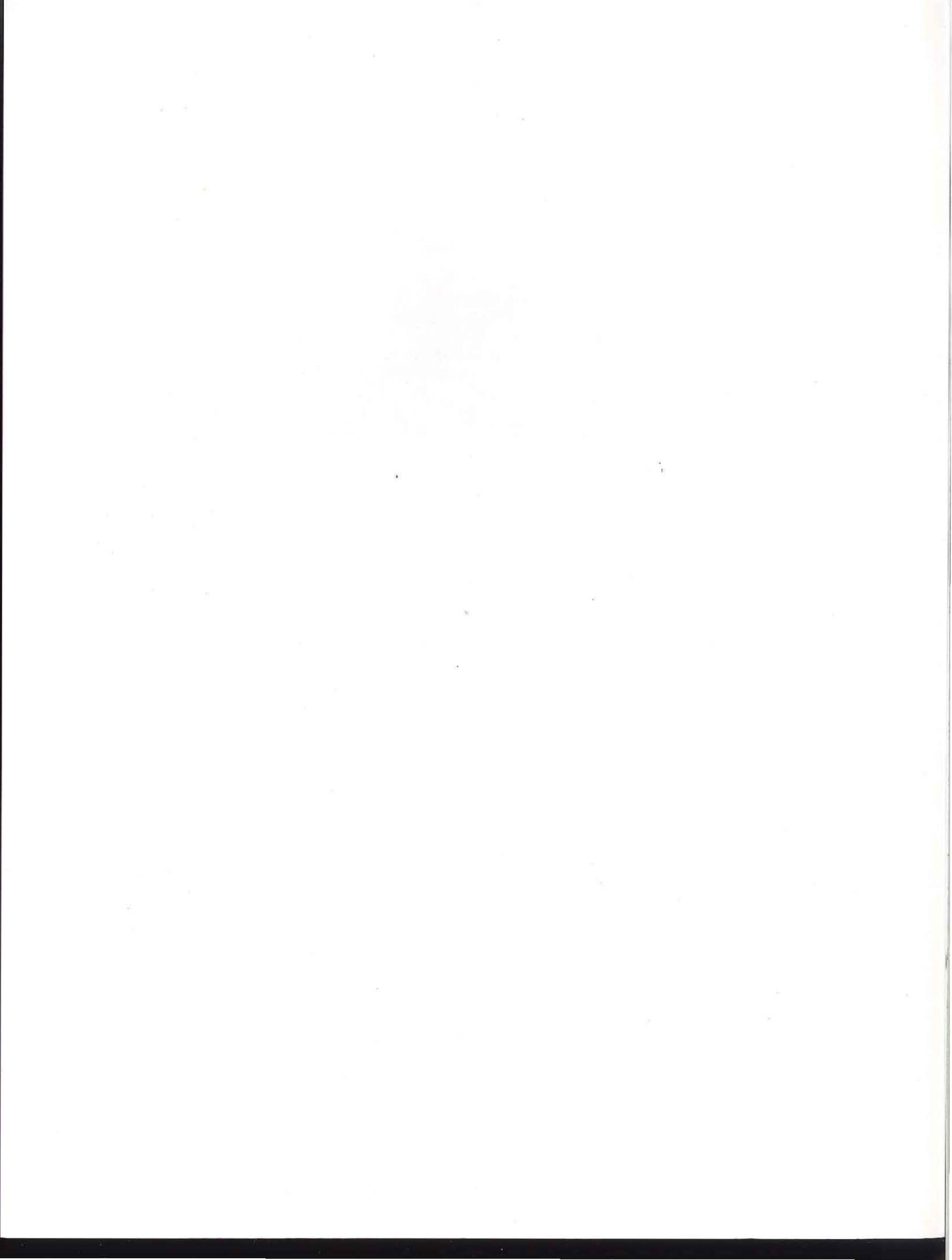


CHAPTER 4

GEOMORPHIC AND GEOARCHEOLOGICAL INVESTIGATIONS

by James T. Abbott

This chapter describes geomorphic and geoarcheological investigations conducted during the Phase II investigations at Justiceburg Reservoir. Butzer (1982:35) defines geoarcheology as "archaeological research using the methods and concepts of the earth sciences." Ideally, geoarcheology deals with the complex interplay between environmental and cultural factors in the location, formation, modification, and preservation of sites of human activity. Geoarcheological research themes may concentrate on sedimentology (e.g., Gladfelter 1977; Butzer 1978; Hassan 1978; Stein 1985); geomorphology (e.g., Gladfelter 1977; Butzer 1978); site formation, modification, and destruction (Wood and Johnson 1978; Schiffer 1983, 1987); pedology and soil formation (Abbott and Tiffany 1985); or specific postdepositional disturbance processes (Stein 1983; Bocek 1986).

The investigations reported here consisted of subsurface testing of selected locations with a backhoe and had two primary goals: first, to better define the character, geometry, and age of late Pleistocene and Holocene alluvial, colluvial, and eolian sediments within the reservoir; and second, to prospect for buried cultural materials within those sediments. Geomorphic priorities included the assessment of the extent, depth, age, and processes responsible for the formation of the late Quaternary deposits, the identification of buried geomorphic surfaces and cultural horizons, and the assessment of the nature and degree of impact of postdepositional disturbance processes.

These investigations were preceded by a Phase I geoarcheological investigation (Blum 1989). This study resulted in the development of a conceptual framework that was used as the springboard for interpretation in the present study. Blum identified four geomorphic subdivisions within the reservoir that are useful conceptual tools for dealing with the range of variation within the study area. These are: (1) the upper reservoir; (2) the central, canyon-confined reservoir; (3) Grape Creek and the lower reservoir; and (4) the "eolian" upland. These subdivisions are used as organizational tools in this discussion.

Methodology

This study was conducted at intervals during August through October 1988 and consisted of 20 days of backhoe trenching during which a total of 77 trenches were excavated (Table 6; see Appendix A for individual trench descriptions). Trench locations were selected to provide as representative a sample of sediments within the reservoir as possible. However, time constraints and the need to place a number of the trenches within the boundaries of archeological sites to aid in the design and implementation of the hand testing reduced the number of trenches that were available for buried site prospection. Another significant impediment to obtaining representative coverage of the sediments in the reservoir was posed by the topography; many areas, particularly in the canyon-confined portion of the study area, were not accessible to the backhoe and therefore were not addressed. 
TABLE 6

SUMMARY OF BACKHOE TRENCH DATA

\begin{tabular}{|c|c|c|c|c|c|c|}
\hline $\begin{array}{l}\text { BHT } \\
\text { No. }\end{array}$ & $\begin{array}{l}\text { Length } \\
\text { (m) }\end{array}$ & $\begin{array}{l}\text { Width } \\
\text { (m) }\end{array}$ & $\begin{array}{l}\text { Depth } \\
\text { (m) }\end{array}$ & $\begin{array}{l}\text { Orientation } \\
\text { (mag) }\end{array}$ & Site & Cultural Materials* \\
\hline 1 & 5.4 & 2.3 & 2.6 & $115^{\circ}$ & 41GR569 & $\begin{array}{l}\text { sandstone abrader, } \\
\text { debitage, burned } \\
\text { sandstone }\end{array}$ \\
\hline 2 & 5.0 & 2.1 & 2.8 & $135^{\circ}$ & - & - \\
\hline 3 & 5.3 & 1.1 & 4.0 & $210^{\circ}$ & - & - \\
\hline 4 & 6.0 & 2.0 & 4.0 & $90^{\circ}$ & 41GR474 & $\begin{array}{l}\text { burned sandstone, } \\
\text { debitage, mussel shell }\end{array}$ \\
\hline 5 & 5.0 & 1.0 & 2.5 & $135^{\circ}$ & 41GR474 & - \\
\hline 6 & 4.7 & 1.0 & 1.57 & $120^{\circ}$ & $41 \mathrm{GR} 474$ & - \\
\hline 7 & 4.7 & 1.0 & 0.7 & $110^{\circ}$ & $41 \mathrm{GR} 474$ & - \\
\hline 8 & 4.9 & 1.0 & 2.08 & $100^{\circ}$ & $41 \mathrm{GR} 474$ & - \\
\hline 9 & 4.7 & 1.0 & 1.08 & $130^{\circ}$ & 41GR4 74 & historic window glass \\
\hline 10 & 4.6 & 1.0 & 1.18 & $170^{\circ}$ & $41 \mathrm{GR} 474$ & - \\
\hline 11 & 5.1 & 3.4 & 4.4 & $35^{\circ}$ & - & - \\
\hline 12 & 5.0 & 1.0 & 2.28 & $110^{\circ}$ & 41GR4 71 & $\begin{array}{l}\text { abraded sandstone, } \\
\text { burned sandstone }\end{array}$ \\
\hline 13 & 5.5 & 1.0 & 2.4 & $120^{\circ}$ & - & - \\
\hline 14 & 5.5 & 2.1 & 4.0 & $110^{\circ}$ & - & - \\
\hline 15 & 5.1 & 1.0 & 2.9 & $10^{\circ}$ & 41GR467 & $\begin{array}{l}\text { ceramic, burned } \\
\text { sandstone }\end{array}$ \\
\hline 16 & 5.8 & 2.1 & 4.5 & $100^{\circ}$ & 41GR467 & $\begin{array}{l}\text { burned sandstone; } \\
\text { possible unlined basin } \\
\text { hearth (lenticular ashy } \\
\text { stain) } 63-66 \mathrm{~cm} \text { bgs }\end{array}$ \\
\hline 17 & 5.9 & 1.0 & 4.35 & $160^{\circ}$ & 41GR468 & $\begin{array}{l}\text { possible burned sand- } \\
\text { stone, bone (may not be } \\
\text { of cultural origin) }\end{array}$ \\
\hline 18 & 5.5 & 1.0 & 1.56 & $30^{\circ}$ & $41 \mathrm{GR} 467$ & $\begin{array}{l}\text { thermally fractured } \\
\text { quartzite }\end{array}$ \\
\hline 19 & 5.2 & 1.0 & 1.68 & $95^{\circ}$ & 41GR515 & - \\
\hline
\end{tabular}

*Includes materials without demonstrated cultural context. 
Table 6, continued

\begin{tabular}{|c|c|c|c|c|c|c|}
\hline $\begin{array}{l}\text { BHT } \\
\text { No. }\end{array}$ & $\begin{array}{l}\text { Length } \\
\text { (m) }\end{array}$ & $\begin{array}{l}\text { Width } \\
\text { (m) }\end{array}$ & $\begin{array}{l}\text { Depth } \\
\text { (m) }\end{array}$ & $\begin{array}{l}\text { Orientation } \\
\text { (mag) }\end{array}$ & Site & Cultural Materials \\
\hline 20 & 5.5 & 1.0 & 4.1 & $120^{\circ}$ & 41GR515 & - \\
\hline 21 & 5.2 & 1.0 & 2.05 & $120^{\circ}$ & 41GR515 & $\begin{array}{l}\text { burned sandstone, } \\
\text { debitage }\end{array}$ \\
\hline 22 & 5.1 & 2.15 & 4.35 & $170^{\circ}$ & - & - \\
\hline 23 & 5.4 & 1.0 & 1.75 & $45^{\circ}$ & - & $\begin{array}{l}\text { bone (probably not } \\
\text { cultural) }\end{array}$ \\
\hline 24 & 5.5 & 2.0 & 4.35 & $90^{\circ}$ & - & $\begin{array}{l}\text { bison bone (possibly } \\
\text { cultural), lenticular } \\
\text { ashy stain } 81-84 \mathrm{~cm} \text { bgs }\end{array}$ \\
\hline 25 & 5.3 & 1.9 & 3.0 & $117^{\circ}$ & $41 \mathrm{KT} 53$ & charcoal stain, $90 \mathrm{~cm}$ \\
\hline 26 & 5.2 & 1.05 & 2.2 & $0^{\circ}$ & $41 \mathrm{KT} 53$ & charcoal stain, $34-40 \mathrm{~cm}$ \\
\hline 27 & 6.0 & 1.05 & 3.3 & $105^{\circ}$ & $41 \mathrm{KT} 53$ & charcoal stain, $35 \mathrm{~cm}$ \\
\hline 28 & 5.6 & 1.05 & 3.8 & $125^{\circ}$ & $41 K T 52$ & debitage \\
\hline 29 & 4.9 & 1.05 & 1.85 & $37^{\circ}$ & - & - \\
\hline 30 & 6.5 & 1.05 & 3.95 & $87^{\circ}$ & $41 \mathrm{KT} 151$ & core \\
\hline 31 & 6.2 & 1.05 & 3.6 & $75^{\circ}$ & $41 \mathrm{KT} 51$ & debitage, mussel shell \\
\hline 32 & 7.7 & 1.1 & 2.55 & $50^{\circ}$ & $41 \mathrm{KT} 53$ & debitage \\
\hline 33 & 4.7 & 1.0 & 2.0 & $40^{\circ}$ & - & - \\
\hline 34 & 5.5 & 1.0 & 2.9 & $55^{\circ}$ & - & - \\
\hline 35 & 3.6 & 1.0 & 0.9 & $105^{\circ}$ & $41 \mathrm{KT} 49$ & - \\
\hline 36 & 4.2 & 1.0 & 1.2 & $110^{\circ}$ & - & - \\
\hline 37 & 5.0 & 1.0 & 1.2 & $10^{\circ}$ & - & - \\
\hline 38 & 5.0 & 1.0 & 1.75 & $10^{\circ}$ & $41 \mathrm{KT} 47$ & - \\
\hline 39 & 4.0 & 1.0 & 0.8 & $40^{\circ}$ & $41 \mathrm{KT} 46$ & - \\
\hline 40 & 4.5 & 1.0 & 1.65 & $45^{\circ}$ & - & - \\
\hline 41 & 4.4 & 1.0 & 2.1 & $90^{\circ}$ & - & - \\
\hline 42 & 3.4 & 1.0 & 0.83 & $125^{\circ}$ & - & - \\
\hline 43 & 4.0 & 1.0 & 1.55 & $160^{\circ}$ & - & - \\
\hline 44 & 3.5 & 1.0 & 0.7 & $165^{\circ}$ & - & - \\
\hline 45 & 4.0 & 1.0 & 1.3 & $45^{\circ}$ & - & - \\
\hline 46 & 4.3 & 1.0 & 1.2 & $175^{\circ}$ & - & - \\
\hline 47 & 4.4 & 1.0 & 1.8 & $10^{\circ}$ & - & - \\
\hline
\end{tabular}


Table 6, continued

\begin{tabular}{|c|c|c|c|c|c|c|}
\hline $\begin{array}{l}\text { BHT } \\
\text { No. }\end{array}$ & $\begin{array}{l}\text { Length } \\
\text { (m) }\end{array}$ & $\begin{array}{l}\text { Width } \\
\text { (m) }\end{array}$ & $\begin{array}{l}\text { Depth } \\
\text { (m) }\end{array}$ & $\begin{array}{l}\text { Orientation } \\
\text { (mag) }\end{array}$ & Site & Cultural Materials \\
\hline 48 & 4.6 & 0.6 & 0.85 & $140^{\circ}$ & - & - \\
\hline 49 & 4.6 & 0.6 & 1.35 & $160^{\circ}$ & - & - \\
\hline 50 & 4.6 & 0.6 & 2.18 & $15^{\circ}$ & - & - \\
\hline 51 & 5.1 & 0.6 & 1.45 & $40^{\circ}$ & - & - \\
\hline 52 & 5.2 & 0.6 & 1.10 & $55^{\circ}$ & - & - \\
\hline 53 & 4.9 & 0.6 & 3.0 & $120^{\circ}$ & - & - \\
\hline 54 & 4.1 & 0.6 & 0.52 & $125^{\circ}$ & 41KT35 & - \\
\hline 55 & 4.3 & 0.6 & 1.47 & $135^{\circ}$ & $41 \mathrm{KT} 33$ & $\begin{array}{l}\text { debitage, burned } \\
\text { sandstone, ground stone }\end{array}$ \\
\hline 56 & 4.2 & 0.6 & 1.12 & $145^{\circ}$ & 41KT33 & - \\
\hline 57 & 4.1 & 0.6 & 0.9 & $160^{\circ}$ & $41 \mathrm{KT} 33$ & $\begin{array}{l}\text { debitage, burned } \\
\text { sandstone }\end{array}$ \\
\hline 58 & 4.5 & 0.6 & 1.0 & $10^{\circ}$ & - & - \\
\hline 59 & 4.8 & 0.6 & 1.2 & $35^{\circ}$ & - & - $\quad-$ \\
\hline 60 & 5.0 & 0.6 & 0.7 & $60^{\circ}$ & - & - \\
\hline 61 & 5.2 & 1.0 & 2.70 & $125^{\circ}$ & - & - \\
\hline 62 & 4.6 & 1.0 & 1.35 & $135^{\circ}$ & $41 \mathrm{KT} 34$ & - \\
\hline 63 & 5.4 & 2.0 & 2.5 & $155^{\circ}$ & - & - \\
\hline 64 & 5.4 & 2.0 & 3.05 & $20^{\circ}$ & - & - \\
\hline 65 & 6.8 & 2.0 & 3.2 & $105^{\circ}$ & - & - \\
\hline 66 & 6.1 & 1.0 & 3.5 & $160^{\circ}$ & - & - \\
\hline 67 & 5.0 & 1.0 & 1.12 & $20^{\circ}$ & 41GR484 & - \\
\hline 68 & 5.0 & 1.0 & 1.55 & $40^{\circ}$ & - & - \\
\hline 69 & 7.0 & 1.0 & 3.0 & $110^{\circ}$ & - & - \\
\hline 70 & 5.2 & 1.0 & 2.25 & $140^{\circ}$ & - & - \\
\hline 71 & 5.0 & 1.0 & 2.3 & $0^{\circ}$ & - & - \\
\hline 72 & 5.0 & 1.0 & 2.1 & $20^{\circ}$ & - & - \\
\hline 73 & 5.3 & 1.0 & 1.92 & $35^{\circ}$ & 41KT148 & - \\
\hline 74 & 5.0 & 1.0 & 3.0 & $110^{\circ}$ & - & - \\
\hline 75 & 5.0 & 1.0 & 3.0 & $120^{\circ}$ & - & - \\
\hline 76 & 5.0 & 1.0 & 2.65 & $175^{\circ}$ & - & - \\
\hline 77 & 5.0 & 1.0 & 2.25 & $40^{\circ}$ & - & - \\
\hline
\end{tabular}


The sediment columns exposed by the trenches were described in the field, consisting of both graphic depictions and verbal descriptions of the exposures. Except where lateral variability made broader exposure records desirable, the descriptions were based on columns of sediment 50-100 cm wide. The neutral term "zone" was adopted to allow both stratigraphic and pedogenic variation in sediment columns to be described under the same nomenclature. Zones were numbered from the top down.

For each zone, the depth, thickness, texture, structure, consistence, reactivity with dilute $\mathrm{HCl}$, Color, and the nature of the contact with the next lower unit were noted. All depths were recorded relative to the present ground surface. Texture was estimated according to the guidelines presented by Birkeland (1984). Structure, consistence, and boundary determinations follow Olson (1976) and the Soil Survey Staff (1951). Dilute HCl was used to determine reactivity and thus suggest relative carbonate content. Color was recorded using a Munsell soil color chart. With the exception of very dry or saturated units, color designations denote moist color. Where used, horizon designations follow the system outlined by Birkeland (1984). Unaltered sediments of a similar nature occurring in section were typically recorded as a single zone (e.g., stacked packets of thin fining-upward overbank deposits); however, the individual stratigraphic contacts were recorded on the accompanying sketch.

Whenever possible, the trenches were entered to allow detailed examination of the sediment column. Significant depth and wall instability precluded safe entry into several trenches without first installing shoring, however. Because no archeological materials were detected at depth in these deep trenches, the time-consuming process of shoring installation was not performed; rather, the sediments were described from the surface based upon examination of the visible exposure and backdirt piles. All such cases are noted in the trench descriptions (see Appendix A). In addition to the trench descriptions, individual profiles representative of the range of variation in the sediments are presented throughout this chapter.

Bulk soil/sediment samples and radiocarbon humate samples were collected from selected trenches. Bulk samples for radiocarbon dating were collected opportunistically when sediments with a suitable clay content for colloidal bonding of organics were encountered. Where possible, soil and sediment samples were removed from controlled locations in trench walls; however, in a few instances, grab samples were taken from backdirt. Humate samples were collected exclusively from controlled locations in trench walls.

\section{Physiography and Bedrock Geology}

Justiceburg Reservoir is located in the southern part of the Great Plains physiographic province in a division variously termed the Low Rolling Plains and the Osage Plains. This area is a southwestern extension of the Interior Lowlands physiographic region, which extends northeast to the Great Lakes (Jordan et al. 1984). In general, the Low Rolling Plains province can be characterized as a highly eroded, undulating to rolling topography developed primarily on rocks of Permian age. Justiceburg Reservoir is situated near the western margin of the province approximately $20 \mathrm{~km}$ east of the escarpment that marks the boundary between the Low Rolling Plains and the Llano Estacado (see Fig. 1). 
The regional geologic history is quite complex and is presented here in a simplified form. Tectonic faulting and deformation resulted in the formation of several structural basins, collectively termed the Permian Basin, that slowly infilled with a variety of terrigenous and marine sediments during the Paleozoic Era (Sellards et al. 1932; Gustavson 1986). Marine carbonates dominate the Mississippian, Pennsylvanian, and Lower Permian, while Upper Permian rocks include redbeds, salts, and limestones deposited in a range of subtidal to supratidal environments (Gustavson 1986).

Sedimentation continued intermittently through the Mesozoic Era, first in the form of a thick deposit of fluvial, lacustrine, and deltaic sediments termed the Dockum Group during the late Triassic Period, then as sandstones and marine carbonates deposited during the Cretaceous Period (Sellards et al. 1932; Barnes 1967; Gustavson 1986). A period of dissection followed during which much of the upper sediment was removed, leaving a number of isolated Cretaceous erosional remnants and wide exposure of Triassic and Permian rocks.

The Tertiary was marked by the deposition of the extensive Ogallala Formation as material shed off the emergent Rocky Mountains was deposited as a series of very large coalescing alluvial fans (Seni 1980). Prolonged subaerial exposure resulted in extensive eolian deposition and the development of a thick caliche cap in the upper Ogallala Formation (Reeves 1970; Dolliver and Holliday 1988). The Quaternary Period saw the addition of the extensive eolian sediments of the Blackwater Draw Formation and interbedded lacustrine deposits of the Tule Formation (Holliday 1985a, 1985b).

The escarpment marking the boundary between the Low Rolling Plains and the Llano Estacado was formed by erosion of the distal ends of the Ogallala Formation fans, exposing underlying Triassic and Permian strata to dissection and further erosion. Headward erosion and downcutting by major streams, including the Canadian, Red, Colorado, and Brazos rivers, has accentuated scarp retreat in many locations. Gustavson et al. (1981) have estimated the average rate of caprock retreat to be between 110 and $180 \mathrm{ft} / 1,000$ years. As the caprock retreated, localized alluvial fan sediments were deposited below the escarpment. Dissected remnants of these features are preserved in places mantling the uplands surrounding the study area.

The formations making up the Low Rolling Plains are exposed as north-south-trending bands which dip gently to the west-northwest (Sellards et al. 1932; Barnes 1967). Two primary rock units are exposed in the Justiceburg Reservoir locality (Sellards et al. 1932; Barnes 1967; Mason Johnston and Associates, Inc. n.d.). The older, stratigraphically lower of these is of Permian age and consists of the Quartermaster Formation of the Double Mountain Group. This unit is poorly exposed at the Justiceburg Reservoir locality but is prominent immediately downstream of the proposed dam site. The Quartermaster Formation is locally up to $107 \mathrm{~m}$ (350 ft) thick and consists of rubified silty shales and slightly sandy siltstones interbedded with thin beds of gypsum and thin lenticular sandstones and clay shales (Mason Johnston and Associates, Inc. n.d.).

The majority of the rocks exposed in the reservoir are of Triassic age and include the Tecovas and Trujillo formations of the Dockum Group. The Tecovas Formation is the stratigraphically lower of the two, locally some $20 \mathrm{~m}(65 \mathrm{ft})$ thick, and bounds unconformably with the Quartermaster Formation. It is composed locally of silty to slightly sandy shale interbedded with thin sandstones and clay shales. The Trujillo Formation is approximately $9 \mathrm{~m}$ (30 ft) thick and is composed of friable, massive, and crossbedded red and greenish gray sandstones, gray calcareous conglomerates, and interbedded lenticular shales (Galowski 1988; Mason Johnston and Associates, Inc. n.d.). 
In addition to the Triassic and Permian rocks, several Cretaceous and Tertiary erosional remnants are preserved in the vicinity of Justiceburg Reservoir. Of particular note is a large extension of the Tertiary surface isolated from the Llano Estacado by subsequent erosion. This feature extends some $90 \mathrm{~km}$ southeast to the Callahan Divide, forming the drainage divide between the Brazos and Colorado rivers. Locally, it is expressed as a prominent topographic scarp up to $100 \mathrm{~m}$ in height some $10-20 \mathrm{~km}$ south of the project area. Rock units exposed in the scarp face include elements of the Triassic Dockum Group, Cretaceous rocks belonging to the Edwards Group, and the Miocene-Pliocene Ogallala Formation. In addition, two other small Cretaceous remnants (Flat Top Mountain and the McKenzie Mountains) are preserved south and southeast of the project area (Barnes 1974).

One characteristic of the rock units with strong implications for prehistoric occupation of the area is the almost total lack of high-grade lithic materials occurring within the deposits. Siliceous materials in the form of alluvial gravels are present in the Dockum Group and alluvial fan deposits reworked from the Ogalalla Formation, but their size is usually quite small. Due to the paucity of local Cretaceous limestones, local chert outcrops are unknown, although some chert cobbles of moderate size do occasionally occur in stream gravels.

The Double Mountain Fork of the Brazos River originates on the Llano Estacado as two different streams. The proposed reservoir is located on the southern branch of the Double Mountain Fork, which originates near the town of Redwine. The North Fork of the Double Mountain Fork heads near the City of Lubbock at the junction of Blackwater Draw and Yellowhouse Draw and joins the southern fork approximately $6 \mathrm{~km}$ east of the proposed dam site.

\section{Geomorphology and Pedology}

The morphology of the valley occupied by the Double Mountain Fork changes dramatically within the confines of the proposed reservoir in response to changes in the resistance of underlying bedrock. The upper portion of the reservoir flows through fairly resistant sandstone and conglomerate beds of the Trujillo Formation. As a result, downcutting is inhibited and the valley is shallow and fairly broad. Downstream, near the middle of the reservoir, the Double Mountain Fork breaks through the Trujillo Formation into the softer Tecovas Formation. At this point channel trenching is no longer inhibited, and the stream has created a relatively deep canyon on the order of $200 \mathrm{~m}$ wide. Lateral expansion of the canyon is inhibited by slump blocks of resistant Trujillo Formation sandstone and conglomerate that break off after being undercut and serve to armor the canyon walls. Rockshelters are common where beds of well-cemented sandstone and conglomerate overlie friable sandstones and mudstones. Farther downstream, near the mouth of Grape Creek, the resistant beds topping the canyon walls disappear and the canyon broadens to more than $1 \mathrm{~km}$ in width.

The Double Mountain Fork of the Brazos River is a braided, ephemeral stream with a bedload dominated by sand-sized particles (Blum 1989). Braided streams are typical of terrains with a moderate slope and moderate to low discharge, and they are characterized by a channel pattern that anastomoses, i.e., bifurcates and rejoins. The anastomosing pattern of flow is primarily a result of variable discharge, which causes the deposition of typically ephemeral longitudinal bars within the channel. Other factors characteristic of a braided channel pattern include a sediment load generally greater than the stream is competent to transport, dominance of gravel- and sand-sized sediments, and a high width-to-depth ratio (Miall 1977; Klein 1980). 
Sediment is carried in a stream as dissolved load, as fine material suspended by turbulent flow, and as coarse bed load or traction load moved along the bottom. The relative importance of these sediments tends to vary with velocity, slope, channel form, bed roughness, and the nature of the sediments supplied to the stream. Deposition occurs as the competence of the stream falls below the level necessary to keep the sediment entrained. All fluvial sediments are effectively in temporary storage and are subject to reentrainment when conditions change. In an ephemeral, braided stream such as the Double Mountain Fork, storage is the norm and sediment entrainment and transport occurs only during infrequent periods of competent flow.

Sedimentary features in the modern Double Mountain Fork channel include longitudinal, transverse, and side bars formed primarily by vertical accretion. Both horizontal and trough crossbedding is present. Hydraulic sorting of the sediment load lends the channel a striking appearance during periods of inactivity because predominantly gray and greenish gray coarse sands and gravels are typical of the elevated bars, while red muds are typical of the multiple low-water thalwegs.

The Double Mountain Fork floodplain is typically composed of vertically accreted, massive, poorly sorted sandy muds and muddy sands. These types of deposits are typical of floodplains in the braided river environment (Miall 1977:37). As flood stage is attained, the water level tops the banks and spreads out over the surrounding floodplain. At this point, increased friction causes water velocity to decrease dramatically, and suspended sediment begins to settle out. Vegetation on the floodplain further retards water velocity, accentuating the process. As the flood recedes, pools of water often remain from which fine silts and clays are deposited (Allen 1965).

In addition to the Double Mountain Fork, several tributaries in the reservoir contribute alluvial sediments. Principal tributaries in the project area include Grape, South Sage, Little Grape, Rocky, and Sand creeks to the south of the Double Mountain Fork and Gobbler Creek and Salt Branch to the north. Like the Double Mountain Fork, the morphology of the tributaries is largely controlled by the lithology of the terrain they traverse. Streams that join the Double Mountain Fork in the upper part of the reservoir (e.g., Salt Branch, Sand Creek) flow primarily over the resistant Trujillo Formation sandstones and conglomerates and, as a result, have a braided pattern similar to the Double Mountain Fork. In the central reservoir, the canyon cut by the river has lowered the base level of surrounding tributaries. As a result, narrow entrenched channels with high gradients and narrow, discontinuous, poorly developed floodplains are typical of Rocky, Little Grape, and Gobbler creeks. At the lower end of the reservoir, the upper reaches of Grape and South Sage creeks are contained in narrow, deep canyons similar to tributaries in the central reservoir. As these streams approach confluence with the Double Mountain Fork, however, their gradient decreases sharply. As a result, wide floodplains and a meandering channel pattern have developed, particularly in the lower reaches of Grape Creek.

In general, floodplains in meandering streams are created by lateral accretion as a result of lateral movement of the channel. The mechanism that initiates meandering is poorly understood but is believed related to helicoidal flow patterns in the channel and is dependent on a relatively low channel slope and the nature of transported sediments (Allen 1965; Schumm 1977). Three basic types of fluvial sediments are recognized in a meandering stream depositional environment: (1) relatively coarse channel lag deposits; (2) somewhat finer point bar or lateral accretion deposits of the channel margin; and (3) finer still, vertical accretion or overbank deposits. Lateral accretion deposits are typically coarse 
in comparison to overbank deposits (Allen 1965); however, suspended load deposition can result in substantial point bar growth in some cases (Wolman and Leopold 1957). Also, point bar deposits tend to fine downstream, and the thickness of overbank fines may increase dramatically on the downstream side of a point bar.

A number of distinct types of deposits may occur in the floodplain environment (Allen 1965; Lewin 1978; Reineck and Singh 1980). Natural levees are typically well-stratified deposits situated on the channel margins. They result from the rapid deposition of suspended load as water leaves the channel during floods and usually consist of graded beds of sands and silts. Backswamps are low-energy areas in which silts and clays accumulate, separated from the channel by the natural levee. Crevass splay deposits are fairly localized sandy deposits formed when floodwaters breach the levee. These vertical accretion deposits often overlie lateral accretion deposits and contain thin channel lag deposits representing ephemeral chute channels established during floods. Organic accumulation in floodplain sediments occurs in tandem with deposition as fresh surfaces are successively vegetated and buried.

The character of spatially contiguous floodplain sediments and soils varies according to differences in geomorphic position and distance from the channel. Flow characteristics vary with respect to position in a meandering system and distance from the channel, resulting in facies variation along and away from the channel. Minor differences in elevation result in different drainage characteristics and rates of chemical weathering. Facies variation results in differences in permeability which can reinforce variation in the duration of wetting and, hence, the rate of weathering.

A second important class of deposits within the study area is alluvial/colluvial fans and aprons shed from the canyon walls and uplands. These features are prominent in the canyon-confined section and the lower reservoir. Alluvial fans are geomorphic features deposited by water that form at a nickpoint, such as the base of a mountain range or escarpment, where a sharp reduction in gradient abruptly alters the competence of a stream carrying a relatively large sediment load (Blissenbach 1954; Rust 1980). Colluvial or talus slopes are wedges of sediment that form at the base of a slope by mass movement of particles under the influence of gravitational forces (Ritter 1978; Chorley et al. 1984). The features referred to here as alluvial/colluvial fans, or simply as fans, represent formation by both processes, although movement by water seems to be dominant. Typically, no incised tributary is present at the apex of fan debris cones, but the bedrock cap of the canyon wall is often concave or notched, serving to concentrate overland flow from the uplands.

Fan sediments in the reservoir typically consist of massive muddy sands containing subrounded to rounded sandstone and siliceous pebbles and angular sandstone cobbles. The massive, poorly stratified nature of the deposits suggests that sedimentation is primarily the result of debris flow rather than streamflow processes (Blissenbach 1954; Hooke 1967). However, the surface is often marked by small-scale (5-10 cm deep) rills lined with gravels suggesting a degree of channelized flow. In cross section, bedding is generally not apparent except in dipping stringers of gravel representing small rill channels incised into old surfaces. Gravels are also abundantly dispersed in the matrix due to debris flow. Deeply incised gullies also exist in some fans, particularly where the morphology of the canyon rim concentrates runoff from the uplands, but these features seem to be primarily erosional rather than depositional. Large-scale cut-and-fill sequences resulting from previous deep gullying of fan surfaces were not observed but probably also exist. There is also a slight 
tendency toward overall textural fining and a sharp reduction in the occurrence of large, angular sandstone fragments moving downslope on the fans, reflecting the diminishing importance of mass movement away from the steep canyon walls.

In the narrow central canyon, the fans are fairly short and steep and commonly override and interfinger with overbank alluvium on the floodplain. Maximum thickness is on the order of 3-4 m. In the lower reservoir, the wider valley has permitted the formation of much larger fans that often develop a distinct cone-shaped morphology and may be 7-8 m thick in their proximal reaches. Due to surface instability and rapid runoff, soil development on fan surfaces appears limited to weak A horizon formation, some rubification, and development of filamental precipitates in the subsurface. Occasional carbonate nodules were observed in section, but their distribution in the fan matrix suggests that they were eroded from the uplands and deposited as clastic particles rather than formed in situ.

In addition to the relatively recent fan deposits in the canyon, much older, dissected alluvial fan deposits are preserved unconformably overlying Triassic bedrock in the uplands. These remnants represent fans several orders of magnitude larger in scale shed off the retreating Caprock Escarpment and are probably of mid-Pleistocene age or older. These fans exhibit considerable textural variation as gravelly channel facies grade laterally into sandy and muddy facies. Pedogenesis, eolian reworking, and reworking by slopewash and minor channels have extensively modified the sediment. Fan sediments are particularly prominent on the uplands surrounding Grape Creek and constitute a significant portion of the upland deposits previously interpreted as eolian sands by Blum (1989).

A third class of late Quaternary deposits in and around the study area is eolian sands. Extensive eolian deposits are present on the uplands surrounding the Double Mountain Fork, and dunes are present on the floodplain at several locations in the upper reservoir. The primary sediment source for eolian dunes in the upper reservoir valley appears to be the channel of the Double Mountain Fork driven by winds from the west and southwest. In section, eolian deposits are typically brown (7.5YR 4/4) to strong brown (7.5YR 4/6) massive fine sands. Bioturbation of units is common, and truncation surfaces are sometimes evident. Soil development is usually limited to weak A horizon formation.

Limited field reconnaissance and examination of the soil surveys of Garza (Richardson et al. 1975) and Kent (Richardson and Girdner 1973) counties suggest that a large area north of the upper reservoir is mantled with relatively recent eolian sediments derived primarily from the broad, low Double Mountain Fork valley. Extensive eolian deposits north of the river appear to decrease slightly to the east, as entrenchment of the channel limits the sediment supply. Localized eolian deposits also occur to the south of the river, deriving from tributary channels, ancient fan sediments, and poorly cemented Dockum sandstones.

Because soil formation is a time-dependent process, it provides valuable information for correlation and temporal assignment of deposited sediments. Common pedogenic processes affecting alluvium in semiarid environments include calcification, the development of blocky structure at the surface and at depth, translocation of fine silts and clays, oxidation, and turbation by roots, animals, and shrink-swell processes. Calcification, oxidation, infiltration of fines, and bioturbation are also important processes in the modification of eolian sediments. These processes not only disrupt the sediments themselves but also may alter or destroy the context of archeological deposits they contain. 
One of the most widely recognized pedogenic processes characteristic of arid and semiarid localities is calcification, which refers to the translocation and accumulation of calcium and magnesium carbonates in sediment from above by percolating waters or by groundwater. Because calcification is an incremental pedogenic process, the morphology of soil carbonate is a useful indicator of the relative age of sediments (Gile and Grossman 1979). Although all of the fluvial sediments in the reservoir are calcareous, they exhibit a range of carbonate morphologies. The most recent deposits are strongly calcareous, but filamental carbonate is seldom visible in the matrix. Slightly older sediments contain thin filaments and films of carbonate, commonly on ped surfaces and in root traces, that increase in number and definition with age. This type of morphology in nongravelly materials is termed Stage I by Gile and Grossman (1979). The source of translocated carbonate is probably a combination of calcareous parent material and aerosolic carbonate dust. With more development, small to large nodules of carbonate develop (Stage II). Due to the recent age of the majority of the fluvial deposits in the reservoir, caliche nodules are present in only a few locations. Advanced Stage III carbonate morphology (e.g., caliche or gravel calcrete) was not observed in any late Quaternary deposits but is present in the uplands.

Another phenomenon visually similar to carbonate filaments that occurs in sediments in the study area is the presence of films and filaments of sodium and potassium salts. Unlike carbonate filaments, these features are not time dependent; in fact, they tend to form in a matter of minutes on freshly cut faces as the sediment dries and the solutes precipitate but are rarely visible on fresh, moist exposures.

Blocky structure is another characteristic of many of the fluvial deposits in the study area. This structure consists of weakly to moderately developed angular and subangular peds. Although limited clay translocation is sometimes suggested, evidence of substantial illuviation, such as coated ped faces and clay bridges, is typically absent. Given the age of the deposits, it is probable that the blocky structure represents the response of finer materials to stresses caused by repeated wetting and drying at and near the surface, rather than pedogenic translocation. In seasonally saturated environments, blocky peds can develop in as little as one year (Brammer 1971), and blocky structure is common in alluvial soils that are not permanently saturated (Gerrard 1987).

Turbation refers to the mixing of soil and sediment through a number of physical and biological processes (Wood and Johnson 1978; Johnson et al. 1987). Mixing by the action of roots and burrowing insects, reptiles, and mammals are processes which appear to have strongly affected some of the sediments, particularly in the overbank environment and in eolian deposits, while expansion-contraction processes due to freeze-thaw and shrink-swell rhythms in montmorillonitic clays appear to have had limited effect.

Alluvial soils develop under conditions that can serve to homogenize stratified sediments, producing an effect opposite to the typical result of the action of pedogenesis upon a stable body of parent material. In most conditions of soil formation, organic accumulation, weathering, and soil constituent translocation act to result in the development of distinct horizons within a formerly uniform sedimentary body. Organic matter accumulates at the surface and is incorporated into an upper Al horizon, feldspars and other unstable minerals are weathered to create clay minerals and are translocated from an eluvial A2 horizon to accumulate in an illuvial B horizon, and translocated carbonate may accumulate in the $\mathrm{B}$ or upper $\mathrm{C}$ horizon. With time, the variation between horizons becomes increasingly pronounced. In an alluvial environment dominated by periodic deposition, however, the 
result of pedogenesis can be a reduction of zonation within the sediment. As pedogenic processes begin to act on a freshly deposited body of sediment, organic accumulation, weathering of unstable minerals, and eluviation of existing clay-sized particles and carbonate commences. At the same time, colonization by plants and animals turbates the deposit, destroying stratification. With the deposition of another packet of sediment, organic accumulation is cut off, and carbonate and fines are translocated from above and begin to accumulate in the unit. Continued turbation by organic agencies and wetting/ drying stresses tends to further mix and homogenize the sediments. As a result, alluvial soils can develop as thick, relatively uniform units with superimposed characteristics of A (e.g., organic matter) and B (e.g., translocated clay, blocky structure, carbonate accumulation) horizons.

\section{Radiocarbon Dating}

The following discussion refers to a series of radiocarbon assays of soil humate, bone, and charcoal samples obtained from archeological and geological contexts within the study area (see Appendix C). These dates provide the temporal framework for the reconstruction of the recent geomorphic history of the reservoir. A number of dates previously reported by Blum (1989) are presented again because they contribute greatly to the overall reconstruction of recent geomorphic history within the study area. The previously reported dates were not d13C corrected; hence, the uncorrected version is given. For all new radiocarbon dates presented for the first time in this chapter, the d $13 \mathrm{C}$-corrected version is given. Calibrations for the radiocarbon dates are presented in Appendix $C$ but are not used here.

Several types of samples are represented in the suite of dates available. The majority are humate dates on organic material extracted from soil and sediment samples. This technique dates finely divided organics bound to the clay fraction. In the case of sediments, the origin of organic matter is as detrital particles deposited with the sediment, and radiocarbon assay provides an approximate measure of the time of deposition. In soils, organic matter is produced continually at the surface and translocated into the B horizon where it is bound; as a result, the technique supplies an estimate of the mean residence time and therefore only provides a reliable measure of minimum age (for a more complete discussion of the theoretical basis of this technique, see Haas et al. 1986). To date, 23 internally consistent soil humate radiocarbon assays provide the majority of the information used to date periods of geomorphic history for the study area. Additional information is provided by charcoal dates from archeological features and bone collagen dates (see Appendix C).

\section{Summary of Backhoe Trench Investigations}

The Upper Reservoir

As stated earlier, canyon cutting is not pronounced in the upper reservoir due to the fairly resistant lithology of the upper Dockum Group. The valley of the Double Mountain Fork is a relatively broad alluvial plain surrounded by erosive and eolian-mantled uplands. 
Two general localities in the upper part of the proposed reservoir were investigated during the testing phase. Both localities consisted of the inside of meander bends on the south side of the river and included Backhoe Trenches (BHTs) 1 through 10 (Fig. 5). A generalized composite cross section is presented in Figure 6.

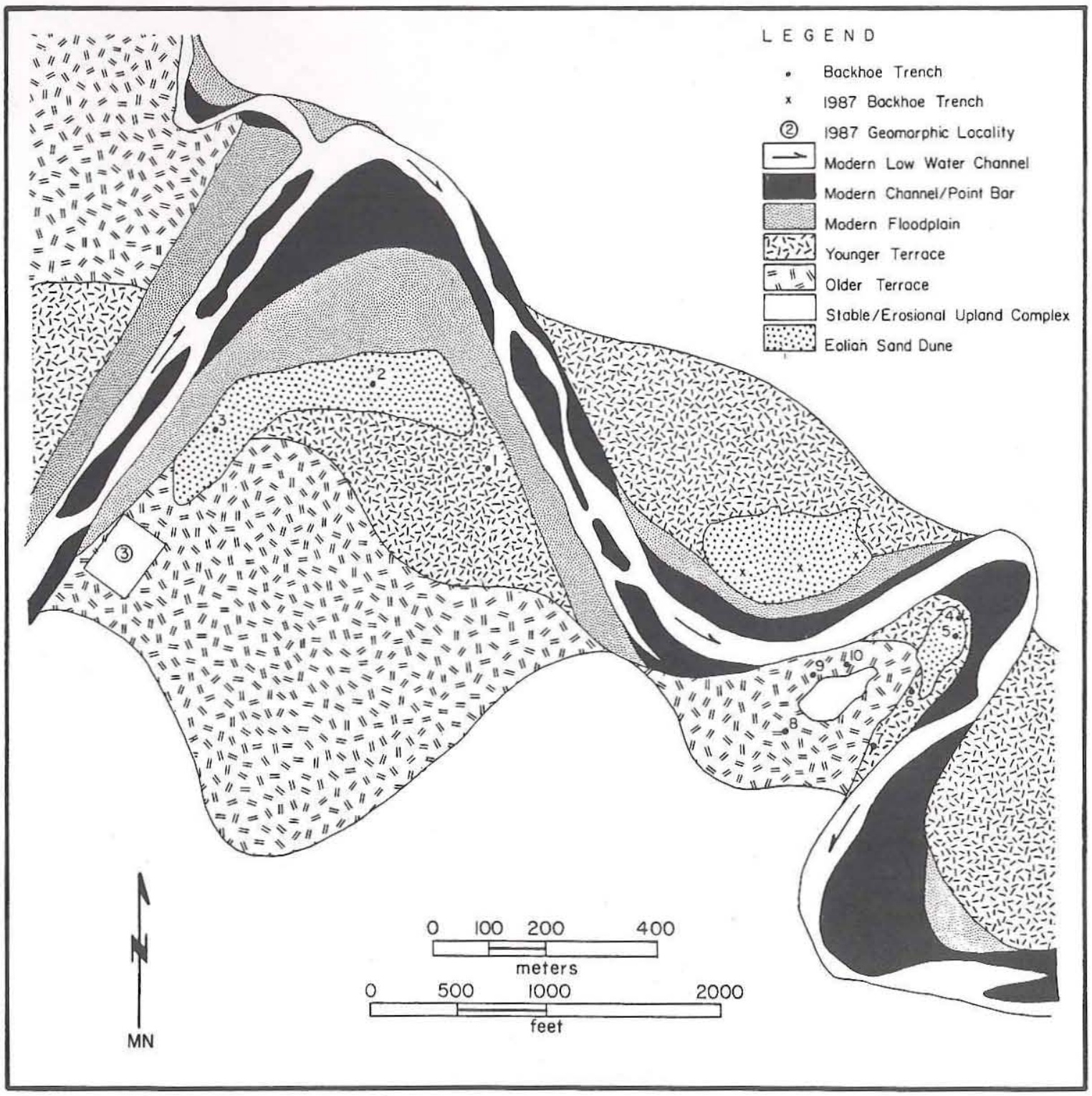

Figure 5. Geomorphic map of the upper reservoir.

Alluvial channel and overbank sediments of at least three ages are preserved at various elevations in the upper reservoir. Modern channel sediments exist as planar and trough crossbedded gravels, sands, and muds deposited as longitudinal, point, and side bars in and around the multiple low-water thalwegs of the stream. Modern floodplain sediments are typically brown (7.5YR 4/4) to strong brown (7.5YR 4/6) massive muddy sands deposited primarily by vertical accretion on a typically flat, vegetated surface. 


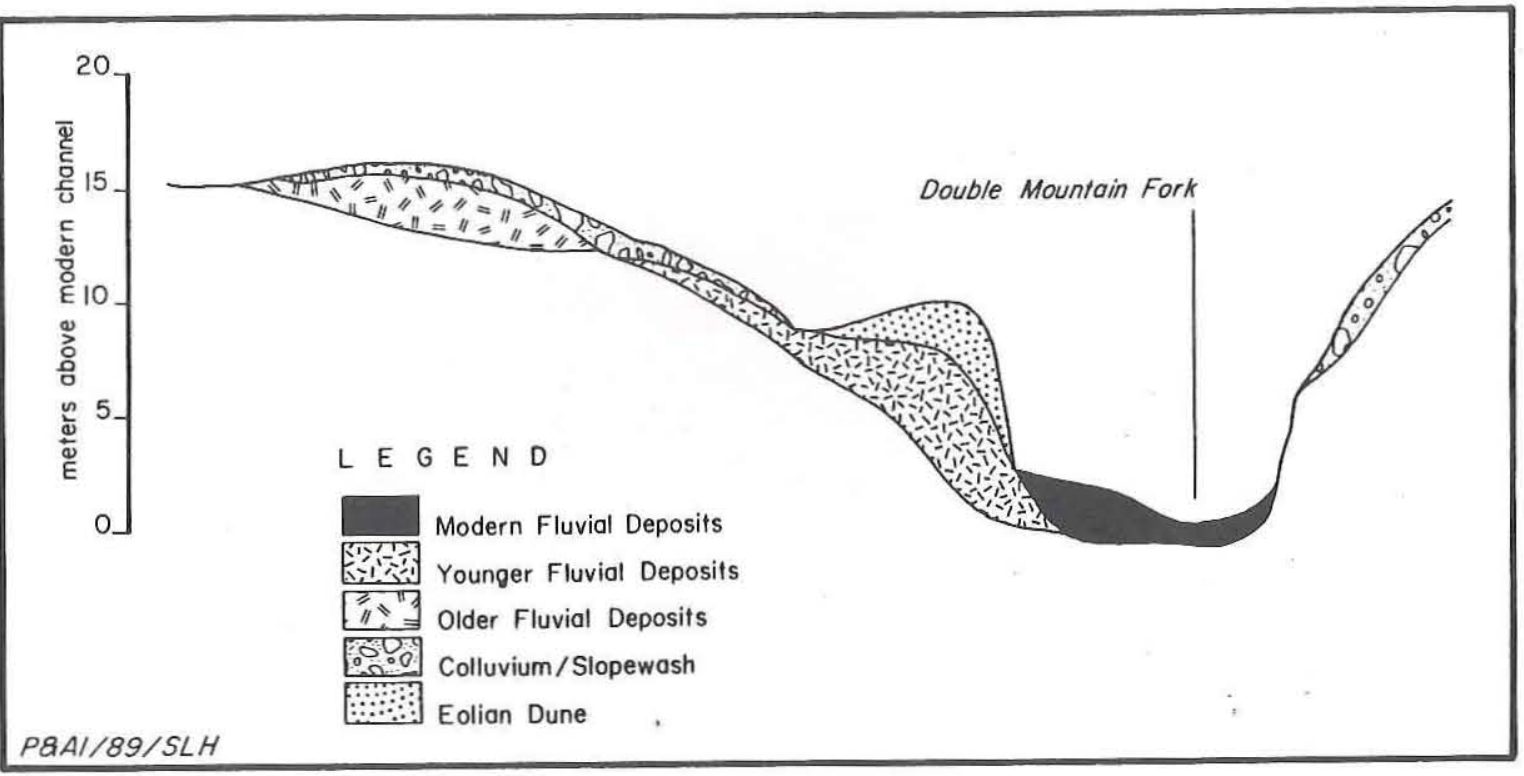

Figure 6. Generalized cross section of the upper reservoir.

Extensive deposits of alluvial sediments dating to at least two previous hydrologic regimes are also present. The younger of these fills is manifest as a discontinuous sloping terrace approximately 5-7 m above the modern stream. Channel deposits encountered in this unit consist of crossbedded to massive sands and gravelly sands at an elevation several meters higher than the modern stream. These deposits are typically overlain by reddish brown ( $5 \mathrm{YR} 4 / 4-5 \mathrm{YR} 5 / 4$ ) to yellowish red (5YR 4/6) massive sandy loam, silty loam, and loamy sand overbank sediments 1-3 m thick. Soil development is limited to weak $A$ horizon formation (observed in BHT 2 only), slight rubification (based on comparison with comparable modern sediments), and development of occasional carbonate films and filaments.

Alluvial sediments resulting from this period of activity were encountered in BHTs 1-4, 6, and 7. Backhoe Trench 1 (Fig. 7) was located at the distal end of the first meander bend on the margin of a cultivated field and revealed both eolian sediments and alluvium. The morphology displayed by the alluvium is characteristic of deposits of the first terrace. The basal zone (Zone 6), at a depth of 247-260 cm, consists of a reddish brown (5YR 5/4) massive to weakly crossbedded gravelly coarse sand representing a bar deposited in or immediately adjacent to the channel (IICu horizon). Zones 3-5 represent overbank alluvium deposited outside the channel margin. Zone 5 is $142 \mathrm{~cm}$ thick and consists of reddish brown (5YR 5/4) sediment that grades from silty loam to loamy fine sand with depth and has weak to moderately subangular blocky structure (IIBw horizon). The intensity of structure decreases with depth, and the entire unit contains abundant fine carbonate filaments. Zone 4 is a thin $(7 \mathrm{~cm}$ ) drape of reddish brown (5YR 4/3) slightly clayey fine sandy loam that exhibits moderately subangular blocky structure and also contains abundant fine carbonate filaments (Cox horizon). Zone 3 is $48 \mathrm{~cm}$ thick and consists of reddish brown (5YR 4/4) fine sandy to silty loam with very weak subangular blocky structure and abundant fine carbonate filaments (Cox horizon). Although this zone is located at the top of the alluvial deposits, no evidence of a buried A horizon was observed. Zone 2 is $43 \mathrm{~cm}$ thick and consists of reddish brown (5YR 4/4) massive fine 


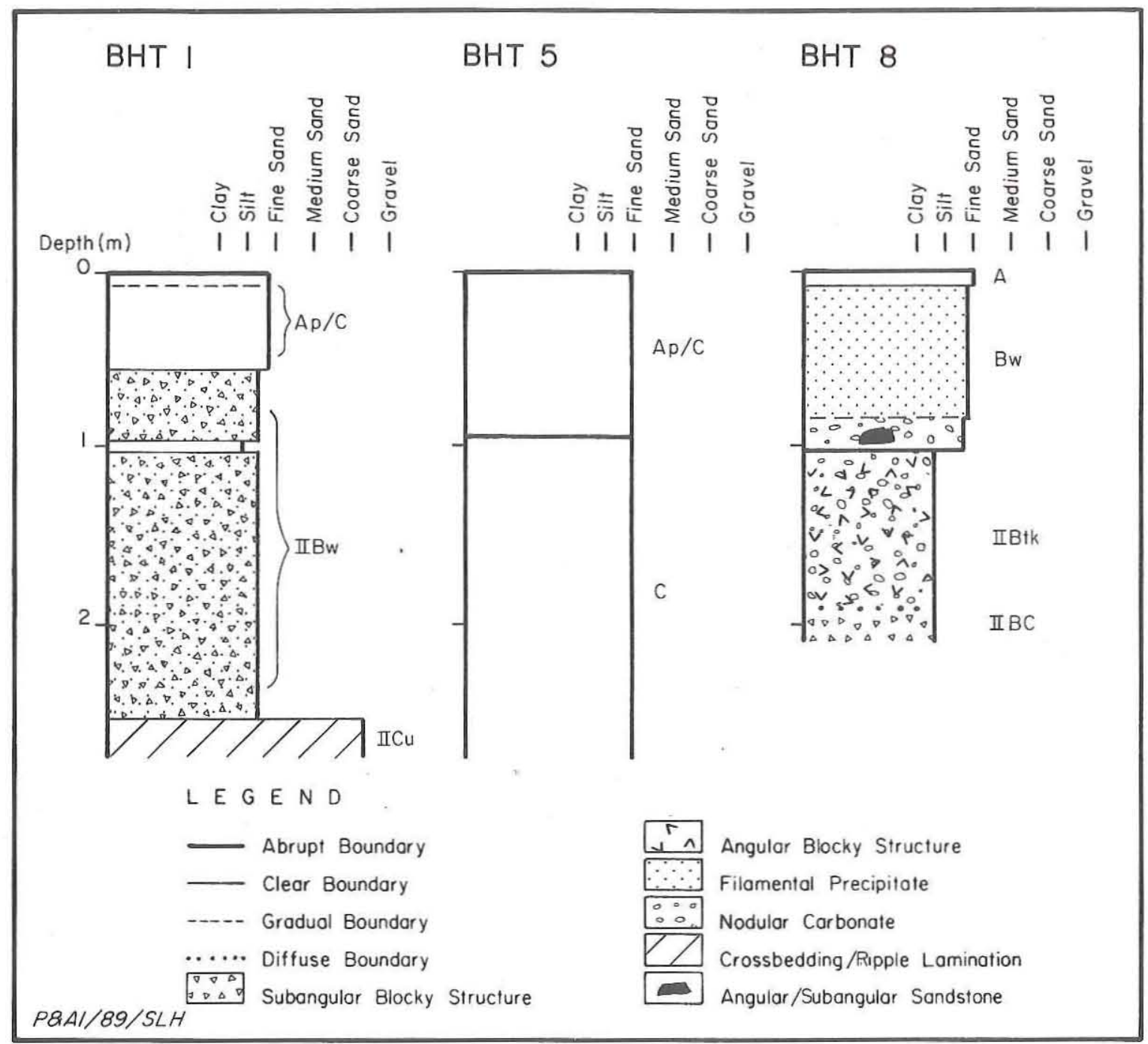

Figure 7. Representative profiles, upper reservoir.

eolian sand containing abundant grass roots (Cox horizon). Zone 1, the surface horizon, is $7 \mathrm{~cm}$ thick and consists of reddish brown (5YR 4/4) loose fine sand with very weak organic enrichment (Ap/C horizon). A small quantity of burned sandstone and a sandstone cobble with an abraded groove were recovered from the upper $50 \mathrm{~cm}$ of the trench. The context of this material was probably disturbed by cultivation.

Several minor differences are apparent in the other trenches. First, BHT 2 is distinguished by the presence of a weak buried A horizon at the top of the fluvial deposits. Second, the alluvium in BHTs 2, 6, and 7 contains small siliceous gravels, suggesting a slopewash component from the surrounding uplands. Finally, the basal channel deposits encountered varies from gravelly silty loam to coarse sandy gravel, reflecting microenvironmental differences in the Double Mountain Fork channel. Although BHT 3 was excavated to a depth of $4 \mathrm{~m}$, no channel sands were encountered. This is probably largely a 
function of the considerable thickness of the eolian overburden, which limited penetration into the underlying fluvial deposits.

Eolian dunes and sheets overlie the first terrace deposits in several locations. Sand appears to have accumulated under the influence of southwesterly and westerly winds with the primary sediment source being the Double Mountain Fork channel. Recent agricultural activity appears to have resulted in coppice dune formation along several fencelines and accelerated deflation in cultivated areas. Backhoe Trench 5 (see Fig. 7) is typical of the character of the eolian deposits. The upper zone is $96 \mathrm{~cm}$ thick and consists of light brown (7.5YR 6/4) massive fine sand. The zone contains abundant grass roots throughout and weak organic enrichment in the upper $20 \mathrm{~cm}$ ( $\mathrm{A} / \mathrm{C}$ horizon). Zone 2 is $154 \mathrm{~cm}$ thick and consists of brown (7.5YR 5/4) massive fine sand. The contact between the two zones is a gently dipping, clear to abrupt erosional boundary.

Backhoe Trenches 8-10 were located at higher elevations and display a distinctly different character in that they are composed of relatively recent fluvial, eolian, and slopewash materials overlying a much older fluvial unit with a strongly developed truncated soil. The upper zones of BHT 8 (see Fig. 7) are $108 \mathrm{~cm}$ thick and grade from brown (7.5YR $4 / 4$ and 7.5YR 5/4) massive loamy fine sand to yellowish red (5YR 4/6) weak medium subangular blocky sandy loam. The lower zones were investigated to a depth of $208 \mathrm{~cm}$ and consist of a reddish brown (5YR 4/4) medium angular blocky sandy clay loam to sandy clay with strong pedogenic caliche development (IIBtk horizon) that grades into a yellowish red (5YR 4/6) medium subangular blocky sandy to silty clay loam (IIBC). The amount of carbonate in the Btkb horizon is very high, with nodules occupying as much as $20-30 \%$ of the matrix. The upper contact is markedly erosive, with a lag of sandstone gravels resting on the erosional surface. Although the soil in BHT 10 was developed on and in crossbedded channel gravels rather than floodplain sediments, BHTs 9 and 10 display profiles similar to BHT 8.

No radiocarbon dates are available from the alluvial and eolian deposits in the upper reservoir; however, stratigraphic and topographic position and pedogenic characteristics allow tentative temporal assignment. The morphology and relative position of sediments on the younger terrace are consistent with well-dated alluvial sediments in the canyonconfined and lower segments of the study area, suggesting late Holocene age. Eolian deposits overlie the younger terrace and thus postdate stabilization of the first terrace. The truncated soil encountered in BHTs 8-10 is unique among deposits encountered in the reservoir. The strong Bt horizon development and considerable carbonate accumulation suggest that the soil is of late Pleistocene age. In all cases where it was encountered, the soil has been erosionally truncated into the B horizon, suggesting that the potential for preservation of any archeological occupations is very low. Older sediments in the upper reservoir, tentatively assigned an early to middle Holocene age, were also described by Blum (1989) from exposures in a gravel pit on the upstream side of the first meander bend near the U.S. Highway 87 bridge (Geomorphic Locality 3; see Fig. 5). The degree of carbonate development and structural development apparent in these deposits is less pronounced than observed in BHTs 8-10, and it is currently unclear whether they represent the same unit or a third terrace of intermediate age.

The Canyon-confined Segment of the Reservoir

Investigations in the canyon-confined section of the Double Mountain Fork were limited by the availability of backhoe access into the canyon. Nevertheless, several localities in 
the canyon were examined in detail, allowing preliminary interpretation of deposits in the canyon as a whole. A generalized geomorphic map of a segment of the canyon-confined Double Mountain Fork is presented in Figure 8, and a generalized composite profile is presented in Figure 9. Alluvial deposits of two ages were identified in the canyon-confined section of the Double Mountain Fork: modern sediments and deposits of the previous hydrologic regime, which is manifested as discontinuous terrace wedges 4-7 m above the modern channel. Channel and overbank sediments dating to this period of activity were detected in BHTs $11-17,20,21$, and 24 . In addition, an elevated gravel deposit possibly representing a lag from a previous alluvial fill was detected in BHT 19.

In addition to generally fining upward, overbank sediments making up individual floodplain wedges tend to thicken and fine downstream. The range of variation in sediment character is represented by BHTs 12,14 , and 16 , located at the proximal, medial, and distal position on a single floodplain segment, respectively. Backhoe Trench 12 (Fig. 10) was located at the upstream end of the wedge. The basal zone (Zone 5) is at a depth of 211-228 cm and consists of reddish brown (5YR 5/4) crossbedded gravelly coarse sand with interbedded loamy clay drapes ( $\mathrm{Cu}$ horizon) representing deposition under fluctuating energy conditions in the channel. The remainder of the section represents a single upward-fining cycle as the floodplain aggraded. Zone 4 is $37 \mathrm{~cm}$ thick and consists of yellowish red (5YR 4/6) massive to weakly horizontally bedded gravelly medium sand (Cox horizon). Gravel lithology is a mixture of sandstone and various siliceous rocks, and the gravels occur in stringers and suspended in the matrix. Zone 3 is $43 \mathrm{~cm}$ thick and consists of yellowish red (5YR 4/6) massive gravelly loamy fine sand (Cox horizon). Zone 2 is $114 \mathrm{~cm}$ thick and consists of yellowish red (5YR 4/6) massive loamy fine sand to gravelly loamy fine sand (Cox horizon). The upper zone is an $\mathrm{A} / \mathrm{C}$ horizon $17 \mathrm{~cm}$ thick and consists of dark brown (7.5YR 3/4) massive fine sand to loamy fine sand.

Backhoe Trench 14 (see Fig. 10) was located on the terrace at the point of maximum meander inflection and consists of nine zones of alternating gravelly sands and sands, suggesting periodic chute-channel overwash of the bend. The basal zone (Zone 9) extends from 325 to $400 \mathrm{~cm}$ and consists of brown (7.5YR 5/4) crossbedded medium to coarse sand (Cu horizon) deposited in the channel. Zones 6-8 represent vertically accreted overbank alluvium. Zone 8 is $135 \mathrm{~cm}$ thick and consists of yellowish red (5YR 4/6) massive sandy loam containing horizontal lenses of siliceous gravel (Cox horizon). Zone 7 is $58 \mathrm{~cm}$ thick and consists of yellowish red (5YR 4/6) massive fine sandy loam containing filamental precipitate (Cox horizon). Zone 6 is $40 \mathrm{~cm}$ thick and consists of yellowish red (5YR 4/6) massive silty loam to sandy loam (Cox horizon). Zone 5 is $9 \mathrm{~cm}$ thick and consists of yellowish red (5YR 4/6) massive to weak planar bedded sandy loam to gravelly sandy loam (Cox horizon) that fines upward. Zone 4 is $21 \mathrm{~cm}$ thick and consists of yellowish red (5YR 4/6) massive to weak planar bedded gravelly sandy loam that fines upward into sandy loam (Cox horizon). Zone 3 is $21 \mathrm{~cm}$ thick and consists of yellowish red (5YR 4/6) massive gravelly sandy loam (Cox horizon). Zones 5-3 probably represent the margins of minor chute channels traversing the floodplain at the meander inflection. Zone 2 is $22 \mathrm{~cm}$ thick and consists of yellowish red (5YR 4/6) massive fine sandy loam (Cox horizon). Zone 1 is a 19-cm-thick dark brown (7.5YR 3/4) massive loamy fine sand $\mathrm{A} / \mathrm{C}$ horizon originating as slopewash.

Backhoe Trench 16 (see Fig. 10) is typical of the downstream end of the floodplain segment. The basal zone (Zone 5) exposed in this trench extends from 290 to $450 \mathrm{~cm}$ and consists of yellowish red (5YR 4/6) planar bedded fine-laminated medium sands, fine sands, silts, and clays deposited under fluctuating energy conditions in the Double Mountain Fork channel (multiple Cu horizons). Zone 4 is approximately $160 \mathrm{~cm}$ thick and consists of 


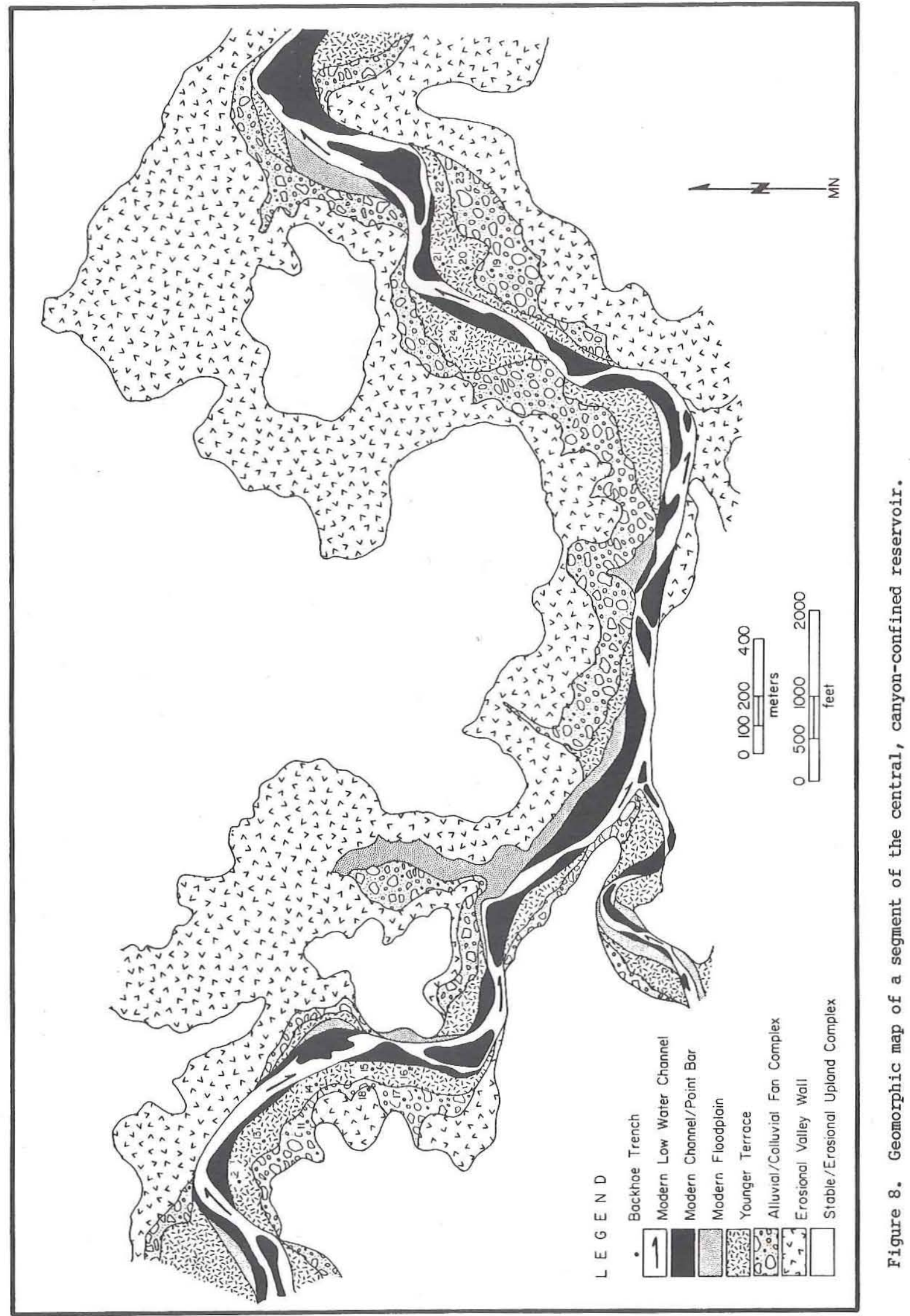




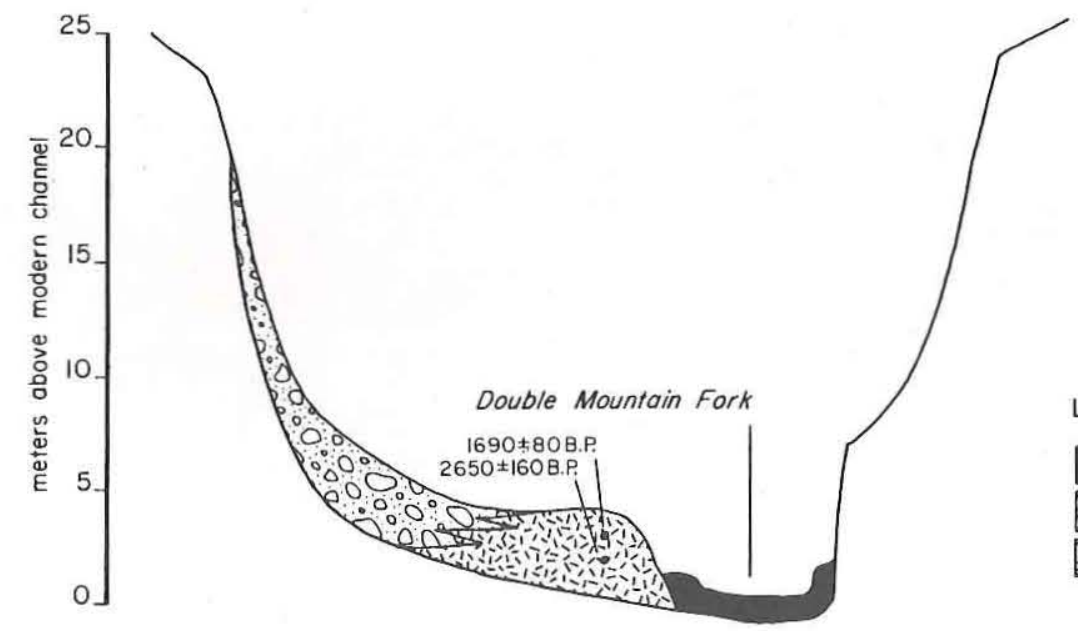

L E G E D

$P Q A / / 89 / S L H$

Figure 9. Generalized cross section of the central, canyon-confined reservoir.

yellowish red (5YR 4/6) massive silty loam to fine sandy silt overbank deposits (Cox horizon). Humate samples were collected from 147-153 and 275-285 cm bgs and yielded corrected radiocarbon ages of $1690 \pm 80$ B.P. $(\mathrm{Tx}-6223)$ and $2650 \pm 160$ B.P. (Tx-6224), respectively. This zone grades into an $81-\mathrm{cm}-$ thick dark brown (7.5YR 4/5) massive sandy loam Cox horizon containing small dispersed gravels and filaments of salt or carbonate. The coarsening texture and presence of dispersed siliceous gravels suggests alluvial/ colluvial sediment influx in addition to overbank stream alluvium. An ashy lenticular stain, representing a possible shallow unlined basin hearth, was observed in the wall of the trench at 63-66 cm. This zone grades up into a 31-cm-thick dark brown (7.5YR 4/4) massive sandy loam with slight organic enrichment. This very weak A horizon is overlain by approximately $20 \mathrm{~cm}$ of fine sand to loamy fine sand that probably represents slopewash mixed with some overbank alluvium ( $A / C$ horizon).

Similar profiles were observed in most of the trenches excavated on the second floodplain segment investigated in the canyon-confined section. However, several trenches possessed attributes of a different character. First, the basal zone of BHT 19 (Fig. 11) is a massive to planar bedded sandy gravel approximately 7-9 $\mathrm{m}$ above the surface of the modern channel. The extreme difference in elevation and the fact that it is overlain by slopewash deposits rather than overbank alluvium suggest that this unit may represent a channel lag from a previous alluvial fill. Second, a thick deposit of saturated sandy clay, rather than crossbedded sands or gravels, forms the basal zone in BHT 24, demonstrating variability in the nature of preserved channel sediments. Finally, sediments revealed by BHT 22 (see Fig. 11) consist of approximately $2.5 \mathrm{~m}$ of loamy fine sands overlying a thick unit of thin horizontally laminated fine to medium sands, silts, and clays. A corrected radiocarbon age of $770 \pm 110 \mathrm{~B} . \mathrm{P}$. $(\mathrm{Tx}-6225)$ was obtained from the upper part of the laminated zone at a depth of 250-260 cm. Both the character and the age of this section are anomalous in comparison with other trenches on the first terrace. Two explanations for this discrepancy are possible. First, it is conceivable that the radiocarbon 


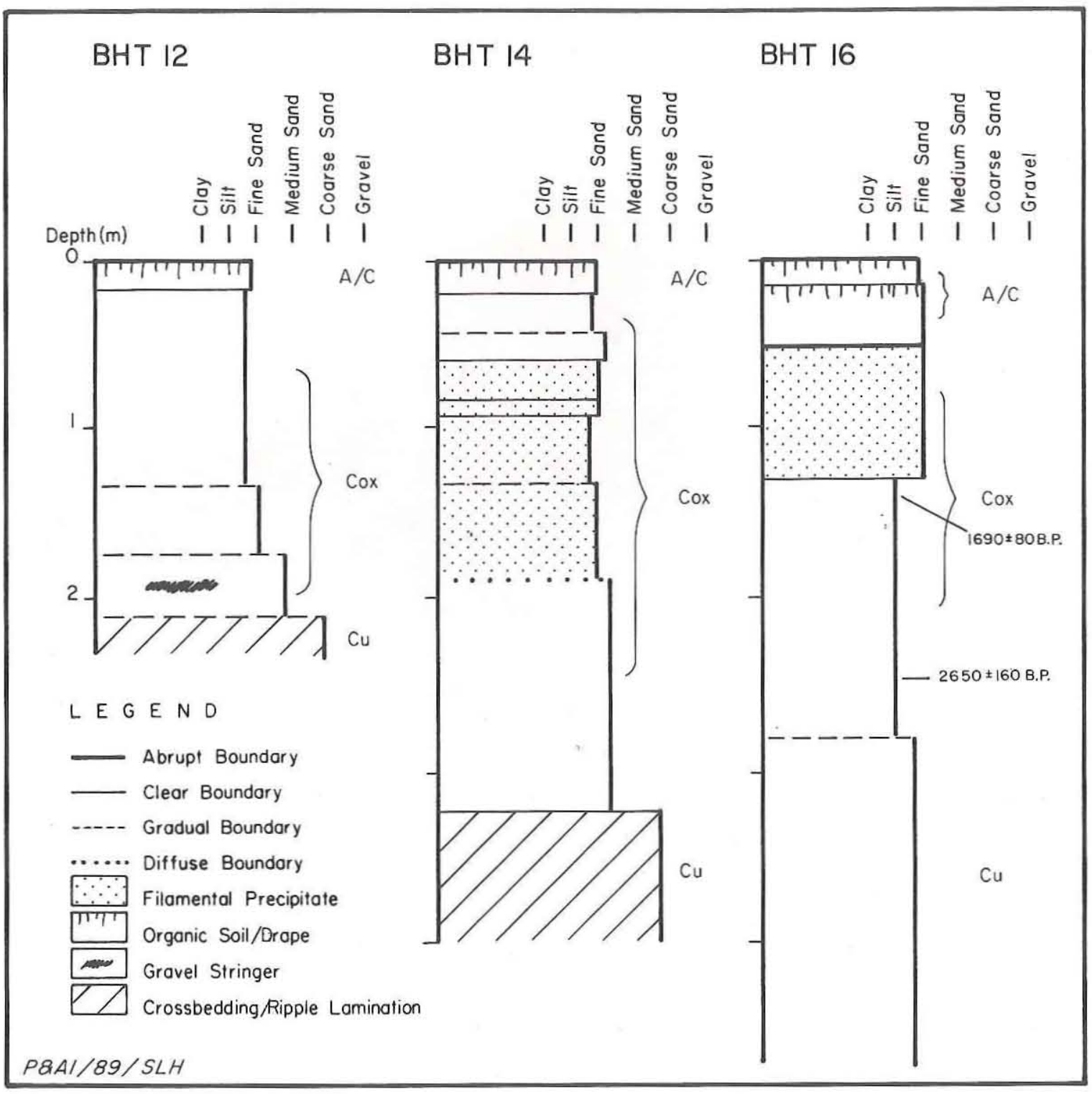

Figure 10. Representative profiles, canyon-confined reservoir.

sample was contaminated, but the apparent integrity and depth of burial of the sampled zone make this possibility unlikely. It is more likely that the sediment represents an infilled gully. The character and texture of the sandy zones overlying the basal laminated zone are starkly different from typical deposits of the first terrace, suggesting a different depositional mechanism. Surface expression is of little use in making the determination due to extensive historic disturbance.

Deposits characteristic of alluvial/colluvial aprons flanking the canyon walls were encountered in BHTs 11, 17, 18, 19, and 23. Backhoe Trench 17 (see Fig. 11) is typical of fan sediments in the canyon. The basal zone of this trench extends from 255 to $435 \mathrm{~cm}$, 


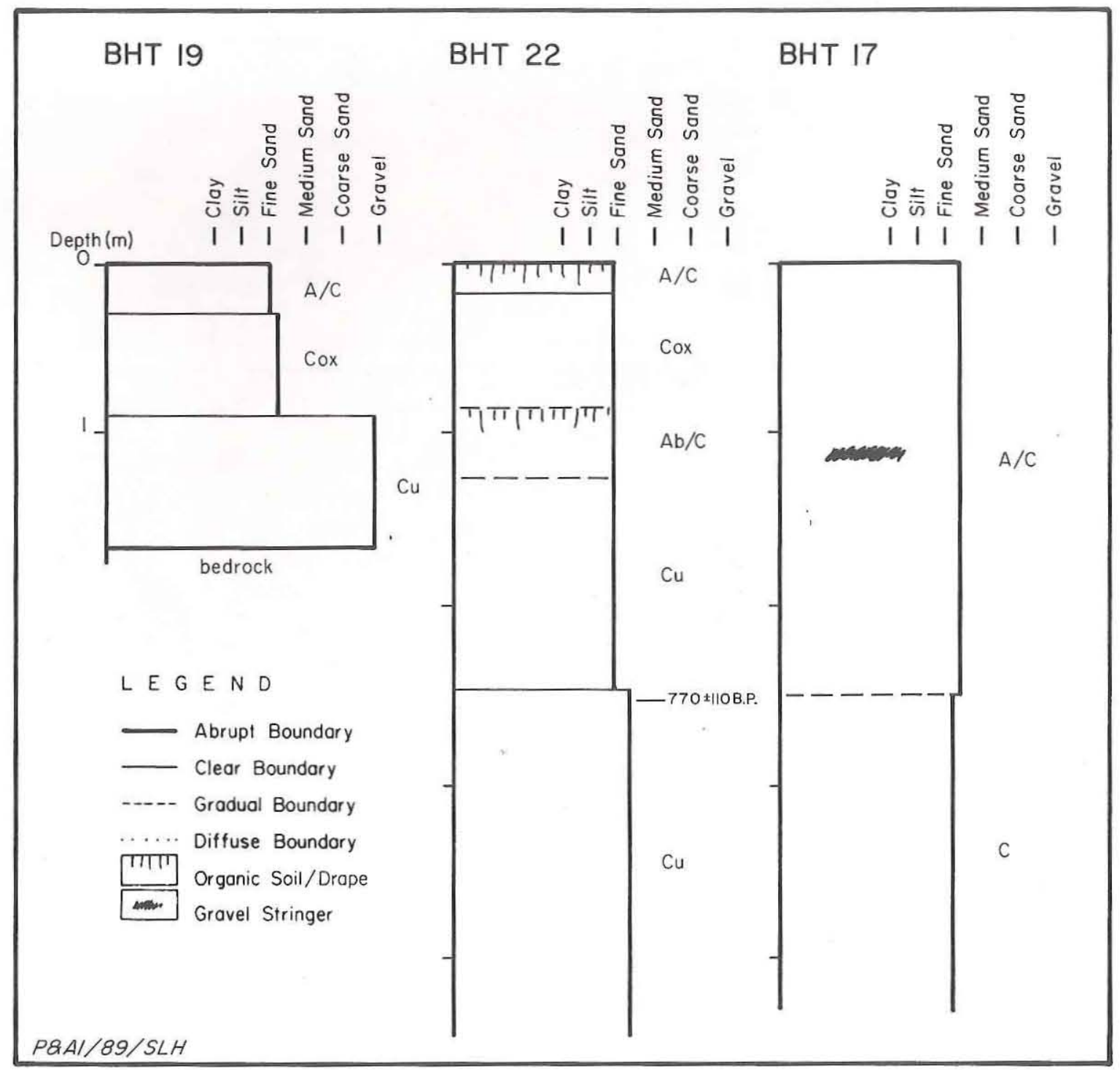

Figure 11. Representative profiles, canyon-confined reservoir.

consists of reddish brown (5YR 4/4) massive silty fine sand to fine sandy loam, and probably represents a mixture of alluvium and slopewash. The overlying alluvial/colluvial fan deposit is a single zone $255 \mathrm{~cm}$ thick that consists of yellowish red (5YR 4/6) massive gravelly fine sand to fine sandy loam. Incorporated gravels include both stream-rounded siliceous pebbles and angular to subangular sandstone pebbles and cobbles derived from the local bedrock and are dispersed in the sandy matrix and in sloping gravel stringers.

Soil development on the surface of the fan deposit is practically nonexistent, implying a high degree of recent geomorphic activity in the colluvial/alluvial fan environment. This conclusion is supported by a number of radiometric dates obtained from bone samples collected from alluvial/colluvial deposits at various locations in the reservoir (see 
Appendix C). A total of seven different bone samples obtained from depths ranging between 10 and $140 \mathrm{~cm}$ below the surface were assayed. All samples proved to be less than 400 years old, suggesting that the upper portions of the fan deposits are being constantly reworked by sheetwash erosion and deposition. This situation is not conducive to archeological preservation and may explain the paucity of cultural materials detected in the fan sediments of the central canyon.

Grape Creek, South Sage Creek, and the Lower Reservoir

Investigations in the lower reservoir centered on the Double Mountain Fork and the relatively broad lower floodplains of Grape and South Sage creeks. Two general localities were investigated in the Grape Creek valley. Nine trenches (BHTs 25-33) were excavated in the first of these, located in the vicinity of sites 41KT51, 41KT52, and 41KT53. Here, the width of the Grape Creek canyon increases abruptly, resulting in the transition from a narrow floodplain and fairly straight channel pattern to a broader floodplain and meandering channel (Fig. 12). Two distinct alluvial surfaces separated by a well-defined terrace riser approximately $1 \mathrm{~m}$ high are present. The higher surface forms a low terrace and is present on both sides of Grape Creek, while the lower surface forms the modern floodplain and is present only on the inside of the meander bend on the east side of the stream. Alluvial/colluvial fan deposits shed from the canyon walls flank and interfinger with the terrace surface. In addition, a low bedrock knoll approximately 8-10 m above the elevation of the modern channel is exposed in the valley floor on the eastern side of the stream. This mound separates the Grape Creek channel from the location of a previous minor ephemeral drainage coming off the valley wall. The area formerly occupied by this drainage is currently infilled with sediments of the terrace, indicating formation of the drainage prior to the aggradational episode responsible for the deposition of all preserved alluvial sediments. A generalized cross section of the central Grape Creek valley is presented in Figure 13.

Backhoe Trench 29 (Fig. 14) was excavated into the surface of the modern floodplain and revealed a coarse, stratified point bar sequence of gravels and sands separated by clear to abrupt, erosionally truncated boundaries. The basal zones (Zones 12 and 13) extend from $125 \mathrm{~cm}$ to the base of the trench at $185 \mathrm{~cm}$ and consist of yellowish brown (10YR 5/4) crossbedded cosets of gravelly coarse sand to sandy gravel forming the body of the point bar. Zones 9-11 extend from 95 to $125 \mathrm{~cm}$ below the surface and consist of planar and lenticular bedded gravelly sands, coarse to medium sands, and sandy loams representing minor bedforms and swale fills on the accreting point bar surface. Zone 8 is $15 \mathrm{~cm}$ thick and consists of a crossbedded, inverse graded gravelly coarse sand representing a chute channel. Zones 3-7 extend from 22 to $80 \mathrm{~cm}$ and consist of planar bedded, vertically accreted medium sands to fine sandy loams. Zones 1 and 2 make up the upper $22 \mathrm{~cm}$ of the section and consist of loose to massive fine sand, reflecting a turbated mixture of recent eolian and alluvial sediments. Soil development is limited to very weak A horizon development at the surface. No radiocarbon dates are available from this lower surface, but the nature of the sedimentary units present suggests that the body of the floodplain is actually a point bar deposit formed contemporaneously with the upper surface and that modern sediments are limited to a thin veneer of recent alluvium and eolian sand.

Backhoe Trench 25 (see Fig. 14) is typical of terrace deposits in and around 41KT53. The basal zone (Zone 7) consists of reddish brown (5YR 4/4) massive medium sands deposited 


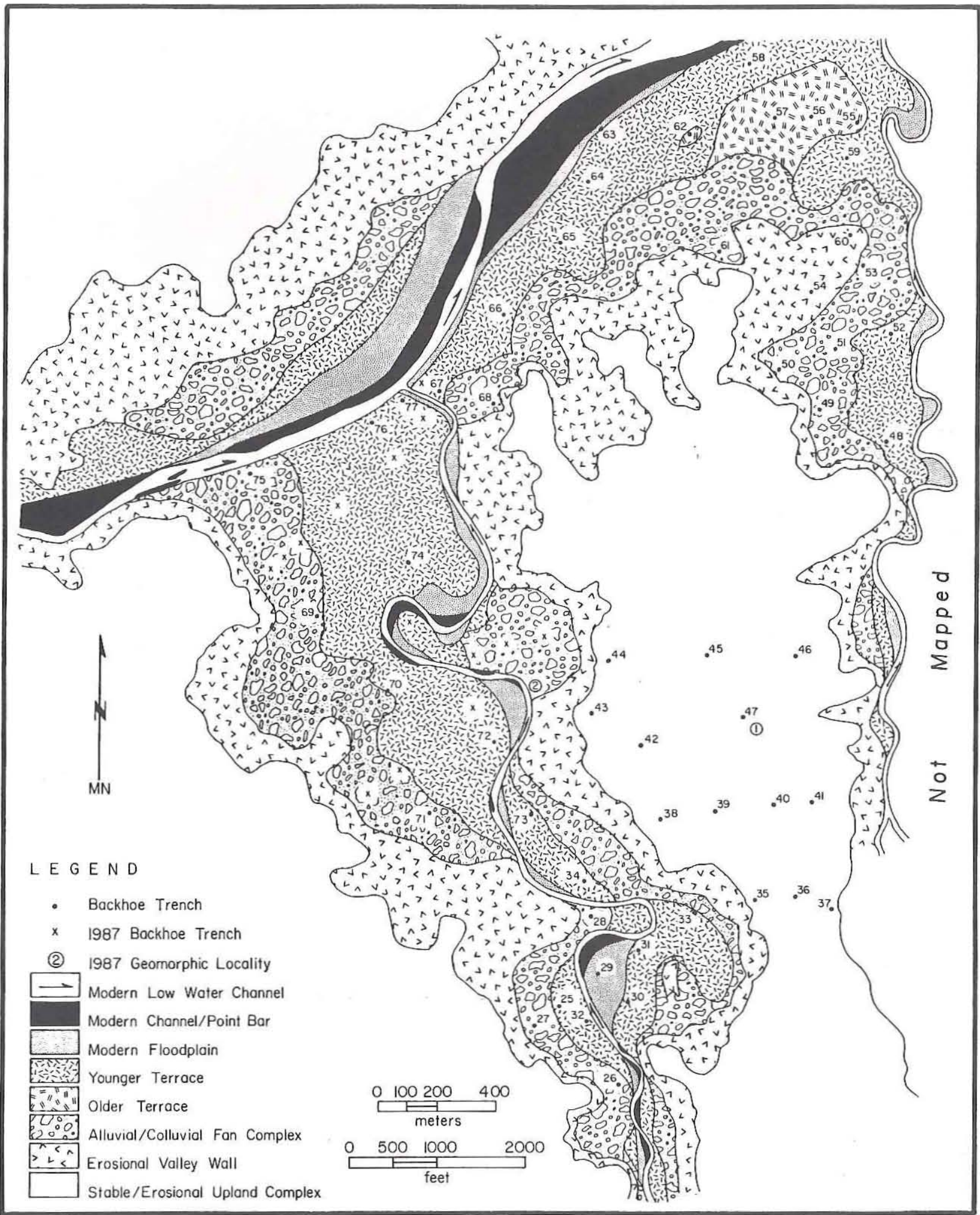

Figure 12. Geomorphic map of central and lower Grape Creek, lower South Sage Creek, and the lower reservoir. 


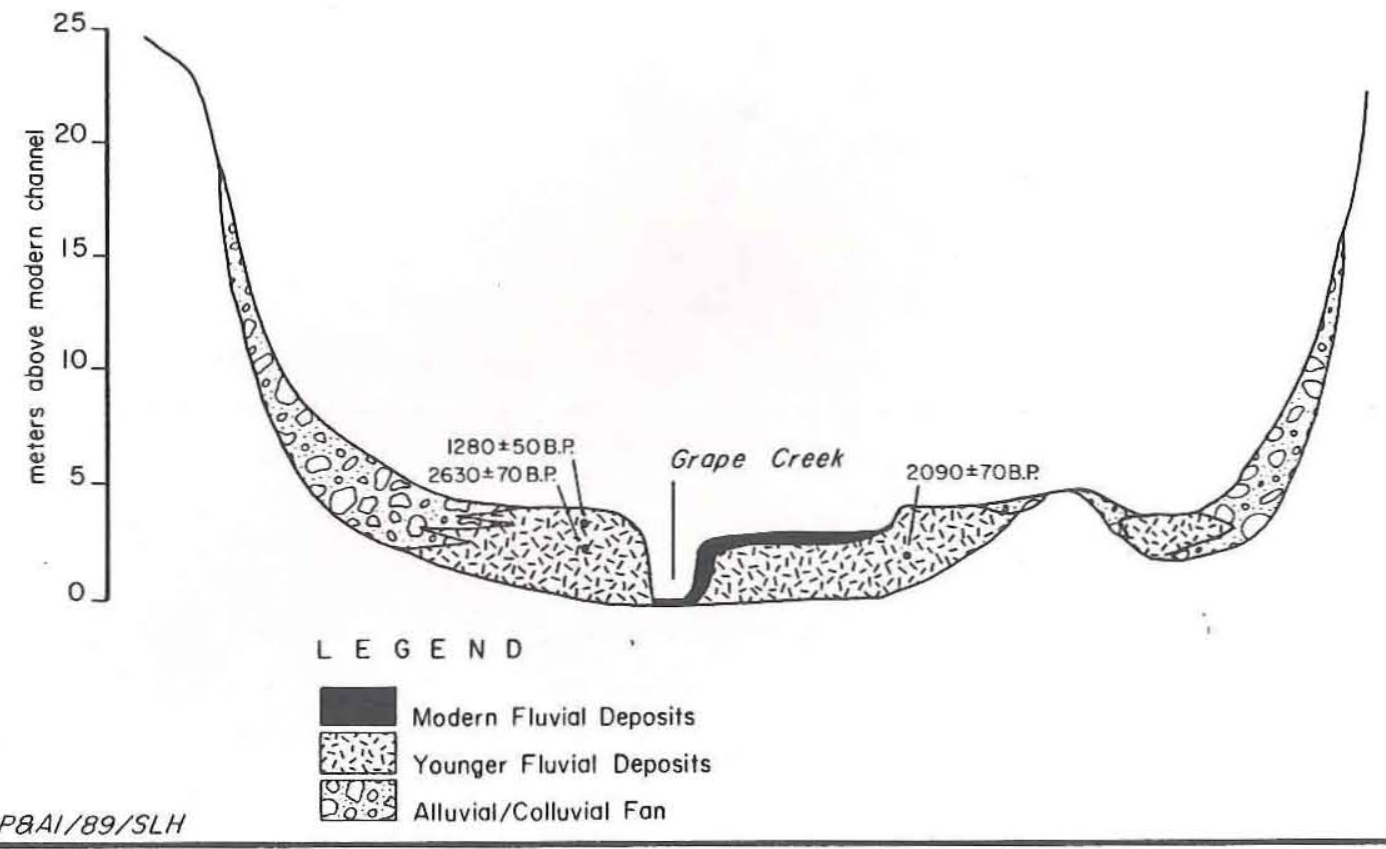

Figure 13. Generalized cross section of the central Grape Creek valley.

by lateral accretion on the channel margin and extends from 270 to $300 \mathrm{~cm}$ below the surface. Zone 6 is $50 \mathrm{~cm}$ thick and consists of reddish brown (5YR 4/4) massive sandy loam with abundant filamental precipitate and incorporated cobbles of tabular sandstone and siliceous gravels, suggesting the unit represents mixed overbank alluvium and alluvial/ colluvial fan deposits. Zone 5 consists of brown (7.5YR 4/2) weak subangular blocky sandy to silty loam $55 \mathrm{~cm}$ thick. Carbonate filaments are abundant throughout the unit, and a zone of organic enrichment representing weak cumulic soil development in a topographic swale is present in the upper part of the zone. A radiocarbon assay of sediment obtained from this organic-rich zone yielded a corrected date of $2630 \pm 70$ B.P (Tx-6227). The interpretation of this organic-rich zone as a localized deposit in a swale is supported by the fact that no similar horizon was observable in the Grape Creek cutbank or in BHT 32 , which was located on the same surface some $30 \mathrm{~m}$ away. Zone 4 is $35 \mathrm{~cm}$ thick, consists of reddish brown (5YR 4/4) massive to weak subangular blocky sandy loam, and contains common carbonate filaments. This zone grades up into a 90-cm-thick dark reddish brown (5YR 3/2) angular blocky clay loam representing another swale fill deposit. Once again, filamental precipitate is common in the matrix, and corresponding deposits are not present in surrounding trenches or the cutbank bordering the site. A radiocarbon assay of sediment obtained from $63-75 \mathrm{~cm}$ below the surface in this zone yielded a corrected date of $1280 \pm 50$ B.P (Tx-6226). This unit is overlain by a $15-\mathrm{cm}-$ thick reddish brown (5YR 4/4) subangular blocky silty clay loam (Bw horizon). The surficial A horizon consists of dark reddish brown (5YR 3/4) subangular blocky silty clay loam. A cultural feature in the surficial horizon, located several meters from the trench and $20 \mathrm{~cm}$ below the surface, yielded a corrected date of $295 \pm 80$ B.P. (GX-14451). 


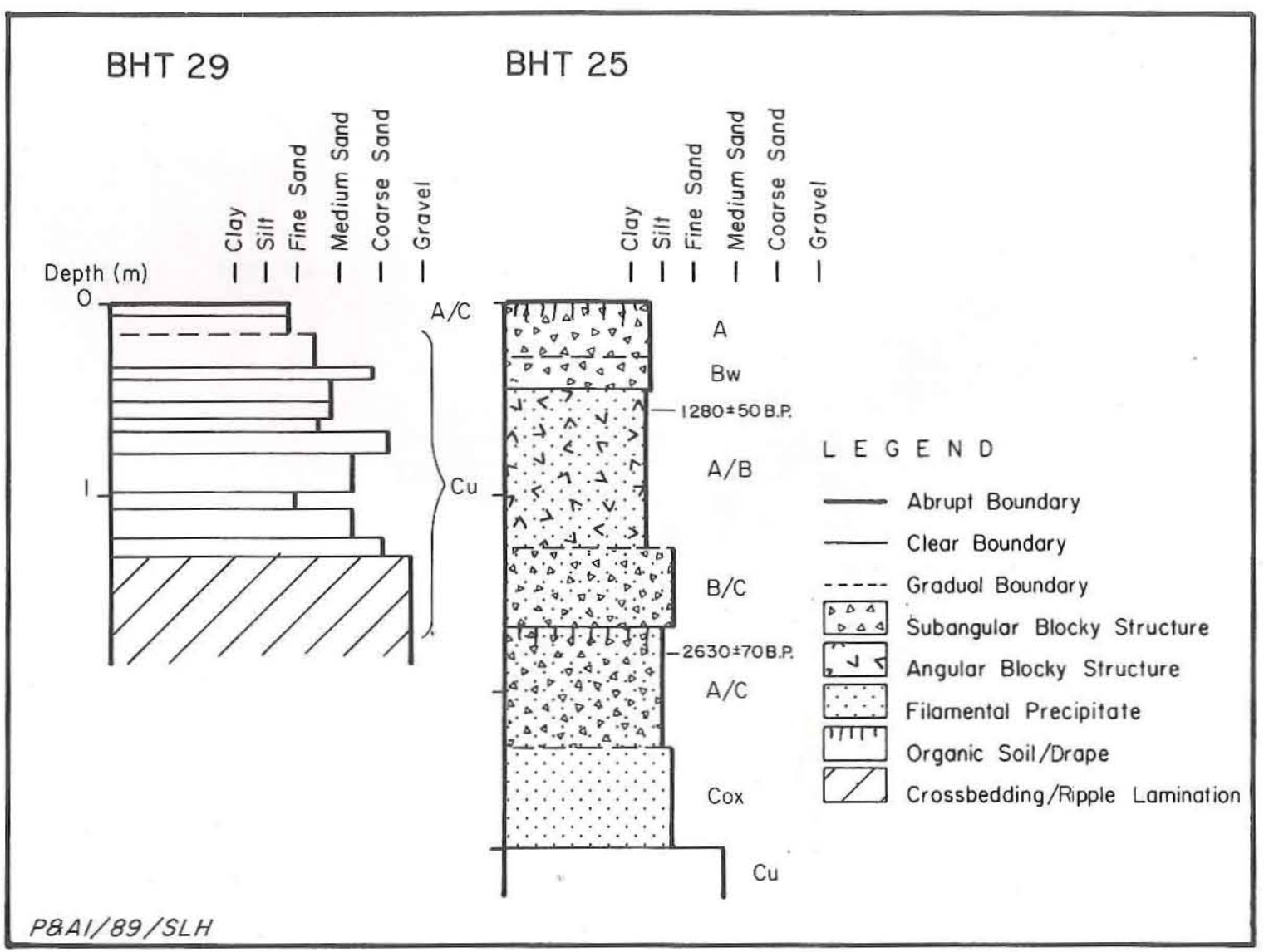

Figure 14. Representative profiles, central Grape Creek valley.

Additional temporal data for the formation of the terrace are available from BHT 30, where a corrected radiocarbon date of $2090 \pm 70$ B.P. (Tx-6228) was obtained from a depth of 250 to $270 \mathrm{~cm}$. This trench was located on the east side of the stream-straddling riser between the modern floodplain and terrace. The variation in depth and age between this humate sample and the deeper sample obtained in BHT 25 probably reflects time-transgressive accretion due to lateral movement of the stream.

Alluvial/colluvial fan deposits in this location are similar to those in the canyonconfined section of the reservoir, consisting of reddish brown to yellowish red massive gravelly, sandy, and clayey loams with subhorizontal stringers and lenses of siliceous gravels. Soil development is limited to weak A horizon formation and sparse filamental carbonate development in the $C$ horizon.

Downstream from the vicinity of $41 \mathrm{KT} 52$ and $41 \mathrm{KT} 53$, the Grape Creek valley constricts briefly and then opens into a broad, meandering alluvial surface surrounded by alluvial/ colluvial fans up to $200 \mathrm{~m} \mathrm{long}$ and 6 to $8 \mathrm{~m}$ thick at their proximal ends. At present, the stream is on the east side of the valley. As a result, the western side of the valley is characterized by coalescing fans that grade imperceptibly into the terrace surface, while the eastern side of the valley is characterized by lateral erosion due to migration of the 
stream. Where the stream has migrated into older deposits, the cutbank has exposed a laterally variable stratigraphic complex of older alluvium, alluvial/colluvial fans, and bedrock (Fig. 15; also see Fig. 12). Of particular note are a thick section of fan sediments that overlie a late Pleistocene cumulic soil at Geomorphic Locality 2 (see Blum 1989) and a sloping bedrock pediment overlain by thin fan deposits near the confluence with the Double Mountain Fork.

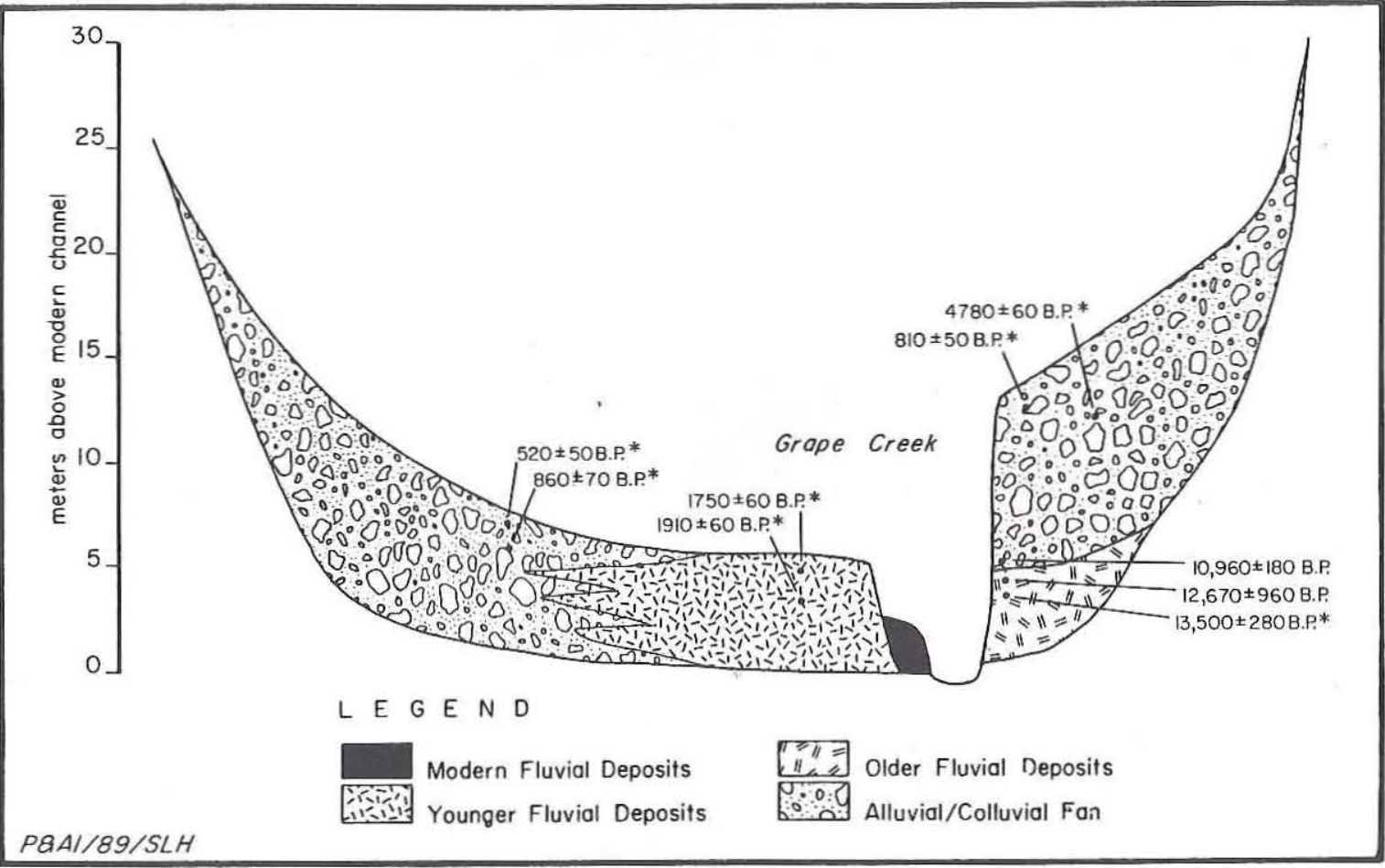

Figure 15. Generalized cross section of the lower Grape Creek valley. Uncorrected radiocarbon dates from Blum (1989:Table 6, Figure 13) are followed by an asterisk.

Ten additional trenches were located in the lower Grape Creek valley, which was previously investigated, described, and dated by Blum (1989). Sediments detected in BHTs 34 and 69-77 are generally similar to those previously described, i.e., gravelly and sandy alluvial fan deposits interfingering with sandy or muddy stream alluvium. Typically, alluvial sediments located away from the present position of the stream (e.g., BHTs 69 and 74) are finer and less heterogeneous than proximal deposits (e.g., BHTs 72 and 77). This appears to be due to variation in the character of the alluvium deposited in the proximal and distal floodplain environments coupled with time-transgressive postdepositional turbation accompanying lateral movement of the stream.

Due to the extreme thickness of the overburden, no backhoe investigation of the late Pleistocene soil underlying the thick fan deposit at Geomorphic Locality 2 was undertaken. However, two additional radiocarbon samples were collected and processed from the exposed cutbank. The stratigraphically lower of these was collected from the cumulic soil at an elevation $140 \mathrm{~cm}$ above the modern stream channel and yielded a corrected date of 12,670 \pm 960 B.P. (Tx-6232). The second sample, collected from the basal alluvial fan deposits 
overlying the soil at an elevation of approximately $160 \mathrm{~cm}$ above the modern channel, yielded a corrected age of $10,960 \pm 180$ B.P. (Tx-6233). This suggests that the former floodplain represented by the soil was only exposed for a short time before the thick alluvial fan began to accrete over it.

Nine trenches (BHTs 48-54, 59, and 60) were located in alluvium derived from the channel and surrounding valley walls of South Sage Creek. The alluvium in South Sage Creek is markedly finer than equivalent deposits of Grape Creek and the Double Mountain Fork and is flanked by alluvial/colluvial fan deposits from the valley walls. In contrast to the sandy alluvium occurring in the Double Mountain Fork and Grape Creek, clay and clay loam dominate the South Sage Creek drainage alluvial deposits, reflecting the shift in the sediment source from sandstone and conglomerate to shale and mudstone.

Backhoe Trench 52 (Fig. 16) is typical of alluvium in the South Sage Creek drainage. The basal zone (Zone 3) extends from 74 to $110 \mathrm{~cm}$ and consists of reddish brown (5YR 4/4) massive clay containing carbonate filaments and a few small carbonate nodules (Ck horizon). Zone 2 extends from 25 to $74 \mathrm{~cm}$ and consists of dark reddish brown (5YR $3 / 3$ ) massive clay (Bw horizon). The A horizon extends to a depth of $25 \mathrm{~cm}$ and is composed of dark reddish brown (5YR 3/3) clay heavily turbated by historic root plowing (Ap horizon).

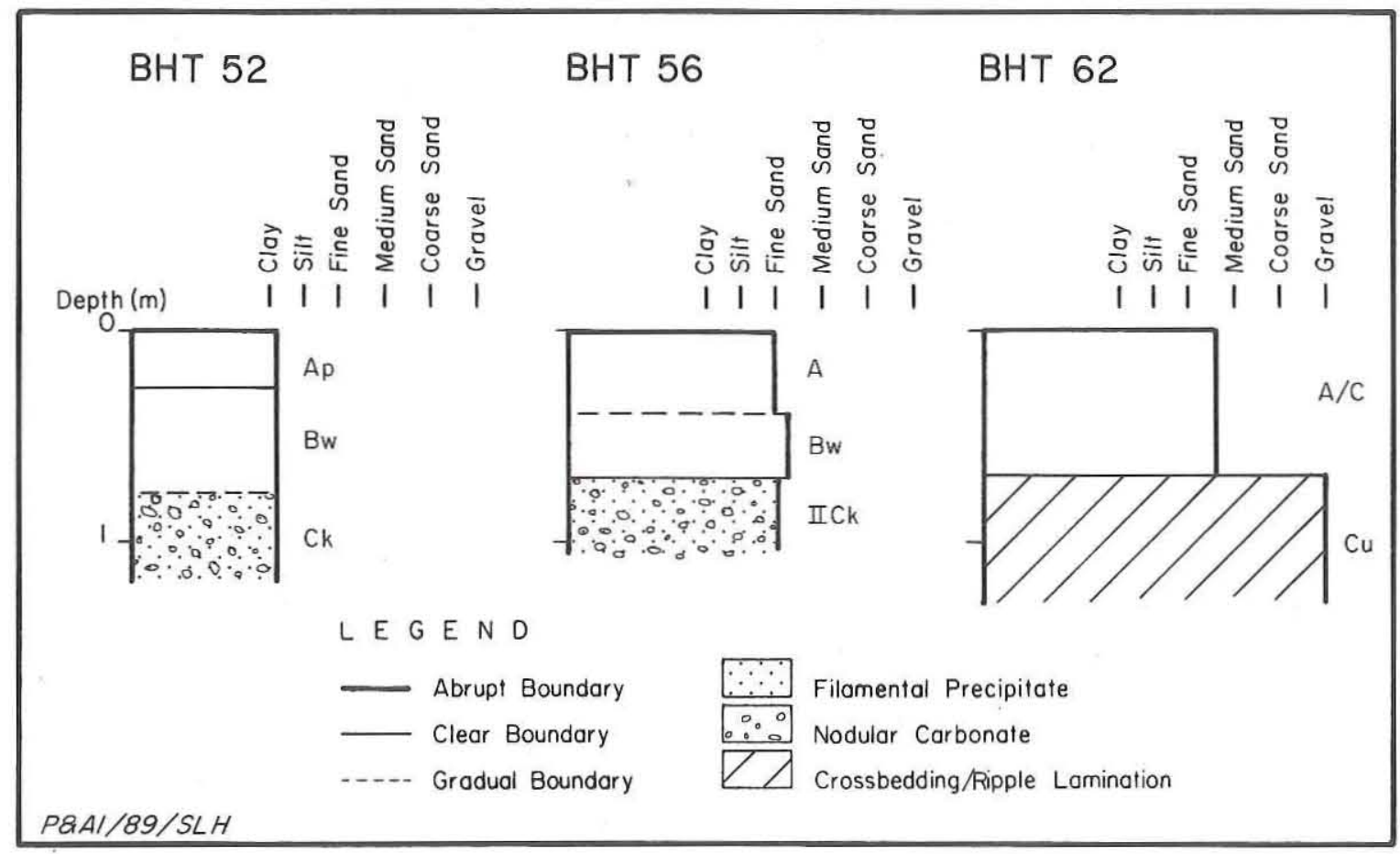

Figure 16. Representative profiles, lower South Sage Creek valley and the lower reservoir.

Twelve trenches (BHTs 55-58 and 61-68) were located in alluvium derived from the channel and surrounding valley walls of the Double Mountain Fork. Geomorphic units present in the lower reservoir include the erosional canyon walls, alluvial/colluvial fan deposits, the modern floodplain, and two terrace surfaces (see Fig. 12). A generalized cross section of the lower reservoir is presented in Figure 17. 


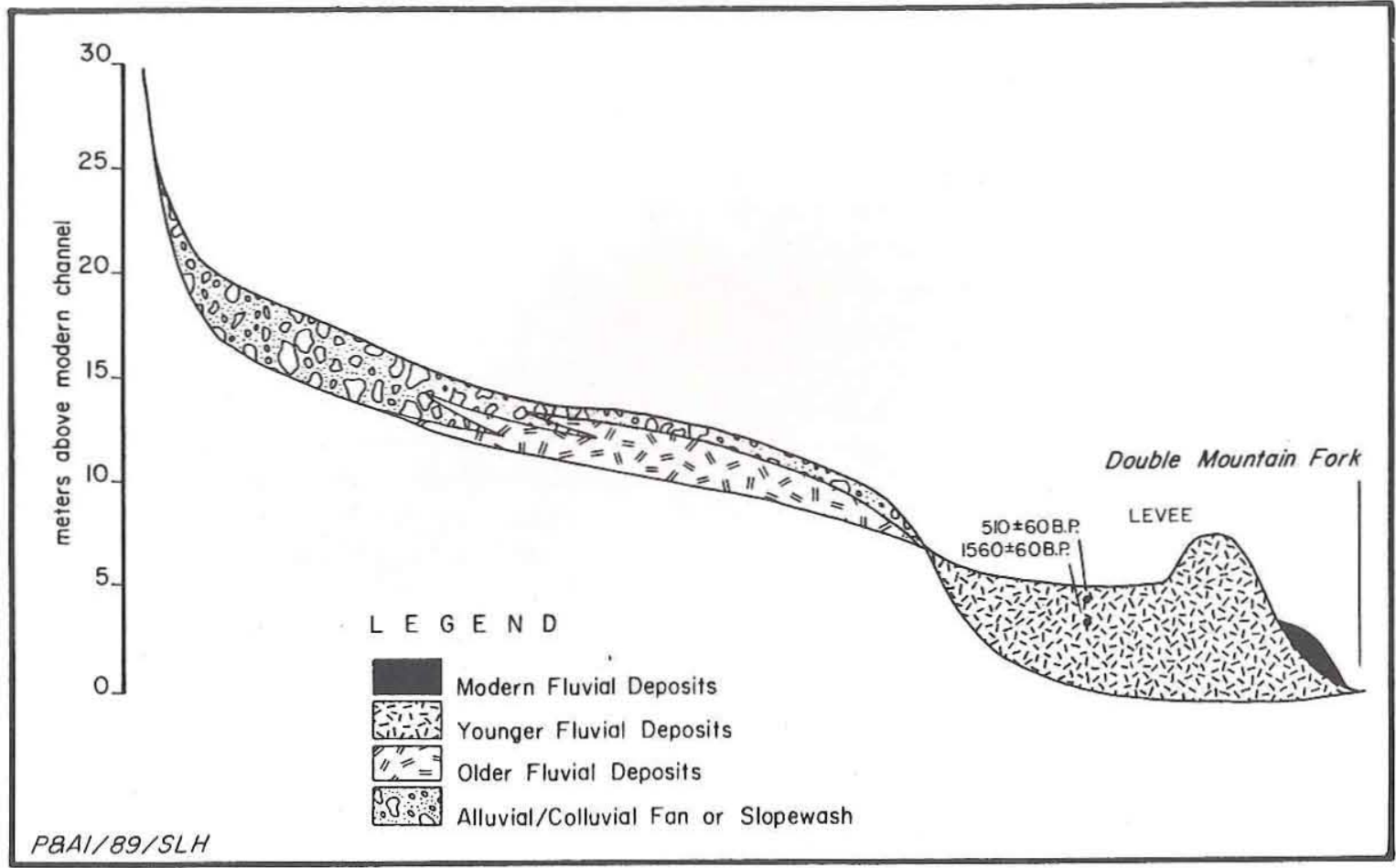

Figure 17. Generalized cross section of the lower reservoir.

Deposits of the upper terrace are limited to a partially dissected surface overlooking the confluence of South Sage Creek and the Double Mountain Fork and resting approximately 10-12 m above the elevation of the modern channel. These deposits consist of both channel gravels (BHT 62) and floodplain sands and silts (BHTs 55-57) overlain by more-recent slopewash sediments (see Fig. 16).

Channel gravels are preserved as an isolated hummock on the lower terrace surface. The exposed faces of these gravels are highly calichified due to the rapid evaporation of calcic groundwater flowing through the gravels. In contrast, channel sediments exposed in BHT 62 (see Fig. 16), excavated into the body of the hummock, are not calichified. They extend from $70 \mathrm{~cm}$ to the base of the trench at $135 \mathrm{~cm}$ and consist of pale red (5YR 6/2) high-angle tabular and trough crossbedded cosets of gravels and medium to coarse sands separated by clear truncation surfaces. Krotovina are common in the zone. The upper zone consists of a reddish brown (5YR 4/4) massive loamy fine sand containing dispersed saprolitic sandstone and siliceous pebbles, probably representing slopewash deposited after an erosional episode truncated the original section. Soil development is limited to very weak A horizon development.

Backhoe Trench 56 (see Fig. 16) is representative of the preserved overbank sediments on the older terrace. The basal zone (Zone 3) extends from 72 to $112 \mathrm{~cm}$ and consists of reddish brown (5YR 4/4) massive silty fine sand. Abundant carbonate is present in the form of small nodules and interstitial whitening (IICk horizon). A clear erosional boundary separates this unit from Zone 2, which extends from 40-72 cm and consists of reddish brown 
(4YR 4/4) massive gravelly silty fine sand (Bw horizon). This unit contains a few fine flecks of carbonate and is interpreted as upland slopewash postdating truncation of the overlying soil. Zone 1 extends from the surface to a depth of $40 \mathrm{~cm}$ and consists of reddish brown (5YR 4/4) massive silty fine sand with weak organic enrichment (A horizon). This zone probably represents a mixture of relatively recent eolian and slopewash sediment.

Younger terrace sediments were detected in BHTs 58 and 63-67. These sediments vary from fairly homogenized massive sandy, silty, and clay loams (e.g., BHTs 58, 65, and 67) to highly stratified, thin laminated silts with interbedded sands and clays (e.g., BHTs 63, 64, and 66). Thin clast-supported gravel lenses, representing chute channels transecting the terrace surface, are common in both massive and stratified deposits. of particular note is BHT 63, which was excavated into a long, linear feature adjacent to the floodplain. Based upon its morphology and sandy surface texture, this feature was originally interpreted as a linear dune on the channel margin (Blum 1989:89). However, trenching demonstrated that the feature is in fact a natural levee and is composed of stacked packets of low-angle, tabular bedded fine, medium, and coarse sands separated by marked erosional boundaries that slope gently away from the channel. The rather abrupt landward face of this feature is unusual for a levee and probably indicates lateral truncation by channelized water in the swale behind the levee during flood events.

Temporal data for the formation of the low terrace are available from two stacked organic-rich swale fill deposits in BHT 65. The deeper of the two was collected from a depth of 205-215 cm and produced a corrected radiocarbon age of $1560 \pm 60$ B.P. (Tx-6231), while the upper sample was obtained from a depth of $48-58 \mathrm{~cm}$ and yielded a corrected age of $510 \pm 60$ B.P. $(\mathrm{Tx}-6230)$.

The Uplands

Due to limitations imposed by the location of the primary impact zone (e.g., the normal reservoir pool), backhoe investigations in the upland environment were limited to a relatively small area situated on a finger of the upland surface dividing Grape and South Sage creeks on and around the location of the emergency spillway of the proposed dam (see Figs. 2 and 12). A total of 13 trenches were excavated in the uplands (BHTs 35-47).

The texture and general character of the upland soils vary considerably in response to several basic controls, including parent material, texture, microtopographic position, slope, and proximity to the canyon edge. Parent materials on the uplands are an admixture of the native Triassic sandstone and dissected remnants of old alluvial fans shed off the retreating Caprock Escarpment and have been heavily reworked by slopewash and eolian processes. Alluvial fan sediments on the uplands are primarily sandy but grade laterally into gravelly and muddy facies. Prolonged slopewash and eolian activity have resulted in extensive additional sorting of the material. As a result, profile characteristics reflect microtopographic variation. Soils developed on high points are typically thin, sandy, and poorly developed due to extensive erosion. In intermediate positions, soils are still predominantly sandy, but the profile is typically thicker and more highly developed. Topographic depressions are commonly filled with clay and sandy clay soils that are thicker still. Proximity to the canyon edge is accompanied by an increase in surface slope and throughflow speed; as a result, water has less time to act on the parent material and horizon development is somewhat inhibited. 
Backhoe Trench 47 (Fig. 18) typifies the thick, clayey sediments accumulated in lowerlying areas of the upland surface. The surficial zone is $16 \mathrm{~cm}$ thick and consists of a dark reddish brown (5YR 3/4) medium subangular blocky sandy clay loam (A/B horizon). This zone grades into a dark reddish brown (5YR $3 / 4$ with 5YR $3 / 3$ ped faces) clay loam B2t horizon with a very intense fine angular blocky structure, thin argillans, and occasional large (possibly reworked) carbonate nodules. This horizon is $102 \mathrm{~cm}$ thick and grades into a $62-\mathrm{cm}$-thick reddish brown $(5 \mathrm{YR} 5 / 4)$ sandy clay loam B3 horizon with blocky structure that varies from small angular to medium subangular with depth. The substrate is a partially indurated sandy caliche and bounds the overlying zone with an abrupt wavy boundary that probably represents an erosional truncation (IIK horizon).

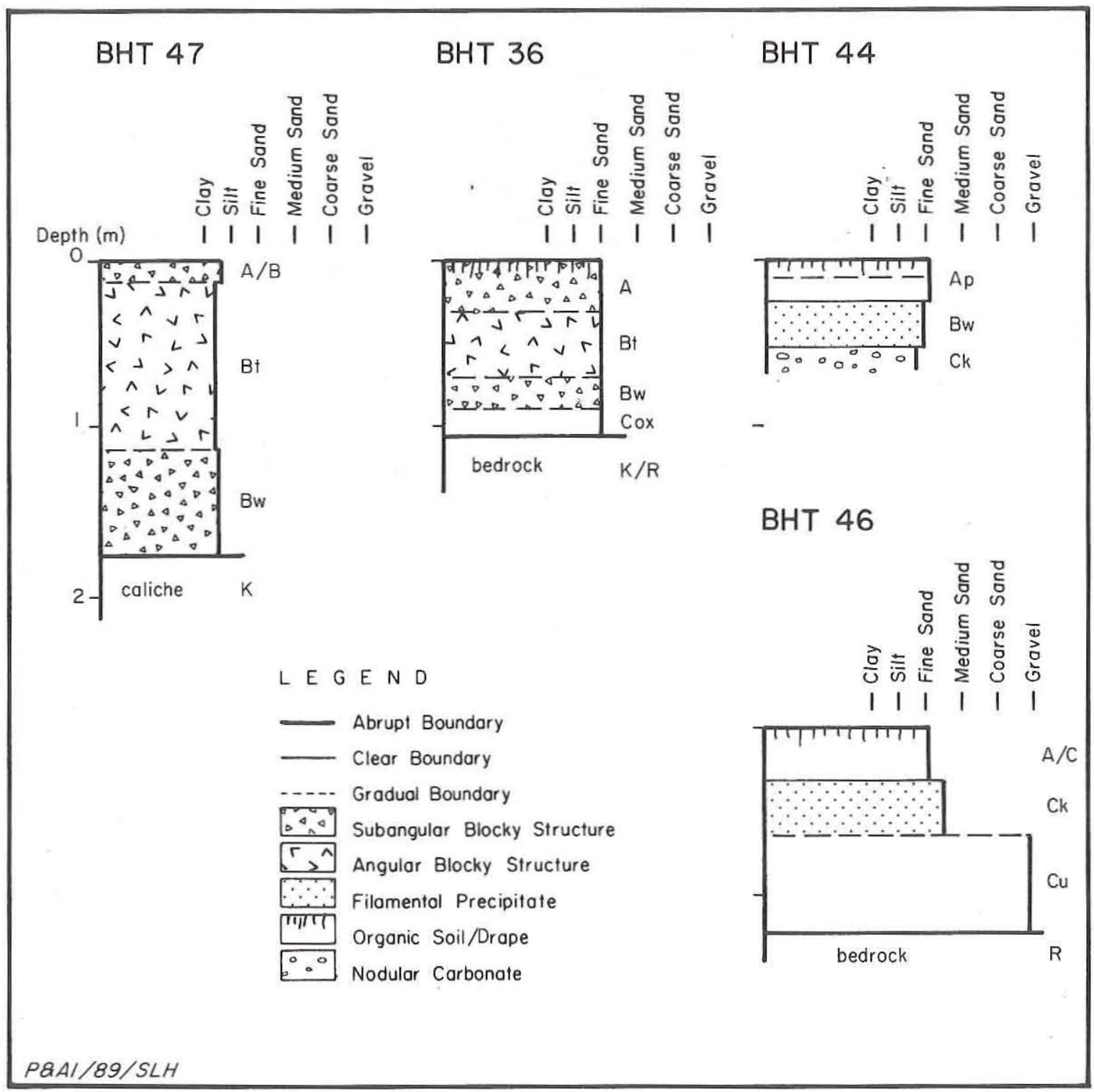

Figure 18. Representative profiles, uplands above Grape Creek. 
The profile exposed in BHT 36 (see Fig. 18) is typical of a well-developed soil in sandier sediments on higher portions of the landscape. The A horizon extends to a depth of $30 \mathrm{~cm}$ and consists of brown (7.5YR 4/4) slightly blocky sandy loam. This zone is underlain by a 40-cm-thick dark brown (7.5YR 3/4) moderate to strong medium subangular blocky sandy loam Bt horizon. This horizon grades into a 20-cm-thick strong brown (7.5YR 4/6) very weak subangular blocky Bw horizon. The Cox horizon is $18 \mathrm{~cm}$ thick and consists of a brown (7.5YR 5/4) massive to weak subangular blocky sandy loam with few to common fine carbonate nodules. The underlying substrate consists of saprolitic sandstone with considerable infiltrated carbonate ( $K / \mathrm{R}$ horizon).

Backhoe Trench 44 (see Fig. 18) is an example of a less-developed profile in sandy materials. The surficial zone is $10 \mathrm{~cm}$ thick and consists of dark brown (7.5YR 3/4) loose loamy fine sand of probable eolian origin. The underlying horizon differs only in the degree of compaction; it is $14 \mathrm{~cm}$ thick and consists of dark brown (7.5YR 3/4) massive loamy fine sand. Mixing apparent in these zones and the presence of a distinct oscillatory lower boundary suggest disturbance by historic root-plow activity (A1p and A2p horizons). The B horizon is $31 \mathrm{~cm}$ thick and consists of strong brown (7.5YR 4/6) massive fine sandy loam. The matrix shows some whitening due to carbonate accumulation, and fine carbonate nodules are common (Bwk horizon). The deepest zone is a very pale brown (10YR 7/3) massive fine sandy to silty loam with abundant large carbonate nodules and interstitial carbonate (Ck horizon).

Backhoe Trench 46 (see Fig. 18) is an example of a profile developed in a gravelly fan facies. The $\mathrm{A} / \mathrm{C}$ horizon is $35 \mathrm{~cm}$ thick and consists of reddish brown (5YR 4/4) massive gravelly sandy loam representing relatively recent slopewash. The underlying $\mathrm{Ck}$ horizon is $35 \mathrm{~cm}$ thick and consists of yellowish red (5YR 4/6) massive to weak subangular blocky gravelly sandy loam. The gravels are primarily siliceous but include some larger subrounded to flaggy sandstone clasts. Fine carbonate filaments, decreasing in concentration with depth, are present in the matrix, and thin coats of carbonate are common on the underside of gravels. This zone is underlain by a 50-cm-thick reddish brown (5YR 4/4) massive coarse sandy gravel composed primarily of small siliceous gravels with mixed clast/matrix support ( $\mathrm{Cu}$ horizon). The substrate is intact sandstone bedrock. Soil development in this horizon is limited due to moderate surface slope, high infiltration rates, and proximity to the scarp bounding the canyon wall.

Two radiocarbon dates are available from the upland soils. Because these assays are obtained from soils, they are indicative of the mean residence time of pedogenically derived organic matter rather than the age of the deposited sediments, and thus they provide only minimum ages for the soils. One sample, collected from $90 \mathrm{~cm}$ below the surface in the Bt horizon of a low-lying, clayey profile (Geomorphic Locality 1) yielded an uncorrected age of $4730 \pm 70$ B.P. (Blum 1989). A second sample, collected from $80-90 \mathrm{~cm}$ below the surface in the Bw horizon of a sandy profile (BHT 40), yielded a corrected age of $2770 \pm 80$ B.P. $(T x-6229)$. These dates suggest that soil development on the upland surface has been progressing since the mid Holocene.

\section{Results of Subsurface Site Prospection}

Subsurface mechanical testing served the dual function of providing stratigraphic data for geomorphic interpretation and prospecting for buried archeological remains. The search 
for buried sites was particularly important in the lower reservoir, where dam construction activities will destroy large floodplain and upland areas near the mouth of Grape Creek (see Fig. 2). In these construction zones, specifically the dam footprint, borrow areas, and emergency spillway, subsurface archeological testing was intensified to insure adequate coverage of the area in searching for buried sites (cf. Figs. 2 and 12).

Of the 77 backhoe trenches excavated during the Phase II investigation, $31(40 \%)$ were located within the boundaries of known sites. A total of 16 (52\%) of these trenches yielded definite or probable prehistoric cultural remains (see Table 6). In contrast, of the 46 trenches excavated in nonsite areas, only $3(7 \%)$ yielded possible cultural evidence, and only 2 (4\%) yielded definite cultural materials. The evidence from the latter two trenches (BHTs 1 and 30) resulted in the recording of two new sites (41GR569 and 41KT151). Backhoe Trenches 23, 24, and 34 contained possible cultural materials, but sites were not assigned due to the paucity of occupational evidence.

Several observations relative to buried site prospection are pertinent. First, the intensive backhoe trenching in the lower reservoir yielded only one new site, 41KT151, located on Grape Creek upstream from the construction impact zone. The intensity of backhoe testing in the floodplain and uplands near Grape and South Sage creeks is not considered adequate to insure that no buried sites are present in the construction zone; however, the subsurface testing is considered to be comprehensive enough to indicate that substantial buried archeological resources are not likely in these areas.

A second observation arising from mechanical prospection is that many sites in the project area lack distinct concentrations of cultural materials. While definite occupation zones, features, and artifacts are found in the subsurface, they are typically isolated or scattered over a wide area, and the sites usually contain sparse lithic debitage and/or tools. Such resources are difficult to locate in randomly placed backhoe trenches. This contention is supported by the frequent fallure to locate cultural materials in trenches excavated in known cultural areas. The fact remains, then, that no matter how intensive subsurface testing is, there is always a possibility of missing the concentration of cultural materials that would indicate the presence of a buried occupation.

A third observation is that it appears that there was a relatively low intensity of occupation of the floodplain during periods of rapid aggradation. This is supported by the fact that most of the cultural materials recovered from deposits of the younger terrace were found at depths of $100 \mathrm{~cm}$ or less, suggesting that occupational intensity increased as the accretion of the floodplain and the frequency of inundation slowed (see following discussion of alluvial sequence). In archeological terms, late Archaic and early Late Prehistoric occupation of the floodplain appears limited, while a substantial increase in occupational intensity is indicated during the latter part of the Late Prehistoric period.

Finally, there are other factors that undoubtedly contribute to the general paucity of lithic materials in floodplain sites. Lithic material sources are located on the uplands, and it is likely that a good deal of lithic reduction took place at the source areas. Good-quality cherts are also scarce in the lithic source areas, perhaps resulting in an extremely conservative utilization of lithic materials. These factors probably further limited the amount of lithic reduction on the floodplains and may help to explain the meager archeological record there. 
Discussion

Geomorphic and Climatic Implications

The results of the current project and the previous investigation by Blum (1989) provide a basis for the development of a preliminary reconstruction of alluvial and pedogenic episodes in the reservoir through the Holocene. The following discussion develops such a reconstruction and compares it with similar reconstructions for other areas on the southern High Plains and in the Southwest.

In addition to detailing the sequence and timing of aggradational, incisional, and relatively stable episodes of landscape evolution, the following discussion addresses climatic implications of the alluvial chronology. The existence of a process-response relationship between climatic change and alluvial aggradation and incision is generally acknowledged (Gregory and Walling 1973; Helgren 1979; Knox 1983; Lowe and Walker 1984), and alluvial chronologies are often used as a tool to infer past climatic conditions (Knox 1983; Hall 1988; Holliday 1985a, 1985b, 1988). The relationship between the climatic stimulus and the geomorphic result is complex, however, and a shift between more-humid and more-arid conditions in either direction may result in either aggradation or incision, depending on many different systemic variables, including preexisting vegetative and soil cover characteristics, sediment availability, and precipitation distribution (Helgren 1979; Blum 1987). Therefore, the paleoclimatic aspects of the following discussion should be considered as a preliminary statement subject to revision based on additional proxy data. Based on existing data, the late Pleistocene/Holocene alluvial sequence represented by sediments in the Justiceburg Reservoir locality can be summarized as follows.

PHASE I: SLOW TO MODERATE ALLUVIATION AND CONTEMPORANEOUS SOIL FORMATION

(before 13,500 B.P. through at least 11,000 B.P.)

The late Pleistocene and early Holocene are represented by locally preserved sediments in the Grape Creek valley, lower reservoir, and upper reservoir. Localized gravel lag deposits in the canyon-confined central reservoir also may date to this period of aggradation but are presently undated. The temporal context of the Grape Creek section is documented by a sequence of three internally consistent radiocarbon dates. The section consists of a cumulic alluvial soil that developed during the terminal Pleistocene overlain by alluvial fan sediments dating to the early to middle Holocene. Radiometric ages of 13,500 and 12,670 B.P. were obtained from the buried soil, suggesting that deposition and pedogenesis occurred prior to demonstrated human occupation of the region. A radiocarbon date of 10,960 B.P. was obtained from the basal alluvial/colluvial fan deposits overlying the soil, demonstrating that accumulation of the fan began in the terminal Pleistocene or very early Holocene, effectively sealing the soil and terminating pedogenesis.

No chronometric data are available for sediments and soils in the other localities. The degree of pedogenic development evident in upper terrace sediments exposed at Geomorphic Locality 3 (Blum 1989) and in preserved upper terrace sediments in the lower reservoir (e.g., development of weak to moderate blocky or prismatic structure, rubification, and development of numerous carbonate nodules) is consistent with that present in the welldated late Pleistocene soil exposed in the Grape Creek cutbank at Geomorphic Locality 2, 
suggesting that they may be roughly contemporaneous. A stronger degree of pedogenic development, implying a longer developmental period, is evident in the soil exposed in BHTs 8-10 in the upper reservoir (e.g., development of a strong small angular blocky structure and formation of very abundant large carbonate nodules). It is unknown whether this difference is due to increased age in comparison to the other soils or to a longer period of subaerial exposure during the early to middle Holocene.

Substantial periods of late Pleistocene/early Holocene alluviation are suggested from a number of surrounding locations in the southern Great Plains and desert Southwest and are commonly interpreted as the result of increasing temperature and decreasing humidity, accompanied by concomitant decrease in vegetative cover and an increase in erosion by slopewash processes (Haynes 1968; Knox 1983). At the Lubbock Lake Site on the Llano Estacado, Holliday (1988) reports a period of fluvial aggradation terminating approximately 11,000 years ago, followed by a period of lacustrine and marsh sedimentation terminating approximately 8,500 years ago. Similar, slightly asynchronous sequences are also reported from the Plainview and Clovis type sites (Holliday 1985c). Blum (1987) documents an aggradational phase dating between 11,000 and 7,000 years ago from the Pedernales River on the eastern side of the Edwards Plateau. Late Pleistocene fluvial aggradation is also reported from the Mustang Springs Site on the Llano Estacado (Hill and Meltzer 1986; Meltzer and Collins 1987) and from Chaco Canyon in west-central New Mexico (Hall 1977a).

PHASE II: CATASTROPHIC STRIPPING (early Holocene-3000 B.P.)

No stream alluvium dating from the early to middle Holocene is preserved in the study area, although the massive alluvial/colluvial fans in the Grape Creek valley continued to accumulate. This indicates that a period of erosion and channel incision occurred that completely removed sediments in the canyon-confined segment and truncated soils developed in the upper and lower sections of the reservoir, sparing only those buried under subsequent fan deposits. Erosion and retreat of the valley walls were also probably accelerated at this time. Soil formation in the uplands apparently continued through this period, but it is likely that slopewash, gullying, and eolian transport and deposition were more common in the upland environment than in the preceding and succeeding phases.

The timing of the shift from relative stability to widespread erosion in the study area is unclear due to the lack of sediment preservation. Although hard evidence is lacking, it is likely that the period of rapid alluviation indicated for the terminal Pleistocene and early Holocene was followed by a relatively stable soil-forming interval prior to the onset of strongly arid conditions and concomitant incision and erosion. A protracted period of middle Holocene aridity has been inferred from a number of localities in the southern Great Plains. This period was first identified by Antevs (1948, 1955), who termed it the Altithermal. Based on data from Arizona, Martin (1963) proposed that extreme aridity was not characteristic of the midale Holocene, but subsequent investigation has demonstrated that the sediments used to infer Martin's moist-summer model were actually of early and late Holocene age and that middle Holocene sediments were not preserved (Haynes 1968; Waters 1985; Hall 1988). Sediments dating to the middle Holocene are rare in the Southern Plains (Hall 1988) and, when present, are typically indicative of a period of pronounced aridity from approximately 7,000 to 4,500 years ago (e.g., extensive eolian sediments preserved at Lubbock Lake [Holliday 1985a] and Mustang Springs [Meltzer and Collins 1987]). 
PHASE III: RAPID TO MODERATE SEDIMENTATION (3000-1000 B.P.)

A period of substantial late Holocene alluviation followed by a relatively stable soil-forming interval has been recognized at a number of locations on the southern Great Plains (Hall 1977b, 1988; Artz 1985; Schuldenrein 1985), the Edwards Plateau (Blum 1987), and the Southwest (Hall 1977a; Knox 1983). This general pattern is replicated at Justiceburg. Beginning about 3,000 years ago, the floodplain of the Double Mountain Fork and its tributaries began to aggrade again. Radiocarbon assays of sediment samples obtained from deposits of the terraces in Grape Creek and the canyon-confined reaches of the Double Mountain Fork demonstrate that aggradation was well under way by approximately 2700 B.P. and that the present elevation of the terrace complex was achieved by approximately 1100 B.P., although data from the lower Double Mountain Fork indicate that localized sedimentation in swales continued for several hundred more years.

Aggradation appears to have resulted primarily from vertical accretion in the Double Mountain Fork drainage and from a combination of lateral and vertical accretion in the Grape Creek and South Sage Creek valleys. Stratification is typically poorly preserved, suggesting intensive bioturbation of successive thin overbank deposits by floodplain vegetation as the floodplain aggraded. Reliable estimates of overall sedimentation rates are not possible based on existing data; however, it is likely that the majority of the alluvium accreted fairly rapidly and that the end of the aggradational phase was characterized by reduced rates of sediment influx. Archeological materials contained in the terrace sediments are concentrated in the upper meter of the deposits, possibly reflecting a combination of an increased incidence of occupation and a decreased rate of sedimentation.

PHASE IV: INCISION, FOLLOWED BY RELATIVE STABILITY AND ALLUVIAL FAN DEVELOPMENT (1000-200 B.P.)

Approximately 1,000 years ago, probably due to a shift to more arid conditions, widespread floodplain aggradation in the study area ceased and the streams began to incise into their deposits, creating the younger terrace. At approximately the same time, the rate of alluvial fan formation increased markedly. Although not well dated, the formation of eolian dunes in the valleys appears to have begun at approximately the same time, further supporting a shift to drier conditions. A similar widespread period of incision, commencing between 1000 and 700 B.P., is indicated from a number of localities on the Southern Plains (Knox 1983; Blum 1987; Hall 1988; Blum and Valastro 1989) and the desert Southwest (Hall 1977a; Knox 1983). A shift to drier conditions is also indicated by other forms of proxy data, including increased colluvial and eolian activity (Holliday 1985b, 1988) and pollen (Henry 1978; Hall 1982, 1985).

Alluvial/colluvial fan formation, slopewash, and eolian activity appear to be the most active geomorphic processes during the last 1,000 years in the study area. Overbank sedimentation has continued to play a relatively minor role, resulting in the formation of the discontinuous low modern floodplain and localized infilling of swales in the younger terrace. Deep gullying of the fans and terrace deposits by ephemeral drainages coming off the uplands is also common. Radiocarbon dates from cultural and natural contexts in the upper fan deposits suggest that reworking of the upper surfaces is very common and occurs relatively rapidly, usually in the span of several hundred years. 
Archeological Implications

The preceding reconstruction of late Quaternary geomorphic activity in the Justiceburg Reservoir study area has several implications that must be weighed in interpretation of the archeological record. One major consideration that follows from the geomorphic results is the probability that sites representing various cultural manifestations are unevenly represented. The frequency of sites from different time periods present in the archeological record at any particular locality is the combined result of the original intensity of each occupation, the nature and intensity of coeval formation processes, and the degree of postoccupational disruption of deposits dating to the period. In an alluvial environment, a temporal bias is introduced that favors preservation of occupations that coincide with aggradational and relatively stable episodes and discriminates against occupations that coincide with or precede erosional episodes. A pertinent example of the bias that can be introduced in this manner is the general paucity of middle Holocene sites documented from the Southern Plains, due primarily to the erosional episode coinciding with the Altithermal climatic stage (Hall 1988:211-212). In contrast, activity in eolian and colluvial environments tends to be accelerated during arid intervals and may cease entirely during mesic periods due to the stabilizing presence of abundant vegetation.

In addition to presence/absence, the nature of site formation processes affecting a given spatial-temporal environment also influences the form and integrity of resultant archeological deposits. Important factors include the mode and rate of sedimentation, the frequency and intensity of individual sedimentary events, and the duration of and the susceptibility to pedogenic and turbation processes. In alluvial and eolian environments, the rate of sedimentation affects the stratigraphic separation between archeological evidence of individual occupations and thereby tempers the degree of discrimination possible between individual behavioral episodes preserved in the record. Rapid sedimentation rates also have the effect of reducing the amount of time that deposits are exposed to pedogenic and biotic alteration and mixing in the near-surface environment. The magnitude and intensity of individual depositional events also affects the preserved record. In the alluvial environment, flood intensity and duration control the nature of sedimentation; low-magnitude flood events tend to deposit vertically accreted, fine-grained sediments in the overbank environment, and higher discharge events are much more likely to result in erosion of preexisting floodplain sediments. The climatic and vegetative conditions characteristic of any particular point in time reinforce this dichotomy, as the flashy nature of discharge and poor vegetative cover characteristic of drier intervals tend to aggravate erosion, while more-sustained discharge and luxuriant vegetation promote deposition. The net effect of eolian processes varies in a similar manner depending on the interrelated variables of wind speed, sediment supply, and vegetative cover.

Up to this point, discussion of the geomorphic context of Justiceburg Reservoir has been primarily organized without regard to the cultural sequence. In order to present an evaluation of the archeological potential of deposits in the study area within a culturehistorical context, the incidence, abundance, and formation processes affecting sediments dating to each of the general temporal periods recognized for the southern Great Plains (Boyd et al. 1989b) are addressed below. The purpose of this review is to explicitly state the range of extant sediments that potentially could contain archeological materials of a given age and, when possible, relate these conclusions to the results of the archeological work in the project area. In the case of valley-fill alluvial and colluvial sediments, investigation has been thorough enough to allow preliminary evaluation of the intensity of 
utilization. Because the range of environments examined in the uplands is not large enough to be representative of the whole due to the areally restricted nature of prospection, however, no conclusions regarding the intensity of occupation will be advanced for this environment.

THE PALEOINDIAN PERIOD (ca. 12,500-8000 B.P.).

Sediments of apparent late Pleistocene/early Holocene age are present in several locations within the study area, but their temporal context is documented by radiocarbon assay at only one locality (Geomorphic Locality 2) in the lower Grape Creek valley. Here, a cumulic floodplain soil is preserved beneath a thick alluvial fan deposit. It is likely that other vestiges of this deposit are preserved beneath other fan deposits in the same general area, but the thickness of the overlying fans prevented confirmation of this hypothesis. The soil represents a potential occupation surface that formed during the terminal Pleistocene and was undergoing burial by fan activity by the onset of the Holocene. The surface of this alluvial deposit therefore represents a fairly restricted temporal window corresponding to the ages characteristic of the Clovis and Folsom cultural traditions. To this point, examination of the deposit has failed to reveal any indication of a Paleoindian occupation; however, the thickness of fan overburden nullified trenching as a means of assessing the deposit, and examination has therefore been limited to repeated scrutiny of the exposed section in the Grape Creek cutbank. Because disturbance of the deposit appears to be minimal, any preserved materials would likely be in primary or semiprimary contexts.

Other alluvial soils exhibiting a degree of pedogenic modification suggesting late Pleistocene or early Holocene age are present in the upper and lower reservoir. Without exception, all examples of these soils within the primary impact zone are erosionally truncated. As a result, the potential for preserved evidence of human occupation is very low, and such evidence would likely be in secondary contexts. To date, no evidence of human occupation has been recovered from any alluvial sediments dating to the Paleoindian period.

Basal alluvial fan deposits in the Grape Creek and lower Double Mountain Fork valleys appear to date to the late Paleoindian period and have the potential to contain archeological materials. Based on the dynamic nature documented for relatively recent fans, any such deposits would likely be in secondary contexts. No evidence of Paleoindian occupation has been detected from fan deposits.

The uplands are composed of a complex of sediments derived from local bedrock, alluvial fan sediments that significantly predate human occupation of the Western Hemisphere, and eolian sediments that variously predate and postdate the Paleoindian period. All sediments have been modified by subsequent slopewash and eolian processes. Although none have been recognized, archeological materials dating to the Paleoindian period are possible in the uplands. Because the range of postdepositional disturbance evident in upland sediments is quite variable on a localized level, the integrity of any preserved evidence of occupation could range from very good to nonexistent.

THE EARLY ARCHAIC PERIOD (ca. 8000-6500 B.P.)

The majority of valley fill sediments dating to this period appear to have been removed by a subsequent widespread erosional episode. No deposits dating to the early 
Archaic period have been identified in the primary impact zone, although alluvium possibly dating to this period is exposed in a borrow pit near the upper end of the reservoir pool. Although none have been identified to this point, early Archaic remains are also possible within the lower zones of the thick alluvial fans in the Grape Creek valley and lower reservoir. The continuing relative stability of upland sediments also provides the potential for early Archaic materials in a wide range of preservation states.

THE MIDDLE ARCHAIC PERIOD (ca. 6500-4500 B.P.)

No fluvial sediments dating to the middle Archaic have been detected in the study area, although fan sediments dating to this period are present in the Grape Creek and lower Double Mountain Fork valleys. Therefore, the potential for preserved middle Archaic materials is practically nonexistent in stream alluvium and very low in the alluvial/colluvial fan environment. Moreover, extreme aridity and very active geomorphic environments indicated for the Altithermal period suggest that any preserved materials would probably be in extensively disturbed contexts. Soil formation in the uplands is documented for this time period, and it is likely that increased colluvial and eolian activity there also accompanied the drier conditions. Therefore, there is a fairly good potential for preservation of middle Archaic remains in the uplands, although the integrity of any such deposits would probably range at best from semiprimary to secondary contexts.

THE LATE ARCHAIC PERIOD (ca. 4500-2000 B.P.)

The majority of alluvial sediments in the reservoir apparently began to accumulate relatively rapidly during the latter half of the late Archaic period. Therefore, there is a low potential for preservation of materials dating to the beginning of this period and a high potential for preservation of later materials within alluvial sediments. The relatively rapid rate of sedimentation implies that occupational episodes contained in the deposits would be of fairly short duration and preserved in primary or semiprimary contexts with good chronostratigraphic control. Disturbance processes affecting the sediments appear largely limited to relatively low magnitude turbation of the accreting floodplain by plants and animals.

Despite excellent preservation potential, late Archaic materials are rare in the alluvial deposits. This suggests that occupation of the floodplain environment was probably not intensive, although the paucity of recovered materials also may be partly attributable to extreme conservation resulting from the limited availability of high-quality lithic resources.

At the same time, alluvial fan formation was continuing in the Grape Creek valley and lower reservoir and beginning anew in the canyon-confined section. Therefore, preserved late Archaic materials in semiprimary to secondary contexts are possible in this environment. Once again, few late Archaic materials were detected during the investigations, suggesting limited occupation of the fan environment.

Upland sediments also have the potential to contain late Archaic materials in a wide range of preservation states. A number of late Archaic sites are known from pedestrian survey of the uplands, but the limited extent of subsurface testing makes any statement concerning the frequency of buried sites premature. 
THE LATE PREHISTORIC PERIOD (ca. 2000-400 B.P.)

The initial Late Prehistoric period is characterized by widespread alluvial sedimentation in the stream valleys, but the rate of sedimentation appears to have slowed through time, terminating approximately 1,000 years ago. As a result, the stratigraphic separation between occupational events is probably less pronounced than that for late Archaic materials in the same suite of deposits. With the onset of the incisional phase, the former floodplain stabilized as a terrace surface subject to minor reworking by overland flow, pedogenesis, and faunal and floral turbation. Due to the lack of appreciable sedimentation, archeological materials in the upper $20-50 \mathrm{~cm}$ of the terrace represent a palimpsest of occupations that postdate stabilization of the surface with little or no stratigraphic separation. The latter portions of the Late Prehistoric period were characterized by an incisional/erosional geomorphic pattern that probably resulted in a net loss of alluvial sediments and an increase in the rate of fan accumulation and colluvial and eolian activity. The results of subsurface prospection indicate that Late Prehistoric remains are common in the alluvial and alluvial/colluvial environments, indicating a moderate to high level of occupational intensity during this period.

THE PROTOHISTORIC PERIOD (ca. 400-75 B.P.)

The character of recent deposits suggests that localized slopewash and alluvial/colluvial fan activity were the dominant geomorphic processes operating during the last 400 years. Although limited fluvial aggradation has resulted in the formation of the modern floodplain, the terrace surface has been subject to very low magnitude sedimentation and relatively minor reworking of preexisting sediments by slopewash, overland flow, and various pedogenic processes. Protohistoric remains should therefore be preserved in primary and semiprimary contexts at the surface and shallowly buried within the terrace sediments, a situation that has been confirmed by pedestrian survey and hand testing. In contrast, the alluvial/colluvial fan environment has apparently been very active, and relatively deeply buried, albeit strongly disturbed, archeological materials are possible in these deposits. Such materials are present but in generally lower frequencies than observed on the stable alluvial terrace. Shallowly buried, relatively undisturbed Protohistoric materials are also indicated for upland environments.

$\underline{\text { Recommendations for Future Work }}$

Geoarcheological investigations performed during the survey and testing phases of the Justiceburg Reservoir project have concentrated on defining the spatial/temporal contexts of late Quaternary sedimentary environments at the mesoscale and macroscale level of resolution. As a result, a regional geomorphic history has been identified that provides a level of environmental context for interpretation of the archeological record. In order to complement the investigations to date, subsequent research should focus on detailed examination of specific localities at the microscale level of resolution. The following summary outlines some of the possible avenues of geoarcheological research for the Phase III investigations of the Justiceburg locality.

In keeping with the scope and goals of the first phases of geomorphic and geoarcheologic investigations, the general level of resolution employed in examination of 
stratigraphic profiles has been relatively coarse and primarily qualitative in nature. Quantitative, microsedimentologic analysis of site stratigraphy has the potential to greatly increase understanding of the nature and rates of formation processes affecting the cultural and environmental records. This is especially true in the case of sites situated in the upper deposits of the first terrace, where a slow rate of deposition has resulted in a concentration of materials within a narrow stratigraphic zone. Additional radiocarbon dates could provide increased detail concerning the alluvial chronology and the sequence of occupation.

Supplemental techniques also have the potential to contribute to the overall data base. Studies of chemical (e.g., Ahler 1973; Sjoberg 1976; Eidt 1977, 1984; Abbott 1987) and magnetic (e.g., Weymouth and Nickel 1977; Weymouth and Huggins 1985; Gibson 1986; Abbott 1987; Appendix B, this report) patterning within site sediments may aid in the recognition of subsurface features and activity areas, increasing the data return from conventional excavation as well as providing a unique data base inaccessible through standard archeological techniques. Other avenues of investigation, including macrobotanical, palynological, faunal, malacological, and phytolith studies, may provide additional insights into prior environmental conditions on a local and regional scale, as well as illuminate aspects of adaptive strategies employed by prehistoric inhabitants. The analysis of organic residues is another technique currently under investigation that has the potential to aid in this regard.

The overall emphasis of the Phase III investigations should be toward integration of various bodies of paleoecologic and cultural data to arrive at a synthetic understanding of culture history and cultural ecology through time in the Justiceburg Reservoir locality. Such a study would contribute greatly to the overall state of knowledge concerning the prehistoric cultures and paleoecology of the Southern Plains. 


\section{CHAPTER 5}

\section{INVESTIGATIONS AT FIRST-PRIORITY SITES}

By Douglas K. Boyd, William A. Bryan, and Colin M. Garvey

This chapter describes the 23 first-priority prehistoric sites in terms of setting, work accomplished, sediments and stratjgraphy, extent and depth, and the data recovered. These consist of 11 campsites, 2 lithic procurement sites, 2 rockshelters, and 8 faunal localities. Detailed descriptions and discussions of supporting data, including information on the magnetometer pilot study, absolute dating, various artifact analyses, organic residue analysis, and studies of botanical and faunal remains, can be found in Volume II. For new radiocarbon dates presented for the first time in this chapter, the dl3c corrected version (as corrected by the radiocarbon labs) is given. Calibrations for the radiocarbon dates are presented in Appendix C but are not given here.

\section{Campsites}

41GR291

\section{SITE SETTING}

Situated in an upland margin on the north rim of the Double Mountain Fork ca. $1.4 \mathrm{~km}$ east of Cedar Hill, the site occupies two southward-projecting ridges that are separated by a small drainage and are flanked by two larger drainages. The upland edge drops sharply to the south and east but slopes gradually to the west. A sandy flat covers the northern upland portion, while sandstone bedrock is exposed in the severely eroded ridges and lower slopes. Elevations range from $2260 \mathrm{ft} \mathrm{msl}$ in the $10 \mathrm{w}$ eroded areas to $2290 \mathrm{ft} \mathrm{msl}$ in the upland flat. A cultivated field lies ca. $25 \mathrm{~m}$ north of an east-west dirt road that traverses the northern sandy flat. Vegetation cover is moderate to heavy in the upland flat and sparse in the lower areas, consisting mainly of grasses, junipers, and mesquites with lesser amounts of cholla, tasajillo, prickly pear, yucca, Mormon tea, and catclaw acacia.

\section{WORK ACCOMPLISHED}

When 41GR291 was recorded in 1987, artifacts and burned rock features were noted in the eroded areas and in the roadcut. Assessed as having a high probability of containing buried cultural remains, controlled surface collection, mapping, and testing were recommended (Boyd et al. 1989). During the current investigations, a detailed site map was prepared, diagnostic artifacts were individually plotted and collected, all artifacts were recovered from a surface collection unit, and 24 auger tests, $61 \times 1-m$ test units, and 1 exploratory backhoe trench were excavated (Fig. 19, Table 7).

The distribution of surface debris indicates that the main occupational area remains buried in the upper portion of the site, and auger tests were excavated in the flat upland 


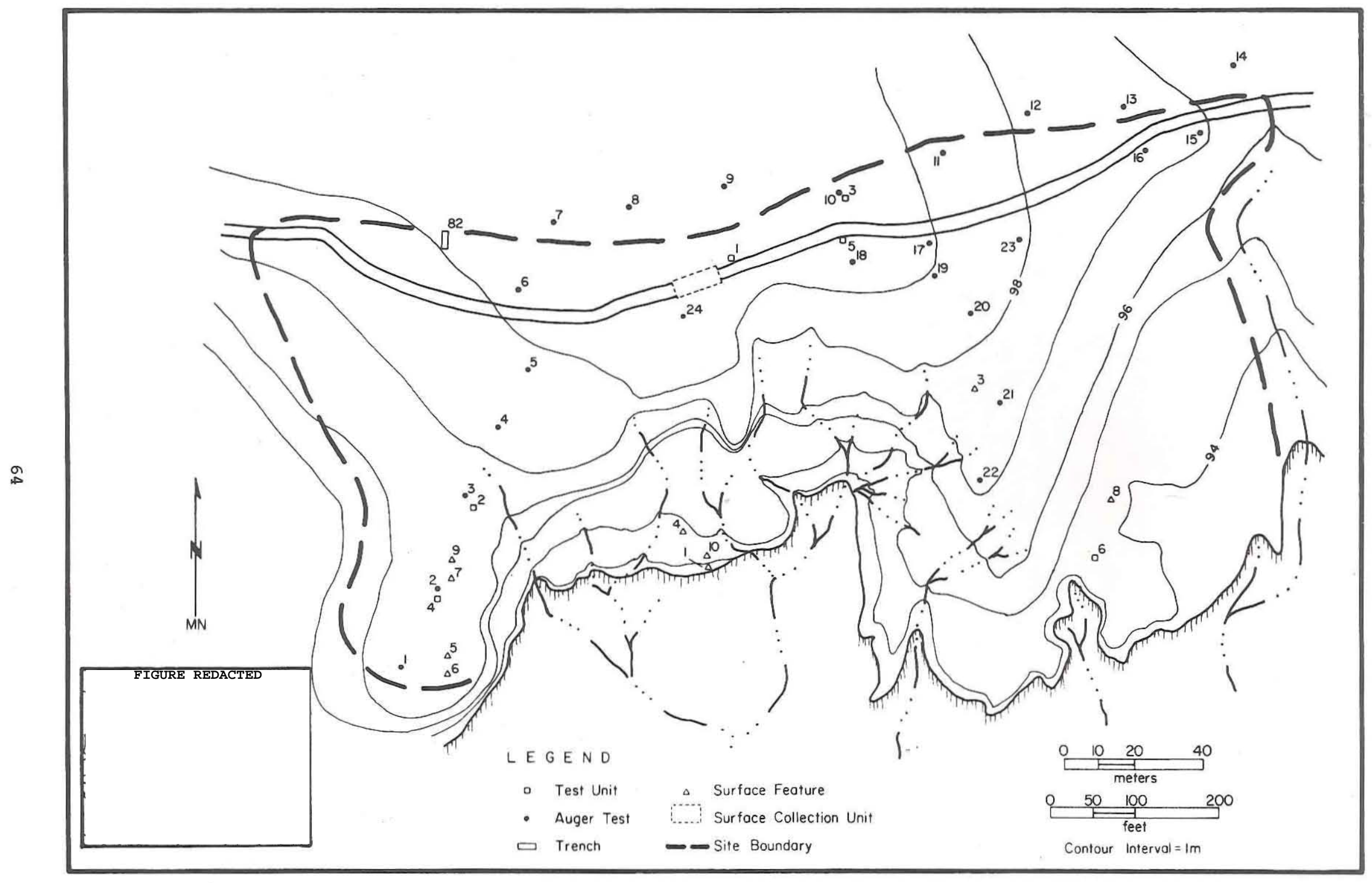

Figure 19. Site map, 41GR291. 
TABLE 7

SUMMARY OF EXCAVATIONS, 41GR291

\begin{tabular}{|c|c|c|c|}
\hline Unit & $\begin{array}{l}\text { Depth of } \\
\text { Excavation } \\
(\mathrm{cm})\end{array}$ & Reason for Ending Unit & $\begin{array}{l}\text { Artifact } \\
\text { Density }\left(\# / \mathrm{m}^{3}\right) \\
\text { or Result }\end{array}$ \\
\hline Test Unit 1 & 60 & Sterile zone reached & 75.0 \\
\hline Test Unit 2 & 66 & Sterile zone reached & 13.6 \\
\hline Test Unit 3 & 50 & Sterile zone reached & 12.0 \\
\hline Test Unit 4 & 57 & Sterile zone reached & 15.8 \\
\hline Test Unit 5 & 75 & Beđrock reached & 30.7 \\
\hline Test Unit 6 & 70 & Sterile zone reached & 42.9 \\
\hline Auger Test 1 & 20 & Bedrock reached & positive \\
\hline Auger Test 2 & $74^{\circ}$ & Bedrock reached & positive \\
\hline Auger Test 3 & 109 & Bedrock reached & negative \\
\hline Auger Test 4 & 58 & Sterile zone reached & positive \\
\hline Auger Test 5 & 60 & Sterile zone reached & negative \\
\hline Auger Test 6 & 102 & Bedrock reached & positive \\
\hline Auger Test 7 & 100 & Bedrock reached & negative \\
\hline Auger Test 8 & 100 & Sterile zone reached & negative \\
\hline Auger Test 9 & 72 & Sterile zone reached & negative \\
\hline Auger Test 10 & 104 & Sterile zone reached & positive \\
\hline Auger Test 11 & 104 & Sterile zone reached & positive \\
\hline Auger Test 12 & 56 & Sterile zone reached & negative \\
\hline Auger Test 13 & 43 & Sterile zone reached & negative \\
\hline Auger Test 14 & 27 & Bedrock reached & negative \\
\hline Auger Test 15 & 38 & Sterile zone reached & negative \\
\hline Auger Test 16 & 70 & Sterile zone reached & negative \\
\hline Auger Test 17 & 110 & Bedrock reached & negative \\
\hline Auger Test 18 & 50 & Sterile zone reached & positive \\
\hline Auger Test 19 & 100 & Sterile zone reached & positive \\
\hline Auger Test 20 & 80 & Bedrock reached & negative \\
\hline Auger Test. 21 & 47 & Bedrock reached & negative \\
\hline Auger Test 22 & 42 & Bedrock reached & positive \\
\hline Auger Test 23 & 22 & Bedrock reached & negative \\
\hline Auger Test 24 & 42 & Bedrock reached & positive \\
\hline Exploratory Trench 82 & 110 & Sterile zone reached & negative \\
\hline
\end{tabular}


area and radiating out along the ridgecrests to delineate the concentration of buried cultural remains. Controlled test units were then excavated; one unit was located near exposed cultural materials in the road, four units were located near positive auger tests, and one (Test Unit 6) was placed in a sandy rise on a lower bench. Exploratory Trench 82 , excavated on the upland flat, revealed no cultural materials. A 4x15-m surface collection unit was placed in a lithic concentration in the roadcut.

\section{SEDIMENTS AND STRATIGRAPHY}

The site exhibits a typical upland stratigraphic profile. Sediments ranging in thickness from a few centimeters in the eroded areas to over $100 \mathrm{~cm}$ in the upland flat overlie well-developed caliche and/or sandstone bedrock. A representative profile in Test Unit 5 consists of four zones: Zone $1,0-8 \mathrm{~cm}$, yellow (10YR 7/6) fine sandy loam, friable to firm; Zone 2, 8-20 cm, dark yellowish brown (10YR 4/4) fine sandy loam, friable to firm, calcareous, sparse siliceous pebbles; Zone 3, 20-40 cm, brownish yellow (10YR 6/6) fine sandy loam, blocky structure, strongly calcareous; and Zone 4, 40-75 cm, yellowish brown (10YR 5/4) silty loam, blocky structure, loose to friable, strongly calcareous.

\section{SITE EXTENT AND DEPTH}

Surface artifacts delineate roughly a 250x150-m site area. Buried cultural materials are limited to a $160 \times 120-\mathrm{m}$ area; however, concentrated occupational debris is restricted to an area of $70 \times 40 \mathrm{~m}$ encompassing the concentration of lithic debitage in the roadcut and Test Units 1,3 , and 5. Tests in this area indicate substantial cultural deposits in the upper $40 \mathrm{~cm}$. A dark, middenlike, organic-enriched cultural zone was present at 5-40 cm in Test Unit 1, and a hearth feature was discovered at $40 \mathrm{~cm}$ in Test Unit 5 . Cultural materials also were recovered from the upper $40 \mathrm{~cm}$ of Test Units 2 and 4 and from 0 -60 cm in Test Unit 6.

\section{FEATURES}

Nine surface features and one buried feature were mapped and recorded. All of the surface features (Features 1 and 3-10) consist of scatters or clusters of burned rocks. Seven are composed of burned sandstone slabs and fragments, and two consist of fire-cracked Potter chert fragments. The sandstone features range from clusters 50-100 cm in diameter to scatters spread over several square meters and probably represent dispersed hearths. The Potter chert features are small (less than $1 \mathrm{~m}^{2}$ ) clusters of angular fragments that may represent boiling stone dumps.

Feature 2 is a slab-lined, shallow, basin-shaped hearth encountered at 40-55 $\mathrm{cm}$ in the northwest corner of Test Unit 5. The one-third exposed suggests an overall diameter of $1 \mathrm{~m}$. The sandstone slabs and fragments dip $5-40^{\circ}$ toward the center. It appears that the hearth basin was excavated into the caliche-rich soil of Zone 4 . No artifacts were directly associated with the feature. Thermoluminescence assay of a sandstone slab yielded an age of $5170 \pm 1040$ B.P. (Dur89TLqi 134-3AS), but this assay is probably erroneously old. Matrix flotation yielded lithics, charred and uncharred juniper wood, charred unidentified hardwood, and noncharred Chenopodium fruit remains, mussel shells, and snail shells. The concentration of organic residue on the single burned rock analyzed was too low for 
identification. Phytolith analysis of feature fill yielded sparse grass phytoliths, primarily choridoid and elongate types. Sparse pollen was preserved in the feature fill but apparently was in a degraded state.

\section{MATERIALS RECOVERED}

Three hundred eighty-seven artifacts were recovered; excluded from this count are seven pieces of microdebitage recovered from flotation samples. Seven specimens are time diagnostic, while another is an exotic trade item (Table 8). Other materials consist of 41 burned rocks, an unidentified tooth enamel fragment, numerous mussel shell fragments, and a snail shell. Projectile points consist of four arrow points (one Scallorn, one Deadman's, one untyped expanding stem, and one untypable serrated blade) and one untyped expandingstem dart point. Two untyped ceramic sherds are similar to the Jornado Brown and Roswell Brown types. A kaolinite pendant fragment represents an exotic trade item. Lithic materials are dominantly fine-grained local chert, but Tecovas jasper and nonlocal Cretaceous chert are also present. Organic residues were extracted from eight artifacts: a mano yielded plant residue; the Deadman's arrow point barb, a side scraper, and an unmodified flake yielded animal residues; and the Scallorn arrow point, a cobble tool, a mano/hammerstone, and a biface yielded indeterminate residues.

\section{DISCUSSION}

Site 41GR291 appears to date chiefly to the early part of the Late Prehistoric period, ca. 1800-1300 B.P., and represents the Palo Duro Complex. A Scallorn arrow point, a Deadman's arrow point barb fragment, two untyped arrow points, two untyped brownware sherds, and the range of other lithic tools constitute an artifact assemblage comparable to the materials recovered from Deadman's Shelter, the type site of the Palo Duro Complex (Hughes and Willey 1978:149-190). A dart point from the surface suggests a possible earlier component, but dart and arrow points were recovered together from the lowest stratum at Deadman's Shelter. A single thermoluminescence age of $5170 \pm 1040$ B.P. obtained from the buried hearth is questionable. The main concentration of cultural materials is contained in a 30-40-cm-thick buried occupational zone in a $40 \times 70-\mathrm{m}$ area. There is no apparent stratigraphic separation within the zone, and the duration of the occupation(s) is not known.

The occupants apparently engaged in a range of subsistence activities. Hearths and fire-cracked rock clusters probably represent different functions related to food processing. Excavation of a portion of a buried slab-lined hearth failed to produce any definitive evidence of its function, but a mussel shell fragment and various plant remains were recovered from the fill. Abundant unmodified mussel shell fragments from the surface and the excavations may indicate that freshwater clams were utilized as a food resource. A single tooth enamel fragment is evidence of animal food utilization but also suggests poor faunal preservation.

Stone tool manufacturing is represented by cores, hammerstones, lithic debitage, and preforms. Finished tools and expedient tools indicate activities such as hunting, food processing, and hideworking, while ground stone tools are associated with food processing. Animal residues, suggesting meat processing or hide preparation, are present on a range of tool types, but a mano was the only tool found to have plant residue only. The existence 
TABLE 8

DISTRIBUTION OF ARTIFACTS, 41GR291

\begin{tabular}{|c|c|c|c|c|c|c|c|c|c|c|c|c|}
\hline Provenience & $\begin{array}{l}\text { Arrow } \\
\text { Points }\end{array}$ & $\begin{array}{l}\text { Dart } \\
\text { Point }\end{array}$ & Bifaces & $\begin{array}{l}\text { Cobble } \\
\text { Tools }\end{array}$ & Unifaces & Cores & $\begin{array}{l}\text { Edge- } \\
\text { modified } \\
\text { Debitage }\end{array}$ & $\begin{array}{l}\text { Unmodified } \\
\text { Debitage }\end{array}$ & $\begin{array}{l}\text { Hammer- } \\
\text { stones }\end{array}$ & $\begin{array}{l}\text { Ground } \\
\text { Stones }\end{array}$ & Ceramics & Pendant \\
\hline Surface & 2 & 1 & 6 & 1 & 9 & 2 & 5 & 4 & 1 & 8 & - & 1 \\
\hline \multicolumn{13}{|l|}{ Surface } \\
\hline Unit & 1 & - & 2 & 5 & 8 & 5 & 7 & 186 & - & 1 & 1 & - \\
\hline Auger Test 1 & - & - & - & - & - & - & 1 & 1 & - & - & - & - \\
\hline Auger Test 2 & - & - & - & - & - & - & - & 2 & - & - & - & - \\
\hline Auger Test 4 & - & - & - & - & - & - & - & 1 & - & - & - & - \\
\hline Auger Test 10 & - & - & - & - & - & - & - & 3 & - & - & - & - \\
\hline Auger Test 18 & - & - & - & - & - & - & - & 3 & - & - & - & - \\
\hline Auger Test 19 & - & - & - & - & - & - & - & 1 & - & - & - & - \\
\hline Auger Test 22 & - & - & - & - & - & 1 & - & 1 & - & - & - & - \\
\hline Auger Test 24 & - & - & - & - & - & - & - & 2 & - & - & - & - \\
\hline Test Unit 1 & - & - & 1 & - & 2 & - & - & 36 & - & - & 1 & - \\
\hline Test Unit 2 & - & - & - & - & - & - & 2 & 7 & - & - & - & - \\
\hline Test Unit 3 & - & - & - & - & - & - & - & 6 & - & - & - & - \\
\hline Test Unit 4 & - & - & - & - & - & - & 1 & 7 & - & 1 & - & - \\
\hline Test Unit 5 & - & - & - & 1 & - & - & 1 & 16 & 1 & 2 & - & - \\
\hline Test Unit 6 & $\underline{1}$ & $=$ & $=$ & $=$ & $=$ & $=$ & $=$ & 28 & $=$ & $\underline{1}$ & $=$ & $=$ \\
\hline Totals: & 4 & 1 & 9 & 7 & 19 & 8 & 17 & 304 & 2 & 13 & 2 & 1 \\
\hline
\end{tabular}


of an intercultural trade network is evidenced by the nonlocal ceramics of probable Southwestern and Jornado area origin and the kaolinite pendant similar to the Apache Canyon kaolinite from Big Bend National Park. Trade or group mobility to the north and south is evidenced by the use of Tecovas jasper and Central Texas varieties of Cretaceous chert.

The variety of tasks documented in the stone tool assemblage, the evidence of stone tool manufacture, and the presence of cooking and heating features indicate that the site functioned as a campsite. No evidence of structures, such as pithouses found at a Palo Duro Complex site in Hall County (Cruse 1989), was encountered.

41GR323

\section{SITE SETTING}

Site 41GR323 is situated on an upper alluvial terrace on the east side of Grape Creek, ca. $0.9 \mathrm{~km}$ south of its confluence with the Double Mountain Fork, Located on a northwestsoutheast linear rise along the west edge of the terrace, it is adjacent to a prominent west-projecting point bar immediately east of a cutoff chute that separates the point bar from the terrace. The terrace slopes gradually to the west, dropping ca. $12 \mathrm{~m}$ in elevation from the edge of the canyon to the cutoff chute. The southern edge of the upper terrace is a vertical cutbank which exposes $2-4 \mathrm{~m}$ of alluvium above the Grape Creek channel. Site elevation is ca. $2140 \mathrm{ft} \mathrm{msl}$.

The ground surface varies from flat and level to undulating, and part or all of the upper terrace has been mechanically cleared of vegetation resulting in some disturbance. Clearing has left the terrace devoid of large trees, and only a few small mesquites have become reestablished. Vegetation is moderate over most of the upper terrace but considerably denser at the lower end and consists mainly of grasses and small viney plants, probably invader species. Lesser amounts of cholla, tasajillo, and Mormon tea also are present. Live oaks, cottonwoods, and salt cedars are found along the creek.

\section{WORK ACCOMPLISHED}

When 41 GR323 was recorded in 1987, burned rock features and associated artifacts were exposed by erosion along the terrace edges in the northwestern (Area $A$ ) and southeastern (Area B) ends of the site. The central portion appeared to have the potential for buried cultural deposits. A 1987 backhoe trench excavated immediately east of the site yielded no cultural materials, but sediments from $140 \mathrm{~cm}$ below the surface yielded an uncalibrated radiocarbon age of $810 \pm 50$ B.P., indicating that the shallowly buried cultural occupation postdates A.D. 1140 (Bryan and Howard 1989:454). Because the site contains buried cultural deposits, mapping and testing were recommended (Boyd et al. 1989). Consequently, the current investigations included a magnetometer survey, detailed site mapping, surface collection of diagnostic artifacts, recovery of all artifacts from 2 surface collection units, and excavation of 11 auger tests and 10 1xl-m test units (Fig. 20, Table 9).

The magnetometer survey was conducted as part of a pilot study to determine the feasibility of magnetic detection of buried cultural features. A $20 \times 54-m$ magnetic survey was conducted in Area B near exposed features along the cutbank. Subsequent testing of 


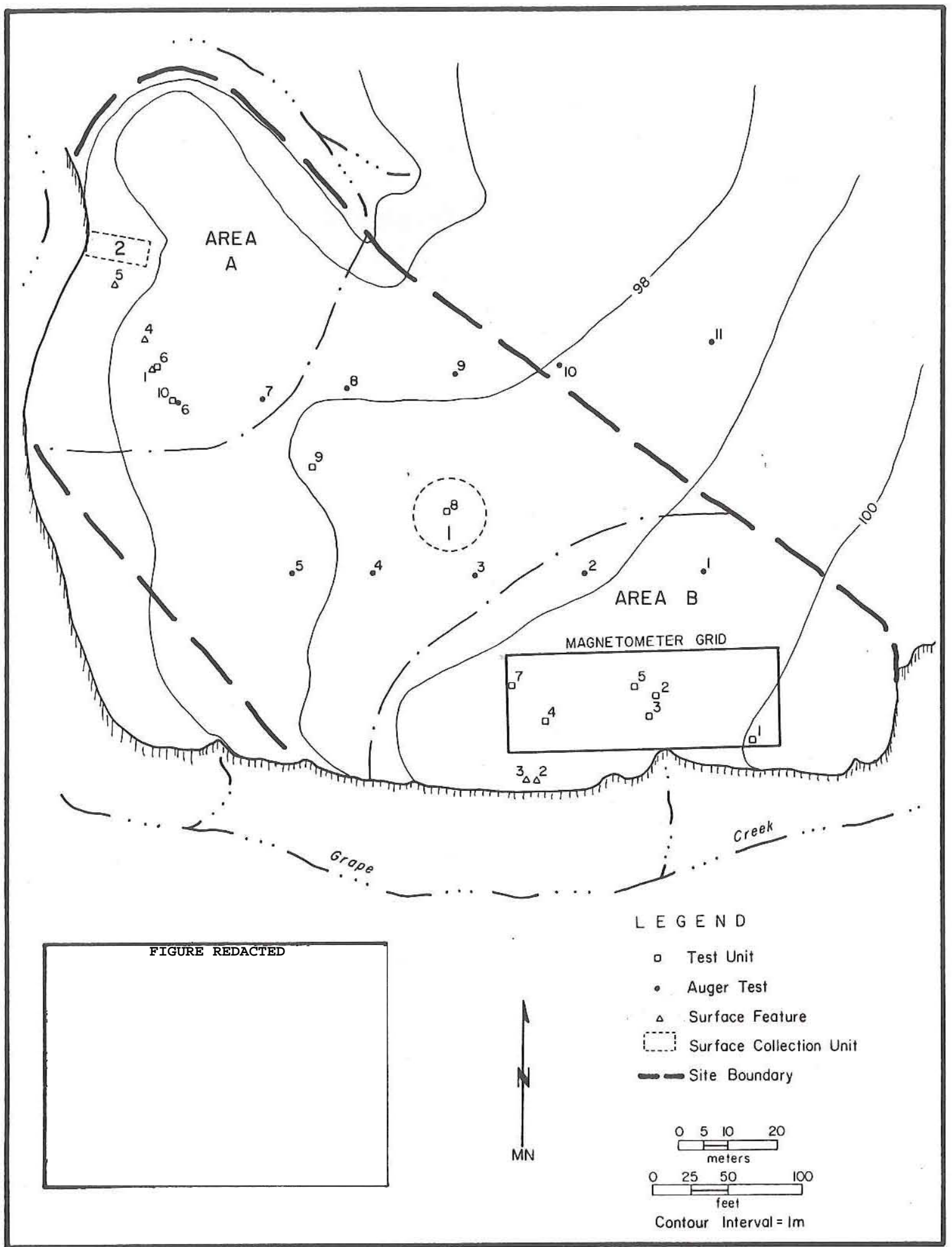

Figure 20. Site map, 41GR323. 
TABLE 9

SUMMARY OF EXCAVATIONS, 41GR323

Depth of

Excavation

Unit (cm)

Reason for Ending Unit
Artifact

Density $\left(\# / \mathrm{m}^{3}\right)$

or Result

$\begin{array}{ll}\text { Test Unit } 1 & 80 \\ \text { Test Unit } 2 & 60 \\ \text { Test Unit } 3 & 70 \\ \text { Test Unit } 4 & 80 \\ \text { Test Unit } 5 & 60 \\ \text { Test Unit } 6 & 70 \\ \text { Test Unit } 7 & 40 \\ \text { Test Unit } 8 & 60 \\ \text { Test Unit } 9 & 70 \\ \text { Test Unit } 10 & 50 \\ & \\ \text { Auger Test } 1 * & 60 \\ \text { Auger Test } 2 * & 58 \\ \text { Auger Test } 3 & 45 \\ \text { Auger Test } 4 & 52 \\ \text { Auger Test } 5 & 60 \\ \text { Auger Test } 6 & 62 \\ \text { Auger Test } 7 & 73 \\ \text { Auger Test } 8 & 64 \\ \text { Auger Test } 9 * & 57 \\ \text { Auger Test } 10 & 58 \\ \text { Auger Test } 11^{*} & 70\end{array}$

Low artifact density

No artifacts

Artifact decrease

Low artifact density

No artifacts

Artifact decrease

Artifact decrease

Artifact decrease

Artifact decrease

Artifact decrease

Arbitrary

Arbitrary

Hardpan clay encountered

Hardpan clay encountered

Gravel encountered

Arbitrary

Arbitrary

Arbitrary

Arbitrary

Hardpan clay encountered

Arbitrary
1.3

0.0

7.1

2.5

0.0

35.7

2.5

80.0

11.4

36.0

positive?

positive?

positive

negative

negative

positive

positive

negative

positive?

negative

positive?

*Encountered possible burned sandstone.

magnetic anomalies revealed that the magnetometer was of limited use in this particular setting. Six test units were excavated within the magnetometer grid. Five of these (Test Units 1-3, 5, and 7) were selected to test positive magnetic anomalies, and one (Test Unit 4) was located in a negative anomaly. These units yielded sparse cultural materials and no evidence of features. The magnetic anomalies are thought to be caused by an organic-rich soil zone underlying the cultural zone.

Considerable amounts of cultural materials are exposed in Area A, and moderate concentrations of lithic debitage were noted in the central area. Exposed cultural materials were collected from both areas; Surface Collection Unit 1 was a 15-m-diameter circle (around Test Unit 8 ) in the central area, and Surface Collection Unit 2 was a $5 \times 12-\mathrm{m}$ block in Area A. 
Auger testing revealed buried cultural deposits in Area A and in the central area. Test Unit 6, located in a burned rock concentration, exposed a burned rock cluster (Feature 1), associated lithic debris, and mussel shell fragments. Test Unit 10, located adjacent to Auger Test 6 from which numerous burned rock fragments were recovered, revealed portions of two burned rock concentrations (Features 6 and 7) and associated lithic debris and mussel shell fragments. Test Unit 8 , located in a surface scatter of lithic debitage, yielded a considerable amount of lithic debris, including an untypable arrow point fragment. Test Unit 9, located near a scatter of burned rocks, yielded lithic debris and mussel shell fragments.

\section{SEDIMENTS AND STRATIGRAPHY}

The alluvial terrace consists of a thick deposit of sands, silts, and clays which are exposed in the Grape Creek cutbank at the southern end. A representative profile in Test Unit 3 consists of three zones: Zone $1,0-40 \mathrm{~cm}$, strong brown (7.5YR 4/6) fine sandy loam, friable; Zone 2, 40-60 cm, dark brown (7.5YR 4/4) silty or clayey loam, blocky, firm to very firm; and Zone 3, 60-80+ cm, brown (7.5YR 5/4) silty loam, blocky, strongly calcareous. Boundaries between zones are gradual. Zone 2 is very clayey and contains organic material including charcoal flecks. This organic-rich clay may represent a marshy pond deposit, perhaps due to ponding behind a former levee.

\section{SITE EXTENT AND DEPTH}

Surface cultural features and artifacts are common in both Areas A and B, but only moderate quantities of artifacts are exposed in the central portion. Based on the distribution of surface materials, the site covers an area of ca. 200x100 m and can be correlated roughly with the slight topographic rise that parallels the cutoff chute at the western edge of the upper terrace. Testing revealed only sparse buried cultural materials to a maximum depth of $50 \mathrm{~cm}$ in Area B. More-abundant cultural materials were found to a maximum depth of $40 \mathrm{~cm}$ in the central area and to at least $50 \mathrm{~cm}$ in Area $\mathrm{A}$. There is no apparent stratification of the cultural materials.

\section{FEATURES}

Five surface burned rock clusters (Features 1-5) were mapped and recorded. Other scatters were observed but were too dispersed to be recorded as features. Surface Feature 1 was tested, and buried Features 6 and 7 were discovered in Test Unit 10. Feature 1 is a $1-\mathrm{m}^{2}$ irregular cluster of burned sandstone slabs partially exposed at 0-13 $\mathrm{cm}$ in Test Unit 6. No charcoal or ashy soil was present. One piece of lithic debitage, mussel shell fragments, and a ground stone fragment recovered from the unit may be associated with the feature. This is probably a hearth that has been scattered by vegetation clearing.

Features 2 and 3 are small clusters of burned sandstone slabs exposed by sheet erosion along the Grape Creek cutbank in Area B. Feature 2 is ovate and measures ca. $45 \times 90 \mathrm{~cm}$; Feature 3 is circular with a diameter of ca. $55 \mathrm{~cm}$. Flakes and mussel shell fragments were noted around Feature 2, and a metate fragment was collected from near Feature 3 . Although neither feature was excavated, both appear to be intact slab-lined hearths. 
Feature 4 is a ca. $250 \times 500-\mathrm{cm}$ surface scatter of burned sandstone and fire-cracked Potter chert fragments in Area A. A chert core, a mano fragment, and two metate fragments were surface collected nearby. The feature was not excavated but probably represents a disturbed hearth or debris scattered on a living surface.

Feature 5 is a ca. $100-\mathrm{cm}$-diameter surface cluster of fire-cracked limestone fragments and a single burned sandstone slab in Area A. The limestone fragments are very small (less than $6 \mathrm{~cm}$ ) and are heat discolored with angular fractures. This feature was not excavated but could be a hearth or a dump of boiling or baking stones.

Feature 6 is a circular hearth of burned sandstone slabs encountered at 9-29 $\mathrm{cm}$ in the southwest corner of Test Unit 10. It extends into the south and west walls of the unit, but ca. $75 \%$ of the feature was excavated. The uppermost slabs are randomly distributed, but the main concentration occurs at 20-29 cm and forms a tight cluster of horizontal slabs with no definite pattern. The rocks dip slightly in various directions and exhibit varying degrees of heat alteration, but no charcoal or ashy soil was present. The upper portion appears to be recently disturbed, while the lower portion does not. Chronometric assays from this feature yielded a corrected radiocarbon age on soil humates of $250 \pm 70$ B.P. (Tx-6222) and a thermoluminescence age of $1840 \pm 375$ B.P. (Dur89TLpfg 135-3BS), but the latter is considered erroneous due to consistent inaccuracies of the thermoluminescence dates on burned rocks. Flotation of feature fill recovered one piece of microdebitage, three bone fragments, snail shells, and a variety of plant remains which could be natural or cultural in origin. The relatively large amount of unburned sunflower seeds and Chenopodium fruit suggests that these remains may be culturally introduced. Organic analysis of a burned rock from Feature 6 yielded probable plant residue, perhaps indicating that the feature was primarily utilized for plant processing. Phytolith analysis of the feature fill produced mostly elongate and chloridoid class phytoliths.

Feature 7 is an irregular-shaped cluster of burned sandstone slabs found at 9-29 $\mathrm{cm}$ in the northeast corner of Test Unit 10. It is similar to Feature 6 in that the uppermost slabs are scattered and the main concentration of burned rocks occurs at $20-29 \mathrm{~cm}$. It extends into the north and east walls of the unit, but there is no apparent patterning and some slabs are vertical. No charcoal or ashy soil was present. The upper portion of this feature appears to be recently disturbed, but the lower concentration appears undisturbed. It probably represents a displaced hearth or burned rock scatter on a living surface. A metate fragment found in the feature and used as a hearthstone yielded probable plant residue. A thermoluminescence assay yielded an age of $1480 \pm 305$ B.P. (Dur89TLqi 135-4BS), which is probably erroneously old.

\section{MATERIALS RECOVERED}

One hundred sixty-three artifacts (excluding 1 microdebitage specimen from a flotation sample) were recovered (Table 10). A single untypable arrow point is the only timediagnostic specimen. Lithic materials are dominantly local chert, but Tecovas jasper and nonlocal Cretaceous chert constitute 10.5\% of the collection. Extraction of organic residues from a bifacial tool yielded indeterminate residue. Other materials recovered consist of 16 burned rocks, numerous mussel shell fragments, and 5 snail shells. 
TABLE 10

DISTRIBUTION OF ARTIFACTS, 41GR323

\begin{tabular}{|c|c|c|c|c|c|c|c|c|c|c|}
\hline Provenience & $\begin{array}{l}\text { Arrow } \\
\text { Point }\end{array}$ & Biface & $\begin{array}{l}\text { Cobble } \\
\text { Tools }\end{array}$ & Unifaces & Cores & $\begin{array}{l}\text { Edge- } \\
\text { modified } \\
\text { Debitage }\end{array}$ & $\begin{array}{l}\text { Unmodified } \\
\text { Debitage }\end{array}$ & Manos & Metates & $\begin{array}{l}\text { Other } \\
\text { Ground } \\
\text { Stones }\end{array}$ \\
\hline Surface & - & - & 1 & 2 & 1 & 1 & 3 & 1 & 5 & 1 \\
\hline \multicolumn{11}{|c|}{ Surface Collection } \\
\hline Unit 1 & - & 1 & - & 1 & - & 3 & 14 & - & - & - \\
\hline \multicolumn{11}{|c|}{ Surface Collection } \\
\hline Unit 2 & - & - & 1 & - & - & 2. & 14 & 1 & - & - \\
\hline Auger Test 3 & - & - & - & - & - & 1 & - & - & - & - \\
\hline Auger Test 6 & - & - & - & - & - & - & 1 & - & - & - \\
\hline Auger Test 7 & - & - & - & - & - & - & 1 & - & - & - \\
\hline Test Unit 1 & - & - & - & - & - & - & 1 & - & - & - \\
\hline Test Unit 3 & - & - & - & - & - & 2 & 3 & - & - & - \\
\hline Test Unit 4 & - & - & - & - & - & 1 & 1 & - & - & - \\
\hline Test Unit 6 & - & - & 1 & 1 & - & 1 & 21 & - & - & 1 \\
\hline Test Unit 7 & - & - & - & - & - & 1 & - & - & - & - \\
\hline Test Unit 8 & 1 & - & - & - & 3 & 1 & 43 & - & - & - \\
\hline Test Unit 9 & - & - & - & - & - & 1 & 7 & - & - & - \\
\hline Test Unit 10 & $=$ & $=$ & $=$ & 1 & $=$ & $\underline{1}$ & 14 & - & 2 & $=$ \\
\hline Totals: & 1 & 1 & 3 & 5 & 4 & $15 \ldots$ & 123 & 2 & 7 & 2 \\
\hline
\end{tabular}




\section{DISCUSSION}

Site 41 GR323 is assigned to the Late Prehistoric period, but the cultural affiliation is unknown. A radiocarbon assay on sediments below the cultural zone yielded an age of $810 \pm 50$ B.P., and a second radiocarbon assay on sediments from Feature 6 yielded an age of $250 \pm 70$ B.P. These are younger than the two thermoluminescence assays on Features 6 and $7,1840 \pm 375$ B.P. and $1480 \pm 305$ B.P. The humate radiocarbon dates represent minimum ages but are considered to be more reliable because of the problems encountered with thermoluminescence dating of burned rocks from this project. A single untypable arrow point is the only time-diagnostic specimen recovered. The best estimate of the age of the occupation is the $810-250$ B.P. range of the two humate radiocarbon dates.

The cultural occupation covers a $100 \times 200-\mathrm{m}$ area and is confined to the upper $40-50 \mathrm{~cm}$, with no apparent vertical separation of cultural materials. Horizontal separation of features and varying densities of artifacts is evidence of discrete activity areas, although the integrity of these deposits may have been compromised by mechanical clearing. The magnetometer survey was of limited usefulness in detecting buried cultural features, probably due to variations in the underlying strata.

A few nonlocal lithics were recovered, but the assemblage is dominated by local materials. Stone tool manufacture is represented by abundant lithic debitage and a few cores. Expedient flake tools are more abundant than finished implements. Burned rock features represent food processing and other unknown activities. Probable plant residue extracted from a metate reused as a hearthstone in Feature 7 and a hearthstone in Feature 6, sparse bone fragments, and numerous mussel shell fragments suggest a range of subsistence activities. Sunflower and Chenopodium were more abundant than other plant remains recovered from Feature 6 and indicate possible food resources. The variety in the artifacts and activities represented suggests a multifunctional campsite. The abundance of cultural materials and the recycling of a broken metate may indicate a relatively long term occupation.

\section{GR359}

\section{SITE SETTING}

Situated in the upland margin on the south side of the Double Mountain Fork ca. $0.8 \mathrm{~km}$ upstream from the mouth of Little Grape Creek, the site occupies the canyon rim surrounding the head of a small box canyon, immediately west of a meander bend in the river. The site is confined to the portion of the upland margin that is dissected by numerous drainages radiating out from the box canyon and does not extend onto the upland flat. Site topography ranges from flat in the upper areas to severely eroded in the lower areas. Bedrock sandstone exposed in the northern portion of the site forms a prominent ledge. Site elevations range from ca. 2210 to $2250 \mathrm{ft} \mathrm{msl}$. An east-west barbed wire fence crosses the southern portion of the site; cattle have probably grazed in the area, but erosion is the dominant disturbance factor. Vegetation is moderate to heavy in the upper portions and sparse in the lower areas, consisting of grasses, junipers, and mesquites, with lesser amounts of prickly pear, tasajillo, hackberry, agarita, catclaw acacia, cholla, Mormon tea, and yucca. 
WORK ACCOMPLISHED

When this site was recorded in 1987, numerous surface artifacts were noted, including an untyped middle Archaic dart point, an untypable dart point fragment, bifaces, ground stones, and lithic debitage. Cores and tested cobbles provided evidence of limited use of the Quaternary gravels on the site. A positive shovel test indicated that buried remains were present, and surface clusters of burned rocks were noted. Because the site contained features and buried deposits, controlled surface collection, mapping, and testing were recommended (Boyd et al. 1989).

The current investigations included mapping, surface collection of diagnostic artifacts, recovery of all artifacts from a surface collection unit, and excavation of 3 shovel tests, 22 auger tests, and 11 test units (FIg. 21, Table 11). Surface inspection revealed considerable quantities of artifacts and scattered burned rocks, and individual artifacts were plotted and collected. No distinct surface features were observed. The surface collection unit was a 12-m-diameter area in a concentration of surface debris in the deflated southeastern end of the site.

A $2-3-m^{2}$ sheltered overhang hidden by vegetation was located along the ledge in the northern portion of the site. Shovel Tests 2 and 3 were excavated inside the sheltered area, and Shovel Test 4 was excavated in the flat terrace immediately in front of the shelter. Although all three tests were very shallow (less than $35 \mathrm{~cm}$ ), Shovel Tests 3 and 4 yielded cultural materials.

of the 22 auger tests excavated in selected locations across the site, 16 yielded cultural evidence. Test unit locations were based on the auger test results. Nine test units were $1 \times 1 \mathrm{~m}$, Test Unit 6 was $1 \times 2 \mathrm{~m}$, and Test Unit 8 was $1 \times 1.5 \mathrm{~m}$. Cultural materials were recovered in 10 of the 11 test units, and two buried features were encountered.

\section{SEDIMENTS AND STRATIGRAPHY}

Excavations revealed that the thickness of sediments above bedrock varies from ca. 20 to $100 \mathrm{~cm}$, with an average of $50-60 \mathrm{~cm}$. A gradual transition into weathered sandstone bedrock occurs with minimal stratigraphic separation. A representative profile in Test Unit 6 consists of thin eolian sands overlying two zones: Zone 1, 3-30 cm, dark yellowish brown (1OYR 4/4) fine sandy loam, friable to firm, contains sparse pebbles; and Zone 2, 30-45 cm, yellowish brown (10YR 5/4) fine silty or sandy loam, firm, granular to blocky structure. The lower boundary of Zone 2 grades into the weathered sandstone on top of the undulating bedrock surface. The sediments seem to represent a combination of colluvial, alluvial, and eolian deposits, with in situ weathering of the sandstone bedrock contributing as well.

\section{SITE EXTENT AND DEPTH}

Based on surface and subsurface artifact distributions, the site covers an area of ca. $250 \times 120 \mathrm{~m}$. Although most concentrated in the upper $30 \mathrm{~cm}$, cultural materials were recovered to a depth of $50 \mathrm{~cm}$. The density of subsurface cultural materials is variable, but no significant concentrations were encountered and no stratification is apparent. 


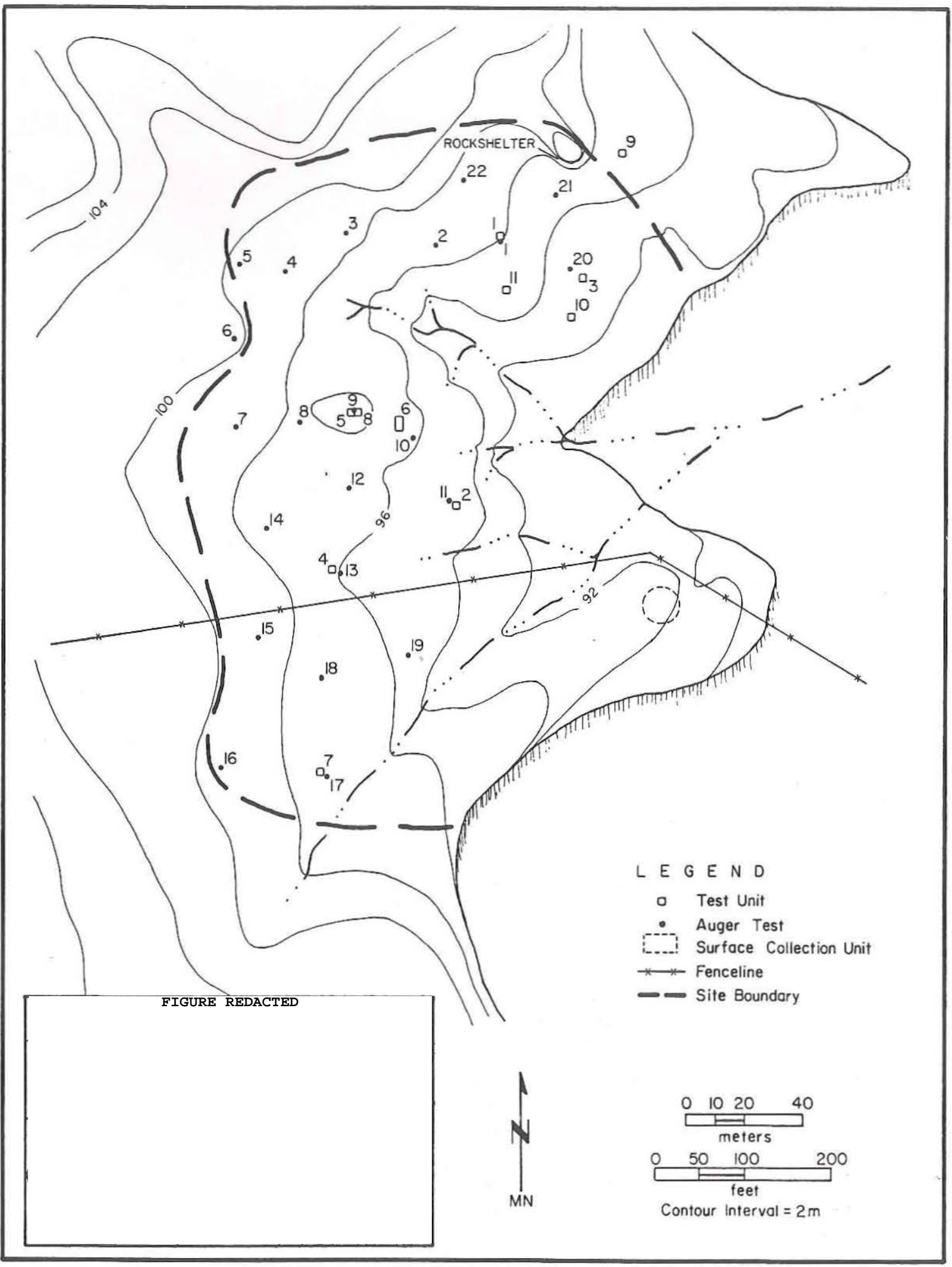

Figure 21. Site map, 41GR359. 
TABLE 11

SUMMARY OF EXCAVATIONS, 41GR359

\begin{tabular}{|c|c|c|c|}
\hline Unit & $\begin{array}{l}\text { Depth of } \\
\text { Excavation } \\
\text { (cm) }\end{array}$ & Reason for Ending Unit & $\begin{array}{l}\text { Artifact } \\
\text { Density }\left(\# / \mathrm{m}^{3}\right) \\
\text { or Result }\end{array}$ \\
\hline Test Unit 1 & 25 & Bedrock reached & 48.0 \\
\hline Test Unit 2 & 60 & Bedrock reached & 65.0 \\
\hline Test Unit 3 & 40 & Bedrock reached & 40.0 \\
\hline Test Unit 4 & 90 & Bedrock reached & 5.6 \\
\hline Test Unit 5 & 32 & Bedrock reached & 53.1 \\
\hline Test Unit 6 & 50 & Bedrock reached & 117.0 \\
\hline Test Unit 7 & 70 & Bedrock reached & 0.0 \\
\hline Test Unit 8 & 60 & - Bedrock reached & 62.2 \\
\hline Test Unit 9 & 30 & Bedrock reached & 6.7 \\
\hline Test Unit 10 & 60 & Bedrock reached & 18.3 \\
\hline Test Unit 11 & 50 & Bedrock reached & 2.0 \\
\hline Shovel Test 2 & 34 & Bedrock reached & negative \\
\hline Shovel Test 3 & 11 & Bedrock reached & positive \\
\hline Shovel Test 4 & 28 & Bedrock reached & positive \\
\hline Auger Test 1 & 75 & Bedrock reached & positive \\
\hline Auger Test 2 & 92 & Bedrock reached & negative \\
\hline Auger Test 3 & 50 & Beđrock reached & negative \\
\hline Auger Test 4 & 98 & Bedrock reached & negative \\
\hline Auger Test 5 & 80 & Bedrock reached & positive \\
\hline Auger Test 6 & 27 & Bedrock reached & negative \\
\hline Auger Test 7 & 24 & Bedrock reached & positive \\
\hline Auger Test 8 & 25 & Bedrock reached & positive \\
\hline Auger Test 9 & 30 & Bedrock reached & positive \\
\hline Auger Test 10 & 25 & Bedrock reached & positive \\
\hline Auger Test 11 & 60 & Bedrock reached & positive \\
\hline Auger Test 12 & 19 & Bedrock reached & positive \\
\hline Auger Test 13 & 103 & Bedrock reached & positive \\
\hline Auger Test 14 & 120 & Arbitrary & negative \\
\hline Auger Test 15 & 77 & Bedrock reached & positive \\
\hline Auger Test 16 & 56 & Bedrock reached & positive \\
\hline Auger Test 17 & 103 & Bedrock reached & positive \\
\hline Auger Test 18 & 33 & Bedrock reached & positive \\
\hline Auger Test 19 & 28 & Bedrock reached & positive \\
\hline Auger Test 20 & 93 & Bedrock reached & positive \\
\hline Auger Test 21 & 105 & Bedrock reached & negative \\
\hline Auger Test 22 & 50 & Bedrock reached & positive \\
\hline
\end{tabular}




\section{FEATURES}

Two subsurface features were encountered. Feature 1 is a 40-cm-diameter cluster of burned sandstone slabs and fragments exposed in the northwest corner of Test Unit 3 at 0-12 $\mathrm{cm}$. It is composed of two to three horizontal, overlapping layers of tabular slabs burned to varying degrees. No charcoal or ashy soil was present, but scattered fire-cracked Potter chert fragments and lithic debitage are associated. This feature is interpreted as a displaced, slab-lined hearth.

Feature 2 is a $40 \times 80-\mathrm{cm}$ cluster of burned rocks exposed at $16-30 \mathrm{~cm}$ in the eastcentral portion of Test Unit 8 . The cluster is composed of ca. 15 sandstone slabs and fragments, ranging from 8-20 cm in maximum length, in one to two horizontal layers. All of the rocks appear to be burned, but no charcoal or ashy soil was present. Fire-cracked Potter chert and lithic debris scattered throughout the unit may be associated. The feature is interpreted as a displaced, slab-lined hearth. A thermoluminescence age of $4740 \pm 960$ B.P. (Dur89TLpfg 134-8AS) from a fire-cracked Potter chert fragment from the same level as the feature is probably erroneous.

\section{MATERIALS RECOVERED}

Four hundred forty-three artifacts were recovered (Table 12). The five timediagnostic artifacts consist of three arrow points (a Granbury and two untyped expandingstem specimens) and two untyped expanding-stem dart points. Lithic materials are dominantly of local cherts, but $2.5 \%$ are of nonlocal cherts. Alibates agate represents ca. $1 \%$ of the chipped stone assemblage, the highest percentage found at any site in the Justiceburg Reservoir project area. Organic residues extracted from five stone tools were analyzed. An end scraper, a mano/hammerstone, and an unmodified flake yielded indeterminate residues; an untyped arrow point yielded animal residue; and a surface-collected end/side scraper had been contaminated with lichen growth. Other materials recovered consist of 106 burned rocks, some mussel shell fragments, and 3 snail shells.

\section{DISCUSSION}

Site 41GR359 is a multicomponent site consisting of Archaic and Late Prehistoric occupations of undetermined cultural affiliation. This assessment is based on the presence of dart and arrow points. A single thermoluminescence assay of a burned rock from Feature 2 yielded a probably incorrect age of $4740 \pm 960$ B.P., although such an age might not be inconsistent with the untyped middle Archaic-style dart point recovered during Phase I.

The components are not vertically or horizontally separable. Cultural materials were recovered from the upper $50 \mathrm{~cm}$ of the sediments but were most concentrated at 0-30 $\mathrm{cm}$. The lack of discrete occupational surfaces and the location in the sloping upland margin suggest that severe erosional disturbance and redeposition of sediments and cultural materials have occurred. Burned rock scatters were noted on the surface, and the features found in the excavations appeared disturbed.

The burned rock features may be related to food processing, but no evidence to support this was found. Scattered mussel shell fragments may indicate the use of freshwater clams as a food resource, and ground stones may be associated with plant processing. Stone tool 
TABLE 12

DISTRIBUTION OF ARTIFACTS, 41GR359

\begin{tabular}{|c|c|c|c|c|c|c|c|c|c|c|}
\hline Provenience & $\begin{array}{l}\text { Arrow } \\
\text { Points }\end{array}$ & $\begin{array}{l}\text { Dart } \\
\text { Points }\end{array}$ & Bifaces & $\begin{array}{l}\text { Cobble } \\
\text { Tools }\end{array}$ & Unifaces & Cores & $\begin{array}{l}\text { Edge- } \\
\text { modified } \\
\text { Debitage }\end{array}$ & $\begin{array}{l}\text { Unmodified } \\
\text { Debitage }\end{array}$ & $\begin{array}{l}\text { Hammer- } \\
\text { stones }\end{array}$ & $\begin{array}{l}\text { Ground } \\
\text { Stones }\end{array}$ \\
\hline Surface & - & 1 & 1 & 3 & 2 & - & - & - & - & 1 \\
\hline \multicolumn{11}{|c|}{ Surface Collection } \\
\hline Unit & 2 & 1 & 3 & 1 & 9 & 13 & 7 & 85 & - & - \\
\hline Auger Test 1 & - & - & - & - & - & - & - & 1 & - & - \\
\hline Auger Test 5 & - & - & - & - & - & $-\cdot$ & - & 1 & - & - \\
\hline Auger Test 7 & - & - & - & - & - & - & - & 1 & - & - \\
\hline Auger Test 8 & - & - & - & - & - & - & - & 1 & - & - \\
\hline Auger Test 9 & - & - & - & 1 & - & - & - & 1 & - & - \\
\hline Auger Test 10 & - & - & - & - & - & - & 1 & 4 & - & - \\
\hline Auger Test 11 & - & - & - & - & - & - & - & 2 & - & - \\
\hline Auger Test 12 & - & - & - & - & - & - & - & 2 & - & - \\
\hline Auger Test 15 & - & - & - & - & - & - & - & 1 & - & - \\
\hline Auger Test 16 & - & - & - & - & - & - & - & - & 1 & - \\
\hline Auger Test 17 & - & - & - & - & - & - & - & - & - & 1 \\
\hline Auger Test 18 & - & - & - & - & - & - & - & 1 & - & - \\
\hline Auger Test 19 & - & - & - & - & - & - & - & 1 & - & - \\
\hline Auger Test 20 & - & - & - & - & 1 & - & - & - & - & - \\
\hline Auger Test 22 & - & - & - & - & - & - & - & 1 & - & - \\
\hline Shovel Test 3 & - & - & - & - & - & - & - & 5 & - & - \\
\hline Shovel Test 4 & - & - & - & - & - & 1 & - & 7 & - & - \\
\hline Test Unit 1 & - & - & - & - & - & - & 1 & 11 & - & - \\
\hline Test Unit 2 & - & - & - & - & - & - & - & 39 & - & - \\
\hline
\end{tabular}


Table 12, continued

\begin{tabular}{|c|c|c|c|c|c|c|c|c|c|c|}
\hline Provenience & $\begin{array}{l}\text { Arrow } \\
\text { Points }\end{array}$ & $\begin{array}{l}\text { Dart } \\
\text { Points }\end{array}$ & Bifaces & $\begin{array}{l}\text { Cobble } \\
\text { Tools }\end{array}$ & Unifaces & Cores & $\begin{array}{l}\text { Edge- } \\
\text { modified } \\
\text { Debitage }\end{array}$ & $\begin{array}{l}\text { Unmodified } \\
\text { Debitage }\end{array}$ & $\begin{array}{l}\text { Hammer- } \\
\text { stones }\end{array}$ & $\begin{array}{l}\text { Ground } \\
\text { Stones }\end{array}$ \\
\hline Test Unit 3 & - & - & - & - & - & - & 1 & 15 & - & - \\
\hline Test Unit 4 & - & - & - & - & - & - & - & 5 & - & - \\
\hline Test Unit 5 & - & - & - & - & - & - & - & 17 & - & - \\
\hline Test Unit 6 & 1 & - & - & 1 & - & 4 & 8 & 101 & 2 & - \\
\hline Test Unit 8 & - & - & - & 2 & 1 & 1 & 3 & 48 & 1 & 3 \\
\hline Test Unit 9 & - & - & - & - & - & - & - & 2 & - & - \\
\hline Test Unit 10 & - & - & - & - & 1 & - & 1 & 9 & - & - \\
\hline Test Unit 11 & - & $=$ & $=$ & - & - & - & $=$ & 1 & $=$ & $=$ \\
\hline Totals: & 3 & 2 & 4 & 8 & 14 & 19 & 22 & 362 & 4 & 5 \\
\hline
\end{tabular}


manufacture is evidenced by the lithic debitage, cores, and hammerstones. The variety of chipped stone tools and preserved organic residues indicate additional activities. All evidence indicates that the locality served as a multifunctional campsite, and the density of cultural materials suggests a relatively intensive occupation. The presence of multiple components and the lack of vertical or horizontal integrity, however, limit the interpretability of the site.

41GR376

\section{SITE SETTING}

Site 41GR376 is situated on an isolated mesa on the north side of the Double Mountain Fork, ca. $0.5 \mathrm{~km}$ northwest of the mouth of Gobbler Creek. The $200 \times 200-\mathrm{m}$ sandstone-capped mesa rises 10-15 $\mathrm{m}$ above the surrounding terrain. A ca. 50x35-m central area rises $5 \mathrm{~m}$ above the rest of the mesa. The surface undulates considerably and alternates between bedrock sandstone and isolated pockets of sediments. The site ranges in elevation from $2280 \mathrm{ft} \mathrm{ms} l$ along the mesa edges to $2313 \mathrm{ft} \mathrm{msl}$ at the highest point on the rise. Vegetation is sparse to moderate and consists mainly of grasses, junipers, and mesquites, with lesser amounts of catclaw acacia, prickly pear, and Mormon tea. Erosion and deflation are evident across the mesa. A buried petroleum pipeline and a parallel barbed wire fence cross the mesa from north to south. Several cull piles attest to considerable artifact collection at the site.

\section{WORK ACCOMPLISHED}

When 41 GR376 was recorded in 1987, burned rocks and abundant lithic tools and debitage were noted, but no features were observed. An untyped dart point, gouges, and unifacial scrapers were collected, and nonlocal Edwards chert and Tecovas jasper were observed. A shovel test yielded lithic debitage and a scraper in the upper $40 \mathrm{~cm}$. Controlled collection, mapping, and testing were recommended (Boyd et al. 1989).

The current investigations consisted of site mapping, controlled surface collection of diagnostic artifacts, and excavation of five 1x1-m test units (Fig. 22, Table 13). Abundant lithic reduction debris, numerous stone tools, and a burned rock cluster (Feature 1) were noted on the surface. Pin-flag probing in sediment pockets revealed that most are extremely shallow (10 cm or less). Test Unit 1 was located over Feature 1, and four additional test units were excavated in areas where surface artifact concentrations were noted and probing indicated some sediment depth. Test Unit 2 yielded no cultural materials, and the other four ylelded only sparse cultural materials.

\section{SEDIMENTS AND STRATIGRAPHY}

The mesa top is covered with a sporadic, thin veneer of sandy sediments and Quaternary gravels. The friable fine sand or sandy loam is light brown (7.5YR 6/4) to brown (7.5YR $5 / 4)$ and varies in thickness from a few centimeters to ca. $20 \mathrm{~cm}$. Site sediments appear to be redeposited (colluvial, alluvial, and eolian) upland sands, indicating severe deflation and erosion. The only substantial accumulations of sediment ( $30 \mathrm{~cm}$ or more) appear to be eolian sands trapped in pockets by vegetation. 


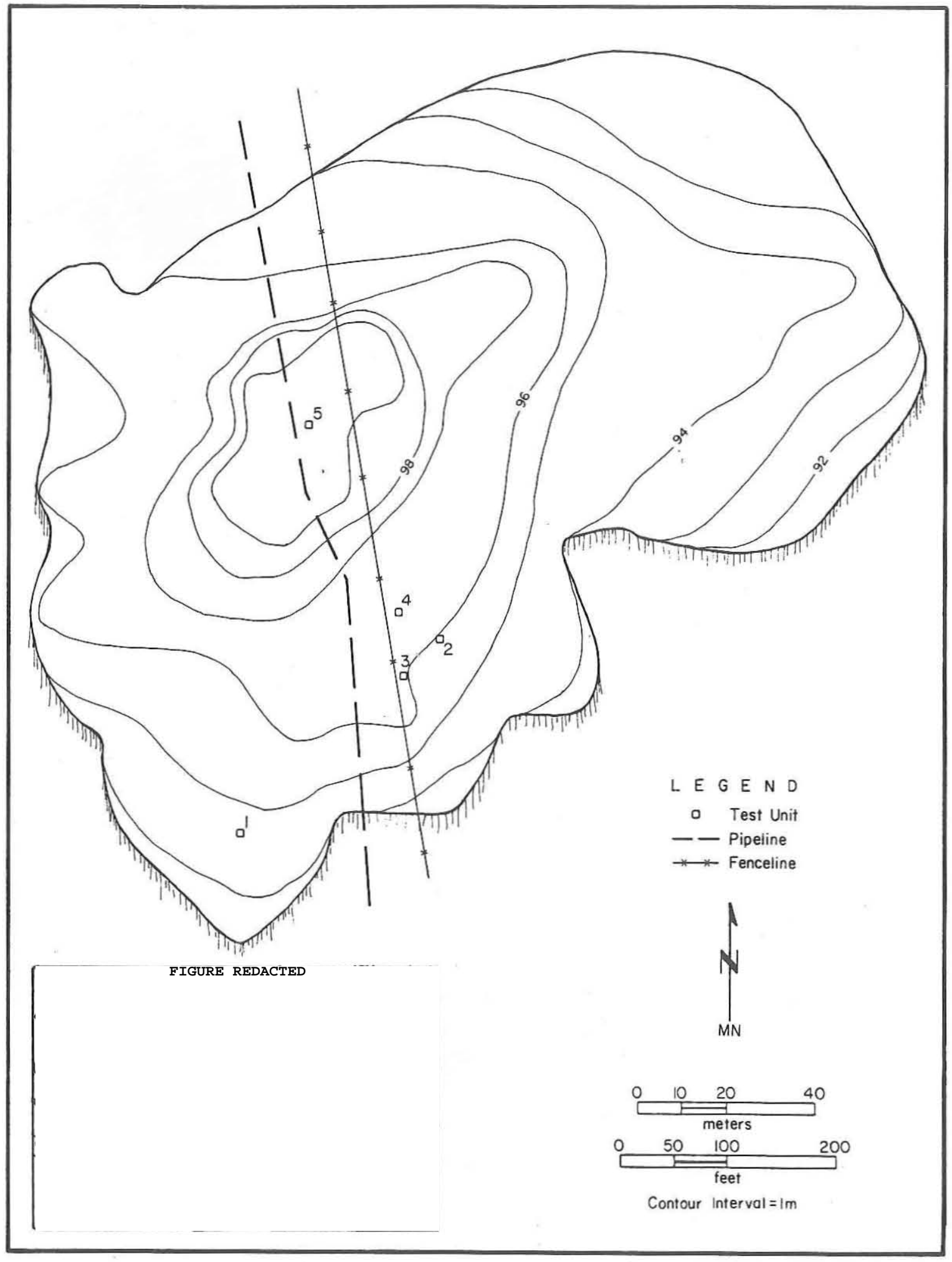

Figure 22. Site map, 41GR376. 
TABLE 13

SUMMARY OF EXCAVATIONS, 41GR376

\begin{tabular}{|c|c|c|c|}
\hline Unit & $\begin{array}{l}\text { Depth of } \\
\text { Excavation } \\
\text { (cm) }\end{array}$ & Reason for Ending Unit & $\begin{array}{l}\text { Artifact } \\
\text { Density }\left(\# / \mathrm{m}^{3}\right)\end{array}$ \\
\hline Test Unit 1 & 30 & Bedrock reached & 23.0 \\
\hline Test Unit 2 & 14 & Bedrock reached & 0.0 \\
\hline Test Unit 3 & 20 & Bedrock reached & 55.0 \\
\hline Test Unit 4 & 20 & Bedrock reached & 0.0 \\
\hline Test Unit 5 & 6 & Bedrock reached & 50.0 \\
\hline
\end{tabular}

\section{SITE EXTENT AND DEPTH}

The site is confined to the $200 \times 200-m$ mesa top, and surface cultural materials occur over the entire area. The sporadic, thin sediments preclude any large areas containing subsurface cultural deposits. Because of the thinness of the sediments, cultural materials are exposed on the surface or very shallowly buried.

FEATURES

Feature 1 is a roughly circular, ca. 75-cm-diameter, single layer of horizontal burned tabular sandstone slabs encountered at 0-5 cm in Test Unit 1 . No charcoal or soil discoloration was noted. An edge-modified flake was found adjacent to the feature. Feature 1 is interpreted as a completely deflated slab-lined hearth.

\section{MATERIALS RECOVERED}

One hundred twenty-three artifacts (Table 14) and six burned rocks were recovered. All artifacts are chipped stone tools and debitage, and no time-diagnostic specimens were found. Also recovered were six burned rocks. The lithic materials are unusual in the amount of nonlocal chert represented; $4.9 \%$ are Tecovas jasper, and $14.6 \%$ are Central Texas varieties of Cretaceous chert. Most of the artifacts were surface collected, but the assemblage is probably biased due to relic collecting. The absence of projectile points may reflect this bias.

\section{DISCUSSION}

Site 41GR376 is tentatively assigned to the Archaic period, but no cultural affiliation is known. A single untyped dart point was recovered during Phase $I$, but testing yielded no time-diagnostic artifacts and no chronometric dates were obtained. Cultural 
TABLE 14

DISTRIBUTION OF ARTIFACTS, $41 \mathrm{GR} 376$

\begin{tabular}{|c|c|c|c|c|c|c|}
\hline Provenience & Bifaces & $\begin{array}{l}\text { Cobble } \\
\text { Tools }\end{array}$ & Unifaces & Cores & $\begin{array}{l}\text { Edge- } \\
\text { modified } \\
\text { Debitage }\end{array}$ & $\begin{array}{l}\text { Unmodified } \\
\text { Debitage }\end{array}$ \\
\hline Surface & 7 & 4 & 13 & 8 & 22 & 48 \\
\hline Test Unit 1 & - & - & - & - & 1 & 6 \\
\hline Test Unit 3 & - & - & - & 2 & - & 9 \\
\hline Test Unit 5 & $=$ & $=$ & $=$ & $\underline{2}$ & $=$ & 1 \\
\hline Totals: & 7 & 4 & 13 & 12 & 23 & 64 \\
\hline
\end{tabular}

materials are limited to chipped stone tools and debitage, but a relatively large amount of nonlocal chert is represented. Lithic reduction and tool manufacture are evident, but relic collection has altered the artifact assemblage to an unknown extent. Only one feature, a deflated hearth, is known, and investigations failed to reveal evidence of its function.

Cultural materials are confined to the mesa top and are surficial or shallowly buried. Sporadic pockets of sediments are unexpectedly shallow, apparently the result of severe deflation and erosion. Cultural materials were recovered to $30 \mathrm{~cm}$, but no cultural or natural stratigraphy was observed, and it is not likely that primary deposits exist. This isolated mesa overlooks a large section of the Gobbler Creek valley and apparently functioned as a lithic workshop and lookout, with only limited camping or food preparation activities occurring. The lack of horizontal and vertical integrity limits the interpretability of the site.

41GR383

\section{SITE SETTING}

Site 41 GR383 is situated in the upland margin on the west side of Gobbler Creek, ca. $1.5 \mathrm{~km}$ northwest of its confluence with the Double Mountain Fork. The northern portion of the site occupies a deflated upland ridge and lower benches, while the southern portion occupies an east-sloping upland flat. The two areas are bisected by an east-west road and borrow ditches which cut into bedrock sandstone, exposing 20-100 cm of sediments. A small gully, ca. $100 \mathrm{~cm}$ wide and $50 \mathrm{~cm}$ deep, has developed on the south side of and parallel to the road, leaving a $100-\mathrm{cm}-$ wide ridge of sediments between the road and gully. The site elevation is $2240-2280 \mathrm{ft} \mathrm{msl}$.

A buried petroleum pipeline across the central portion of the site has caused considerable disturbance. A surface pipeline, barbed wire fences along both sides of the road, 
and a powerline parallel to the road have caused minimal disturbance. Vegetation consists mostly of grasses, junipers, and mesquites, with lesser amounts of Mormon tea, hackberry, yucca, and various shrubs. The northern site area has sparse vegetation, resulting in good surface visibility. The southern site area is covered with dense grasses creating very little surface visibility.

\section{WORK ACCOMPLISHED}

When 41GR383 was recorded in 1987, exposed cultural materials and burned rock features were noted in the northern portion of the site. A gouge and a planar tool were collected, and observed items included a pile of seven manos and several piles of lithic debris considered to be cull piles from artifact collection. A large concentration of burned sandstone exposed in the south roadcut was interpreted as an intensive cooking area or burned rock midden. Controlled collection, mapping, and testing were recommended (Boyd et al. 1989).

The current investigations consisted of site mapping, controlled surface collection of diagnostic artifacts, recovery of all artifacts from a surface collection unit, and excavation of 11 auger tests and 8 test units (Fig. 23, Table 15). Individual artifacts were collected from the northern portion of the site where deflation and erosion have exposed a large area of occupational debris. A concentration of lithic reduction materials was observed along the eroding ridge on the south side of the road. A 60-m-long, 1-m-wide surface collection unit was established along the ridgecrest from which all cultural materials except burned sandstone were collected.

Five $1 \times 1-m$ test units were excavated in the northern portion, and 11 auger tests and 3 test units were excavated in the southern portion. Test units in the northern area (Test Units 2-6) yielded varying amounts of cultural materials and one burned rock cluster (Feature 2). The units in the southern area (Test Units 1, 7, and 8) were located along the surface collection unit and also yielded varying amounts of cultural materials. A burned rock scatter (Feature 1) was encountered in Test Unit 1. The 11 auger tests were located south of the road; of these, 10 yielded cultural materials.

\section{SEDIMENTS AND STRATIGRAPHY}

Sediments in the southern portion of the site consist of only one zone, a brown (7.5YR 4/6) sand or sandy loam which varies in thickness from ca. $30 \mathrm{~cm}$ to over $100 \mathrm{~cm}$ and is thickest south of the road in the area of Auger Test 5. It is friable and structureless and has an abrupt lower boundary, resting directly on a layer of light gray (10YR 7/2) weathered sandstone bedrock.

In the northern portion of the site, the stratigraphy is more variable due to erosion and deflation of the ridge and lower benches. This area generally has two soil zones: an upper zone of friable, calcareous, dark yellowish brown (10YR 4/6) sandy loam with small pebbles; and a lower zone of firm, calcareous, yellowish brown (10YR 5/6) silty loam with blocky structure. The upper zone varies in thickness from a few centimeters to $40 \mathrm{~cm}$, and the lower zone is typically only $20-30 \mathrm{~cm}$ thick above caliche bedrock. 


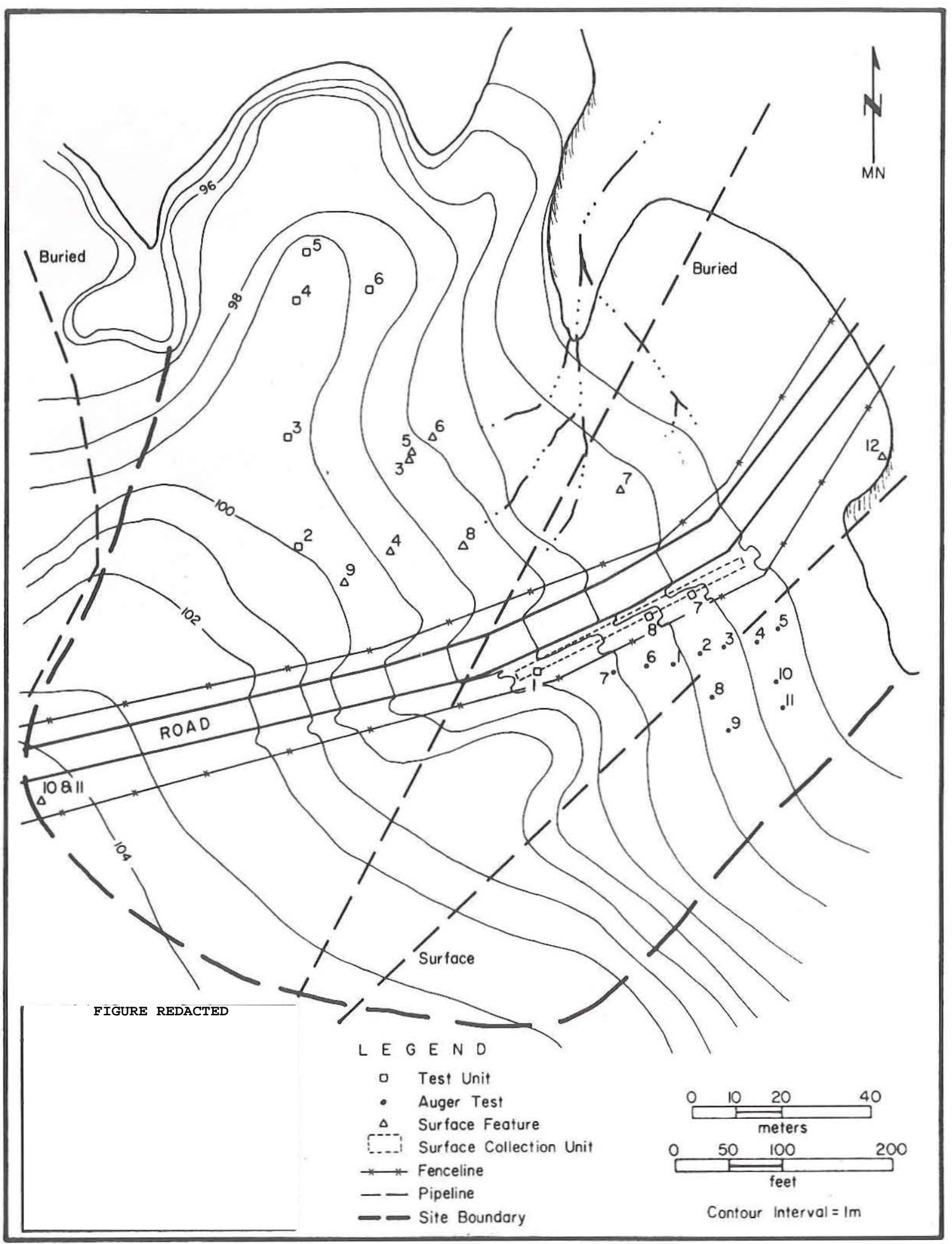

Figure 23. Site map, 41GR383. 
TABLE 15

SUMMARY OF EXCAVATIONS, 41GR383

\begin{tabular}{|c|c|c|c|}
\hline Unit & $\begin{array}{l}\text { Depth of } \\
\text { Excavation } \\
\text { (cm) }\end{array}$ & Reason for Ending Unit & $\begin{array}{l}\text { Artifact } \\
\text { Density }\left(\# / \mathrm{m}^{3}\right) \\
\text { or Result }\end{array}$ \\
\hline Test Unit 1 & 56 & Bedrock reached & 0.0 \\
\hline Test Unit 2 & 40 & Sterile caliche reached & 80.0 \\
\hline Test Unit 3 & 40 & Sterile caliche reached & 45.0 \\
\hline Test Unit 4 & 60 & Artifact decrease & 35.0 \\
\hline Test Unit 5 & 40 & Sterile caliche reached & 7.5 \\
\hline Test Unit 6 & 50 & Sterile caliche reached & 42.0 \\
\hline Test Unit 7 & 45 & Bedrock reached & 57.8 \\
\hline Test Unit 8 & 90 & . Difficulty in digging & 95.6 \\
\hline Auger Test 1 & 85 & Bedrock reached & positive \\
\hline Auger Test 2 & 45 & Bedrock reached & positive \\
\hline Auger Test 3 & 50 & Bedrock reached & positive \\
\hline Auger Test 4 & 103 & Bedrock reached & positive \\
\hline Auger Test 5 & 130 & Bedrock reached & positive \\
\hline Auger Test 6 & 40 & Bedrock reached & positive \\
\hline Auger Test 7 & 100 & Difficulty in digging & positive \\
\hline Auger Test 8 & 70 & Bedrock reached & positive \\
\hline Auger Test 9 & 80 & Bedrock reached & negative \\
\hline Auger Test 10 & 90 & Difficulty in digging & positive \\
\hline Auger Test 11 & 65 & Bedrock reached & positive \\
\hline
\end{tabular}

\section{SITE EXTENT AND DEPTH}

The site conforms to the surface topography on the north and east, following the edges of the upper ridge and lower benches. The western boundary is established by the extent of surface materials on the deflated ridge. The southern boundary is arbitrary at present since auger testing did not extend far enough to adequately define this boundary. The site size is estimated to be ca. $200 \times 150 \mathrm{~m}$.

Cultural materials were recovered on the surface and to a depth of $40 \mathrm{~cm}$ in test units in the northern portion of the site. Cultural materials in the southern area were recovered from the surface collection unit along the roadcut and to $90 \mathrm{~cm}$ in Test Unit 8 ; cultural materials were scattered throughout Test Unit 8, but vertical separation into occupational zones is possible. The auger tests south of the road, where no surface artifacts were found, indicate a substantial buried component. 


\section{FEATURES}

Features at the site consist of two burned rock clusters (Features 1 and 2) encountered in test units, seven surface burned rock concentrations (Features 3-9), and three pointed-oval bedrock mortar holes (Features 10-12). Features 3-9 are burned sandstone slab concentrations which range from small (ca. 30-cm-diameter) circular clusters of 6-10 rocks to large $(120 \times 250-\mathrm{cm})$ irregular clusters of $25-50$ rocks. All are located north of the road in deflating/eroding areas and are interpreted as hearths in various stages of exposure. The bedrock mortar holes were mapped but were not investigated further.

Feature 1 is an amorphous cluster of burned sandstone slabs exposed at 34-50 cm in Test Unit 1. It is composed of ca. 100 sandstone slabs and fragments of various sizes and exhibiting various degrees of thermal discoloration. Some rodent disturbance is present, and no charcoal or ashy soil was noted. The feature probably represents a scatter of burned rocks on a living surface. No cultural materials were associated. Phytolith analysis of feature fill yielded mostly festucoid types. Probable plant residue was extracted from a burned rock.

Feature 2 is a dense cluster of ca. 300 burned and unburned sandstone slabs and fragments encountered at $2-20 \mathrm{~cm}$ in Test Unit 3 . The feature extends into all four walls, but ca. $85 \%$ of the feature is contained within the unit. Two to three layers of tightly packed horizontal rocks encompass a roughly circular, 30-cm-diameter central area which is devoid of rocks but contains charcoal and ashy soil. The feature seems to represent one or more hearths within a dense scatter of burned rocks, and several episodes of rock recycling may be represented. A number of unburned slabs are present but may be natural and incidental to the cultural activities. Phytolith analysis of feature fill yielded mostly festucoid types. Residues of indeterminate origin were extracted from a burned rock. A thermoluminescence assay on burned sandstone yielded a questionable age of 4595 t 925 B.P. (Dur89TLpfg 135-5BS).

\section{MATERIALS RECOVERED}

Three hundred forty-one artifacts were recovered (Table 16) along with 25 burned rocks, an unidentifiable bone fragment, and numerous mussel shell fragments. Temporally diagnostic artifacts consist of four untyped dart points (two expanding-stem specimens and two medial fragments) and one Granbury arrow point. Nonlocal lithic materials, mostly Tecovas jasper, comprise $4.6 \%$ of the chipped stone. Plant residue was extracted from a metate recovered in Test Unit 8.

\section{DISCUSSION}

Site 41GR383 contains evidence of multicomponent Archaic and Late Prehistoric occupations of unknown cultural affiliation. The untyped dart points and Granbury arrow point are not particularly time diagnostic; however, the single thermoluminescence age of $4595 \pm$ 925 B.P. from Feature 2 is probably erroneously old.

Cultural materials were recovered at depths of 0-40 cm in the deflated northern area and at 0-90 cm in the southern area where buried remains are most concentrated. Vertical separation of stratified cultural remains is possible in the southern portion of the site. 
TABLE 16

DISTRIBUTION OF ARTIFACTS, 41GR383

\begin{tabular}{|c|c|c|c|c|c|c|c|c|c|c|c|c|}
\hline Provenience & $\begin{array}{l}\text { Arrow } \\
\text { Point }\end{array}$ & $\begin{array}{l}\text { Dart } \\
\text { Points }\end{array}$ & Bifaces & $\begin{array}{l}\text { Cobble } \\
\text { Tools }\end{array}$ & Unifaces & Cores & $\begin{array}{l}\text { Edge- } \\
\text { modified } \\
\text { Debitage }\end{array}$ & $\begin{array}{l}\text { Unmodified } \\
\text { Debitage }\end{array}$ & $\begin{array}{l}\text { Hammer- } \\
\text { stone }\end{array}$ & Manos & Metate & $\begin{array}{l}\text { Ground } \\
\text { Stones }\end{array}$ \\
\hline Surface & 1 & 3 & 7 & 5 & 26 & 1 & 4 & 21 & 1 & 5 & - & 2 \\
\hline \multicolumn{13}{|l|}{ Surface Collection } \\
\hline Unit & - & 1 & - & - & 3 & - & 4 & 18 & - & 1 & - & 2 \\
\hline Auger Test 1 & - & - & - & - & 1 & - & - & 3 & - & - & - & - \\
\hline Auger Test 2 & - & - & - & - & - & - & - & 4 & - & - & - & - \\
\hline Auger Test 3 & - & - & - & - & - & - & - & 2 & - & - & - & - \\
\hline Auger Test 4 & - & - & 1 & - & - & - & - & 5 & - & - & - & - \\
\hline Auger Test 5 & - & - & - & - & - & - & - & 3 & - & - & - & - \\
\hline Auger Test 6 & - & - & - & - & - & - & - & 3 & - & - & - & - \\
\hline Auger Test 7 & - & - & - & - & - & - & - & 2 & - & - & - & - \\
\hline Auger Test 8 & - & - & - & - & - & - & - & 1 & - & - & - & - \\
\hline Auger Test 10 & - & - & - & - & - & - & - & 1 & - & - & - & - \\
\hline Auger Test 11 & - & - & - & - & - & - & - & 2 & - & - & - & 1 \\
\hline Test Unit 2 & - & - & - & - & - & - & 1 & 31 & - & - & - & - \\
\hline Test Unit 3 & - & - & - & 1 & 2 & - & - & 14 & - & - & - & 1 \\
\hline Test Unit 4 & - & - & - & - & - & - & 1 & 20 & - & - & - & - \\
\hline Test Unit 5 & - & - & - & - & - & 1 & 1 & 1 & - & - & - & - \\
\hline Test Unit 6 & - & - & - & - & - & - & $4-$ & 17 & - & - & - & - \\
\hline Test Unit 7 & - & - & - & 1 & - & - & - & 25 & - & - & - & - \\
\hline Test Unit 8 & $=$ & $=$ & $=$ & $\underline{2}$ & $=$ & 1 & 7 & 74 & $=$ & $=$ & 1 & 1 \\
\hline Totals: & 1 & 4 & 8 & 9 & 32 & 3 & 22 & 247 & 1 & 6 & 1 & 7 \\
\hline
\end{tabular}


Features and variable artifact densities indicate spatial segregation of activities, but horizontal separation of components was not observed.

A wide variety of activities is evident, and the site appears to be a multifunctional campsite. Burned rock features, bedrock mortar holes, and a range of chipped and ground stone tools suggest various subsistence-related activities. Plant residue extracted from a metate fragment and probable plant residue from a burned rock in Feature 1, abundant mussel shell fragments, and a poorly preserved bone fragment indicate possible food processing. Tool manufacturing is indicated by lithic debitage, a hamerstone, and probable preforms, and nonlocal lithic materials indicate limited intercultural exchange or group mobility.

\section{$41 \mathrm{GR} 456$}

\section{SITE SETTING}

Site 41 GR456 is situated on a west-bank bedrock/alluvial terrace at the mouth of Rocky Creek. The terrace slopes gently to moderately eastward, and bedrock is exposed in the eastern end of the site. Elevations range from $2210 \mathrm{ft} \mathrm{ms} 1$ in the upper portion to $2180 \mathrm{ft}$ msl along the cutbank of Rocky Creek. Active erosion has cut west-east gullies across the site, but the main disturbance is a north-south petroleum pipeline cut through the eastern end of the terrace; erosion along the cut continues to expose cultural materials. Vegetation is moderate to dense over most of the terrace except where erosion is active. It consists mainly of grasses, junipers, and mesquites, with lesser amounts of cholla, prickly pear, yucca, agarita, and small shrubs.

\section{WORK ACCOMPLISHED}

When this site was recorded in 1987, chipped and ground stone tools, lithic debitage, and burned rock features were concentrated along the pipeline cut and in erosional gullies. Among the collected artifacts was a biface of Tecovas jasper. Controlled collection, mapping, and testing were recommended (Boyd et al. 1989).

The current investigations consisted of site mapping, controlled surface collection of diagnostic artifacts, and excavation of 16 auger tests and $71 \times 1-m$ test units (Fig. 24, Table 17). Surface inspection located six burned rock concentrations (Features 2 and 6-10) and two bedrock mortar holes (Features 11 and 12). Pin-flag probing in the thin sands overlying the surrounding bedrock failed to locate additional mortar holes, but the potential for buried mortar holes exists.

An east-west line of auger tests was excavated across the terrace, and additional auger tests were placed north of this line. Of the 16 auger tests, 10 yielded cultural evidence. Test unit locations were based on auger test results and the distributions of surface artifacts and features. Test units were excavated to depths ranging from 40 to $150 \mathrm{~cm}$, and all seven yielded cultural materials. Test Unit 1 was located within a surface scatter of burned rocks, and Features 2 and 3 were encountered. Test Units 2, 4, and 6 were located in areas where auger tests indicated that buried cultural materials were likely. Test Units 3, 5, and 7 were located near exposed cultural materials in the eroded area near the pipeline cut; Test Unit 5 was located within a surface scatter of burned 


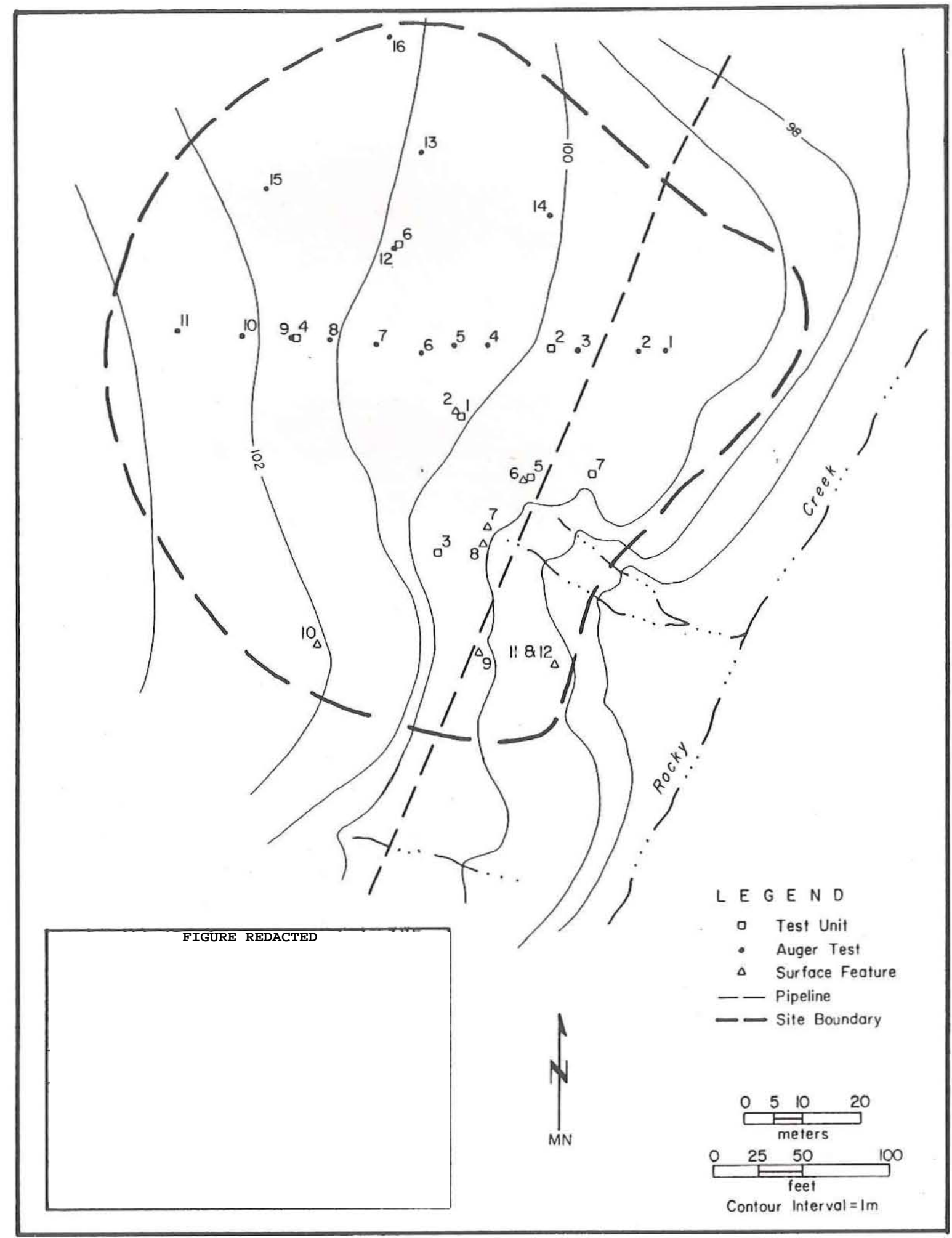

Figure 24. Site map, 41GR456. 
TABLE 17

SUMMARY OF EXCAVATIONS, 41GR456

\begin{tabular}{|c|c|c|c|}
\hline Unit & $\begin{array}{l}\text { Depth of } \\
\text { Excavation } \\
(\mathrm{cm})\end{array}$ & Reason for Ending Unit & $\begin{array}{l}\text { Artifact } \\
\text { Density }\left(\# / \mathrm{m}^{3}\right) \\
\text { or Result }\end{array}$ \\
\hline Test Unit 1 & 100 & Artifact decrease & 36.0 \\
\hline Test Unit 2 & 140 & Artifact decrease & 32.1 \\
\hline Test Unit 3 & 40 & Low artifact density & 12.5 \\
\hline Test Unit 4 & 58 & Bedrock reached & 13.8 \\
\hline Test Unit 5 & 80 & Arbitrary & 31.3 \\
\hline Test Unit 6 & 150 & Arbitrary & 16.7 \\
\hline Test Unit 7 & 80 & Artifact decrease & 25.0 \\
\hline Auger Test 1 & $125^{\circ}$ & Maximum depth of auger & negative \\
\hline Auger Test 2 & 125 & Maximum depth of auger & negative \\
\hline Auger Test 3 & 125 & Maximum depth of auger & negative \\
\hline Auger Test 4 & 130 & Maximum depth of auger & positive* \\
\hline Auger Test 5 & 125 & Maximum depth of auger & positive* \\
\hline Auger Test 6 & 100 & Arbitrary & positive \\
\hline Auger Test 7 & 125 & Maximum depth of auger & positive \\
\hline Auger Test 8 & 120 & Maximum depth of auger & positive \\
\hline Auger Test 9 & 55 & Bedrock reached & positive \\
\hline Auger Test 10 & 85 & Bedrock reached & positive* \\
\hline Auger Test 11 & 100 & Bedrock reached & positive \\
\hline Auger Test 12 & 120 & Maximum depth of auger & positive \\
\hline Auger Test 13 & 110 & Arbitrary & positive* \\
\hline Auger Test 14 & 100 & Arbitrary & negative \\
\hline Auger Test 15 & 110 & Arbitrary & negative \\
\hline Auger Test 16 & 90 & Bedrock reached & negative \\
\hline
\end{tabular}

rocks (Feature 6). Two burned rock concentrations (Features 1 and 5) and a small patch of burned earth (Feature 4) were discovered in Test Unit 3.

SEDIMENTS AND STRATIGRAPHY

Sediments overlying the bedrock terrace consist of sands and silty loams with a general increase in small siliceous and caliche pebbles with depth. The sediments vary in thickness from $58 \mathrm{~cm}$ in Test Unit 4 to over $150 \mathrm{~cm}$ in Test Unit 6 and are generally thickest in the northern portion. A representative profile in Test Unit 1 consists of six zones: Zone 1, 0-5 cm, strong brown (7.5YR 4/6) silty loam, friable, contains sparse pebbles; Zone 2, 5-20 cm, strong brown (7.5YR 4/6) silty loam, firm, blocky structure, 
calcareous, contains sanđstone slabs (manuports); Zone 3, 20-55 cm, strong brown (7.5YR 4/6), friable, blocky structure, calcareous; Zone 4, 55-75 cm, brown to dark brown (7.5YR 4/4) silty loam, friable, blocky structure, sparse pebbles; and Zone 5, 75-100 cm, brown to dark brown (7.5YR 4/4) silty loam, friable, blocky structure, calcareous, sparse gravels. Rodent disturbance was noted throughout. All boundaries are gradual, and zones are distinguished only on the basis of subtle differences in structure and consistency. Similar stratigraphic profiles were observed in the other test units, but zones cannot be correlated directly between units. The sediments appear to be alluvial floodplain deposits with some mixing of colluvial materials from the valley slopes immediately to the west.

\section{SITE EXTENT AND DEPTH}

The east and west boundaries are defined by the edge of Rocky Creek and the base of the valley slope, respectively. The southern boundary is formed by the extent of surface artifacts, but the northern boundary is more arbitrary, being the extent of buried materials encountered in auger tests. The site covers an area of ca. $110 \times 120 \mathrm{~m}$.

Cultural materials are exposed on the surface in the eastern portion and are buried in the western and northern areas. The sediments vary from ca. 50 to $150 \mathrm{~cm}$ in thickness but average over $100 \mathrm{~cm}$. Cultural materials were recovered from all zones to a depth of $150 \mathrm{~cm}$ with no apparent vertical separation; a considerable amount of rodent disturbance was noted throughout, particularly below ca. $80 \mathrm{~cm}$.

\section{FEATURES}

Twelve features are present, including 10 burned rock concentrations (Features 1-10) and 2 bedrock mortar holes (Features 11 and 12). Four burned rock concentrations (Features 1 and 3-5) were discovered in the excavations, two (Features 2 and 6) were exposed on the surface and tested, and four (Features 7-10) are exposed on the surface and were not further investigated. The latter four are all scatters or small clusters of burned sandstone; of these, only Feature 10 appears to be concentrated enough to represent an intact hearth.

Feature 1 is a concentration of burned and unburned sandstone exposed at 5-20 cm in the southern half of Test Unit 3. It consists of ca. 25 slabs and fragments dipping slightly to form a rough basin. The feature covers a ca. 40x70-cm area and is irregular in plan view, with no apparent patterning. No charcoal, ashy soil, or artifacts were associated. This feature is interpreted as a disturbed hearth on an occupational surface. It may be associated with Feature 4.

Feature 2 is a cluster of burned sandstone slabs and fragments exposed at $0-21 \mathrm{~cm} \mathrm{in}$ the southwest corner of Test Unit 1. The feature consists of ca. $75 \%$ of an $80-\mathrm{cm}-\mathrm{diameter}$ circular concentration. Scattered burned rocks are found across the entire unit, and some burned limestone fragments are also present. The feature is somewhat irregular but has a basin-shaped configuration with slabs dipping toward the center. It is interpreted as a slab-lined hearth, but no charcoal, ashy soil, or artifacts are associated.

Feature 3 is a portion of a burned rock cluster exposed at 24-35 cm in the east half of Test Unit 1. It consists of a dense concentration of burned sandstone slabs in a 
half-circle which extends into the east wall. The feature represents ca. 50-60\% of a 70-cm-diameter circular hearth with slabs generally horizontal or dipping slightly in various directions. No charcoal or ashy soil was present. A large, functional sandstone metate fragment was found face-down on top of the feature, and probable plant residue was extracted from it. Several technical studies of Feature 3 were performed. A thermoluminescence assay of a burned rock yielded a questionable age of $4495 \pm 900$ B.P. (Dur89TLqi 135-6BS). Plant and probable plant residues were extracted from two burned rocks, perhaps a result of food processing activities. Phytolith analysis of the feature fill yielded mostly festucoid, chloridoid, and elongate types. Flotation of feature fill yielded burned and unburned juniper wood, snail shells, two flakes, and a microdebitage specimen.

Feature 4 is a small circular patch of intensively burned earth found at 24-26 cm in the east-centrai portion of Test Unit 3. The 14-cm-diameter area of heat-reddened earth forms a shallow basin, but no charcoal or ashy soil was associated. It may be associated with burned rock Features 1 or 5 found at approximately the same level. Feature 4 is interpreted as representing the location of a hearth; burned rocks in the nearby features may be displaced from this location.

Feature 5 is a cluster of sandstone slabs and fragments exposed at 20-35 cm in Test Unit 3. It consists of a dense cluster of horizontal tabular slabs, varying from 8-35 cm in maximum length, in two to four layers with no patterning to the arrangement. A few rocks are burned, but most appear to be unburned. Charcoal flecks were found only in the upper part. The function is unknown; it may represent a combination of natural rocks and cultural debris accumulating on an occupational surface or displaced rocks from Feature 4.

Feature 6 is an amorphous $50 \times 80-\mathrm{cm}$ scatter of horizontal burned sandstone slabs scattered in an apparently random pattern at 0-18 cm in the northern portion of Test Unit 5 . The rocks are burned to various degrees, but no charcoal or ashy soil was noted; some lithic debitage was associated. This feature is interpreted as a scatter of debris on an occupational surface, possibly representing a displaced hearth.

Two sediment-filled bedrock mortar holes (Features 11 and 12) were discovered along the edge of a prominent bedrock exposure along Rocky Creek. Excavation revealed that they are of the pointed-oval type common in the region (Fig. 25). The northernmost mortar hole (Feature 11) is a long narrow oval measuring $42 \times 8 \times 16 \mathrm{~cm}$. Feature 12 is a wider oval measuring $41 \times 17 \times 27 \mathrm{~cm}$. The depths are estimated since the upper portion of the bedrock sandstone slab has broken along a bedding plane and slipped horizontally. The bottom 3-5 cm of the mortar holes remains undiscovered in the underlying slab of sandstone. A ground sandstone pestle fragment (distal end) was found inside Feature 12. Residues of indeterminate origin were extracted from the specimen. A scraping off the wall of the mortar hole was dominated by microhair, festucoid, and elongate phytoliths.

\section{MATERIALS RECOVERED}

One hundred ninety-four artifacts (excluding 1 microdebitage specimen from flotation) were recovered (Table 18) along with 23 burned rocks, 5 poorly preserved unidentified bone fragments, mussel shell fragments, and numerous snail shells. The two time-diagnostic artifacts are a distal arrow point fragment and a medial dart point fragment. Nonlocal lithic materials represent $10.9 \%$ of the chipped stone and are dominantly Tecovas jasper. 


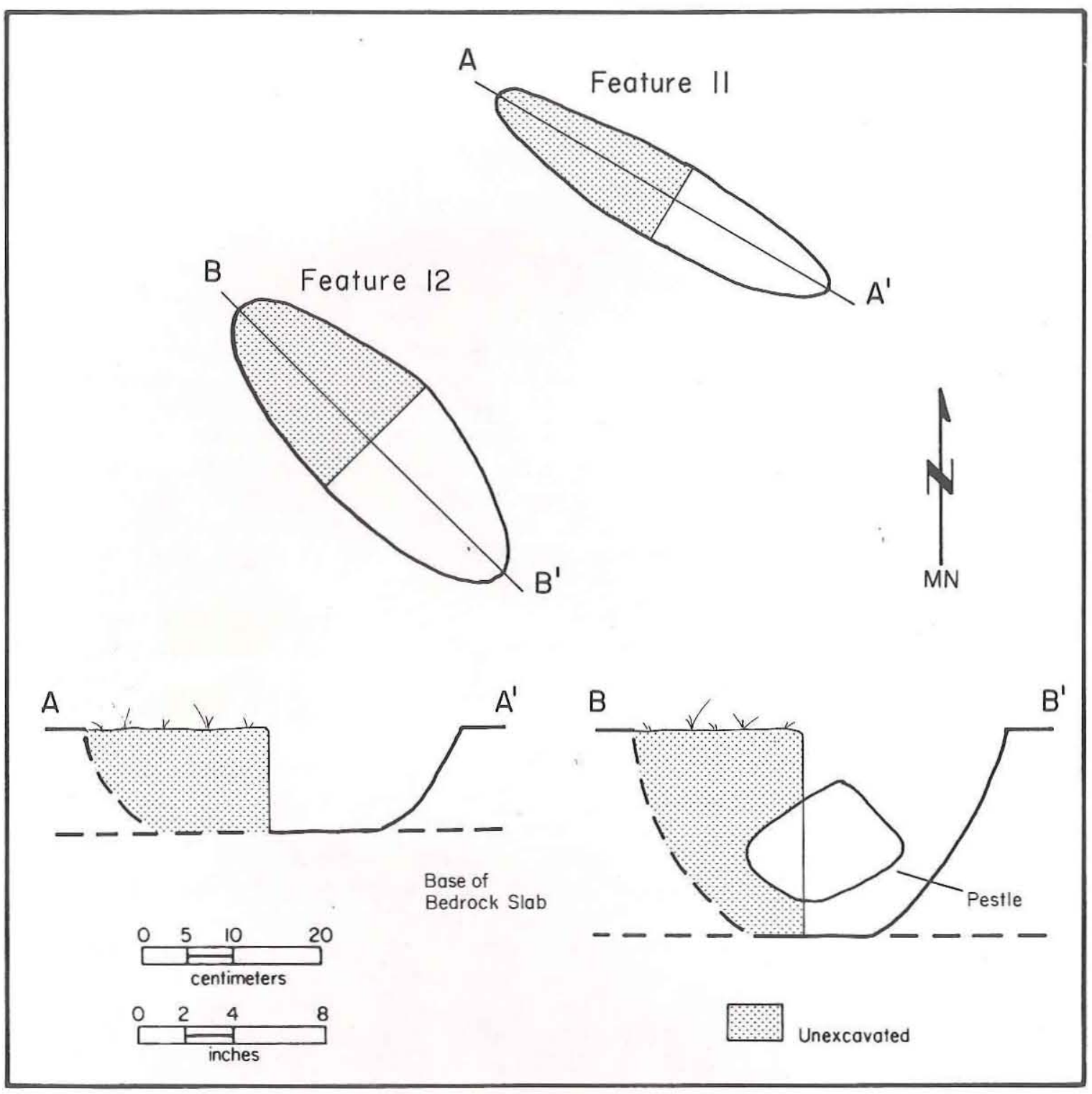

Figure 25. Pointed-oval bedrock mortars at 41GR456.

\section{DISCUSSION}

Based on the presence of untypable dart and arrow point fragments, multicomponent Archaic and Late Prehistoric occupations of unknown cultural affiliation are tentatively indicated. The single thermoluminescence age of $4495 \pm 900$ B.P. from Feature 3 is of questionable accuracy. Cultural materials were recovered from depths of 0-150 cm with no apparent vertical separation. Rodent disturbance noted throughout the alluvial sediments may account for the presence of most or all of the artifacts found below ca. $80 \mathrm{~cm}$. Spatially discrete activities are evidenced by features and variable artifact densities, but no horizontal separation of components was observed. 
TABLE 18

DISTRIBUTION OF ARTIFACTS, 41GR456

\begin{tabular}{|c|c|c|c|c|c|c|c|c|c|}
\hline Provenience & $\begin{array}{l}\text { Arrow } \\
\text { Point }\end{array}$ & $\begin{array}{l}\text { Dart } \\
\text { Point }\end{array}$ & Bifaces & $\begin{array}{l}\text { Cobble } \\
\text { Tools }\end{array}$ & Unifaces & Cores & $\begin{array}{l}\text { Edge- } \\
\text { modified } \\
\text { Debitage }\end{array}$ & $\begin{array}{l}\text { Unmodified } \\
\text { Debitage }\end{array}$ & $\begin{array}{l}\text { Ground } \\
\text { Stones }\end{array}$ \\
\hline Surface & - & - & 1 & 2 & 3 & 1 & - & 2 & - \\
\hline Feature 12 & - & - & - & - & - & - & - & - & 1 \\
\hline Auger Test 6 & - & - & - & - & - & - & - & 2 & - \\
\hline Auger Test 7 & - & - & - & - & - & - & - & 1 & - \\
\hline Auger Test 8 & - & - & - & - & - & - & - & 2 & - \\
\hline Auger Test 9 & - & - & - & - & - & - & - & 2 & - \\
\hline Auger Test 11 & - & - & . - & - & - & - & - & 4 & - \\
\hline Auger Test 12 & - & - & 1 & - & - & - & 1 & 7 & - \\
\hline Test Unit 1 & - & - & - & - & 1 & 1 & 2 & 31 & 1 \\
\hline Test Unit 2 & - & - & 1 & - & - & - & 1 & 43 & - \\
\hline Test Unit 3 & - & - & - & - & - & - & - & 5 & - \\
\hline Test Unit 4 & - & - & - & - & - & - & - & 8 & - \\
\hline Test Unit 5 & 1 & 1 & - & - & - & - & 1 & 22 & - \\
\hline Test Unit 6 & - & - & - & - & 1 & - & 2 & 22 & - \\
\hline Test Unit 7 & $=$ & $=$ & $=$ & $=$ & $=$ & $=$ & $\underline{2}$ & 18 & $=$ \\
\hline Totals: & 1 & 1 & 3 & 2 & 5 & 2 & 9 & 169 & 2 \\
\hline
\end{tabular}

Burned rock features and bedrock mortar holes are evidence of food preparation. Probable plant residues were extracted from two burned rocks and a metate associated with Feature 3, and a wide range of phytoliths were recovered from a bedrock mortar (Feature 12). Numerous mussel shell fragments and unidentified bone fragments may indicate the exploitation of faunal resources. Evidence of tool manufacture is limited to lithic debitage, but the range of formal stone tools indicates that other tasks were also being performed. Nonlocal lithic materials are evidence of intercultural trade or group mobility. The variety of activities represented suggests that the locality is a multifunctional campsite, but the presence of multiple components and lack of vertical integrity limit the interpretability of the site.

41GR515

SITE SETTING

Site 41GR515 is situated on an erosional remnant terrace on the south side of the Double Mountain Fork, ca. $1 \mathrm{~km}$ downstream from the mouth of Red Branch and immediately east of the river channel at a point where the river runs almost due north. The site occupies 
the eroding bedrock edge and sandy flats of the remnant terrace. Two deflated knolls in the southwestern portion are the highest points. The western edge, including the knolls, is dissected by erosion, exposing minor amounts of siliceous gravels. An east-west dirt road across the northern portion exposes over $2 \mathrm{~m}$ of sediments. A north-south barbed wire fence through the site marks a property line. The elevation is ca. 2210-2230 ft msl. Vegetation cover is moderate to sparse in the upper area and moderate to heavy in the lower area and consists mainly of grasses, junipers, and mesquites, with lesser amounts of cholla, agarita, prickly pear, yucca, and small shrubs.

\section{WORK ACCOMPLISHED}

When this site was recorded in 1987, two distinct hearth features were noted. One was exposed in a roadcut at a depth of $130 \mathrm{~cm}$ and contained charcoal inside a cluster of burned rocks. A Harrell arrow point was collected, and numerous stone tools (e.g., scraper, mano, hammerstone) were noted. The roadcut exposure and a positive shovel test indicated the presence of buried cultural materials. Controlled collection, mapping, and testing were recommended (Boyd et al. 1989).

The current investigations consisted of site mapping, surface collection of diagnostic artifacts, and excavation of 3 backhoe trenches, 19 auger tests, and 7 test units (Fig. 26, Table 19). A surface inspection relocated the two hearths and three additional burned rock features. Surface artifacts were not abundant, and all lithic tools were collected. The auger tests were excavated in north-south transects across the site; only 3 of the 19 yielded cultural materials.

Test unit locations were selected on the basis of surface exposures and auger test results. Test Units 1-3 were located on top of knolls in the southern portion, and Test Unit 5 was located in the southern site area near Auger Test 14. A buried burned rock cluster (Feature 1) was discovered in Test Unit 1; as a result, the original 1xl-m test unit was expanded to $1 \times 1.5 \mathrm{~m}$. Test Units 4,6 , and 7 were located in the northern portion, with Test Unit 4 located over the buried hearth observed in 1987 (Feature 2). Backhoe Trenches 19-21 were excavated along the eastern site boundary. Only Backhoe Trench 21 yielded cultural materials.

\section{SEDIMENTS AND STRATIGRAPHY}

The sediments along the western edge consist of sporadic sandy sediments generally less than $100 \mathrm{~cm}$ thick. Bedrock and siliceous gravels are exposed along the edges of the knolls and drainages. The sandy sediments increase in thickness to the east and north of the knolls. The stratigraphy of Backhoe Trench 21 (see Appendix A) in the northern portion is representative: Zone $1,0-35 \mathrm{~cm}$, loose fine sand; Zone 2, 35-140 cm, gravelly fine loamy sand; and Zone 3, 140-205 cm, bedded coarse sandy gravel. Zone 3 is considered an alluvial channel deposit, while Zones 1 and 2 are probably colluvial/alluvial fan deposits. Sandy sediments were noted in Backhoe Trench 20 to a depth of $410 \mathrm{~cm}$, and bedrock was not reached.

\section{SITE EXTENT AND DEPTH}

The site is bounded on the west by the topographic drop to the river channel, but the boundaries on all other sides are defined by the extent of buried cultural materials. The 


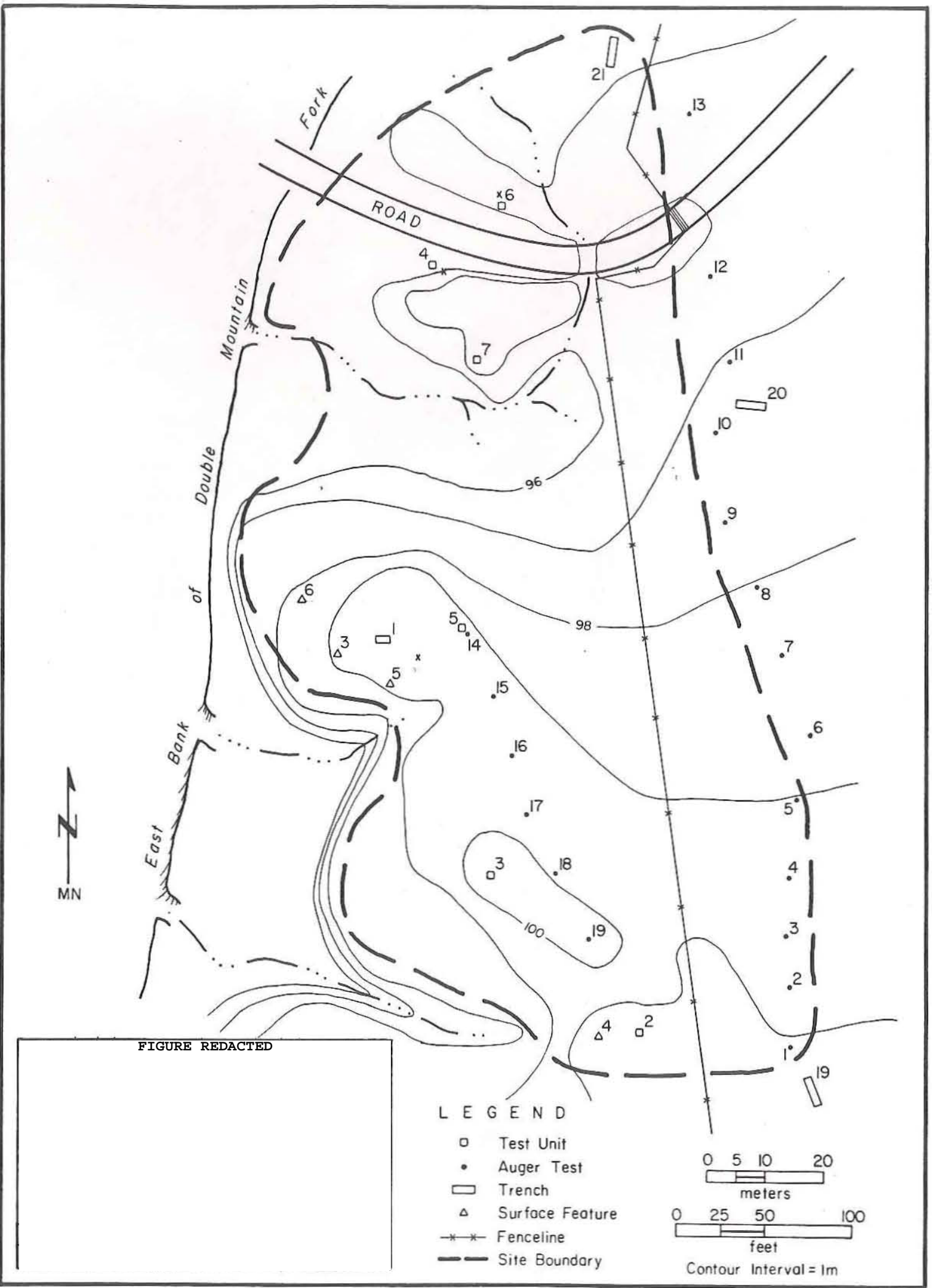

Figure 26. Site map, 41GR515. 
TABLE 19

SUMMARY OF EXCAVATIONS, 41GR515

\begin{tabular}{|c|c|c|c|}
\hline Unit & $\begin{array}{l}\text { Depth of } \\
\text { Excavation } \\
\text { (cm) }\end{array}$ & Reason for Ending Unit & $\begin{array}{l}\text { Artifact } \\
\text { Density }\left(\# / \mathrm{m}^{3}\right) \\
\text { or Result }\end{array}$ \\
\hline Test Unit 1 & 80 & Decrease in artifacts & 23.8 \\
\hline Test Unit 2 & 160 & Decrease in artifacts & 6.9 \\
\hline Test Unit 3 & 75 & Decrease in artifacts & 14.7 \\
\hline Test Unit 4 & 85 & Low artifact density & 2.4 \\
\hline Test Unit 5 & 70 & Decrease in artifacts & 11.4 \\
\hline Test Unit 6 & 160 & Low artifact density & 0.6 \\
\hline Test Unit 7 & 220 & Low artifact density & 0.9 \\
\hline Auger Test 1 & 110 & 'Arbitrary & negative \\
\hline Auger Test 2 & 105 & Bedrock reached & negative \\
\hline Auger Test 3 & 110 & Bedrock reached & positive \\
\hline Auger Test 4 & 125 & Maximum depth of auger & positive \\
\hline Auger Test 5 & 110 & Bedrock reached & negative \\
\hline Auger Test 6 & 100 & Arbitrary & negative \\
\hline Auger Test 7 & 97 & Bedrock reached & negative \\
\hline Auger Test 8 & 117 & Bedrock reached & negative \\
\hline Auger Test 9 & 105 & Bedrock reached & negative \\
\hline Auger Test 10 & 114 & Arbitrary & negative \\
\hline Auger Test 11 & 110 & Arbitrary & negative \\
\hline Auger Test 12 & 68 & Bedrock reached & negative \\
\hline Auger Test 13 & 123 & Maximum depth of auger & negative \\
\hline Auger Test 14 & 102 & Bedrock reached & positive \\
\hline Auger Test 15 & 120 & Bedrock reached & negative \\
\hline Auger Test 16 & 125 & Bedrock reached & negative \\
\hline Auger Test 17 & 120 & Maximum depth of auger & negative \\
\hline Auger Test 18 & 112 & Arbitrary & negative \\
\hline Auger Test 19 & 130 & Maximum depth of auger & negative \\
\hline Backhoe Trench 19 & 168 & Beđrock reached & negative \\
\hline Backhoe Trench 20 & 410 & Maximum depth of backhoe & negative \\
\hline Backhoe Trench 21 & 205 & Gravel layer reached & positive \\
\hline
\end{tabular}

site size is estimated to be $180 \times 90 \mathrm{~m}$. Cultural materials are exposed or shallowly buried on the knolls in the southeastern portion but are deeper in all other areas. Artifacts were recovered at depths of over $1 \mathrm{~m}$ in Zone 2 sediments in Test Units 2, 6, and 7 and in Backhoe Trench 21, but there is no apparent cultural stratification. 


\section{FEATURES}

Four clusters of burned sandstone fragments (Features 3-6) exposed on the surface are probably hearths; all are less than $100 \mathrm{~cm}$ in diameter. A sandstone mano was found near Feature 3. Two subsurface clusters of burned sandstone (Features 1 and 2) were excavated.

Feature 1 is a ca. $90 \times 75-\mathrm{cm}$ cluster of burned sandstone slabs and a few smaller fragments found at $30-38 \mathrm{~cm}$ in Test Unit 1. The cluster has no distinctive shape, but the slabs appear to dip toward the center; charcoal flecks were noted around but not in the feature. Some burned rocks are present in the $10-30-\mathrm{cm}$ levels above the feature, and there is a definite increase in cultural materials from 10 to $40 \mathrm{~cm}$. The feature is interpreted as a disturbed hearth probably associated with an occupational surface.

Feature 2, a cluster of burned sandstone, was discovered at a depth of $130 \mathrm{~cm}$ in the roadcut in 1987. Test Unit 4 was excavated over the feature. The depth partly reflects the deposition of sand on top of the cutbank during blading of the roadcut. No stratigraphic break between the natural sediments and the upper spoil accumulation could be discerned, but the feature is estimated to be $46-63 \mathrm{~cm}$ below the original surface. It appears to be ca. two-thirds of a circular, 80-cm-diameter, slab-lined hearth, the remainder having been destroyed by the roadcut. The partial hearth consists of 15 sandstone slabs and fragments dipping toward a central area. A thermoluminescence assay of a burned rock yielded a questionable age of $3415 \pm 690$ B.P. (Dur89TLqi 135-7BS), and a charcoal sample was too small to yield an acceptable radiocarbon date (GX-14596). Flotation of the feature fill yielded burned and unburned juniper wood and numerous snail shells. No artifacts were found in association with the feature, and the highest concentration of cultural debris was found stratigraphically above the feature, at 10-40 cm below the supposed surface elevation.

\section{MATERIALS RECOVERED}

Seventy-three artifacts, consisting of ground and chipped stone tools and lithic debitage but no temporally diagnostic specimens, were recovered (Table 20). The lithic materials are predominantly of local origin, although $13.6 \%$ are Tecovas jasper and $4.5 \%$ are nonlocal Cretaceous cherts. Also collected were 14 burned rocks.

\section{DISCUSSION}

The temporal placement and cultural affiliation of site 41 GR515 are unknown. A single thermoluminescence age of $3415 \pm 690$ B.P. from Feature 2 could indicate a middle to late Archaic occupation, but this date is of questionable validity due to consistent inaccuracies of thermoluminescence dates on burned rocks from the project area. Based on paired thermoluminescence and radiocarbon dates from other sites, the best estimate is that this date is too old and that the occupation falls within the late Archaic period. This interpretation is consistent with the geomorphic setting.

Cultural materials were recovered from the surface to a depth of over $1 \mathrm{~m}$, but there is no apparent vertical separation. It is not clear whether the materials represent a single or multiple occupations. Distributions of features and artifacts indicate that discrete activities can be horizontally separated, however. 
TABLE 20

DISTRIBUTION OF ARTIFACTS, 41GR515

\begin{tabular}{|c|c|c|c|c|c|c|c|c|}
\hline Provenience & Biface & $\begin{array}{l}\text { Cobble } \\
\text { Tools }\end{array}$ & Unifaces & Cores & $\begin{array}{l}\text { Edge- } \\
\text { modified } \\
\text { Debitage }\end{array}$ & $\begin{array}{l}\text { Unmodified } \\
\text { Debitage }\end{array}$ & $\begin{array}{l}\text { Hammer- } \\
\text { stones }\end{array}$ & $\begin{array}{l}\text { Ground } \\
\text { Stones }\end{array}$ \\
\hline Surface & - & 2 & 3 & 4 & 1 & 1 & 1 & 3 \\
\hline Backhoe Trench 21 & - & - & - & - & - & 1 & - & - \\
\hline Auger Test 3 & - & - & - & - & - & 1 & - & - \\
\hline Auger Test 4 & - & - & - & - & - & 1 & - & - \\
\hline Auger Test 14 & - & - & - & - & - & - & - & 1 \\
\hline Test Unit 1 & 1 & - & 2 & - & 2 & 13 & 1 & - \\
\hline Test Unit 2 & - & - & $-\cdot$ & - & - & 11 & - & - \\
\hline Test Unit 3 & - & - & 1 & - & - & 10 & - & - \\
\hline Test Unit 4 & - & - & - & - & - & 2 & - & - \\
\hline Test Unit 5 & - & - & - & 2 & 1 & 5 & - & - \\
\hline Test Unit 6 & - & - & - & - & - & - & - & 1 \\
\hline Test Unit 7 & $=$ & 二 & $=$ & $=$ & 1 & 1 & $=$ & $=$ \\
\hline Totals: & 1 & 2 & 6 & 6 & 5 & 46 & 2 & 5 \\
\hline
\end{tabular}

Burned rock features, ground stones, a poorly preserved bone fragment, and scattered mussel shell fragments are probable evidence of subsistence-related activities. Limited intercultural trade or exploitation of nonlocal resources is evidenced by the presence of exotic lithic materials. These activities, along with stone tool manufacture indicated by hammerstones and lithic debitage, suggest a multifunctional campsite. The lack of temporal control, however, limits the interpretability of the site.

\section{KT34}

\section{SITE SETTING}

Site 41KT34 is situated on a prominent erosional remnant in the lower alluvial terrace of the main channel of the Double Mountain Fork, ca. $1.3 \mathrm{~km}$ downstream from the mouth of Grape Creek. The ca. $120 \times 60-\mathrm{m}$ knoll rises ca. $6 \mathrm{~m}$ above the surrounding floodplain; it drops off sharply on the west and north but levels off gradually to the south and east. Elevations range from $2140 \mathrm{ft} \mathrm{msl}$ around the edges of the knoll to ca. $2155 \mathrm{ft} \mathrm{msl}$ at the highest point. It is covered by sparse vegetation, primarily grasses but also including yuccas and small mesquites. The surrounding area and probably the knoll have been cleared of vegetation (i.e., mesquite removal). 
WORK ACCOMPLISHED

When 41KT34 was recorded in 1987, it consisted of a scatter of surface artifacts and several burned rock features. Cultural materials were recovered from shovel tests. Controlled collection, mapping, and testing were recommended (Boyd et al. 1989). As a result of these recommendations, the current investigations consisted of site mapping, controlled surface collection of diagnostic artifacts, and the excavation of 31 auger tests, 9 1xl-m test units, and 1 backhoe trench (Fig. 27, Table 21).

A surface inspection revealed eight burned rock features exposed on the west side of the knoll below the crest. A grid was set up over the knoll, and transect lines of auger tests at 10-m intervals were excavated. The auger tests defined the main concentration of buried cultural materials as being along the ridgecrest in the northern portion of the knoll. Six test units were excavated in the northern area, one in the westernmost end of the knoll, and one on the southern slope. Two features were excavated; Test Unit 9 was located over surface Feature 3, and buried Feature 1 was encountered in Test Unit 1 . After hand testing was completed, Backhoe Trench 62 was excavated to obtain detailed geomorphic information.

\section{SEDIMENTS AND STRATIGRAPHY}

The stratigraphic profile in Backhoe Trench 62 (see Appendix A) is characteristic of the knoll, but the thicknesses of the zones vary across the site. The trench profile consists of only two zones. Zone $1,0-70 \mathrm{~cm}$, is reddish brown loamy fine sand and contains sandstone and siliceous pebbles and cobbles. A clear lower boundary marks the transition to Zone 2, 70-135 cm, which consists of pinkish gray stratified crossbedded sands and gravels. The trench was ended arbitrarily at $135 \mathrm{~cm}$, and the full thickness of the lower zone is unknown. Extensive bioturbation (i.e., rodent disturbance) is evident in both zones.

The lower zone is a channel deposit of the Double Mountain Fork and is probably of Pleistocene age. The upper zone is apparently colluvial/alluvial fan sediments. The knoll is an isolated erosional remnant of these deposits.

\section{SITE EXTENT AND DEPTH}

The cultural materials are contained within the upper sediments and are confined to the $60 \times 120-\mathrm{m}$ top of the knoll. Cultural materials were found at $0-120 \mathrm{~cm}$, but extensive rodent disturbance, especially below ca. $70 \mathrm{~cm}$, may account for materials found in the lower levels. The majority of the cultural materials from undisturbed contexts occurred at 0-70 cm, but there is no apparent stratification within the upper zone.

\section{FEATURES}

Nine features were recorded. Feature 1, a burned rock concentration, was discovered in Test Unit 1. All others are surface features, consisting of one rock cairn (Feature 3) which was tested and seven burned rock concentrations (Features 2 and 4-9). The latter are composed of various materials, including burned sandstone and fire-cracked Potter chert, limestone, and quartzite. These may be hearths or dumps of fire-cracked rocks. 


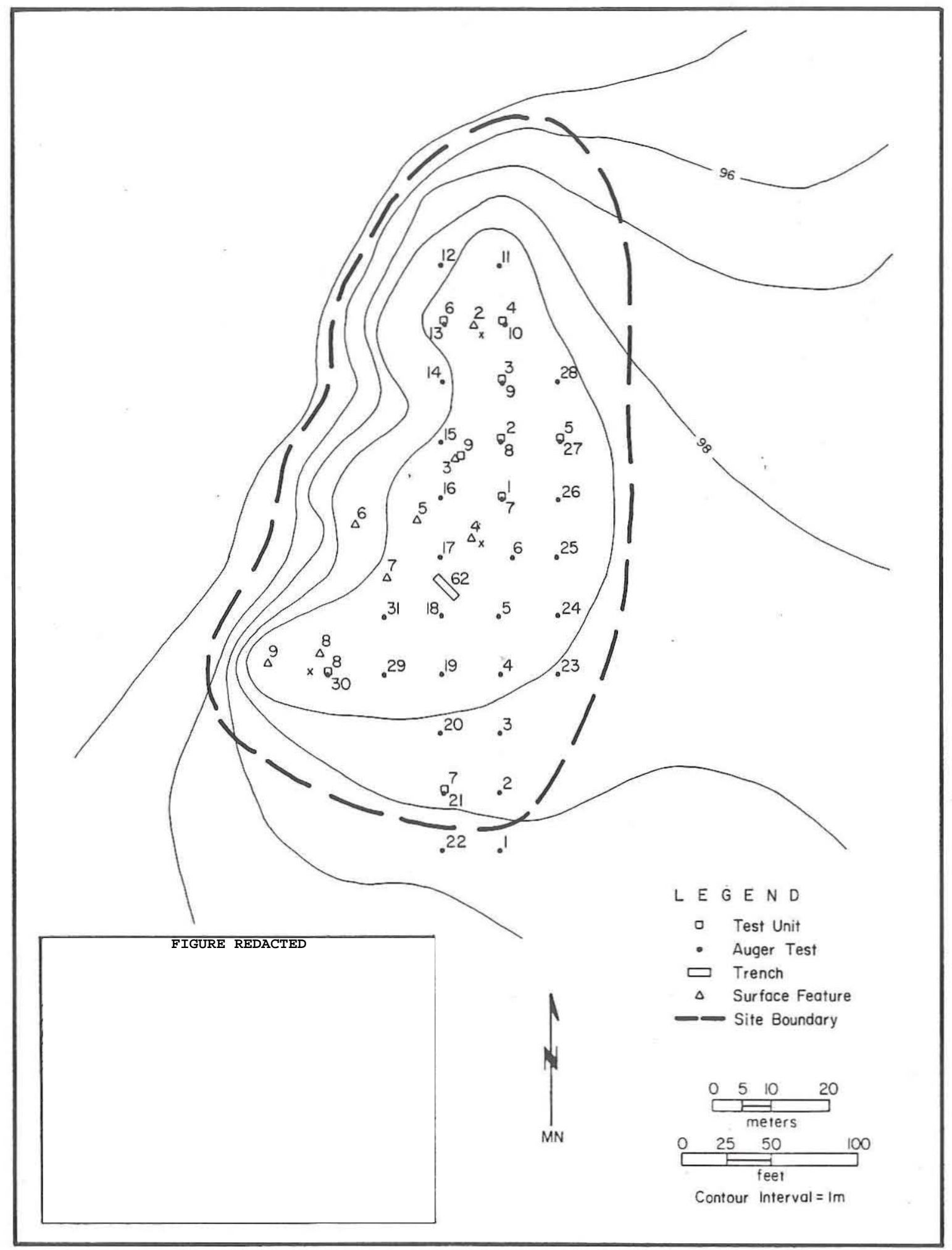

Figure 27. Site map, 41KT34. 
Feature 1 is a single-layer scatter of 10 burned sandstone slabs or fragments, one quartzite fragment, and small angular Potter chert fragments exposed at 5-22 cm in the west half of Test Unit 1. A few charcoal flecks were noted, but no artifacts were found in direct association with the feature. This feature may be a portion of a disturbed hearth. A thermoluminescence assay on a burned rock yielded a questionable age of $2550 \pm 520 \mathrm{~B} . \mathrm{P}$. (Dur89TLqi 135-11AS).

Feature 3 was observed as a surface cluster of large vertical sandstone slabs and was exposed at $0-25 \mathrm{~cm}$ in Test Unit 9. Excavation revealed 14 large sandstone slabs (most 10-30 cm in maximum length) over most of the unit. None are burned, and they are oriented at various angles with several being vertical. The base of the feature is firmly planted in undisturbed sediments. Charcoal flecks, fragments of burned and fire-cracked rocks, a bifacial tool, and a flake found among the rocks may be incidental surface debris. Animal residue was extracted from the bifacial tool. The function of this cairnlike feature remains unknown.

\section{MATERIALS RECOVERED}

The 127 artifacts include a variety of stone tools, but no temporally diagnostic specimens were recovered (Table 22). Lithic materials represented by the chipped stone include 9\% Tecovas jasper and $0.8 \%$ nonlocal Cretaceous chert. Other materials recovered include 157 burned rocks and numerous snail shells and mussel shell fragments. Organic residues extracted from a cobble tool and an end scraper were of indeterminate origin, and animal residue was extracted from a biface.

\section{DISCUSSION}

The occupation at $41 \mathrm{KT} 34$ is culturally undefined and is tentatively assigned to the late Archaic or beginning of the Late Prehistoric period. No time-diagnostic artifacts were recovered, and the single thermoluminescence age of $2550 \pm 520$ B.P. from Feature 1 is probably erroneous. Paired thermoluminescence and radiocarbon dates from other sites suggest the date may be too old, but the best estimate of the age of the occupation is terminal Archaic. This assessment is consistent with the age interpretation for 41KT33, a nearby site in a similar geomorphic setting (see Chapter 6).

Cultural materials were recovered from the surface to $120 \mathrm{~cm}$, but severe rodent disturbance may account for most or all of the artifacts found below ca. $70 \mathrm{~cm}$. No vertical separation was observed, and a single disturbed occupation is likely. The distribution of features and the variable artifact densities indicate that spatially discrete activities are represented.

The range of activities indicated by the artifacts and features suggest a multifunctional campsite. Stone tool manufacture is represented by hammerstones and lithic debitage. Metates, burned rock features, mussel shell fragments, and animal residues extracted from a stone tool are probable evidence of food-processing activities. A rock cairn (Feature 3) represents an unknown activity. Nonlocal lithic material utilization indicates interregional exchange or exploitation of distant resources. The uncertain temporal placement, however, limits the interpretability of the site. 
TABLE 21

SUMMARY OF EXCAVATIONS, 41KT34

Depth of

Excavation

Unit (cm)

Reason for Ending Unit
Artifact

Density $\left(\# / \mathrm{m}^{3}\right)$

or Result

\begin{tabular}{|c|c|c|c|}
\hline Test Unit 1 & 70 & Artifact decrease & 0.0 \\
\hline Test Unit 2 & 80 & Artifact decrease & 3.8 \\
\hline Test Unit 3 & 120 & Artifact decrease & 20.0 \\
\hline Test Unit 4 & 120 & Artifact decrease & 3.3 \\
\hline Test Unit 5 & 100 & Artifact decrease & 40.0 \\
\hline Test Unit 6 & 80 & Artifact decrease & 17.5 \\
\hline Test Unit 7 & 110 & Artifact decrease & 5.5 \\
\hline Test Unit 8 & 60 & Artifact decrease & 8.3 \\
\hline Test Unit 9 & 45 & Artifact decrease & 6.7 \\
\hline Auger Test 1 & 53 & Difficulty in digging & negative \\
\hline Auger Test 2 & 54 & Difficulty in digging & negative \\
\hline Auger Test 3 & 113 & Difficulty in digging & negative \\
\hline Auger Test 4 & 125 & Maximum depth of auger & negative \\
\hline Auger Test 5 & 124 & Maximum depth of auger & negative \\
\hline Auger Test 6 & 98 & Difficulty in digging & positive* \\
\hline Auger Test 7 & 90 & Arbitrary & positive* \\
\hline Auger Test 8 & 96 & Arbitrary & negative \\
\hline Auger Test 9 & 94 & Arbitrary & positive \\
\hline Auger Test 10 & 98 & Arbitrary & positive* \\
\hline Auger Test 11 & 75 & Gravel lens reached & negative \\
\hline Auger Test 12 & 61 & Gravel lens reached & negative \\
\hline Auger Test 13 & 87 & Gravel lens reached & positive \\
\hline Auger Test 14 & 25 & Gravel lens reached & positive \\
\hline Auger Test 15 & 45 & Gravel lens reached & positive* \\
\hline Auger Test 16 & 98 & Arbitrary & positive* \\
\hline Auger Test 17 & 95 & Gravel lens reached & positive \\
\hline Auger Test 18 & 100 & Gravel lens reached & negative \\
\hline Auger Test 19 & 110 & Arbitrary & negative \\
\hline Auger Test 20 & 114 & Bedrock reached & negative \\
\hline Auger Test 21 & 96 & Arbitrary & positive \\
\hline Auger Test 22 & 86 & Arbitrary & negative \\
\hline Auger Test 23 & 90 & Arbitrary & positive \\
\hline Auger Test 24 & 94 & Arbitrary & negative \\
\hline Auger Test 25 & 96 & Arbitrary & positive* \\
\hline Auger Test 26 & 100 & Arbitrary & positive \\
\hline Auger Test 27 & 95 & Arbitrary & positive \\
\hline Auger Test 28 & 100 & Arbitrary & negative \\
\hline
\end{tabular}

*Probable burned rocks observed but not collected. 
Table 21, continued

Depth of

Excavation

Unit

(cm)

Reason for Ending Unit

Artifact

Density $\left(\# / \mathrm{m}^{3}\right)$

or Result

Auger Test 29

Auger Test 30

Auger Test 31

91

68

75

Backhoe Trench 62

135

Arbitrary

Gravel lens reached

Gravel lens reached

Gravel lens reached negative

negative

positive

negative

TABLE 22

DISTRIBUTION OF P.RTIFACTS, 41KT34

\begin{tabular}{|c|c|c|c|c|c|c|c|c|}
\hline Provenience & Bifaces & $\begin{array}{l}\text { Cobble } \\
\text { Tool }\end{array}$ & Unifaces & Cores & $\begin{array}{l}\text { Edge- } \\
\text { modified } \\
\text { Debitage }\end{array}$ & $\begin{array}{l}\text { Unmodified } \\
\text { Debitage }\end{array}$ & $\begin{array}{l}\text { Hammer- } \\
\text { stones }\end{array}$ & Metates \\
\hline Surface & 2 & - & 2 & 1 & 3 & 6 & 3 & 2 \\
\hline Auger Test 9 & - & - & - & - & - & 1 & - & - \\
\hline Auger Test 13 & - & - & - & - & - & 1 & - & - \\
\hline Auger Test 14 & - & - & - & - & - & 1 & - & - \\
\hline Auger Test 17 & - & - & - & - & - & 1 & - & - \\
\hline Auger Test 21 & - & - & - & - & - & 1 & - & - \\
\hline Auger Test 26 & - & - & - & - & - & 1 & - & - \\
\hline Auger Test 27 & - & - & 1 & - & - & - & - & - \\
\hline Auger Test 31 & - & - & - & - & - & 2 & - & - \\
\hline Test Unit 2 & - & - & - & - & - & 3 & - & - \\
\hline Test Unit 3 & - & - & - & 2 & - & 22 & - & - \\
\hline Test Unit 4 & 2 & - & 1 & - & 1 & - & - & - \\
\hline Test Unit 5 & - & 1 & - & - & - & 39 & - & - \\
\hline Test Unit 6 & - & - & - & - & - & 14 & - & - \\
\hline Test Unit 7 & - & - & - & - & 1 & 5 & - & - \\
\hline Test Unit 8 & - & - & - & - & - & 5 & - & - \\
\hline Test Unit 9 & 1 & $=$ & $=$ & 二 & $\underline{1}$ & 1 & $=$ & $=$ \\
\hline Totals: & 5 & 1 & 4 & 3 & 6 & 103 & 3 & 2 \\
\hline
\end{tabular}


$41 \mathrm{KT} 49$

SITE SETTING

Site $41 \mathrm{KT} 49$ is situated on the upland margin on the east side of Grape Creek, ca. $2 \mathrm{~km}$ southeast of its confluence with the Double Mountain Fork. The site occupies a slight rise on the upland flat and the eroding lower benches along the canyon rim, overlooking a wide segment of the Grape Creek valley to the south and west. The upland flat ends abruptly on the west with a 1-m-high escarpment separating it from the eroding lower benches.

Elevations range from ca. 2240 to $2280 \mathrm{ft} \mathrm{msl}$. Vegetation is heavy in the upland flat and sparse to moderate in the lower areas. It consists mainly of grasses and mesquites in the upland flat and junipers, mesquites, and grasses in the eroded area. Lesser amounts of cholla, agarita, yucca, catclaw acacia, and other shrubs are also present.

\section{WORK ACCOMPLISHED}

When 41KT49 was recorded in 1987, burned rock features and artifacts were observed eroding out along the escarpment edge and in the lower benches. Collected artifacts included an untyped dart point, bifaces, unifaces, a scraper, and a mano. A shovel test revealed buried cultural materials. Mapping and testing were recommended (Boyd et al. 1989). As a result of these recommendations, the current investigations consisted of site mapping, controlled surface collection of diagnostic artifacts, and excavation of 29 auger tests, 8 1x1-m test units, and 1 backhoe trench (Fig. 28, Table 23). A surface inspection confirmed that the main concentration of cultural materials is eroding out of the sandy sediment along the upland escarpment, and sparse cultural materials were found in the lower area.

A grid was established in the upland flat, and auger tests were excavated at 5-m intervals in north-south and east-west transects. Additional auger tests were located near the escarpment where the highest density of cultural materials was recovered. Test Units 1 and 5 were isolated, while all other test units were in the upland flat or along the eroding escarpment. Test Unit 1 was excavated in a sediment remnant in the lower western area and exposed Feature 1. Test Unit 5 was excavated in a deflated west-projecting upland ridge in the southern portion. Test Units 2 and 3 were excavated along the escarpment and exposed Features 2 and 6 . Test Units 4 and $6-8$ were located in the upland flat where auger tests indicated high densities of buried cultural materials. Features 4 and 5 were discovered in Test Units 6 and 7. Backhoe Trench 35, excavated at the northern end to obtain detailed geomorphic data, yielded no cultural materials.

\section{SEDIMENTS AND STRATIGRAPHY}

The stratigraphic profile in Backhoe Trench 35 (see Appendix A) characterizes the upland sediments: Zone $1,0-10 \mathrm{~cm}$, brown loamy fine sand, friable; Zone 2, 10-45 cm, reddish brown fine sandy loam to loamy fine sand, blocky (possible A horizon); Zone 3, 45-83 cm, yellowish red sandy loam, massive to blocky; and Zone 4, 83-90 cm, pale brown hard sandy loam. All zones are strongly calcareous, and some calcium carbonate cementing is evident in Zone 4. This profile represents sediments that have been stable for an 


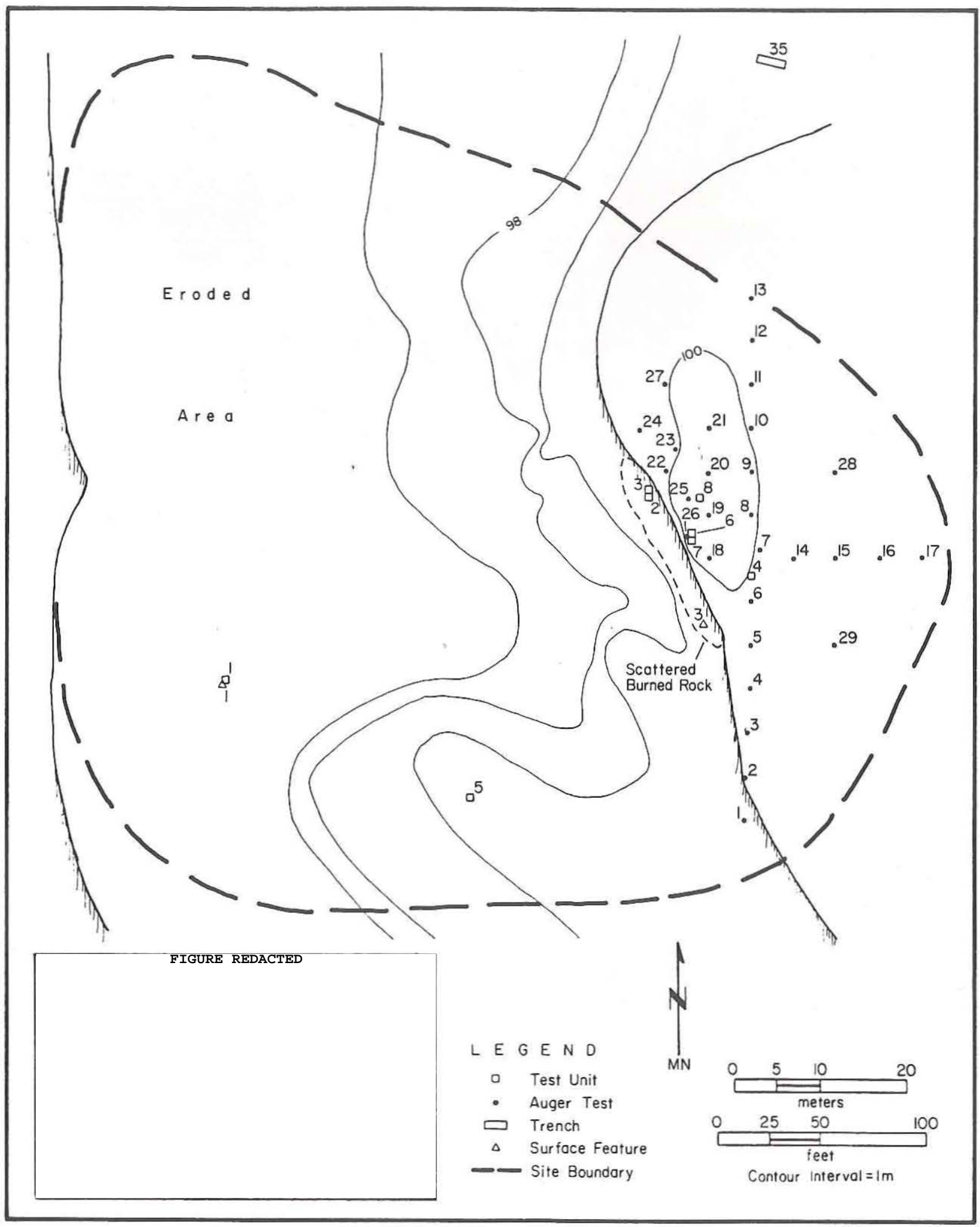

Figure 28. Site map, 41KT49. 
TABLE 23

SUMMARY OF EXCAVATIONS, 41KT49

Depth of

Excavation

Unit (cm)

Reason for Ending Unit
Artifact

Density $\left(\# / \mathrm{m}^{3}\right)$

or Result
Test Unit 1

Test Unit 2

Test Unit 3

Test Unit 4

Test Unit 5

Test Unit 6

Test Unit 7

Test Unit 8

Auger Test 1

Auger Test 2

Auger Test 3

Auger Test 4

Auger Test 5

Auger Test 6

Auger Test 7

Auger Test 8

Auger Test 9

Auger Test 10

Auger Test 11

Auger Test 12

Auger Test 13

Auger Test 14

Auger Test 15

Auger Test 16

Auger Test 17

Auger Test 18

Auger Test 19

Auger Test 20

Auger Test 21

Auger Test 22

Auger Test 23

Auger Test 24

Auger Test 25

Auger Test 26

Auger Test 27

Auger Test 28

Auger Test 29

Backhoe Trench 35
20

20

20

60

10

40

40

38

20

16

25

85

73

77

75

74

70

79

80

41

71

80

60

75

60

90

86

80

80

85

80

60

90

25

85

70

70

90
Arbitrary

Arbitrary

Arbitrary

Dug into sterile caliche

No artifacts

Arbitrary

Arbitrary

Arbitrary

Contact with bedrock

Contact with bedrock

Contact with bedrock

Contact with bedrock

Contact with bedrock

Contact with bedrock

Contact with bedrock

Contact with bedrock

Contact with bedrock

Contact with bedrock

Contact with bedrock

Contact with bedrock

Arbitrary

Arbitrary

Arbitrary

Arbitrary

Arbitrary

Arbitrary

Arbitrary

Arbitrary

Arbitrary

Contact with bedrock

Arbitrary

Dug into bedrock

Arbitrary

Arbitrary

Dug into bedrock

Arbitrary

Arbitrary

Dug into sterile caliche
30.0

20.0

35.0

10.0

0.0

25.0

32.5

23.7

negative negative negative positive* positive positive positive positive negative positive positive negative negative positive positive positive positive positive positive* negative negative positive positive negative positive positive negative negative negative negative

*Probable burned rocks observed but not collected. 
extended period of time, probably since the middle Holocene or earlier. Severe erosion and deflation of the lower benches has exposed large patches of bedrock sandstone and isolated remnants of redeposited upland sands. Quaternary gravels are exposed along the eroding edge of the upland flat in the northwest site area.

\section{SITE EXTENT AND DEPTH}

The western boundary is the Grape Creek canyon rim, and the northwestern and southwestern boundaries are defined by the extent of surface artifacts. The eastern, northeastern, and southeastern site boundaries are established by the distribution of subsurface cultural materials and are tentative, considering the limited amount of testing. The site area is ca. $100 \times 100 \mathrm{~m}$.

Buried cultural materials in the eastern portion are concentrated in a $30 \times 50-m$ area at depths of 0-35 cm. Cultural materials were not found below $50 \mathrm{~cm}$, and no stratification is apparent. Cultural materials in the western portion are surficial or shallowly buried.

\section{FEATURES}

Six burned rock features were recorded. Feature 1 is a deflated hearth at $0-10 \mathrm{~cm}$ in the northern half of Test Unit 1. It consists of a $60 \times 100-\mathrm{cm}$ scatter of burned horizontal sandstone slabs and fragments with a $40 \times 40-\mathrm{cm}$ central concentration. Limited lithic debitage and a core were associated with the feature.

Feature 2 is a $50 \times 80-\mathrm{cm}$ cluster of burned sandstone slabs exposed in Test Units 2 and 3. The main concentration is a 50-cm-diameter, circular hearth at 20-30 cm in the northwest corner of Test Unit 2 and the southwest corner of Test Unit 3 . The sandstone slabs are intensively heat-reddened and form a shallow basin shape, dipping slightly toward the center. No artifacts were associated.

Feature 3 is a $50 \times 75-\mathrm{cm}$ surface cluster of burned sandstone slabs exposed along the eroding escarpment. It appears to be a small disturbed hearth, but it was not excavated.

Feature 4 is a large, amorphous, $85 \times 120-\mathrm{cm}$ scatter of horizontal burned sandstone slabs exposed at 20-30 cm in the northeast corner of Test Unit 7 and the southeast corner of Test Unit 6. This feature probably represents a scattered hearth on an occupational surface. Scattered lithic debitage was recovered from the units. Additional technical studies of Feature 4 were performed. A thermoluminescence assay of a burned rock yielded a questionable age of $825 \pm 175$ B.P. (Dur89TLqi 135-12BS). Organic residue was extracted from the top and bottom of one of the burned rocks; the top (burned) yielded plant residue, while the bottom (unburned) yielded animal residue. Flotation of the feature fill yielded one microdebitage specimen, burned hardwood, unburned Chenopodium fruit, and a snail shell.

Feature 5 is a $30 \times 70-\mathrm{cm}$ cluster of burned rocks exposed at $20-30 \mathrm{~cm}$ in the southwest corner of Test Unit 7. The feature is not arranged in a recognizable pattern and may be only a portion of a hearth or scattered debris on an occupational surface. It is similar to Feature 4 , and the two features may be associated.

Feature 6 is an amorphous scatter of burned sandstone slabs exposed at 15-30 cm in the east half of Test Unit 3 . The burned rocks are concentrated in two unpatterned clusters 
and are generally horizontal with some dipping slightly in various directions. Feature 6 may represent a portion of an occupational surface with scattered burned rocks, or it may represent disturbed hearths. It is at the same level as and may be associated with Feature 2 .

\section{MATERIALS RECOVERED}

Ninety artifacts (excluding 1 microdebitage specimen from a flotation sample) were recovered (Table 24) along with 43 burned rocks and mussel shell fragments. A reworked Marcos dart point is the only temporally diagnostic specimen. The lithic materials represented are predominantly local, but $4.5 \%$ of the chipped stone artifacts are of nonlocal Cretaceous chert.

TABLE 24

DISTRIBUTION OF ARTIFACTS, 41KT49

\begin{tabular}{|c|c|c|c|c|c|c|c|c|}
\hline Provenience & $\begin{array}{l}\text { Dart } \\
\text { Point }\end{array}$ & $\begin{array}{l}\text { Cobble } \\
\text { Tool }\end{array}$ & Unifaces & Cores & $\begin{array}{l}\text { Edge- } \\
\text { modified } \\
\text { Debitage }\end{array}$ & $\begin{array}{l}\text { Unmodified } \\
\text { Debitage }\end{array}$ & $\begin{array}{l}\text { Hammer- } \\
\text { stone }\end{array}$ & Mano \\
\hline Surface & 1 & - & 1 & - & - & - & - & 1 \\
\hline Auger Test 5 & - & - & - & - & - & 1 & - & - \\
\hline Auger Test 6 & - & - & - & - & - & 4 & - & - \\
\hline Auger Test 7 & - & - & - & - & - & 1 & - & - \\
\hline Auger Test 8 & - & - & - & 1 & - & 2 & - & - \\
\hline Auger Test 10 & - & - & - & - & - & 3 & - & - \\
\hline Auger Test 11 & - & - & - & - & - & 1 & - & - \\
\hline Auger Test 14 & - & - & - & - & - & 1 & - & - \\
\hline Auger Test 15 & - & - & - & - & - & 1 & - & - \\
\hline Auger Test 16 & - & - & - & - & - & 2 & - & - \\
\hline Auger Test 17 & - & - & - & - & - & 1 & - & - \\
\hline Auger Test 18 & - & - & - & - & - & 2 & - & - \\
\hline Auger Test 22 & - & - & - & - & - & 2 & - & - \\
\hline Auger Test 23 & - & - & - & - & - & 4 & - & - \\
\hline Auger Test 25 & - & 1 & - & - & - & 4 & - & - \\
\hline Auger Test 26 & - & - & - & - & - & 1 & - & - \\
\hline \multicolumn{9}{|l|}{ Test Unit 1 , } \\
\hline Feature 1 & - & - & - & 1 & - & 5 & - & - \\
\hline Test Unit 2 & - & - & - & - & - & 4 & - & - \\
\hline Test Unit 3 & - & - & - & - & - & 7 & - & - \\
\hline Test Unit 4 & - & - & 1 & - & 1 & 4 & - & - \\
\hline Test Unit 6 & - & - & - & - & 2 & 7 & 1 & - \\
\hline Test Unit 7 & - & - & - & - & - & 13 & - & - \\
\hline Test Unit 8 & $=$ & - & $=$ & $=$ & 1 & 8 & $=$ & $=$ \\
\hline Totals: & 1 & 1 & 2 & 2 & 4 & 78 & 1 & 1 \\
\hline
\end{tabular}


DISCUSSION

A single occupation of unknown cultural affiliation is represented at $41 \mathrm{KT} 49$. It is assessed as Archaic based on two surface-collected dart points (an untyped specimen from the 1987 investigations and a reworked Marcos), and the upland setting of this buried component is consistent with this interpretation. A single thermoluminescence age of $825 \pm$ 175 B.P. from Feature 4, however, is contradictory. Paired radiocarbon and thermoluminescence dates from other sites suggest that thermoluminescence dates on burned rocks are generally too old, but this date is much younger than expected. No satisfactory explanation can be offered to account for this discrepancy, and the diagnostic artifacts are considered to be more reliable.

Cultural materials are concentrated in a $30 \times 50-\mathrm{m}$ area in the eastern upland portion of the site. A 20-30-cm-thick cultural zone within the upper $50 \mathrm{~cm}$ of the sediments contains most of the materials, but there is no stratigraphic separation within these sediments. Variable artifact densities and features suggest that horizontally discrete activity areas are represented. Burned rock features and mussel shell fragments indicate possible subsistence activities. Plant and animal residues were preserved on opposite sides of a burned rock from Feature 4, perhaps reflecting food processing.' Lithic debitage and a hammerstone indicate tool manufacture, and utilization of nonlocal Cretaceous chert is evident. The variety of activities represented indicates a multifunctional campsite.

41KT52

\section{SITE SETTING}

Site 41KT52 is situated on the upper alluvial terrace on the west side of Grape Creek, ca. $2 \mathrm{~km}$ south-southeast of its confluence with the Double Mountain Fork. It is located within a prominent east-projecting meander bend along the southern edge of the 70-120-mwide terrace remnant. The upper terrace is 2-4 $\mathrm{m}$ higher than the lower terrace, with a point bar cutoff chute separating the two. The upper terrace, at an elevation of ca. $2170 \mathrm{ft} \mathrm{msl}$, is flat and slopes gently to the east; it is covered with moderate to heavy vegetation, mainly grasses, mesquites, and chollas. Lesser amounts of hackberry, catclaw acacia, tasajillo, prickly pear, and small shrubs are also present. Cottonwood trees are present along the creek. No disturbance other than cutbank erosion was noted.

\section{WORK ACCOMPLISHED}

When 41KT52 was recorded in 1987, cultural materials were observed eroding out of the cutbank. Four possible features were exposed in the cutbank at depths of 95-170 cm. Three of the four shovel tests yielded cultural materials at depths of 0-120 cm. Three metate fragments were collected from slump deposits along the cutbank. Due to the potential for stratified, multicomponent cultural deposits, mapping and testing were recommended (Boyd et al. 1989).

The current investigations consisted of site mapping, recording the cutbank stratigraphy, surface collection of cultural materials along the cutbank, and excavation of 14 auger tests, 1 backhoe trench, and 2 1x2-m test units (Fig. 29, Table 25). Auger tests 


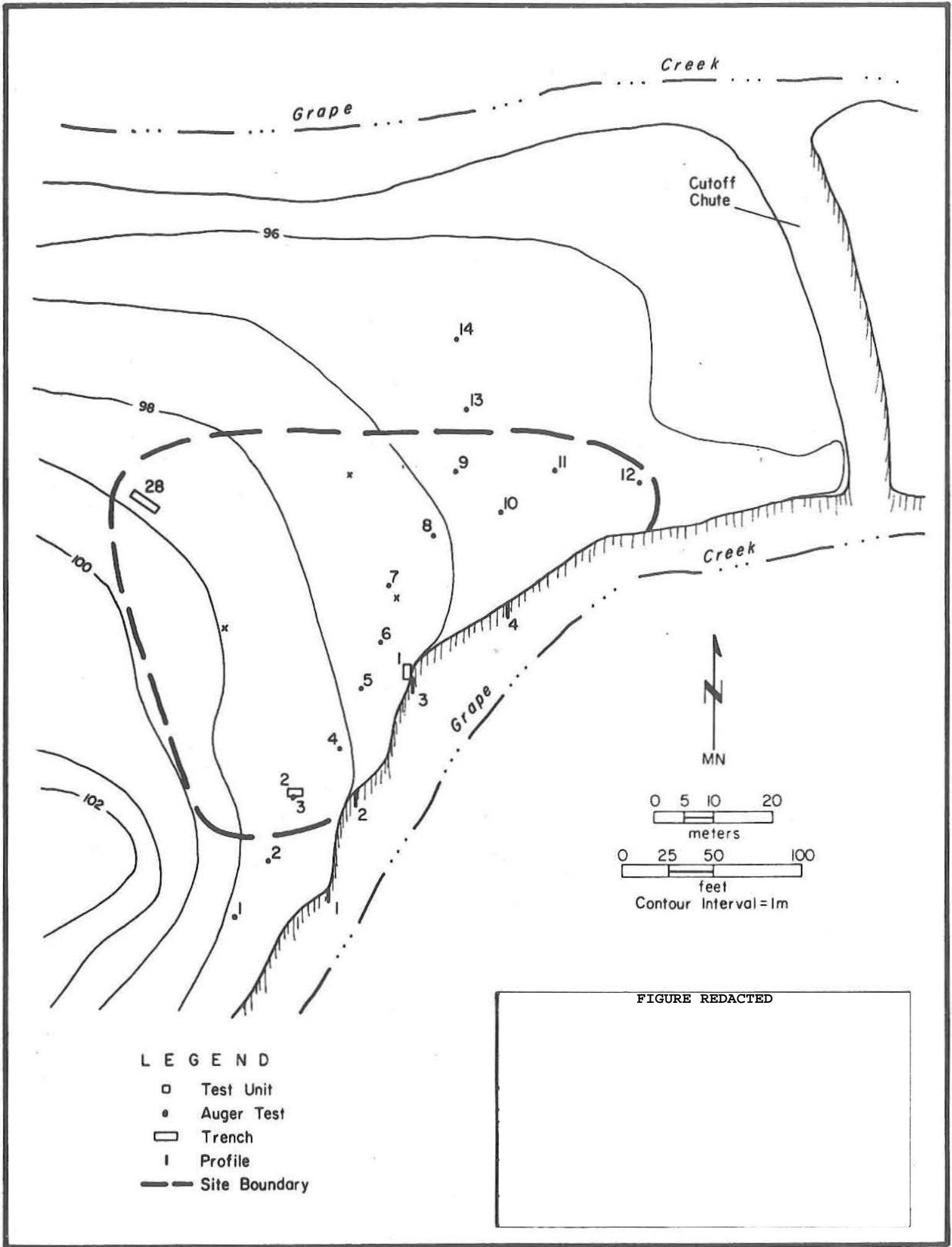

F1gure 29. Site map, 41KT52. 
TABLE 25

SUMMARY OF EXCAVATIONS, 41KT52

\begin{tabular}{|c|c|c|c|}
\hline Unit & $\begin{array}{l}\text { Depth of } \\
\text { Excavation } \\
(\mathrm{cm})\end{array}$ & Reason for Ending Unit & $\begin{array}{l}\text { Artifact } \\
\text { Density }\left(\# / \mathrm{m}^{3}\right) \\
\text { or Result }\end{array}$ \\
\hline Test Unit $1^{*}$ & 150 & Arbitrary & 1.2 \\
\hline Test Unit 2* & 150 & Arbitrary & 0.0 \\
\hline Auger Test 1 & 100 & Difficulty in digging & negative \\
\hline Auger Test 2 & 90 & Difficulty in digging & negative \\
\hline Auger Test 3 & 108 & Difficulty in digging & $\star \star$ \\
\hline Auger Test 4 & 100 & Difficulty in digging & negative \\
\hline Auger Test 5 & 100 & Difficulty in digging & positive \\
\hline Auger Test 6 & $95^{\circ}$ & Difficulty in digging & ** \\
\hline Auger Test 7 & 110 & Difficulty in digging & negative \\
\hline Auger Test 8 & 87 & $\begin{array}{l}\text { Encountered sandstone } \\
\text { concentration }\end{array}$ & $\star \star$ \\
\hline Auger Test 9 & 65 & Difficulty in digging & negative \\
\hline Auger l'est 10 & 110 & Difficulty in digging & negative \\
\hline Auger Test 11 & 55 & Difficulty in digging & negative \\
\hline Auger Test 12 & 55 & Difficulty in digging & negative \\
\hline Auger Test 13 & 55 & Difficulty in digging & negative \\
\hline Auger Test 14 & 60 & Difficulty in digging & negative \\
\hline Backhoe Trench 28 & 380 & Maximum depth of backhoe & positive \\
\hline \multicolumn{4}{|c|}{$\begin{array}{l}\text { *Both test units were } 1 \times 2 \mathrm{~m} \text {; only the western half of the } 140-150-\mathrm{cm} \text { level in Test Unit } 2 \\
\text { was excavated, and only the northern half of the } 100-150-\mathrm{cm} \text { level of Test Unit } 1 \text { was } \\
\text { excavated. }\end{array}$} \\
\hline
\end{tabular}

were excavated along the cutbank edge and across the terrace. One flake was recovered from Auger Test 5; concentrations of rocks, possibly representing buried features, were encountered at 85-90 cm in Auger Tests 3, 6, and 8. Test Unit 1 was located over a buried hearth (Feature 1) exposed in the cutbank. Test Unit 2, located adjacent to Auger Test 3, encountered a possible feature (Feature 2), but no definite cultural materials were associated. Excavation was extremely difficult in the dense, blocky, sandy loam sediments. The auger tests were excavated to various depths, but most were terminated due to difficulty in digging. Backhoe Trench 28 was excavated to provide stratigraphic information and yielded cultural materials. 
SEDIMENTS AND STRATIGRAPHY

The stratigraphy of the site was evident along the 4-8-m-high vertical cutbank. Profiles show a high degree of continuity (Fig. 30) and are comparable to Zones 1 and 2 recorded in Backhoe Trench 28 (see Appendix A). Zone $1(0-60 \mathrm{~cm}$ ) is hard, blocky, reddish brown (5YR 3/4) fine sandy loam with an abrupt lower boundary. Zone $2(60-295 \mathrm{~cm})$ is a hard, blocky, reddish brown ( 5 YR $3 / 4$ to 5 YR 4/4) fine sandy loam, with calcium carbonate staining increasing with depth. Some small siliceous gravels are present in both zones. An organic-rich, 5-18-cm-thick, reddish brown (5YR 3/4) layer within Zone 1 is interpreted as a buried $A$ horizon. It can be traced along the cutbank profile at depths from 0 to $50 \mathrm{~cm}$ but was not observed in Backhoe Trench 28.

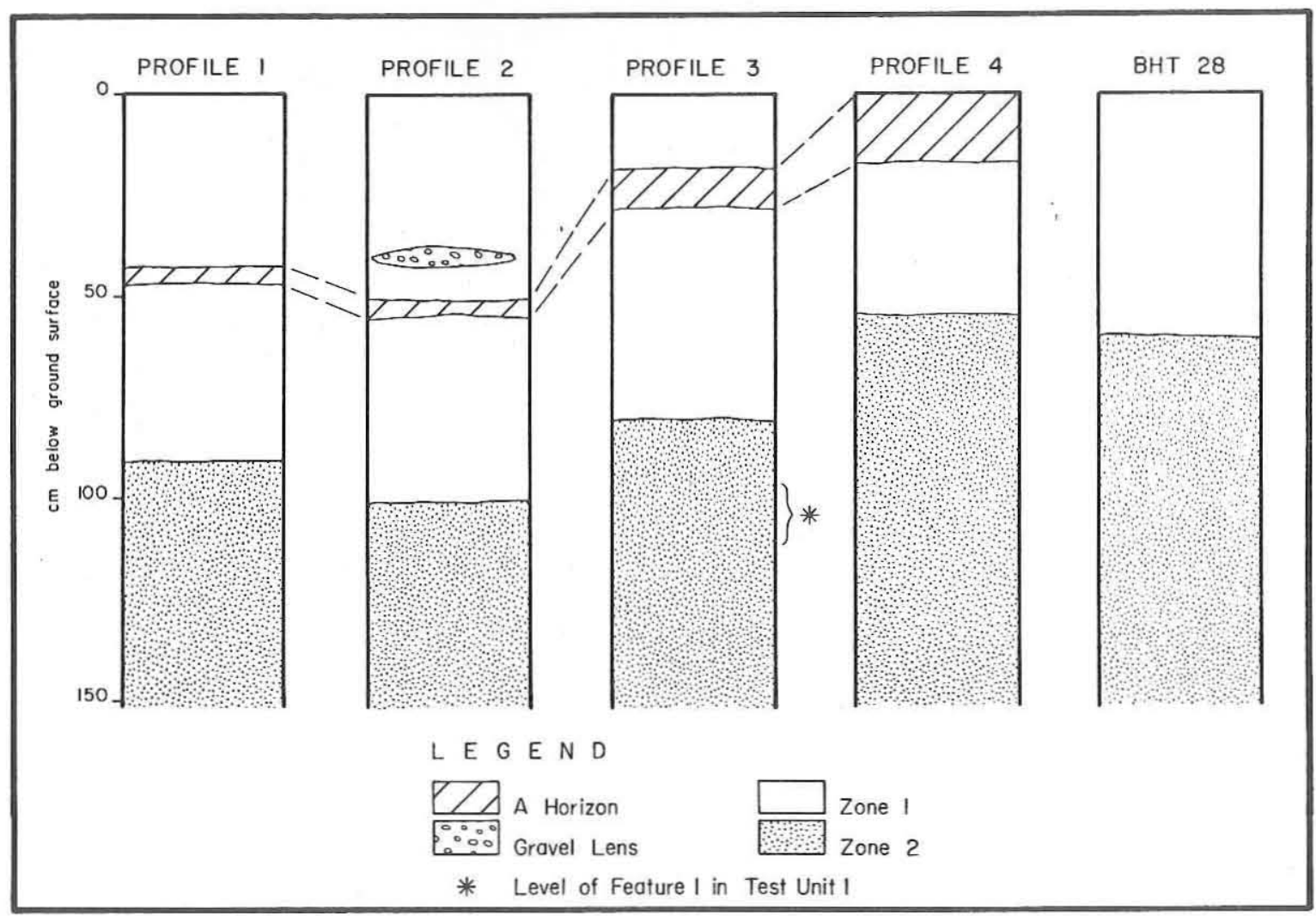

Figure 30. Stratigraphic profiles along Grape Creek cutbank and in Backhoe Trench 28, $41 \mathrm{KT} 52$.

\section{SITE EXTENT AND DEPTH}

The site boundaries are defined by Grape Creek on the south, the base of the valley slope on the west, and the extent of buried cultural materials on the east and north. The latter are not well defined due to the limited amount of testing. Site size is estimated to be $100 \times 70 \mathrm{~m}$. 
All cultural materials were recovered from the cutbank exposure or from subsurface contexts. A definite occupational zone was encountered in Test Unit 1 at a depth of over $100 \mathrm{~cm}$. A flake found in the upper $45 \mathrm{~cm}$ of Backhoe Trench 28 and materials from Phase I shovel tests indicate a sparse upper component. Ceramic sherds found in the cutbank slump could be from either component but are most likely associated with the upper occupation.

\section{FEATURES}

Although two features were recorded, Feature 1 is the only one of definite cultural origin. It was observed partially exposed in the Grape Creek cutbank during the 1987 survey. Subsequent excavation exposed ca. $60 \%$ of the partially destroyed feature at 96$113 \mathrm{~cm}$ in the southern half of Test Unit 1. This slab-lined, 130-cm-diameter, circular, basin-shaped hearth (Fig. 31) consists of one to three layers of tabular sandstone slabs and fragments. A mussel bivalve (Uniomerus declivus) was found immediately outside the feature at the same level.

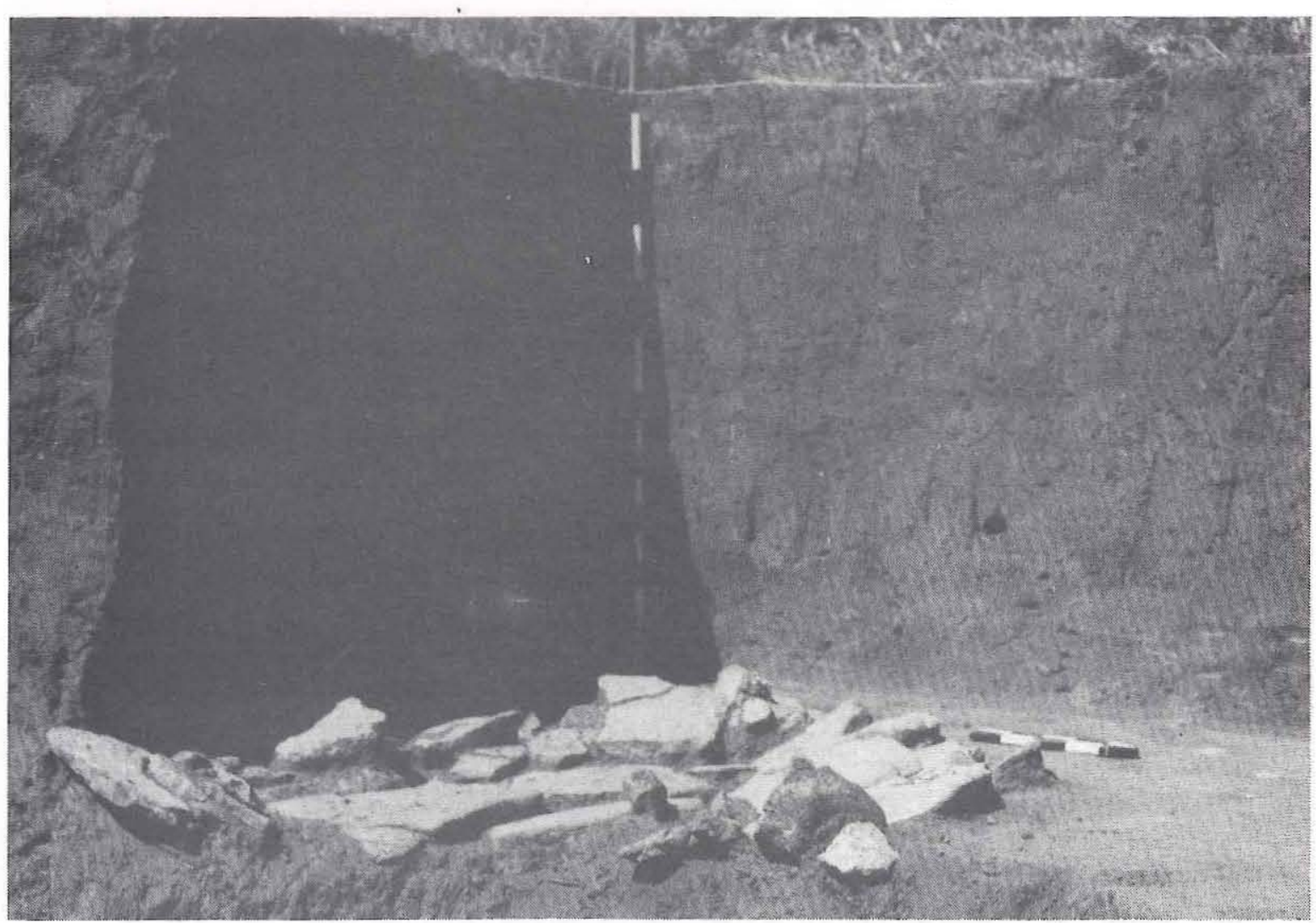

Figure 31. Feature 1, 41KT52. View southwest.

Several technical studies of Feature 1 were performed. A thermoluminescence assay on a burned rock was attempted but the specimen was found to contain poor thermoluminescence characteristics (Dur89TL 135-13). A radiocarbon assay on a small charcoal sample yielded 
an age of less than 200 B.P. (GX-14450), although this assay is questionable due to the small size of the sample. A burned rock from this feature yielded indeterminate organic residues, and phytolith analysis of the feature fill yielded chloridoid, festucoid, elongate, and panicoid types. Flotation of the feature fill yielded burned juniper wood, Chenopodium fruit, an Amaranthus seed, Portulaca seeds, an unidentified bone fragment, snail shells, and two microdebitage specimens. The charred wood is definitely cultural, probably introduced as fuel, and the microdebitage and bone fragment also are cultural. The other materials could be cultural or natural.

Feature 2 is a 5-cm-diameter, circular charcoal stain found at 116-121 cm along the north wall of Test Unit 2. It consists of charcoal fragments in a matrix of soft sediments. The feature could be a rodent burrow, but it could not be traced and no rodent disturbance was noted in other levels. The feature must be considered potentially cultural, but its function is unknown.

\section{MATERIALS RECOVERED}

Thirteen artifacts (excluding two microdebitage specimens recovered from flotation of the Feature $1 \mathrm{fill}$ ), two burned rocks, one unidentifiable bone fragment, a mussel bivalve, and fragmentary mussel shells were recovered from two separate components (Table 26). Materials from the upper component are not associated with a definable living surface but are scattered through the upper $75 \mathrm{~cm}$ of alluvial sediments. Conversely, the lower component materials are associated with a defined cultural zone and a hearth (Feature 1) between 95 and $120 \mathrm{~cm}$. Specimens surface collected along the cutbank cannot be assigned definitely to either component, although the ceramics are likely to be from the upper component and the metate fragment (and three other metate fragments collected during the 1987 investigations) from the lower. The ceramics consist of three Type II sherds (probably Pecos Faint Striated) and one Type VI sherd (unidentified).

\section{DISCUSSION}

Site $41 K T 52$ is a stratified site with two components. The upper component is a Late Prehistoric occupation consisting of an ephemeral scatter of cultural materials at a depth of 0-75 cm. No definable occupational surface or features were observed. The sparse cultural materials are not functionally diagnostic, although mussel shell fragments may be evidence of food processing. The occupation is not dated, but ceramic sherds (Types II and VI) indicate an occupation postdating A.D. 1600, an age comparable to the upper component at 41KT53 and the occupation of 41KT5I (see Chapter 6), both of which also yielded Type II sherds. The similar geomorphic setting and close proximity of these three sites support this interpretation.

The lower component, from ca. $95-120 \mathrm{~cm}$, is defined by a large slab-lined basin hearth (Feature 1) and cultural materials recovered from Test Unit 1, additional rock clusters (probable hearths) exposed in the cutbank, and large rocks (probably manuports) encountered in auger tests. No temporally diagnostic artifacts were recovered, and the cultural affiliation is unknown. A radiocarbon assay on charcoal from the hearth yielded an age of less than 200 B.P., but this date is questionable because of the small sample size and the deeply buried alluvial context. Feature 1 is similar in size, shape, and depositional context to Feature 3 at 41KT53, which appears to be at least 2,000 years old (see below). 
TABLE 26

DISTRIBUTION OF ARTIFACTS, 41KT52

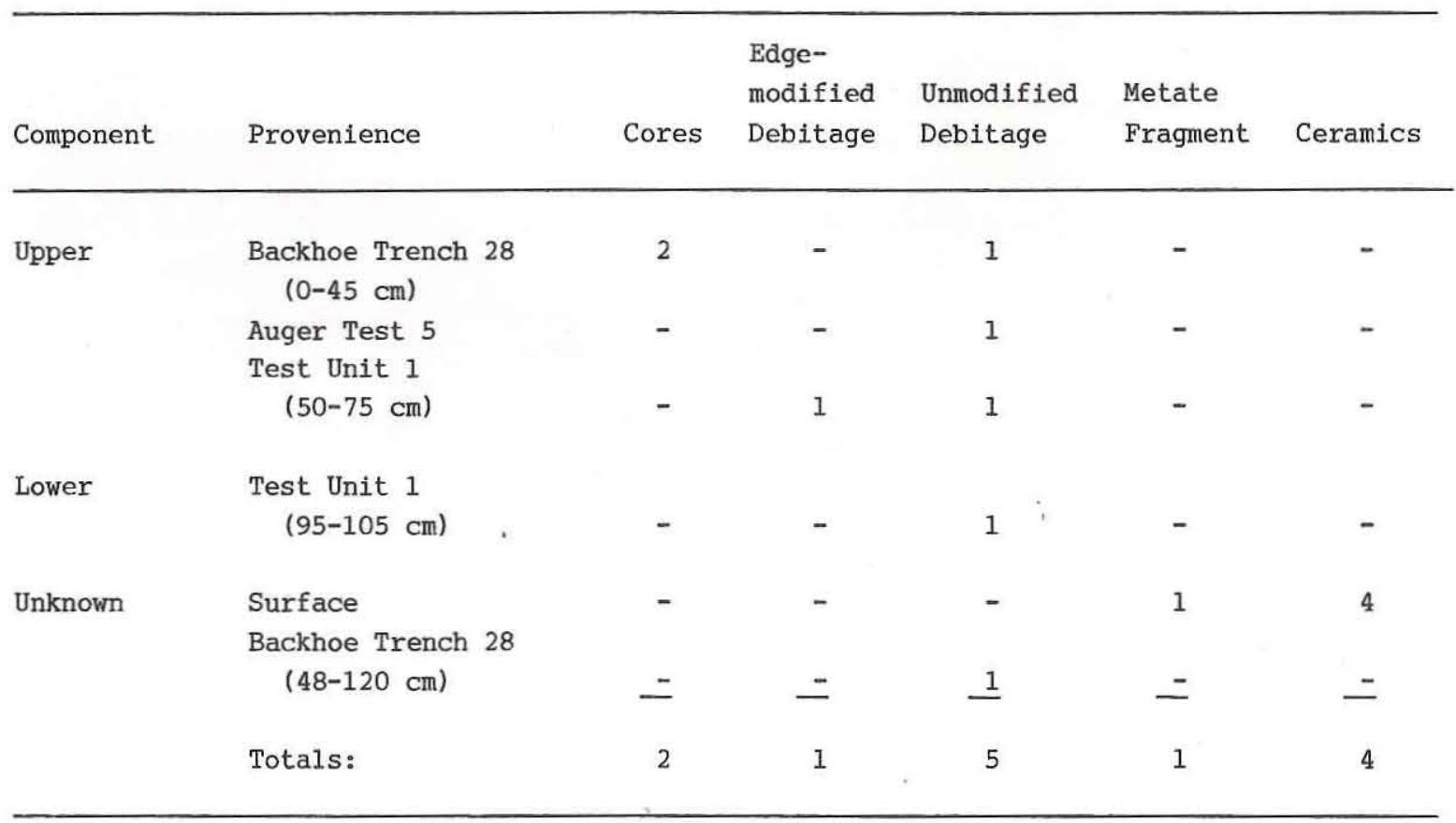

Based on these similarities and assuming that the radiocarbon date from Feature 1 is erroneous, it is surmised that the lower component dates to the late Archaic period.

The lower component appears to represent a specialized processing locality. There is a definite paucity of lithic tools and debitage, yet the hearth is undisturbed and represents a discrete activity. The unmodified mussel bivalve found adjacent to the hearth is probable evidence of the utilization of shellfish as a food resource. The four surface collected metates are likely to be associated with the lower component and probably represent plant processing. If the lower component represents a short-term shellfish and plant processing station, then substantial accumulations of artifacts and debris would not be expected. The presence of rock clusters in the cutbank and in Auger Test 8 indicates that additional slab-linea hearths are likely and that spatially discrete activity areas could be defined.

41KT53

SITE SETTING

Site 4lKT53 is situated on an alluvial terrace on the west side of Grape Creek, ca. $2.25 \mathrm{~km}$ southeast of its confluence with the Double Mountain Fork. The Grape Creek valley is considerably broader here than to the north and south. The site is located along the 
creek cutbank in the east-central portion of the ca. 500x250-m terrace. The surface is generally flat at an elevation of $2170 \mathrm{ft} \mathrm{msl}$ and slopes gently toward the creek. Dense mesquites, chollas, and grasses cover the terrace, which does not appear to have been cleared or cultivated. Erosion along the cutbank is the only disturbance present.

\section{WORK ACCOMPLISHED}

Site 41KT53 was recorded in 1987 as a multicomponent site with an upper Late Prehistoric (possibly Garza Complex) component and a lower undefined component. Surface collections included an isolated end scraper and ceramic sherds which had been brought to the surface by animal burrowing. One shovel test yielded sherds to $60 \mathrm{~cm}$. The ceramics, identified as Pecos Glaze Polychrome V and Pecos Faint Striated, consisted of 27 decorated sherds from a single vessel and 4 plain sherds. The lower component was indicated only by a slab-lined hearth exposed in the cutbank $100 \mathrm{~cm}$ below the surface. Mapping and testing were recommended (Boyd et al. 1989).

The current investigations consisted of a magnetometer survey, site mapping, and excavation of 4 backhoe trenches, 4 exploratory trenches, and 13 test units (Fig. 32, Table

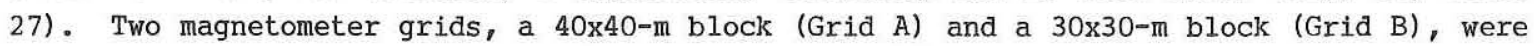
surveyed, and the results were used to select areas for subsurface testing. Grid A was minimally productive due to methodological problems; the magnetic anomalies could not be definitely correlated with cultural features, although one particularly strong magnetic anomaly was apparently caused by a concentration of ceramic sherds and a burned tree stump. Grid B, however, was extremely productive. Three of the five discrete positive magnetic anomalies tested were found to be caused by cultural features, one was caused by a deeply buried facies change in the underlying strata, and testing of the fifth was inconclusive.

Backhoe Trenches 25-27 and 32 were excavated in the site area. Backhoe Trench 32 yielded cultural materials, and Backhoe Trenches 25-27 produced possible cultural evidence (charcoal staining in the sediment) at $90 \mathrm{~cm}, 34-40 \mathrm{~cm}$, and $35 \mathrm{~cm}$, respectively. Exploratory Trenches 102-105 yielded no definite cultural evidence, but a charcoal/ash-stained soil was noted at 7-10 cm in Exploratory Trench 102. Test Units 1-7 were excavated in magnetometer Grid B to test anomalies. A burned post (Feature 1) was encountered in Test Unit 2, a ceramic concentration (Feature 6) was recovered in Test Unit 4, and an unlined hearth (Feature 4) was encountered in Test Unit 7. Test Units 8 and 9 were excavated in magnetometer Grid A. A ceramic concentration and a burned tree stump (Features 5 and 12) were encountered in Test Unit 8 . Test Units 10,11 , and 13 were excavated to determine site extent, and Test Unit 12 was excavated to test the buried hearth (Feature 3) exposed in the Grape Creek cutbank. All units were $1 \times 1 \mathrm{~m}$, except Test Units 1 and 8 (1x2 m), Test Unit $9(1 \times 1.5 \mathrm{~m})$, and Test Unit $12(1.25 \times 1.25 \mathrm{~m})$.

\section{SEDIMENTS AND STRATIGRAPHY}

The stratigraphy in Backhoe Trench 25 (see Appendix A) is typical of the alluvial terrace deposits in this segment of the Grape Creek valley. The upper zones are: Zone $I_{\text {, }}$ 0-25 cm, dark reddish brown silty clay loam with organic enrichment; Zone 2, 25-40 cm, reddish brown silty clay loam; Zone 3, 40-130 cm, dark reddish brown clay loam; and Zone 4, 130-165 cm, brown sandy loam. The sediments are all strongly calcareous, hard to very hard, and have blocky structure. Two radiocarbon assays of humates from Backhoe Trench 25 


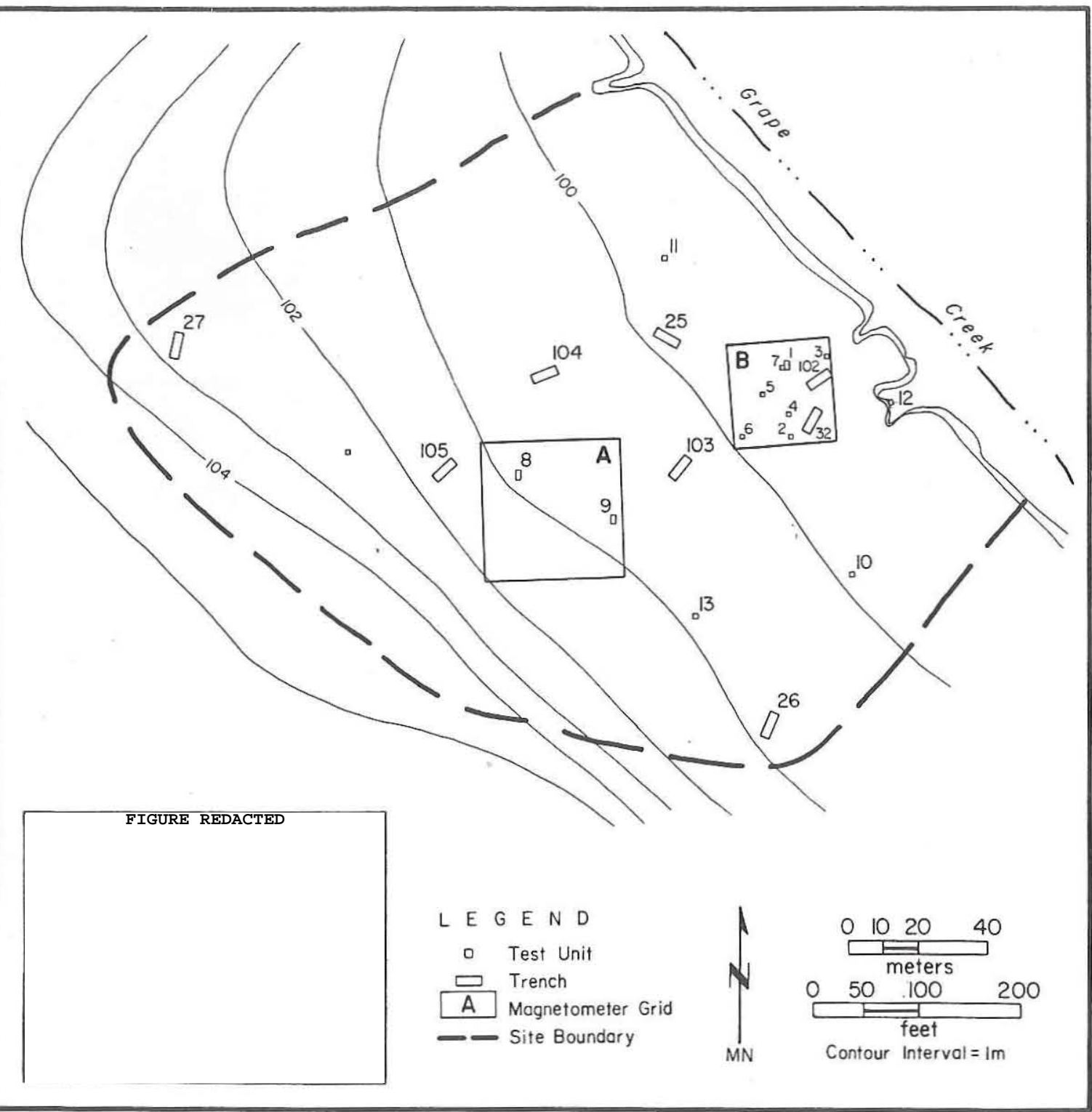

Figure 32. Site map, 41KT53.

yielded corrected radiocarbon ages of $1280 \pm 50$ B.P. (Tx-6226) on sediment from 63-75 cm and $2630 \pm 70$ B.P. $(\mathrm{Tx}-6227)$ on sediment from $160-175 \mathrm{~cm}$.

SITE EXTENT AND DEPTH

The eastern site boundary is defined by the Grape Creek cutbank, but the other boundaries are more tentative, being based on limited testing. Cultural materials were recovered ca. $110 \mathrm{~m}$ west of the cutbank in Test Unit 8, and possible cultural charcoal staining was noted in Backhoe Trench $27 \mathrm{ca}$. $160 \mathrm{~m}$ west of the cutbank. Cultural evidence 
TABLE 27

SUMMARY OF EXCAVATIONS, 41KT53

Depth of

Excavation

Unit (cm)

Reason for Ending Unit
Artifact

Density $\left(\# / \mathrm{m}^{3}\right)$

or Result

$\begin{array}{lrlr}\text { Test Unit } 1 & 70 & \text { Artifact decrease } & 41.4 \\ \text { Test Unit } 2 & 45 & \text { Artifact decrease } & 4.4 \\ \text { Test Unit } 3 & 100 & \text { Low artifact density } & 1.0 \\ \text { Test Unit } 4 & 20 & \text { Arbitrary } & 195.0 \\ \text { Test Unit } 5 & 18 & \text { Low artifact density } & 38.0 \\ \text { Test Unit } 6 & 20 & \text { Low artifact density } & 5.0 \\ \text { Test Unit } 7 & 30 & \text { Artifact decrease } & 260.0 \\ \text { Test Unit } 8 & 22 & \text { Artifact decrease } & 259.0 \\ \text { Test Unit } 9 & 30 & \text { No artifacts } & 0.0 \\ \text { Test Unit 10 } & 20 & \text { No artifacts } & 0.0 \\ \text { Test Unit } 11 & 20 & \text { Low artifact density } & 0.0 \\ \text { Test Unit } 12 & 110 & \text { Low artifact density } & 0.0 \\ \text { Test Unit } 13 & 20 & \text { Low artifact density } & 5.0 \\ \text { Exploratory Trench } 102 & 80 & \text { Arbitrary } & * \\ \text { Exploratory Trench } 103 & 102 & \text { Arbitrary } & \text { negative } \\ \text { Exploratory Trench } 104 & 100 & \text { Arbitrary } & \text { negative } \\ \text { Exploratory Trench } 105 & 96 & \text { Arbitrary } & \text { negative } \\ \text { Backhoe Trench } 25 & 300 & \text { Arbitrary } & * \\ \text { Backhoe Trench } 26 & 330 & \text { Arbitrary } & * \\ \text { Backhoe Trench 27 } & 270 & \text { Arbitrary } & \text { Arbitrary } \\ \text { Backhoe Trench } 32 & & & \text { positive }\end{array}$

*Possible cultural charcoal staining noted.

was recovered in Test Units 11 and 13, which are ca. $100 \mathrm{~m}$ apart north-south. The site size is estimated to be ca. $180 \times 180 \mathrm{~m}$.

Two stratigraphically separate cultural components are present. The upper component consists of cultural materials and features found at 0-25 cm, except for an intrusive burned post (Feature 1) which extended to $47 \mathrm{~cm}$. The lower component consists of a hearth in the cutbank (Feature 3 ) at $100-130 \mathrm{~cm}$ and possible cultural charcoal staining at $90 \mathrm{~cm}$ in Backhoe Trench 25. The upper component covers the entire site area, but the lower component appears to be less extensive, although testing of the latter was minimal.

FEATURES

Six features were discovered. Features 1, 4, and 5 were located by testing anomalies in magnetometer Grid B. Features 2 and 6 were located by testing a anomaly in magnetometer 
Grid A. Feature 3 was partially exposed in the Grape Creek cutbank and is the only feature associated with the lower component.

Feature 1 is a burned post found at $13-47 \mathrm{~cm}$ in the central portion of Test Unit 2 . The circular post mold contained a mixture of large chunks of intensively charred hackberry wood, fragments of partially charred wood, and some clayey sediments (Fig. 33). A ring of burned (reddened) clay sediments surrounding the post was traced from 25 to $50 \mathrm{~cm}$ in depth. The post dipped $75^{\circ}$ to the west, and its base was flat. Flotation of the fill inside the post mold yielded large amounts of charred hackberry wood, noncharred Chenopodium fruit and Mollugo seeds, two microdebitage flakes, and a snail shell. The post apparently burned in place, but the noncharred remains in the fill indicate some later intrusive disturbance. The function of the post is not known. A radiocarbon assay of charcoal from this feature yielded a corrected age of $295 \pm 80$ B.P. (GX-14451).

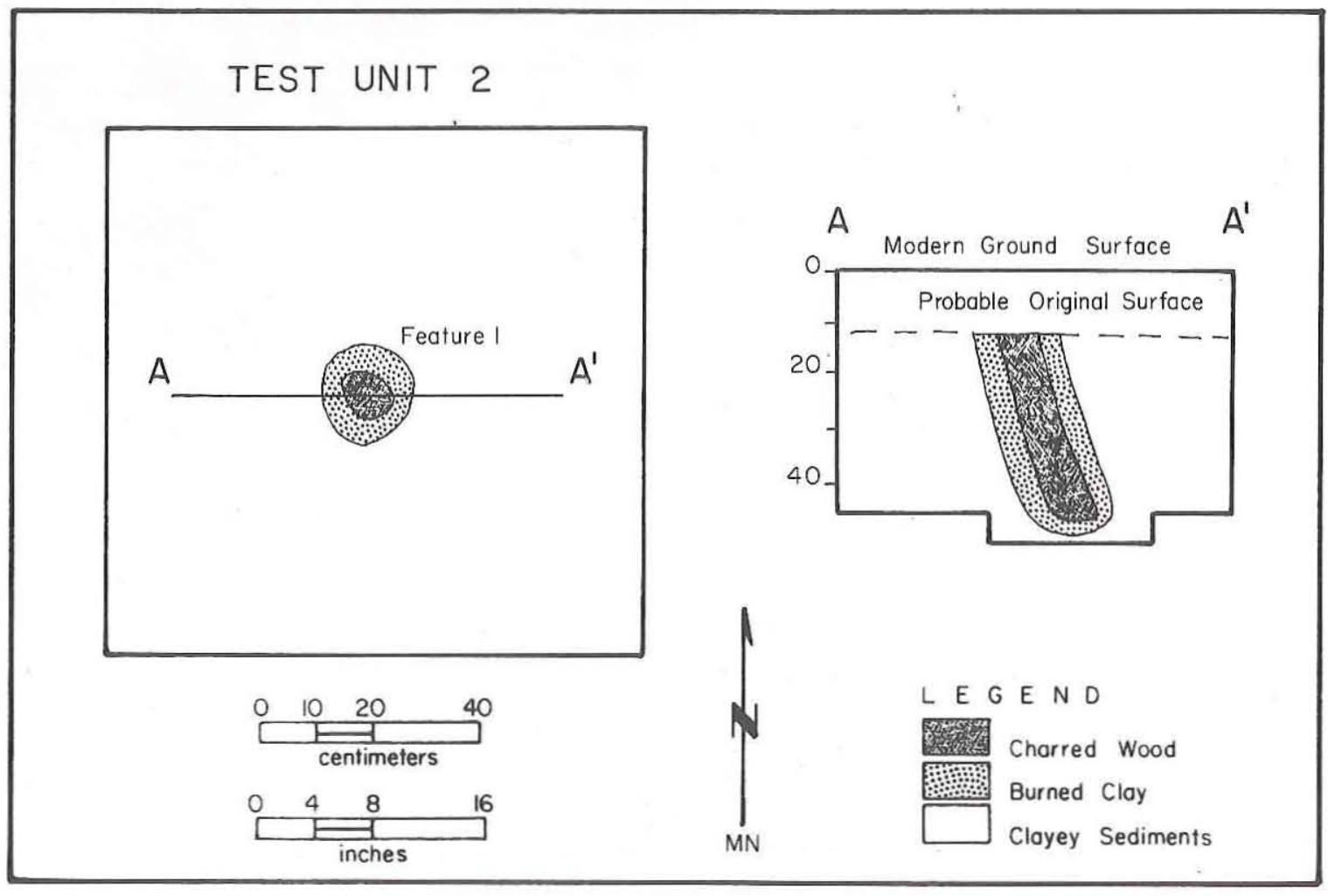

Figure 33. Plan and profile views of Feature 1, 41KT53.

Feature 2 consist.s of dark gray organic-stained soil and a partially burned tree stump found at 15-42 cm along the south wall of Test Unit 8 . Only a 50x60-cm block in the southwest corner was excavated to $42 \mathrm{~cm}$, and much of the feature remains unexcavated in Test Unit 8 and extends into the south wall. No cultural materials were found in association, and the feature appears to be a modern, partially burned tree stump that is decaying in place. The recent age of the site and the presence of scattered ceramics in the test unit, however, make this interpretation questionable. 
Feature 3 is a slab-lined hearth (Fig. 34) discovered in the Grape Creek cutbank in 1987 and exposed at 100-129 cm in Test Unit 12. A portion had been destroyed by erosion, but ca. $75 \%$ remained intact. It is circular, with a diameter of ca. $110 \mathrm{~cm}$, and is composed of one to two layers of ca. 30 sandstone slabs and fragments which dip slightly toward the center of the feature. The central area is devoid of rocks and contains gray ash-stained sediment with charcoal flecks. No associated cultural materials were found. A charcoal sample submitted for radiocarbon dating was too small to produce an acceptable date $(G X-14452)$, but the humate radiocarbon dates from Backhoe Trench 25 suggest that the sediments surrounding the feature are between 1,300 and 2,600 years old. A hearthstone yielded a thermoluminescence date of $2800 \pm 570$ B.P. (Dur89TLqi 135-14AS), but the date is questionable since it is much younger than the humate dates. The dated hearthstone was found to contain residues of indeterminate origin. Phytolith analysis yielded mostly festucoid and elongate types. Flotation of feature fill yielded burned oak wood and unidentified hardwood, an unidentified uncharred fruit fragment, and snail shells.

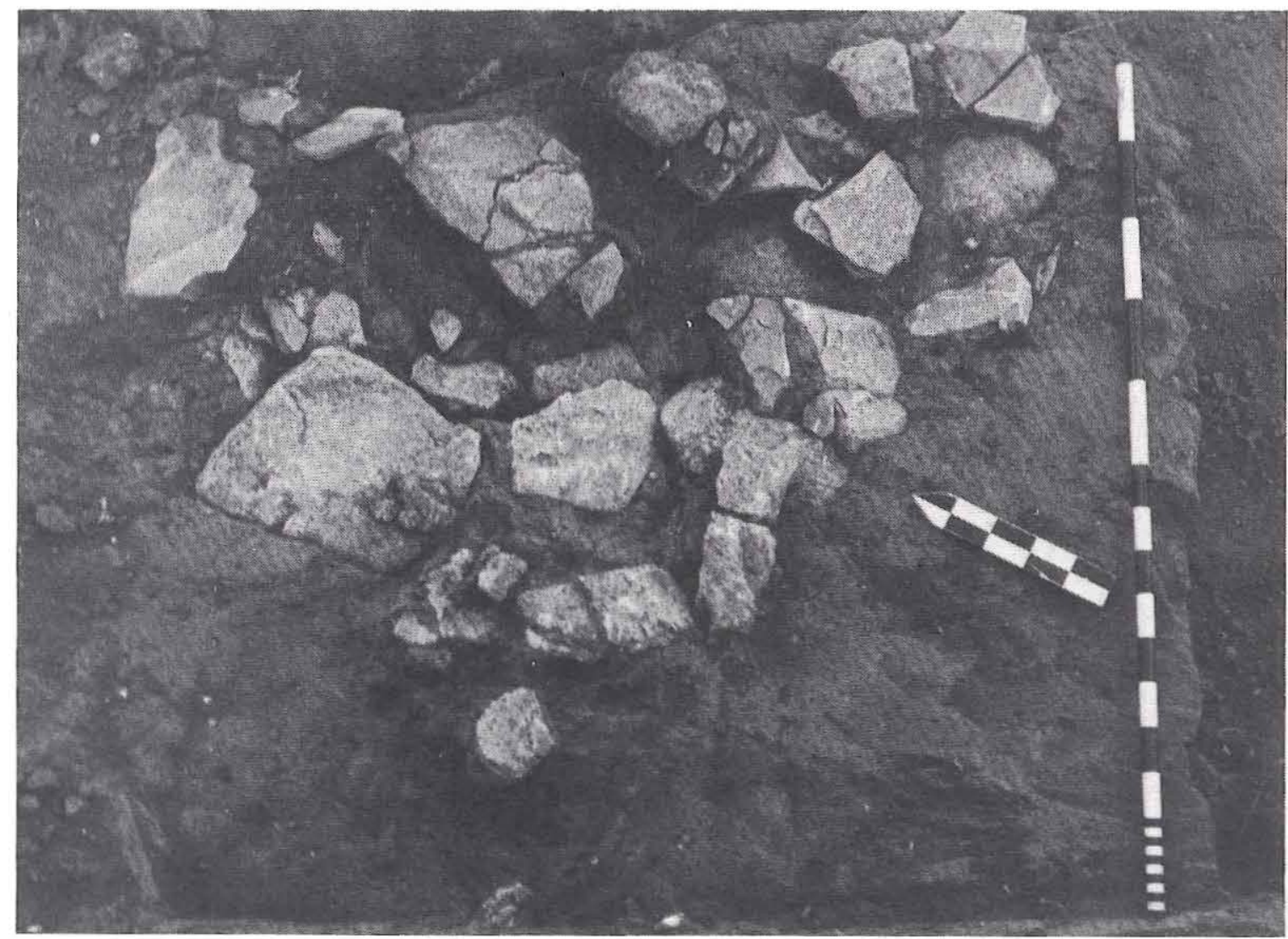

Figure 34. Photo of Feature 3, 41KT53. View from above.

Feature 4 (Fig. 35) is a circular, unlined, ash-filled hearth found at 18-25 $\mathrm{cm}$ in the center of Test Unit 7. It consists of a $64 \times 67-\mathrm{cm}$ shallow basin with an in situ burned clay perimeter, completely filled with a gray ashy soil and cultural debris. Three small unmodified fragments of sandstone and a ca. 5-cm-diameter pocket of unburned hackberry 


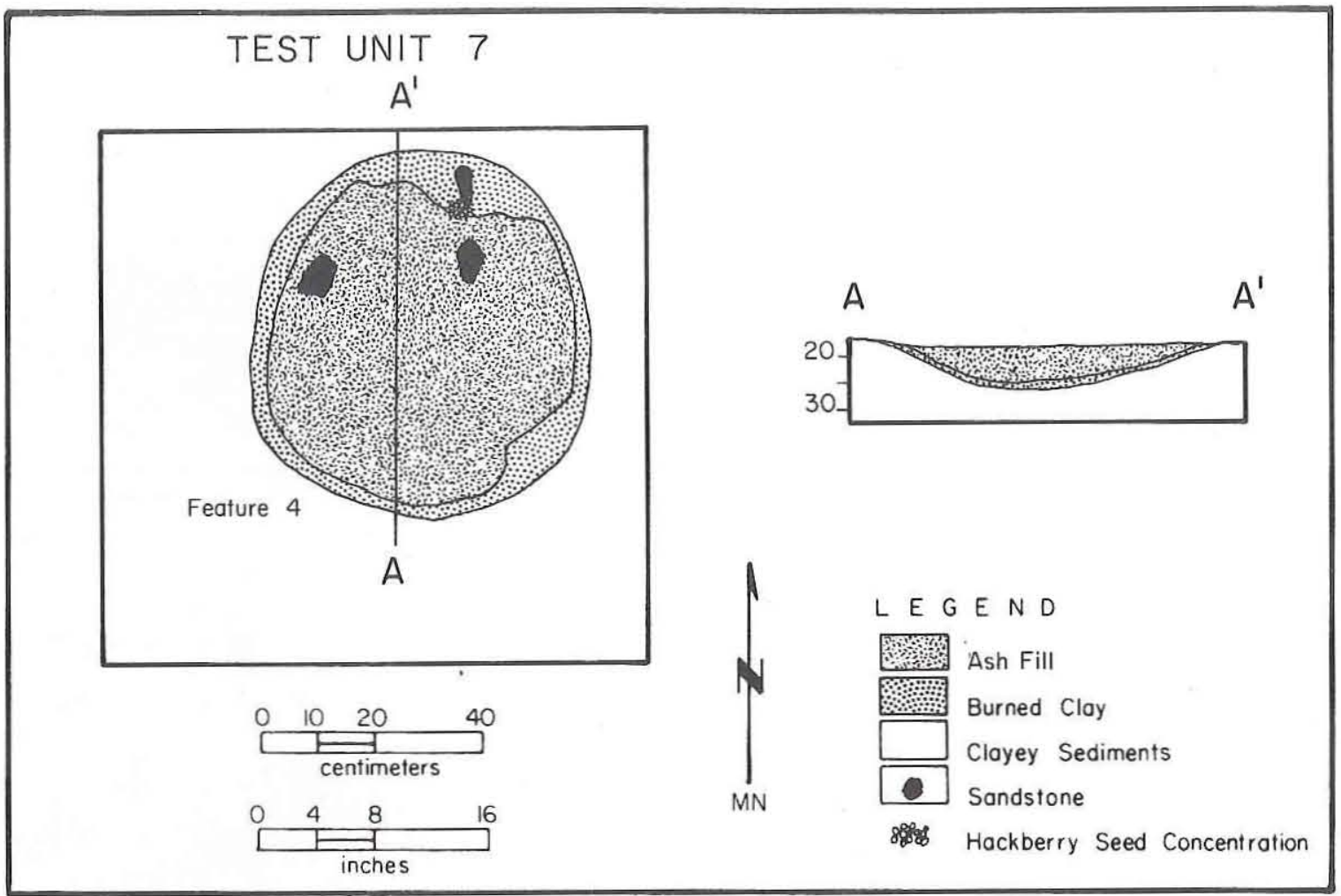

Figure 35. Plan and profile views of Feature 4, 41KT53.

seeds were recovered from the feature. Lithic debitage was abundant in and around the hearth. A radiocarbon assay on a small charcoal sample yielded a corrected age of less than 200 B.P. (GX-14453). The apparent poor pollen preservation in the feature fill probably reflects methodological problems of the pollen analysis. Phytolith analysis of feature fill yielded mostly festucoid, chloridoid, and elongate types. Organic analysis of a burned rock from the fill yielded residues of indeterminate origin. Flotation of feature fill yielded a variety of materials, including burned turtle carapace fragments, rodent bones, unidentified bone fragments, and snail shells. Large pieces of charred wood were identified as hackberry, but a charred nut fragment and charred unidentified hardwood fragments were also present. Noncharred plant remains consist of Chenopodium fruit, hackberry seeds, Mollugo seeds, unidentified seeds, and a grass seed. Also recovered by flotation were 98 flakes and microdebitage (many exhibiting evidence of burning), and 13 fire-cracked chert fragments. The lithic debris, which suggests that stone tool manufacturing was occurring nearby, was probably intentionally discarded into the hearth. There are several possible origins for the other materials. The charred hackberry wood was probably the fuel for the fire. Some items, such as the grass seed, Mollugo seeds, and snail shells, may have been incidentally present or were later introduced by natural processes. Other materials are probably related to the function of the feature, and the turtle carapace fragments, rodent bones, hackberry seeds, and Chenopodium fruit may be food resources that were processed in the hearth. 
Feature 5 is a concentration of 57 ceramic sherds found randomly distributed at 0-20 cm in Test Unit 8 and 27 sherds surface-collected from the same provenience in 1987. These sherds are all from a single decorated polychrome (Type I) bowl. Organic analysis of one sherd identified probable plant residue. A thermoluminescence assay of one sherd yielded an age of $145 \pm 40$ B.P. (Dur89TLpfg 134-13BS).

Feature 6 consists of 16 ceramic sherds recovered at $10-20 \mathrm{~cm}$ in Test Unit 4 . Most were found in a $12 \times 15-\mathrm{cm}$ cluster in the west half of the unit and represent a portion of a vessel that was broken in place. The plainware vessel (Type II) appeared to be lying, interior side down, on an occupational surface. Other artifacts recovered from this level consist of a biface found adjacent to the ceramic cluster, 11 burned and unburned bone fragments, 8 flakes, 10 additional Type II sherds, a single decorated sherd (Type I), and 3 plainware sherds (Types III and V). Ash-stained sediments, charcoal flecks, and probable burned sandstone fragments were also noted throughout the level. Most of the cultural materials were concentrated in the west half of the unit, indicating that the occupational surface is intact to the west of Test Unit 4. Organic analysis of one sherd (Type II) and the biface revealed indeterminate residues. A thermoluminescence assay of one sherd yielded an age of $180 \pm 45$ B.P. (Dur89TLpfg 134-14BS). Phytolith analysis of the feature fill revealed festucoid, chloridoid, panicoid, and elongate types.

\section{MATERIALS RECOVERED}

The 216 artifacts recovered consist of 111 chipped stones, 2 ground stones, and 103 ceramic sherds (Table 28); excluded from this count are 61 pieces of microdebitage recovered from flotation samples. All of these, except for one unmodified flake found in Test Unit 13, are associated with the upper component. The chipped stone assemblage is predominantly of local chert, but an unusually high frequency of nonlocal chert is represented (14.4\% Cretaceous chert and 0.9\% Tecovas jasper). Few chipped stone tools were recovered, and the lithic debitage contains many rejuvenation flakes from resharpening unifacial tools. The ceramic assemblage consists of 62 Type I sherds, 32 Type II sherds, 7 Type III sherds, and 2 Type $\mathrm{V}$ sherds. Two vessels were partially reconstructed from the sherds, a Pecos Glaze Polychrome V bowl (Type I, see Feature 5) and a Pecos Faint Striated jar (Type II, see Feature 6). Types III and V are unidentified plainwares. Also recovered were 21 burned rocks.

Organic residues were extracted from four artifacts. A biface and Type II sherd associated with Feature 6 and an unmodified flake from Test Unit 2 yielded residues of indeterminate origin. Probable plant residue was found on a Type I sherd from Feature 5.

\section{DISCUSSION}

Site 41 KT53 is stratified with two components. The lower component, at $100-130 \mathrm{~cm}$, is not well defined; Test Unit 12, the only test unit excavated deep enough to reach the lower component, exposed a slab-lined hearth (Feature 3) with no associated artifacts. Radiocarbon dates obtained from sediments in Backhoe Trench 25 stratigraphically above and below the level of the hearth bracket this zone at 1280-2630 B.P. The best estimate of the occupation, based on the conservative humate dates, is late Archaic, ca. 2000 B.P. or older. Feature 3 is similar in size, shape, and stratigraphic position to Feature 1 at 41KT52, and the two may be related in age and function. The lower component probably represents a 
TABLE 28

DISTRIBUTION OF ARTIFACTS, 41KT53

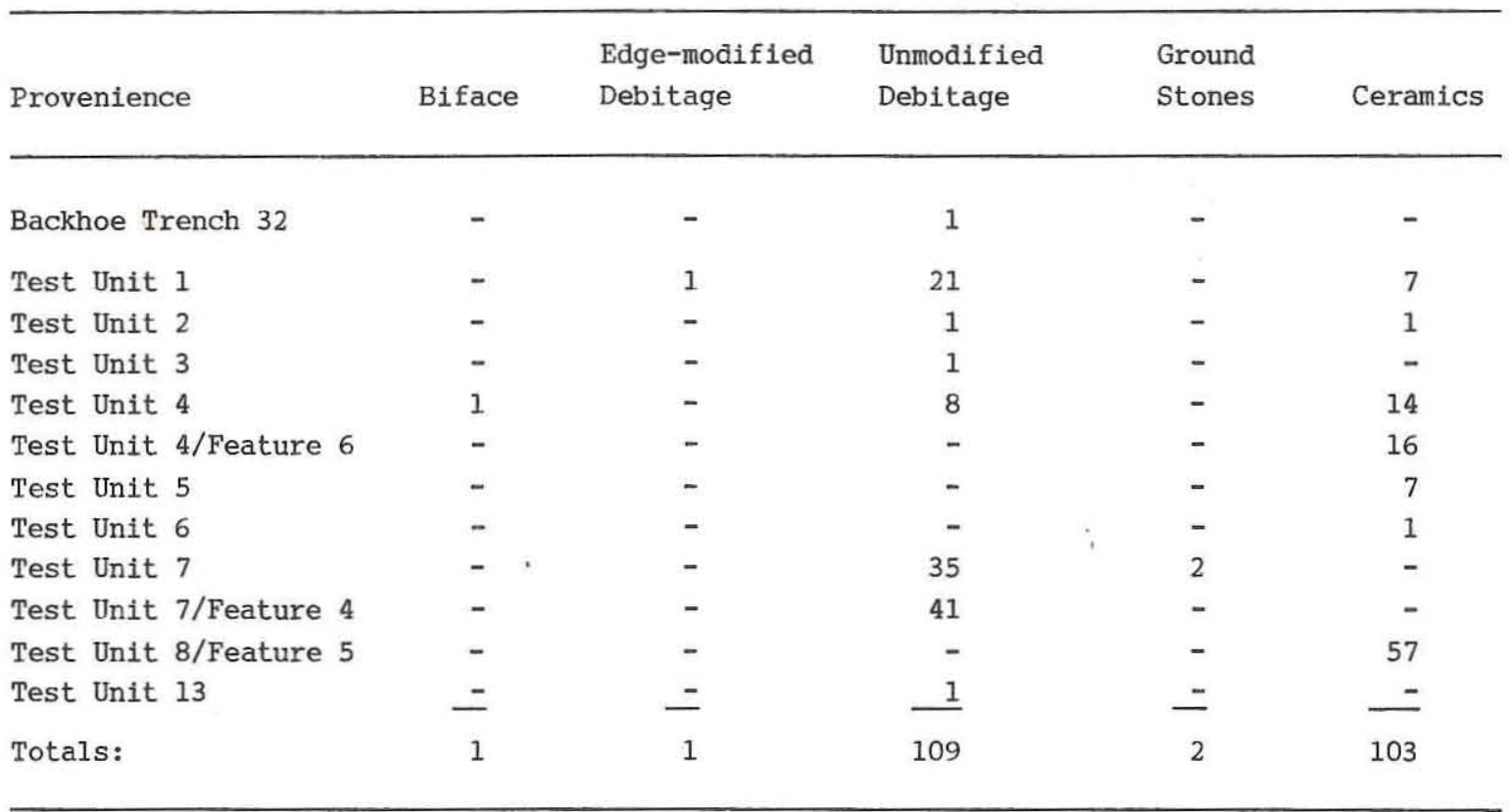

specialized activity locality, presumably related to food processing. The extent of this component, however, is not known due to the limited testing.

The upper component is represented by four definite cultural features (a burned post, an unlined ash-filled hearth, and two ceramic concentrations), a very few stone tools, and lithic debitage. Distinct spatial patterning of activities is represented by the features and varying artifact densities between units. The occupational zone is vertically discrete (except for intrusive features) at a depth of 0-25 cm and is most concentrated at 10-25 cm.

The upper component is firmly dated to the terminal portion of the Late Prehistoric period. Radiocarbon dates, thermoluminescence dates on ceramics, and ceramic typology place the occupation at A.D. 1650-1800, but no evidence of European contact was encountered. The dates suggest that this component could be a very late Garza Complex occupation or that it may be related to late Historic Plains Indian groups, such as the Comanche, Kiowa, or Kiowa-Apache, who moved into the region in the early 1700s. The apparent absence of European trade goods may indicate that the occupation is earlier.

Various activities are represented by the features and artifacts. The function of the burned post is unknown, but it could be evidence of a structure. The circular, ash-filled, unlined hearth is an interesting feature with evidence of a variety of activities. Lithic debitage, mainly rejuvenation flakes from uniface resharpening, was discarded into the hearth. Macrobotanical and faunal remains suggest that several resources were processed in the hearth, i.e., turtle, rodent, hackberry seeds, and Chenopodium fruit. This hearth was probably a multifunctional heating and cooking feature. 
The two partially reconstructed ceramic vessels are a decorated glazed polychrome bowl, which may have been a storage or serving vessel for plant foods, and a small plainware jar used primarily for cooking. The decorated vessel is definitely from Pecos Pueblo, and the plainware vessel is likely also from Pecos Pueblo. These vessels and the nonlocal lithic materials indicate widespread exchange and/or high mobility of aboriginal groups.

The limited range of lithic tools, the peculiar nature and relatively sparse amount of lithic debitage, and the discrete occupational zone suggest that the upper component reflects a relatively short occupation and possibly specialized activities. It is most likely a temporary campsite oriented toward specialized procurement/processing tasks. Another possibility is that the component reflects a short-term, multifunctional campsite, and that the use of metal tools accounts for the limited lithic assemblage. The vertical and horizontal integrity of this component are exceptionally good, and the faunal and macrobotanical remains are apparently well preserved.

\section{Lithic Procurement Sites}

Two lithic procurement sites were investigated to provide data on the variability in and the utilization of the lithic materials found in the Quaternary gravel outcrops throughout the project area. These sites are described separately, but the materials recovered and the results of the investigations are described together.

41GR327

\section{SITE SETTING}

Located in the upland margin at the mouth of Little Grape Creek, the site occupies the eroding canyon rim on the east side of the creek and south of the Double Mountain Fork. It is partially bisected on the west by a drainage and small box canyon, and two prominent knolls occupy the southern portion of the site. Quaternary gravels are exposed on the knolls and eroding upland edges, and redeposited gravels occur in the drainage and on the lower bedrock benches. Large areas of bedrock sandstone are exposed in the central, lower portion of the site. A barbed wire fence marking a property line runs east-west across the northern portion of the site. Elevations range from ca. 2220 to $2270 \mathrm{ft} \mathrm{msl}$. Vegetation cover is sparse in the lower eroded areas and moderate in the upland; it consists mainly of grasses, junipers, and mesquites, with lesser amounts of cholla, tasajillo, prickly pear, and small shrubs.

WORK ACCOMPLISHED

This site was initially recorded in 1975 (Campbell and Judd 1977a). When it was revisited in 1987, evidence of early-stage lithic reduction was noted, but no burned rock features were observed. Controlled collection and mapping were recommended (Boyd et al. 1989). The current investigations consisted of mapping, surface collection of diagnostic artifacts, recovery of materials from two $25-\mathrm{m}^{2}$ lithic reduction units, and recovery of all materials from one lithic material unit (Fig. 36). The lithic reduction units and the lithic material unit were located in the sloping eastern portion of the site. 


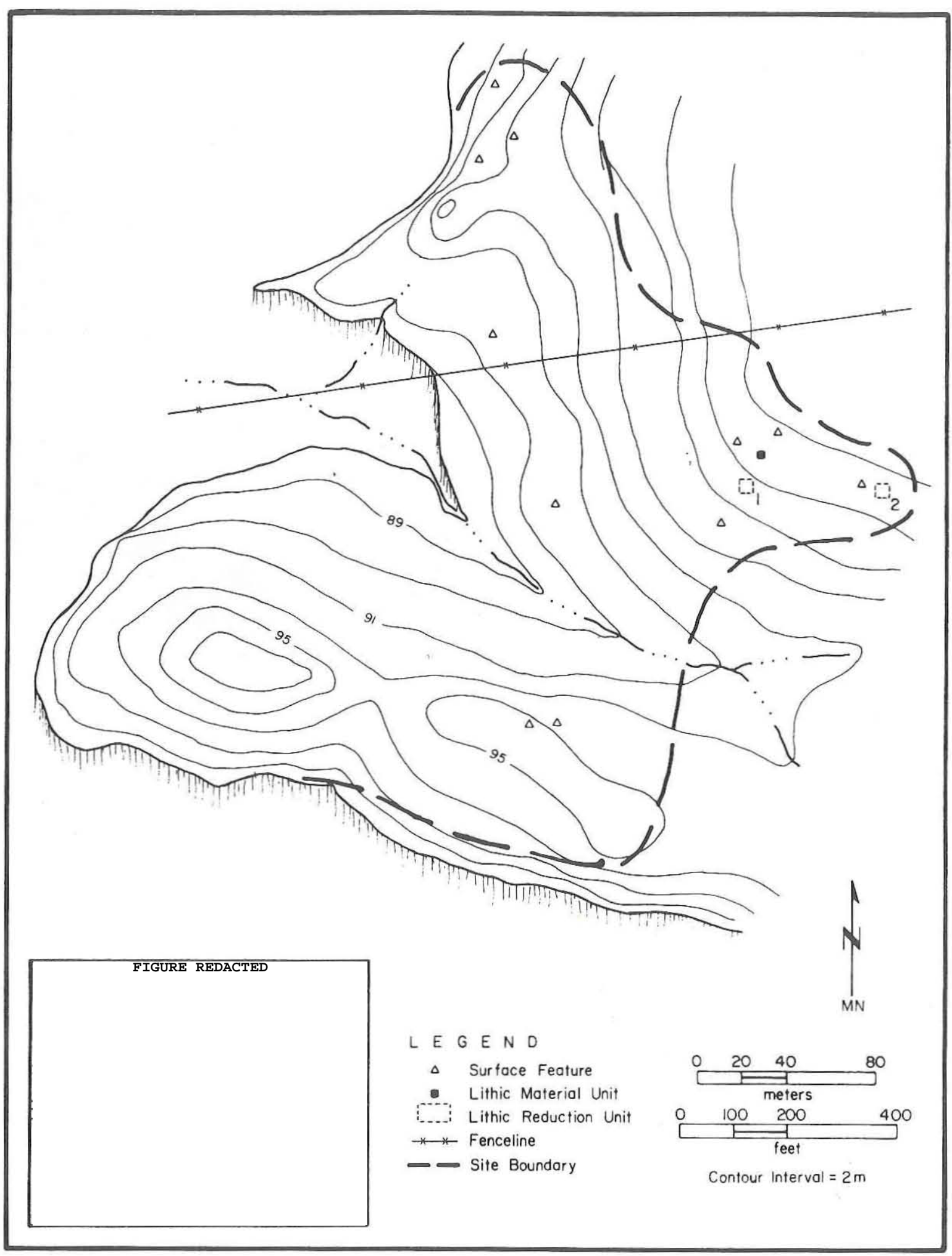

Figure 36. Site map, 41GR327. 
Eleven ephemeral burned rock features were mapped but were not investigated further. These features, distributed across the site in no apparent pattern, are small concentrated clusters or large thin scatters ranging in size from ca. 1 to $10 \mathrm{~m}$ in diameter. They consist primarily of fire-cracked Potter chert and quartzite with occasional burned sandstone fragments. Sparse lithic debitage was noted in association with some features. One possible hearth is a small ring (ca. $75-\mathrm{cm}$-diameter) of Potter chert cobbles. This site has been reclassified as a lithic procurement/campsite, although evidence of campsite activities is minor.

\section{SITE SEDIMENTS AND EXTENT}

The upland sediments consist of Quaternary gravels overlain by a thin veneer of finegrained sand. The gravels are predominantly siliceous materials, but limestone cobbles and Cretaceous pelecypods also occur. The lower portion of the site consists of isolated erosional remnants and gravels and sands redeposited onto exposed sandstone bedrock.

The site extent of ca. $300 \times 300 \mathrm{~m}$ is determined primarily by the distribution of exposed Quaternary gravels. Evidence of lithic procurement occurs throughout the gravel outcrop. The site boundaries are considered to be the canyon rim on the south, west, and north, and the extent of the upland surface-exposed gravels on the east. All cultural materials are surficial or very shallowly buried.

41GR381

\section{SITE SETTING}

Site 41GR381 is situated in the upland margin on the east side of Gobbler Creek, ca. $1.25 \mathrm{~km}$ northwest of its confluence with the Double Mountain Fork. The site occupies the eroding upland edge and the level upland along the east canyon rim of Gobbler Creek. An improved gravel road and concrete bridge cross Gobbler Creek in the valley northwest of the site; a buried pipeline, a barbed wire fence, and electric power lines cross the site. Elevations range from ca. $2250 \mathrm{ft} \mathrm{msl}$ in the northern end of the site to ca. $2290 \mathrm{ft} \mathrm{ms} \mathrm{in}$ the eastern upland portion. Vegetation cover is moderate in the upland and sparse along the eroding canyon edge and consists mainly of grasses, junipers, and mesquites, with lesser amounts of prickly pear, cholla, tasajillo, and small shrubs.

\section{WORK ACCOMPLISHED}

When 41GR381 was recorded in 1987, no surface features were observed, but two gouges were collected and a chopper tool was noted. The site was considered to be a good example of a lithic procurement site, and controlled collection and mapping were recommended (Boyd et al. 1989). The current investigations consisted of mapping, and the recovery of materials from two lithic reduction units and one lithic material unit in the northwestern portion of the site (Fig. 37). Also, surface artifacts were individually mapped and collected, and two $25-\mathrm{m}^{2}$ scatters of fire-cracked rocks were mapped and recorded. Feature 1, at the northwestern end of the site near Lithic Reduction Unit 1, is a ca. 10x15-m area covered with sparse fire-cracked rocks and some chipped lithic debris. Feature 2, at the 


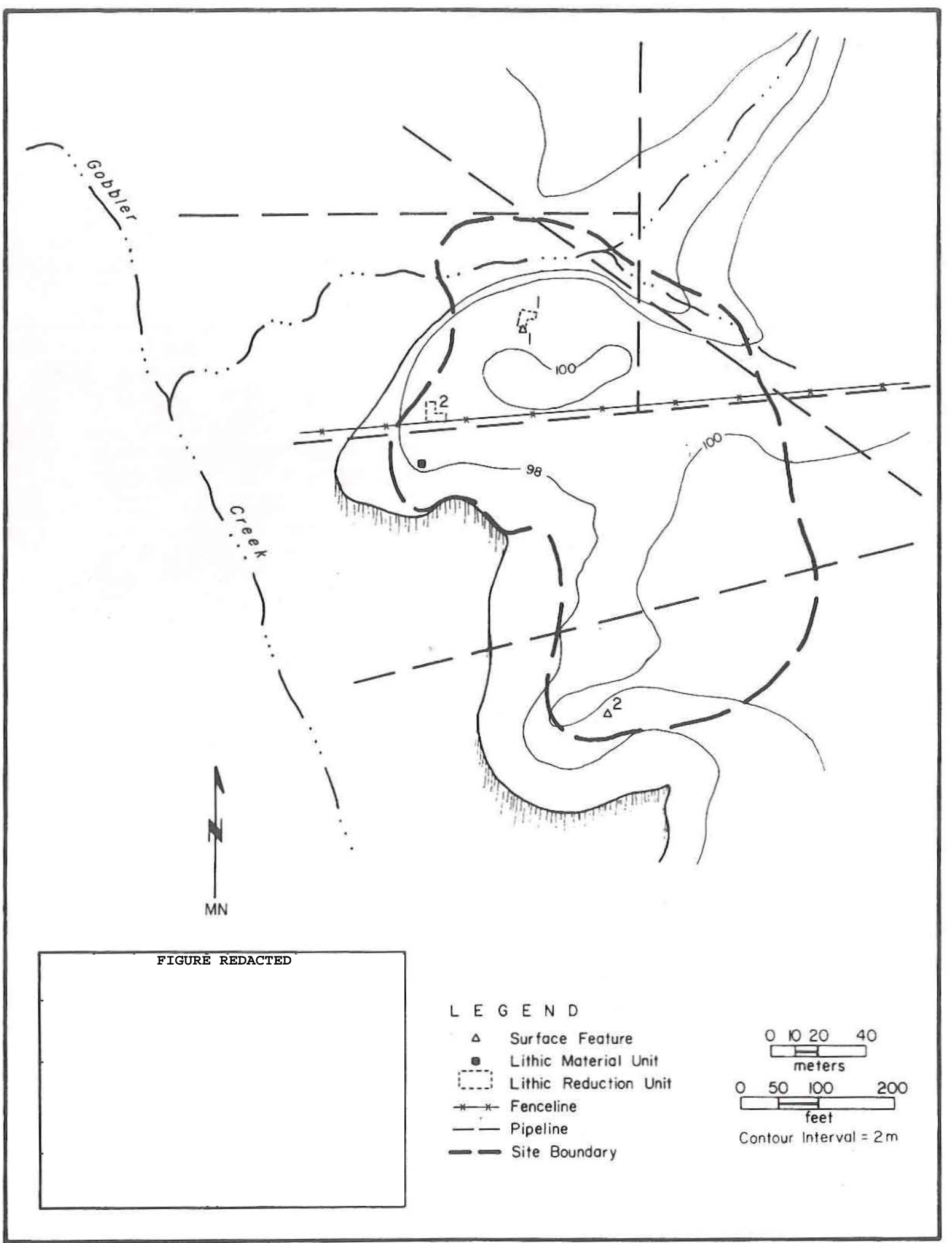

Figure 37. Site map, 41GR381. 
southwestern end of the site, is a ca. 10x25-m scatter which is similar to Feature 1 but which also contains some burned sandstone fragments. Both features are surficial scatters only. This site has been reclassified as a lithic procurement/campsite, although evidence of campsite activities is minor.

\section{SITE SEDIMENTS AND EXTENT}

Upland sediments at the site consist of a varying thickness of Quaternary gravels overlain by a thin veneer of fine-grained sands. The sands thin downslope, exposing primary gravel deposits along the eroding upland edges. Redeposited gravels and sands occur in the lower areas and in the drainage at the north end of the site. The site boundaries are determined by the distribution of the Quaternary gravel outcrop. The western boundary is the canyon rim of Gobbler Creek, and the extent of the gravel outcrop in the upland area forms the eastern boundary. The north and south boundaries are marked by deep drainages. Site size is ca. $220 \times 170 \mathrm{~m}$. All cultural materials are surficial or shallowly buried.

\section{Discussion of Lithic Procurement Sites}

The goal of the lithic procurement site investigations was not to understand sitespecific activities. Gravel outcrops with associated surface artifacts which cannot be chronologically separated and represent unknown spans of time are not well suited to analysis on a site-specific basis. More appropriately, then, the goal was to document the broad pattern of lithic resource utilization within the project area and the region. The two sites investigated constitute only a $1.7 \%$ sample of the 120 sites in the reservoir where lithic procurement is evident. These sites represent widespread utilization of an abundant local resource, but few details concerning the nature of the resource and its prehistoric exploitation are known. In the broadest sense, two important research questions are appropriate. First, what lithic resources were available, and second, how were they used?

\section{CHARACTERIZATION OF THE LITHIC MATERIALS}

The late Quaternary gravels in the Lower Plains are remnants of alluvial sediments deposited as outwash from the Caprock Escarpment as it retreated westward. The escarpment is actively eroding today, continuing the depositional process which began several hundred thousand years ago. A mantle of late Quaternary sediments once covered much or all of the region; only sporadic, but often widespread, remnants are preserved today. The gravels deposited in the eastern half of the Lower Plains, ca. $75 \mathrm{~km}$ east of the project area, are called the Seymour Formation (Gustavson and Finley 1985:36), and the gravels in the western half of the region, within ca. $80 \mathrm{~km}$ of the Caprock Escarpment, have recently been informally named the Lingos Formation (Caran and Baumgardner 1988). The Seymour gravels are ca. 600,000 years old while the Lingos gravels are much younger, but both resulted from the same depositional process. The Seymour Formation and the Lingos Formation may be appropriately considered as part of a continuum in which the deposits are progressively younger from east to west. 
Although the lithologically similar Lingos and Seymour gravels both are derived from erosion of the Caprock Escarpment, the lithic materials originated from four separate sources. The vast majority of the materials are from the Tertiary Ogallala Formation gravels which contain a wide variety of siliceous materials, including quartzites, metaquartzites, and fine-grained cherts. Cretaceous formations, which today survive only as isolated remnants in the southern part of the Lower Plains, contribute limestone, fossil shells, and fine-grained cherts (the latter are generally more variable and of somewhat poorer quality than most of the distinctive varieties of Central Texas Cretaceous chert). Pebble-sized quartzites and fine-grained cherts from Triassic conglomerates and fusilinidbearing cherts from Permian formations are minor components of the gravels. Cretaceous, Triassic, and Permian materials may have been deposited directly into the Lingos and Seymour gravels, or they may have arrived via deposition in the Ogallala Formation and subsequent redeposition into the Quaternary sediments.

The Lingos gravels, which crop out throughout the Justiceburg Reservoir project area, are a mixture of a variety of locally derived lithic materials (Table 29). The specific sources from which the materials originated is not particularly important; rather, the distinctive quality of many of the material types and their ease of recognition as local resources is significant. The challenge then is to document the range of lithic variation in the Lingos gravels in order to sort out the nonlocal materials with some degree of confidence and establish the relative frequency of the different grades of locally available raw materials (i.e., chert, Potter chert, quartzite).

TABLE 29

LITHIC MATERIAL TYPES REPRESENTED IN THE LINGOS GRAVELS, JUSTICEBURG RESERVOIR*

\begin{tabular}{llrr}
\hline Lithic Material Types & Source* & Number & Percent \\
& & & \\
& & & 50.5 \\
Quartzites/quartz (includes Ogallala quartzite) & Undifferentiated & 462 & 42.1 \\
Fine-grained cherts & Undifferentiated & 385 & 0.1 \\
Fusilinid-bearing chert & Permian & 1 & 5.3 \\
Limestone & Cretaceous & 48 & 0.2 \\
Fossil pelecypod & Cretaceous & 2 & 1.2 \\
Potter chert & Ogallala Formation & 11 & 0.1 \\
Silicified wood & Ogallala Formation & 1 & 0.4 \\
Unidentified & Unknown & 4 & 99.9 \\
Totals: & & 914 & 99
\end{tabular}

*Consists of the 1-2-inch and over 2-inch size classes from the lithic material units at 41GR327 and 41GR381.

**Source of origin for materials deposited in the Lingos Formation. 


\section{LITHIC MATERIALS AT JUSTICEBURG RESERVOIR}

In order to document the range in qualitative and quantitative variation in the Lingos gravels, all gravels were recovered from lithic material units at the two lithic procurement sites. The samples consist of all surface and shallowly buried lithic materials collected from $1 \times 1-m$ units placed in moderately dense gravel outcrops with no evidence of lithic reduction in the immediate vicinity. These samples were collected and analyzed to provide data comparable to those derived from studies of the Seymour gravels in Truscott (Hood 1978) and Crowell (Hood and Wright 1979) reservoirs. The collected gravels were first sorted into three size categories: 0.5-1 inch, 1-2 inches, and over 2 inches (no materials under 0.5 inch were collected). The size classes employed standard English measurements to be consistent with the Truscott and Crowell studies but are roughly analogous to Wentworth's scale; the 0.5-1-inch category consists of medium to large pebbles, the 1-2-inch category consists of large to very large pebbles, and the over-2-inch category consists of very large pebbles to cobbles.

The size range of the Lingos gravels from Justiceburg Reservoir is similar to that of the Seymour gravels from Truscott and Crowell reservoirs in Cottle, Foard, King, and Knox counties (Table 30). The majority of the materials, by weight, are either in the 1-2-inch or the over-2-inch categories in all but one of the samples, and all of the samples have at least $12 \%$ of the material in the larger category. Hence, a significant portion of the materials are of a size suitable for lithic reduction. In general, less of the Lingos gravels are in the unusable 0.5-1-inch size category than are the Seymour gravels. While considerable variability in gravel size is expected between samples, this may reflect an eastward fining trend (going away from the original source) within the Ogallala Formation gravels. The average size and the maximum size of the Ogallala gravels should increase to the west toward the source. If such a trend actually exists, it should be reflected in the locally redeposited Seymour and Lingos gravels.

The gravels in the 1-2-inch and the over-2-inch categories were then sorted into lithic material types and compared with the Truscott and Crowell samples (Tables 31 and 32). Although there are undoubtedly minor differences in the sampling strategies and in the identifications of the material types, one similarity is clear. Quartzites and quartz are the dominant materials in both size classes for all the samples. Other materials represented vary from sample to sample and probably reflect normal intraregional variation. Regional trends due to depositional phenomena, such as source variability or sorting, may also be evident. Cretaceous limestone and fossils are more abundant in the Justiceburg samples, probably due to the proximity of the project area to Cretaceous remnants (which indicate the former presence of a greater areal extent of the Cretaceous formations). The increased frequency of fine-grained cherts in the Justiceburg samples may also be due in part to an influx from Cretaceous sources that were not present farther north and east.

A few additional observations can be offered based on the lithic material data. Relatively few fine-grained cherts are in the larger size class, possibly reflecting a characteristic of the gravels or perhaps due to the selective prehistoric procurement of larger specimens. The frequency of Potter chert varies between samples and may also be due to natural or cultural processes. Minor components of the gravels, such as silicified wood, rhyolite, and Permian cherts, vary in frequency between samples, probably reflecting the natural distribution of the materials. 


\begin{tabular}{|c|c|c|c|c|c|c|c|}
\hline \multirow{2}{*}{\multicolumn{2}{|c|}{ Samples }} & & & \multicolumn{3}{|c|}{ Size Range } & \multirow[b]{2}{*}{ Totals } \\
\hline & & & & $0.5-1$ inch & 1-2 inches & $>2$ inches & \\
\hline \multicolumn{8}{|c|}{ Justiceburg Reservoir, Lingos } \\
\hline \multirow[t]{2}{*}{ 41GR327: } & $\mathrm{Kg}$ weigh & & & 0.6 & 11.3 & 3.0 & 14.9 \\
\hline & Percent & & & 4.0 & 75.9 & 20.1 & 100.0 \\
\hline \multirow[t]{2}{*}{ 41GR381: } & Kg weigh & & & 1.8 & $4: 7$ & 8.9 & 15.4 \\
\hline & Percent & & & 11.7 & 30.5 & 57.8 & 100.0 \\
\hline \multicolumn{8}{|c|}{ Truscott Reservoir*, Seymour } \\
\hline \multirow[t]{2}{*}{ Random: } & $\mathrm{Kg}$ weig & & & 5.16 & 9.55 & 3.42 & 18.13 \\
\hline & Percent & & & 28.46 & 52.68 & 18.86 & 100.00 \\
\hline \multirow[t]{2}{*}{ Selected: } & $\mathrm{Kg}$ weig & & " & 6.77 & 10.00 & 16.89 & 33.66 \\
\hline & Percent & & & 20.11 & 29.71 & 50.18 & 100.00 \\
\hline \multicolumn{8}{|c|}{ Crowell Reservoir**, Seymour } \\
\hline \multirow[t]{2}{*}{ Y Ranch, } & Random: & Kg weight & & 10.60 & 14.55 & 7.82 & 32.97 \\
\hline & & Percent & & 32.16 & 44.12 & 23.72 & 100.00 \\
\hline \multirow[t]{2}{*}{$78-113, \mathrm{~F}$} & andom: & Kg weight & & 8.84 & 19.27 & 3.96 & 32.07 \\
\hline & & Percent & & 27.56 & 60.07 & 12.37 & 100.00 \\
\hline \multirow[t]{2}{*}{$78-114, \mathrm{~s}$} & elected: & Kg weight & & 10.49 & 18.93 & 14.55 & 43.97 \\
\hline & & Percent & & 23.85 & 43.06 & 33.09 & 100.00 \\
\hline \multirow{2}{*}{\multicolumn{2}{|c|}{ 78-115, Selected: }} & Kg weight & & 8.95 & 4.42 & 5.21 & 18.58 \\
\hline & & Percent & & 48.17 & 23.78 & 28.05 & 100.00 \\
\hline
\end{tabular}

*From Hood (1978:Table 1). Weights are converted to metric and recalculated to eliminate the less-than-0.5-inch class.

**From Hood and Wright (1979:Table 3). Weights are converted to metric. 
TABLE 31

COMPARISON OF LINGOS AND SEYMOUR GRAVEL LITHOLOGY FOR THE 1-2-INCH SIZE CLASS

\begin{tabular}{|c|c|c|c|c|c|c|c|c|c|c|c|c|c|c|c|c|c|}
\hline \multirow[b]{3}{*}{ Material Type } & \multicolumn{4}{|c|}{ Justiceburg Reservoir, Lingos } & \multicolumn{5}{|c|}{ Truscott Reservoir, Seymour } & \multicolumn{8}{|c|}{ Crowell Reservoir, Seymour } \\
\hline & \multicolumn{2}{|c|}{ 41GR327 } & \multicolumn{2}{|c|}{$41 \mathrm{GR} 381$} & \multicolumn{2}{|c|}{ Random } & \multicolumn{2}{|c|}{ Selected } & \multicolumn{3}{|c|}{ Y Ranch* } & \multicolumn{2}{|c|}{$78-113 *$} & \multicolumn{2}{|c|}{$78-114 * *$} & \multicolumn{2}{|c|}{$78-115 * *$} \\
\hline & $\#$ & $\%$ & $\#$ & $\%$ & $\#$ & $\%$ & \# & $\%$ & & $\#$ & $\%$ & $\#$ & $\%$ & $\#$ & $\%$ & $\#$ & \# \\
\hline \multicolumn{18}{|l|}{ Quartz and } \\
\hline quartzite & 296 & 54.2 & 135 & 45.6 & 150 & 96.2 & 137 & 93.8 & & 171 & 98.3 & 240 & 93.0 & 251 & 97.3 & 29 & 38.7 \\
\hline $\begin{array}{c}\text { Fine-grained chert, } \\
\text { undifferentiated }\end{array}$ & 231 & 42.3 & 131 & 44.3 & - & - & 4 & 2.7 & · & 2 & 1.1 & 11 & 4.3 & 4 & 1.6 & 46 & 61.3 \\
\hline \multicolumn{18}{|l|}{ Fusilinid-bearing } \\
\hline chert & - & - & 1 & 0.3 & 1 & 0.6 & - & - & & - & - & - & - & - & - & - & - \\
\hline Limestone & 15 & 2.7 & 24 & 8.1 & 4 & 2.6 & 2 & 1.4 & & - & - & - & - & - & - & - & - \\
\hline Fossil pelecypod & 2 & 0.4 & - & - & - & - & - & - & & - & - & - & - & - & - & - & - \\
\hline Potter chert & 1 & 0.2 & 1 & 0.3 & - & - & 2 & 1.4 & & 1 & 0.6 & 3 & 1.2 & 1 & 0.4 & - & - \\
\hline Silicified wood & - & - & 1 & 0.3 & - & - & 1 & 0.7 & & - & - & - & - & - & - & - & - \\
\hline Rhyolite & - & - & - & - & 1 & 0.6 & - & - & & - & - & 4 & 1.6 & 2 & 0.8 & - & - \\
\hline \multicolumn{18}{|l|}{$\begin{array}{l}\text { Other, includes } \\
\text { unidentified }\end{array}$} \\
\hline materials & 1 & 0.2 & 3 & 1.0 & - & - & $=$ & - & - & - & - & - & - & - & - & $=$ & - \\
\hline Totals: & 546 & 100.0 & 296 & 99.9 & 156 & 100.0 & 146 & 100.0 & & 174 & 100.0 & 258 & 100.1 & 258 & 100.1 & 75 & 100.0 \\
\hline \multicolumn{18}{|l|}{ *Random } \\
\hline$* *$ Selected & & & & & & & & & & & & & & & & & \\
\hline
\end{tabular}




\section{TABLE 32}

COMPARISON OF LINGOS AND SEYMOUR GRAVEL LITHOLOGY FOR THE OVER-2-INCH SIZE CLASS

\begin{tabular}{|c|c|c|c|c|c|c|c|c|c|c|c|c|c|c|c|c|}
\hline \multirow[b]{3}{*}{ Material Type } & \multicolumn{4}{|c|}{ Justiceburg Reservoir, Lingos } & \multicolumn{4}{|c|}{ Truscott Reservoir, Seymour } & \multicolumn{8}{|c|}{ Crowell Reservoir, Seymour } \\
\hline & \multicolumn{2}{|c|}{ 41GR327 } & \multicolumn{2}{|c|}{ 41GR381 } & \multicolumn{2}{|c|}{ Random } & \multicolumn{2}{|c|}{ Selected } & \multicolumn{2}{|c|}{ Y Ranch* } & \multicolumn{2}{|c|}{$78-113 *$} & \multicolumn{2}{|c|}{$78-114 * *$} & \multicolumn{2}{|c|}{$78-115 * *$} \\
\hline & $\#$ & $\%$ & $\#$ & $\%$ & $\#$ & 웅 & \# & $\%$ & $\#$ & $\%$ & $\#$ & \% & $\#$ & $\%$ & \# & \# \\
\hline Quartz and & & & & & & & & & & & & & & & & \\
\hline quartzite & 17 & 42.5 & 14 & 43.8 & 6 & 75.0 & 22 & 81.5 & 16 & 100.0 & 10 & 90.9 & 21 & 80.8 & 4 & 50.0 \\
\hline $\begin{array}{c}\text { Fine-grained chert, } \\
\text { undifferentiated }\end{array}$ & 17 & 42.5 & 6 & 18.8 & - & - & - & - & - & - & 1 & 9.1 & 1 & 3.8 & - & - \\
\hline Limestone & 5 & 12.5 & 4 & 12.5 & - & - & - & - & - & - & - & - & - & - & 4 & 50.0 \\
\hline Potter chert & 1 & 2.5 & 8 & 25.0 & 2 & 25.0 & 4 & 14.8 & - & - & - & - & 2 & 7.7 & - & - \\
\hline Silicified wood & - & - & $=$ & - & $=$ & - & $\underline{1}$ & 3.7 & $=$ & - & 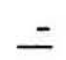 & - & $\underline{2}$ & 7.7 & $=$ & - \\
\hline Totals: & 40 & 100.0 & 32 & 100.1 & 8 & 100.0 & 27 & 100.0 & 16 & 100.0 & 11 & 100.0 & 26 & 100.0 & 8 & 100.0 \\
\hline \multicolumn{17}{|l|}{ *Random } \\
\hline **Selected & & & & & & & & & $\therefore$ & & & & & & & \\
\hline
\end{tabular}


UTILIZATION OF THE LITHIC RESOURCES

In order to document how materials were selectively utilized, materials were recovered from two lithic reduction units at each lithic procurement site. These samples consist of all modified lithic materials from $25-\mathrm{m}^{2}$ blocks in areas where moderate to intensive 1 ithic reduction was evident. Eighty-seven specimens recovered from the lithic reduction units and eight individually surface-collected artifacts constitute the collection from the lithic procurement sites (Table 33). The lithic tools from the general surface collection include only one specimen made of nonlocal material (a biface of nonlocal Cretaceous chert from 41GR327), with all others being made of local quartzites, Potter chert, or silicified wood.

The samples from the lithic reduction units are very small because many of the collected specimens were later determined to be unmodified. All together, however, the samples represent the types of artifacts and lithic materials found at sites where lithic reduction is the dominant activity (Table 34). The limited range of tool types at these sites, in contrast to the assemblage variability at multifunctional campsites, reflects a specialization of activities, with stone tool manufacture evidenced by hammerstones and debitage. Tertiary flakes constitute only $13 \%$ of the lithic debitage, indicating that the early stages of reduction are well represented. The presence of unifaces, bifaces, edgemodified flakes, and the ground stone specimen indicate, however, that activities other than lithic reduction were also performed at the sites. It is possible that lithic procurement sites in the project area consistently served as locations where limited domestic resource processing activities were performed in addition to lithic reduction.

Artifacts recovered from the lithic reduction units are all made of local materials available in the Lingos gravels; Potter chert accounts for $46 \%$, Ogallala quartzite accounts for $23 \%$, and fine-grained cherts account for $15 \%$. The remainder consists of various materials that are minor components of the Lingos gravels. Basalt is the only material that may be nonlocal; it has not yet been found in the Lingos gravels, but small quantities are likely to be present. In general, the frequencies of artifact material types mirror the relative abundance of the natural material types in the gravels and simply reflect the aboriginal tendency to utilize whatever materials were most readily available.

Demonstrable correlations between tool types and lithic materials are not possible based on the limited lithic reduction sample data, but the more-inclusive analysis presented in Appendix $D$ does provide such data. The data from the open campsites indicate that specific lithic materials were consciously selected for certain types of tools, that nonlocal lithics were brought in, and that the late stages of lithic reduction are clearly dominant. This suggests a pattern in which lithic source materials were tested, selected, and trimmed into preforms at the lithic procurement sites and then transported to campsites for final tool preparation.

\section{Rockshelters}

$41 \mathrm{GR} 546$

SITE SETTING

Site 41 GR546 is a rockshelter on the uppermost sandstone bluff forming the east canyon rim of an unnamed drainage, ca. $40 \mathrm{~m}$ north of its confluence with the Double Mountain Fork 
TABLE 33

ARTIFACTS RECOVERED FROM LITHIC PROCUREMENT SITES, 41GR327 AND 4IGR381

\begin{tabular}{|c|c|c|c|c|c|c|c|c|c|}
\hline Provenience & Bifaces & $\begin{array}{l}\text { Cobble } \\
\text { Tools }\end{array}$ & Unifaces & Cores & $\begin{array}{l}\text { Edge- } \\
\text { modified } \\
\text { Debitage }\end{array}$ & $\begin{array}{l}\text { Unmodified } \\
\text { Debitage }\end{array}$ & $\begin{array}{l}\text { Hammer- } \\
\text { stones }\end{array}$ & $\begin{array}{l}\text { Ground } \\
\text { Stone }\end{array}$ & Totals \\
\hline & & & & & $\cdot$ & & & & \\
\hline \multicolumn{10}{|l|}{$41 \mathrm{GR} 327$} \\
\hline General Surface & 1 & - & 2 & - & - & - & - & - & 3 \\
\hline Lithic Reduction Unit 1 & - & 1 & 4 & 6 & 5 & 30 & 4 & - & 50 \\
\hline Lithic Reduction Unit 2 & $=$ & - & $=$ & 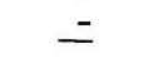 & $=$ & - & 3 & $=$ & $\underline{3}$ \\
\hline Totals: & 1 & 1 & 6 & 6 & 5 & 30 & 7 & - & 56 \\
\hline \multicolumn{10}{|l|}{ 41GR381 } \\
\hline General Surface & 2 & 1 & 1 & - & 1 & - & - & - & 5 \\
\hline Lithic Reduction Unit 1 & - & 1 & 1 & - & 1 & 13 & 2 & 1 & 19 \\
\hline Lithic Reduction Unit 2 & - & $=$ & $\underline{2}$ & $\underline{3}$ & 1 & $\underline{9}$ & - & - & $\underline{15}$ \\
\hline Totals: & 2 & 2 & 4 & 3 & 3 & 22 & 2 & 1 & 39 \\
\hline
\end{tabular}


TABLE 34

LITHIC MATERIAL TYPES REPRESENTED IN ALL LITHIC REDUCTION UNIT SAMPLES, 41GR327 AND 41 GR381

\begin{tabular}{|c|c|c|c|c|c|c|c|c|c|}
\hline Material Type* & $\begin{array}{l}\text { Cobble } \\
\text { Tools }\end{array}$ & Unifaces & Cores & $\begin{array}{l}\text { Edge- } \\
\text { modified } \\
\text { Debitage }\end{array}$ & $\begin{array}{l}\text { Unmodified } \\
\text { Debitage }\end{array}$ & $\begin{array}{l}\text { Hammer- } \\
\text { stones }\end{array}$ & $\begin{array}{l}\text { Ground } \\
\text { Stone }\end{array}$ & Totals & $\begin{array}{l}\text { Total } \\
\text { Percent }\end{array}$ \\
\hline Fine-grained Potter chert & - & 3 & 1 & 2 & 25 & - & - & 31 & 35.6 \\
\hline Coarse-grained Potter chert & 1 & 1 & - & - & 7 & - & - & 9 & 10.3 \\
\hline Fine-grained chert & 1 & - & 2 & 2 & 8 & - & - & 13 & 14.9 \\
\hline Coarse-grained chert & - & - & - & 1 & 1 & - & - & 2 & 2.3 \\
\hline Ogallala quartzite & - & 2 & 3 & 2 & 4 & 8 & 1 & 20 & 23.0 \\
\hline Unidentified quartzite & - & - & - & - & - & 1 & - & 1 & 1.1 \\
\hline Milk white quartzite & - & - & 3 & - & 2 & - & - & 5 & 5.7 \\
\hline Opalized caliche & - & - & - & - & 2 & - & - & 2 & 2.3 \\
\hline Silicified wood & - & - & - & - & 1 & - & - & 1 & 1.1 \\
\hline Conglomerate quartzite & - & - & - & - & 1 & - & - & 1 & 1.1 \\
\hline Basalt & - & 1 & - & - & - & - & - & 1 & 1.1 \\
\hline Unidentified & $\underline{-}$ & - & - & - & 1 & - & - & 1 & 1.1 \\
\hline Totals: & 2 & 7 & 9 & 7 & 52 & 9 & 1 & 87 & 99.6 \\
\hline Total Percent: & 2.3 & 8.0 & 10.3 & 8.0 & 59.8 & 10.3 & 1.1 & 99.8 & \\
\hline
\end{tabular}


and ca. $500 \mathrm{~m}$ upstream from the mouth of Sand Creek. Facing west and overlooking the drainage, it is ca. $60 \mathrm{~m}$ south of rockshelter 41GR559. Formed by erosion of friable sandstone directly beneath the harder sandstone canyon rim, the shelter extends 3 to $4 \mathrm{~m}$ back into the bedrock. The ceiling is a hard conglomeratic sandstone layer; from the present ground surface, its height varies from $0.6 \mathrm{~m}$ at the back to $1.8 \mathrm{~m}$ along the dripline. The shelter has a small protected floor area of ca. $12 \mathrm{~m}^{2}$ but is immediately south of a section of collapsed ledge that was once a continuation of the shelter. The floor slopes gently west, and the talus slope drops off sharply at the front. Historic graffiti (sites 41 GR536 and 41GR537) occur nearby, but there is no evidence of vandalism to the shelter. Site elevation is $2250 \mathrm{ft} \mathrm{msl}$.

The sheltered area is devoid of vegetation except along the front edge, where small viney plants are encroaching. A dense row of agarita along the dripline helps protect the talus slope from erosion and shield the shelter from view. Junipers, mesquites, grasses, and various cacti are found on the upland above and in the valley below the shelter. Hackberries are also present along the drainage.

\section{WORK ACCOMPLISHED}

When 41 GR546 was recorded in 1987, possible smoke blackening of the ceiling, sparse lithic debris on the floor, and cultural materials in a shovel test indicated that the shelter had been occupied. Mapping and testing were recommended (Boyd et al. 1989). As a result of these recommendations, the current investigations included mapping of the general site area, detailed mapping and profiling of the shelter, and excavation of a shovel test in the area of the collapsed ledge and a single $1 \times 1-m$ test unit in the shelter floor (Fig. 38). The $20-\mathrm{cm}$-deep Shovel Test 2 yielded no cultural materials, indicating that the ledge collapse probably predates the occupation of the shelter. The test unit, located over the 1987 shovel test, was excavated to bedrock at 70-96 cm below the surface. Cultural materials were recovered in the upper $80 \mathrm{~cm}$, and portions of two burned rock features were found.

\section{SEDIMENTS AND STRATIGRAPHY}

Only two soil zones separated by a gradual boundary are visually distinguishable. Zone $1,0-65 \mathrm{~cm}$, is a homogenous, loosely consolidated yellowish brown (10YR $6 / 3$ to $10 \mathrm{YR}$ 6/4) fine to coarse sand with sandstone and angular conglomerate eboulis (roof fall fragments) of various sizes and siliceous (conglomerate) pebbles. It appears that these sediments are derived mainly from wind erosion of the soft friable sandstone and spalling of the conglomerate sandstone, but a minor amount of eolian sand may have come from outside the shelter. Zone 1 appears to be a dry shelter deposit with no evidence of periodic wetting.

Zone 2, 65-100 cm, is dominated by large eboulis in a matrix of gray (5Y 6/1) silt or clay loam with dark gray $(5 \mathrm{Y} 4 / 1)$ laminations. The eboulis in zone 2 is more heavily weathered than that in Zone 1, indicating that Zone 2 sediments may be quite old. The silt or clay loam matrix appears to be derived from the bedrock (i.e., Triassic mudstone) at the base of the shelter but could also contain sediments washed into the shelter from outside. 


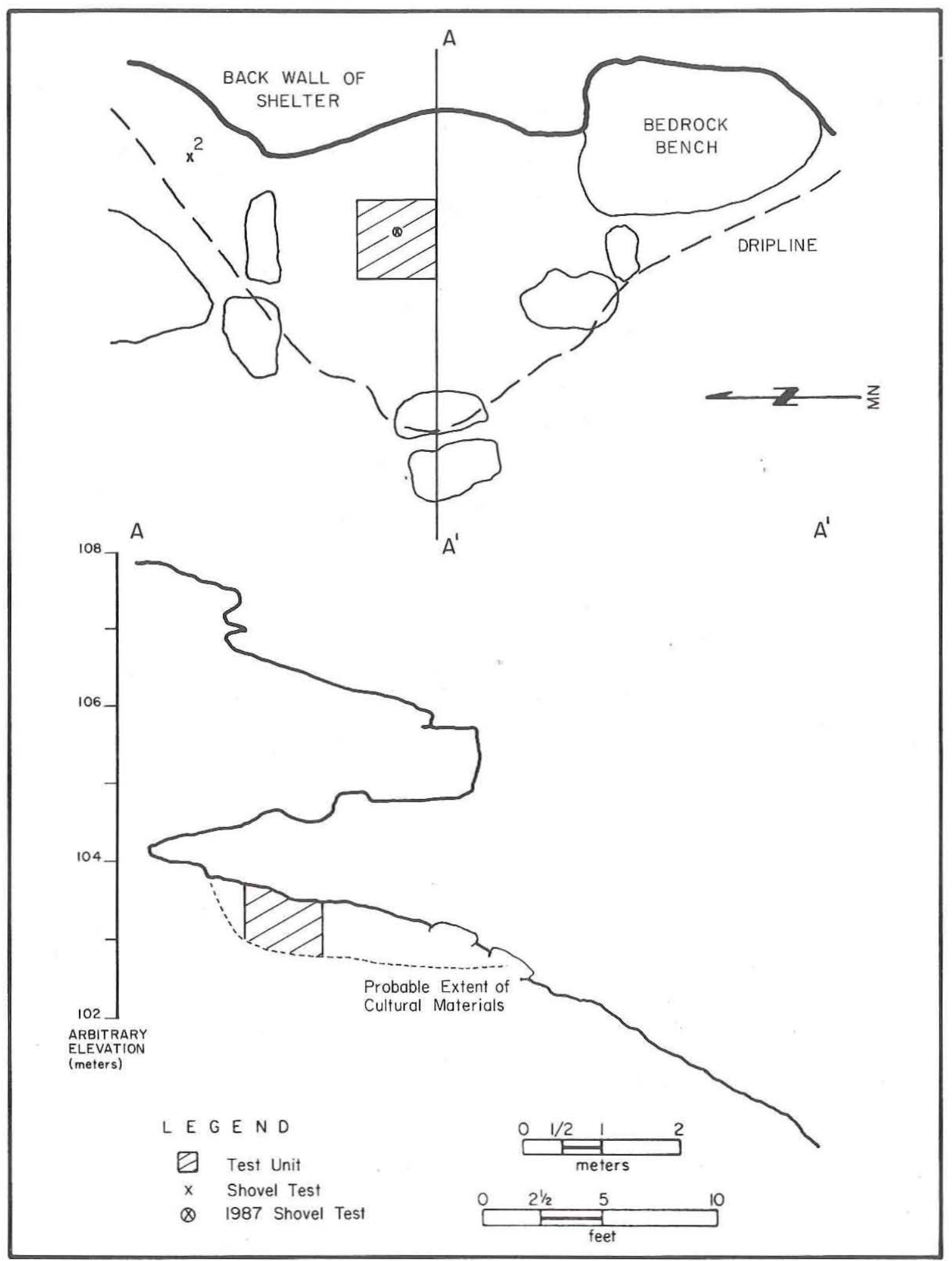

Figure 38. Site map, 41GR546. 


\section{SITE EXTENT AND DEPTH}

Cultural materials are confined to the deposits inside the $3.0 \times 3.5-\mathrm{m}$ sheltered area. The steep talus slope directly in front of the shelter precludes any additional cultural deposits, and the collapsed shelter area to the north appears to be devoid of cultural deposits. Evidence of cultural occupation is contained in the upper $80 \mathrm{~cm}$ of sediments, which includes all of Zone 1 and the upper part of Zone 2 .

\section{FEATURES}

Two partial burned rock features were encountered at the same level in the test unit. Feature 1 is a slab-lined hearth exposed at 25-35 cm in the southeast corner of the unit (Fig. 39). Approximately one-half of this 45-cm-diameter circular feature was excavated; the remainder extends into the south wall. It consists of nine sandstone and conglomerate slabs which dip toward the center, with scattered flecks of charcoal in and around the cluster. No cultural materials were definitely associated with Feature 1 , but some scattered lithic debris, fire-cracked rocks, and mussel shell fragments were recovered from the unit.

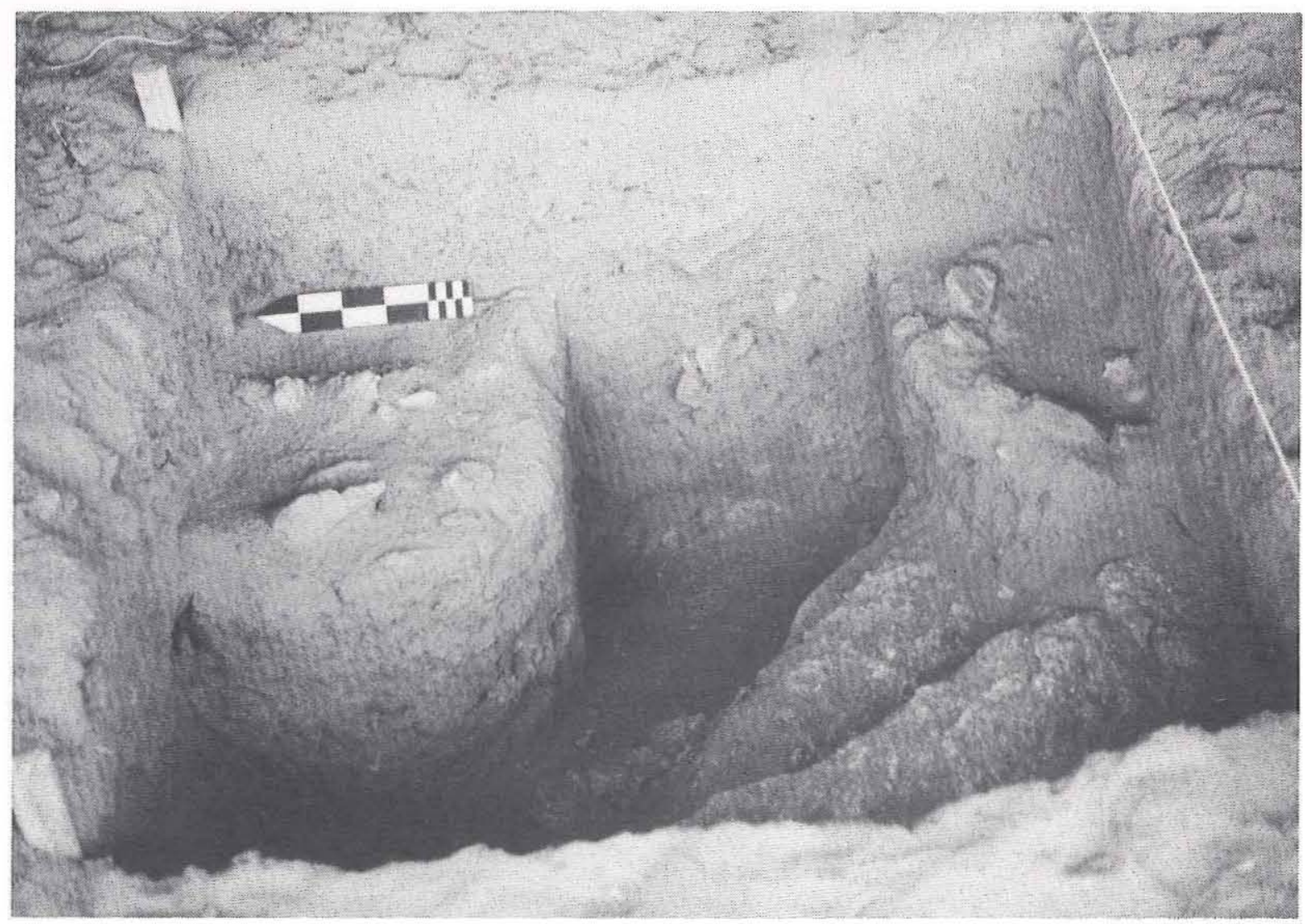

Figure 39. Feature $I$ on the right and Feature 2 on the left in test unit at 41GV546. View to east. 
Feature 2 is a concentration of 12 burned sandstone and conglomerate slabs exposed at 20-40 cm in the northeast corner of the test unit (see Fig. 39). The excavated portion is less than half of a roughly circular, 50-cm-diameter, disturbed hearth which extends into the north wall and possibly the east wall. It is somewhat more irregular than Feature 1 and does not have a well-defined basin. Some charcoal flecks were noted in and around the feature, and one flake and an unidentified bone fragment were recovered from the feature fill. Unburned rodent bones were also recovered in the feature but probably represent natural disturbance. Feature 2 is dated by a corrected radiocarbon assay on charcoal to $275 \pm 210$ B.P. (GX-14447); a thermoluminescence assay yielded no date, probably due to insufficient heating of the sample (Dur89TL 135-8). Organic residues were virtually absent in an extraction from a hearthstone.

The fill from Features 1 and 2 and five sediment samples from various levels were subjected to flotation or fine-screen recovery. Burned juniper, hackberry, oak, rose, unidentified hardwood, a variety of unburned plant seeds and fragments, burned and unburned bone fragments, snail shells, and seven pieces of microdebitage were recovered. All of the burned bone and wood fragments are probably cultural, but it is difficult to determine the origin of the unburned materials. Some bones and plant remains were undoubtedly introduced by packrats or carnivores. A comparison of the macrobotanical remains found in the features to the materials recovered from the sediment samples suggests that the Chenopodium fruits, found only in the features and in high frequencies relative to the other plants represented, could be cultural in origin.

\section{MATERIALS RECOVERED}

Cultural materials recovered from the single test unit consist of lithic debitage (including one flake of nonlocal Cretaceous chert), microdebitage, burned and unburned bones, eggshell fragments, burned rocks, and a snail shell (Table 35). Much of the material was recovered by flotation or fine screening. The only identifiable burned bone is a snake vertebra; unburned bones represent snake, rabbit, bird, and rodent.

TABLE 35

DISTRIBUTION OF MATERIALS RECOVERED, 41 GR546

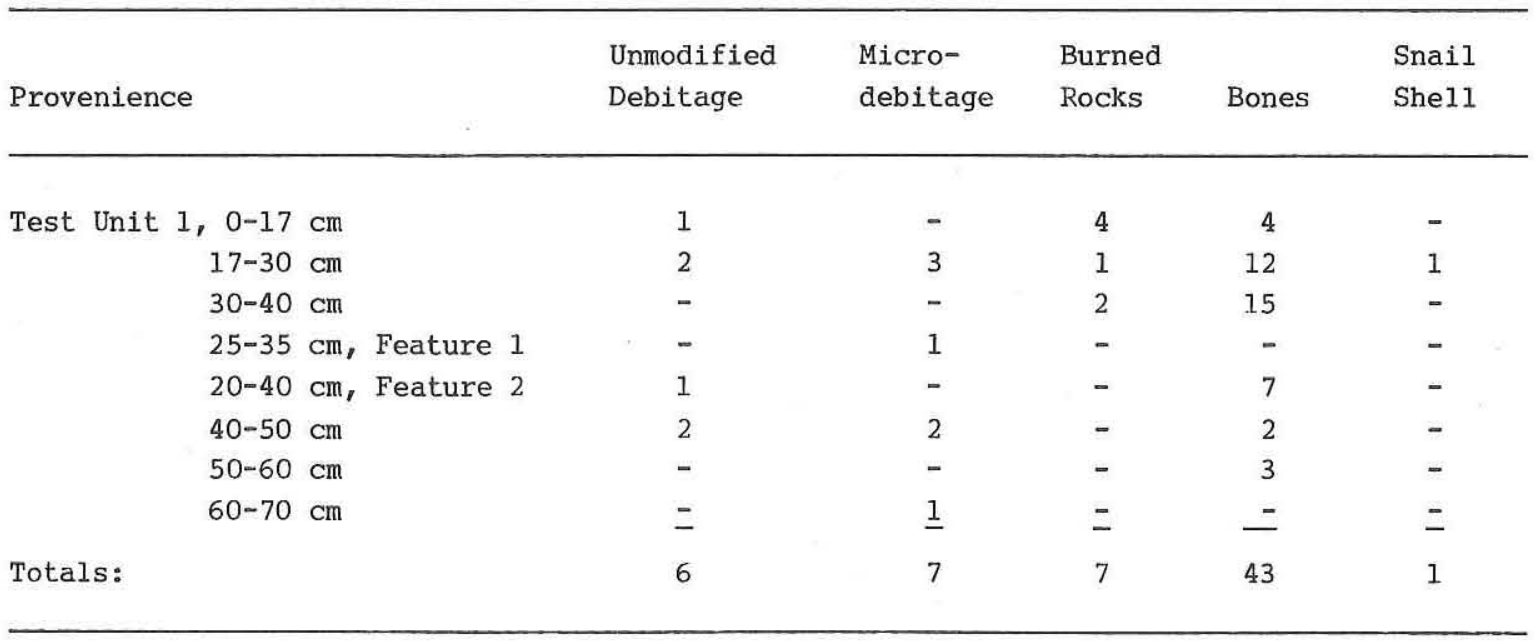




\section{DISCUSSION}

Site 41 GR546 is a ca. $12-\mathrm{m}^{2}$ rockshelter that contains almost $100 \mathrm{~cm}$ of sediments. Cultural materials were recovered from 0 to $70 \mathrm{~cm}$ in a single test unit in the center of the shelter and were most concentrated at 0-40 cm. Portions of two hearths were encountered at 20-40 cm. Multiple occupations are probably represented, but a charcoal radiocarbon age of $275 \pm 210$ B.P. from Feature 2 provides the only chronological evidence since no diagnostic artifacts were found. Similar sediments in nearby rockshelter 41 GR559 represent a minimum of 300 years and most likely ca. 500-1,000 years; a similar time span is probably represented at this site.

The lack of recognizable stone tools and the low density of cultural materials indicate that the rockshelter was not intensively utilized. Occupations were probably sporadic, short-term events involving a limited range of activities. Cooking and/or heating is indicated by the hearths, and the sparse lithic debitage reflects stone tool manufacture. Evidence of activities that may have occurred in front of the shelter has long since washed away.

Macrobotanical and faunal remains are abundant and well preserved. Burned wood from features represents several species loak, juniper, hackberry, rose, and unidentified hardwood). Evidence of probable food resources includes a burned snake vertebra, unidentifiable burned bone fragments, and the relatively abundant Chenopodium fruits recovered from Features 1 and 2. Although the macrobotanical and faunal remains probably represent both cultural activities and natural scavenger or predator utilization of the shelter, cautious interpretations based on careful data recovery and comparative flotation sample analysis could identify culturally introduced materials and also provide considerable environmental data. The combination of enhanced preservation of organic remains, horizontally discrete activities, and vertically separable components represented in this rockshelter is not found at open campsites in the project area.

41GR559

SITE SETTING

Site 41 GR559 is a rockshelter on the uppermost sandstone bluff forming the east canyon rim of an unnamed drainage on the north side of the Double Mountain Fork, Ca. $100 \mathrm{~m}$ north of the confluence of the drainage and the Double Mountain Fork. Facing south and overlooking the mouth of the drainage, 41 GR559 is ca. $60 \mathrm{~m}$ north of rockshelter $41 \mathrm{GR} 546$. It was formed by erosion of the friable sandstone immediately below the hard bluff-forming conglomerate sandstone. The ceiling height from the present ground surface ranges from $0.4 \mathrm{~m}$ at the back of the shelter to over $4 \mathrm{~m}$ at the dripline in some places, with an average height of less than $1 \mathrm{~m}$. The shelter floor is ca. $30 \mathrm{~m}^{2}$, and an additional ca. $30-\mathrm{m}^{2}$ area in front of the shelter is protected from erosion by a line of boulders ca. 2-5 $\mathrm{m}$ out from the dripline. Beyond this line of boulders, the talus slope drops sharply into the drainage valley. The floor is extremely level, but a rill has developed recently where rainwater drips into the east end of the shelter and runs along the back wall. Site elevation is $2240-2250 \mathrm{ft} \mathrm{msl}$. 
Adjacent to the shelter on the east is a collapsed section of ledge which once was a sizable shelter. There is very little ground exposure in this area, most being covered by the large jumble of boulders. Historic graffiti (two sets of initials and 1918 dates) in this area indicate that the site has been visited, but there is no evidence of vandalism.

Vegetation is limited to a few spindly vines and buried tubers inside the shelter and a row of agarita and catclaw acacia along the dripline. The latter help control erosion and hide the shelter from view. Upland vegetation above the shelter is mainly junipers, mesquites, grasses, and cacti, while the valley below contains mainly tall grasses with mesquites, junipers, and hackberries.

\section{WORK ACCOMPLISHED}

When 41GR559 was recorded in 1987, two shovel tests yielded cultural materials at depths of 30 to $75 \mathrm{~cm}$, but no cultural materials were present on the surface. Mapping and testing were recommended (Boyd et al. 1989). Consequently, the current investigations included mapping of the general site area, detailed mapping and profiling of the shelter, and excavation of two shovel tests and three lxl-m test units (Fig. 40, Table 36). Shovel Test 3, in the east end of the shelter adjacent to the pile of collapsed ledge boulders, was excavated to $90 \mathrm{~cm}$ and yielded no cultural materials, although bedrock was not reached. Additional probing into the cracks and crevices of the collapsed ledge produced no cultural materials, but once again bedrock was not reached. Shovel Test 4 was excavated to $55 \mathrm{~cm}$ in front of the shelter and yielded a considerable amount of rodent and rabbit bones, perhaps indicating the presence of a midden area. Test Units 1 and 2 . were excavated inside the shelter, and Test Unit 3 was excavated at the dripline. They were excavated to various depths, and all yielded cultural materials. Features 1-5 were exposed in Test Units 2 and 3 , and a cluster of bones (Feature 6) was encountered in Test Units 1 and 2.

\section{SEDIMENTS AND STRATIGRAPHY}

The sediments in this shelter are similar to those at rockshelter 41 GR546 and can be visually separated into two zones. Zone $1,0-75 \mathrm{~cm}$, is composed of unconsolidated brown (7.5YR 4/6) to dark yellowish brown (10YR 4/6) fine to coarse sand or sandy loam with eboulis of varying size scattered throughout. The eboulis is slightly to moderately weathered, fine-grained hard sandstone or coarse-grained friable sandstone. There is a gradual increase with depth in the number, size, and degree of weathering of these roof fall fragments. A large roof fall conglomerate slab encountered in Test Unit 1 indicates substantial ceiling collapse. Zone $2,75-100 \mathrm{~cm}$, is composed of intensively weathered eboulis in a matrix of brown (1OYR 5/3) to yellowish brown (1OYR 5/4) silty or clayey loam with large splotches of light grayish brown $(2.3 \mathrm{Y} 6 / 2)$ weathered sandstone. Zone 1 appears to reflect dry depositional conditions, while Zone 2 may reflect periodic wet conditions during deposition. There is a gradual boundary between the two zones.

\section{SITE EXTENT AND DEPTH}

Cultural deposits occur inside the ca. $3 \times 10-\mathrm{m}$ shelter and directly in front in an area of approximately the same size paralleling the shelter front. A cursory examination of the collapsed ledge that extends ca. 10-15 $\mathrm{m}$ to the east of the shelter failed to produce 


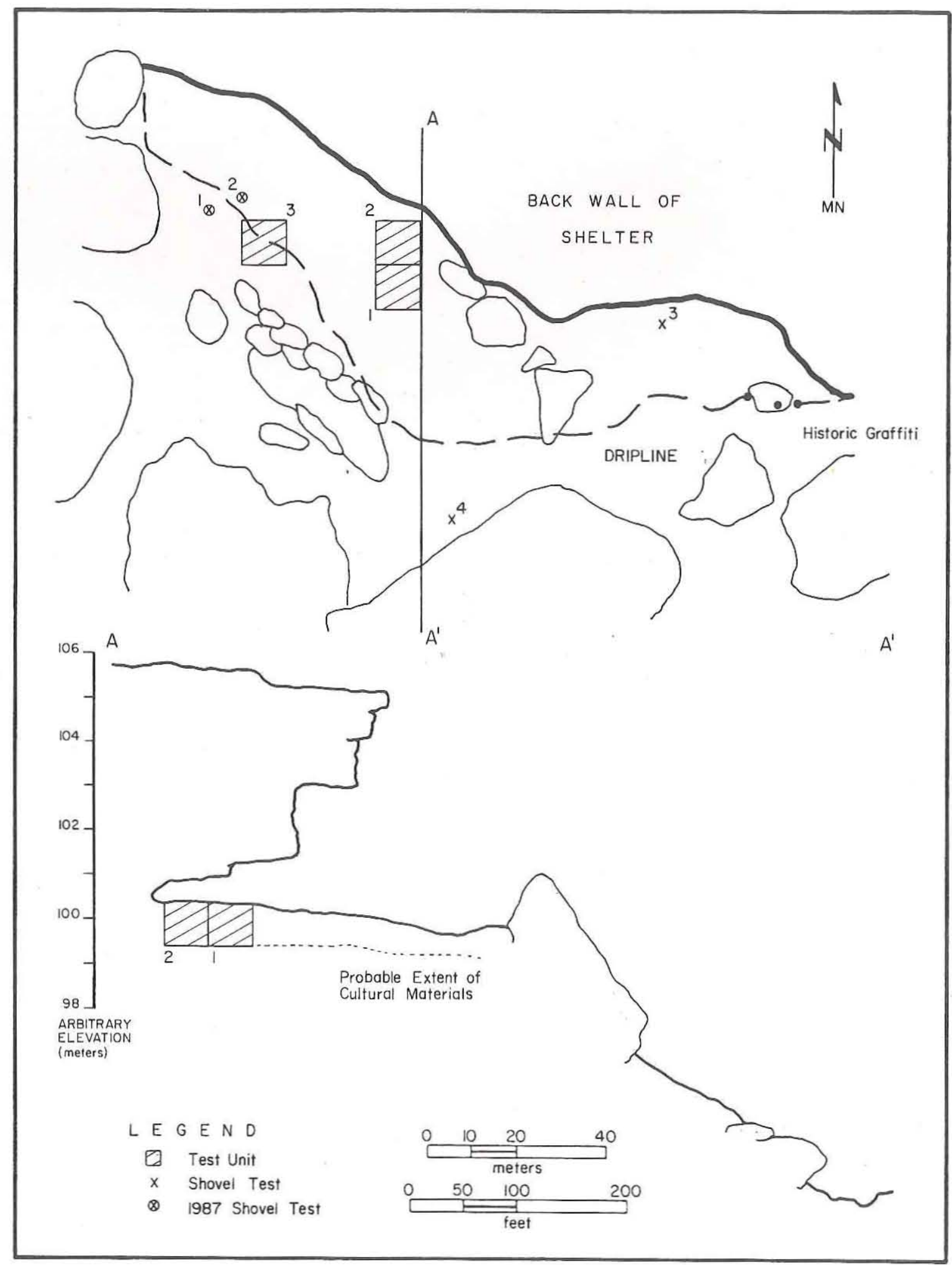

Figure 40. Site map, 41GR559. 
TABLE 36

SUMMARY OF EXCAVATIONS, 41GR559

\begin{tabular}{|c|c|c|c|}
\hline Unit & $\begin{array}{l}\text { Depth of } \\
\text { Excavation } \\
\text { (cm) }\end{array}$ & Reason for Ending Unit & $\begin{array}{l}\text { Artifact } \\
\text { Density }\left(\# / \mathrm{m}^{3}\right) \\
\text { or Result }\end{array}$ \\
\hline Test Unit 1 & 30 & $\begin{array}{l}\text { Encountered roof fall fragments } \\
\text { over most of unit }\end{array}$ & 0.0 \\
\hline Test Unit 2 & 100 & $\begin{array}{l}\text { Dug into sterile clay loam } \\
\text { over most of unit }\end{array}$ & 7.0 \\
\hline Test Unit 3 & 80 & $\begin{array}{l}\text { Arbitrary, bottom of cultural } \\
\text { zone not reached }\end{array}$ & 35.0 \\
\hline Shovel Test 3 & 90 & Difficulty in digging & negative \\
\hline
\end{tabular}

cultural evidence; however, this does not preclude the possibility that cultural deposits may be buried below the pile of boulders. Cultural remains were encountered to a depth of $83 \mathrm{~cm}$ inside the shelter and to at least $55 \mathrm{~cm}$ in front of the shelter.

\section{FEATURES}

Five burned rock concentrations (Features 1-5) and a bone cluster (Feature 6) were excavated. Feature 1 is a scatter of horizontal burned sandstone slabs exposed at $12-24 \mathrm{~cm}$ in the east-central portion of Test Unit 3. The scatter covers ca. $75 \%$ of the unit and extends into the east wall. It consists of ca. 20 rocks, most with evidence of burning but in no apparent arrangement. Some scattered charcoal is associated. The feature is interpreted as a displaced hearth or a scatter of debris on an occupational surface.

Feature 2 is a scatter of horizontal burned sandstone slabs in Test Unit 3 at 28-42 cm. It is composed of two distinct concentrations, a scatter of some random slabs in the northern half of the unit and a cluster of ca. 10 overlapping slabs in the southwest corner. A few other burned rocks and charcoal are scattered throughout the unit. The cluster in the southwest corner may be an in situ disturbed hearth surrounded by scattered debris on an occupational surface. Flotation of the fill from this cluster recovered some cultural specimens (burned juniper and hackberry wood and a burned rabbit tooth fragment) and many specimens that may be noncultural (noncharred plant remains, rodent bones, a rabbit tooth, and snail shells).

Feature 3 is a $50 \times 60-\mathrm{cm}$ cluster of burned sandstone slabs in the southeast corner of Test Unit 2 at 71-83 cm. It is interpreted as approximately one-third of an in situ hearth consisting of eight horizontal sandstone and conglomerate slabs around a patch of burned, discolored soil with charcoal flecks. The ring of stones extends into the east and south 
walls of the unit, and the hearth is estimated to be $75-80 \mathrm{~cm}$ in maximum diameter. Flakes and a hamerstone were found inside the feature. Several technical studies of Feature 3 were performed. A radiocarbon assay on charcoal yielded a corrected age of $855 \pm 190$ B.P. (GX-14448), and a thermoluminescence assay on burned sandstone yielded an age of $480 \pm$ 105 B.P. (Dur89TLpfg 135-10AS). The thermoluminescence date could be in error (although it almost overlaps with the radiocarbon date), or the difference could be due to recycling of hearthstones. Phytolith analysis of feature fill yielded mostly chloridoid and elongate types. Analysis of an organic extraction from a burned rock identified probable plant residue. Flotation of feature fill recovered burned oak and hackberry wood, noncharred hackberry seeds, small mammal and rodent bones, and snail shells. Of these, only the burned wood is definitely cultural.

Feature 4 consists of an amorphous cluster of eight burned sandstone slabs, eight scattered burned sandstone slabs, and a concentration of charcoal flecks in Test Unit 3 at 61-71 cm. The scattered slabs are randomly distributed across the unit, and the cluster of burned rocks is in the south half of the unit and extends into the central portion of the south wall. Charcoal flecks are concentrated in an irregular $25 \times 45-\mathrm{cm}$ area in the northwest corner of the unit. This feature probably represents a scatter of displaced cultural debris on an occupational surface, but the dense cluster of burned rocks along the south wall may be the edge of a hearth.

Feature 5 is an amorphous cluster of ca. 10 horizontal and randomly distributed burned sandstone slabs and charcoal-stained soil covering all of Test Unit 3 at $72-80 \mathrm{~cm}$. The feature is interpreted as a scatter of cultural debris on an occupational surface. Four unidentified bone fragments were recovered from the feature. A radiocarbon assay on charcoal yielded a corrected age of $1180 \pm 210$ B.P. (GX-14449); a thermoluminescence assay on burned sandstone yielded no date, probably due to insufficient heating of the specimen (Dur89TL 135-9). Preservation of pollen in the feature fill was poor; this assessment, however, could be biased by the pollen extraction technique used by the analyst. Phytolith analysis of the feature fill yielded mostly festucoid and elongate types. Organic remains extracted from a burned rock were identified as probable plant residue.

Feature 6 is a $30 \times 60-\mathrm{cm}$ bone cluster exposed at $8-22 \mathrm{~cm}$ in Test Units 1 and 2 . It consists of a deer mandible, maxilla fragments, and teeth, as well as unidentified mammal bone fragments, some with canine tooth marks. Rodent bones are also scattered throughout the test unit at this level. This cluster of bones may represent a natural accumulation by predators, a cultural midden, or a combination of these.

\section{MATERIALS RECOVERED}

Materials recovered consist of lithic debitage and tools, burned rocks, bones, and mussel and snail shells (Table 37). The lithics are all of local materials except for one flake of Tecovas jasper and represent stone tool manufacture (cores, debitage, and hammerstones). Animals represented in the bone assemblage consist of deer, snake, rabbit, canine (including a probable dog/wolf hybrid), and several species of rodents. Cut marks were observed on a canine bone, and a few small mammal, rabbit, and rodent bones were burned. The remainder of the assemblage could have been introduced by predators or humans. The microdebitage and many of the bones and shells were recovered by flotation. One nonfeature sediment sample from Test Unit 3 was subjected to flotation recovery in addition to the feature sediment samples. Materials recovered consist of burned juniper, oak, hackberry, 
TABLE 37

DISTRIBUTION OF MATERIALS RECOVERED, 41GR559

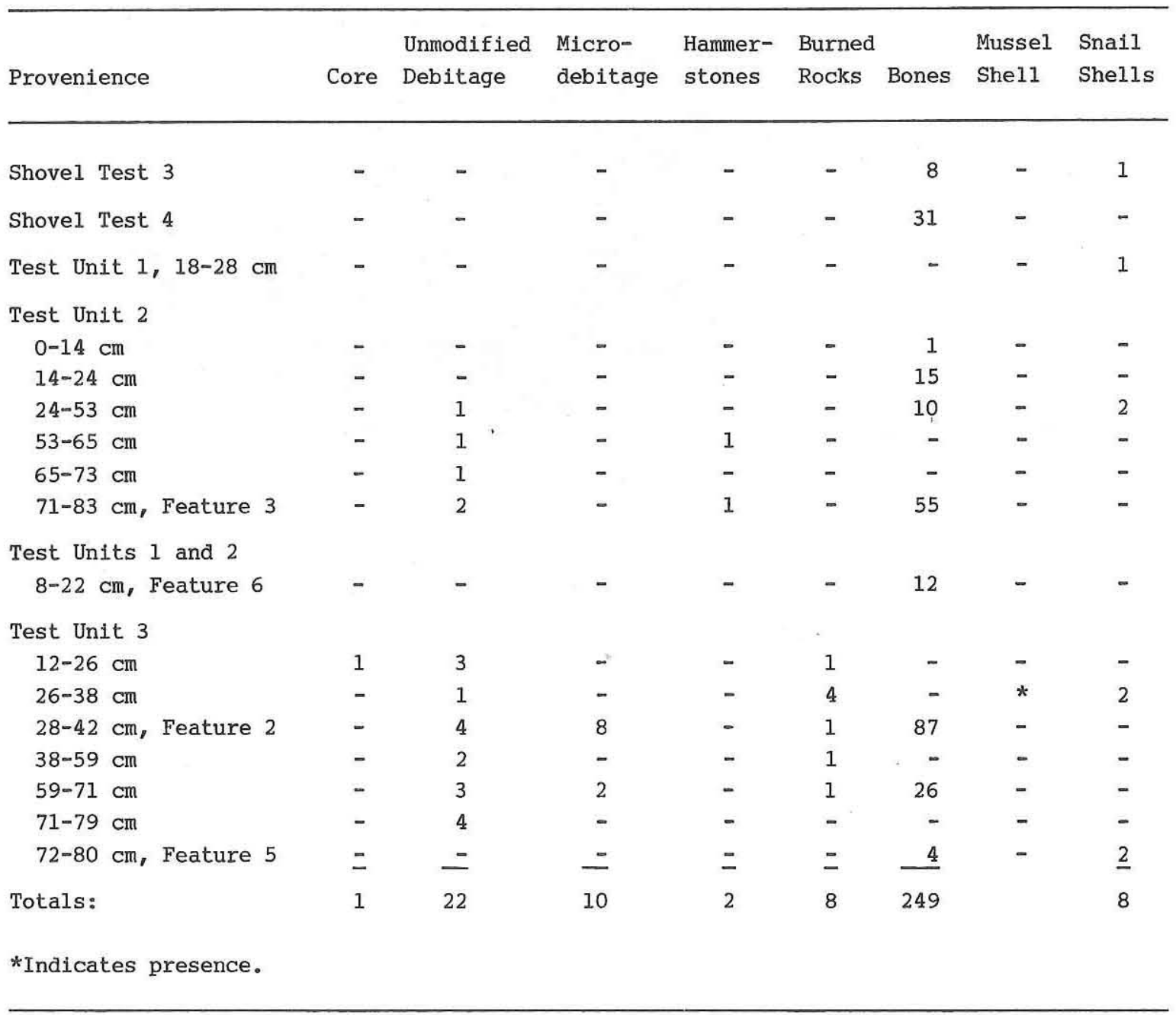

and unidentified hardwood; noncharred plant remains of several species; bone fragments (one burned); and snail shells. Only the burned bone fragment and charred wood are considered to be of cultural origin.

DISCUSSION OF COMPONENTS

Site 4 IGR559 is a ca. 30- $\mathrm{m}^{2}$ rockshelter (with $\mathrm{ca} .30 \mathrm{~m}^{2}$ of additional deposits in front) containing ca. $100 \mathrm{~cm}$ of sediments with multiple stratified occupations. No temporally diagnostic artifacts were recovered, but three chronometric assays--a charcoal radiocarbon age of $855 \pm 190$ B.P. and a thermoluminescence age of $480 \pm 105$ B.P. from Feature 3 and a charcoal radiocarbon age of $1180 \pm 210$ B.P. from Feature 5--provide good temporal control. The site stratigraphy is complex, and while vertical separation of components is 
evident, the exact number of occupations cannot be determined. The radiocarbon dates, from features at corresponding depths $(70-80 \mathrm{~cm})$ in different parts of the shelter, indicate a minimum time span of 300 years. A much greater time span, perhaps 500-1,000 years, is probably represented by the site as a whole.

The artifacts recovered provide evidence of stone tool manufacture. Food processing (and heating) is represented by burned rock features and scattered burned rocks and probable plant residues on burned rocks; mussel shell, and burned or butchered small mammal, rodent, rabbit, and canine bones indicate possible food resources. Bone concentrations, which may be cultural, could indicate refuse disposal areas. Evidence of other activities is probably preserved in and outside the shelter.

Macrobotanical remains are well preserved, but only the burned wood fragments are definitely of cultural origin. Taxa represented include juniper, oak, hackberry, and unidentified hardwood. Noncharred plant remains and unburned bones could be of cultural or natural origin. Two medium mammal rib fragments exhibit canine teeth marks, evidence that animal predation has contributed to the assemblage. Comparative flotation sampling and intrasite analysis of distribution patterns would be important techniques for identifying culturally introduced botanical and faunal remains.

The limited range of activities represented and limited number of artifacts recovered indicate that the shelter was not intensively occupied for extended periods. Occupations were most likely sporadic, short-term events. The combination of enhanced preservation potential of organic remains, horizontally discrete activities, and vertically separable occupations is not found at open campsites in the project area.

Faunal Localities

41GR249

\section{SITE SETTING}

Site 41GR249 is situated within the narrow Grape Creek valley, ca. $3.9 \mathrm{~km}$ south of its confluence with the Double Mountain Fork. The site is exposed in a terrace on the east bank of the creek near the base of the valley talus slope. The terrace is covered with dense grasses, mesquites, and junipers, with live oaks occurring along the creek.

\section{WORK ACCOMPLISHED}

When the site was recorded in 1987, a cluster of bison bones including the left and right mandibles, a metapodial, and a long bone were exposed 65-90 cm below the surface. The site was considered potentially cultural, and mapping and testing were recommended (Boyd et al. 1989). The current investigations consisted of site mapping and excavation of a $1 \times 1-m$ test unit directly over the exposed bone concentration to a depth of $85 \mathrm{~cm}$. The partially articulated right front quarter, two mandibles, and other minor elements were recovered. The bones were in a reddish brown sandy loam with abundant pebbles, considered to be mixed alluvial/colluvial fan deposits. 


\section{DISCUSSION}

The faunal elements recovered represent the partial remains of a single bison, probably a male between 5 and 6 years old; they either are disturbed or represent a secondary deposit. A corrected radiocarbon age of $90 \pm 115$ B.P. (GX-14418-G) was obtained from the radius. No cultural evidence was observed, and the find is considered to represent an isolated natural death. The excavation appears to have recovered all of the remains present.

41GR2 70

SITE SETTING

Site 41 GR270 is situated in a terrace on the west side of Grape Creek, ca. $3.2 \mathrm{~km}$ south of its confluence with the Double Mountain Fork. The site is exposed in the head of an erosional gully at the base of the valley talus slope, ca. $50 \mathrm{~m}$ west of the creek. The surface is eroded, and there is considerable gully erosion in the immediate vicinity. Vegetation in the vicinity consists of grasses, junipers, mesquites, and cacti.

\section{WORK ACCOMPLISHED}

When the site was recorded in 1987, disarticulated bison bones were exposed ca. $75 \mathrm{~cm}$ deep in a cutbank. Elements noted included ribs, a scapula, and long bones. The site was considered potentially cultural, and mapping and testing were recommended (Boyd et al. 1989). The current investigations consisted of site mapping and excavation of a $1 \times 2-m$ test unit over the exposed bone concentration to a depth of $100 \mathrm{~cm}$. The elements recovered consist of a right mandible, right scapula, right humerus, ribs, vertebrae, and several minor elements. The bones were found in a reddish brown sandy loam with abundant pebbles, considered to be mixed alluvial/colluvial deposits.

\section{DISCUSSION}

The faunal elements represent a partial, disarticulated male bison between 5 and 6 years of age. They probably were in a disturbed or secondary context. A corrected radiocarbon age of $70 \pm 110$ B.P. $(G X-14417-G)$ was obtained from the humerus. No cultural evidence was observed, and the find is considered to represent an isolated natural death.

41 GR310

\section{SITE SETTING}

Site 41 GR310 is situated in a terrace at the mouth of Gobbler Creek, ca. $200 \mathrm{~m}$ west of its confluence with the Double Mountain Fork. The site is exposed in the cutbank immediately north of the creek and $15 \mathrm{~m}$ east of a buried petroleum pipeline. The terrace is covered with dense grasses, junipers, and mesquites, but erosional exposure along the creek cutbank and nearby gullies is good. 
WORK ACCOMPLISHED

When the site was recorded in 1987, bison ribs and vertebrae were exposed ca. $120 \mathrm{~cm}$ deep in the Gobbler Creek cutbank. Charcoal flecks were observed in the sediments among the concentration of bones, and an isolated long bone was noted $20 \mathrm{~m}$ away at the same depth on the opposite side of the creek. The site was considered potentially cultural, and mapping and testing were recommended (Boyd et al. 1989). The current investigations consisted of site mapping, excavation of a $2 \times 2-m$ test unit over the bone concentration, and investigation of the isolated bone. The test unit, excavated to a depth of $145 \mathrm{~cm}$, exposed a concentration of bone fragments at 120-135 cm. Some of the fragments are charred, and charcoal flecks were present. Elements represented are the skull, vertebrae, and ribs. The isolated long bone, a partial humerus, was collected, and probing of the cutbank indicated that no other bones were present. All bones were found in alluvial sediments with alternating layers of light brown sandy loam and dark brown clay loam.

\section{DISCUSSION}

Burned fragments and charcoal flecks, along with some cut lines interpreted as butchering marks, suggest that these faunal remains were associated with human activities. The isolated humerus also exhibits possible human modification in the form of flake scars and wear that may have resulted from use as a tool. All of the faunal elements are too fragmentary for age and sex determinations. The alluvial context of these materials indicate that they likely represent primary deposition, although they appear to be in a disturbed setting. This faunal locality is undated but is interpreted as an isolated cultural episode, possibly a processing station. The excavation at the site appears to have recovered all of the materials.

41GR488

\section{SITE SETTING}

Site 41 GR488 is situated on an upper terrace on the north side of the Double Mountain Fork, ca. $6.4 \mathrm{~km}$ east of the U.S. Highway 84 bridge over the river. The site is exposed at the head of an erosional gully at the base of the valley talus slope. The terrace is covered with dense mesquites, junipers, grasses, chollas, prickly pears, and agaritas, but there is considerable erosional exposure in the vicinity.

\section{WORK ACCOMPLISHED}

When the site was recorded in 1987, scattered bone fragments thought to be bison were exposed ca. $120 \mathrm{~cm}$ deep in the cutbank. A possible burned rock and charcoal flecks were also noted nearby. Two shovel tests were excavated; charcoal flecks were noted in one, but no definite cultural evidence was found. The site was considered potentially cultural, and mapping and testing were recommended (Boyd et al. 1989). The current investigation consisted of site mapping and excavation of a $2 \times 2-m$ test unit over the bone fragments. The test unit was excavated to a depth of ca. $117 \mathrm{~cm}$, exposing a concentration of disarticulated bison bones and bone fragments at 110-115 cm. Scattered charcoal was noted above 
that level but not in direct association with the bones. Elements recovered consist of both mandibles, right radius, left femur, right tibia, and several "minor elements. The bones were found in a reddish brown sandy loam mixed with pebbles interpreted as alluvial/ colluvial fan deposits.

\section{DISCUSSION}

The bone concentration yielded no evidence of cultural association. Faunal elements recovered represent a single male bison, 10-11 years old. A corrected radiocarbon age from a tibia indicates that the site is less than 200 years old (GX-14420-G). The site is interpreted as a natural death and is most likely in a redeposited context. The charcoal scattered throughout the sediments above the bone concentration is also considered to be natural.

41 GR512

SITE SETTING

Site 41 GR512 is situated in a terrace on the south side of the Double Mountain Fork, ca. $1.8 \mathrm{~km}$ west of the mouth of Rocky Creek and $6.6 \mathrm{~km}$ east of the U.S. Highway 84 bridge over the river. The site is located in a $3-$ m-deep gully, ca. $75 \mathrm{~m}$ south of the river cutbank and $\mathrm{ca}$. $75 \mathrm{~m}$ northeast of the base of the valley talus slope. Terrace vegetation consists of dense grasses, junipers, mesquites, prickly pears, and chollas, but there is considerable erosional exposure in the vicinity.

\section{WORK ACCOMPLISHED}

When the site was recorded in 1987, a bison bone fragment and charcoal were exposed at 40-60 cm in the cutbank, and a shovel test yielded a silicified wood core at $40 \mathrm{~cm}$. The site was considered to be cultural, and mapping and testing were recommended (Boyd et al. 1989). The current investigations consisted of site mapping and excavation of a $1 \times 2-m$ test unit located over the bone to a depth of $80 \mathrm{~cm}$. A fragmentary bison vertebra and a humerus, as well as numerous fragments, were recovered. Some flecks of charcoal were noted throughout the sediments, and a single chert flake was recovered from the same level as the bones. All materials were found in a brown sandy loam alluvial deposit.

\section{DISCUSSION}

The faunal remains likely represent a single bison but are too fragmentary for age or sex determination. The humerus displays a green bone spiral fracture on the neck of the shaft, but no other cultural evidence was found. This undated site is considered to be a primary cultural deposit and probably represents an isolated processing station. The excavation at the site appears to have recovered all of the materials. 
41GR539

SITE SETTING

Site 4 IGR539 is situated in a terrace on the east side of an unnamed drainage, $0.7 \mathrm{~km}$ north of its confluence with the Double Mountain Fork and $3.7 \mathrm{~km}$ east of the U.S. Highway 84 bridge over the river. The site is exposed in over $2 \mathrm{~m}$ of sediments at the base of the valley talus slope within a very narrow valley. Dense terrace vegetation consists of grasses, junipers, and mesquites, with live oaks and hackberries along the drainage.

\section{WORK ACCOMPLISHED}

When the site was recorded in 1987, an articulated bison vertebral column and isolated toe bones were exposed at $120-160 \mathrm{~cm}$ in the cutbank. The site was considered potentially cultural, and mapping and testing were recommended (Boyd et al. 1989). The current investigations consisted of site mapping and excavation of a test unit. A $2.5 \times 2.5-m$ unit was excavated to the top of the bone level at $120 \mathrm{~cm}$ and was continued as a $1 \times 2-\mathrm{m}$ unit to $150 \mathrm{~cm}$. A bison bone concentration encountered at 122-148 cm consisted of a number of articulated ribs, the sternum, and the articulated right hind leg and foot. The bones were found in a reađish brown sand or sandy clay loam mixed with pebbles, which is interpreted as an alluvial/colluvial fan deposit. One unmodified flake was recovered at $100 \mathrm{~cm}$ but was not associated with the faunal remains.

\section{DISCUSSION}

The faunal elements recovered consist of two groups of articulated bones representing a partial male bison older than 6 years of age. A corrected radiocarbon age of $205 \pm$ 75 B.P. (GX-14416-G) was obtained from the metatarsal. The remains are probably in a disturbed or secondary context. Since no associated cultural evidence was found, the remains are interpreted as a natural death.

\section{$41 \mathrm{KT} 44$}

\section{SITE SETTING}

Site $41 \mathrm{KT} 44$ is situated in a terrace on the east side of Grape Creek, ca. $1.2 \mathrm{~km}$ south of its confluence with the Double Mountain Fork. It is located $100 \mathrm{~m}$ east of Grape Creek, at the base of the valley talus slope, in an area where pouroff from the canyon rim has created extensive gully erosion. Dense terrace vegetation consists of grasses, junipers, mesquites, Mormon tea, and hackberries.

\section{WORK ACCOMPLISHED}

When the site was recorded in 1987, disarticulated bison bones were exposed at ca. $65 \mathrm{~cm}$ in a cutbank. Elements noted included a femur, tibia, and numerous fragments. The 
site was considered potentially cultural, and mapping and testing were recommended (Boyd et al. 1989). The current investigations consisted of site mapping and excavation of a $2 \times 2-m$ test unit to a depth of $100 \mathrm{~cm}$ (Fig. 41). Articulated elements recovered at 80-95 cm consist of a section of vertebrae and ribs, and disarticulated elements recovered consist of the mandibles and right leg and foot bones. A single chert flake with a snapped distal end was recovered from the same level as the bones. The remains were found in a reddish brown sandy loam mixed with pebbles and pebble stringers, considered to be an alluvial/colluvial fan deposit. Some rodent disturbance was noted.

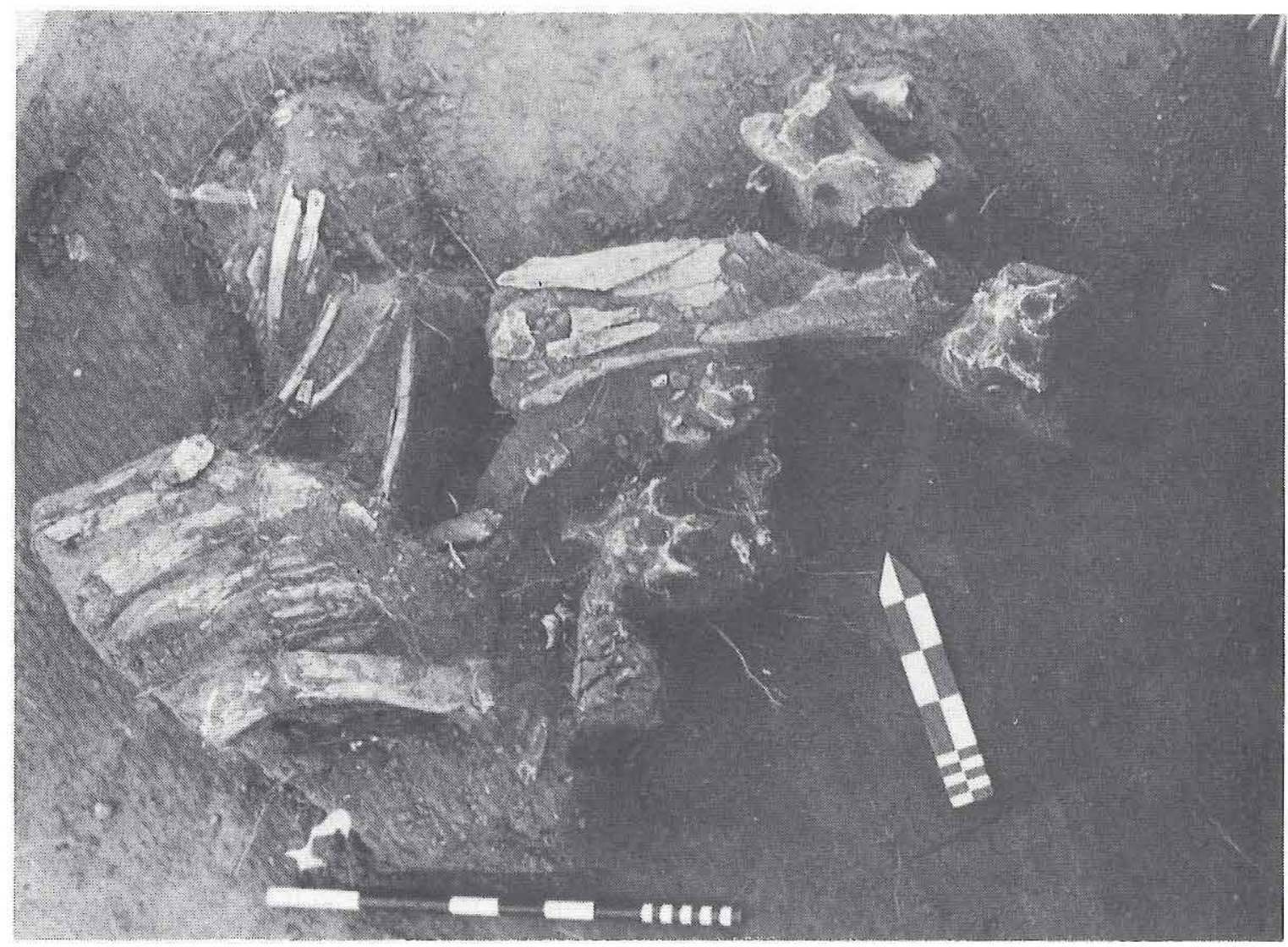

Figure 41. Bison bones exposed in test unit, 41KT44.

\section{DISCUSSION}

The faunal elements recovered represent a single male bison, 10-11 years old. A corrected radiocarbon age of $375 \pm 115$ B.P. (GX-14422-G) was obtained from a radius. The recovered flake is cultural in origin and appears to be associated with the bones. The combined evidence of several spiral fractures, cut marks, partially articulated elements, a pile of disarticulated bones, and a single flake tool indicate a probable processing station involving a single bison, dating to ca. A.D. 1575. However, the presence of the pebbles and pebble stringers mixed throughout the bone concentration indicates that the remains may be a secondary deposit. The excavation removed all materials present. 
$41 \mathrm{KT} 69$

\section{SITE SETTING}

Site $41 \mathrm{KT} 69$ is situated on the east side of Grape Creek, ca. $4.6 \mathrm{~km}$ south of its confluence with the Double Mountain Fork. The site is exposed in the east terrace cutbank near the base of the valley talus slope. The remaining terrace is extremely narrow and varies from 3 to $12 \mathrm{~m}$ in width. Dense terrace vegetation consists of grasses, mesquites, and junipers, but erosional exposure is good in the vicinity of the site.

\section{WORK ACCOMPLISHED}

When the site was recorded in 1987, a cluster of bison bones and several isolated bison bones were exposed at 40-80 cm along a 50-m stretch of the cutbank. Charcoal lenses were noted at the same level as the bones but appeared to be natural. The site was considered potentially cultural, and mapping and testing were recommended (Boyd et al. 1989). The current investigations consisted of site mapping, excavation of a $1 \times 2-m$ test unit, and investigation of an additional bone cluster in a nearby cutbank. Bones were scattered for $80 \mathrm{~m}$ along the cutbank, but two concentrations were noted.

Area A consists of a cluster of disarticulated bones and charcoal stains along a 10-m section of the terrace. Half of the $1 \times 2-\mathrm{m}$ test unit was excavated to $40 \mathrm{~cm}$, and the other half was excavated to $50 \mathrm{~cm}$. The charcoal stains were determined to be burned and/or decaying roots or tree stumps, and considerable rodent disturbance was noted. Bones recovered at 20-40 $\mathrm{cm}$ in the reddish brown sandy loam consist of a rib, vertebrae, a right ulna, a right carpal, a left ilium fragment, a right femur, and a right tibia. All are bison except for one unidentified small mammal bone.

The second cluster of bones, Area B, is located in an erosional gully ca. $60 \mathrm{~m}$ north of Area A. Disarticulated bison bones were exposed at a depth of 5-12 cm in the cutbank of a 1-2-m-wide strip of terrace remnant composed of reddish brown sandy loam mixed with pebbles. Elements recovered consist of a right ulna and radius, foot bones, a sternum, and a rib fragment.

\section{DISCUSSION}

All but one of the faunal elements recovered from Area A were identified as bison or probable bison. Two animals are represented, but the elements are too fragmentary to determine age or sex, although one is immature. The nonbison element is a long bone fragment from a small mammal. No definite cultural evidence was encountered, but a partial bison rib appears to have a green bone fracture. This assemblage is interpreted as a probable processing station based on the presence of at least two bison, a small mammal bone, and a probable manmade green bone break. A corrected radiocarbon age of less than 200 B.P. (GX-14419-G) was obtained from a femur from Area A.

Faunal elements recovered from Area B represent a mature male bison of unspecified age. These bones were found in alluvial/colluvial fan deposits and are probably redeposited or in a disturbed context. No evidence of cultural modification was noted. A 
corrected radiocarbon age of less than 200 B.P. (GX-14421-G) was obtained from a radius from Area B.

In both Areas $A$ and $B$, the faunal remains are preserved in a narrow, 1-3-m-wide strip of alluvial terrace or alluvial/colluvial fan sediments near the base of the talus slope. Although Area A is interpreted as a cultural site, future investigation is hampered by the lack of associated cultural materials and by the limited extent of the potential site area. Area $B$ is likely to be an isolated natural death in a disturbed or secondary deposit. 


\section{CHAPTER 6}

\section{INVESTIGATIONS AT SECOND-PRIORITY SITES}

by Douglas K. Boyd and William A. Bryan

This chapter describes investigations at 28 second-priority prehistoric sites, consisting of 22 open campsites, 2 lithic procurement sites, 2 lithic scatters, and 2 isolated finds. Three sites (41GR570, 41KT148, and 41KT149) were discovered and recorded during the current investigations. All other sites were investigated as part of the geoarcheological testing or by subsequent backhoe exploration in archeological sites. Additional investigations (e.g., hand testing and surface collecting) were undertaken if the backhoe trenches or exploratory trenches yielded substantial cultural materials. For various reasons, the investigations at second-priority sites did not necessarily correspond to the recommendations offered after the Phase I survey (see Chapter 3). As for the first-priority sites, supporting data for the descriptions below are presented in the appendixes (Volume II of this report). For new radiocarbon dates presented for the first time in this chapter, the dl3C corrected version (as corrected by the radiocarbon labs) is given. Calibrations for the radiocarbon dates are presented in Appendix $C$ but are not given here.

\section{Campsites}

41GR207

\section{SITE SETTING}

Site 41GR207 is situated in the upland margin on a south-projecting upland ridge and lower bedrock benches north of the Double Mountain Fork. The ridge overlooks the Cat Hollow drainage to the west and is flanked by a smaller unnamed drainage on the east. An east-west dirt road crosses the northern upland portion of the site, and a cultivated field is located $\mathrm{ca} .20 \mathrm{~m}$ north of the road. Flevations range from $2260 \mathrm{ft} \mathrm{msl}$ in the southern eroded areas to $2300 \mathrm{ft} \mathrm{msl}$ in the level upland area. Vegetation consists of grasses, junipers, prickly pears, agaritas, Mormon tea, yuccas, and various shrubs.

\section{WORK ACCOMPLISHED}

When 41GR207 was first recorded by Emmett Shedd in 1977, dart points, burned rock features, and a scatter of lithic debitage and tools were noted. It was revisited in 1987 and was described as an Archaic site consisting of burned rock features and surface artifacts. The site was assessed as warranting further work (Boyd et al. 1989).

The current investigations involved a small surface collection and excavation of two exploratory trenches and three Ixl-m test units (Table 38). The two exploratory trenches were excavated to determine the potential for buried cultural deposits; Exploratory Trench 85 , located on the east slope of the main upland ridge just south of the road, yielded no cultural materials, but Exploratory Trench 86, located ca. $90 \mathrm{~m}$ south of the road toward 
TABLE 38

SUMMARY OF EXCAVATIONS, 41GR207

\begin{tabular}{lcll}
\hline & $\begin{array}{l}\text { Depth of } \\
\text { Excavation } \\
\text { Unit }\end{array}$ & Reason for Ending Unit & $\begin{array}{l}\text { Artifact } \\
\text { Density }\left(\# / \mathrm{m}^{3}\right) \\
\text { or Result }\end{array}$ \\
\hline Test Unit 1 & 10 & Caliche-rich zone reached & 0.0 \\
Test Unit 2 & 38 & Bedrock sandstone reached & 26.3 \\
Test Unit 3 & 70 & Artifact decrease & 30.0 \\
Exploratory Trench 85 & 120 & Caliche-rich zone reached & negative \\
Exploratory Trench 86 & 50 & Bedrock sandstone reached & positive \\
\hline
\end{tabular}

the nose of the main ridge, yielded lithic debitage and probable burned rocks. Test Units 1 and 2 were located near Exploratory Trench 86, and Test Unit 3 was located near the road where lithic debitage was exposed. A unifacial gouge was surface collected from the road ca. 30 m east of Test Unit 3 , but a surface inspection of the cultivated field located no cultural materials.

\section{SEDIMENTS AND STRATIGRAPHY}

A representative stratigraphic profile of the northern portion of the site, present in Exploratory Trench 85 and Test Unit 3, consists of four zones: Zone 1, 0-8 cm, brown (7.5YR 4/6) sandy loam; Zone 2, 8-10 cm, dark brown (7.5YR 3/4) sandy loam, probable organic-rich A horizon; Zone 3, 10-40 cm, dark brown (7.5YR 4/4) silty loam with sparse pebbles, calcareous; and Zone 4, 40-70 cm, brown (7.5YR 5/4) silty loam with sparse pebbles, strongly calcareous. The stratigraphy of the southern eroded areas, present in Exploratory Trench 86 and Test Units 1 and 2, consists of a varying thickness $(0-30 \mathrm{~cm})$ of loose light brown $(7.5 Y R \quad 6 / 4)$ fine sand with weathered sandstone fragments. These sediments reflect redeposition of materials from upslope and/or in situ weathering of bedrock.

\section{SITE EXTENT AND DEPTH}

Cultural materials at 41GR207 are exposed on the surface in the lower eroded areas and in the upland area along the dirt road. The $100 \times 160-\mathrm{m}$ site area is defined by the extent of surface materials; boundaries are the cultivated field on the north, bedrock exposures on the east and west edges of the main ridge, and the southernmost extent of redeposited cultural materials on the lower bedrock benches. The northern boundary is arbitrary because of the limited amount of subsurface testing.

Cultural materials were recovered from 0 to $20 \mathrm{~cm}$ in the lower portion of the site, indicating little buried remains. In the upland portion of the site, however, cultural materials were recovered from 0 to $60 \mathrm{~cm}$, with the highest concentration at 30-60 cm in Test Unit 3. 


\section{MATERIALS RECOVERED}

The 36 lithic artifacts recovered are all of local materials, but none are temporally diagnostic (Table 39). Lithic reduction is the primary activity represented, but other activities (possibly food processing) are indicated by the unifacial gouge and the edgemodified flakes.

TABLE 39

DISTRIBUTION OF ARTIFACTS, 41GR207

\begin{tabular}{|c|c|c|c|c|}
\hline Provenience & Gouge & $\begin{array}{l}\text { Edge-modified } \\
\text { Debitage }\end{array}$ & $\begin{array}{l}\text { Unmodified } \\
\text { Debitage }\end{array}$ & Hammerstone \\
\hline Surface & 1 & - & - & - \\
\hline Backhoe Trench 86 & $\therefore$ & - & 4 & - \\
\hline Test Unit 2 & - & 4 & 5 & 1 \\
\hline Test Unit $3,0-30 \mathrm{~cm}$ & - & - & 7 & - \\
\hline $30-60 \mathrm{~cm}$ & $=$ & $=$ & $\underline{14}$ & 二 \\
\hline Totals: & 1 & 4 & 30 & 1 \\
\hline
\end{tabular}

DISCUSSION

Site 4lGR207 is tentatively assigned to the Archaic period based on the presence of dart points noted by previous investigators. No chronometric dates were obtained, but the buried upland setting is compatible with this assessment. Cultural materials were found at 0-60 cm, and although no vertical separation was observed, it is possible that distinct components are present. Lithic reduction and probable food processing are the only apparent activities represented at this open campsite, but this probably reflects the limited nature of the testing rather than the absence of other activities.

41 GR239

\section{SITE SETTING}

Site 41GR239 is situated in the upland margin on and around a prominent rise known locally as Cedar Hill. Cedar Hill, the highest point in the project area at an elevation of ca. $2340 \mathrm{ft} \mathrm{msl}$, is located at the head of several small unnamed drainages and is ca. $0.5 \mathrm{~km}$ northwest of the main channel of the Double Mountain Fork. The site extends from the top of the hill down to ca. $2290 \mathrm{ft} \mathrm{msl}$. To the south and southeast, Cedar Hill drops steeply onto an eroded lower bedrock bench, while to the southwest the transition from upland to lower bench is more gradual. To the west, north, and east, Cedar Hill slopes gradually into the surrounding upland. Quaternary gravels are extremely dense in areas, 
and the top of the hill has been disturbed by blading and/or gravel operations. Large oil storage tanks and other equipment have been stored on the flattened hilltop. Unimproved dirt roads, an earthen stock tank, an electric powerline, and a buried petroleum pipeline have also disturbed portions of the site. The vegetation cover, consisting of junipers, mesquites, grasses, yuccas, Mormon tea, and other shrubs, is moderate in the gently sloping upland flat but sparse on the gravelly hill and on the lower benches to the south.

\section{WORK ACCOMPLISHED}

Site 41GR239 was initially recorded in 1975 (Campbell and Judd 1977a), revisited in 1982 (Alexander 1982), and revisited again in 1987 (Bryan and Howard 1989:424-425). The latter investigation described it as a lithic procurement/campsite of undefined prehistoric age. Utilized gravel outcrops, surface artifacts, and burned rock scatters were noted. The site was assessed as warranting further work (Boyd et al. 1989).

The current investigations consisted of a small surface collection and excavation of two exploratory trenches and five 1x1-m test units (Table 40). Exploratory Trenches 88 and 89, located in the flat upland areas north and northeast of the top of Cedar Hill, yielded cultural evidence. The five test units were excavated nearby, but these yielded only sparse artifacts. Fire-cracked rocks were found throughout Test Units 3 and 5, but no features were present.

TABLE 40

SUMMARY OF EXCAVATIONS, 41GR239

\begin{tabular}{lll}
\hline & $\begin{array}{l}\text { Depth of } \\
\text { Excavation }\end{array}$ & Artifact \\
Unit & $(\mathrm{cm})$ & Rensity (\#/m $\left.{ }^{3}\right)$ \\
or Result
\end{tabular}

Test Unit 1

Test Unit 2

Test Unit 3

Test Unit 4

Test Unit 5

Exploratory Trench 88

Exploratory Trench 89
Artifact decrease

Bedrock sandstone reached

Bedrock sandstone reached

Artifact decrease

Caliche-rich zone reached

Caliche-rich zone reached

Caliche-rich zone reached
2.5

7.7

0.0

0.0

16.7

positive

positive

The prominent location of the site in a heavily developed oilfield area has attracted much attention. Local collectors interviewed during the 1988 investigations attest to its popularity as a collecting locality. Only unifacial tools and a sandstone mano were surface collected, although a thorough surface reconnaissance and detailed topographic mapping were not attempted. 


\section{SEDIMENTS AND STRATIGRAPHY}

A representative stratigraphic profile, present in Test Unit 1, consists of three zones: Zone 1, 0-10 cm, compact light brown sandy loam; Zone 2, 10-20 cm, light brown sandy loam with sparse pebbles, calcareous; and Zone 3, 20-40 cm, brown sandy loam with sparse pebbles, calcareous. This profile is present only in the level or gently sloping upland. The top of Cedar Hill has been bladed down to gravels or bedrock, and the lower portion of the site has only sporadic remnants of redeposited upland sands. Quaternary gravels are exposed everywhere except where they are buried by upland sands.

\section{SITE EXTENT AND DEPTH}

The site area is defined on the basis of the surface extent of Quaternary gravel outcrops, lithic debitage, or burned rocks, and is estimated to be ca. $300 \times 450 \mathrm{~m}$. From the center of Cedar Hill, the site extends ca. $100 \mathrm{~m}$ to the north, $150 \mathrm{~m}$ to the west, $300 \mathrm{~m} \mathrm{to}$ the east, and 100-200 $\mathrm{m}$ to the southwest, south, and southeast. All materials recovered from subsurface contexts were found at depths of less than $20 \mathrm{~cm}$.

\section{MATERIALS RECOVERED}

The 11 artifacts recovered consist of 5 surface-collected tools ( 3 unifaces, 2 edgemodified flakes, and a sandstone mano) and 5 unmodified flakes (2 from Test Unit 5 and 1 each from Exploratory Trench 88 and Test Units 1 and 5). Also recovered were two burned rocks. All are of local materials.

\section{DISCUSSION}

Cultural materials at 41GR239 are very shallowly buried or surficial and have been subjected to severe disturbance. The site lacks temporal diagnostics, probably due in part to intensive relic collecting, and remains chronologically undefined. The prominent location and density of surface materials suggest a probable multicomponent campsite, but the thin deflated deposits offer little chance of vertical separation of occupational debris. Likewise, the amount of disturbance severely limits the potential for horizontal separation of components.

\section{$41 \mathrm{GR} 286$}

\section{SITE SETTING}

Site 4 IGR286 is located in the upland margin on the north side of the Double Mountain Fork, $1 \mathrm{~km}$ east-northeast of the mouth of Cat Hollow. The site, situated on the upland flat and two upland ridges divided by a small erosional drainage, is flanked by larger drainages to the east and west. An east-west dirt road crosses the upland flat. The edges of the ridges are eroded exposing large areas of sandstone bedrock, Quaternary gravels, or remnant sediment accumulations. Vegetation cover, consisting of junipers, mesquites, and 
grasses, is moderate to heavy in the upland flat and sparse in the lower areas. The site extends from an elevation of 2240 to $2270 \mathrm{ft} \mathrm{msl}$.

\section{WORK ACCOMPLISHED AND DISCUSSION}

When this site was recorded, a thin surface scatter of lithic debris, ca. 12 burned rock features along the ridge edges, and some exposures of Quaternary gravels were noted. Only two tools, a chopper and a mano, were observed, but tested cobbles, cores, and flakes were abundant. The cultural deposits were considered to be mainly surficial, but the site was assessed as warranting further work (Boyd et al. 1989).

The current investigations consisted of the excavation of two $1 \mathrm{x} 1-\mathrm{m}$ test units placed in areas that appeared to have the potential for buried remains based on the results of mechanical testing in nearby sites. Test Unit 1 was located in the upland portion of the site and was excavated to $38 \mathrm{~cm}$. Test Unit 2 was located on the gentle east slope of the easternmost ridge and was excavated to $60 \mathrm{~cm}$.

The cultural materials recovered consist of 11 artifacts of local materials: 2 flakes from 0-20 cm in Test Unit 1; 5 flakes from 0-20 cm in Test Unit 2; and 3 flakes and 1 hammerstone from 20-40 cm in Test Unit 2. Surface features consist of clusters of burned sandstone or clusters of fire-cracked Potter chert, possibly representing hearths and boiling stone dumps. No artifacts were found in association with the surface features, and no evidence of subsurface features was found. Ten burned rocks also were collected.

Because no temporal diagnostics were recovered, the occupations at the site remain chronologically undefined. Lithic procurement and lithic reduction are evident, but food processing may be represented by the burned rock features. The buried component at this multifunctional lithic procurement/campsite is not adequately defined, however, by the limited testing.

41GR287

\section{SITE SETTING}

Site 41GR287 is located in the upland margin on the north side of the Double Mountain Fork, ca. $0.5 \mathrm{~km}$ northeast of the mouth of Cat Hollow. The site, situated on a flat upland ridge projecting southward toward the river, is flanked by a deep drainage on the west and an eroding secondary bench on the east. The southern end of the ridge terminates at the bluff edge of the Double Mountain Fork channel. An east-west dirt road crosses the level upland ca. $50 \mathrm{~m}$ north of the site. The elevation is ca. $2280 \mathrm{ft} \mathrm{ms}$ l along the ridge edges and over $2290 \mathrm{ft} \mathrm{msl}$ at the crest. Vegetation cover, consisting mainly of junipers and grasses, with lesser amounts of cholla, yucca, and tasajillo, is moderate to heavy on top of the ridge and sparse along the eroding edges.

\section{WORK ACCOMPLISHED}

When this site was recorded in 1987, a scatter of lithic debitage and fire-cracked Potter chert and a single burned Potter chert feature were noted. The site contained an 
unusually high density of scattered burned rocks, but no tools were found. The site was assessed as warranting further work (Boyd et al. 1989).

The current investigations consisted of the excavation of two exploratory trenches and five $1 \times 1-m$ test units (Table 41). The exploratory trenches were located in areas where buried cultural remains were considered likely based on the mechanical testing of nearby sites. Exploratory Trench 80, located near the burned Potter chert feature, yielded no artifacts but contained possibly cultural charcoal staining in the upper $20 \mathrm{~cm}$. Exploratory Trench 81, located along the ridgecrest in the northern portion of the site, yielded no cultural evidence. Test Units 1-4 were excavated in a contiguous 4-m-long trench to expose two burned rock clusters, Features 1 and 2, and Test Unit 5 was excavated to $30 \mathrm{~cm}$ adjacent to Exploratory Trench 80 but yielded no cultural materials.

TABLE 41

SUMMARY OF EXCAVATIONS, 41GR287

\begin{tabular}{lrlr}
\hline & $\begin{array}{l}\text { Depth of } \\
\text { Excavation } \\
\text { Unit }\end{array}$ & Reason for Ending Unit & $\begin{array}{l}\text { Artifact } \\
\left.\text { Density (\#/m }{ }^{3}\right) \\
\text { or Result }\end{array}$ \\
\hline & 30 & No artifacts & 0.0 \\
Test Unit 1 & 10 & Completed feature excavation & 30.0 \\
Test Unit 2 & 25 & Completed feature excavation & 8.0 \\
Test Unit 3 & 5 & Completed feature excavation & 0.0 \\
Test Unit 4 & 30 & No artifacts & 0.0 \\
Test Unit 5 & 75 & Caliche-rich zone reached & negative \\
Exploratory Trench 80 & 90 & Caliche-rich zone reached & negative \\
Exploratory Trench 81 & & & \\
\hline
\end{tabular}

SEDIMENTS AND STRATIGRAPHY

The ridgetop is covered with a varying thickness of sandy sediments which have eroded from the edges and the southern end of the ridge, exposing the sandstone bedrock. The upland profile consists of Zone 1, a reddish yellow (5YR 6/6) sandy loam with an abrupt transition at $\mathrm{ca} .30-40 \mathrm{~cm}$, and Zone 2, a darker reddish yellow (5YR 6/6) silty loam with calcium carbonate staining to a depth of 70-90 cm. Although excavations did not extend below this level, it is likely that a substantial caliche zone overlies the sandstone bedrock. The thickness of the sandy sediments decreases toward the ridge edges.

\section{SITE EXTENT AND DEPTH}

The 50x200-m site area is defined by the ridge topography on the west, south, and east and by the distribution of surface artifacts on the north. Cultural materials are surficial or shallowly buried, with none found below $20 \mathrm{~cm}$. 
FEATURES

Test Units 1-4 exposed a hearth (Feature 1) and a cluster of fire-cracked Potter chert (Feature 2) which are considered to represent associated activities (Fig. 42). Feature 1 is a ca. 55-cm-diameter circular hearth exposed at 0-10 cm in Test Units 1 and 2 . It is composed of a single layer of 59 burned sandstone slabs which are horizontal or dip slightly toward the center, but there is no pronounced basin shape to the feature. The hearthstones appear to have been subjected to different intensities of heating, with some of the central rocks being intensively heat discolored (reddened or blackened interiors) and most of the outer rocks being only slightly discolored. One large and several small fragments of fire-cracked Potter chert were also present but appeared to be displaced.

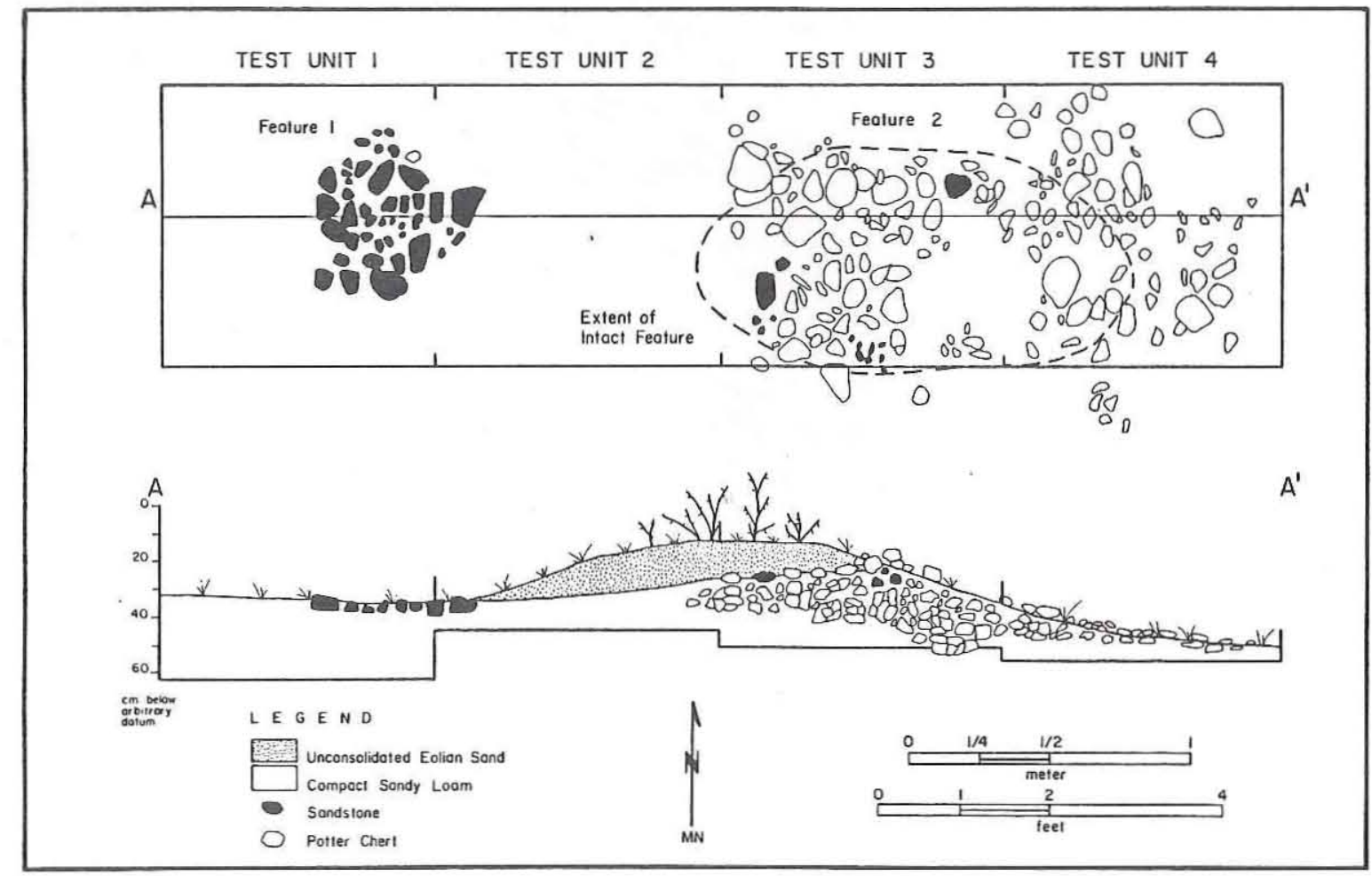

Figure 42. Generalized plan and profile views of Features 1 and 2, Test Units 1-4, $41 \mathrm{GR} 287$.

Feature 2, 2 m east of Feature 1, is almost entirely within Test Units 3 and 4, but some displaced materials were found on the surface in adjacent units. The feature consists of a dense concentration of angular fragments of fire-cracked Potter chert, the majority of which have some thermally discolored (reddened) cortex. A 1.3x2.0-m scatter of firecracked rocks was exposed; the central $80 \times 160-\mathrm{cm}$ portion was protected by tasajillo and Mormon tea and was buried to a maximum depth of $25 \mathrm{~cm}$. Within the buried portion of the feature, several fire-cracked cobbles were observed among the tightly packed cluster of fragments. Anticipating that many of the scattered fragments could be reconstructed into cobbles, the entire feature was collected. It consisted of 278 angular fragments of Potter chert weighing $34,298 \mathrm{~g}$. Individual fragments ranged in size from a few grams to over $1,000 \mathrm{~g}$, averaging $123 \mathrm{~g}$. Eighty-eight of the fragments (58\% of the total by weight) were 
reconstructed into 13 complete or nearly complete cobbles. Other fragments undoubtedly fit together, but time constraints limited the reconstruction effort. Feature 2 appears to represent a boiling stone or baking pit dump consisting of an estimated 20 large cobbles which were heat- and impact-fractured into 278 fragments. At the time the feature was deposited, many of the cobbles had already been fractured and separated into fragments, as would be expected during intensive heating. Other cobbles or cobble fragments apparently fractured on impact but were not scattered. If Feature 2 is a boiling stone dump, it is most likely associated with the adjacent hearth. The presence of fire-cracked Potter chert fragments in the hearth suggests that the two features are contemporaneous.

Several technical studies of these features were performed. Samples of burned rock from each feature were submitted for thermoluminescence dating. An assay on burned sandstone from Feature 1 yielded no date (Dur89TL 134-1), most 1ikely due to insufficient heating of the sample, and an assay on a Potter chert fragment from Feature 2 yielded a questionable age of $3600 \pm 730$ B.P. (Dur89TLqi 134-2BS). Organic residues extracted from the burned rocks were analyzed; probable plant residue was present in Feature 1, and indeterminate residue was present in Feature 2. Flotation of the fill from Feature 1 yielded a burned juniper wood fragment, one hackberry seed, and one Mollugo seed.

\section{MATERIALS RECOVERED}

Only five artifacts were recovered in testing, and no surface materials were collected. A core and two flakes were found in Test Unit 2, and an edge-modified and an unmodified flake were found in Test Unit 3. These specimens were not definitely associated with the features.

\section{DISCUSSION}

No temporally diagnostic artifacts were recovered from 41GR287, and a single thermoluminescence age of $3600 \pm 730$ B.P. from Feature 2 provides the only chronological indicator. Paired radiocarbon and thermoluminescence dates from other sites suggest that this date may be erroneous. Cultural materials are confined to the surface or the upper $20 \mathrm{~cm}$ and are relatively sparse. The limited range of artifacts and the presence of only two features suggest a short-duration campsite occupation or perhaps a specialized activity (i.e., food processing) site. The seemingly associated hearth and possible boiling stone dump may represent a single processing episode, and the organic residues tentatively suggest that plants were being prepared.

$41 \mathrm{GR} 302$

\section{SITE SETTING}

Site 41GR302 is situated in the upland margin on the north side of the Double Mountain Fork, ca. $1.5 \mathrm{~km}$ east of Cedar Hill. The site occupies two south-projecting ridges flanked by small drainages. Elevations range from $2270 \mathrm{ft} \mathrm{msl}$ along the ridge edges to $2280 \mathrm{ft} \mathrm{msl}$ along the eastern ridgecrest. An east-west dirt road cuts across the north edge of the site, and the moderate vegetation cover consists of grasses, junipers, mesquites, prickly pears, and cholla. 
WORK ACCOMPLISHED

This site was initially recorded between 1974 and 1977 (Campbell and Judd 1977a) and was revisited in 1982 (Alexander 1982). The latter investigation reported numerous burned rock features, lithic tools and debitage, and gravel outcrops with evidence of lithic procurement. When the site was again revisited in 1987, scattered burned rocks and two surface features were noted, but no evidence of lithic procurement activity was documented. The site was assessed as warranting further work (Boyd et al. 1989).

The current investigations consisted of surface collection of a single artifact, and excavation of two exploratory backhoe trenches and four lxl-m test units (Table 42). Exploratory Trench 78, located in the eastern portion of the site $9 \mathrm{~m}$ south of exposed cultural materials in the dirt road, yielded burned rocks but no artifacts. Exploratory Trench 79, located in the western portion of the site near the dirt road, yielded no cultural materials. Test Unit 1 was $10 \mathrm{~m}$ southwest of Exploratory Trench 78 within a large surface scatter (ca. $20 \mathrm{~m}$ in diameter) of fire-cracked Potter chert (Feature 1) and exposed a smaller burned rock cluster (Feature 2). Test Units 2-4 were located alcng the eastern ridgecrest southwest of Exploratory Trench 78; all yielded lithic debitage, burned rock fragments, and/or mussel shell fragments.

TABLE 42

SUMMARY OF EXCAVATIONS, 41GR302

\begin{tabular}{lcll}
\hline & $\begin{array}{l}\text { Depth of } \\
\text { Excavation } \\
\text { Unit }\end{array}$ & Reason for Ending Unit & $\begin{array}{l}\text { Artifact } \\
\text { Density }\left(\# / \mathrm{m}^{3}\right) \\
\text { or Result }\end{array}$ \\
\hline Test Unit 1 & 40 & Caliche-rich zone reached & 50.0 \\
Test Unit 2 & 65 & Caliche-rich zone reached & 55.4 \\
Test Unit 3 & 60 & Caliche-rich zone reached & 40.0 \\
Test Unit 4 & 30 & Caliche-rich zone reached & 20.0 \\
Exploratory Trench 78 & 100 & Caliche-rich zone reached & positive \\
Exploratory Trench 79 & 85 & Caliche-rich zone reached & negative \\
\hline
\end{tabular}

\section{SEDIMENTS AND STRATIGRAPHY}

A representative stratigraphic profile in Test Unit 2 consists of three zones: Zone 1, 0-25 cm, yellowish red (5YR 5/6) sandy loam with pebbles, slightly calcareous; Zone 2, 25-45 cm, yellowish red (5YR 5/8) sandy loam, calcareous; and Zone 3, 45-65 cm, reddish brown (5YR 5/4) coarse sand with decomposing bedrock sandstone, strongly calcareous. Other excavations indicate that a well-developed caliche zone overlies the sandstone bedrock. 


\section{SITE EXTENT AND DEPTH}

No detailed mapping was done and the areal extent of this site is not well defined; it is estimated to cover an area of $150 \times 150 \mathrm{~m}$. Cultural materials are exposed on the surface and were found in test excavations to a depth of $60 \mathrm{~cm}$. No obvious vertical separation of components was noted, but there is a potential for discrete multiple occupations.

\section{FEATURES}

Burned rock features at this site consist of two surface features reported in 1987 (Features 1 and 3 ) and one buried feature discovered during testing (Feature 2). Feature 1 is a $20 \times 20-\mathrm{m}$ sparse scatter of fire-cracked Potter chert and quartzite, and Feature 3 is a $2 \times 2-m$ cluster of fire-cracked Potter chert.

Feature 2 consists of burned sandstone slabs and a few fire-cracked Potter chert fragments at 18-40 cm in Test Unit 1. It is amorphous, and scattered fragments indicate that it was probably disturbed prior to burial. Burned slabs are near-vertical or dip in various directions, but no patterning could be discerned. The lower slabs are apparently unburned and could represent the original surface on which the feature lay or an unburned part of the feature. Two unifacial tools and an edge-modified flake found in the unit may be associated. Flotation of a sample of the feature fill yielded an unidentified seed coat and two snail shells; these are probably noncultural. This could be a disturbed slab-lined hearth or possibly part of a slab-lined baking pit which was disturbed when it was cleaned out. While no pit edges could be discerned, the near-vertical slabs indicate that the latter is likely. The surface scatter of fire-cracked Potter chert (Feature 1) around Test Unit 1 may be associated with this feature.

\section{MATERIALS RECOVERED}

The 87 artifacts recovered consist of 86 chipped stone items and 1 ground stone specimen (Table 43). All of the chipped stones are of local materials with the exception of two specimens of Tecovas jasper. Forty-two burned rocks were collected. Mussel shell fragments were recovered at $40-65 \mathrm{~cm}$ in Test Unit 2. Indeterminate organic residues were extracted from an end/side scraper associated with Feature 2.

\section{DISCUSSION}

Site 41GR302 is temporally and culturally undefined; no diagnostic artifacts were recovered, and̃ no chronometric dates were obtained. The burned rock features and the limited variety in the stone tool assemblage suggest a short-duration campsite or specialized activity site; food processing and stone tool manufacture are represented. Limited interregional mobility or exchange is indicated by the nonlocal lithic material. Based on the depth to which cultural materials were found, it is surmised that multiple occupations may be represented. The limited amount of testing is inadequate to fully evaluate the buried deposits. 
TABLE 43

DISTRIBUTION OF ARTIFACTS, 41GR302

\begin{tabular}{|c|c|c|c|c|c|}
\hline Provenience & Unifaces & Cores & $\begin{array}{l}\text { Edge-modified } \\
\text { Debitage }\end{array}$ & $\begin{array}{l}\text { Unmodified } \\
\text { Debitage }\end{array}$ & $\begin{array}{l}\text { Ground } \\
\text { Stone }\end{array}$ \\
\hline Surface & 1 & - & - & - & - \\
\hline Test Unit $1,0-20 \mathrm{~cm}$ & 1 & - & 1 & 15 & - \\
\hline $20-40 \mathrm{~cm}$ & 1 & - & - & 2 & - \\
\hline Test Unit $2,0-20 \mathrm{~cm}$ & - & 1 & 3 & 17 & - \\
\hline $20-40 \mathrm{~cm}$ & - & 1 & - & 9 & - \\
\hline $40-65 \mathrm{~cm}$ & - & - & - & 5 & - \\
\hline Test Unit $3,0-20 \mathrm{~cm}$ & - & - & 1 & 21 & - \\
\hline $20-40 \mathrm{~cm}$ & - & - & - & 2 & - \\
\hline Test Unit $4,0-20 \mathrm{~cm}$ & - & 1 & - & 3 & 1 \\
\hline $20-30 \mathrm{~cm}$ & $=$ & $=$ & $=$ & 1 & $=$ \\
\hline Totals: & 3 & 3 & 5 & 75 & 1 \\
\hline
\end{tabular}

41GR303

\section{SITE SETTING}

Site 41 GR303 is situated in the upland margin west of Cat Hollow and north of the Double Mountain Fork of the Brazos, ca. $0.5 \mathrm{~km}$ east of Cedar Hill. The site occupies an isolated, east-projecting upland ridge and the surrounding lower benches ca. $300 \mathrm{~m}$ north of the Double Mountain Fork. The edges of the ridge and the lower benches are severely eroded with abundant sandstone bedrock exposures. The lower benches north and east of the ridge are exposed bedrock with isolated remnants of sandy sediments, while the lower benches to the west and south contain larger remnants of sediments but are also dissected by numerous small drainages. A dirt road runs east from Cedar Hill onto the main ridge, but no other land alteration is apparent. Vegetation consisting of grasses, junipers, prickly pears, agaritas, and small shrubs is moderate to heavy on the rise and on lower bench sediment remnants but sparse to absent in the eroded areas. Site elevations range from 2240 to $2310 \mathrm{ft} \mathrm{msl.}$

\section{WORK ACCOMPLISHED}

When this site was recorded in 1987, scattered burned rocks and a $1 \times 3-m$ burned rock cluster were noted. Buried cultural materials were noted on the main ridge, and displaced cultural materials were noted in the lower bench to the north and east. The site was assessed as warranting further work (Boyd et al. 1989). 
The current investigations involved limited site mapping, surface collection, and excavation of two exploratory trenches and five test units (Fig. 43, Table 44). Exploratory Trench 91 was located on the highest part of the ridge where sediments were presumed to be thin but where surface artifacts indicated possible buried remains. Excavation surprisingly revealed over $100 \mathrm{~cm}$ of sediments and burned sandstone (possibly a feature) and lithic debitage at ca. 30-40 cm. A unifacial gouge was found in the west wall at 40 $\mathrm{cm}$. Exploratory Trench 92 was excavated in the central portion of the ridge and encountered a rock cluster (Feature 1 ) and associated lithic debitage at ca. 30-40 cm.

The positive results of the exploratory trench excavations spurred additional work at the site. Surface inspection revealed two areas warranting testing: Area $A$, the flat portion of the upper ridge where the exploratory trenches were excavated; and Area B, a sediment remnant in the lower eroded area to the northeast. No surface cultural materials were noted in the remnant sediment deposits south and west of the main ridge.

Surface artifacts noted in Area A included unifaces, bifaces, hammerstones, cores, and choppers, but time did not permit accurate mapping and surface collection. Three test units were excavated to bedrock and yielded cultural materials and buried features. Test Unit 1, at the west end of Exploratory Trench 91, encountered three burned rock features (Features 3, 4, and 7) at various depths between 30 and $100 \mathrm{~cm}$. Test Unit 2, at the south end of Exploratory Trench 92, was selected to test the large rock cluster (Feature 1) found in the trench wall. Test Unit 3 was located in a flat portion of the ridge where scattered burned rocks were noted and encountered a burned rock feature (Feature 2) at ca. $20 \mathrm{~cm}$.

Area $B$ is an isolated $25 \times 75-m$ remnant of sediments exposed on all sides by erosion. Considerable amounts of burned rocks and lithic artifacts were exposed. Diagnostic artifacts were individually plotted and collected, and a 10x10-m surface collection unit was situated in an area where cultural materials were exposed on bedrock. Cull piles from artifact collecting were noted, and the amount of disturbance by relic hunters is unknown.

Two test units were excavated in Area B. Test Unit 4 yielded a considerable amount of lithic debitage at 0-110 cm and clusters of burned rocks (Features 6 and 8 ) at $70-100 \mathrm{~cm}$. A shovel probe in the northwest corner of the unit hit sandstone bedrock at $145 \mathrm{~cm}$. Test Unit 5 was excavated to sandstone bedrock at $65 \mathrm{~cm}$, yielding lithic debitage and tools throughout and a large concentration of burned rocks (Feature 5) at 5-20 cm.

\section{SEDIMENTS AND STRATIGRAPHY}

The sediments in Areas A and B represent different depositional histories, although the deposits in both appear to be relatively old. The sediments in Area A consist of ca. $100 \mathrm{~cm}$ of yellowish brown (10YR 6/4 to 10YR 5/4) calcareous sandy loam with small pebbles overlying a well-developed caliche layer above bedrock conglomeratic sandstone. These deposits appear to represent a combination of sandy upland sediments and weathered bedrock. This type of deposit, probably a mixture of alluvial, colluvial, and eolian materials, is common along the eroding upland margin but is unusually thick at this site.

The Area B stratigraphy, represented in Test Unit 4, consists of a few centimeters of eolian sand over ca. $100 \mathrm{~cm}$ of homogenous, calcareous yellowish brown (10YR 5/4) sandy loam with small pebbles. At $100 \mathrm{~cm}$, the sediments change abruptly to a strongly calcareous dark yellowish brown $(7.5 \mathrm{YR} 4 / 6)$ sandy loam with larger and more abundant pebbles. Sandstone 


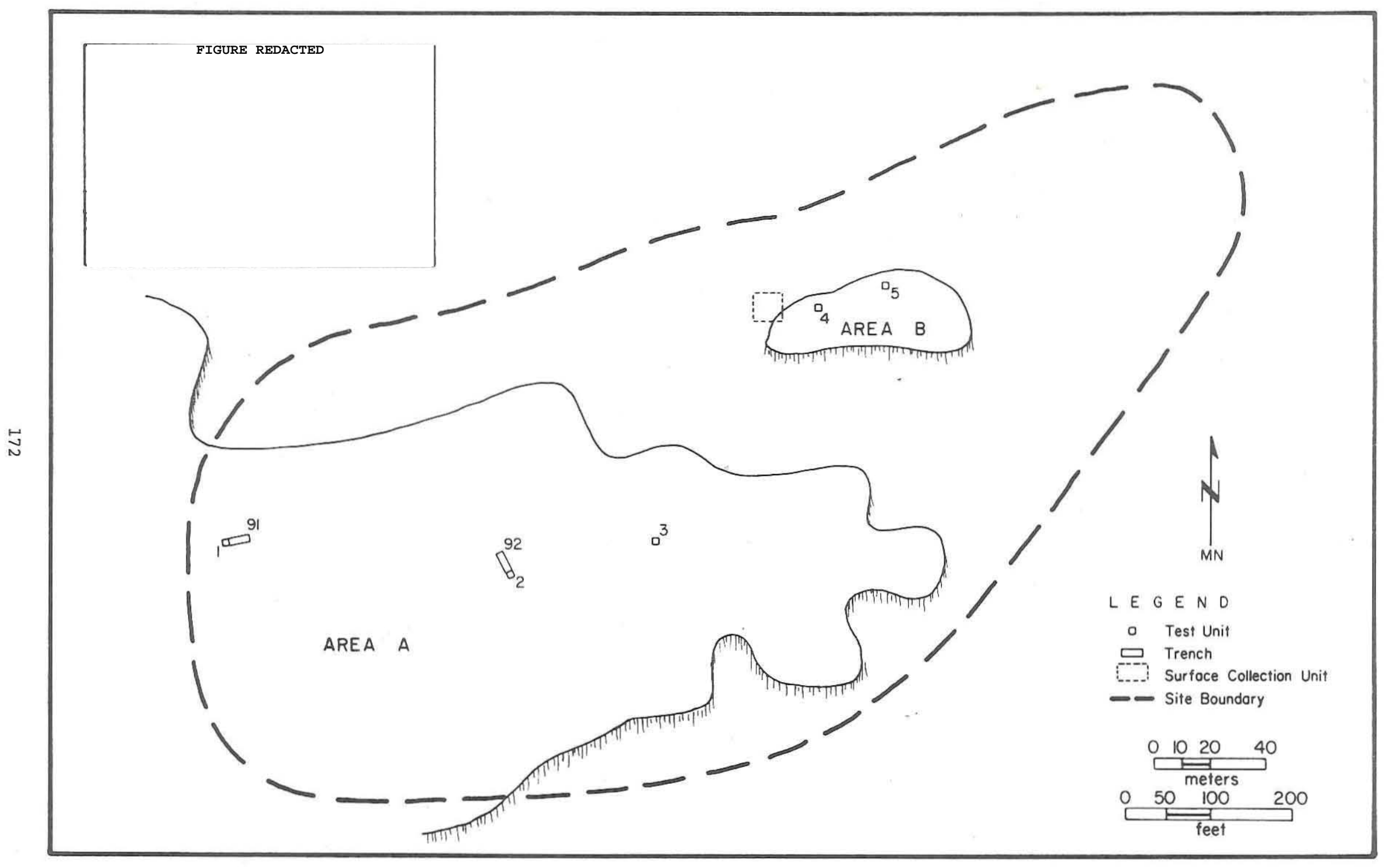

Figure 43. Site map, 41GR303. 
TABLE 44

SUMMARY OF EXCAVATIONS, 41GR303

\begin{tabular}{lrll}
\hline & $\begin{array}{l}\text { Depth of } \\
\text { Excavation } \\
\text { Unit }\end{array}$ & Reason for Ending Unit & $\begin{array}{l}\text { Artifact } \\
\text { Density (\#/m }{ }^{3} \text { ) } \\
\text { or Result }\end{array}$ \\
\hline Test Unit 1 & 115 & Bedrock reached & 22.6 \\
Test Unit 2 & 60 & Bedrock reached & 53.3 \\
Test Unit 3 & 35 & Bedrock reached & 57.1 \\
Test Unit 4 & 110 & Arbitrary & 156.4 \\
Test Unit 5 & 65 & Bedrock reached & 192.3 \\
Exploratory Trench 91 & 120 & Bedrock reached & positive \\
Exploratory Trench 92 & 75 & Bedrock reached & positive \\
\hline
\end{tabular}

bedrock was reached at $145 \mathrm{~cm}$. The stratigraphy in Test Unit 5 is similar, but sandstone bedrock appears at 55-65 cm. The Area B sediments appear to be alluvial deposits, perhaps an alluvial terrace remnant of Cat Hollow or one of its tributary drainages.

\section{SITE EXTENT AND DEPTH}

No attempt was made to map the entire site area, but it is estimated to cover some $350 \mathrm{~m}$ east-west by $200 \mathrm{~m}$ north-south. Intact cultural deposits in Area B are confined to the $25 \times 75-m$ sediment remnant. The extent of Area $A$, which comprises roughly the western half of the site, corresponds generally to the exposed bedrock along the edges of the ridge.

All test units contained buried cultural materials and features. The three test units in Area $A$ indicate that a substantial amount of cultural materials is present throughout the deposits, which are up to $100 \mathrm{~cm}$ thick. There is an excellent chance for the preservation of intact buried cultural deposits along the upper ridge. In Area B, cultural materials were found throughout the deposits, which vary from 50 to $145 \mathrm{~cm}$ in thickness, and the occupation appears to have been somewhat more intense than in Area A. Vertical separation of cultural materials and features was noted in both areas.

\section{FEATURES}

Although scattered burned and fire-cracked rocks and a single burned rock cluster were noted on the surface, no distinct, undisturbed surface features were found. Buried features were encountered in both areas; Features $1-4$ and 7 were in Area $A$, and Features 5-6 and 8 were in Area B. A possible feature, consisting of burned sandstone slabs and angular Potter chert fragments at $30-40 \mathrm{~cm}$, was destroyed by Exploratory Trench 91 . Feature 1 is a large, irregular cluster of sandstone slabs discovered in and partially 
destroyed by Exploratory Trench 92. Test Unit 2 was excavated adjacent to the south wall of the trench and exposed the feature at 9-48 cm. It consists of ca. 100 rocks ranging from 10 to $40 \mathrm{~cm}$ in maximum length. There is no apparent patterning, with rocks scattered randomly and dipping in various directions and angles, but the cluster did appear to follow the undulating bedrock. A few of the rocks appear to have been burned, but the majority show no evidence of burning. No ashy soil or charcoal was present. Feature 1 is difficult to interpret. It appears to be a portion of a cairn, but its function is unknown. A faint, vertical soil contact appearing in the west wall of Test Unit 1 could represent a pit edge. If this is indeed evidence of a pit, several possible functions may be indicated. The rocks may have been associated with a storage pit or lined a cooking pit, but there is no firm evidence of either. The rock pile may also represent cultural trash thrown into a natural depression. The sparse evidence of burning suggests that the latter is most likely.

Feature 2 consists of $\mathrm{ca} .20$ burned and fragmented sandstone and conglomerate slabs at 10-20 cm in the southwest corner of Test Unit 3. Interpreted as a portion of a roughly circular, 45-cm-diameter, slab-lined hearth, it has no distinct basin shape and may be disturbed. A uniface was found directly on top of the feature.

Feature 3 is a burned rock cluster at 30-60 cm in the northwest corner of Test Unit 1. The main concentration, $\mathrm{ca}$. 25 sandstone slabs and fragments forming a 60-cm-diameter circular cluster at 50-60 cm, extends into the west wall of the unit. It is interpreted as ca. $85 \%$ of a slab-lined hearth, but it does not have a well-defined basin shape. Associated scattered burned rocks indicate that it may have been disturbed prior to burial. No charcoal or ashy soil was present. The gouge found in the west wall of Exploratory Trench 91 may be associated with this feature. A thermoluminescence assay on burned sandstone yielded a questionable age of $6825 \pm 1375$ B.P. (Dur89TLpfg 134-4AS). Organic remains extracted from a burned rock are of indeterminate origin.

Feature 4, a burned rock cluster at $70-90 \mathrm{~cm}$ in the southwest corner of Test Unit 1, is interpreted as ca. $25 \%$ of a small hearth which extends into the south wall of the unit. The burned rocks cover a $30 \times 55-\mathrm{cm}$ area, but only a few tightly clustered rocks along the south wall appear to be intact hearthstones. No charcoal or ashy soil was present. A questionable thermoluminescence age of $6410 \pm 1290$ B.P. was obtained from an assay on burned sandstone (Dur89TLpfg 134-5AS). A burned rock was found to be essentially devoid of any organic residue.

Feature 5 is a dense cluster of randomly arranged sandstone slabs and fragments in an ashy soil matrix at $5-23 \mathrm{~cm}$ in Test Unit 5. It covers the entire unit except for some obvious rodent intrusions. The rocks are burned to varying degrees, and some are broken in place. Flotation of the feature fill recovered burned and unburned juniper wood, burned oak wood, 1 Chenopodium fruit, 13 pieces of microdebitage, and snail shells. The feature may represent an intensive occupation on a living surface, a hearth or cooking features, or a midden layer. A radiocarbon assay on charcoal yielded a corrected age of $810 \pm 195$ B.P. (GX-14597); a thermoluminescence assay on burned sandstone yielded no date, probably due to insufficient heating of the sample (Dur89TL 135-1). A pollen preservation assessment of the feature fill found the preservation to be very poor. Phytolith analysis of feature fill yielded mostly elongate types, and probable plant residue was extracted from a burned rock. 
Feature 6 is a large cluster of randomly arranged burned sandstone rocks at 56-80 cm in Test Unit 4. Slabs and fragments found in horizontal layers covering the entire unit are concentrated in the western half and appear to slope downward to the east, perhaps resting on an old surface. They are burned to varying degrees, and some may be unburned. A few charcoal flecks and abundant lithic debris were found at $60-80 \mathrm{~cm}$. This feature probably represents disturbed hearths on a living surface or a midden deposit.

Feature 7 consists of three scattered sandstone rocks lying horizontally at $101 \mathrm{~cm}$ in Test Unit 1. An elongated, ca. $25 \times 40-\mathrm{cm}$ unburned slab and a ca. $10 \times 10-\mathrm{cm}$ burned fragment are in the southeast corner of the unit, and a smaller burned fragment is in the northeast corner. The larger slab, probably a manuport, is broken in situ into three pieces but does not appear to have been modified. No other materials were associated. These rocks are probably lying on a living surface. A thermoluminescence assay on the 10x10-cm fragment yielded no date, probably due to insufficient heating (Dur89TL 134-6); a radiocarbon assay on a humate sample yielded a corrected age of $1510 \pm 60$ B.P. (Tx-6294). An organic extraction from the other burned fragment was essentially devoid of residue. Phytolith analysis of the sediments around the large slab yielded chiefly chloridoid and elongate types.

Feature 8 is a dense concentration of burned sandstone slabs at $80-95 \mathrm{~cm}$ in the southeast corner of Test Unit 4. The rocks are generally horizontal and occur in two to four overlapping layers that form a tight half-circle cluster extending into the east and south walls of the unit; the estimated diameter is $100 \mathrm{~cm}$. The rocks, burned to varying degrees and fractured in place, are interpreted as approximately $30 \%$ of an in situ hearth. Abundant lithic debris was recovered in these levels and is probably associated. A thermoluminescence assay on burned sandstone yielded an age of $4150 \pm 850$ B.P. (Dur89TLqi 134-7AS), and a radiocarbon assay on hunates yielded a corrected age of $1250 \pm 50 \mathrm{~B} . \mathrm{P}$. $(\mathrm{Tx}-6295)$. Although the humate date represents a minimum age, the discrepancy of 2,900 years suggests that the thermoluminescence date is considerably too old. Given the lack of diagnostic artifacts or charcoal radiocarbon dates, this problem remains unresolved. Phytolith analysis of feature fill yielded primarily elongate forms. Organic residue extracted from a burned rock is of indeterminate origin.

\section{MATERIALS RECOVERED}

None of the 591 artifacts recovered are temporally diagnostic (Table 45). While the artifact assemblages from both parts of the site lack projectile points, the Area B assemblage shows a greater diversity in the range of tool types than does that from Area $A$. Both areas have artifacts distributed thoughout ca. $100 \mathrm{~cm}$ of sediment in places and probably represent multiple occupations, but the variations in artifact density and morphology suggest different intensities of occupation or perhaps represent functional differences. Nonlocal cherts account for $3.4 \%$ of the total chipped stone, but most is from Area B. Additional materials recovered include 59 burned rocks, 14 pieces of microdebitage from flotation samples, 13 small and medium mammal bone fragments (all from Area B), mussel shell fragments (most from Area B), and snail shells.

Organic residues were extracted from eight stone tools. The residues on three gouges, one end/side scraper, and one drill were of indeterminate origin; an end/side scraper and a gouge yielded plant or probable plant residue; and animal residue was found on another gouge. The soil immediately surrounding one of the gouges was also analyzed, but only small amounts of probable plant residue were identified, thus supporting the assumption 
TABLE 45

DISTRIBUTION OF ARTIFACTS, 41GR303

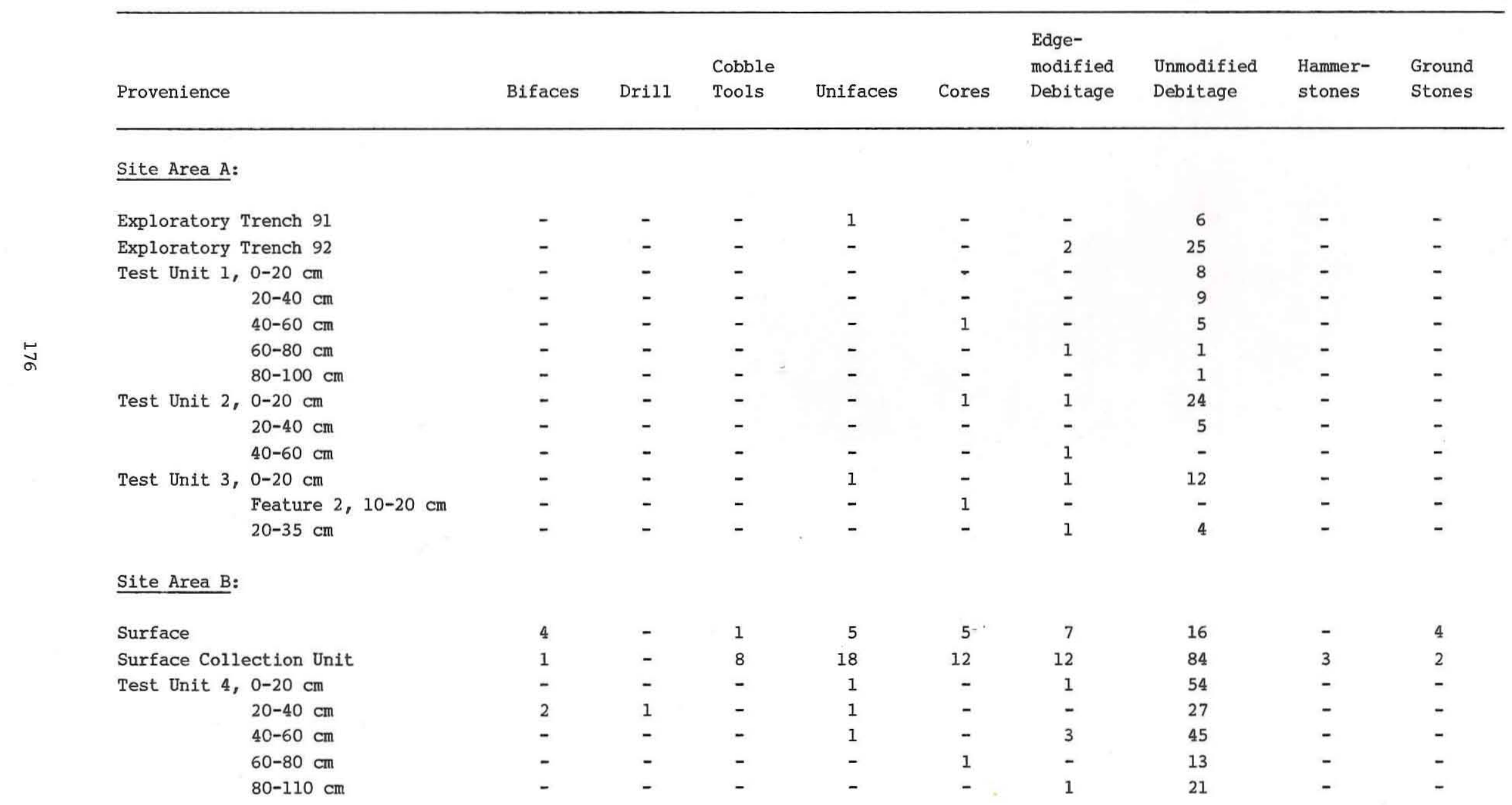


Table 45 , continued

\begin{tabular}{|c|c|c|c|c|c|c|c|c|c|c|}
\hline Provenience & & Bifaces & Drill & $\begin{array}{l}\text { Cobble } \\
\text { Tools }\end{array}$ & Unifaces & Cores & $\begin{array}{l}\text { Edge- } \\
\text { modified } \\
\text { Debitage }\end{array}$ & $\begin{array}{l}\text { Unmodified } \\
\text { Debitage }\end{array}$ & $\begin{array}{l}\text { Hammer- } \\
\text { stones }\end{array}$ & $\begin{array}{l}\text { Ground } \\
\text { Stones }\end{array}$ \\
\hline Test Unit 5, & $0-20 \mathrm{~cm}$ & - & - & - & - & - & 2 & 31 & - & - \\
\hline & Feature $5,5-23 \mathrm{~cm}$ & - & - & 2 & - & - & - & 16 & - & - \\
\hline & $20-40 \mathrm{~cm}$ & - & - & - & 2 & - & 3 & 50 & - & 1 \\
\hline & $40-65 \mathrm{~cm}$ & $=$ & $=$ & - & - & $\underline{1}$ & $\underline{2}$ & 15 & $=$ & $=$ \\
\hline Totals: & & 7 & 1 & 11 & 30 & 22 & 38 & 472 & 3 & 7 \\
\hline
\end{tabular}


that the indeterminate residues on the tool were cultural in origin. The plant and animal residues identified on the gouges tentatively suggest either a multifunctional use for these tools or the possibility that the animal residue resulted from hafting.

The triangular gouge recovered from Exploratory Trench 91 (found at $40 \mathrm{~cm}$ along the west wall) is one of the few Clear Fork type gouges to have come from an excavated context in the Lower Plains region, and special attempts to chronometrically date the sediments and associated cultural materials were made. A thermoluminescence assay on burned Potter chert from ca. $40 \mathrm{~cm}$ in Exploratory Trench 91 (associated with a possible burned rock feature destroyed by the backhoe) yielded an age of $6050 \pm 1200$ B.P. (Dur89TLqi 135-2BS), and a second thermoluminescence age of $6825 \pm 1375$ B.P. was obtained from Feature 3 . A radiocarbon assay on sediments immediately surrounding the gouge yielded an age of $700 \pm 70 \mathrm{~B} . \mathrm{P}$. $(T x-6296)$. The interpretation of these dates is open to debate. The humate date represents a minimum age, and the thermoluminescence dates are questionable given the consistent problem with thermoluminescence dates on burned rocks. Also, a direct association between the burned rocks and the gouge cannot be demonstrated. The gouge most likely predates 700 B.P., but by how much is unknown.

\section{DISCUSSION}

Two spatially separate areas of 41GR303, an upper Area A and a lower Area B, contain multiple stratified occupations in different depositional contexts. Both areas contain ca. $100 \mathrm{~cm}$ of cultural deposits with buried features and artifacts; vertical separation into discrete components was not possible based on the limited testing. Relative temporal placement of the occupations is possible through chronometric dates but is not without problems. Three thermoluminescence dates and two radiocarbon dates were obtained for Area $A$, and one thermoluminescence and two radiocarbon dates were obtained for Area B (Table 46). A discrepancy of 3,000-5,000 years exists between the paired humate radiocarbon and thermoluminescence dates; this discrepancy cannot be fully resolved at present. The charcoal radiocarbon date is probably accurate, but the humate dates represent minimum ages for the sediments, and the cultural deposits could be considerably older. The thermoluminescence dates are very questionable since consistent discrepancies were noted at other sites. The occupations in both areas apparently span much of the Late Prehistoric period and are tentatively estimated to range from ca. 1600 to 700 B.P.

A range of subsistence activities appear to be represented by the burned rock features, the mussel shells and faunal remains, the variability in tool types, and the range of organic residues preserved on stone tools. A wider range of tool types is present in Area B, and nonlocal lithic materials are also more abundant. Stone tool manufacture is represented in both areas, but the density of unmodified debitage is much greater in Area B. Both areas apparently reflect multifunctional campsite locations, although the more limited range of tools and lower artifact density indicate that the occupation of Area $A$ was less intense, or perhaps more specialized. The close proximity, similarity in artifact assemblages, and probable contemporaneity suggest that the occupations are related. 
TABLE 46

SUMMARY OF CHRONOMETRIC DATES, 41GR303

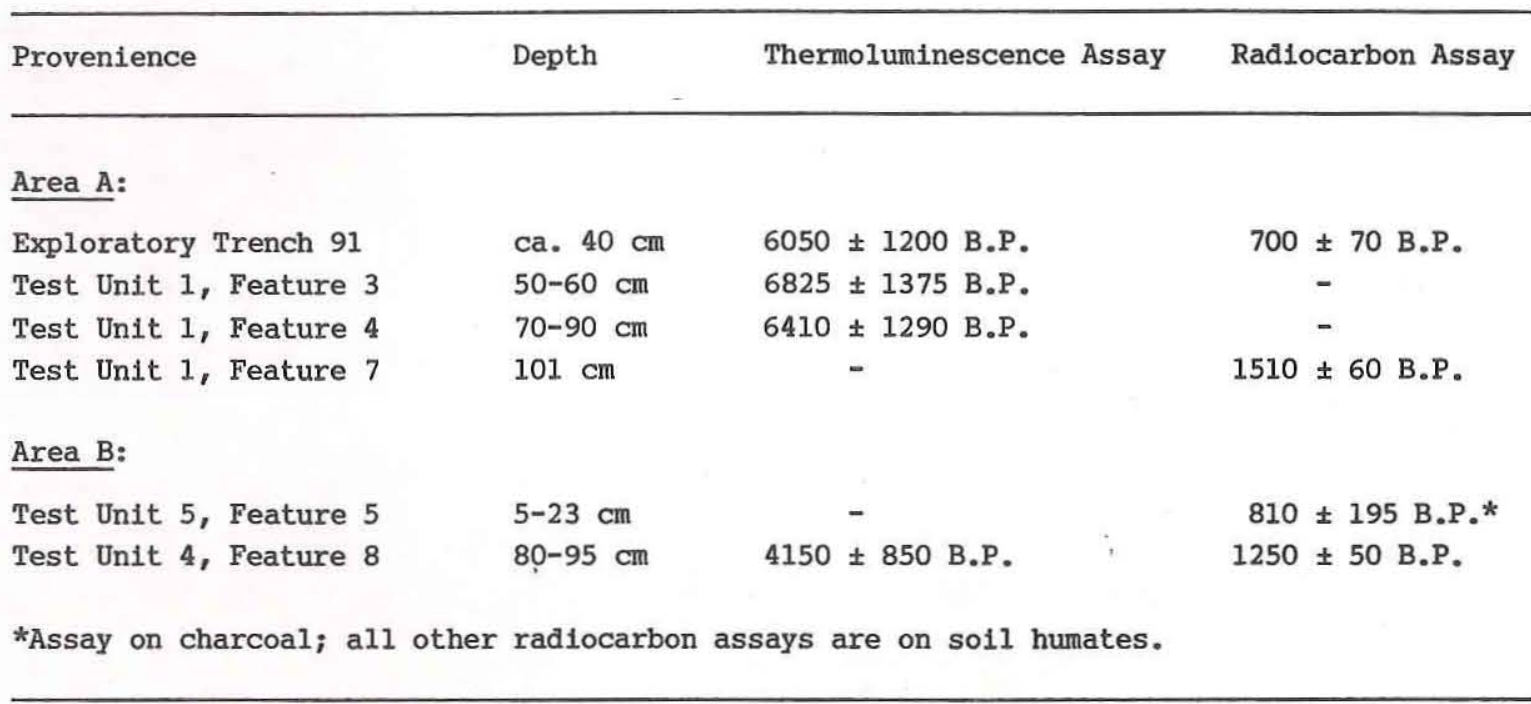

41GR374

SITE SETTING

Site 41 GR374 is situated in the upland margin $8.5 \mathrm{~km}$ northwest of the confluence of Gobbler Creek and the Double Mountain Fork and $0.5 \mathrm{~km}$ southwest of Cedar Hill. It occupies a generally flat south-projecting ridge, the surface of which is covered with a thin veneer of gravelly sands that are deflated along the edges. Vegetation consists of grasses, junipers, mesquites, Mormon tea, agaritas, and prickly pears. The only disturbance noted is a north-south dirt road crossing the site, although an oil well pad is located immediately adjacent and some relic hunting may have taken place. The elevation is $2280 \mathrm{ft} \mathrm{msl}$.

\section{WORK ACCOMPLISHED AND DISCUSSION}

When this site was recorded in 1987, a burned rock cluster and a sparse lithic scatter were noted. The site was assessed as having low research potential, and no further work was recommended (Boyd et al. 1989). The current investigations consisted of excavation of two exploratory trenches and two $1 \times 1-m$ test units (Table 47). Exploratory Trench 93 yielded no cultural materials and indicated a soll depth of $10 \mathrm{~cm}$, while Exploratory Trench 94 yielded an unmodifled and an edge-modified flake and indicated a soll depth of $70 \mathrm{~cm}$. The test units were located near Exploratory Trench 94, and 10 items (a core, 2 edgemodified flakes, 4 unmodifled flakes, and 3 fire-cracked rock fragments) were recovered. The sparse cultural materials were randomly scattered from 0 to $40 \mathrm{~cm}$, and no vertical separation or natural stratification was observed. A single component is probably 
TABLE 47

SUMMARY OF EXCAVATIONS, 41GR374

\begin{tabular}{lcll}
\hline & $\begin{array}{l}\text { Depth of } \\
\text { Excavation } \\
\text { Unit }\end{array}$ & Reason for Ending Unit & $\begin{array}{l}\text { Artifact } \\
\left.\text { Density (\#/m }{ }^{3}\right) \\
\text { or Result }\end{array}$ \\
\hline Test Unit 1 & 50 & Caliche-rich zone reached & 8.0 \\
Test Unit 2 & 40 & Caliche-rich zone reached & 7.5 \\
Exploratory Trench 93 & 60 & Bedrock reached & negative \\
Exploratory Trench 94 & 90 & Bedrock reached & positive \\
\hline
\end{tabular}

represented, but it remains temporaliy undefined. The results of the limited testing support the original assessment of the site.

41GR378

\section{SITE SETTING}

Site 41 GR378 is situated in the upland margin on the north side of the Double Mountain Fork east of Gobbler Creek, $0.6 \mathrm{~km}$ southwest of Cedar Hill. The site occupies an eroded alluvial/colluvial bench at the head of a small drainage which flows south into Gobbler Creek. Quaternary gravels are exposed in some areas. Vegetation consists of junipers, mesquites, grasses, prickly pears, and agaritas. A buried pipeline crosses the northern end of the site, and an oil well pad is located at the southern end. The elevation is 2260-2280 ft msl.

\section{WORK ACCOMPLISHED AND DISCUSSION}

When this site was recorded in 1987, a sparse lithic scatter of cores, tested cobbles, and flakes was noted in an area of exposed gravels. Large diffuse scatters of burned rocks were also noted. One positive shovel test yielded a flake at 20-40 cm and indicated a soil depth of $80 \mathrm{~cm}$. The site was assessed as having good research potential, and further work was recommended (Boyd et al. 1989).

The current investigations consisted of excavation of two exploratory trenches and four 1xl-m test units (Table 48). Exploratory Trench 95, on the east side of the small drainage, yielded no definite cultural materials, but burned rocks and a possible flake were noted. Exploratory Trench 96 , on the west side of the small drainage, yielded no cultural evidence. Sandy sediments were found in both trenches to a depth of over $50 \mathrm{~cm}$. The four test units were excavated on the east side of the small drainage in the vicinity of Exploratory Trench 95. 
TABLE 48

SUMMARY OF EXCAVATIONS, 41GR378

Depth of Excavation

Unit (cm)
Reason for Ending Unit
Artifact

Density $\left(\# / \mathrm{m}^{3}\right)$

or Result
Test Unit 1

Test Unit 2

Test Unit 3

Test Unit 4

Exploratory Trench 95

Exploratory Trench 96

\section{0}

90

34

50

60

100
Bedrock reached

Bedrock reached

No artifacts

Bedrock reached

Arbitrary

Bedrock reached
2.5

3.3

0.0

2.0

Positive?

Negative

Hardpan caliche or bedrock sandstone was encountered in the test units at depths of 40 to $90 \mathrm{~cm}$, and cultural materials were recovered at $0-70 \mathrm{~cm}$. The density of materials is very sparse; one edge-modified flake, four unmodified flakes, and seven burned rocks were recovered. Organic residue of indeterminate origin was extracted from the edge-modified flake. Although occasional fragments of burned rock were present, no features were encountered. There is no apparent natural stratification of the sediments, and no occupational horizons or surfaces could be discerned. The limited testing at this temporally undefined site inđicates a minimal occupation.

\section{GR380}

\section{SITE SETTING}

Site 41 GR3 80 is situated in the upland margin along the east side of Gobbler Creek, ca. $0.8 \mathrm{~m}$ southwest of Cedar $\mathrm{Hill}$ and $1.6 \mathrm{~km}$ west-northwest of the confluence of Gobbler Creek and the Double Mountain Fork. The site occupies a series of eroded and deflated ridges along the bluff immediately north and east of Gobbler Creek. Quaternary gravels are exposed across the deflated surfaces and in the drainages. Vegetation consists of junipers, mesquites, grasses, prickly pears, and other shrubs. Elevations range from 2240 to $2270 \mathrm{ft} \mathrm{msl}$.

\section{WORK ACCOMPLISHED}

When this site was recorded in 1987, sparse gravels, tested cobbles, and lithic debitage were noted. The site was assessed as having a low research potential, and no further work was recommended (Boyd et al. 1989). The current investigations consisted of a surface collection unit and excavation of two exploratory trenches and four $1 \times 1-m$ test units (Table 49). Surprisingly, Exploratory Trenches 97 and 98 yielded lithic debitage and 
TABLE 49

SUMMARY OF EXCAVATIONS, 4IGR380

\begin{tabular}{|c|c|c|c|}
\hline Unit & $\begin{array}{l}\text { Depth of } \\
\text { Excavation } \\
\text { (cm) }\end{array}$ & Reason for Ending Unit & $\begin{array}{l}\text { Artifact } \\
\text { Density }\left(\# / \mathrm{m}^{3}\right) \\
\text { or Result }\end{array}$ \\
\hline Test Unit 1 & 60 & Bedrock reached & 18.3 \\
\hline Test Unit 2 & 28 & Artifact decrease & 14.3 \\
\hline Test Unit 3 & $30 / 55^{*}$ & Bedrock reached & 14.1 \\
\hline Test Unit 4 & 15 & Arbitrary & 33.3 \\
\hline Exploratory Trench 97 & 80 & Arbitrary & positive \\
\hline Exploratory Trench 98 & 70 & Arbitrary & positive \\
\hline
\end{tabular}

tools and indicated sandy sediments to depths of over $70 \mathrm{~cm}$. A surface inspection located a dense scatter of fire-cracked Potter chert fragments (Feature 1) and a possible bedrock mortar hole (Feature 2). Test Unit 1 was located adjacent to Exploratory Trench 98, Test Unit 2 was located within a large scatter of lithic reduction materials and fire-cracked rocks, Test Unit 3 was located near Exploratory Trench 97, and Test Unit 4 was located over the fire-cracked Potter chert feature. A $2 \times 5-\mathrm{m}$ surface collection unit was situated near Test Unit 4.

\section{FEATURES}

The two features recorded are a $2.5 \times 2.5-\mathrm{m}$ fire-cracked rock concentration (Feature 1) and a probable beđrock mortar hole (Feature 2); the latter was not investigated. Test Unit 4 was excavated in Feature 1 and exposed a dense layer of angular fire-cracked Potter chert at 0-10 cm. A total of 446 fragments weighing ca. $40.5 \mathrm{~kg}$ were randomly distributed in the unit. The majority of the fragments were less than $5 \mathrm{~cm}$ in diameter, but some were as large as $10 \mathrm{~cm}$. Most had some cortex remaining. Several clusters of fragments within the feature were observed as in situ broken nodules. This feature is interpreted as a dump of intensively heated rocks, most likely a boiling stone or baking pit dump, dispersed across a living surface. Four flakes and a fragment of a ground stone were recovered in the test unit but are probably not directly associated with the features.

\section{DISCUSSION}

Fifty-one artifacts were recovered at 0-60 cm (Table 50), and 25 burned rocks were collected. Stratigraphic separation of the cultural materials into two or more components is likely, but no definite occupational surfaces were encountered. The lithic debitage, cores, and hammerstone indicate that lithic reduction was an important activity; and the unifaces, ground stones, and features indicate that food processing occurred. Testing 
TABLE 50

DISTRIBUTION OF ARTIFACTS, 41GR380

\begin{tabular}{|c|c|c|c|c|c|}
\hline Provenience & Unifaces & Cores & $\begin{array}{l}\text { Unmodified } \\
\text { Debitage }\end{array}$ & Hammerstone & $\begin{array}{l}\text { Ground } \\
\text { Stones }\end{array}$ \\
\hline Surface Collection Unit & - & 2 & 12 & 1 & 1 \\
\hline Exploratory Trench 97 & - & - & - & - & 1 \\
\hline Exploratory Trench 98 & - & 1 & 7 & - & - \\
\hline Test Unit 1 & - & 2 & 9 & - & - \\
\hline Test Unit 2 & 1 & - & 3 & - & - \\
\hline Test Unit 3 & 1 & - & 5 & - & - \\
\hline Test Unit 4 & - & $=$ & 4 & - & 1 \\
\hline Totals: & . 2 & 5 & 40 & 1 & 3 \\
\hline
\end{tabular}

revealed more-substantial cultural deposits than previously suspected, and the site was reclassified as a lithic procurement area/open campsite. The age and duration of the occupation is unknown, and the limited testing was not adequate to fully evaluate the site.

41 GR393

\section{SITE SETTING}

Site 41GR393 is situated in the upland margin on the north side of the Double Mountain Fork, ca. $0.4 \mathrm{~km}$ north of the confluence of Cat Hollow and the Double Mountain Fork and ca. $0.9 \mathrm{~km}$ east-northeast of Cedar Hill. It occupies two eroding, south-projecting ridges east of Cat Hollow. Intact sediments are located along the upper portion of the ridges, but the edges are eroded and deflated. Some relic collecting is evidenced by cull piles. Vegetation consists of junipers, mesquites, grasses, Mormon tea, agaritas, yuccas, and prickly pears. Elevation is $2240-2290 \mathrm{ft} \mathrm{msl}$.

\section{WORK ACCOMPLISHED AND DISCUSSION}

This site was initially recorded in 1982 (Alexander 1982) and revisited in 1987 (Bryan and Howard 1989:486-487). The latter investigation described an Archaic open campsite consisting of a scatter of lithic debris and tools and four burned rock features. A shovel test yielded no cultural materials but revealed $45 \mathrm{~cm}$ of sediments. Although evidence of relic collecting was noted, the site was assessed as having good research potential and warranting further work (Boyd et al. 1989). 
The current investigations consisted of excavation of a single exploratory trench. Exploratory Trench 84, placed in the upland portion of the site, revealed $100 \mathrm{~cm}$ of sediments above the sandstone bedrock but yielded no cultural evidence; however, subsurface testing of this large temporally undefined site is not considered adequate to preclude the possibility of buried cultural remains.

41GR467

SITE SETTING

Site 4IGR467 is situated in low eolian sand dunes along the edge of a 150-m-wide lower alluvial terrace on the south side of the Double Mountain Fork, ca. $3.2 \mathrm{~km}$ east-southeast of the U.S. Highway 84 bridge crossing the river. The terrace and overlying sand dunes are covered with moderate to heavy vegetation consisting of grasses, mesquites, and junipers, with salt cedars along the edge of the river. While there is relatively little erosional disturbance, occasional gullies dissect the terrace. A dirt road runs east-west across the site. Elevation is $2230 \mathrm{ft} \mathrm{msl}$.

\section{WORK ACCOMPLISHED AND DISCUSSION}

When this site was recorded in 1987, lithic debitage was noted on the surface, but the majority of the site appeared to be buried. Three shovel tests yielded cultural materials to a maximum depth of $120 \mathrm{~cm}$. The site area was not well defined but was estimated to be $35 \times 95 \mathrm{~m}$. It was assessed as having good research potential, and further work was recommended (Boyd et al. 1989).

The current investigation involved excavation of three backhoe trenches and three 1xl-m test units (Table 51). Backhoe Trenches 15, 16, and 18 yielded cultural evidence and indicated a larger site area than previously recognized. The site boundary was expanded to $100 \mathrm{~m}$ east-west by $200 \mathrm{~m}$ north-south to include all three trenches. Burned sandstone rocks were observed at $100 \mathrm{~cm}$ in Backhoe Trench 15, and a ceramic sherd collected from trench fill could be from the same level. An ashy soil stain was observed at 63-66 cm in Backhoe Trench 16. A fire-cracked rock fragment was noted at ca. 80-120 cm, and an apparently unmodified nodule of Potter chert (probable manuport) was noted at $140 \mathrm{~cm}$ in Backhoe Trench 18. Test Unit 1, adjacent to Backhoe Trench 15, yielded five flakes and two bone fragments; Test Unit 2, adjacent to Backhoe Trench 18, yielded five flakes; Test Unit 3, adjacent to Backhoe Trench 16, yielded three flakes. The cultural materials were scattered throughout the sandy sediments, and some rodent disturbance was noted. No cultural stratification was observed.

Thirteen pieces of lithic debitage and one untyped ceramic sherd constitute all of the recovered artifacts. Although the site testing failed to reveal buried features, burned rocks in the backhoe trenches (two were collected) indicate the probable presence of features. The density of cultural materials observed was somewhat low, but this may be a function of the limited amount of testing. The occupation is defined as Late Prehistoric, and the ceramic sherd is similar to the Jornado or Roswell Brown types. 
TABLE 51

SUMMARY OF EXCAVATIONS, 41GR467

\begin{tabular}{lcll}
\hline & $\begin{array}{l}\text { Depth of } \\
\text { Excavation } \\
\text { Unit }\end{array}$ & Reason for Ending Unit & $\begin{array}{l}\text { Artifact } \\
\text { Density }\left(\# / \mathrm{m}^{3}\right) \\
\text { or Result }\end{array}$ \\
\hline Test Unit 1 & 120 & Decrease in artifacts & 4.2 \\
Test Unit 2 & 110 & Bedrock reached & 4.5 \\
Test Unit 3 & 90 & No artifacts & 3.3 \\
Backhoe Trench 15 & 290 & Arbitrary & Maximum depth of backhoe \\
Backhoe Trench 16 & 450 & Bedrock reached & positive \\
Backhoe Trench 18 & 200 & & positive \\
\hline
\end{tabular}

41GR471

SITE SETTING

Site 41GR471 is situated in an eolian dune and alluvial terrace on the south side of the Double Mountain Fork, $2.75 \mathrm{~km}$ east of the U.S. Highway 84 bridge over the river. The terrace consists of alluvial sediments near the river and alluvial/colluvial sediments on a bedrock erosional remnant near the bluff edge. A large eolian aune covers a portion of the site area, and erosional gullies cut deeply into the dune and the terrace. Vegetation consists of grasses, mesquites, junipers, and other shrubs. Elevations range from 2220 to $2245 \mathrm{ft}$ msl.

\section{WORK ACCOMPLISHED}

When this site was recorded in 1987, burned rock fragments were observed in the gullies dissecting the terrace. No in situ cultural materials were noted in the 2-3-m-deep gullies, and the depth of the buried component could not be determined. No cultural materials were found on the surface. Five shovel tests were excavated, but none yielded cultural materials. The site was considered to have an unknown research potential and was assessed as warranting further work (Boyd et al. 1989).

The current investigations consisted of surface collection of a single artifact and excavation of a backhoe trench and two Ixl-m test units (Table 52). Backhoe Trench 12 yielded a ground stone fragment from the upper meter of trench fill, and a possible burned rock feature was encountered at $140 \mathrm{~cm}$. Test Unit 1, excavated adjacent to the trench, yielded one flake and one ground stone fragment from the upper $100 \mathrm{~cm}$ and nine flakes, two ground stone fragments, and a burned bone fragment from 100-140 cm. Some burned rock fragments were encountered, but no features were located. Test Unit 2, excavated to $50 \mathrm{~cm}$ along a sloping gully edge from which burned rocks were eroding, yielded four ground stone 
TABLE 52

SUMMARY OF EXCAVATIONS, 41GR471

\begin{tabular}{|c|c|c|c|}
\hline Unit & $\begin{array}{l}\text { Depth of } \\
\text { Excavation } \\
(\mathrm{cm})\end{array}$ & Reason for Ending Unit & $\begin{array}{l}\text { Artifact } \\
\text { Density }\left(\# / \mathrm{m}^{3}\right) \\
\text { or Result }\end{array}$ \\
\hline Test Unit 1 & 150 & Decrease in artifacts & 8.7 \\
\hline Test Unit 2 & $50 *$ & Decrease in artifacts & 8.0 \\
\hline Backhoe Trench 12 & 230 & Arbitrary & positive \\
\hline
\end{tabular}

fragments and exposed a hearth in the upper $30 \mathrm{~cm}$. A shovel probe in the center of the unit was excavated to $100 \mathrm{~cm}$, but no cultural materials were recovered.

FEATURE

Feature 1 consists of a roughly circular concentration of ca. 50 burned sandstone slabs and fragments at $8-40 \mathrm{~cm}$ in Test Unit 2. Most of the stones dip slightly toward the center forming a well-defined, 90-100-cm-diameter basin shape. Ashy soil and charcoal flecks were present in the sediment surrounding the feature. A thermoluminescence assay on burned sandstone yielded an age of $3310 \pm 670$ B.P. (Dur89TLqi 134-9BS), although this assay is of questionable validity. Flotation of feature fill yielded a hackberry seed, burned and unburned juniper wood, snall shells, and three microflakes. Organic remains extracted from a burned rock were of indeterminate origin but an organic extraction from a mano fragment found above the feature was identified as plant residue.

\section{DISCUSSION}

The artifacts recovered consist of 10 pieces of unmodified debitage (excluding 3 microdebitage specimens recovered by flotation) and 8 fragments of ground stone from excavations and 1 surface-collected complete ground stone pestle (2 fitted fragments). Also recovered. were two burned rocks. The assemblage is unusual because of the high frequency of ground stones. The pestle is unique, and although no bedrock mortar holes were located, such features are likely to be buried by the eolian sand dunes. Numerous bedrock mortar holes are also present at nearby site 41GR31. The pestle is the right size and shape to have been used with average to large pointed-oval bedrock mortar holes. It is made of a thin, tabular piece of conglomeratic sandstone, chipped and ground into a long oval shape. Use-wear is present on both ends and along portions of the lateral edges but is most concentrated on one end, leaving little doubt as to its function. Organic remains extracted from the heavily worn end are of indeterminate origin. 
No distinct cultural horizons were observed in the sandy sediments, but the buried component appears to be concentrated at 100-140 cm below the current terrace surface. The feature and cultural materials recovered from 0-30 cm in Test Unit 2 are considered to be stratigraphically comparable to the cultural materials recovered from $100-140 \mathrm{~cm}$ in Test Unit 1. The single thermoluminescence date is questionable, and the occupation is tentatively assigned to the late Archaic or early part of the Late Prehistoric period. The limited testing was inadequate for full evaluation of the deeply buried component at this large site.

$41 \mathrm{GR} 474$

\section{SITE SETTING}

Site 4lGR474 is situated on an erosional remnant terrace forming a prominent northeast-projecting peninsula within a meander bend on the south side of the Double Mountain Fork, $1.4 \mathrm{~km}$ east of the U.S. Highway 84 bridge over; the river. Bedrock is exposed along the river, but the terrace is covered with a thick veneer of alluvial/ colluvial sediments with some eolian dune formation near the point. A northeast-southwest dirt road crosses the central portion of the site, ending at the river. Vegetation consists of grasses, mesquites, junipers, yuccas, and other shrubs. Elevations range from 2220 to $2260 \mathrm{ft} \mathrm{msl}$.

\section{WORK ACCOMPLISHED AND DISCUSSION}

When this site was recorded in 1987, it was described as a Late Prehistoric open campsite (Bryan and Howard 1989:513) with a substantial historic component (Bryan et al. 1989: 618-619). Surface features and artifacts were noted across a large area, and positive shovel tests and exposed cultural materials along the roadcut indicated the presence of a buried prehistoric component. The prehistoric component was assessed as having excellent research potential and warranting further work (Boyd et al. 1989).

The current investigations concentrated on the historic component (see Freeman and Boyd 1990), but seven backhoe trenches were excavated across the large erosional remnant landform to provide geomorphic data (Table 53). Backhoe Trench 4, located on the crest of the northeast point, was the only trench that yielded prehistoric evidence. Mussel shell fragments and a unifacial tool were collected from the trench fill, and three separate clusters of burned rocks (probable hearths) were observed at 120-180 cm below surface. One piece of burned sandstone was also collected. Additional clusters of burned rocks were observed in the roadcut, ca. $25 \mathrm{~m}$ west of the trench. Four additional prehistoric artifacts were recovered; an untyped arrow point and two unifacial tools were surface collected, and a uniface was found in the excavated trash fill inside the historic dugout.

The cultural materials recovered and the probable features observed in Backhoe Trench 4 provide evidence of a substantial buried component of probable Late Prehistoric age. The limited subsurface testing is not adequate, however, to fully define the extent and nature of the buried component. 
TABLE 53

SUMMARY OF EXCAVATIONS, 41GR474

\begin{tabular}{llll}
\hline & $\begin{array}{l}\text { Depth of } \\
\text { Excavation } \\
\text { Unit }\end{array}$ & Reason for Ending Unit & $\begin{array}{l}\text { Artifact } \\
\left.\text { Density (\#/m }{ }^{3}\right) \\
\text { or Result }\end{array}$ \\
\hline Backhoe Trench 4 & 400 & Arbitrary & positive \\
Backhoe Trench 5 & 250 & Arbitrary & negative \\
Backhoe Trench 6 & 157 & Bedrock reached & negative \\
Backhoe Trench 7 & 80 & Bedrock reached & negative \\
Backhoe Trench 8 & 210 & Arbitrary & negative \\
Backhoe Trench 9 & 110 & Arbitrary & negative \\
Backhoe Trench 10 & 130 & Bedrock reached & negative \\
\hline
\end{tabular}

$41 \mathrm{GR} 483$

\section{SITE SETTING}

Site 41GR483 is situated on the upper alluvial terrace on the west side of Grape Creek at the base of the valley wall. It is approximately $0.8 \mathrm{~km}$ southwest of the confluence of Grape Creek and the Double Mountain Fork within the wide alluvial valley at the mouth of Grape Creek. Vegetation consists of moderate to heavy grass cover, and the site area has been mechanically cleared of mesquite trees. Site elevation is $2160 \mathrm{ft} \mathrm{msl}$.

\section{WORK ACCOMPLISHED AND DISCUSSION}

When the site was recorded in 1987, two clusters of sandstone rocks were observed in a backhoe trench during geoarcheological investigations. A cluster at 75-95 cm appeared to be a hearth, and another at 200-220 cm consisted of a few possible burned rocks and flecks of charcoal. No surface cultural materials were noted, and nearby trenches yielded no cultural evidence. The site was assessed as having unknown research potential, and further work was recommended (Boyd et al. 1989).

The current investigations consisted of a single $1 \times 1-m$ test unit excavated to $150 \mathrm{~cm}$ at the west end of Backhoe Trench 1987-1. One chert flake was recovered from the 110-120-cm level, but no burned rocks, charcoal, or other cultural materials were found. The sediments are severely bioturbated, with rodent activity noted throughout but increasing considerably below $100 \mathrm{~cm}$. The testing revealed no definable cultural zone and indicates that the density of occupational debris is extremely low, but the limited nature of these investigations does not allow full evaluation of the buried component. 
41GR484

\section{SITE SETTING}

Site 41GR484 is situated on a lower alluvial terrace on the east side of Grape Creek overlooking its confluence with the Double Mountain Fork. The Grape Creek cutbank forms the southern boundary of the site and varies from ca. $4 \mathrm{~m}$ to over $8 \mathrm{~m} \mathrm{high}$. A north-south dirt road forms the eastern boundary of the site and crosses Grape Creek southeast of the site. The surface of the terrace slopes generally west and varies from level to undulating, the latter resulting from the removal of mesquite trees. Vegetation cover consisting of grasses, a few small mesquite trees, and small shrubs is moderate along the edge of the cutbank but quite heavy a few meters back from the edge. Elevations range from 2130 to $2150 \mathrm{ft} \mathrm{ms} 1$.

\section{WORK ACCOMPLISHED}

When this site was recorded in 1987, a radiocarbon assay on charcoal associated with a hearth exposed in the cutbank provided an uncorrected age of $260 \pm 70$ B.P. Two other radiocarbon assays on humate samples from 100 and $150 \mathrm{~cm}$ in Backhoe Trench 1987-14 provided uncorrected ages of $1160 \pm 60$ and $1830 \pm 70$ B.P. from sediments below the cultural zone. A bone fragment, possibly cultural in origin, was recovered from $40 \mathrm{~cm}$ in the same trench. The site was assessed as having good research potential, and further work was recommended (Boyd et al. 1989).

The current investigations consisted of excavation of one backhoe trench and five lxl-m test units, limited site mapping, and surface collection (Fig. 44, Table 54). Backhoe Trench 1987-14, somewhere in the western portion of the site, could not be relocated, but the exposed hearth was easily found and had changed very little. Backhoe Trench 67 was excavated $\mathrm{ca}$. $10 \mathrm{~m}$ from the exposed hearth to provide geomorphic data. Bone fragments and a biface were recovered from the upper $40 \mathrm{~cm}$. Surface artifacts were noted in the eastern portion of the site, and collections include a quartzite mano from the roadway and materials from a $15 \times 15-m$ surface collection unit. Test Units 1 and 5 were excavated near Backhoe Trench 67, and Test Unit 3 was excavated within the surface collection unit. Test Units 2 and 4 were excavated along the cutbank edge where buried cultural materials were observed; the latter unit exposed a buried hearth (Feature 2).

\section{SEDIMENTS AND STRATIGRAPHY}

The Grape Creek cutbank exposes 1-3 m of sediments resting unconformably on red Permian mudstone. A representative profile in Backhoe Trench 67 consists of 3 zones: Zone 1, 0-6 cm, dark brown (7.5YR 4/4) soft sandy loam; Zone 2, 6-36 cm, reddish brown (5YR 4/3) mottled with darker reddish brown (5YR 4/4) fine sandy to silty loam; and Zone 3 , 36-112 cm, yellowish red (5YR 4/6) silty loam to sandy clay loam, blocky structure. Zone 1 is a loose eolian sand, and Zone 2 is interpreted as mixed organic-rich sediments resulting from root plowing and rodent disturbance. It is estimated that the upper $30-40 \mathrm{~cm}$ across most of the site is disturbed, but a 5-7-m-wide strip along the cutbank appears to be intact. 


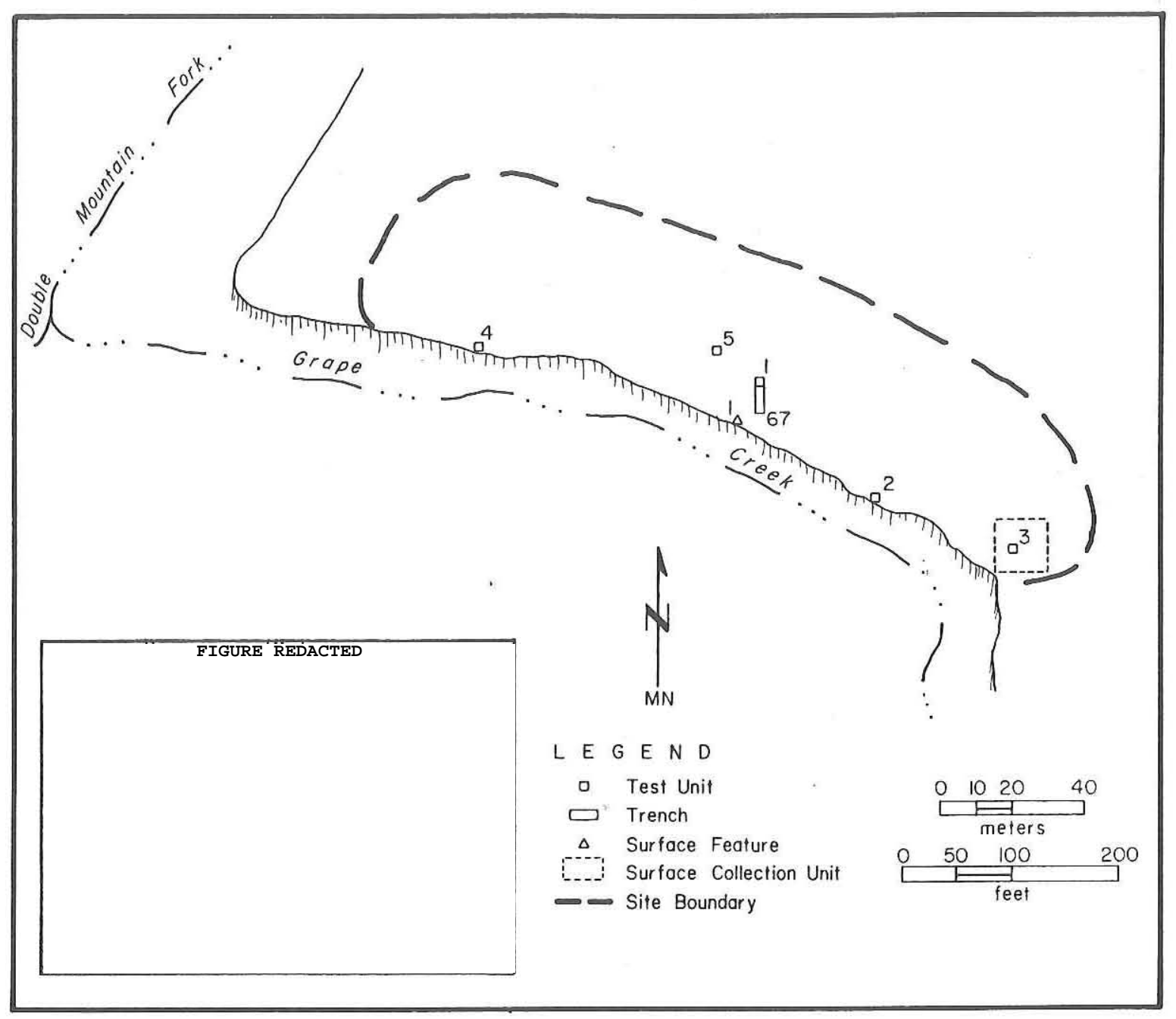

Figure 44. Site map, 41GR484.

\section{SITE EXTENT AND DEPTH}

The site area, defined by surface and subsurface cultural materials, is estimated to be ca. $200 \mathrm{~m}$ east-west by $50 \mathrm{~m}$ north-south. The southern site boundary is well defined by the Grape Creek cutbank and the eastern boundary by the extent of surface debris at or near the road. The west and north boundaries, however, are the estimated extent of the buried component based on limited testing.

Cultural materials were recovered at $0-50 \mathrm{~cm}$ in the eastern portion of the site, but no buried features were encountered. Feature 1 and sparse cultural materials were exposed on the surface in the central area, and artifacts were shallowly buried (ca. $40 \mathrm{~cm}$ ) in Backhoe Trench 67. Feature 2, at ca. $60 \mathrm{~cm}$ in Test Unit 4, indicates that the cultural zone is deeper in the western portion of the site. The bone fragment found at $40 \mathrm{~cm}$ in Backhoe Trench 1987-14 may also be part of the this component. Cultural materials appear 
TABLE 54

SUMMARY OF EXCAVATIONS, 41GR484

\begin{tabular}{lclc}
\hline & $\begin{array}{l}\text { Depth of } \\
\text { Excavation } \\
\text { Unit }\end{array}$ & Reason for Ending Unit & $\begin{array}{l}\text { Artifact } \\
\text { Density }\left(\# / \mathrm{m}^{3}\right) \\
\text { or Result }\end{array}$ \\
\hline & 50 & No artifacts & 0.0 \\
Test Unit 1 & 50 & Decrease in artifacts & 16.0 \\
Test Unit 2 & 40 & Decrease in artifacts & 52.5 \\
Test Unit 3 & 80 & Decrease in artifacts & 3.8 \\
Test Unit 4 & 30 & No artifacts & 0.0 \\
Test Unit 5 & 112 & Arbitrary & positive \\
Backhoe Trench 67 & & & \\
\hline
\end{tabular}

to represent a single occupation, although the limited testing was not adequate to confidently confirm this.

The extent of site disturbance by mechanical vegetation clearing is not known. Although there is disturbance to ca. $40 \mathrm{~cm}$ in some areas, it is likely that much of the cultural component lies below this depth, and undisturbed cultural deposits are preserved adjacent to Grape Creek because mechanical clearing could not be done close to the steep cutbank.

FEATURES

Feature 1, discovered in 1987, is a sandstone slab-lined shallow basin hearth, $90 \mathrm{~cm}$ in diameter, partially exposed along the edge of the Grape Creek cutbank. It is shallowly buried (ca. $5 \mathrm{~cm}$ ) due to sheet erosion along the cutbank edge, and an estimated $30 \%$ has been lost to erosion. A 1987 uncorrected radiocarbon assay on charcoal dates the feature to $260 \pm 70$ B.P. Analysis of organic remains extracted from a burned rock found no interpretable quantities of residue, even though the specimen was covered with charcoal staining.

Feature 2 is approximately one-half of a 50-70-cm-diameter circular sandstone slablined hearth at 58-70 cm in Test Unit 4. Half of the hearth was lost to cutbank erosion, but the excavated portion consists of a single-layer cluster of horizontal slabs and a few isolated slabs. A sandstone metate fragment and a quartzite hammerstone were found associated with the feature. Small flecks of charcoal were preserved under some rocks. A thermoluminescence assay on burned sandstone was attempted, but the sample was unsuitable for dating (Dur89TL 134-10). Flotation of the feature fill yielded burned juniper wood, Chenopodium fruit, a purslane seed, and several snail shells, but only the burned wood is definitely of cultural origin. Phytolith analysis of feature fill yielded mostly chloridoid and elongate forms. Organic residues were extracted from a hearthstone and from the two associated stone tools; residues of indeterminate origin were found on the hearthstone and the hammerstone, but plant residue was identified on the metate. 
MATERIALS RECOVERED

Sixty-five stone artifacts (Table 55), two bone fragments, two burned rock fragments, and numerous mussel shell fragments were recovered. An untypable arrow point fragment is the only temporally diagnostic artifact. Of the chipped stone, $11 \%$ is of nonlocal materials. Organic remains extracted from an edge-modified flake were identified as animal residue, and those from a biface were of indeterminate origin. The biface, however, is intensively heat fractured and was probably discarded into a fire; hence, the residues may be associated with some postdiscard activity rather than the utilization of the tool. Organic residues from two tools and a hearthstone associated with Feature 2 were also analyzed (see above).

\section{DISCUSSION}

The chronological placement of 41GR484 is Late Prehistoric, based on an untypable arrow point fragment and a radiocarbon age on charcoal of $260 \pm 70$ B.P. associated with a hearth. Cultural materials and features exposed on the surface or in cutbank profiles and buried at depths of 0-60 cm appear to represent a single component, although multiple occupations are possible. The range of chipped stone and ground stone tools and the slab-lined hearths indicate that the locality was a multifunctional campsite. Lithic tool manufacture is evident, and probable subsistence activities are suggested by the animal and plant residues from stone tools and features. Mussel shell fragments may also represent food resource exploitation. Interregional resource exploitation or exchange networks are indicated by nonlocal lithic materials.

\section{GR566}

\section{SITE SETTING}

Site 41 GR566 is situated on a large upland rise near the head of an unnamed drainage, ca. $2.5 \mathrm{~km}$ north of the Double Mountain Fork. It is ca. $100 \mathrm{~m}$ east of a manmade stock pond and windmill, and an east-west dirt road crosses the southern end. Vegetation cover consists of a moderate growth of grasses, cacti, and small mesquite trees; the site has probably been cleared of vegetation in the past. Elevation is $2385 \mathrm{ft} \mathrm{msl}$ at the northern end of the site and slopes south to $2360 \mathrm{ft}$ msl near the road.

\section{WORK ACCOMPLISHED AND DISCUSSION}

When this site was recorded in 1987, a burned rock feature and a sparse scatter of lithic debitage and tools (including a possible Paleoindian scraper) were noted. Although a shovel test was negative, the site was considered to have moderate research potential, and further work was recommended (Boyd et al. 1989). The current investigations consisted of excavation of three exploratory trenches. Exploratory Trenches 99-101 yielded no cultural evidence. All three trenches were excavated to 80-90 cm, at which depth caliche bedrock was encountered. These investigations indicate that a buried component is unlikely but are too limited to allow full evaluation of the site. 
TABLE 55

DISTRIBUTION OF ARTIFACTS, 41GR484

\begin{tabular}{|c|c|c|c|c|c|c|c|c|c|}
\hline Provenience & $\begin{array}{l}\text { Arrow } \\
\text { Point }\end{array}$ & Biface & $\begin{array}{l}\text { Cobble } \\
\text { Tools }\end{array}$ & Uniface & Cores & $\begin{array}{l}\text { Edge- } \\
\text { modified } \\
\text { Debitage }\end{array}$ & $\begin{array}{l}\text { Unmodified } \\
\text { Debitage }\end{array}$ & Hammerstone & $\begin{array}{l}\text { Ground } \\
\text { Stones }\end{array}$ \\
\hline Surface & - & - & - & - & - & - & 1 & - & - \\
\hline Surface Collection Unit & 1 & - & 2 & - & 2 & 1 & 23 & - & 2 \\
\hline Backhoe Trench 67 & - & 1 & - & - & - & - & - & - & - \\
\hline Test Unit 2 & - & - & - & - & - & - & 8 & - & - \\
\hline Test Unit 3 & - & - & - & 1 & - & 2 & 18 & - & - \\
\hline Test Unit 4 & 二 & 二 & $=$ & $=$ & 二 & 二 & $\underline{1}$ & 1 & $\underline{1}$ \\
\hline Totals: & 1 & 1 & 2 & 1 & 2 & 3 & 51 & 1 & 3 \\
\hline
\end{tabular}


41 GR569

SITE SETTING

Site 41 GR569 is situated on an alluvial terrace within a north-projecting meander on the south side of the Double Mountain Fork, $1.3 \mathrm{~km}$ east of the community of Justiceburg and $0.6 \mathrm{~km}$ south of County Road 2458. It is located at the eastern edge of a large fenced cultivated field. Elevation is ca. $2235 \mathrm{ft} \mathrm{msl}$.

WORK ACCOMPLISHED AND DISCUSSION

This site was recorded in 1988 during geomorphological subsurface testing and is known exclusively from cultural materials recovered in Backhoe Trench 1. Backhoe Trenches 2 and 3 were excavated nearby in the same terrace but yielded no cultural evidence. Four artifacts were recovered at 10-50 cm in Backhoe Trench 1, but no definite cultural stratification was observed. No surface artifacts were noted in the recently cleared field. The cultural materials recovered--one cobble tool, one ground stone fragment, one flake, and a possible burned rock--indicate the presence of a buried prehistoric component, but the limited testing was not adequate to define the extent or nature of the deposits.

$41 \mathrm{KT} 33$

\section{SITE SETTING}

Site $41 \mathrm{KT} 33$ is situated on an upper terrace remnant which forms an elongated, eastwest ridge, $0.5 \mathrm{~km}$ south of the confluence of South Sage Creek and the Double Mountain Fork. The ridgetop is flat but drops off sharply into the Double Mountain Fork floodplain on the west and north, slopes gently toward South Sage Creek on the east, and is separated from the valley wall on the south by a wide swale. A north-south dirt road crosses the east end of the site, and an old north-south road crosses the center of the site. Vegetation is moderate over most of the site, consisting mainly of grasses. Clearing in some portions of the site is obvious, while other areas appear undisturbed. Elevations range from 2150 to $2170 \mathrm{ft} \mathrm{msl}$.

\section{WORK ACCOMPLISHED}

When this site was recorded in 1987, surface features and artifacts were noted; positive shovel tests and cultural materials and features exposed in a roadcut indicated the presence of buried cultural remains. The site was assessed as having excellent research potential, and further work was recommended (Boyd et al. 1989). The current investigations consisted of excavation of three backhoe trenches and six test units, limited site mapping, and surface collection (Fig. 45, Table 56). Backhoe Trenches 55-57 were excavated to obtain geomorphic data and were located in the eastern, central, and western portions of the site. Backhoe Trench 56 was negative, but cultural materials were recovered in the upper $30 \mathrm{~cm}$ of the other two trenches. Four $1 \times 1-\mathrm{m}$ test units, one $1 \times 1.5-\mathrm{m}$ test unit, and one $1 \times 2-m$ test unit were placed to test surface features, positive backhoe trenches, and 


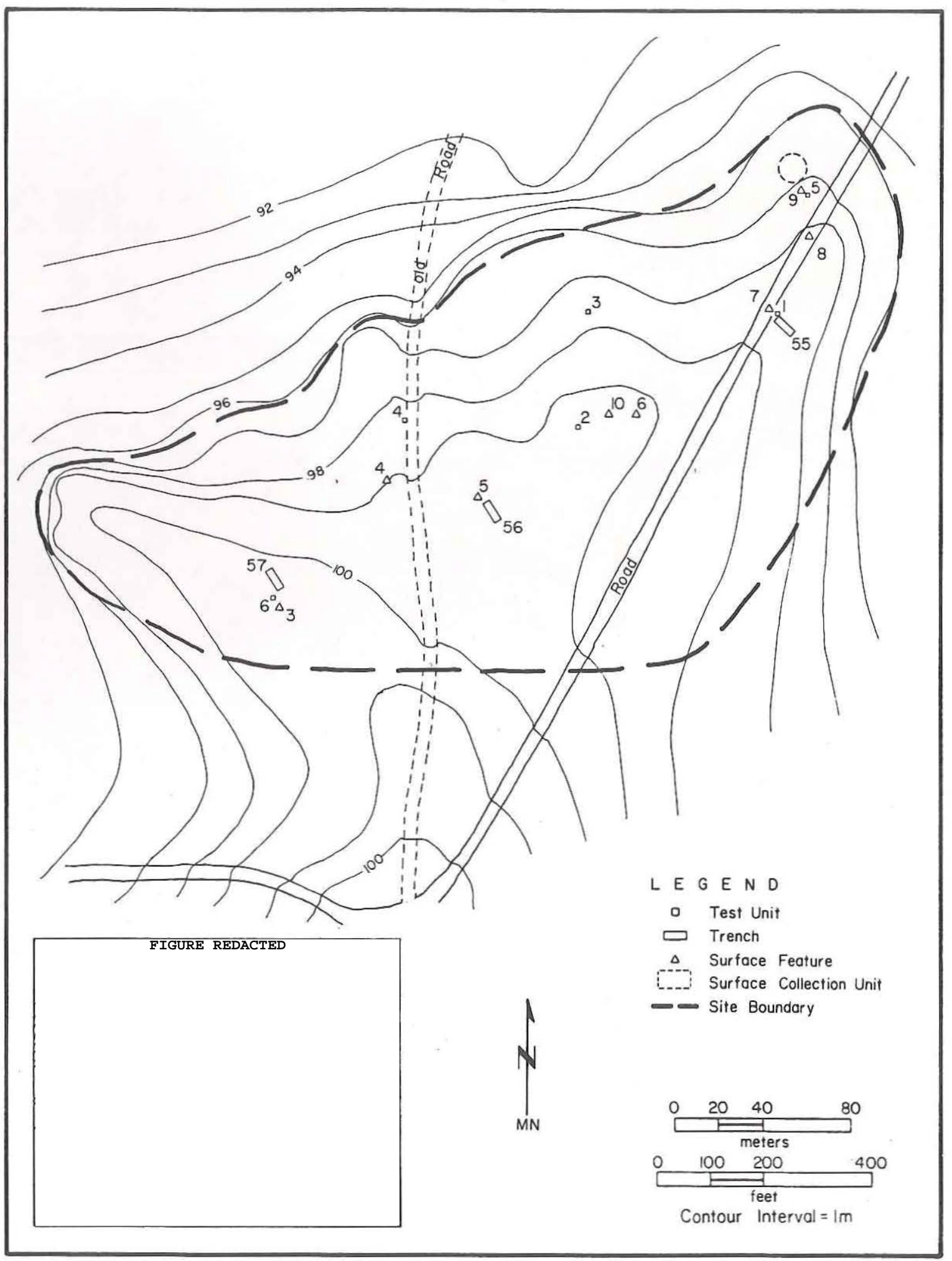

Figure 45. Site map, 41KT33. 
TABLE 56

SUMMARY OF EXCAVATIONS, 41KT33

Depth of

Excavation

Unit (cm)

Reason for Ending Unit
Artifact

Density $\left(\# / \mathrm{m}^{3}\right)$

or Result
Test Unit 1

Test Unit 2

Test Unit 3

Test Unit 4 *

Test Unit 5

Test Unit 6

Backhoe Trench 55

Backhoe Trench 56

Backhoe Trench 57

40
20
40
$30 / 10$
30
20
147
115
90

30

20

147
Decrease in artifacts

No artifacts

Decrease in artifacts

Arbitrary

Decrease in artifacts

Decrease in artifacts

Caliche-rich zone reached

Arbitrary

Arbitrary
72.5

0.0

25.0

45.0

103.0

243.0

positive negative positive

*Test Unit 4 is a $1 \times 2-m$ unit; half was excavated to $10 \mathrm{~cm}$, half to $30 \mathrm{~cm}$.

concentrations of exposed artifacts. Test Unit 1 was adjacent to Backhoe Trench 55; Test Unit 2 was near surface artifacts and Features 6 and 10; Test Unit 3 was near surface artifacts; Test Unit $4(1 \times 2-m)$ was situated over Feature 1; Test Unit 5 was near surface artifacts and Feature 9; and Test Unit $6(1 \times 1.5-\mathrm{m})$ was placed over Feature 2 . A large sandstone metate (a $15 \times 56-\mathrm{cm} \mathrm{slab}, 4-10 \mathrm{~cm}$ thick) was found on the surface but was not collected because it appeared to be associated with adjacent buried slabs; lack of time precluded testing this possible feature.

\section{SEDIMENTS AND STRATIGRAPHY}

A representative stratigraphic profile in Backhoe Trench 55 consists of five soil zones: Zone 1, 0-7 cm, brown (7.5YR 4/6) loose fine-grained eolian sand; Zone 2, 7-35 cm, dark brown $(7.5 \mathrm{YR}$ 4/4) friable sandy or silty loam with some organic material (weak $A$ horizon); Zone 3, 35-80 cm, reddish brown (5YR 4/4) friable sandy or silty loam with some caliche nodules; Zone 4, 80-102 cm, reddish brown (5YR 4/4) friable sandy or silty loam with some calcium carbonate staining and larger caliche nodules; and Zone 5, $102-147 \mathrm{~cm}$, reddish brown (5YR 4/4) soft silty loam with abundant calcium carbonate staining and caliche nodules. There is no evidence of disturbance in any of the trench profiles, although some vegetation clearing in the site area is likely.

\section{SITE EXTENT AND DEPTH}

This site is extremely large, ca. $380 \mathrm{~m}$ east-west by $240 \mathrm{~m}$ north-south, and conforms roughly to the topography of the upper terrace ridge. The site boundary corresponds to the 
ridge edge on the west, north, and east but is less definite to the south where the cultural occupation ends in a wide swale. Cultural materials were found as deep as $40 \mathrm{~cm}$, but the majority occurred at $0-20 \mathrm{~cm}$. There is no apparent cultural stratification to the deposits, and the cultural materials appear to represent a single occupation.

FEATURES

Ten surface burned rock features were recorded, and two of these (Features 1 and 2) were tested. Features 3-10 are surface clusters (under $100 \mathrm{~cm}$ in diameter) or scatters (100-300 cm in diameter) of burned rocks. Features 3, 7, and 8 are composed mainly of sandstone slabs and appear to be partially exposed hearths, while Features 4-6, 9, and 10 are composed of various materials including sandstone, fire-cracked limestone, quartzite, and Potter chert; these may be stone dumps.

Feature 1, a $100 \times 120-\mathrm{cm}$ ovate cluster of fire-cracked and burned rocks, was partially exposed by erosion along the edge of the old roadcut. Approximately $90 \%$ of the feature was exposed at 0-18 cm (concentrated at 0-10 cm) in Test Unit 4, but a portion extends into the west wall. Feature 1 consists of 182 rock fragments weighing $48.5 \mathrm{~kg}$, with 63 fragments being burned sandstone ( $16.8 \%$ by weight), 51 fragments being fire-cracked Potter chert (33.7\% by weight), 48 cobbles and fire-cracked fragments being limestone ( $43.8 \%$ by weight), and 20 fragments being fire-cracked quartzite (5.7\% by weight). Most of the sandstone fragments are small and could not be reconstructed. Thirty-three Potter chert fragments (63\% of the total Potter chert by weight) were reconstructed into seven nearly complete cobbles. A few limestone fragments could be reconstructed, but most are complete cobbles; an estimated 25-30 cobbles ranging in size from 7-17 cm are represented. Three quartzite cobbles were reconstructed or partially reconstructed, including a possible ground stone tool, perhaps a recycled mano. A uniface and 11 flakes were recovered from the test unit but are not necessarily associated with the feature. Feature 1 is interpreted as a burned rock dump. Some rocks were broken on impact and were found as fragmented cobbles, while others were apparently fragmentary prior to being dumped. The various types of rocks indicate that most are likely from some type of baking pit rather than stone boiling. In particular, the sandstone is not a good material for stone boiling. Flotation of the sediment from the feature yielded six microdebitage flakes, six fire-cracked chert fragments, one flake, several snail shells, and macrobotanical remains consisting of a burned hardwood fragment, unburned Chenopodium fruit, a Rosaceae seed, and onion and aster fragments. Only the lithics and the burned wood fragment are definitely culturally. Analysis of organic remains preserved on a burned rock in Feature 1 identified plant residue. Phytolith analysis of feature fill identified mostly chloridoid and enlongate forms. A thermoluminescence assay on burned sandstone yielded an age of $4425 \pm 895$ B.P. (Dur89TLqi 134-1.1BS), but this may be erroneously old.

Feature 2, exposed at $0-28 \mathrm{~cm}$ in the southern half of Test Unit 6 , was a dense $60 \times 80-\mathrm{cm}$ ovate cluster of burned rocks, predominantly sandstone and conglomeratic sandstone slabs with some limestone and Potter chert fragments. The sandstone fragments, exhibiting varying degrees of thermal alteration, were horizontal or dipped slightly toward a central area (ca. 10-cm-diameter) devoid of rocks. This feature appears to be a small slab-lined, slightly basin-shaped hearth, but scattered burned rocks outside the main cluster indicate some disturbance. No charcoal or ashy soil was observed. Numerous stone tools and lithic debitage--3 cores, 2 cobble tools, 54 flakes (4 edge-modified), and 14 microflakes--were recovered from the unit and may be associated. Mussel shell fragments were also present. 
A fire-cracked limestone fragment was submitted for thermoluminescence assay (Dur89TL 134-12), but it was not suitable for dating. Organic remains extracted from a burned rock were identified as probable plant residue, but animal residue was identified on a cobble tool associated with the feature. Flotation of feature fill yielded burned juniper wood, unburned aster and grass remains, and several snail shells. Only the burned wood is definitely cultural.

\section{MATERIALS RECOVERED}

Two hundred twenty artifacts (Table 57), 122 burned rock fragments, 4 unidentifiable mammal bone fragments, and mussel shell fragments were recovered. In addition, 20 microdebitage flakes were recovered from flotation but were not analyzed. Two untyped, expanding-stem dart points are the only temporally diagnostic artifacts. Nonlocal lithic materials account for $7 \%$ of the chipped stone artifacts.

Organic residue analysis of seven stone tools was performed with the following results: animal residues were identified on a dart point base, an unmodified flake, and a cobble tool associated with Feature 2 (see above); plant residues were identified on a scraper and two unmodified flakes; and one unmodified flake revealed no interpretable quantity of residue. As discussed above, a burned rock from Feature 1 revealed plant residue, and a burned rock from Feature 2 exhibited probable plant residue.

\section{DISCUSSION}

Cultural materials at 41 KT33 occur at depths of $0-40 \mathrm{~cm}$ but are most concentrated in the upper $20 \mathrm{~cm}$. They most likely represent a single occupation of unknown duration. A late Archaic occupation is suspected based on two untyped, expanding-stem dart points. A single thermoluminescence age of $4425 \pm 895$ B.P. from Feature 1 is probably too old but may suggest a late Archaic occupation.

Two types of features, hearths and fire-cracked rock dumps (possible stone boiling or baking pit debris) suggest different subsistence-related activities. Bone and mussel shell fragments may also indicate food processing. The range of chipped and ground stone tool types and the abundant evidence of stone tool manufacture (1.e., lithic debitage and hammerstones) also support a multifunctional campsite interpretation. The presence of nonlocal lithic materials reflects interregional trade or high group mobility. Organic residues from several types of stone tools and from features suggest additional activities. Individual specimens exhibit either animal, plant, or probable plant residues, suggesting a distinct spatial separation of processing tasks. Horizontal separation of discrete activities is further evident by intact features and variable frequencies of artifacts.

$41 \mathrm{KT} 47$

\section{SITE SETTING}

Site 4IKT47 is situated in the upland between Grape Creek and South Sage Creek, ca. $1.8 \mathrm{~km}$ south-southeast of the confluence of Grape Creek and the Double Mountain Fork. The 
TABLE 57

DISTRIBUTION OF ARTIFACTS, 4IKT33

\begin{tabular}{|c|c|c|c|c|c|c|c|c|c|}
\hline Provenience & $\begin{array}{l}\text { Dart } \\
\text { Points }\end{array}$ & Bifaces & $\begin{array}{l}\text { Cobble } \\
\text { Tools }\end{array}$ & Unifaces & Cores. & $\begin{array}{l}\text { Edge- } \\
\text { modified } \\
\text { Debitage }\end{array}$ & $\begin{array}{l}\text { Unmodified } \\
\text { Debitage }\end{array}$ & Hammerstones & $\begin{array}{l}\text { Ground } \\
\text { Stones }\end{array}$ \\
\hline Surface & 1 & 2 & 3 & 5 & - & - & - & 3 & 4 \\
\hline Surface Collection Unit & - & - & 1 & 1 & - & 3 & 41 & 1 & - \\
\hline Backhoe Trench 55 & - & - & 1 & - & - & - & 12 & - & 1 \\
\hline Test Unit I & - & - & - & - & - & 2 & 27 & - & - \\
\hline Test Unit 3 & 1 & - & - & - & - & - & 9 & - & - \\
\hline Test Unit 4 & - & - & - & 1 & - & - & 11 & - & - \\
\hline Test Unit 5 & - & - & - & - & 1 & 2 & 28 & - & - \\
\hline Test Unit 6 & $=$ & $=$ & $\underline{2}$ & $=$ & 3 & $\underline{4}$ & $\underline{50}$ & 二 & $=$ \\
\hline Totals: & 2 & 2 & 7 & 7 & 4 & 11 & 178 & 4 & 5 \\
\hline
\end{tabular}


entire upland tract between Grape and South Sage creeks has been cleared of vegetation and is currently covered in native grasses and cacti. The site is located on the western edge of an upland rise, ca. $100 \mathrm{~m}$ east of the Grape Creek canyon rim. Elevation is ca. $2280 \mathrm{ft}$ msl.

WORK ACCOMPLISHED AND DISCUSSION

When this site was recorded in 1987, it was described as a Late Prehistoric open campsite possibly associated with the Garza Complex. Sparse surface materials were noted, but an ovate scraper and a decorated ceramic sherd were collected. Two shovel tests were excavated; one yielded lithic debitage at 20-60 cm. No features were observed. Although site disturbance from vegetation clearing was noted, it was considered to have good research potential, and further work was recommended (Boyd et al. 1989). The current investigations consisted of excavation of a single backhoe trench to provide geomorphic data. Backhoe Trench 38 was excavated to sandstone bedrock at a depth of 170-180 cm. No cultural materials were recovered, and some disturbance was noted in the upper $15 \mathrm{~cm}$. The limited subsurface testing is inadequate to fully evaluate the site, but it failed to produce evidence of a buried prehistoric component and suggests that such evidence is likely to be sparse and probably disturbed.

41 KT51

\section{SITE SETTING}

Site 41KT51 is situated in the alluvial terrace on the east side of Grape Creek, ca. $2.1 \mathrm{~km}$ upstream from its confluence with the Double Mountain Fork. It occupies a slight rise, possibly a natural levee, immediately adjacent to the Grape Creek channel opposite a point bar in a prominent east-projecting meander bend. The rise is a long (ca. $160 \times 40 \mathrm{~m}$ ) oval oriented roughly northeast-southwest paralleling the channel. The site is covered with dense vegetation, primarily grasses and mesquites. A dirt road runs across the top of the rise, and recent or historic ground disturbance has occurred in the southern portion of the site where an artificial levee has been constructed. Elevation is $2170 \mathrm{ft} \mathrm{ms}$.

\section{WORK ACCOMPLISHED}

When this site was recorded in 1987, very sparse surface materials were noted along the roadway, and a single shovel test yielded buried cultural materials. The site was assessed as having good research potential, and further work was recommended (Boyd et al. 1989). The current investigations consisted of excavation of a backhoe trench and three 1xl-m test units, limited site mapping, and surface collection (Fig. 46, Table 58). Backhoe Trench 31 yielded a flake, mussel shell fragments, and an unmodified sandstone slab, probably a manuport. Three test units excavated along the crest of the rise yielded cultural materials at 0-40 cm. An ashy middenlike soil with charcoal flecks was noted at 10-30 cm in Test Unit 3. No buried features were encountered, but isolated burned rock fragments were found. One ceramic sherd was collected in the roadway between Test Units 1 and 2 , and ceramic sherds and lithic debitage were recovered from a ca. 40- $\mathrm{m}^{2}$ surface collection unit along the road near Test Unit 2. 


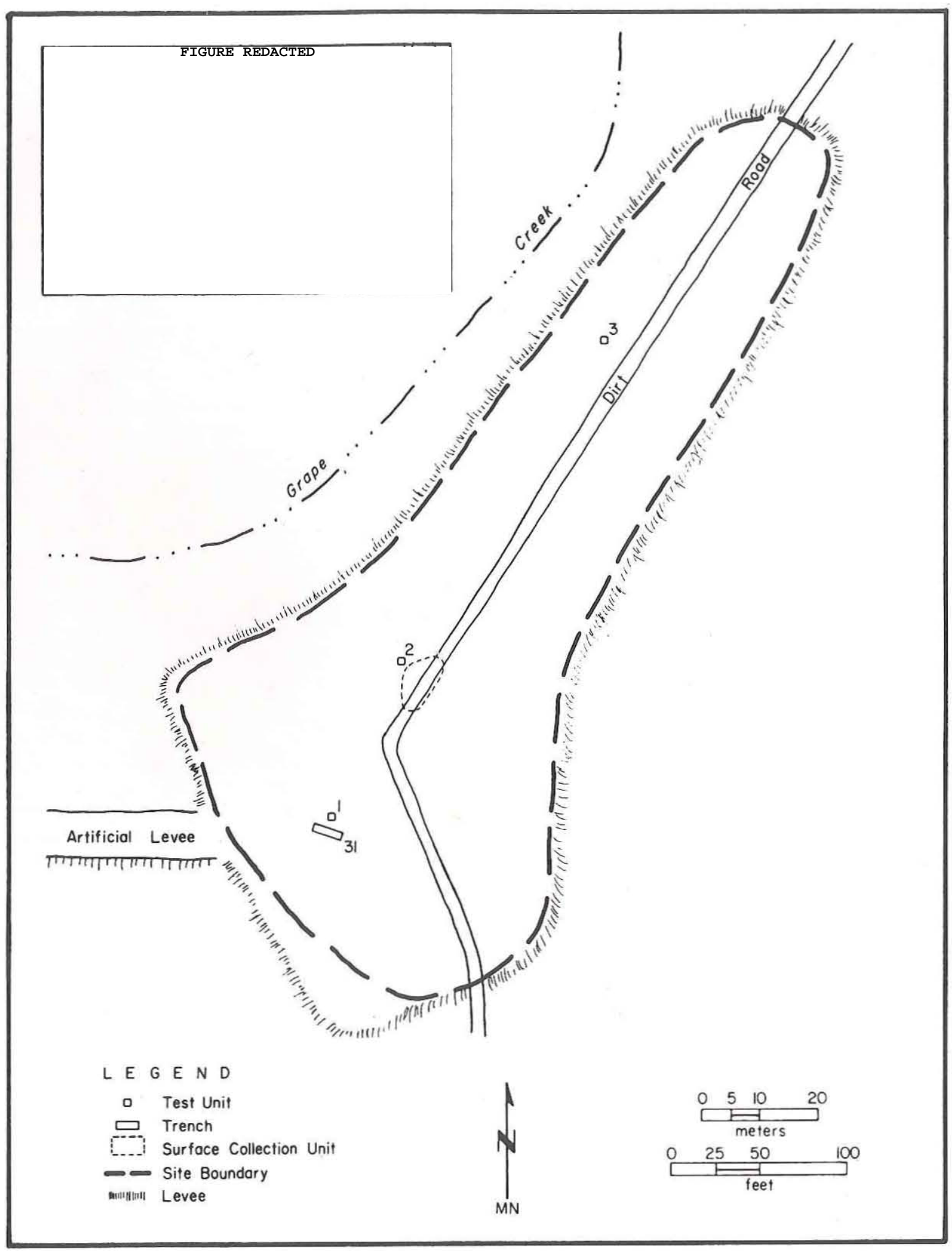

Figure 46. Site map, 41KT51. 
TABLE 58

SUMMARY OF EXCAVATIONS, 41KT51

\begin{tabular}{lclc}
\hline & $\begin{array}{l}\text { Depth of } \\
\text { Excavation } \\
\text { (cm) }\end{array}$ & Reason for Ending Unit & $\begin{array}{l}\text { Artifact } \\
\text { Density (\#/m } \mathbf{m}^{3} \\
\text { or Result }\end{array}$ \\
\hline Test Unit 1 & 40 & Arbitrary & 50.0 \\
Test Unit 2 & 30 & Arbitrary & 103.3 \\
Test Unit 3 & 40 & Arbitrary & 40.0 \\
Backhoe Trench 31 & 360 & Arbitrary & positive \\
\hline
\end{tabular}

\section{SEDIMENTS AND STRATIGRAPHY}

A representative stratigraphic profile of the upper portion of Backhoe Trench 31 consists of: Zone $1,0-55 \mathrm{~cm}$, reddish brown (5YR 4/4) fine sandy loam to silty loam; and Zone 2, 55-200 cm, reddish brown (5YR 4/4) blocky fine sandy loam to silty loam. Zone 1 in this trench is severely mixed, possibly due to recent disturbance related to the nearby artificial levee. Wire fragments recovered at $0-20 \mathrm{~cm}$ in Test Unit 1 indicate historic or recent disturbance. Only minor bioturbation was noted in Test Units 2 and 3 . Except for the disturbance noted in the southern end of the site, the deposits are apparently intact.

\section{SITE EXTENT AND DEPTH}

The ca. 160 $40-\mathrm{m}$ site area conforms to the extent of the possible levee. Cultural materials are very sparse on the surface and are exposed mainly along the road. A relatively high density of buried artifacts occurs in the upper $40 \mathrm{~cm}$, with no apparent cultural or natural stratification.

\section{MATERIALS RECOVERED}

The 83 artifacts recovered consist of 5 stone tools, 65 pieces of unmodified debitage, and 13 ceramic sherds (Table 59). Other materials recovered include three burned rocks, eight unidentifiable bone fragments, eight large mammal bone fragments, and mussel shell fragments. The three ceramic types represented are: Type I, Pecos Glaze Polychrome V; Type II, Pecos Faint Striated; and Type VI, unidentified. Organic material extracted from a Type II sherd was identified as plant residue, indeterminate residues were identified on two scrapers, and animal residue was identified on an edge-modified flake.

\section{DISCUSSION}

Cultural materials recovered from 41KT51 appear to represent a single-component Late Prehistoric occupation. Identifiable Puebloan ceramics (Pecos Glaze Polychrome V and Pecos 
TABLE 59

DISTRIBUTION OF ARTIFACTS, 41KT51

\begin{tabular}{lcccc}
\hline Provenience & Unifaces & $\begin{array}{l}\text { Edge-modified } \\
\text { Debitage }\end{array}$ & $\begin{array}{l}\text { Unmodified } \\
\text { Debitage }\end{array}$ & Ceramics \\
\hline Surface & - & - & - & 1 \\
Surface Collection Unit & - & 1 & 11 & 2 \\
Test Unit 1 & 1 & - & 18 & 1 \\
Test Unit 2 & 2 & - & 20 & 8 \\
Test Unit 3 & - & - & 15 & 1 \\
Backhoe Trench 31 & - & 2 & -1 & - \\
Totals: & 3 & & 65 & 13 \\
\hline
\end{tabular}

Faint Striated) indicate the existence of an intercultural exchange network. The manufacture dates for the decorated ware, Ca. A.D. 1600-1700, place the occupation of the site within the last 400 years. No definite cultural affiliation is evident, but the site could be associated with the Garza Complex or perhaps an early Plains Indian occupation. The site is contemporaneous with the upper component at 41KT53 (see Chapter 5).

A substantial buried component is present in the upper $40 \mathrm{~cm}$ across the $40 \times 160-\mathrm{m}$ probable levee. Although no features were encountered, scattered burned rocks indicate their probable presence. Variable artifact densities between test units suggest that horizontally discrete activity areas are present. Bone fragments and mussel shells are probable evidence of food resources. The limited stone tool assemblage could reflect specialized activities, or perhaps the use of metal tools could account for the apparent scarcity of tools in this high-density cultural deposit.

41KT148

SITE SETTING

Site 41 KT148 is situated in the alluvial terrace on the east side of Grape Creek, ca. $1.5 \mathrm{~km}$ upstream from its confluence with the Double Mountain Fork. It occupies a slight rise, oriented northwest-southeast, ca. $35 \mathrm{~m}$ east of the Grape Creek channel. A low swale parallels the rise forming a 50-cm-high cutbank on the west. The site area is covered with dense grasses except where erosion is occurring along the rise, and it has been cleared of mesquite trees in the past. The rise and swale are most likely natural features, probably a levee and an old channel, but considering the land disturbance, it is possible that they resulted from blading of an old road. Elevation is $2150 \mathrm{ft} \mathrm{msl}$. 
WORK ACCOMPLISHED AND DISCUSSION

This site was initially recorded in 1988 when sparse cultural materials (a flake and some bone fragments) were observed eroding out along the edge of the rise during the geoarcheological investigations. Backhoe Trench 73, located ca. $10 \mathrm{~m}$ north of the rise, was excavated to $192 \mathrm{~cm}$ and revealed homogenous alluvial sediments, although no cultural materials were found. The single negative backhoe trench suggests that buried cultural deposits are sparse, but the investigations are too limited to allow full evalution.

$41 \mathrm{KT} 151$

SITE SETTING

Site 41 KT151 is situated in the alluvial floodplain ca. $75 \mathrm{~m}$ east of the Grape Creek channel and ca. $2.2 \mathrm{~km}$ upstream from its confluence with the Double Mountain Fork. The site is covered with dense vegetation consisting of grasses, mesquites, chollas, and prickly pears. Elevation is $2170 \mathrm{ft}$ misl.

WORK ACCOMPLISHED AND DISCUSSION

This site was discovered in 1988 during the geomorphic investigations and is evidenced by a single quartzite core recovered at $270 \mathrm{~cm}$ in the east wall of Backhoe Trench 30 . The artifact indicates the presence of deeply buried cultural materials in the alluvial terrace. The depth of the find suggests that it may be of considerable antiquity, and a radiocarbon assay on a humate sample from 250-270 cm yielded a corrected age of $2090 \pm$ 70 B.P. (Tx-6228), which represents a minimum age for the deposits. The limited investigation suggests that this is a probable Archaic occupation.

\section{Lithic Procurement Sites}

$41 \mathrm{KT} 35$

\section{SITE SETTING}

Site 41 KT35 is situated on a erosional bedrock remnant terrace ca. $250 \mathrm{~m}$ west of South Sage Creek, approximately $1 \mathrm{~km}$ south of its confluence with the Double Mountain Fork. It is near the base of the valley wall immediately south of a small round knoll in a flat gravel-covered area. The bedrock terrace slopes gradually to the east until it disappears under the alluvial terrace of South Sage Creek. Vegetation is sparse, consisting of grasses, yuccas, and prickly pears.

\section{WORK ACCOMPLISHED AND DISCUSSION}

When this site was recorded in 1987, no features were noted and cultural materials were limited to cores, tested cobbles, and flakes. The site was assessed as having low 
research potential and as not warranting further work (Boyd et al. 1989). The current investigations consisted of excavation of a single backhoe trench to obtain geomorphic data. Backhoe Trench 54 was excavated to $52 \mathrm{~cm}$; the stratigraphy consists of a gravelly fine loam lying unconformably on Permian mudstone. The gravels are siliceous and vary considerably in size up to ca. $15 \mathrm{~cm}$. No cultural materials were encountered. The site is a surficial lithic procurement area with sparse cultural materials.

41 KT149

\section{SITE SETTING}

Site $41 \mathrm{KT} 149$ is situated on a $30 \times 60-\mathrm{m}$ bedrock erosional remnant which rises $10 \mathrm{~m}$ above the Grape Creek floodplain ca. $2.2 \mathrm{~km}$ south-southeast from its confluence with the Double Mountain Fork. A slight ridge of exposed bedrock (composed of red and white mudstones, probably of Permian age) extends west from the eastern valley wall and is easily visible because the deflated, gravelly surface supports only sparse vegetation. The site occupies the western end of the bedrock remnant immediately overlooking the alluvial terrace to the west. Elevation is ca. $2170 \mathrm{ft} \mathrm{msl}$.

\section{WORK ACCOMPLISHED AND DISCUSSION}

The site was discovered during the current investigations while conducting backhoe testing nearby. Sparse cultural materials consisting of cores, tested cobbles, lithic debitage, and unifacial tools were observed on the bald surface of the erosional remnant. All cultural materials are surficial. Limited procurement of the local gravels is represented, but some lithics appear to be nonlocal. No features or burned rocks are present.

\section{Lithic Scatters}

4].GR373

\section{SITE SETTING}

Site 41GR373 is situated in the upland near the head of a Cat Hollow tributary, ca. $0.7 \mathrm{~km}$ northeast of Cedar Hill. It is located in the southwest corner of a cultivated field and extends south an unknown distance into an uncultivated area. A northeastsouthwest dirt road separates the two areas, and a parallel barbed wire fence marks a property boundary. The cultivated portion is deflated and devoid of vegetation, while the southern portion is covered with moderate to heavy vegetation, predominantly mesquites and grasses. Flevation is $2290 \mathrm{ft} \mathrm{msl}$.

\section{WORK ACCOMPLISHED AND DISCUSSION}

When this site was recorded in 1987, artifacts were observed on the surface, and two items, a quartzite mano and a rectangular planar tool, were collected. No features were 
observed in spite of the excellent exposure in the cultivated area. The site was assessed as having low research potential and not warranting further work (Boyd et al. 1989). The current investigations consisted of excavation of a single exploratory trench. Exploratory Trench 87 was located in the southern portion of the site $25 \mathrm{~m}$ south of the road and fence and was excavated to caliche bedrock at $90 \mathrm{~cm}$. No cultural materials were recovered. The site appears to contain a sparse, probably surficial cultural deposit of undefined prehistoric age.

41 GR570

\section{SITE SETTING}

Site 41 GR570 is situated on the lower alluvial terrace $20 \mathrm{~m}$ west of Grape Creek, ca. $3.4 \mathrm{~km}$ south of its confluence with the Double Mountain Fork. It is located in a narrow valley segment within a small box canyon. Site size is $100 \times 150 \mathrm{~m}$ and includes both sides of an erosional gully which is $2 \mathrm{~m}$ deep in places and exposes much of the alluvial terrace. Vegetation consists of grasses, mesquites, hackberries, agaritas, chollas, and prickly pears. Elevation is $2180 \mathrm{ft} \mathrm{msl}$.

\section{WORK ACCOMPLISHED AND DISCUSSION}

When this site was recorded during the current investigations, lithic debitage, a hammerstone, and two bifacial tool fragments were observed eroding out of the terrace at 25-70 cm. A 20-30-cm-thick layer of organic-rich sandy loam, possibly an A horizon, was noted just above the exposed cultural materials. No concentrations of cultural materials, features, or diagnostic artifacts were noted in spite of the excellent erosional exposure. The site is a low-density lithic scatter of undefined prehistoric age.

\section{Isolated Finds}

$41 \mathrm{GR} 468$

\section{SITE SETTING}

Site 41GR468 is located in the flat alluvial terrace on the south side of the Double Mountain Fork, $4.7 \mathrm{~km}$ north of the U.S. Highway 84 bridge over Sand Creek. It is situated within a meander bend $30 \mathrm{~m}$ east of the valley wall and $120 \mathrm{~m}$ west of the river. Vegetation consists of a dense growth of grasses and mesquites. Elevation is $2230 \mathrm{ft} \mathrm{ms}$.

\section{WORK ACCOMPLISHED AND DISCUSSION}

When this site was recorded in 1987, a single bison long bone was exposed at $80 \mathrm{~cm}$ in a cutbank. It was assessed as having low research potential and as warranting no further work (Boyd et al. 1989). The current investigations consisted of excavation of a single 
backhoe trench and one $1 \times 1-m$ test unit. Backhoe Trench 17 was excavated to $435 \mathrm{~cm}$ to obtain geomorphic data, and two unmodified bone fragments were recovered at 0-110 $\mathrm{cm}$. The test unit was located $2 \mathrm{~m}$ from the trench and was excavated to $110 \mathrm{~cm}$. Homogeneous fine alluvial sands mixed with colluvial gravels were noted throughout, and no cultural materials were recovered. The bones recovered from the trench may or may not be cultural and probably are in a secondary deposit.

\section{KT46}

\section{SITE SETTING}

Site 41 KT46 is situated on a slight rise in the upland between Grape Creek and South Sage Creek, ca. $1.85 \mathrm{~km}$ south-southeast of the mouth of Grape Creek and $0.25 \mathrm{~km}$ northwest of the east canyon rim. It is located on the eastern end of the rise, ca. $50 \mathrm{~m}$ west of a dirt road which runs north-south. The entire upland tract between the creeks has been cleared of mesquite trees and is covered with moderate to dense grasses. Elevation is $2280 \mathrm{ft} \mathrm{msl}$.

\section{WORK ACCOMPLISHED AND DISCUSSION}

When this site was recorded in 1987, a Potter chert core and a possible ground stone fragment were noted on the surface; two shovel tests yielded no cultural materials. It was considered possibly to be associated with $41 \mathrm{KT} 47, \mathrm{ca} .250 \mathrm{~m}$ to the west, and was assessed as having low research potential (Boyd et al. 1989). The current investigations consisted of excavation of a single backhoe trench to obtain geomorphic data. Backhoe Trench 39 was excavated to $80 \mathrm{~cm}$, terminating in a caliche-rich C horizon. No cultural materials were recovered, and thus the site appears to consist of sparse cultural remains. 


\section{CHAPTER 7}

\section{INVESTIGATIONS AT ROCK ART SITES}

by Douglas K. Boyd and Colin M. Garvey

This chapter describes the intensive recording of 11 sites with aboriginal rock art. The methods used are discussed first, followed by detailed descriptions of the investigations and the rock art. The final section summarizes the Justiceburg Reservoir rock art in a regional perspective. Four aspects of the treatment of rock art sites as cultural resources are inventory, documentation, management, and conservation (Klassen and Magne 1988). The first of these, inventory and preliminary documentation, was completed in 1987 at 33 sites with aboriginal rock art and consisted of measured drawings and minimal photographic documentation (Boyd 1989d). Although this work portrayed the rock art with a high degree of accuracy, the current investigations involved more-accurate and more-detailed recording at 11 complex sites. This more-detailed recording provided important contextual information that enhances the interpretability of these valuable resources.

\section{Methods}

The documentation of rock art is particulary important given the instability of these resources in general and, more specifically, the immediate threats posed by construction of the reservoir. For some of the Justiceburg Reservoir rock art sites, this documentation will be all that survives the completion of the project. The current investigations document the sites and rock art according to the standards set forth by Swartz (1981) and attempt to go a step further. Schaafsma (1985) describes the importance not only of recording the rock art and a wide range of contextual information but also of exploring potential dating techniques and attempting to interpret the rock art images using the theoretical concepts of style, symbol and meaning, and site function. These topics are discussed in the final section of this chapter.

The terms used in this chapter are fairly standard. Rock art refers to any human-made images on rock surfaces and includes petroglyphs and pictographs. Petroglyphs are produced by altering the surface of a rock, for example, by pecking, incising, rubbing, scratching, or abrading. Pictographs are produced by applying some substance, usually a colored pigment, to a rock surface. The two techniques are sometimes used together, resulting in painted petroglyphs. A panel refers to a single rock face that is isolated and distinct from other rock faces. A site may have numerous rock panels containing artwork, but the art on several panels may be related. Conversely, the art on a single panel is not necessarily related and may even represent the work of several different artists at different times. An element or figure is a single, definable unit produced by a single artist at one particular time. A glyph refers to a single petroglyph element. A motif or figure type refers to a distinctive and recurring form, shape, or element. Style refers to "a shared repertoire of rock art elements, figure types, figure complexes, and aesthetic modes signifying participation in a given ideographic system, interaction sphere, or panregional information exchange network" (Schaafsma 1985:253). A style has definable cultural, temporal, and spatial characteristics based on the assumption that it is peculiar to a particular culture, time, and place. 
Standard recording procedures at each site included (1) site mapping, (2) objective observation and description of the site and the rock art, (3) subjective observation and description of the rock art, (4) detailed photographic documentation, and (5) full-size tracings of the rock art. Site mapping included a plan view of the site area and a profile view, or several if necessary, of the rock art panels, shelter, overhang, and any other physiographic features. Objective data recording included such details as the size and orientation of panels, relationships between panels, and color of natural rock surfaces. Subjective data recording included interpretive observations relating to the rock art, such as how the petroglyphs were produced, superimposition of figures, extent of weathering or vandalism, and recognizable styles or motifs. Objective and subjective data were recorded on a rock art data form devised specifically to standardize recording. Photographic documentation consisted of 35-mm black-and-white prints and color slides. General site photos, overviews of panels, and close-ups of all rock art images were taken. Lightreflective boards were used to obtain the optimum lighting using sunlight. Tracings of the rock art were made using either visquene or acetate and colored pens. The recorders attempted to interject as little bias as possible when tracing the rock art. For example, at sites that had historic and recent vandalism in and around aboriginal rock art, different colors were used to denote origin. In cases where the origin of a particular element was in question, that element was recorded in a different color, or footnote comments were added.

The objective of the Phase II rock art investigations was to obtain the maximum amount of data without disturbance to the art. Exceptions included collection of very small pigment samples (less than $0.5 \mathrm{~g}$ ) from $41 \mathrm{GR} 426$ located below the floodpool and from $41 \mathrm{GR} 437$ where pigments were located on a badly weathered, spalling rock surface. These samples were obtained to determine the potential for organic or mineralogical pigment analysis and radiocarbon dating (see Appendix F).

\section{Site Investigations}

\section{GR51 (Dorward Ranch Site)}

\section{SITE SETTING}

The site is situated at the head of the first small unnamed drainage east of Rocky Creek on the south side of the Double Mountain Fork, ca. $0.4 \mathrm{~km}$ east of the mouth of Rocky Creek. It is ca. $150 \mathrm{~m}$ upstream from the mouth of the small drainage at a point where the stream bends to the north along the bluff. Site elevation is ca. 2200-2220 ft msl. The 10-m-deep, narrow stream valley is lined with vegetation, including large cottonwood trees. Pools of water collect in the shaded bend in the stream, creating a cool spot that is a favorite picnicking area for local residents.

All of the aboriginal petroglyphs and most of the nonaboriginal graffiti and vandalism occur 2-3 $m$ above the base of a 15-m-wide and 8-m-tall west-facing bluff composed of soft, friable brown sandstone. There is no potential for recovering associated artifacts as bedrock sandstone is exposed directly below the panel and no sediments are preserved. If the petroglyphs were originally at eye level, erosion could account for their current position on the bluff. 
WORK ACCOMPLISHED

This site was recorded in 1965 (Riggs 1965) and rerecorded in 1987 (Bryan and Howard 1989:420). In 1987, historic aboriginal and nonaboriginal petroglyphs and a substantial amount of modern vandalissm were noted. Full-scale recording of the site was not undertaken at that time, and Riggs's (1965:Fig. 1) original drawing was reproduced by Boyd (1989d: Fig. 41). The nonaboriginal inscriptions documented by Boyd (1989d:Table 22) date mostly to the early 1900s, although a few date to the 1880s and 1890s. Vandalism consisted of numerous recent inscriptions and bullet holes. Riggs's drawing and description were slightly different than the rock art observed at the site in 1987 (Boyd 1989d:177-181), and it appeared that some possible aboriginal elements had been deleted in Riggs's recording in an attempt to differentiate the historic graffiti from the aboriginal art. The significance of the historic aboriginal rock art was noted, and additional work was recommended (Boyd et al. 1989). As a result of this recommendation, the current investigations consisted of site mapping and detailed recording of the aboriginal rock art and all historic graffiti and modern vandalism in the immediate vicinity.

\section{DISCUSSION OF ROCK ART}

The aboriginal rock art consists of a concentration of petroglyph figures on the bluff face and a single isolated glyph at the top of the bluff face. The isolated glyph is a geometric figure consisting of an oval on top of a branching staff (Fig. 47). It is deeply incised and weathered and appears to be much older than the rest of the aboriginal art. It is visible from below and can be reached from above by crawling along a wind-worn cavity and hanging over the edge.

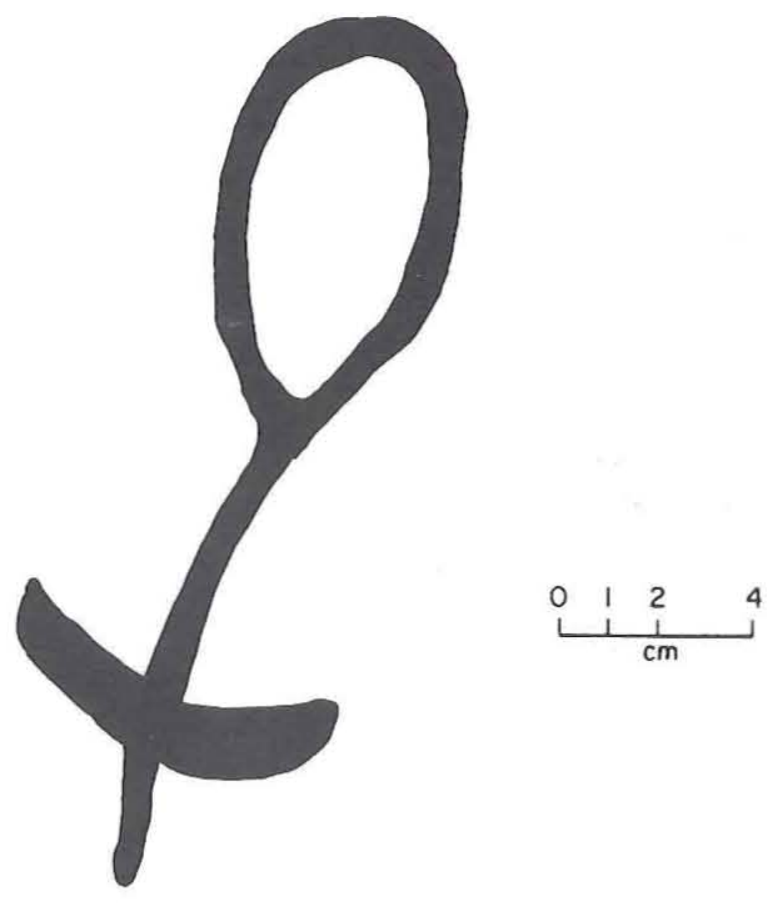

Figure 47. Isolated petroglyph at 41GR51. 
The main rock art panel consists of a series of apparently related aboriginal glyphs covered by extensive Euro-American inscriptions and modern vandalism. The two illustrations in Figure 48 provide a graphic example of what can happen to a rock art site with uncontrolled and unlimited public access. The aboriginal incised or abraded glyphs consist of two groups of related elements and a few isolated elements which may or may not be related (see Fig. 48). One group consists of nine wagons in single file. They appear to be covered wagons with consistently smaller front wheels. Each is pulled by two oxen, probably representing a team of four. Two human figures are riding oxen. One is on the lead ox of the last wagon; this figure faces backwards, is shooting a pistol, and is wearing a brimmed hat and some type of shoes, possibly boots and spurs. There is some question as to the authenticity of this figure because of certain stylistic differences from the others, i.e., the rider is shown in profile, and some features are exaggerated. The gun does, however, show several bullets being fired, an artistic convention common in late Plains Indian art (Keyser 1987:62). This figure may be an authentic aboriginal element, but Riggs (1965:Fig. 1) did not include it in his original illustration of the aboriginal elements. Alternatively, it may have been added by recent visitors, or it may be an authentic figure modified by recent visitors. The second rider, on the lead ox of the fourth wagon, is wearing some type of headdress, possibly horns, and is shown in frontal view. There are also two small figures, possibly representing people, just below the fifth wagon. The small triangular figures above and below the wagon train may represent tipis but do not appear to be directly associated with the scene. Two deeply incised lines near the fourth wagon appear to be old but also are probably not associated with the wagon train.

The second group of related glyphs consists of a cluster of figures on the right, connected by a horizontal line to another cluster of figures on the left. The petroglyphs on the right consist of a large wooden building with a probable human figure standing in the doorway; a smaller wooden building with a window and a probable stovepipe; a small triangle, possibly a building or tipi; and an unidentified figure, possibly representing a person. The glyphs on the left consist of a wooden building; an unidentified boxlike figure; a horse-drawn cart or wagon, with the driver wearing a brimmed hat; two faint animal figures, possibly representing dogs or horses; and a mounted rider with a hornlike headdress, holding reins. The mounted rider is shown in frontal view with both legs on the same side of the horse.

The Dorward Ranch petroglyphs are characteristic of the Plains Biographic Style of rock art (Keyser 1987). Several motifs are commonly associated with this style, including the wagons, the oxen with characteristic curved horns, the mounted riders, and the boardand-batten buildings. The petroglyphs seem to tell at least one and probably two separate stories. The upper glyphs depict a wagon train probably witnessed by the artist(s). The lower glyphs appear to represent a landscape with a town on the right and a small wagon traveling along the ground surface approaching a rise, perhaps a representation of the Caprock Escarpment. The small animals, the mounted rider, and the single building on the left are probably associated with the landscape. The building could represent an isolated settlement near the Caprock. The small wagon appears to be ascending the Caprock and could represent a buggy, a carriage, or a stagecoach. All of the lower glyphs seem to tell a single story, presumably an event or series of events witnessed by the artist. They are fainter and more heavily weathered than the wagon train, but this may be due to differential weathering on the bluff face rather than an age difference. 
(4) 8 (

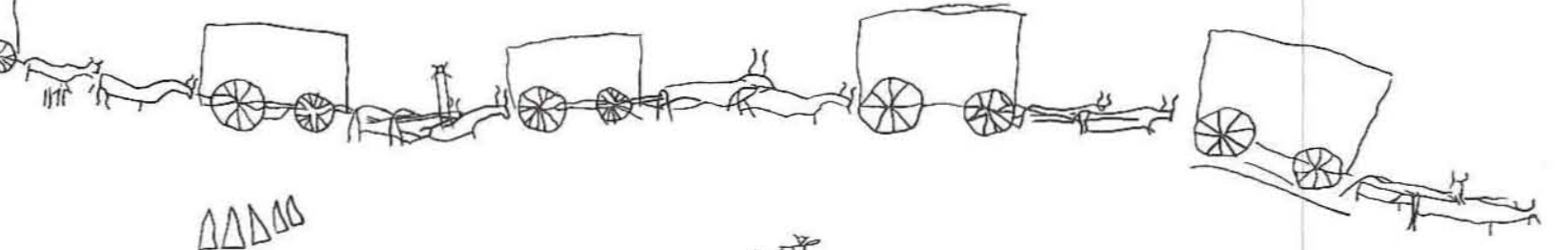

\section{$\underset{\mathrm{cm}}{\stackrel{1020}{1} \underbrace{1} \quad 40}$}

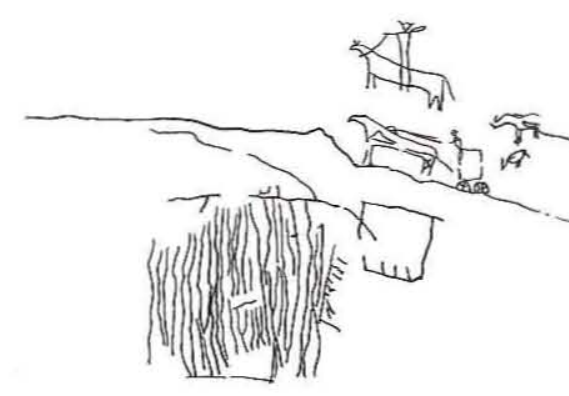

Figure 48. Petroglyphs at the Dorward Ranch Site, 41GR51. (a) Rock art panel with 


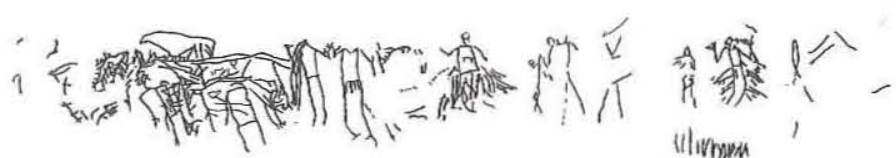 \\ is

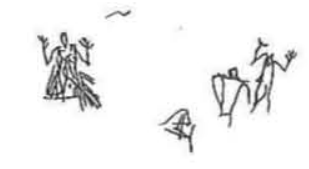

का

Group 2

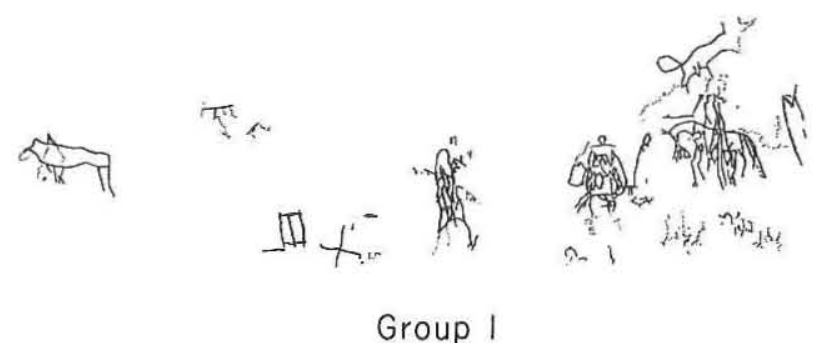

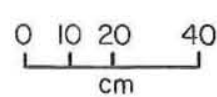

$\rightarrow \operatorname{trn}$ Group 4

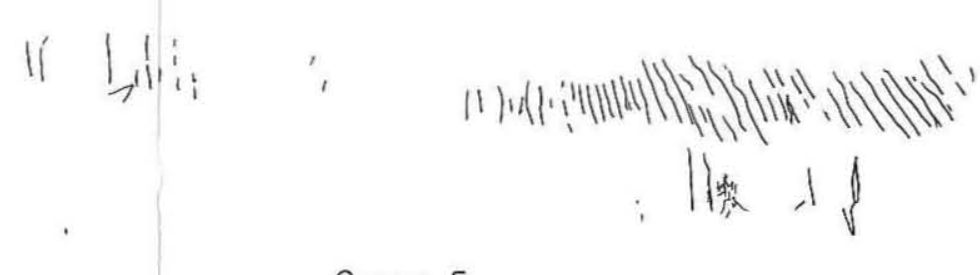

Group 5

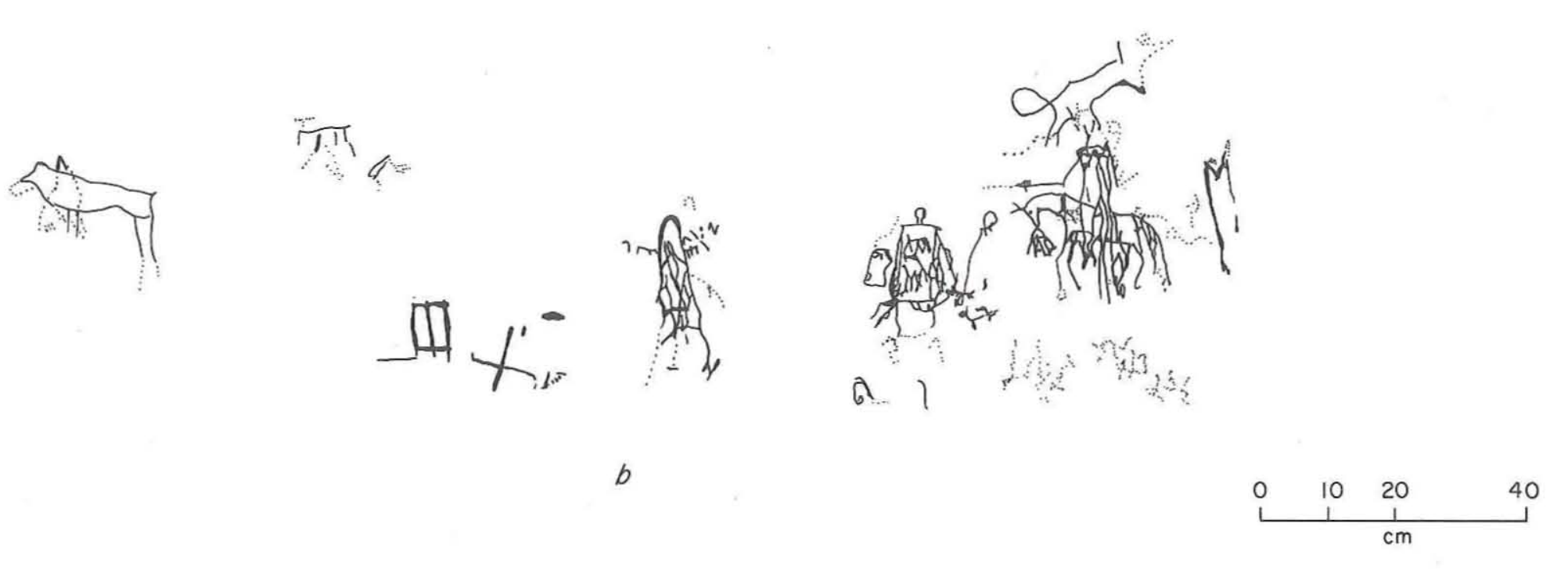

Figure 49. Rock art at the Ward Petroglyph Site, 41GR282. (a) Groups 1 through 5 as they appear on the rock face; (b) close-up of Group 1; (c) close-up of Group 3.

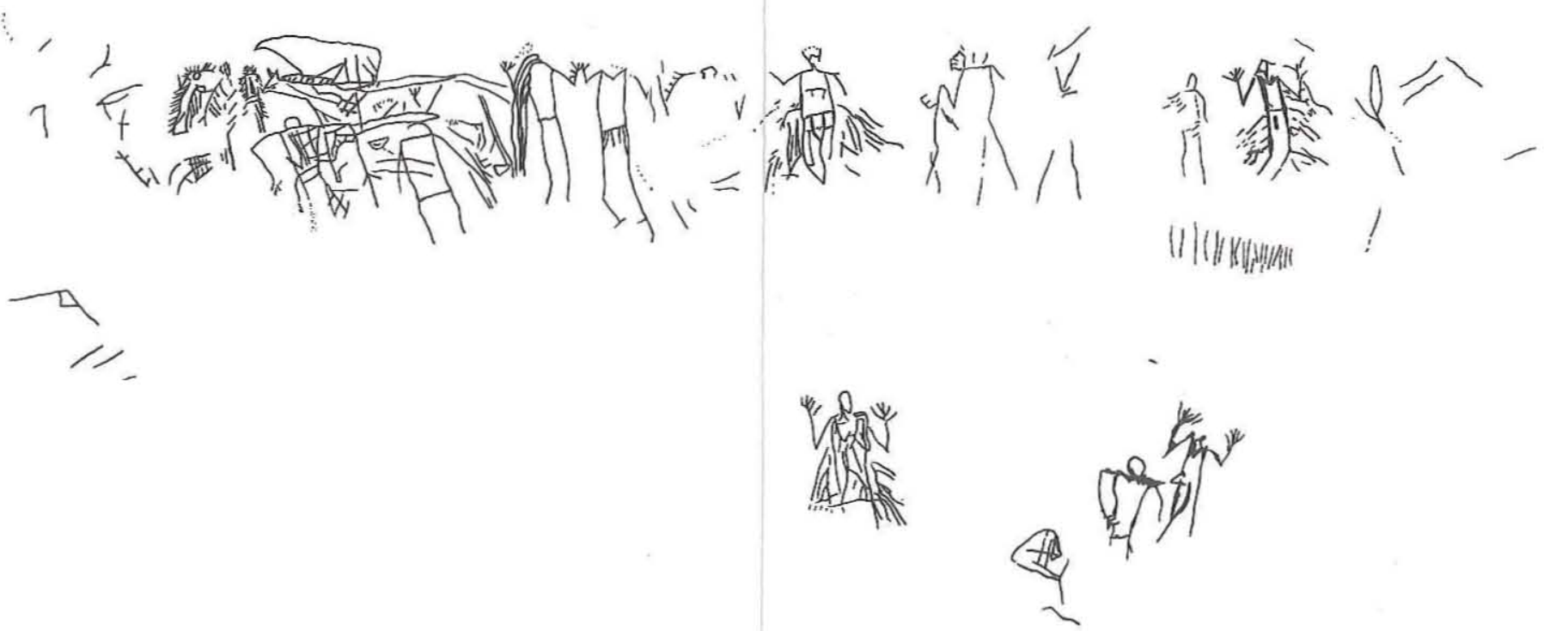


41GR282 (Ward Petroglyph Site)

\section{SITE SETTING}

The site is situated just below the north canyon rim ca. $20 \mathrm{~m}$ above the Double Mountain Fork at an elevation of $2220 \mathrm{ft} \mathrm{msl}$. It is ca. $0.8 \mathrm{~km}$ downstream from the mouth of Cat Hollow and overlooks a broad expanse of the river valley to the south. The talus slope below the site is quite steep and is covered with sandstone rocks and dense vegetation.

The aboriginal petroglyphs are within a 15-m-long section of the south-facing bluff. The glyphs are protected by a 2.5-m-thick overhanging ledge and are found vertically within the $3 \mathrm{~m}$ between the overhang and the floor of the sheltered area. The profile of the bluff under the overhang consists of four horizontal layers of sandstone, from top to bottom: (1) a soft, friable brown sandstone ca. $120 \mathrm{~cm}$ thick; (2) a hard, dense sandstone with a black patinated surface ca. $50 \mathrm{~cm}$ thick; (3) a conglomerate sandstone layer ca. $50 \mathrm{~cm}$ thick; and (4) a soft, friable brown sandstone layer ca. $100 \mathrm{~cm}$ thick. The glyphs occur on the upper and lower layers of soft sandstone and the middle layer of hard sandstone.

\section{WORK ACCOMPLISHED}

The site was recorded in 1987 as an aboriginal petroglyph site that included historic motifs but no historic graffiti or vandalism. The rock axt was photographed in detail, but no tracings were made at that time. The illustrations of the rock art in Boyd (1989d: Figures 43 and 44) were drawn from the photographs. Additional recording of the site was recommended (Boyd et al. 1989). The current investigations consisted of site mapping and detailed rock art recording. The site is quite complex in terms of the undulating rock art panels, the topography within the overhang, and the petroglyphs themselves. Several measured profiles were drawn to document the site. Many images were apparent only under certain lighting conditions, which varied during the course of the day. Light-reflective boards were extremely useful, not only for the photographic documentation but also to search for faint images in all parts of the rock face. The thin sandy sediments below the overhang were not tested but may contain associated archeological deposits.

\section{DISCUSSION OF ROCK ART}

Figure 49 illustrates all of the rock art in its correct spatial orientation, bearing in mind that the petroglyphs are on different rock layers and undulating surfaces. The glyphs are not on distinct panels but are clustered into five groups, numbered 1-5 from left to right. Groups 1, 4, and 5 are located on the lower soft sandstone layer, Group 2 is on the middle hard sandstone layer, and Group 3 is on the upper soft sandstone layer.

The majority of the petroglyphs, Groups 1 and 3-5, are incised or abraded into the soft sandstone layers. The rock faces in the soft sandstone undulate considerably, with numerous wind-worn cavities present. Wind erosion is still affecting the rock surfaces, and the glyphs are weathered to some degree. The lower soft sandstone is deteriorating near the bottom, primarily due to insect boring which causes the face to weaken and spall off. This has damaged some of the lower petroglyphs, and other glyphs may have been completely destroyed. 
Group 1 consists of several indistinct figures on the left and a group of figures on the right (see Fig. 49b). The latter group contains a mounted rider facing a standing human figure. These images are complicated by faint scratchings surrounding them, but the entire cluster is probably related. The mounted rider is characteristic of the Plains Biographic Style (Keyser 1987). The rider has many vertical lines flowing downward from the head, possibly representing long hair or a headdress. A horizontal line in front of the figure may represent an object or weapon (e.g., a lance) held by the rider. The horse has a rakelike design hanging from its head, a classic depiction of a Plains Indian decorated halter (see Keyser 1987:57). Grinnell (1910:304) notes the use of scalps to decorate the bridles of war horses among the Cheyenne. The standing figure to the left, shown in frontal view with a rectangular body, is holding a staff in one hand and possibly another object in the other hand. Some type of garment or blood flowing from wounds on the body may also be depicted. Wounds are commonly shown in this manner in Plains Indian art, and it is possible that the two figures depict a combat scene in which the mounted warrior was the victor. The indistinct figure above the mounted rider possibly represents a name glyph (see Keyser 1987:64).

Only the Group 2 figures are found on the hard black sandstone, and these may not be related to the rest of the petroglyphs: These images are scratched very shallowly into the rock surface with a sharp or pointed tool, exposing fresh light-colored sandstone beneath. These images, which are very faint and somewhat repatinated, were not noted during the 1987 investigation. The figures include some unidentified complex designs on the left and two possible human stick figures on the right.

Group 3 consists of a cluster of horses and human figures over a few isolated human figures (see Fig. 49c). The group is complicated by overlapping figures and seemingly unrelated scratchings. There is no indication that the overlapping images were superimposed at a later time. They all are consistent in depth, width, and degree of weathering and are probably contemporaneous. At least one horse, shown with a mane and apparently running, is depicted in the cluster. Several human figures overlap the horse(s) and may be related. All of the human figures in Group 3 have rectangular bodies, and most have their arms pointing upward, bent at the elbow. Several of the figures have garments or wounds on their bodies, and some seem to be holding objects in their hands. The human figures are similar to those of the Plains Ceremonial Style (Keyser 1987:45), and some are of the V-neck type.

Group 4 consists of three partial animal figures disturbed by insect-related spalling of the rock face. The animal on the right is a deer, and it is likely that the other two also represent deer. Group 5 is a cluster of tally marks and indistinct geometric figures which are more heavily weathered than the other groups, probably due to their exposed location.

41 GR344 (Huddleston Shelter)

\section{SITE SETTING}

The site is situated $7 \mathrm{~m}$ below the north canyon rim on a narrow eastward-projecting upland peninsula paralleling the Double Mountain Fork at an elevation of $2240 \mathrm{ft} \mathrm{msl}$. The shelter faces south-southeastward and overlooks the river valley downstream. The back of 
the shelter is a single large rectangular sandstone block which forms a flat rock panel $3.8 \mathrm{~m}$ wide and $1.5 \mathrm{~m}$ high. The rock art occurs on this back wall; the panel is hard and light-colored with horizontal crossbedding. It has patinated to a medium dark brown and is streaked with dark black, vertical water stains which seem to predate the rock art. The ceiling is a large tabular block of sandstone which has broken along a bedding plane and slid out past the edge of the lower block, forming a shelter $5 \mathrm{~m}$ wide and $2 \mathrm{~m}$ deep. A collapsed section of the upper sandstone ledge indicates the shelter once extended ca. $4 \mathrm{~m}$ farther west. No rock art is present on the exposed rocks at the back of the collapsed shelter, indicating that the ledge collapsed before the art was produced.

\section{WORK ACCOMPLISHED}

The site was recorded in 1987 as a rockshelter containing a single panel of petroglyphs, pictographs, and painted petroglyphs. Red, black, and white pigments were noted. The rock art was considered to represent multiple episodes with some superimposition of figures. Historic aboriginal motifs were noted. The site displays no historic nonaboriginal graffiti or vandalism, and the shelter setting is such that the panel is well protected from the elements. A shovel test in the sediments below the panel indicated a depth of $25 \mathrm{~cm}$ to bedrock but yielded no cultural evidence. The rock art was photographed, and a measured sketch of the rock art panel was completed. The 1987 assessment indicated that the site was significant, and additional work was recommended (Boyd et al. 1989). The current investigations consisted of site mapping and detailed recording of the rock art. Different filters were tested with the color slide film to enhance the pigments, but the best results were obtained with no filters and reflected sunlight. Although there is a potential for recovering rock art tools or other artifacts from the sediments in the shelter, no excavations were done.

\section{DISCUSSION OF ROCK ART}

The petroglyphs were scratched very shallowly into the hard surface with a sharp or pointed tool. Red, and possibly some black, pigments were applied to portions of a few glyphs, while the pictograph figures are in black only. The white pigment noted during the original investigation (Boyd 1989d:187) seems to be the color of the fresh rock rather than a pigment.

The rock art consists of 1 animal figure, ca. 16 human figures, a tipi, and several geometric figures (Fig. 50). A series of vertical and horizontal lines form the large squares and ladderlike figures in the central portion of the panel; human figures are superimposed over these. Some figures on the panel appear similar in the degree of weathering and repatination, while others look quite different. Several different styles and methods of production are represented, suggesting reuse of the panel. One of the olderappearing figures is the ox or longhorn at the left end of the panel, indicating that all of the rock art probably was made in historic times. The longhorn in this panel is a classic historic motif, and the interior of the petroglyph is rubbed or smoothed. Kirkland and Newcomb $(1967: 208)$ note that this technique is typically associated with historic rock art and was used in longhorn petroglyphs at Mujares Creek in Oldham County. Depictions of longhorn cattle were particularly popular among the Kiowa (Ewers 1976). 


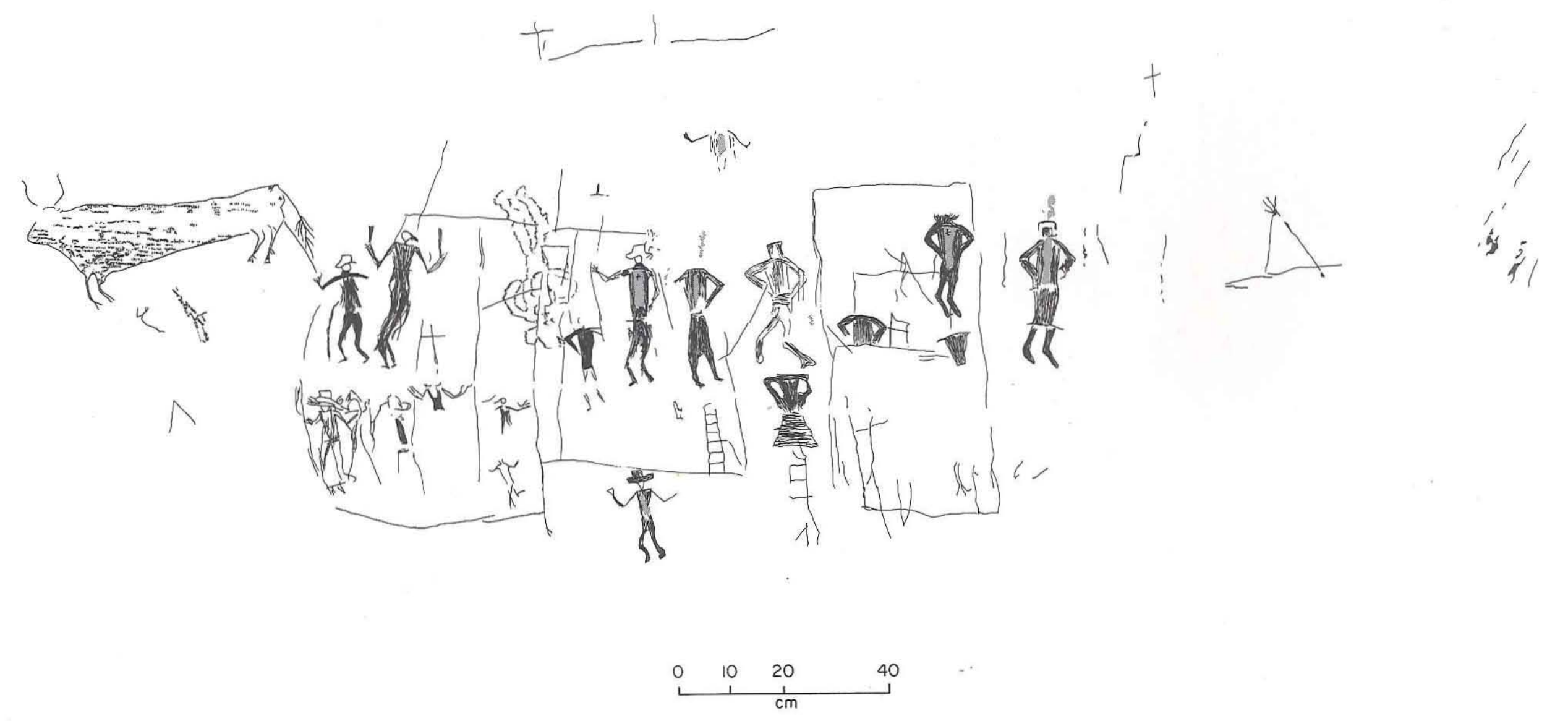

Figure 50. Rock art panel at Huddleston Shelter, 41GR344. Red pigment is shown in gray; black pigments are described in text. 
The black painted figures found at the right end of the panel consist of several indistinct images and a tipi. Some black pigment also may be associated with the faded human figure in the upper center of the panel. One questionable figure, the upside-down cowboy near the left center of the panel, consists of a black outline similar to natural water staining; the humanlike form, however, suggests that this may be a faded pictograph.

Six human figures are painted petroglyphs with red pigment used to highlight the chest areas, and two of these figures have red near their heads. The red paint may represent garments, or possibly blood or death. One figure in the center of the panel is an obvious historic European wearing a brimmed hat and carrying a staff in one hand while the other arm is akimbo. A cross scratched into the red pigment on the chest suggests that this figure represents a priest. The second human figure from the right end of the panel has both arms akimbo and a cross on its red chest; it is also interpreted as a priest. Other human figures are petroglyphs produced by scratching outlines and then scratching the interiors. Several of these wear brimmed hats or unusual headdresses, and some have their arms akimbo. Some are likely Europeans, while others may represent Indians.

This rock art is attributed to the Early Plains Biographic;Style (Keyser 1987:48). Historic motifs are shown as isolated figures, and the panel lacks the integration of elements and artistic conventions of the Late Biographic Style. The various techniques and motifs suggest that these images were produced at different times and possibly by different cultural groups.

41GR390

\section{SITE SETTING}

The site is located on the west side of Gobbler Creek, ca. $0.25 \mathrm{~km}$ north of the concrete water crossing where the Cedar Hill road crosses the creek. The site is immediately north of the creek at a point on a wide meander bend where the stream flows west. The pictographs are at the southern edge of the site, ca. $25 \mathrm{~m}$ due north of Reed Shelter (41GR54), which also contains a few petroglyphs.

The pictographs are on the ceiling of a small overhang along the edge of Gobbler Creek, which is 3-4 $\mathrm{m}$ south of and 2-3 $\mathrm{m}$ below the overhang. The creek appears to have recently flooded to the level of the overhang, probably causing some of the pigment deterioration noted. Erosion of a soft sandstone layer between two hard sandstone layers formed the small overhang cavity, 0.5-1.0 m tall and ca. $2 \mathrm{~m}$ deep, but no sediments are present inside. The pictographs are painted on the bottom of the overhanging sandstone slab, which is very hard and is patinated dark brown-gray.

\section{WORK ACCOMPLISHED}

Pictographs and a series of bedrock mortar holes discovered across the creek from Reed Shelter (41GR54) were initially recorded as part of that site (Riggs 1966). Subsequent investigations in 1987 discovered the mortar holes and pictographs to be part of a large prehistoric campsite; this site was recorded as 41GR390. Both 41GR390 and Reed Shelter are Late Prehistoric habitation sites. The 1987 investigations, which concentrated on the 
campsite rather than the rock art, noted some deterioration of the pigments but did not attempt to rerecord the rock art. Additional work was recommended (Boyd et al. 1989). The current investigations consisted of site mapping and detailed recording of the rock art. Photographic documentation utilized various filters in an attempt to enhance the pigments, but the best results were achieved using reflected sunlight without filters.

\section{DISCUSSION OF ROCK ART}

The faint pictographs on the ceiling of the overhang consist of a human figure apparently holding a round shield and two clusters of indistinct stains (Fig. 51). The human figure and the outline of the shield are in red or reddish orange. Riggs (1966:51) noted a design within the shield and could discern several different pigment colors. All of the colors have faded to the point that they can only be considered as reddish; the shield design is no longer evident to the unaided human eye, but it is barely perceptible in some photographs. A considerable amount of deterioration has occurred since the pictographs were first recorded in 1966 (cf. Fig. 5la and b). The shield is a common motif in the Plains Ceremonial and Plains Protohistoric styles (Keyser 1987) but is less frequent in the later Plains Biographic Style.

The two clusters of indistinct images appear now as little more than stains but prob$\mathrm{ably}$ represent badly weathered pictographs. One cluster contains red and black pigments; the other contains only black. A possible black pigment stain was also noted at the back of the overhang.

There is no direct evidence to date the pictographs at 41GR390. They may or may not be associated with the Late Prehistoric occupation at the site or at Reed Shelter. It is doubtful if pictographs could survive many hundreds of years in such a setting, and thus it is probable that the rock art is only a few hundred years old at most.

4IGR423

\section{SITE SETTING}

This site is located ca. $0.15 \mathrm{~km}$ southeast of the confluence of Rocky Creek and the Double Mountain Fork along the base of the valley wall. The rock art, at an elevation of ca. $2220 \mathrm{ft} \mathrm{msl}$, is $80 \mathrm{~m}$ east and ca. $10 \mathrm{~m}$ above Rocky Creek. Dense vegetation (juniper, agarita, mesquite, and hackberry) obscures the site from the creek and limits access.

The rock art is situated on a north-facing, 9-m-high and 8-m-wide sandstone face that is protected by a slight overhanging lip at the top of a friable yellowish sandstone bluff. Some reddish vertical water staining has been caused by dripping from the overhanging lip. The rock face has tiny pebble cavities but is worn smooth by the wind and is relatively flat. The eye-level rock art is confined within $1 \mathrm{~m}^{2}$ of the rock face. Some insect boring, vegetation damage, and spalling of the rock face have occurred, but no damage to the images is apparent. The base of the bluff is formed by a talus slope of rockfall from the canyon walls. An accumulation of thin sandy sediments along the top of the talus slope forms a narrow path 1-2 $\mathrm{m}$ wide along the base of the bluff. 

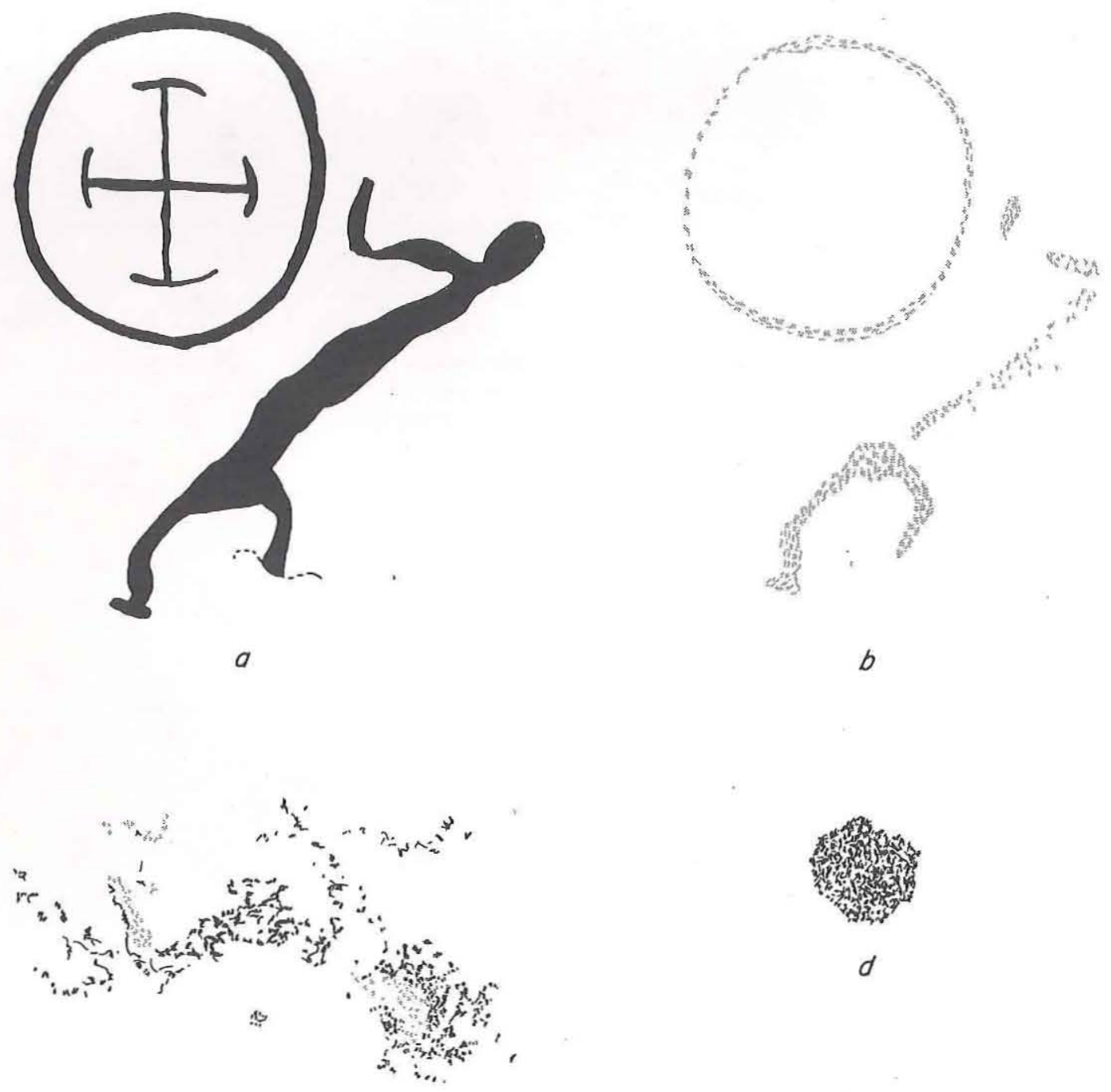

c

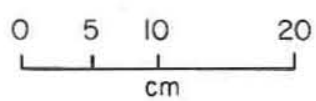

Figure 51. Pictographs at 41GR390. (a) Human figure holding shield, as recorded by Riggs (1966:Fig. 6); (b) human figure holding shield, as seen in 1989; (c) indistinct black and red pignent stain; (d) indistinct black pigment stain.

\section{WORK ACCOMPLISHED}

Site 41GR423 was recorded in 1987 as a single panel of painted petroglyphs of undefined age. A measured sketch and preliminary photographs of the rock art were made. No historic graffiti or modern vandalism were noted. Additional work was recommended (Boyd et al. 1989). As a result of this recommendation, the current investigations consisted of site mapping and detailed recording of the rock art. Only sparse sediments are preserved below the rock art panel, but these may contain associated archeological deposits. 


\section{DISCUSSION OF ROCK ART}

The rock art consists of two human figures, each composed of a petroglyph outline with red painted interiors (Fig. 52). The two figures are almost identical in size, shape, and style. Each is ca. $60 \mathrm{~cm}$ tall and $15 \mathrm{~cm}$ wide, and they are ca. $50 \mathrm{~cm}$ apart. They have elongated rectangular bodies with short legs, rounded heads, and upturned arms bent at the elbows. The outlines of the bodies and appendages are shallowly incised, and the upper portion of each figure is very faint. The left figure may be wearing a headdress. The torsos and legs are painted red, but the heads and arms are not painted. The red pigment is obvious on the figure on the left but is very faded on the right figure. This rock art is unusual in that the images are painted petroglyphs, but similar rectangular-bodied human-figure petroglyphs are present at 41GR409 and 41KT65 in the project area.
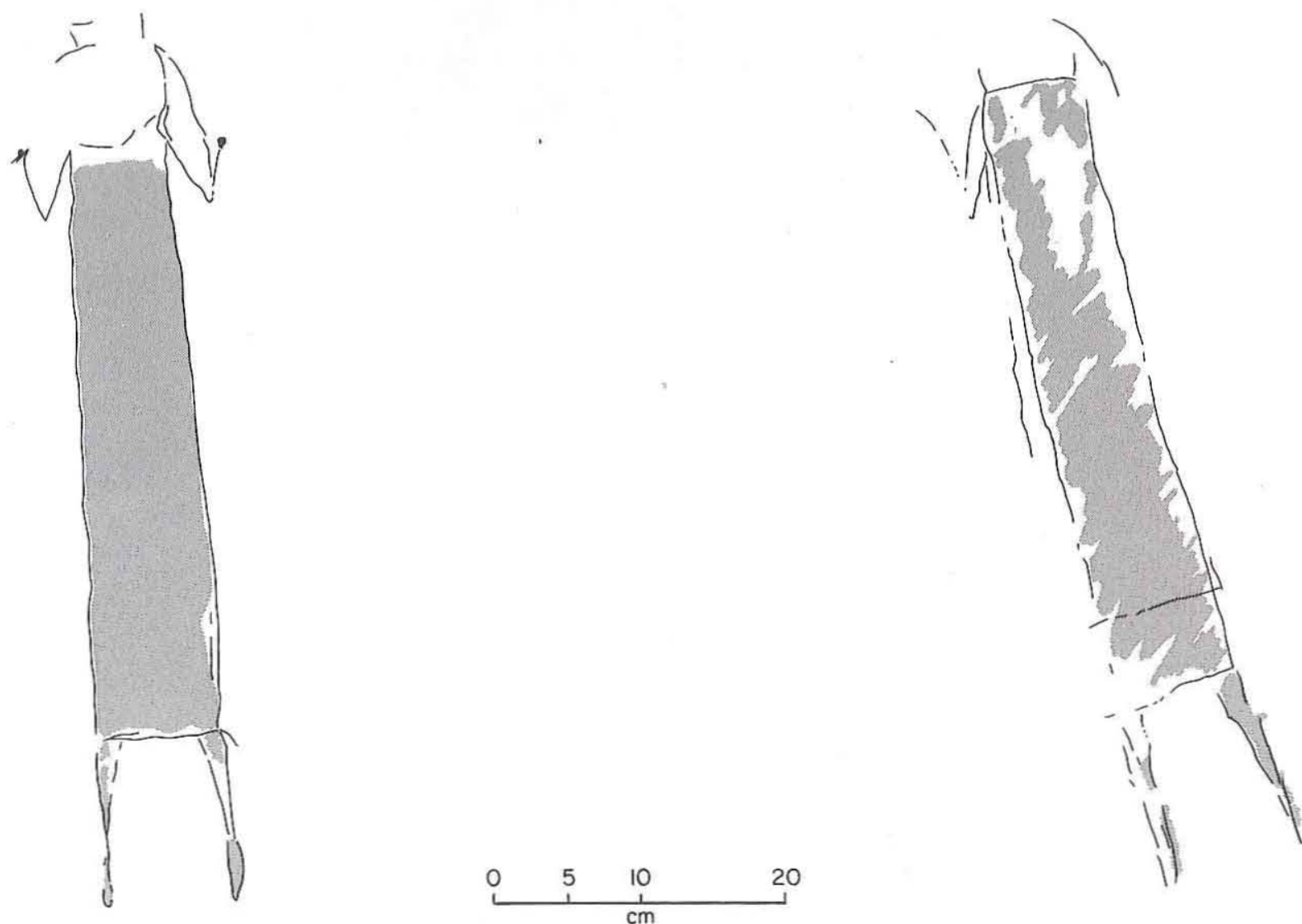

Figure 52. Painted petroglyphs at 41GR423. Shaded areas are red pigment.

41GR426

\section{SITE SETTING}

The site is situated along an exposed sandstone ledge $11 \mathrm{~m}$ below the rim at the base of the valley talus slope on the east side of Rocky Creek, $0.5 \mathrm{~km}$ south of its confluence 
with the Double Mountain Fork. The rock art is located beneath an overhanging ledge creating a small sheltered area $30 \mathrm{~m}$ east and $4.5 \mathrm{~m}$ above Rocky Creek at an elevation of $2210 \mathrm{ft}$ msl.

The small sheltered area is $2 \mathrm{~m}$ high, $2.5 \mathrm{~m}$ wide, and $2.5 \mathrm{~m}$ deep. Within the overhang are various layers of sandstone which form a stair-stepped ceiling. The pictograph is near eye level ( $1.5 \mathrm{~m}$ above the floor) on a $70 \times 250-\mathrm{cm}$ vertical panel of friable gray sandstone near the front of the shelter, just below the hard sandstone ceiling. The floor of the shelter contains thin sediments with no surficial evidence of habitation, although associated archeological deposits could be present.

\section{WORK ACCOMPLISHED}

Site 41GR426 was recorded in 1987 as a single pictograph figure of undefined age. It was undisturbed by vandalism and in a good state of preservation. A single shovel test in the overhang revealed ca. $30 \mathrm{~cm}$ of sediments but yielded no cultural materials. Additional work was recommended (Boyd et al. 1989). The current investigations consisted of site mapping and detailed recording of the rock art. The pictograph is located below the proposed reservoir floodpool and is one of two sites from which pigment samples were obtained. A small amount of pigment was scraped from a $2-\mathrm{cm}^{2}$ area of the pictograph. The red pigment contained rust-colored quartz grains, most likely crushed red sandstone (see Appendix F). The sample was too small to test for organic carbon but probably had some organic binder. No additional testing of the sediments was attempted.

\section{DISCUSSION OF ROCK ART}

The rock art consists of a single pictograph element, a red-painted, negative-image, right human handprint (Fig. 53) apparently produced by holding the palm flat against the rock surface and spattering or blowing red paint over the hand. The painted area is roughly $20 \mathrm{~cm}$ long by $15 \mathrm{~cm}$ wide. Human handprints are a very common motif, although there is some variation in the styles found in Texas (Jackson 1938:374-377). A number of similar negative handprints are reported in rockshelters ca. $60 \mathrm{~km}$ southwest of Justiceburg in Dawson County (Quinn and Holden 1949:123-124), and a positive etched handprint is located in the project area at 41GR567 (Boyd 1989d:174).

$41 \mathrm{GR} 437$

\section{SITE SETTING}

The site is located at a meander bend $15 \mathrm{~m}$ below the valley rim near the base of the talus slope along a lower bedrock terrace bluff $35 \mathrm{~m}$ east of Rocky Creek and ca. $1.5 \mathrm{~km}$ south-southwest of its confluence with the Double Mountain Fork. The rock art is in a protected overhang ca. $5 \mathrm{~m}$ above the Rocky Creek floodplain at an elevation of $2230 \mathrm{ft} \mathrm{msl}$.

The art is located immediately below the ceiling of the overhang which is composed of layers of soft, friable, gray sandstone which have eroded out from under a ledge of hard sandstone. The sheltered area is $8 \mathrm{~m}$ wide and $2 \mathrm{~m}$ deep, and the sandstone ledge forms a 


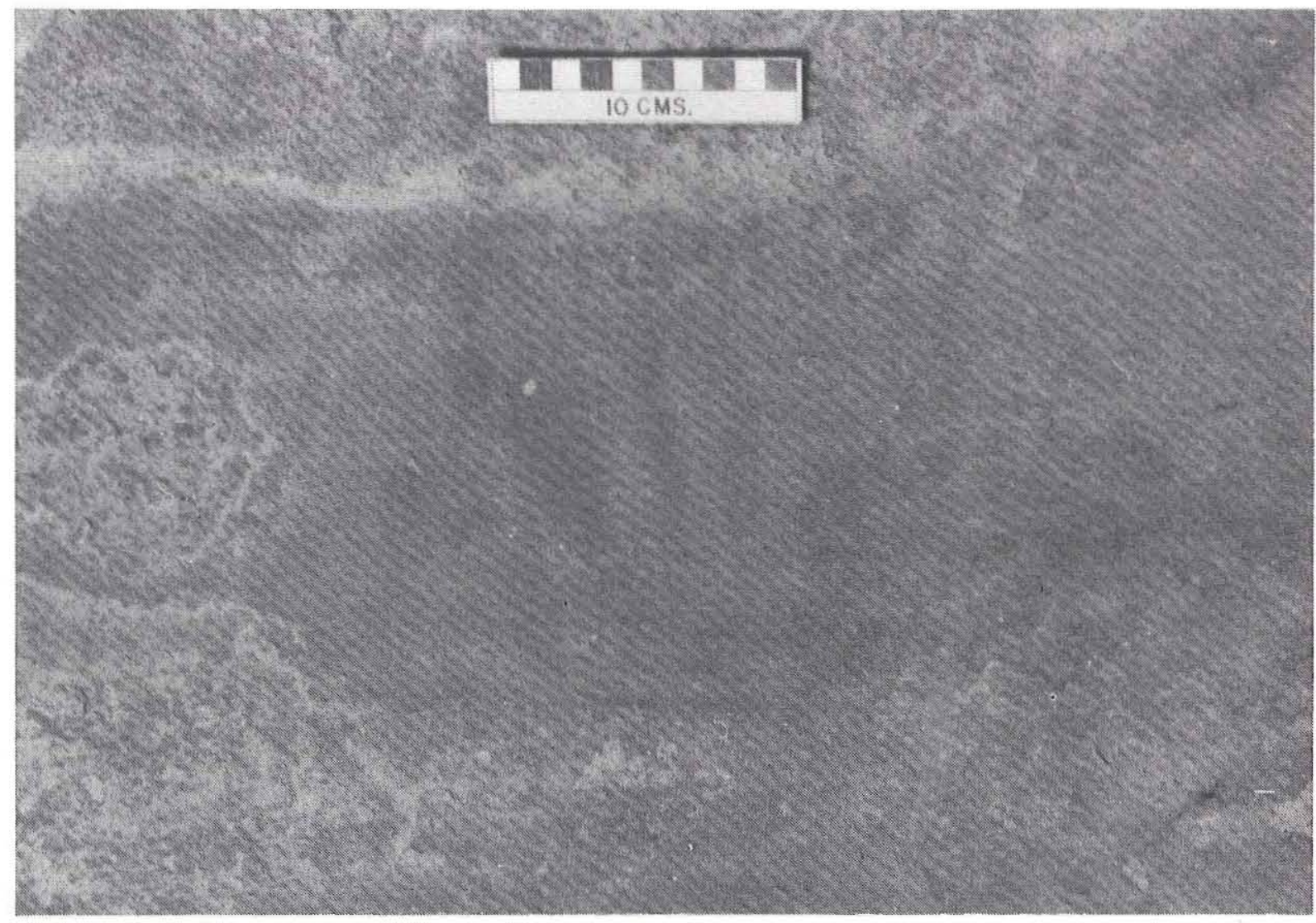

Figure 53. Pictograph handprint at 41GR426.

flat ceiling ca. $1.6 \mathrm{~m}$ high. The fairly level floor of the sheltered area consists of thin loose sands overlying bedrock. The weathered bedrock sediments apparently do not contain occupational evidence but could yield rock art tools or pigment.

WORK ACCOMPLISHED

Site 41GR437 was recorded in 1987 as petroglyphs and pictographs of undefined age in a sheltered overhang and historic graffiti in an adjacent overhang. Measured sketches and minimal photographic documentation were completed. The aboriginal rock art was badly weathered and partially destroyed due to wetting and drying of the rock face. Additional work was recommended (Boyd et al. 1989). The current investigations consisted of site mapping and detailed recording of only the aboriginal rock art. Some faint scratchings in association with the aboriginal art are thought to be historic graffiti. Due to the advanced state of deterioration of portions of the rock surface containing the pictographs, pigment samples were taken from spalling surfaces. The coloring agent in the pigment is a dark brown or green mineral, possibly chromian dravite of the tourmaline group. The sample also contained $1 \%$ organic carbon, probably representing an organic binder (see Appendix F). The shallow sandy sediments were not tested but appear to have a low potential for yielding associated cultural materials. 


\section{DISCUSSION OF ROCK ART}

The rock art consists of two panels, one in a wind-worn circular alcove and the other on the flat surface to the right of the alcove. Both panels are within a $50 \times 200-\mathrm{cm}$ area. The first panel includes both black (or dark) pictographs and a simple cross petroglyph. The upper figures near the ceiling of the overhang are black pictographs (Fig. 54a). They appear to be simple tally marks and an unidentified figure originally reported as a possible animal (bison?) (Boyd 1989d:174), but the image has since deteriorated. The pictographs are faded, and the rock surface is spalling off in some areas. Toward the lower portion of the wind-worn cavity, about $50 \mathrm{~cm}$ below the pictographs, is the cross petroglyph and an indistinct black pictograph cluster (Fig. 54b).

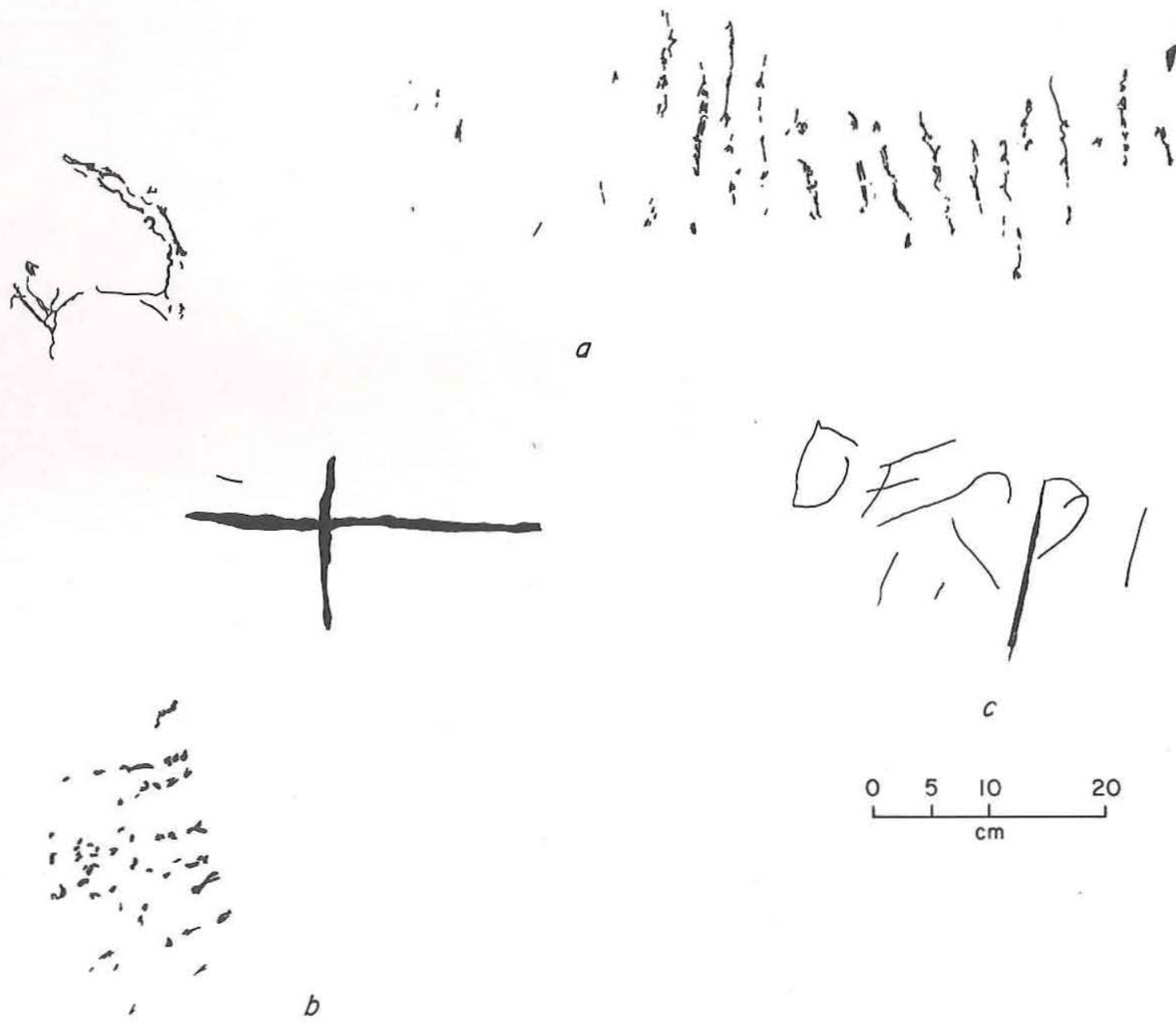

Figure 54. Rock art at 41GR437. (a) Black pictographs in the upper part of Panel 1; (b) petroglyph cross and black pictographs in the lower part of Panel 1; (c) petroglyphs in Panel 2.

The second panel (Fig. 54c) is on a flat surface ca. $70 \mathrm{~cm}$ to the right of the windworn cavity; it consists of a single deeply incised line, similar in style to the cross 
figure, and light scratches around it. The incised line is $16 \mathrm{~cm}$ long, $0.5 \mathrm{~cm}$ wide, and 3 cm deep, and is probably aboriginal; the light scratches are considered historic graffiti (possibly a date) which were superimposed over the aboriginal element.

$41 \mathrm{GR} 472$

\section{SITE SETTING}

The site is situated on a sandstone outcrop forming the canyon rim and bluffs on the south side of the Double Mountain Fork, ca. $0.5 \mathrm{~km}$ downstream from the Santa Fe Lake (or Justiceburg Lake) dam. It is a small overhang shelter located ca. $120 \mathrm{~m}$ south of and ca. $15 \mathrm{~m}$ above the Double Mountain Fork channel overlooking a meander bend in the river; it is at an elevation of ca. $2270 \mathrm{ft} \mathrm{msl}$. A prehistoric campsite, 41GR471, located on a wide alluvial terrace directly north of the site may or may not be associated with the rock art.

The shelter is $7 \mathrm{~m}$ wide and $2 \mathrm{~m}$ deep; it is $2.3 \mathrm{~m}$ high at the front and less than $1 \mathrm{~m}$ high at the back. The petroglyphs are clustered in an area $200 \mathrm{~cm}$ long and $20 \mathrm{~cm}$ high along the upper edge of a soft sandstone layer just below its contact with the hard conglomerate sandstone that forms the ceiling. Moderate to heavy wind erosion of the sandstone rock face is apparent.

\section{WORK ACCOMPLISHED}

Site 4IGR472 was recorded in 1987 as petroglyphs of undefined age. A measured sketch and photographs of the rock art were completed. The sparse sediment accumulations noted in the shelter were not tested. No graffiti or vandalism were noted. Additional work was recommended (Boyd et al. 1989). The current investigations consisted of site mapping, detailed recording of the rock art, and excavation of four shovel tests under the rock art panel. These tests revealed ca. $25 \mathrm{~cm}$ of sandy sediments above bedrock, but no cultural materials were recovered.

\section{DISCUSSION OF ROCK ART}

The rock art consists entirely of geometric petroglyphs (Fig. 55). Two clusters of vertical and horizontal lines are interpreted as tally marks, although their function or significance is unknown. The cluster on the right includes numerous vertical lines superimposed over long horizontal lines. The vertical lines are slightly eroded but appear to represent ca. 60-80 tally marks. The cluster to the left is badly wind eroded. The glyphs consist of ca. 20 short vertical lines which are probably partial tally marks. The tally marks on the right may once have extended farther and included the tally marks on the left.

Little in the way of interpretation is possible. The glyphs may be associated with 41GR471 in the floodplain below, but the potential for dating the rock art is very low. Although the shelter's sediments were tested and yielded no cultural materials, there is a chance that rock art tools may have been discarded or lost in the small sheltered area. 
$11 / 11,111,1111$

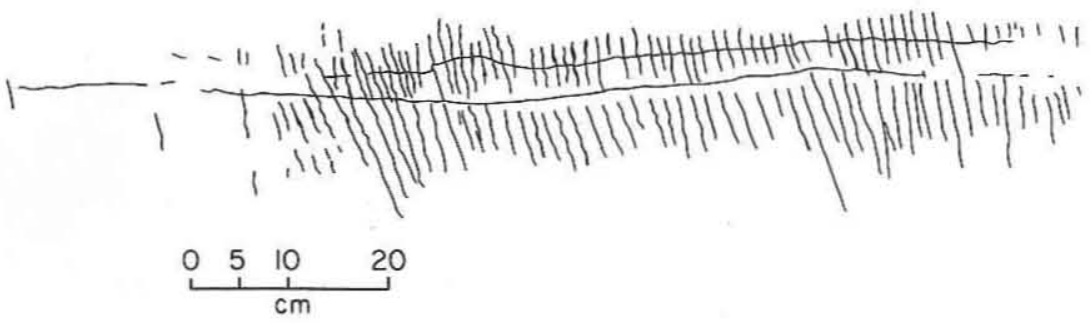

Figure 55. Petroglyphs at 41GR472.

41GR494

\section{SITE SETTING}

This site is situated on the canyon rim at the head of a small unnamed drainage on the north side of the Double Mountain Fork, ca. $0.5 \mathrm{~km}$ northwest of the river within the heavily developed Justiceburg $0 j .1$ Field area. A tank battery, access roads, powerlines, and buried pipelines are located within $75 \mathrm{~m}$ of the site. The accessibility probably accounts for recent graffiti noted at the site.

The site is a rockshelter with aboriginal rock art on an eroded layer of soft, friable sandstone. The south-to-southwest-facing shelter is $15 \mathrm{~m}$ wide, $4.8 \mathrm{~m}$ deep, and $2 \mathrm{~m}$ high at an elevation of $2260 \mathrm{ft} \mathrm{msl}$. The floor is covered with thin, sporadic sandy sediments, and a row of roof fall slabs lines the front of the shelter. A drainage that runs through the shelter has scoured out most of the sediments, but there is a chance that rock art tools may be present in sediment patches that remain.

\section{WORK ACCOMPLISHED}

Site 41GR494 was recorded in 1987 as a rock art site containing aboriginal petroglyphs and historic and recent nonaboriginal graffiti. No substantial sediments were present in the shelter, and no testing was done. A preliminary sketch and photographs of the aboriginal rock art were completed. Additional work was recommended (Boyd et al. 1989). As a result of this recommendation, the current investigations consisted of site mapping and detailed recording of the aboriginal rock art; no attempt to record all of the graffiti was made.

\section{DISCUSSION OF ROCK ART}

Separate rock art clusters are located within a 5-m-wide and 1.8-m-tall section of the back wall and are protected by an overhanging ledge of hard sandstone. The upper part of this panel contains only historic and recent graffiti. The lower portion contains aboriginal petroglyphs within a ca. $1 \times 4-m$ area. The aboriginal petroglyphs consist of geometric linear figures clustered in three groups (Fig. 56). The group on the left is a complex arrangement of geometric linear figures, mostly vertical lines. The chevronlike figure 

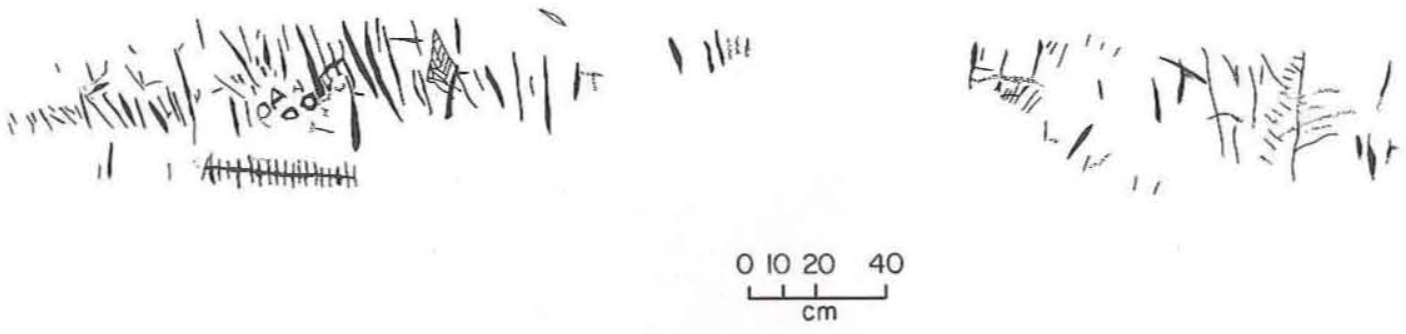

Figure 56. Petroglyphs at 41GR494.

superimposed over the other marks is incised differently from the others and may be an historic or recent addition. At the bottom of this group are 18-19 short vertical lines connected by a horizontal line which appear to be tally marks. The cluster to the right consists of numerous vertical and horizontal lines with no apparent patterning. To the far right, a few isolated linear figures appear.

Other than the probable tally marks on the left, these petroglyphs have no apparent patterning. They are stylistically similar to the Fort Chadbourne type of petroglyphs noted in Coke and Taylor counties (Kirkland and Newcomb 1967:166-169). Age, cultural affiliation, or distribution has not been defined for the Fort Chadbourne type. Some of the deeply incised lines may be abrading grooves, but it is doubtful that this accounts for many of the linear figures.

$41 \mathrm{KT} 65$

SITE SETTING

This site is located on the canyon rim on the east side of Grape Creek, ca. 2.3 km upstream from its confluence with the Double Mountain Fork. It is a south-facing rockshelter at an elevation of $2270 \mathrm{ft} \mathrm{msl}$ overlooking the narrow Grape Creek floodplain ca. $20 \mathrm{~m}$ below. Erosion of a soft sandstone layer beneath the hard sandstone caprock has created this 5-m-wide, 2-m-deep, and 1.5-m-high sheltered area. The shelter layout is quite complex. The west half is a large open chamber, while the east half is a smaller, wind-worn alcove separated by sandstone columns. The east half is closed in by columns in front, with two windows through the soft sandstone opening into the alcove chamber from the front (Fig. 57). The floor of both areas is covered with a thin layer of sand weathered from the parent bedrock. The front of the shelter has a gently sloping accumulation of sediments.

\section{WORK ACCOMPLISHED}

Site 41KT65 was recorded in 1987 as aboriginal petroglyphs and historic nonaboriginal inscriptions. A shovel test excavated directly in front of the shelter indicated a soil depth of $50 \mathrm{~cm}$, but no cultural materials were recovered. Photographs and measured sketches were completed. Some disturbance by bushes rubbing against the rock face was 


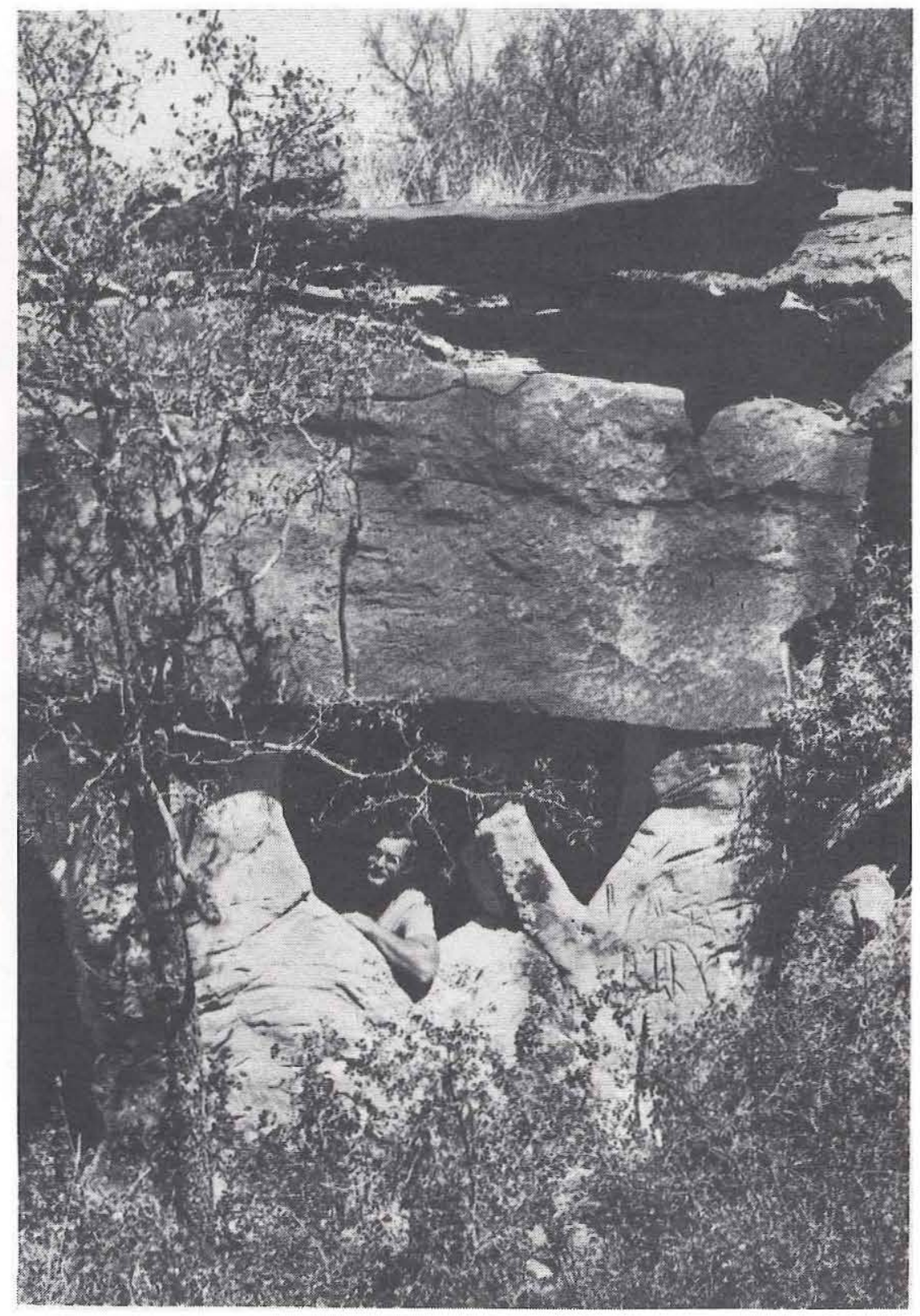

Figure 57. Photograph of rock art site 41KT65. View is to the north-northeast of the east half of the chamber. Person is inside the small chamber, looking out of the small window. Rock art panel 4 is below and to the right of the person.

noted, but otherwise the petroglyphs were in good condition. Additional work was recommended (Boyd et al. 1989). The current investigations consisted of site mapping and detailed recording of the rock art. Four panels of petroglyphs were recorded; three contain only aboriginal glyphs, and one contains historic inscriptions and possible aboriginal glyphs. No additional testing was done, but there remains the potential for 
recovering rock art tools or other cultural materials inside or immediately in front of the shelter.

\section{DISCUSSION OF ROCK ART}

The rock art consists of four panels. Panel 1 is located at the back of the large chamber and can be viewed from the front of the shelter. Panel 2 is located on the column between the two chambers and can be seen from inside the small chamber. Panel 3 is located at the back of the small chamber and can be viewed from the front of the shelter through the large window. Panel 4 is located at the front of the small chamber, below and to the east of the small window (see Fig. 57). Although the panels are close together, they are separated by the undulating topography of the rock surface within the shelter.

Panel 1 (Fig. 58a) measures ca. $80 \times 100 \mathrm{~cm}$ and consists of two historic inscriptions: the initials "WWG" accompanied by a 1908 date and the initials "JHG." The panel also includes two long vertical lines which are similar in style and depth to the inscriptions but may be aboriginal. Panel 2 (Fig. 58b) measures ca. $80 \times 80 \mathrm{~cm}$ and consists of 11 parallel vertical tally marks and an assortment of irregular geometric figures. One short line and a V-shaped figure are deeply incised and wider than the others and may be abrading grooves. Panel 3 (Fig. 58c) covers ca. $1 \mathrm{~m}^{2}$ and consists of ca. 28 vertical parallel lines above a cross figure. Some vertical lines are deeply incised, and others are more weathered; they may be tally marks or abrading grooves.

Panel 4 (Fig. 58d-e) covers over $1 \mathrm{~m}^{2}$ and consists of parallel linear figures, a boxlike figure, and three anthropomorphic figures; it has been damaged by vegetation, evident as concentric arc-shaped grooves caused by bushes swaying in the wind (see Fig. 58d). Spalling of the rock face has obscured some of the glyphs and makes it difficult to determine if some of the markings are natural or manmade. The petroglyphs are distinguished from the recent damage because the former are deeply incised and appear weathered (see Fig. 58e). The three anthropomorphs are front-view, rectangular-bodied figures that incorporate triangular, pointed legs into the torso. The figures have pointed or rounded heads with arms extending outward, and two have their arms bent at the elbows and turned upward. The central human figure is more elaborate than the others, perhaps portraying an individual of higher status. It has a vertical line on its chest, possibly representing a garment, a belt with a pendant sashlike object, and a long curved line coming from its head, probably representing a headdress.

The petroglyphs at this site remain undefined in age, and there is little chance that they can be dated. The geometric figures, however, show some similarities to the Fort Chadbourne type of petroglyphs (Kirkland and Newcomb 1967:166-169). The human figures are similar to anthropomorphs at 41 GR409 and 41GR423 in the project area.

\section{$41 \mathrm{KT} 68$}

\section{SITE SETTING}

This site is situated in a talus slope sandstone outcrop below the canyon rim on the west side of Grape Creek, ca. $4.6 \mathrm{~km}$ upstream from its confluence with the Double Mountain 


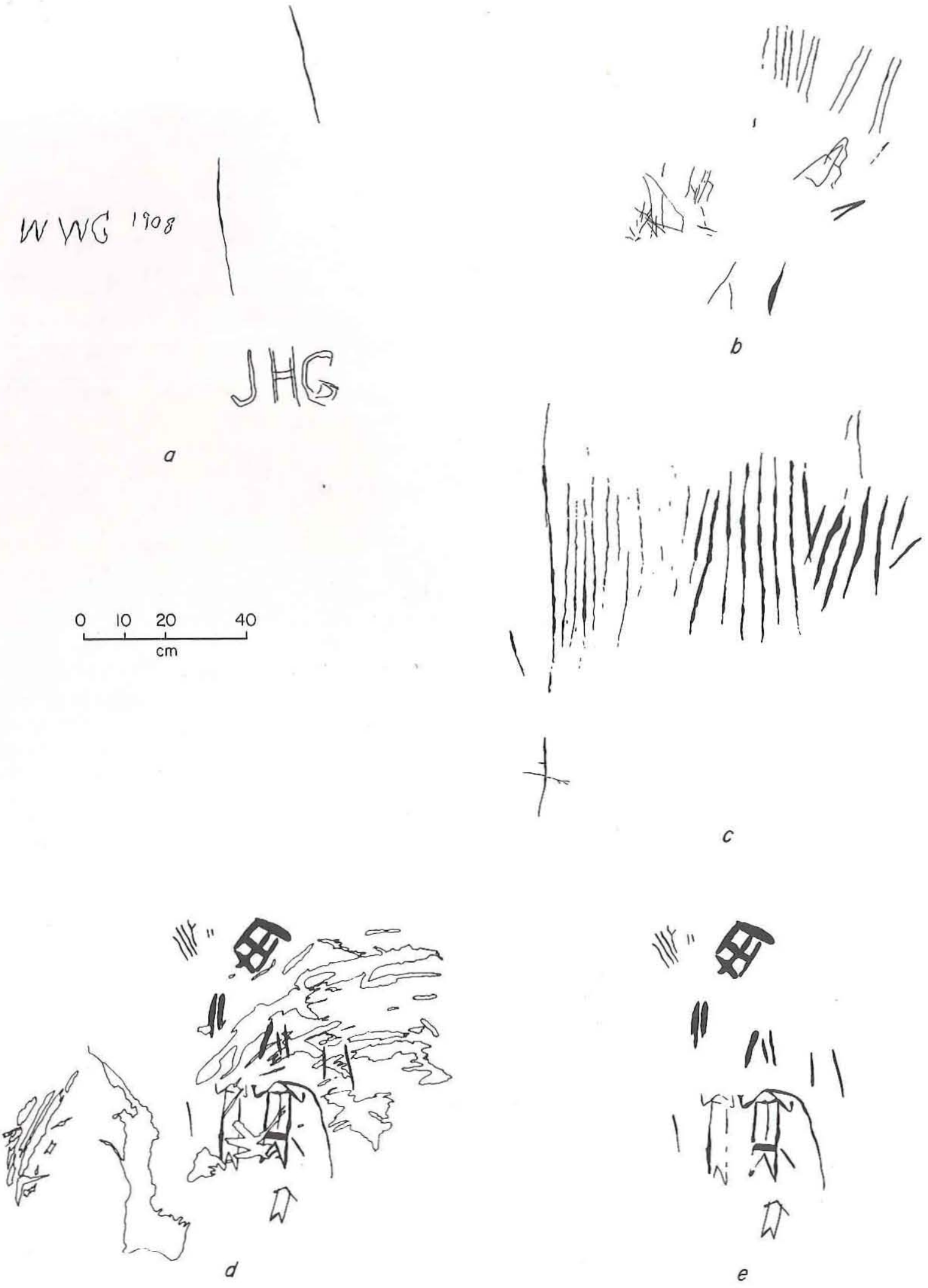

Figure 58. Petroglyphs at 41KT65. (a) Panel 1; (b) Panel 2; (c) Panel 3; (d) Panel 4, shown with vegetation damage; (e) Panel 4, shown without vegetation damage. 
Fork. It is a rockshelter at an elevation of ca. $2250 \mathrm{ft} \mathrm{msl}, \mathrm{ca} .7 \mathrm{~m}$ below the canyon rim and ca. $15 \mathrm{~m}$ above Grape Creek. The shelter is $35 \mathrm{~m}$ wide, $1.6 \mathrm{~m}$ deep, and $1.9 \mathrm{~m} \mathrm{high;} \mathrm{it}$ is protected by an overhanging ledge of hard sandstone. The rock art is in a small windworn cavity which extends into the back of the shelter for another meter.

\section{WORK ACCOMPLISHED}

Site 41KT68 was recorded in 1987 as an aboriginal petroglyph site of unknown age. A considerable amount of recent vandalism (i.e., graffiti) was noted, but no historic inscriptions were present. Preliminary photographs and a measured sketch of the rock art were completed. No sediments were observed on the floor of the shelter, and no testing was done. Additional work was recommended (Boyd et al. 1989). The current investigations consisted of site mapping and detailed recording of the rock art. The single panel of aboriginal petroglyphs and the associated recent vandalism were recorded. Several of the recent additions are superimposed over the aboriginal petroglyphs.

\section{DISCUSSION OF ROCK ART}

The petroglyphs are incised within a $1.5 \times 2-\mathrm{m}$ area on the sloping floor of the windworn cavity (Fig. 59a). The aboriginal glyphs are damaged to a minor extent by wind erosion and insect boring, but the majority of the damage is caused by recent vandalism. None of the nonaboriginal elements are considered to have historic significance since no dates are associated and the style and lack of weathering indicate they are of recent origin. With the recent graffiti deleted (Fig. 59b), the aboriginal petroglyphs are clustered into two groups and a single isolated element. The glyphs at the left consist of a horizontal line and numerous (over 65) vertical lines which are incised to different depths or are differentially weathered; they are probably tally marks. Vandalism damage to this group of glyphs is minimal. The second group is faint, probably due to weathering, and severely damaged by vandalism. The glyphs consist of several single lines and two rectangular-bodied human figures with rounded heads. The lines around the uppermost figure may represent a garment. The single isolated element is a deeply incised and weathered cross within a circle.

A few other figures are of questionable origin. The number of recent inscriptions, however, indicates that any questionable elements most likely are recent. Some of the straight linear geometric figures may be recently modified aboriginal elements. It is doubtful that any of the curvilinear figures (e.g., the profile head) are of aboriginal origin.

\section{$\underline{\text { Summary }}$}

The 11 investigated sites consist of three with Plains Biographic Style rock art (Connor and Connor 1971; Keyser 1987) and eight of undefined temporal or cultural affiliation. The Dorward Ranch petroglyphs depict Late Plains Biographic motifs and artistic conventions, while the Ward Petroglyph Site has some Late Plains Biographic images but also contains motifs that may be Early Plains Biographic and/or Ceremonial Style. The pictographs, petroglyphs, and painted petroglyphs at Huddleston Shelter depict historic motifs 

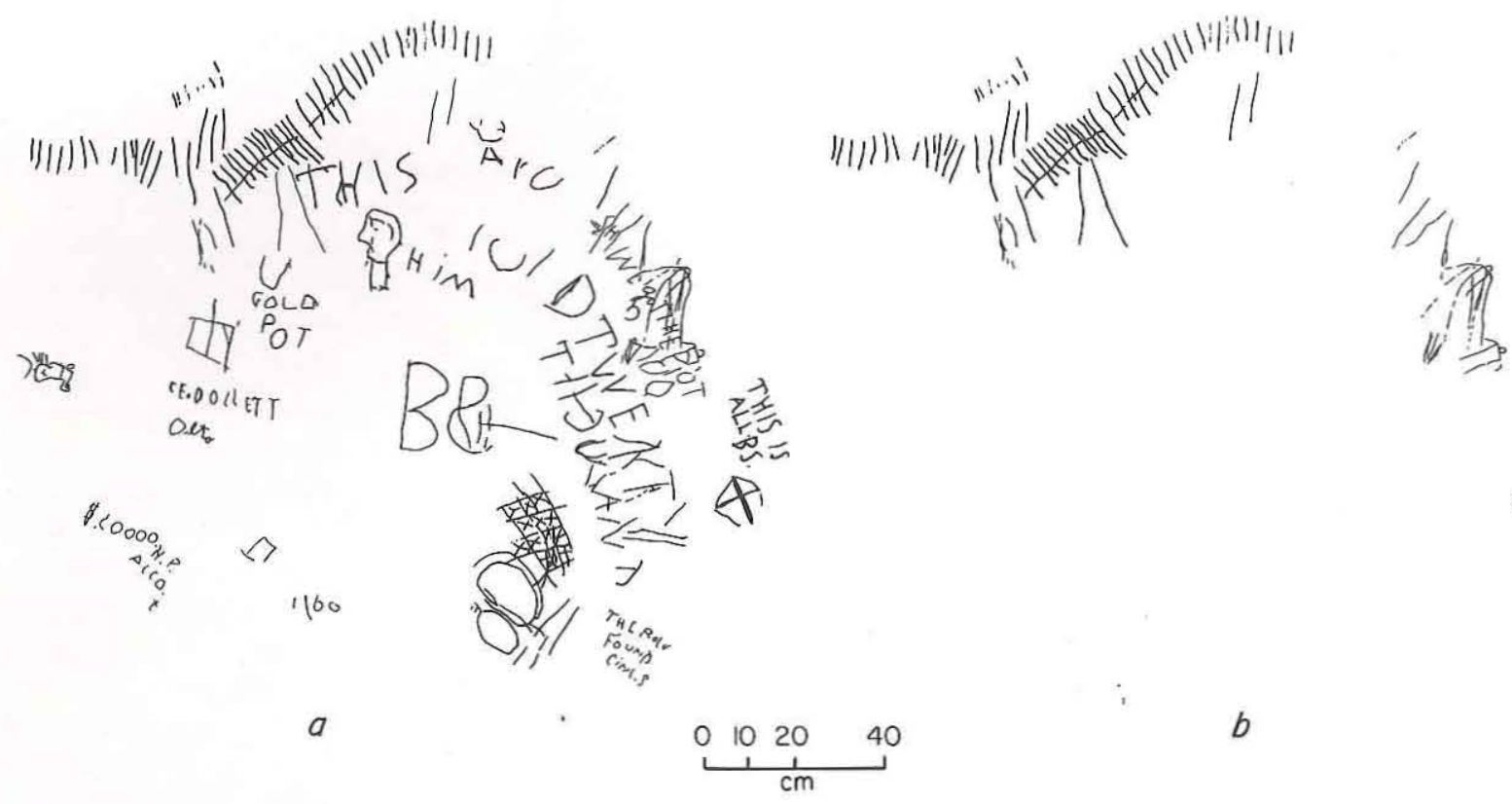

Figure 59. Rock art panel at 41KT68. (a) Aboriginal petroglyphs with recent vandalism; (b) aboriginal petroglyphs with recent vandalism deleted.

which may be in the Early Plains Biographic Style. These three sites are the work of historic Indians but cannot be attributed to specific cultural groups.

The variety of motifs and artistic techniques employed at Huddleston Shelter, including the use of painted petroglyphs, suggests that this panel represents numerous separate depictions by different artists. Conversely, the continuity of motifs and artistic techniques at the Dorward Ranch Site suggests that these images were created by the same group of artists within a short span of time. These petroglyphs are obviously the work of a late Plains Indian group, whereas the Huddleston Shelter art was probably made by an early Plains Indian or even a non-Plains historic Indian group. The Ward Petroglyph Site seems to fall somewhere between the other two sites. The mixture of Late Plains Biographic imagery with Early Plains Biographic or Ceremonial motifs may reflect temporal and/or cultural differences, or it may be the work of a single Plains group in a state of transition.

The rock art at the eight temporally undefined sites cannot be attributed to any defined style. Some similiarities are noted between the shield motif and human figures at 41GR390, 41GR423, and 41KT65 and Ceremonial or Protohistoric Style depictions (Keyser 1987: 45-47), but no definite conclusions can be drawn. The petroglyphs at 4lGR454 are similar in many respects to the Fort Chadbourne type petroglyphs from the Abilene area (Kirkland and Newcomb 1967:166-169), but the significance of this kind of rock art is unknown. Given the limited amount of rock art data that exists for the region (Boyd 1990), further interpretations of these sites cannot yet be supported. 
From a functional perspective, the eight temporally undefined sites cannot be interpreted within a cultural context. It is likely that the symbolism served some religious or social function and that the sites themselves were significant locations, perhaps as social or ceremonial gathering places. Further interpretations would be speculative at best. Conversely, the three sites with Plains Biographic art can be interpreted within a cultural context. Most Plains Indian iconography is biographic in nature. At the simplest level, biographic symbolism tells stories about events in the lives of its creators. At a more significant level, however, a great deal of Plains Indian artistic expression was symbolic of social stratification, an extremely important facet of their society. A person of high stature exhibited his importance through decorative costumes and headdresses, horse accoutrements, painted tipi covers, and many other media. Rock art functioned in a similar manner and probably took on an additional level of significance. While most of the biographic art, such as paintings on tipi covers, was available for the entire community to view, rock art locations are often isolated and were probably meant to be viewed by select. groups. It has been suggested that some Plains Indian rock art sites were ceremonial locations where stories of counting coup or tribal events were told (Parsons 1987). It is likely that the Plains Indian rock art at Justiceburg functioned in this capacity and that the locations had some special significance (e.g., sacred areas) to the artists. 
CHAPTER 8

\section{SUMMARY AND CONCLUSIONS}

by Douglas K. Boyd and Steve A. Tomka

The Phase I investigation at Justiceburg Reservoir initiated the geoarcheological study of the project area, located and documented 375 archeological sites (including 45 isolated finds), and conducted historic archival/informant research. Two hundred thirtyeight sites judged to be potentially eligible for listing on the National Register of Historic Places were considered to warrant further work. The Phase II investigations reported here continued the integrated studies of geoarcheology, archeological sites, and historic resources. The geoarcheological investigations included mechanical testing to provide geomorphic and archeological data and interpretations. Sixty-seven archeological sites (51 prehistoric, 11 rock art, and 5 historic) were investigated; 37 are firstpriority sites which were intensively tested or documented to provide full National Register assessments, and 30 are second-priority sites investigated at various levels of intensity (see Chapter 3). The historical investigations are discussed in a separate report (Freeman and Boyd 1990). This chapter provides a summary of the geoarcheological study and of the investigations at prehistoric and aboriginal sites. It also provides an assessment of the various technical studies employed during the course of these investigations and presents a synthetic prehistoric chronology for the project area. The chapter closes with an explication of a model of late Holocene human adaptations for the project area; this model is intended to provide contextual data for the site assessments (see Chapter 9) and to guide future archeological investigations at Justiceburg Reservoir.

\section{Geoarcheological Investigations}

The Phase II geoarcheological study conducted by Abbott (Chapter 4) involved backhoe testing with two primary goals, to obtain data to develop a geomorphic history of the project area and to search for buried archeological remains, particularly in the reservoir construction zones. Subsurface testing in four topographically distinct sections of the project area--the upper reservoir, the canyon-confined segment, the lower reservoir, and the uplands--revealed different sets of depositional processes. The upland sediments are characterized as remnant alluvial fan deposits shed off the retreating Caprock Escarpment and which have been reworked by slopewash and eolian action. Conversely, the sediments within the valley are characterized as a complex mix of alluvial and colluvial deposits controlled by local topography.

The data recovered support a tentative geomorphic history of the project area. The sequence of depositional/climatic events proposed for the project area consists of four broad periods: (1) slow to moderate alluviation and soil formation in the late Pleistocene and early Holocene; (2) catastrophic stripping of sediments in the early to middle Holocene; (3) rapid to moderate sedimentation in the late Holocene; and (4) incision followed by relative stability and alluvial fan development within the last 1,000 years. This scenario partly explains the skewed archeological record observed at Justiceburg Reservoir, i.e., the abundance of late Archaic and Late Prehistoric sites and the apparent lack of late Pleistocene to middle Holocene sites. Similarly biased archeological records have 
been observed elsewhere in the region, and Abbott's proposed geomorphic sequence may be applicable as a model for fluvial systems thoughout the Lower Plains.

The mechanical search for buried archeological remains located only two previously unknown sites (41GR569 and 41KT151). It is somewhat surprising that no buried archeological remains were encountered in the large floodplains at the mouths of Grape and South Sage creeks, but this lack of sites may be due to the fact that these floodplain deposits represent rapid accumulations rather than slow aggradation and thus are not particularly favorable contexts for the occurrence of substantial archeological sites.

\section{Site Investigations}

The Phase II investigations included the initial discovery and recording of 6 new sites (5 prehistoric and 1 historic), bringing the total number of sites in the project area to 381 (280 prehistoric/aboriginal sites, 13 mixed historic nonaboriginal and prehistoric/aboriginal sites, 18 historic nonaboriginal sites, and 70 , aboriginal and/or nonaboriginal rock art sites). Various levels of investigation conducted at 61 of these, including open campsites, lithic procurement sites, rockshelters, faunal localities, and rock art sites, provided the data for the interpretations offered in this chapter.

\section{Campsites}

The work at 33 prehistoric campsites defined 7 single-component sites with Archaic occupations, 6 single-component sites with Late Prehistoric occupations, 8 multicomponent sites with Archaic and Late Prehistoric occupations, and 12 single-component sites with temporally undefined occupations (Table 60 ). Of the 41 recognized components, 20 are further defined chronologically: 9 are late Archaic (ca. 4500-2000 B.P.), 6 are Late Prehistoric I (ca. 2000-1000 B.P.), and 5 are Late Prehistoric II (ca. 1000 B.P. to European contact).

The feature and artifact data recovered from these sites constitute the bulk of the information on the prehistoric inhabitants of the project area. Subsurface cultural features investigated at 18 of these sites are predominantly burned rock concentrations and scatters but also include unburned rock clusters or cairns of unknown function, a burned post, ceramic clusters, and bedrock mortar holes (Table 61).

Burned rock features are presumed to be related to food processing and consist of slab-lined and unlined hearths of various shapes and sizes, burned rock clusters which probably represent displaced hearths, and clusters of intensively fire cracked rocks which appear to be dumps. The latter may reflect stone boiling or baking pit activities. Firecracked rock features (see Table 61) and scattered fire-cracked rocks (see Appendix D) generally are absent from Late Prehistoric II sites, perhaps indicating a reduction in stone boiling/baking activities.

Bedrock mortar holes are fairly common in the project area, but only two were investigated. Features 11 and 12 at 41 GR456 are typical of the pointed-oval bedrock mortars in the region, and a sandstone pestle was recovered from inside Feature 12 . A second 
TABLE 60

SUMMARY OF TEMPORAL ASSESSMENTS OF PREHISTORIC CAMPSITES

\begin{tabular}{llll}
\hline Site & Temporal Assignment & Site & Temporal Assignment \\
& & & \\
41GR207 & Archaic & & \\
41GR239 & Unknown & $41 G R 471$ & Late Archaic/Late Prehistoric I \\
41GR286 & Unknown & $41 G R 474$ & Late Prehistoric \\
41GR287 & Late Archaic & 41 GR483 & Unknown \\
41GR291* & Late Prehistoric I & 41 GR484 & Late Prehistoric II \\
41GR302 & Unknown & 41 GR515* & Late Archaic \\
41GR303 & Late Archaic/Late Prehistoric I & 41 GR569 & Unknown \\
41GR323* & Late Prehistoric II & $41 \mathrm{KT} 33$ & Late Archaic \\
41GR359* & Archaic/Late Prehistoric & $41 \mathrm{KT} 34 *$ & Late Archaic/Late Prehistoric I \\
41GR374 & Unknown & $41 \mathrm{KT} 47$ & Unknown \\
41GR376* & Archaic & $41 \mathrm{KT} 49 *$ & Archaic \\
41GR378 & Unknown & $41 \mathrm{KT} 51$ & Late Prehistoric II \\
41GR380 & Unknown & $41 \mathrm{KT} 52 *$ & Late Archaic/Late Prehistoric II \\
41GR383* & Late Archaic/Late Prehistoric I & $41 \mathrm{KT} 53 *$ & Late Archaic/Late Prehistoric II \\
41GR393 & Unknown & $41 \mathrm{KT} 148$ & Unknown \\
41GR456* & Archaic/Late Prehistoric & $41 \mathrm{KT} 151$ & Archaic \\
41GR467 & Late Prehistoric I & & \\
& & & \\
*First-priority site. & & \\
& & &
\end{tabular}

sandstone pestle was surface-collected from 41 GR471 but was not associated with any mortar holes. While bedrock mortars have long been presumed to be associated with plant processing, there is little conclusive evidence for this interpretation. Organic residues were recovered from the two pestles but are of indeterminate origin. Phytoliths recovered from a scraping off a wall of Feature 12 include a variety of classes, but it is difficult to interpret this evidence.

The artifacts recovered from prehistoric campsites consist of 3,264 lithic specimens and 123 ceramic sherds (Table 62, see Appendix D). A range of activities is represented by the various artifact types. Stone tool manufacture is indicated by the unmodified debitage, cores, and hammerstones, and many bifaces represent preforms or manufacturing failures. The arrow points and dart points are probably related to hunting, while ground stones are generally considered to be indicative of plant processing. Several types of tools, such as cobble tools, bifaces, unifaces, and edge-modified expedient tools, can serve a variety of purposes such as plant food procurement and processing, butchering of animals, hide processing, etc. The functions and variability of these tool types are not well defined, however, because of the limited sample sizes. Ceramics are generally considered to be related to food storage or preparation, but the nonlocal trade wares, especially the decorated vessels, may have functioned in some nonutilitarian capacity; however, a pendant made of kaolinite is the only specimen that definitely reveals a nonutilitarian function. 
TABLE 61

SUBSURFACE FEATURES AT PREHISTORIC CAMPSITES

\begin{tabular}{|c|c|c|c|c|c|c|c|c|c|c|c|}
\hline \multirow{2}{*}{\multicolumn{2}{|c|}{ Site }} & \multicolumn{5}{|c|}{ Burned Rock Features } & \multicolumn{5}{|c|}{ Other Features } \\
\hline & & $\begin{array}{l}\text { Fire-Cracked } \\
\text { Rock Dump }\end{array}$ & $\begin{array}{l}\text { Unlined } \\
\text { Basin } \\
\text { Hearth }\end{array}$ & $\begin{array}{l}\text { Small } \\
\text { Slab-lined } \\
\text { Hearth }\end{array}$ & $\begin{array}{l}\text { Large } \\
\text { Slab-lined } \\
\text { Hearth* }\end{array}$ & $\begin{array}{l}\text { Burned Rock } \\
\text { Cluster }\end{array}$ & $\begin{array}{l}\text { Rock Cluster } \\
\text { or Cairn }\end{array}$ & $\begin{array}{l}\text { Burned } \\
\text { Post }\end{array}$ & $\begin{array}{l}\text { Charcoal/ } \\
\text { Ash Stain }\end{array}$ & $\begin{array}{l}\text { Ceramic } \\
\text { Cluster }\end{array}$ & $\begin{array}{l}\text { Bedrock } \\
\text { Mortar } \\
\text { Holes }\end{array}$ \\
\hline 41GR287 & & 1 & - & 1 & - & - & - & - & - & - & - \\
\hline 41GR291 & & - & - & - & 1 & - & - & - & - & - & - \\
\hline 41GR302 & & - & - & - & - & 1 & - & - & - & - & - \\
\hline 41GR303 & & - & - & 3 & 1 & 2 & 2 & - & - & - & - \\
\hline 41GR323 & & - & - & - & - & 3 & - & - & - & - & - \\
\hline 41GR359 & & - & - & 1 & 1 & - & - & - & - & - & - \\
\hline 41GR376 & & - & - & - & 1 & - & - & - & - & - & - \\
\hline 41GR380 & & 1 & - & - & - & - & - & - & - & - & 1 \\
\hline 41GR383 & & - & - & - & - & 2 & - & - & - & - & 3 \\
\hline 41GR456 & & - & - & 2 & 2 & 1 & - & - & 1 & - & 2 \\
\hline 41GR471 & & - & - & - & 1 & - & - & - & - & - & - \\
\hline $41 \mathrm{GR} 484$ & & - & - & 1 & 1 & - & - & - & - & - & - \\
\hline 41GR515 & & - & - & - & 2 & - & - & - & - & - & - \\
\hline 41KT33 & & 1 & - & - & 1 & - & - & - & - & - & - \\
\hline 41KT34 & & - & - & - & - & 1 & 1 & - & - & - & - \\
\hline $\begin{array}{l}41 \mathrm{KT} 49 \\
41 \mathrm{KT} 52\end{array}$ & & - & - & 1 & 1 & 3 & - & - & - & - & - \\
\hline $\begin{array}{l}\text { Lower } \\
41 \text { KT53 }\end{array}$ & Component & - & - & - & 1 & - & - & - & 1 & - & - \\
\hline $\begin{array}{l}\text { Upper } \\
\text { 41KT53 }\end{array}$ & Component & - & 1 & - & - & - & - & 1 & 1 & 2 & - \\
\hline Lower & Component & $=$ & $=$ & $=$ & 1 & $=$ & $=$ & $=$ & $=$ & $=$ & $=$ \\
\hline Totals: & & 3 & 1 & 9 & 14 & 13 & 3 & 1 & 3 & 2 & 6 \\
\hline
\end{tabular}

*Over $75 \mathrm{~cm}$ in diameter or maximum dimension. 
TABLE 62

SUMMARY OF ARTIFACTS RECOVERED FROM PREHISTORIC CAMPSITES

Artifact Type

Arrow Points

Dart Points

Bifaces*

Cobble Tools

Unifaces

Cores

Edge-modified Debitage

Unmodified Debitage

Hammerstones

Ground Stones

Pendant Fragment

Ceramics

Total:
No. of Specimens

*Includes one drill or perforator.

The lithic materials at campsites consist of $90.5 \%$ materials derived locally from the Lingos gravels, $6.3 \%$ nonlocal materials, and $3.2 \%$ materials of unknown origin (Table 63). Some chipped stone artifact types, such as projectile points and other bifaces, are predominantly of fine-grained cherts and nonlocal lithics, while other artifacts, such as cobble tools and hammerstones, are consistently of coarser-grained materials (i.e., Potter chert and quartzites).

Projectile points are not abundant in the project area and tend to be concentrated in a few sites. Whether this reflects temporal or functional variability (or both) is not clear. Most of the arrow and dart points are broken, representing both use breakage (i.e., impact fractures) and manufacturing failures. Recognizable point styles are rare. of the 12 arrow points, 4 are classified to type (1 Deadman's, 2 Granbury, and 1 Scallorn), while only 1 of the 11 dart points is typed (Marcos) (Suhm and Jelks 1962). Within the existing Lower Plains cultural chronology, only one of these point styles is indicative of cultural affiliation; the Deadman's point is generally associated with the Palo Duro Complex. Granbury and Scallorn arrow points are indicative of the Austin Phase (ca. 1250-650 B.P.), and Marcos dart points are associated with the Uvalde Phase (ca. 2250-1800 B.P.) in Central Texas (Prewitt 1981:81-83, 1985:Figure 5), but these phases probably are not applicable in the Lower Plains.

Bifacial artifacts include some finished tools, such as a drill (or perforator) and probable cutting tools, but the majority represent various stages of manufacture (e.g., complete preforms or manufacturing failures). Bifaces are predominantly of fine-grained, high-quality chert, and over $30 \%$ exhibit evidence of heat-treating. Cobble tools are made almost exclusively of Potter chert and quartzite, and over $80 \%$ have one or more edges 
TABLE 63

LITHIC MATERIAL TYPES REPRESENTED AMONG THE CHIPPED, GROUND, AND BATTERED STONES AT PREHISTORIC CAMPSITES

Material Type

No. of Specimens

Local Materials:

Potter Chert 672

Fine-grained Chert

1,679

Coarse-grained Chert

Quartz/Quartzite (includes Ogallala quartzite,

unidentified quartzites, and milk white quartzite)

Opalized Caliche

Silicified Caliche

Silicified Wood

10

Sandstone

Subtotal:

Nonlocal Materials:

Alibates Agate

Tecovas Jasper

Cretaceous Chert

Subtotal:

Materials of Unknown Origin:

Miscellaneous Unidentified

Conglomerate Quartzite

33

Basalt

Subtotal:

exhibiting step fracturing and/or edge rounding. This distinctive use-wear patterning apparently resulted from chopping/cutting materials of different types and hardnesses.

Unifaces consist, in decreasing frequency, of end scrapers, side scrapers, combination end/side scrapers, and gouges. The scrapers tend to be made of fine-grained chert. Such tools typically are considered to have been used in processing hide and meat, an interpretation that is supported by microwear analysis of a sample of the scrapers in this collection (see Appendix E). Other unifacial artifacts include a few flake cutting tools, unidentified fragments, and rejuvenation fragments. The latter provide evidence diagnostic of resharpening and maintaining unifacial tools. 
Gouges, including the triangular Clear Fork type tools, are made of coarse-grained materials (mainly Potter chert) which do not exhibit use-wear patterns well. The use of hard and durable lithic materials for making gouges reflects a pattern of intentional selection which is probably related to the function of the tools. Gouges are a diagnostic tool of the late Archaic Summers Complex in southwestern Oklahoma (Leonhardy 1966:30-32) and may be associated with the middle Archaic occupation at the Gore Pit Site (Hammatt 1976:255). They are fairly common throughout the Lower Plains and in Central and South Texas, although they are not well understood functionally (Boyd 1989c). Clear Fork tools in South Texas are thought to have functioned as woodworking tools (Hester et al. 1973), but this assessment may not be applicable for gouges in Central Texas and the Lower Plains. Microwear analysis of one Justiceburg specimen identified no visible wear (probably because resharpening had obliterated the bit edge), but a second specimen was apparently used as a hide-scraping tool (see Appendix E). The function of this tool type in the project region remains in question but may be resolved through complementary organic residue and use-wear analyses (see discussion in this chapter).

The cores recovered indicate a heavy reliance on the Lingos gravel materials since all but three specimens are of local materials (two are Tecovas jasper and one is Cretaceous chert). Approximately 25\% of the cores exhibit evidence of heat treating, and the majority of these are Potter chert. Most specimens are flake cores, but a few smaller ones were reduced by bipolar techniques.

The majority of the edge-modified flakes exhibit use-wear patterns indicative of scraping tasks, but cutting and sawing are also represented. Minimal evidence of graving and boring is present. Microwear analysis of two Justiceburg specimens indicates that they functioned as drilling or graving tools (see Appendix E). A tentative correlation between function and material type is evident. Coarse-grained materials appear to have been preferred for cutting/sawing tasks, while fine-grained materials were used mainly for scraping. Edge-modified flakes represent expedient tools; most are complete and apparently were discarded after use, although some are fragments and may reflect use breakage.

Lithic debitage and hammerstones are indicative of stone tool manufacture. The unmodified debitage recovered from the campsites is heavily dominated by locally available materials; only ca. $7 \%$ is of nonlocal origin (Cretaceous chert and Tecovas jasper). All of the hammerstones are of local quartzite except for one specimen of basalt, which may also be available in the local gravels.

The collection of ground stones from campsites consists of quartzite manos and mano/ hammerstones and sandstone manos, metates, and pestles. The quartzite tools appear to be grinders/crushers used to process plants and/or meat, as well as bone or other hard materials. The sandstone tools reveal processing of soft materials, most likely plants. The two sandstone pestles recovered from campsites constitute the only documented examples of pestles associated with pointed-oval bedrock mortar holes. One specimen was found inside a bedrock mortar hole (Feature 12) at 41GR456, and the second specimen was surface collected from 41GR471. These tools exhibit evidence of intentional shaping and distinctive use-wear patterns.

The ceramics recovered from the campsites are classified into six types. Type I, identified as Pecos Glaze Polychrome V, was apparently manufactured at Pecos Pueblo ca. A.D. 1600-1700, and Type II, identified as probable Pecos Faint Striated, may have been made there at about the same time (Warren 1987). Two partial vessels, a Type I bowl and a 
Type II jar, were reconstructed from sherd concentrations (Features 5 and 6) excavated at 41KT53. Types III, V, and VI are unidentified types contemporaneous with Types I and II. Type IV is also unidentified but is similar to the Jornado Mogollon plainwares of southern New Mexico and western Texas, e.g., Jornado Brown, El Paso Brown, Roswell Brown, and Alma Plain. Jornado Brownware dates to ca. A.D. 900 and later, but its ancestral form, Alma Plain, dates much earlier (Jelinek 1967:47-49; Runyan and Hedrick 1987: 26-30). Sherds similar to the Jornado Brown or Alma Plain types were recovered from strata dating to A.D. 120 and A.D. 210 at the Deadman's Shelter Site in the Texas Panhandle.

Lithic Procurement Sites

Investigations at two lithic procurement sites (41GR327 and 41GR381) consisted of sampling the lithic raw materials and the modified lithic materials. These samples demonstrate the variability within the Lingos gravels and some general trends in prehistoric utilization of these materials. The Lingos gravels are part of a widespread deposit resulting from erosion of the Caprock Escarpment. They are lithologically similar and genetically related to the Seymour gravels in Knox and King counties and presumably to all of the upland gravel deposits throughout the Lower Plains, although local variability is expected. The gravels are dominated by quartzites and Potter chert, which were the preferred materials for some types of tools and probably for use as boiling or baking stones. They are not well suited, however, for some kinds of tools, such as projectile points and scrapers. Coarse- and fine-grained cherts are represented in the gravels and were selectively utilized, but cobbles of the fine-grained materials tend to be relatively small. Cretaceous cherts are found in minor quantities in the Lingos gravels, but specimens similar in quality to the Central Texas Cretaceous cherts were not observed. The recognition of local vs. nonlocal varieties of Cretaceous chert is subjective but is of critical importance to interpreting lithic use patterns.

The 95 artifacts recovered from the two lithic procurement sites include 52 pieces of unmodified lithic debitage (the majority being primary and secondary flakes), 9 hammerstones, and 9 cores. Early-stage lithic reduction is documented by these artifacts. Biface preforms and manufacturing failures are indicative of stone tool manufacture. Minor activities are probably represented by the few other tool types recovered (unifaces, edgemodified flakes, cobble tools, and ground stones).

Both of the lithic procurement sites are isolated with no intensively occupied campsites nearby, although ephemeral hearths noted at these two sites provide minimal evidence of camping. They apparently functioned mainly as source areas where materials were selected and reduced to transportable sizes, with the materials then being carried back to campsites to be manufactured into finished tools. The early stages of lithic reduction are well represented at the procurement sites, and the late stages of lithic reduction are dominant in campsites.

Rockshelters

Investigations at two rockshelters (41GR546 and 41GR559) revealed ca. 1-m-thick stratified deposits indicating intermittent occupations during the Late Prehistoric period. 
No diagnostic artifacts were recovered, so it is difficult to associate these occupations with those at the prehistoric campsites. These small rockshelters were not intensively occupied and may have functioned as temporary shelters for small groups.

Cultural materials recovered from the rockshelters include 2 hammerstones, 1 core, 28 unmodified flakes, 17 microflakes, and scattered burned rocks. A wide range of macrobotanical and faunal remains recovered from flotation samples probably represent a combination of culturally and naturally introduced materials. Rodent activity, evidenced by wood rat and gopher bones and burrows, may account for some of the macrobotanical remains. Wood rats frequently inhabit rockshelters and are notorious collectors. Differentiating between natural and cultural plant remains in such a context is difficult, but comparative analysis of flotation samples from feature and nonfeature contexts may provide some interpretive clues.

Faunal remains recovered consist of 292 bones and bone fragments and also reflect natural and cultural activities. Canine teeth marks were noted on some bone fragments, indicating that carnivores are responsible for some of the assemblage. On the other hand, burned bones and butcher marks indicate cultural influences. Animals that were apparently culturally introduced and that'probably represent food resources include medium mammal (burned fragments and possible deer bones with butcher marks), canid (possible wolf/dog bones with butcher marks), snake, small mammal, and rodent (burned fragments). The preservation of perishable materials such as bones and macrobotanical remains is much greater in these rockshelters than in the open campsites. The interpretive potential is correspondingly increased, especially in regard to subsistence and functional data.

All along the Caprock Escarpment, rockshelters occur immediately below the Ogallala caprock caliche or the Triassic Dockum Group sandstones. Both of these formations are erosion resistant and are underlain by softer sediments which have been eroded to form the rockshelters. Such overhangs and rockshelters are rapidly formed and destroyed as escarpments and canyon walls retreat. Simpkins and Gustavson (1987:33) present a model of escarpment retreat for the Ogallala caliche-capped Caprock Escarpment. The model is applicable to Triassic exposures throughout the Lower Plains region since Gustavson and Simpkins.(1989:29-31) describe similar processes which affect the Triassic Dockum Group formations.

The formation of rockshelters in Triassic Dockum Group sediments involves a few very simple processes. Erosion of the softer mudstones undercuts the hard sandstone layers to form overhanging ledges. The erosion can be fluvial from surface runoff, eolian, or a combination of both, but spring sapping and seepage erosion below the Dockum sandstones is an even more significant factor (Gustavson and Simpkins 1989:29). If the erosion is rapid enough, it can scour out larger areas to form rockshelters. The weight of the unsupported sandstone ledges then causes tension cracks, and eventually mass wastage occurs leaving blocks of sandstone scattered downslope as talus debris. The process of rockshelter formation in the Triassic sediments (and in the Ogallala Formation of the Caprock Escarpment) cannot go on indefinitely, and the shelter must eventually collapse after reaching its maximum size limit. Rockshelters along the Caprock Escarpment and elsewhere in the Lower Plains region are relatively small due to the nature of the sediments and erosion process. They are never as large as rockshelters formed in the Cretaceous limestones of Central or West Texas. 
The archeological implication of these processes is that rockshelters along the Caprock Escarpment and in the Lower Plains are created and destroyed very quickly, and hence the extant shelters are very recent and their deposits are likely to date only to the late Holocene. In fact, archeological investigations of rockshelters in the region reveal a lack of late Pleistocene and early Holocene deposits. In the Justiceburg project area, the three archeologically investigated rockshelters- 41GR54 (Reed Shelter), 41GR546, and 41GR559--contain only Late Prehistoric occupations. Rockshelters of any antiquity were probably destroyed long ago, and it would be rare indeed to find any substantial Paleoindian or Archaic deposits in a rockshelter in the region. In addition, the relatively small size of the shelters would preclude occupations by large numbers of people. The archeological evidence seems to support an interpretation of repeated but ephemeral occupations by small groups.

Faunal Localities

The eight faunal localities tested produced a considerable amount of environmental data but were disappointing from a cultural standpoint (Table 64). Cultural evidence was recovered at only four sites and consists of burned bones, butcher marks, and flake scars at 41GR310; a core (from a 1987 shovel test) and a heat-shattered flake recovered from 41GR512; a flake tool and butcher marks at 41KT44; and a green bone fracture and multiple animals at 41KT69, Area A. The lack of cultural evidence at the other four sites does not preclude the possiblility of human association. Testing apparently removed all of the materials from these eight sites.

TABLE 64

SUMMARY OF FAUNAL LOCALITIES

\begin{tabular}{|c|c|c|c|}
\hline Site & Animals Represented & $\begin{array}{l}\text { Corrected } \\
\text { Radiocarbon Age }\end{array}$ & Interpretation \\
\hline 41GR249 & 1 bison, male $5-6$ years & $90 \pm 115$ B.P. & Natural death \\
\hline 41GR2 70 & 1 bison, male 5-6 years & $70 \pm 110$ B.P. & Natural death \\
\hline 41GR310 & bison, indeterminate & -- & Processing station \\
\hline $41 G R 488$ & 1 bison, male $10-11$ years & $<200$ B.P. & Natural death \\
\hline 41GR512 & 1 bison, indeterminate & - & Processing station \\
\hline 41GR539 & 1 bison, male $6+$ years & $205 \pm 75$ B.P. & Natural death \\
\hline $41 \mathrm{KT} 44$ & 1 bison, male $10-11$ years & $375 \pm 115$ B.P. & Processing station \\
\hline \multirow[t]{2}{*}{$41 \mathrm{KT} 69 \mathrm{~A}$} & 1 immature bison/1 mature & & \\
\hline & bison/1 small mammal & $<200$ B.P. & Processing station \\
\hline $41 \mathrm{KT} 69 \mathrm{~B}$ & 1 bison, male & $<200$ B.P. & Natural death \\
\hline
\end{tabular}

Bison bones were recovered at all of the sites, and seven probably contain individual animals. Nonbison remains were also recovered at 4lKT69. Of the single bison, at least five, and possibly seven, are mature to old (5-11 years) males. These sites apparently 
represent natural deaths or hunting/processing episodes involving isolated males, which are known to roam solitary during much of the year. Seven radiocarbon-dated bison bone samples from the faunal localities provide paleoenvironmental evidence in the form of carbon isotope data (see Paleoenvironmental Studies below).

Rock Art Sites

Only 3 of the 11 rock art sites investigated contain stylistically recognizable motifs and can be assigned to a temporal period. These sites--41GR51, 41GR282, and 41GR344-contain Plains Biographic Style historic aboriginal art and probably functioned as social or ceremonial gathering places. Plains Indian biographic rock art may have served as a visual aid to facilitate story-telling related to status and coup counting.

Eight of the rock art sites (41GR390, 41GR423, 41GR426, 41GR437, 41GR472, 41GR494, $41 \mathrm{KT} 65$, and 41KT68) cannot be temporally or stylistically classified. Petroglyph and pictograph techniques were utilized at these sites, and the motifs represented include stylized rectangular-bodied human figures, a handprint, tally marks, and geometric designs. The function of this rock art is not known, although it is speculated that some images are ceremonial/religious in nature while others may have had a purely practical function. The images are presumed to be relatively recent since it is likely that rock art cannot survive long on rapidly eroding sandstone. There is no chronological evidence to support this assumption, however. The only potential for dating these sites lies in radiocarbon dating of the organic components (binders) of pictograph pigments, or possibly relative or chronometric dating of associated rock art tools.

\title{
Assessment of Technical Studies
}

The diversity of the prehistoric archeological evidence obtained required a wide range of analytical approaches to aid in interpretation. Various specialized techniques were employed to extract specific kinds of data. The following discussion evaluates the methods and results of the various technical studies.

\author{
Magnetometer Survey
}

Magnetometer surveys conducted at 41 GR 323 and 41 KT53 were designed to test the utility of magnetic prospection for locating buried archeological features in different settings (see Appendix B). The results were encouraging at 41KT53, where a good correlation between specific types of discrete magnetic anomalies and cultural features was found. Testing of several small dipole anomalies revealed that they were caused by cultural features (an unlined basin hearth, a burned post, and ceramic concentrations). In this particular case, the effectiveness of site testing was enhanced greatly by the magnetic data. A comparable level of random or systematic testing almost certainly would have missed the cultural features at this site. 
The magnetic survey at 41GR323 was less productive. No discrete anomalies (such as those caused by cultural features at 41KT53) were observed, and it was determined that the magnetic variability detected at this site was due primarily to subsurface stratigraphy. Most cultural features would not be detectable in such a setting because small cultural anomalies would be obscured by the larger anomalies caused by underlying sediment changes. These surveys indicate that magnetic prospection is a useful technique in certain settings but that its utility is controlled by local conditions. Far too many variables are involved in most cases to accurately predict settings where a magnetometer survey would be productive. With regard to magnetic surveying, "one can never really be certain of its feasibility, to be sure, until a survey is attempted" (Breiner 1973:47).

\section{Chronometric Dating}

Radiocarbon and thermoluminescence dating were employed to provide absolute chronological controls. Forty-one radiocarbon dates (26 humate, 7 bone, and 8 charcoal) and 20 thermoluminescence dates ( 2 ceramic and 18 burned chert and sandstone) have been obtained to date (see Appendix $\mathrm{C}$ ). The radiocarbon assays were conducted by two labs, the Radiocarbon Dating Laboratory at The University of Texas at Austin and Geochron Laboratories Division of Krueger Enterprises, Inc., Cambridge, Massachusetts. The thermoluminescence assays were conducted by the TL Laboratory, Department of Archaeology, University of Durham, England.

When possible, thermoluminescence and radiocarbon dating were employed on associated samples (e.g., from a single feature) to provide comparisons of the dating techniques. Of 11 attempts at pairing samples, however, only 4 obtained satisfactory results. These four paired sets of dates, along with a few thermoluminescence dates associated with accurately dated cultural occupations, provide a basis for evaluating the utility of the dating techniques as they were applied to this project.

The charcoal radiocarbon dates appear to be accurate and produced results consistent with the archeological (i.e., cultural stratigraphic and typological) evidence. The humate radiocarbon dates also appear to be in general agreement with the archeological evidence, although it is acknowledged that they most likely represent minimum ages. Radiocarbon dates derived from soil organic fractions have some inherent problems (Taylor 1987:62) and are generally considered less reliable than dates derived from charcoal.

Thermoluminescence dating of ceramics (from the upper component at 41KT53) produced dates that correspond well with the other chronological evidence (i.e., charcoal radiocarbon dates and ceramic typology). This general agreement suggests that ceramic thermoluminescence dating can yield reliable results which increase the interpretability of the Justiceburg archeological data. Conversely, thermoluminescence dating of burned rocks produced ambiguous results which are difficult to interpret. A set of paired dates--a charcoal radiocarbon and a burned rock thermoluminescence date--from a burned rock feature (Feature 3 at rockshelter 41GR559) produced somewhat consistent results (279 years difference), while several sets of paired humate radiocarbon and burned rock thermoluminescence dates disagreed substantially, with the latter being ca. 1,500 to 5,000 years older. In addition, the remaining (i.e., unpaired) burned rock thermoluminescence dates are generally older than expected based on temporally diagnostic cultural materials and geomorphic settings. The discrepancies between the dates on paired samples of burned rocks and 
humates (i.e., the thermoluminescence dates being consistently older) cannot yet be satisfactorily explained, but two possibilities bear examination.

The first is that the thermoluminescence dates are relatively accurate, and it is the humate radiocarbon dates that have a higher margin of error than expected. A variety of complex factors affect radiocarbon assays of soil organic fractions (Taylor 1987:62), but past experience suggests that humate date errors do not account for the discrepancies in the Justiceburg samples. The second possibility is that the thermoluminescence dates exhibit the higher degree of error. Given the current state of knowledge relating to both techniques, it is most likely a combination of these factors which caused the discrepancies, but it is suggested that the highest margin of error lies with the thermoluminescence dates for a variety of reasons.

If in fact the thermoluminescence dates are in error (i.e., much too old), then the problem is most likely related to the thermoluminescence dating technique. The technique is relatively new as it is applied to burned rocks, and there is an acknowledged lack of data available for demonstrating and assessing its utility on a wide variety of materials (Dr. Ian Bailiff, personal communication 1989). From Justiceburg, 15 sanđastone and 3 chert samples did yield dates, but a single limestone sample could not be dated. In addition, five samples of sandstone could not be dated due to suspected insufficient heating, and two sandstone samples had poor thermoluminescence material characteristics. These factors suggest that the main source of error when dating burned rocks could be technical problems with the technique. If the burned rocks are not heated sufficiently and the currently employed techniques are unable to recognize insufficient heating in all cases, then it would be impossible to identify specimens which should not be dated. The resulting dates would therefore be too old, which is the phenomenon observed in the Justiceburg sample. The dating technique depends upon a complete release of all stored thermoluminescence energy, known as zeroing, when a specimen is heated. Zeroing of energy occurs at different temperatures for different materials (Aitken 1985:9), but most silicate materials require heating to $400-500{ }^{\circ} \mathrm{C}\left(752-932{ }^{\circ} \mathrm{F}\right)$, which is at the upper end of the range of temperatures expected for open fires. It is likely that temperature of $400-500{ }^{\circ} \mathrm{C}$ or higher are reached only in the central portion of most open campfires, while the outer edges of a campfire would never be as hot. Hearthstones would be differentially heated depending upon their relative positions within the feature, but it is also probable that there is differential heating within individual hearthstones. Aitken (1985:9) acknowledges a problem with poorly fired samples which are not fully zeroed but suggests that this can be detected. If, however, insufficient heating is not readily detectable during the assay, then the resulting dates would be too old since the measurement would include some degree of contamination from previously stored energy.

While it is likely that the most significant portion of the discrepancies between the burned rock thermoluminescence and humate radiocarbon dates is due to problems with one or both of the dating techniques, some degree of error may be culturally and/or archeologically introduced. An example of culturally introduced errors is recycling of hearthstones. Burned rocks from older occupations were often recycled and incorporated into later features. They may be either insufficiently reheated or not reheated at all, but in both cases the resulting thermoluminescence dates would be too old and would partially or wholly reflect earlier heating episodes. Other problems are undoubtedly created by existing archeological biases or sampling strategies. It is much more tempting to declare the thermoluminescence dates in error when they do not match the archeological expectations than it is to question the expectations. For example, based on very limited evidence, the 
archeological expectation might be that a burned rock sample is associated with a single, young component when it is actually from a mixed cultural deposit. It is also possible that disturbed secondary cultufral deposits are sometimes misinterpreted as being intact primary deposits. If interpreted as such, a burned rock sample might yield a date that is considerably older than expected, but the date itself is correct. Understanding the archeological context of a burned rock sample is crucial to interpreting the dating results.

In summary, the Justiceburg burned rock thermoluminescence dates are thought to reflect a substantial margin of error, the sources of which are not fully understood at present. Unrecognized cultural activities, preconceived archeological expectations, or archeological sampling problems may account for some portion of the perceived errors. It is also probable that some portion, perhaps most, of the errors are due to unresolved technical aspects of the dating method as it is applied to burned rocks. At this point, burned rock thermoluminescence dating should neither be discontinued nor considered reliable. Archeological burned rock samples for dating should be critically selected, and the archeologist should work closely with laboratory technicians to eliminate as many sources of error as possible. Thermoluminescence dating of burned rocks should not be used as the sole chronometric means to date a site and, in fact, should be attempted only in conjunction with other absolute dating methods (such as charcoal or bone radiocarbon dating) to aid in the resolution of these problems.

Paleoenvironmental Studies

The reconstruction of past environments must incorporate multiple lines of evidence, such as geomorphology and faunal and botanical remains from archeological sites as well as from noncultural settings. The paleoenvironmental contributions of the geoarcheological study are summarized above, but three additional kinds of evidence are particularly relevant when considering noncultural settings: pollen, phytolith, and carbon isotope analyses. To provide an assessment of the paleoenvironmental data contained in nonarcheological sediments in the project area, a series of 11 dated sediment samples analyzed for pollen and/or phytoliths are discussed (Table 65, see Appendixes G-I), as are carbon isotope data from dated sediment and bone samples.

Two separate analyses of pollen produced contradictory results. The assessment of pollen preservation by Jones (Appendix H) concluded that pollen is poorly preserved in all but the most recent samples and hence is not worth pursuing to provide paleoenvironmental data. The pollen analysis by Cummings (Appendix I), on the other hand, concluded that pollen preservation is good and that the pollen record is quite diverse, indicating that pollen studies can make substantial contributions to paleoenvironmental reconstruction efforts. These discrepancies are most likely due to methodological differences in extraction techniques rather than real differences in pollen preservation between samples. Paleoenvironmental interpretations based on this limited sample are not warranted, but the presence of suitable pollen in the project area and the utility of the technique have been demonstrated.

The phytolith samples from nonarcheological contexts were analyzed by Cummings (Appendix I). The study concluded that plant phytoliths are well preserved and are useful as paleoenvironmental data. The current sample is too small to define many patterns or 
TABLE 65

NONCULTURAL SEDIMENT SAMPLES USED FOR ASSESSMENT OF PALEOENVIRONMENTAL RECONSTRUCTION POTENTIAL

\begin{tabular}{|c|c|c|c|c|}
\hline \multirow[b]{2}{*}{ Sample No. } & \multirow[b]{2}{*}{ Age B.P. } & \multirow[b]{2}{*}{ Location } & \multicolumn{2}{|c|}{ Analyses } \\
\hline & & & Pollen & Phytolith \\
\hline-- & Modern* & Grape Creek terrace & $\mathrm{J}$ & C \\
\hline GX-14451 & $295 \pm 80 * *$ & Grape Creek terrace & - & $\mathrm{C}$ \\
\hline $\mathrm{Tx}-6230$ & $510 \pm 60$ & Double Mountain Fork terrace & - & $\mathrm{C}$ \\
\hline$T x-6225$ & $770 \pm 110$ & Double Mountain Fork terrace & - & $\mathrm{C}$ \\
\hline $\mathrm{Tx}-6226$ & $1280 \pm 50$ & Grape Creek terrace & - & $\mathrm{C}$ \\
\hline $\mathrm{Tx}-6231$ & $1560 \pm 60$ & Double Mountain Fork terrace & - & C \\
\hline $\mathrm{Tx}-6228$ & $2090 \pm 70$ & Grape Creek terrace & $\mathrm{C}$ & $\mathrm{C}$ \\
\hline $\mathrm{Tx}-6227$ & $2630 \pm 70$ & Grape Creek terrace & $\mathrm{C}$ & $\mathrm{C}$ \\
\hline$T x-6233$ & $10,960 \pm 180$ & Grape Creek terrace & $\mathrm{J}$ & - \\
\hline $\mathrm{Tx}-6232$ & $12,670 \pm 960$ & Grape Creek terrace & $\mathrm{J}$ & - \\
\hline$T x-5796$ & $13,500 \pm 280$ & Grape Creek terrace & - & C \\
\hline \multicolumn{5}{|c|}{$\begin{array}{l}\text { *Sample of modern A horizon sediment from } 41 \mathrm{KT} 53 . \\
\text { **Sediment sample is from below the upper cultural zone at } 41 \mathrm{KT} 53 \text {; date is from charcoal } \\
\text { associated with an intrusive burned post (Feature } 1 \text { ). }\end{array}$} \\
\hline \multicolumn{5}{|c|}{$\begin{array}{l}\text { Note: All radiocarbon ages are dl3C corrected except for } \mathrm{Tx}-5796 . \\
\mathrm{J}=\text { analyzed by John Jones (see Appendix H) } \\
\mathrm{C}=\text { analyzed by Linda Scott Cummings (see Appendix I). }\end{array}$} \\
\hline
\end{tabular}

temporal changes in phytolith distribution, but a few general observations are possible. The phytoliths indicate a mixed grass environment with festucoid, chloridoid, and panicoid types well represented. Elongate phytoliths are also abundant but are produced by all grasses and are not particularly useful for interpreting past plant communities. Evidence of the presence of specific plants, such as probable mesquite phytoliths from the 2630 B.P. sample and the Opuntia calcium oxylate crystals from the 13,500 B.P. sample, is potentially useful but is not very interpretable given the limited sample size. The single paleoenvironmental trend suggested by the limited phytolith data involves the abundance of panicoid phytoliths in the samples after 510 B.P., possibly indicating an increase in C4 grasses and a corresponding warming trend. Such an interpretation is supported by the carbon isotope data discussed below.

Carbon isotope data on selected humate and bison bone samples also provide paleoenvironmental information (Fig. 60). Carbon isotopes are generally used as a correction factor for radiocarbon dating (see Appendix C) but recently have been applied to other archeological problems (see Van der Merwe 1982). A carbon isotope ratio, given as a d13C fractionation value in parts per thousand, measures the relative amounts of the stable isotopes carbon 13 and carbon 12 and reflects the relative amount of C3 (cool season) to C4 (warm season) plants in the sample. Thus, carbon isotope ratios can be used to estimate 


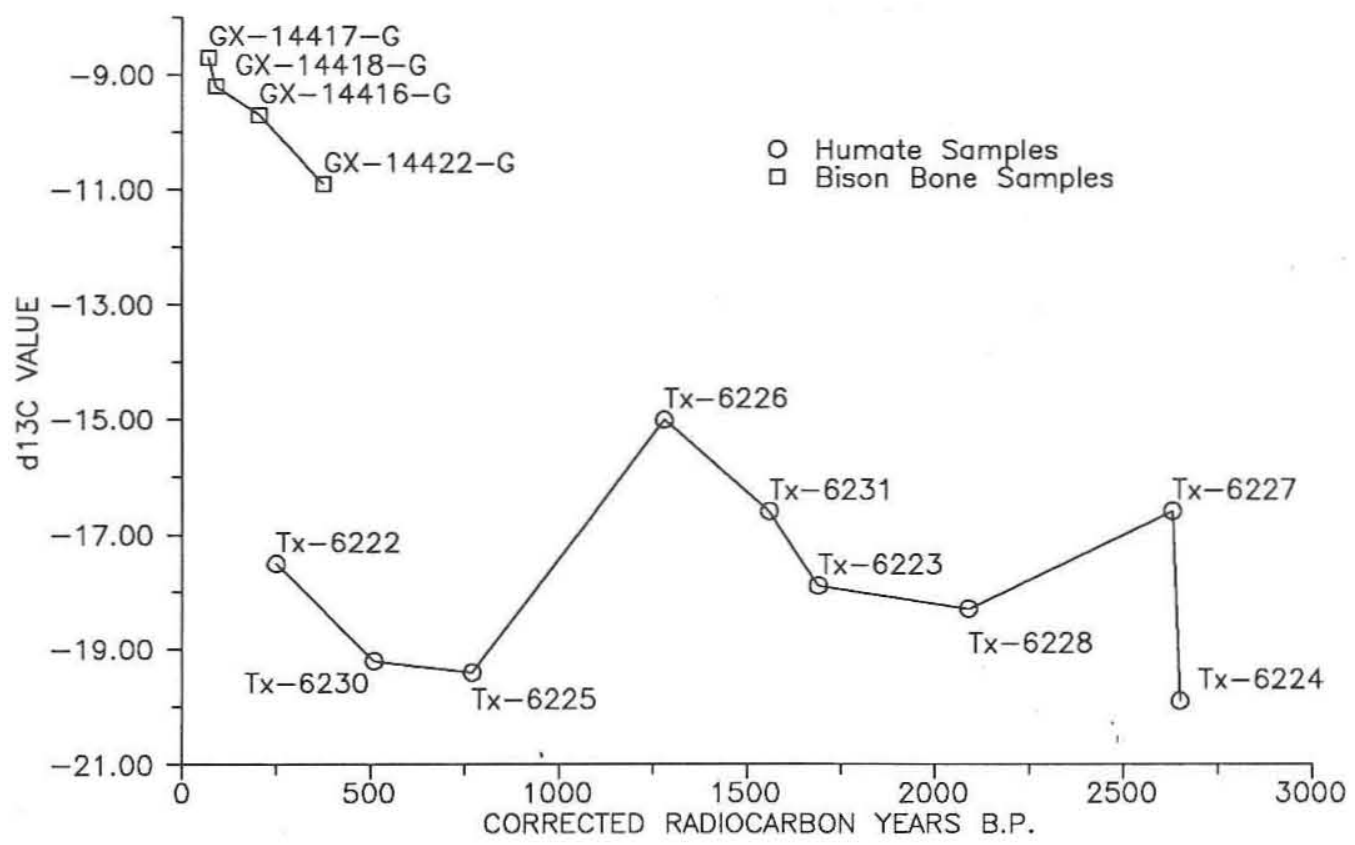

Figure 60. Stable carbon isotope data for humate and bison bone samples; dl3c values are not corrected for fractionation.

the relative percentages of these plants as general climatic indicators and to study bones as an indication of diet.

The sediment sample data are limited to the Double Mountain Fork and tributary valleys and provide information on the local plant communities within the valley environment at the time of deposition. The sediment samples in Figure 60 illustrate a fluctuation in the C3/C4 plant ratio through time, which suggests climatic and corresponding vegetation changes. These data constitute an extremely small sample, however, and it is possible that they reflect microenvironmental variability rather than regional climatic trends.

The carbon isotope chemistry of bones may be a more reliable paleoenvironmental indicator than that of sediments. Carbon isotope studies have been more widely applied to bones as a means of determining diet (see De Niro 1987). It is even possible to estimate the percentage of $\mathrm{C} 3$ and $\mathrm{C} 4$ plants in the diet of herbivores based directly on carbon isotope ratios (Sullivan and Krueger 1981). This method was used to infer climatic changes based on archeological bison populations from the Garnsey Bison Kill Site in southeastern New Mexico (Speth 1983:137-141) and from the Lubbock Lake Site (Meltzer and Collins 1987: 22-23).

The carbon isotope ratios for the Justiceburg Reservoir bison are assumed to provide an indication of the upland grass communities at the time the animals were alive. The four samples shown in Figure 60 illustrate an increase in the amount of C4 grasses in the bison diet over the last ca. 400 years. The data suggest that the relative proportion of $\mathrm{C} 4$ plants increased from ca. $30 \%$ to $60 \%$ in roughly 300 years (based on Sullivan and Krueger 1981:334), perhaps indicating a warming trend. The carbon isotopes do show a shift in the 
dietary constituents of the individual animals, and it is assumed that all of the animals are local Southern Plains bison and reflect the local vegetation. The interpretation of a recent warming trend must be taken cautiously but is supported by the carbon isotope data of the two youngest sediment samples.

Subsistence Studies

Understanding prehistoric subsistence is one of the major goals of the Justiceburg Reservoir research, and many of the same kinds of evidence used to reconstruct past environments also provide data on human subsistence practices. The two areas of investigation must be integrated to adequately interpret the archeological record. The investigations described here concentrated on archeological features and stone tools, and various analyses were employed to extract subsistence data.

\section{POLLEN AND PHYTOLITH ANALYSES}

Analyses of pollen and phytolith samples from archeological feature and nonfeature contexts were conducted to assess the utility of such data for interpreting subsistence and feature function (Table 66). Two independent pollen studies obtained contradictory results due to differences in extraction techniques. Jones (Appendix H) found pollen to be poorly preserved in feature contexts (except for the samples from the most recent site, 41KT53), while Cummings found good preservation and diversified pollen assemblages in feature samples (Appendix I). Two independent analyses of phytoliths from features were performed by Marchbanks (Appendix G) and Cummings (Appendix I); somewhat inconsistent results were obtained from these studies, although direct comparisons are not possible since paired samples were not analyzed. The interpretations of the phytolith and pollen data offered here are derived mainly from the analysis by Cumings.

Function and subsistence cannot be inferred directly from the presence of specific pollen and phytoliths in feature sediments. Like other evidence (e.g., macrobotanical remains) found in and around features, pollen and phytoliths can be natural or cultural. Paired sediment samples from inside and outside features are needed to determine the origin of specific pollen or phytolith types. In addition, culturally introduced remains can be related to food resources or fuels, and distinguishing between these may be difficult in some cases.

Phytolith recovery was lower in features than in nonsite contexts, with the majority being chloridoid and undiagnostic elongate forms. Some panicoid and festucoid phytoliths were also recovered. Due to the limited number of samples, however, functional interpretations based on grass phytoliths are not possible. Calcium oxylate crystals, formed by prickly pear cacti and some tubers, were noted in some feature samples and may indicate food resources.

The four pollen samples analyzed by Cummings do not provide enough data to support interpretations of feature function or subsistence but do indicate that a sufficient diversity and quantity of pollen are preserved to allow such interpretations if adequate-sized samples can be obtained. Pollen is considered more useful for subsistence interpretations than are phytoliths for several reasons. For example, the analysis and interpretation of 
TABLE 66

POLLEN AND PHYTOLITH ANALYSES OF ARCHEOLOGICAL CONTEXTS

\begin{tabular}{|c|c|c|c|c|}
\hline \multirow[b]{2}{*}{ Provenience } & \multicolumn{2}{|c|}{ Pollen Analyses } & \multicolumn{2}{|c|}{ Phytolith Analyses } \\
\hline & Cummings & Jones & Cummings & Marchbanks \\
\hline 41GR291, Feature 2 & & $\mathrm{X}$ & $\mathrm{X}$ & \\
\hline 41GR303, Feature 5 & $\mathrm{X}$ & $\mathrm{X}$ & $\mathrm{X}$ & \\
\hline 41GR303, Feature 7 & & & $\mathrm{X}$ & \\
\hline 41GR303, Feature 8 & & & $\mathrm{X}$ & \\
\hline 41GR323, Feature 6 & & & $\mathrm{X}$ & \\
\hline 41GR383, Feature 1 & & & & $\mathrm{X}$ \\
\hline 41GR383, Feature 2 & & & & $\mathrm{X}$ \\
\hline 41GR383, outside Feature 3 & & & & $\mathrm{X}$ \\
\hline 41GR456, Feature 3 & $\cdot$ & & & $\mathrm{X}$ \\
\hline 41GR456, Feature 12 & & & & $\mathrm{X}$ \\
\hline 41GR484, Feature 2 & $\mathrm{X}$ & & $\mathrm{X}$ & \\
\hline 41GR546, Feature 2 & $\mathrm{X}$ & & $\mathrm{X}$ & \\
\hline 41GR559, Feature 3 & $\mathrm{X}$ & & $\mathrm{X}$ & \\
\hline 41GR559, Feature 5 & & $\mathrm{X}$ & & $\mathrm{X}$ \\
\hline 41KT33, Feature 1 & & & $\mathrm{X}$ & \\
\hline 41KT52, Feature 1 & & & & $\mathrm{X}$ \\
\hline 41KT53, outside Feature 1 & & $\mathrm{X}$ & & \\
\hline 4IKT53, Feature 3 & & & & $\mathrm{X}$ \\
\hline 41KT53, outside Feature 3 & & & & $\mathrm{X}$ \\
\hline 41KT53, Feature 4 & & $\mathrm{X}$ & & $\mathrm{X}$ \\
\hline 41KT53, Feature 6 & & & & $\mathrm{X}$ \\
\hline
\end{tabular}

phytoliths is a relatively new field, while pollen analysis has been widely employed in archeological work. Also, pollen can often provide genus and species information, while phytoliths usually provide less-specific information. Finally, most plants produce pollen while many plants, especially some that were commonly used as food resources, apparently do not produce phytoliths.

Although the limited samples of pollen and phytolith data are too small at present to interpret subsistence and feature function, these studies do have the potential to contribute useful information which can be better interpreted as sample size increases and as more experimental work is done. The combination of pollen and phytolith data from inside and outside features may prove to be of enormous help in interpreting cultural features in the project area.

FAUNAL AND MACROBOTANICAL ANALYSES

The faunal remains recovered from faunal localities and from feature and nonfeature contexts in the campsites and rockshelters were analyzed by Quigg (Appendix J), and the 
macrobotanical remains recovered by flotation of feature and nonfeature sediments were analyzed by Jones (Appendix H). These studies provided a considerable amount of data useful for subsistence interpretations.

A wide range of taxa is represented by the faunal remains recovered, but not all are interpreted as representing prehistoric food remains. In fact, only a few circumstances suggest strongly that specific animals were utilized, while most cases must be considered to represent possible food resources or even noncultural remains. Analysis of the faunal remains recovered from the eight faunal localities provided a limited amount of cultural evidence, i.e., four of the sites are interpreted as representing bison processing stations. Faunal remains were quite abundant and well preserved in the rockshelters but were relatively sparse in the open campsites. Burned and/or butchered bones from rockshelters provided direct evidence that snakes, rodents, small mammals, and medium mammals, including deer and wolf/dog, probably served as food resources for the human inhabitants. Vertebrate faunal remains from campsites exhibit varying degrees of preservation, reflecting temporal differences and/or variations in soil chemistry. Only the burned bone fragments provide direct cultural evidence indicating probable human food remains; no evidence of butchering was observed. All of the burned bones are unidentifiable except for turtle and rodent remains recovered in and around an unlined hearth (Feature 4) at 41KT53. The unburned bone fragments are mostly unidentifiable, but identified specimens represent numerous small and medium mammals, a few large mammals, and rodents. Although these cannot be attributed definitely to human activity, the context of many of the unburned bones suggests a cultural origin.

Flotation (or fine screening) of site and feature sediments greatly increased the recovery of macrobotanical remains. A variety of botanical remains were recovered from the campsites, but a much greater quantity and variety were preserved in the rockshelters. Interpretation of the macrobotanical remains is difficult, however, because such materials can be naturally present or culturally introduced in any site setting. Materials recovered in feature fill, for instance, are not necessarily indicative of the function of the feature. Charred remains are considered to be culturally introduced but could have been burned as fuel or as food being cooked. Noncharred remains may be natural or cultural. The most secure interpretations can be obtained when botanical remains recovered from features are compared with those from complementary nonfeature sediment samples. Substantial differences can then be interpreted as probably reflecting cultural activities. For example, Chenopodium fruits were recovered from Features 1 and 2 at 41 GR546 but not in any of the nonfeature sediment samples, indicating a probable cultural origin.

The charred plant remains consist only of wood fragments, most of which are from feature contexts and probably represent fuel. A variety of species were utilized, including juniper, oak, hackberry, rose, willow, and unidentified hardwoods. The unburned plant remains are considered to be noncultural in most cases, but in a few contexts, particularly at the very late sites, noncharred macrobotanical remains are likely to be cultural. Only one feature, however, yielded noncharred remains in an indisputably sealed cultural context. Flotation of the ash fill from the unlined hearth (Feature 4) at 41 KT53 yielded a wide range of floral and faunal remains, including numerous noncharred hackberry and Chenopodium seeds. In this context, some of the noncharred remains probably reflect food resources. 
ORGANIC RESIDUE AND USE-WEAR ANALYSES

Organic residues preserved on artifacts and burned rocks and in sediments were analyzed by Marchbanks (Appendix G), and a microwear analysis of a small sample of chipped stone tools was conducted by Yerkes (Appendix E). These studies were performed independently, but most of the tools analyzed for use-wear were selected for residue analysis to provide complementary data.

The analysis of organic residues focused on identifying lipids and comparing the archeological samples to a suite of control samples. Of the 80 archeological samples analyzed, 49 were stone tools, 26 were burned rocks from feature contexts, 3 were ceramics, and 2 were sediment samples ( 1 from a noncultural context and 1 associated with a stone tool). Eight of these samples were found to contain insufficient quantities of organic residues to permit interpretation or could not be interpreted for other reasons. The 72 other samples were classified into four groups. Twelve samples are interpreted as representing plant residues, and 13 are interpreted as probable plant residues. Twelve samples are interpreted as representing animal residues. The remaining 35 samples have residues of indeterminate origin, either plant or animal, or both.

This analysis indicates that lipids are well preserved in features and on stone tools from all site types and ages and suggests that organic residues may be helpful in archeological interpretations (see Marchbanks 1989). Despite certain sampling and diagnostic problems with this type of data, the results obtained to date are provocative. Of 11 ground stone specimens analyzed, 7 yielded plant or probable plant residues, and 4 yielded indeterminate residues. The chipped stone tools are more evenly distributed between the interpretive groups. These data suggest that ground stone tools were utilized mostly in plant processing, an assumption that is usually taken for granted but rarely supported by physical data, while chipped stone tools had less-specialized functions. of the three sherds analyzed for residue, two contained plant or probable plant residues, suggesting that the vessels were used chiefly for the processing or storage of plant foods.

The 20 chipped stone artifacts analyzed for microwear represent a range of functions which correlate roughly with tool type. Unifacial scrapers were used as scraping and cutting tools, edge-modified flakes were used as drills or gravers and for scraping and cutting, and one cobble tool was used for scraping. Gouges, which generally have been considered to be woodworking tools, exhibit evidence of use as hide scrapers. Several tools apparently were not utilized, or the lithic materials were too coarse grained to allow wear patterns to be discerned. Eighteen of the 20 stone artifacts were also analyzed for organic residues. At the current level of interpretability, the organic residue and microwear results are not particularly corroborative (Table 67). Only one specimen provides supporting interpretations (animal residue identified on a hide scraper), while another specimen yielded contradictory evidence (probable plant residue identified on a hide scraper). The remaining 16 specimens either yielded indeterminate residues or exhibit uninterpretable microwear patterns and hence provide insufficient evidence for evaluating these techniques.

\section{Prehistoric Chronology of Justiceburg Reservoir}

The cultural sequence proposed here is based on both the existing regional cultural chronology and the archeological evidence from the Justiceburg Reservoir project area. The 
TABLE 67

COMPARISON OF RESULTS OF MICROWEAR AND ORGANIC RESIDUE ANALYSES

\begin{tabular}{|c|c|c|c|c|}
\hline \multirow[b]{2}{*}{ Site } & \multirow[b]{2}{*}{ Provenience } & \multirow[b]{2}{*}{ Specimen } & \multicolumn{2}{|l|}{ Results } \\
\hline & & & Microwear & Organic Residue \\
\hline 41GR291 & $\begin{array}{l}\text { Test Unit } 1,20-30 \mathrm{~cm} \\
\text { Test Unit } 5,31-35 \mathrm{~cm}\end{array}$ & $\begin{array}{l}\text { side scraper } \\
\text { cobble tool }\end{array}$ & $\begin{array}{l}\text { scraping dry hide? } \\
\text { none visible }\end{array}$ & $\begin{array}{l}\text { animal } \\
\text { indeterminate }\end{array}$ \\
\hline 41GR302 & Test Unit 1, Feature 2 & end/side scraper & none visible* & indeterminate \\
\hline 41GR303 & $\begin{array}{l}\text { Test Unit } 4,20-30 \mathrm{~cm} \\
\text { Surface Collection Unit } \\
\text { Surface Collection Unit } \\
\text { Surface Collection Unit } \\
\text { Exploratory Trench } 91,40 \mathrm{~cm}\end{array}$ & $\begin{array}{l}\text { drill } \\
\text { end/side scraper } \\
\text { end/side scraper } \\
\text { gouge } \\
\text { gouge }\end{array}$ & $\begin{array}{l}\text { none visible } \\
\text { scraping dry hide } \\
\text { scraping unknown material* } \\
\text { none visible* } \\
\text { scraping hide?* }\end{array}$ & $\begin{array}{l}\text { indeterminate } \\
\text { probable plant } \\
\text { indeterminate } \\
\text { probable plant } \\
\text { indeterminate }\end{array}$ \\
\hline $41 \mathrm{GR} 323$ & Surface Collection Unit 1 & biface & none visible & indeterminate \\
\hline 41GR359 & Test Unit $8,0-10 \mathrm{~cm}$ & end scraper & none visible & indeterminate \\
\hline 41GR378 & Test Unit $2,40-70 \mathrm{~cm}$ & edge-modified flake & drilling unknown material & indeterminate \\
\hline $41 \mathrm{GR} 484$ & Test Unit 3, 0-10 cm & edge-modified flake & drilling or graving unknown material & animal \\
\hline $41 \mathrm{KT} 33$ & Test Unit 6 , Feature 2 & cobble tool & scraping? unknown material* & animal \\
\hline $41 \mathrm{KT} 34$ & $\begin{array}{l}\text { Auger Test } 27 \\
\text { Test Unit 9, Feature } 3\end{array}$ & $\begin{array}{l}\text { end scraper } \\
\text { biface }\end{array}$ & $\begin{array}{l}\text { scraping/cutting dry hide* } \\
\text { none visible }\end{array}$ & $\begin{array}{l}\text { indeterminate } \\
\text { animal }\end{array}$ \\
\hline $41 \mathrm{KT} 51$ & $\begin{array}{l}\text { Test Unit 1, 20-30 cm } \\
\text { Test Unit 2, } 10-20 \mathrm{~cm}\end{array}$ & $\begin{array}{l}\text { side scraper } \\
\text { end/side scraper }\end{array}$ & $\begin{array}{l}\text { scraping/cutting fresh hide or meat } \\
\text { none visible }\end{array}$ & $\begin{array}{l}\text { indeterminate } \\
\text { indeterminate }\end{array}$ \\
\hline $41 \mathrm{KT} 53$ & Test Unit 4 , Feature 6 & biface & none visible & indeterminate \\
\hline
\end{tabular}

*Coarse-grained crystalline rock, difficult to identify micropolish. 
archeological record of the project area is limited to the late Holocene and is segmented into three time periods: late Archaic, Late Prehistoric I, and Late Prehistoric II. This classification is supported by perceived differences in material culture, feature and site characteristics, and subsistence strategies, in addition to the archeological and paleoenvironmental data for the region. Although very little data exist on the millenia prior to the late Archaic, the discussion below commences with the Paleoindian and early to middle Archaic periods.

\section{Paleoindian and Early to Middle Archaic Periods}

(ca. 11,000-4500 B.P.)

The Justiceburg Reservoir area was undoubtedly utilized by humans during the Paleoindian, early Archaic, and middle Archaic periods (ca. 11,000-4500 B.P.). Evidence from the nearby Lubbock Lake Site indicates sporadic but continuous use of the High Plains throughout these periods (Johnson 1983, 1987; Johnson and Holliday 1986), but much of the Lower Plains is lacking definable components of comparable age. Isolated Paleoindian sites in the region, such as the Rex Rodgers and Lake Theo sites in Briscoe County (Willey et al. 1978; Harrison and Killen 1978) and the Adair-Steadman Site in Fisher County (Tunnell 1975), have been investigated. The Paleoindian sequence defined for the Lubbock Lake Site is applicable for the Lower Plains, but no early or middle Archaic regional cultural complexes have been defined. In fact, isolable occupations dating to these time periods are virtually unknown; the Gore Pit Site in southwestern Oklahoma (Hamatt 1976) is one of the few sites in the Lower Plains that has a documented early or middle Archaic occupation. The scarcity of identifiable Archaic components, particularly early and middle Archaic, in the Texas Panhandle and Lower Plains has been noted by many previous researchers (Suhm et al. 1954:66; Kelley 1964:6-8; Collins 1971:87; Hughes 1976, 1978; Bandy 1977).

In the Justiceburg Reservoir project area, no Paleoindian, early Archaic, or middle Archaic components are identified. Many temporally undefined or undefined Archaic sites may date to these periods, and the inability to recognize such occupations due to the lack of diagnostic artifacts probably contributes to the skewed archeological record. More important, however, the geoarcheological data indicate that intensive middle Holocene erosion scoured the Double Mountain Fork and its tributaries of almost all of the earlier alluvial deposits. Severe erosion of the upland sediments along the canyon rim probably occurred at this time as well. The result is an archeological record heavily dominated by evidence of late Holocene human occupations (i.e., late Archaic and Late Prehistoric sites).

This erosional episode corresponds with the proposed Altithermal period (Antevs 1955), which is characterized as a long severe drought or period of multiple droughts. A similar geomorphic history was proposed for Chalk Hollow, a tributary of the Palo Duro in Randall County, where deposits dating prior to 2000 B.C. are notably absent (Wedel 1975:273). Geomorphic data from the Lubbock Lake Site suggest two lengthy Altithermal droughts during the middle Archaic, ca. 6400-4500 B.P. (Johnson and Holliday 1986:47). Prehistoric water wells excavated at Blackwater Draw Locality No. 1, Rattlesnake Draw, and Mustang Springs are presumed to have been dug during Altithermal droughts (Hester 1972; Meltzer 1986; Meltzer and Collins 1987). Hall (1988:212) summarizes the archeological, geomorphic, and paleoenvironmental data for the Lower Plains region and presents a good case for a middle Holocene Altithermal period. 
The Altithermal droughts and resulting erosion apparently left behind few deposits dating to the middle Archaic, and most of the deposits dating to the Paleoindian and early Archaic periods have been destroyed. The harsh environment likely would have limited human occupations as well. This scenario serves as a model to account for the biased archeological record noted at Justiceburg Reservoir and throughout the Texas Panhandle and Lower Plains regions.

Late Archaic Period (ca. 4500-2000 B.P.)

The late Archaic period is best documented at the Lubbock Lake Site (Johnson and Holliday 1986:46-49). It roughly corresponds to the Medithermal climatic period (Antevs 1955), which was cooler and wetter than the preceding Altithermal. Hall (1988:206) suggests that the late Archaic climate was somewhat dryer than the modern Lower Plains climate.

Late Archaic cultural complexes in the region are not yet adequately defined. The Little Sunday Complex (Hughes 1955) proposed for the Texas Panhandle represents the earliest attempt at identifying cultural groups. It is defined on the basis of surfacecollected materials from an apparently multicomponent site in Randall County and is no longer useful as a comparative cultural unit. Likewise, the Lawton Aspect (Shaeffer 1966: 62-86), proposed as an Archaic cultural unit for western Oklahoma with the Little River and Lake Altus foci as subunits, is based on surface-collected artifacts and is not considered to be a valid cultural unit by current researchers (see Hughes $1984: 116$ ) .

The Summers Complex (Leonhardy 1966:30-32), proposed for southwestern Oklahoma, is better defined and may be a valid late Archaic cultural unit (Hughes 1984:117). It is based on excavated features and artifacts at 34GR12, an open campsite in Greer County, Oklahoma, but has not yet been supported by additional excavation data. The chronological position is established by a single charcoal radiocarbon age of $2770 \pm 150$ B.P., but the small sample size casts some doubt on the validity of the date. Leonhardy (1966:31) stated that the Summers Complex is characterized by a specialized bison-hunting subsistence. A few other late Archaic occupations, including the lower components at the Deadman's Shelter Site (Willey and Hughes 1978), the Canyon City Club Cave (Hughes n.d.), and the Chalk Hollow Site (Wedel 1975; Bandy 1977:20; Hughes 1978:41), have been investigated but have not been assigned to cultural complexes. These and other sites could be associated with the Summers Complex.

Late Archaic sites in the Lower Plains region include bison kills and open campsites, but very few have been adequately investigated. Hughes (1977) reported on several bison kill sites, including excavations at the Twilla Site in Hall County (see Tunnell and Hughes 1955). Evidence of bison procurement is also present at 34GR12, where excavations revealed a cooking pit containing bison bones (Feature 1) and a probable bison processing station (Feature 5) (Leonhardy 1966:20). The late Archaic period in the Lower Plains correlates with Dillehay's (1974) proposed bison presence period II, ca. 4450-1450 B.P.

Diagnostic late Archaic artifacts are limited to corner-notched and stemmed varieties of dart points, the most common being Castroville, Elam, Ellis, Kent, Lange, Marcos, Marshal1, and Palmillas (Leonhardy 1966:30; Hughes 1977; Willey and Hughes 1978:165). Gouges often have been considered to be diagnostic of the Archaic, but this assumption is not supported by any convincing evidence. 
The Phase II investigations at Justiceburg Reservoir identified only three sites (41KT33, 41KT49, and the lower component at 41KT52) that contain probable late Archaic occupations, as revealed by diagnostic artifacts, radiocarbon dates, and stratigraphic data. Many of the temporally undefined or undefined Archaic sites in the project area could date to this period, but chronological evidence is lacking. Of the 11 dart points recovered during Phase II, only one, a Marcos point from 41KT49, could be typed. Features investigated at these sites include fire-cracked rock dumps from stone boiling or baking, slab-lined hearths, and other burned rock features. Bedrock mortar holes also may be associated with late Archaic occupations.

Two sites (41KT33 and 41KT49) appear to be multifunctional open campsites, while the third (the lower component at 41KT52) appears to be a specialized processing locality. No evidence of bison hunting was recovered from any of these sites, but projectile points found at the campsites suggest that hunting was occurring. One basal fragment of a cornernotched, expanding-stem dart point recovered at $41 \mathrm{KT} 33$ exhibits obvious evidence of impact fracture. Evidence of plant processing appears in the ground stone artifacts, which were recovered from all three sites but were most abundant at 41KT33 and 41KT52.

Late Prehistoric I Period (ca. 2000-1000 B.P.)

The beginning of the Late Prehistoric period is marked by the introduction of ceramics and/or the bow and arrow. Neither of these events is well documented in the region, and they did not necessarily occur contemporaneously; both appear to have occurred within a short time span around A.D. 1. The earliest dated occurrence of arrow points and ceramics in the region is in Stratum D at the Deadman's Shelter Site (41Sw23) in Swisher County (Willey and Hughes 1978:185-190). Unnotched triangular, corner-notched Scallorn-like, and basally notched Deadman's arrow points were recovered along with probable Alma Plain or Jornado Brownware sherds. Two charcoal radiocarbon dates of A.D. $120 \pm 60$ and A.D. $210 \pm$ 40 place Stratum D in the early part of the Late Prehistoric period. Dart points recovered from Stratum D appear to be contemporaneous with the arrow points and ceramics.

The Late Prehistoric I period is dated tentatively to ca. 2000-1000 B.P. and is roughly contemporaneous with the Incipient Plains Village period (A.D. 100-1100) proposed for western Oklahoma (Moore 1986:101) and with the Plains Woodland period (ca. A.D. 1-1000) in the Texas Panhandle (Couzzourt 1985:77; see Hughes n.d. for discussion of Lake Creek Complex). Both of these periods incorporate the transition from an Archaic foraging lifestyle to a horticultural village lifestyle. The Late Prehistoric I period in the Lower Plains may be quite different, however, since no evidence of horticulture or a shift to a semisedentary village lifestyle has yet been found. In this region, it may be appropriate to think of the Late Prehistoric I period as a time in which new technologies appeared but the Archaic foraging lifestyle remained.

Paleoenvironmental conditions during this period are not well understood, but recent studies indicate that the 2000-1000 B.P. period was characterized by a moister climate than that of today (Hall 1988:206-208). The effects of this wetter climate on plant and animal communities, as well as aboriginal cultures, are not clear. Dillehay (1974) postulates that during part of this period, ca. 1450-750 B.P., bison were scarce on the Southern Plains, probably as a result of climatic shifts and corresponding vegetation changes. If bison were scarce during much or all of the Late Prehistoric I period, it is likely that 
human populations altered their subsistence strategies to deal with the changing resource base. The regional archeological data support this idea, but much more information is needed to correlate the paleoenvironmental and archeological records.

The only defined cultural complex in the Late Prehistoric I period is the Palo Duro Complex, and one characteristic of this complex is the scarcity of bison bones (Willey and Hughes 1978:188). The only definite food remains recovered from the Deadman's Shelter Site are deer and antelope, which dominated the faunal assemblage. A variety of other animals, such as rabbits, rodents, turtles, snakes, and fish, were also recovered but could be either cultural or natural. One molar and a toe bone are the only bison remains from the site, which strongly suggests that the occupants of the shelter were not exploiting bison to any significant extent at ca. 1830-1240 B.P. (Schultz and Rawn 1978:197).

The Kent Creek Site (41HL66) in Hall County, Texas, has yielded Palo Duro Complex materials in association with pithouse structures of probable Mogollon influence (Cruse 1989). While the possibility of horticulture at this site could not be ruled out, no evidence of its practice was recovered. A wide variety of floral and faunal remains were recovered and indicate that the inhabitants utilized numerous plant and animal resources. Four varieties of wild plants--pigweed (Amaranthus), goosefoot (Chenopodium), purslane (Portulaca), and oak acorns (Quercus)--probably represent food resources. Animal resources that were exploited consist of deer, antelope, skunk, rabbit, prairie dog, turtle, various rodents, and freshwater mussels. The mussels and artiodactyls (deer and antelope) dominated the faunal assemblage and appear to have been favorite resources. Of particular note is the near absence of bison remains; only one bison toe bone was recovered (Cruse 1989: 141-145).

The Palo Duro Complex is similar to and contemporaneous with the Plains Woodland culture in the northern Texas Panhandle (Couzzourt 1985:66-77). The cultures share many traits and are currently distinquished only by their characteristic arrow point and ceramic styles. The Plains Woodland culture was first defined in the Texas Panhandle at the Lake Creek Site in Hutchinson County (Hughes 1962) and since has been investigated at only a handful of sites. The Palo Duro and Plains Woodland manifestations overlap geographically between the Canadian River and the Red River drainages, and it is likely that the two cultures interacted to some degree. Evidence of such interaction may be present at the Tascosa Creek Site in Oldham County (Couzzourt 1985:93-99).

Six sites (41GR291, 41GR303, 41GR383, 41GR467, 41GR471, and 41KT34) investigated during Phase II at Justiceburg Reservoir appear to contain components dating to the Late Prehistoric I period, although other sites defined only as Late Prehistoric may also belong in this group. These assessments are based on the presence of early arrow point styles and radiocarbon dates. Enough data were obtained from three of these sites (41GR291, 41GR303, and 41GR383) to suggest that they contain isolable Late Prehistoric I occupations. All three sites appear to be multifunctional campsites based on the variety of feature and artifact types. Slab-lined hearths, burned rock clusters, and bedrock mortar holes are probably subsistence-related features; the latter may reflect plant processing. Ground stones are relatively abundant, perhaps also indicating some dependence on plant resources. A full range of chipped stone tools was recovered, but only one of these sites yielded an adequate artifact assemblage to be assigned to a cultural complex. Deadman's and Scallorn arrow points and ceramics similar to Jornado Brownware or Alma Plain recovered at 41 GR291 are diagnostic of the Palo Duro Complex. A pendant, made of kaolinite perhaps obtained from the Trans-Pecos region, recovered from this site is further evidence of interregional trade or group mobility. 
Late Prehistoric II Period (ca. 1000 B.P. to European Contact)

The transition from Late Prehistoric I to Late Prehistoric II is not well defined. The Late Prehistoric II period is contemporaneous with the Plains Village period to the north and west. In western Oklahoma, the Plains Village period (e.g., Custer Phase) begins ca. A.D. 1100 and was characterized by a semisedentary village horticultural subsistence pattern (Moore 1986:103). The Plains Village period in the Texas Panhandle (i.e., Panhandle Aspect and Buried City Complex) is marked by similar cultural developments at ca. A.D. 1200 (Lintz 1982:38; Hughes and Hughes-Jones 1987). For the Texas Lower Plains, however, there is no apparent Plains Village manifestation. It is possible that a hunting and gathering (i.e., Archaic) lifestyle prevailed throughout this time period over much of the region.

Paleoenvironmental data indicate that the climate from 1000 B.P. to the present was considerably drier than the preceding 1,000 years (Hall 1988:208-209), although certainly not as dry as the middle Holocene Altithermal climate. The Lower Plains environment appears to have remained relatively stable for the past 1,000 years, and it was during this time that the modern climate became established. This period is one of the least understood in terms of environmental conditions, however (Hall 1988:208).

The Late Prehistoric II archeological record in the Lower Plains is heavily biased toward the latter half of this period. Only one cultural complex is defined for this time span. The Garza Complex (Runkles 1964) began ca. 550-650 years ago (A.D. 1300-1400), but it is not clear what cultural changes took place during the preceding several hundred years. The Garza Complex is sufficiently different from the preceding Palo Duro Complex, however, to suggest that it represents a nonlocal group that moved into the Lower Plains rather than an in situ cultural development. The influx of Garza Complex peoples into the region appears to correlate well with Dillehay's (1974) proposed bison presence period III, and the dated bison remains from the faunal localities at Justiceburg Reservoir attest to the abundance of bison during the last 400 years. It is likely that this influx of people was directly related to bison herd movements. There is no definite evidence that these groups practiced horticulture, although they traded extensively with the agricultural Puebloan groups in New Mexico and certainly had access to domesticated plants and knowledge of horticulture. It has been suggested that the Garza Complex in the Lower Plains and the similar Tierra Blanca Complex in the Texas Panhandle represent Apachean groups that migrated from the north into the Southern Plains Ca. A.D. 1300 (Johnson et al. 1977:104107; Speilmann 1982:341-344; Hughes n.d.:79-83). Alternatively, Baugh (1986) speculates that Garza sites represent a westward extension of the Wheeler Phase out of southwestern Oklahoma. At present, there is little substantive evidence to support either of these interpretations. Only a few sites in the region have produced Garza materials, and most of those have received only limited investigation (see Boyd 1989b:50-56).

The Phase II investigations defined five Late Prehistoric II components in the project area (41GR323, 41GR484, 41KT51, and the upper components at 41KT52 and 41KT53). Sites 41GR323 and 41GR484 yielded no ceramics but are dated by radiocarbon assays. Diagnostic ceramics (Pecos Glaze Polychrome V and Pecos Faint Striated) recovered from 41KT51, 41KT52, and 41KT53 date these occupations to ca. A.D. 1600-1800. These ceramics also document interregional trade. Late occupations dating to this time period are often referred to as Protohistoric, but as yet the only evidence of European contact in the project area consists of three historic aboriginal rock art sites (41GR51, 41GR282, and 41GR344). 
All five of the Late Prehistoric II sites at Justiceburg Reservoir are open campsites with various ranges of activities indicated by artifacts and features. Late Prehistoric II features include an unlined ash-filled basin hearth, slab-lined hearths, other burned rock features, a burned post, and ceramic concentrations. The unlined basin hearth (at 41KT53) appears to be a diagnostic feature of the Late Prehistoric II period. Similar hearths at the Lubbock Lake Site (Johnson et al. 1977:86), near the Garnsey Springs campsite in southeastern New Mexico (Parry and Speth 1984:34), inside a tipi ring at the Tierra Blanca Site (Spielmann 1982:284-285), and at two sites in Mackenzie Reservoir in Briscoe and Swisher counties (Hughes and Willey 1978:233-239, 261) all have been dated to the last few hundred years, and some have associated evidence of European contact. A similar hearth feature is reported inside a structure at a Dismal River site in the Central Plains (Wedel 1986:145). Bedrock mortar holes and fire-cracked rock dumps from stone boiling or baking were apparently absent or scarce during this time. Lithic debitage from this period indicates that resharpening of unifacial tools was an important activity, perhaps related to hide scraping.

Summary

There is a growing body of evidence that indicates a close relationship between paleoenvironmental conditions and human adaptive strategies in the Southern Plains over the last 5,000 years. The data seem to reflect two major economic strategies. Archeological evidence suggests that a bison-oriented subsistence pattern prevailed during the late Archaic and Late Prehistoric II periods, when relatively dry conditions occurred and bison were abundant. Undoubtedly, this strategy was supplemented by additional plant and animal resources, but bison were the focus of subsistence activities. The intervening Late Prehistoric I period appears to have been wetter, and vegetation changes may have resulted in decreases in bison herds. Bison probably were not absent during this time, but the archeological evidence indicates that bison were not exploited as consistently as during earlier and later periods. Human subsistence during the Late Prehistoric I period in the Southern Plains may have shifted to a less focal hunting and gathering strategy. This scenario provides the building blocks from which a detailed model of late Holocene human adaptations in the project area can be constructed. This model, which constitutes the remainder of this chapter, is offered as a guide for future investigations at Justiceburg Reservoir.

\section{A Model of Late Holocene Human Adaptation for Justiceburg Reservoir}

To maximize the interpretive potential of the Justiceburg Reservoir archeological record, a model of human adaptation and cultural development is proposed. It incorporates the regional archeological data outlined above and provides a series of expectations and implications which will serve to assess its utility.

The model follows Butzer's (1982:285) perspective that human culture is an adaptive system composed of three interrelated subsystems: social behavior, technology, and resource opportunities and limitations. Within this framework, the theoretical issues relating to human subsistence and settlement strategies are put forth as the primary objective of continued archeological investigations at Justiceburg Reservoir. More 
specifically, the relevant theoretical issues are those that explore adaptive strategies of hunter-gatherer societies as they relate to resource opportunities and limitations. This is not to suggest, however, that sociocultural and technological factors will not be taken into account in explaining certain elements of the archeological record, for example, the occurrence of ceramics from the Southwest (Spielmann 1982; Lintz 1986; Habicht-Mauche 1987) and nonlocal raw materials (Vehik 1986) in the region or the impact of the horse upon resource procurement patterns (Oliver 1962; Hanson 1986). Using Binford's (1980) foragercollector continuum and viewing resource structure as the primary factor conditioning subsistence and settlement strategies (Kelly 1980, 1983), the proposed goal of future archeological work at Justiceburg Reservoir is the extraction of regional land-use patterns and the explication of factors that conditioned shifts in land use through time.

Specifically, the model proposes that a single resource, bison, was pivotal in causing shifts between collector- and forager-oriented subsistence and settlement systems in the project area. It is maintained that bison is the only resource in the Lower Plains that could have supported a logistically organized collector strategy. Conversely, it is proposed that land-use patterns that depended primarily on resources other than bison had a strong forager component. In its simplest form, the model suggests that as bison populations fluctuated in response to environmental changes (Dillehay 1974), human populations responded by changing their subsistence and settlement strategies to maximize exploitation of the changing resource base.

The issue of how bison populations on the Southern Plains fluctuated during the Holocene is far from resolved (Lynott 1979; Baugh 1986; Bamforth 1987; Turpin 1987; Brooks and Flynn 1988). However, a possible compromise can be reached by viewing the question not strictly in terms of bison presence and absence (e.g., Dillehay 1974), but rather in terms of abundance and scarcity. This allows for the possibility of small quantities of bison in archeological sites dating to Dillehay's (1974) suggested bison absence periods.

The model is separated into three temporal periods: late Archaic, Late Prehistoric I, and Late Prehistoric II. As described earlier in this chapter, these periods appear to represent notable cultural and environmental changes; earlier time periods are not defined in this model because of the lack of archeological deposits predating the late Archaic in the project area. The model proposes that distinctive land-use patterns characterized the three temporal/cultural units and that these patterns are definable archeologically based on the contrast between forager and collector subsistence and settlement strategies.

In assessing the interpretive utility of the model, it is important to bear in mind that individual archeological sites represent parts of cultural systems and cannot be interpreted in isolation. Similarly, the Justiceburg Reservoir project area must be considered within the context of the region as a whole before overall land-use strategies can be defined. Settlement and subsistence patterns cannot be reconstructed using data from a single, or even a few, sites; rather, they must be supported by a substantial regional data base. In the absence of such a data base, interpretations of human subsistence and settlement strategies must be approached cautiously.

Theoretical Background

Recent works by Binford (1980), Hayden (1986, 1987), and Kelly (1980, 1983) have illustrated how patterns of resource acquisition among groups in the ethnographic present 
can be categorized in broad terms as either collector or forager oriented. Forager groups tend to move consumers to the resources and, as such, appear to map onto resources wherever they may be found spatially and temporally. Storage plays a minor role in the economy because few resources are available in large enough quantities to permit bulk acquisition for lean-period consumption. Collector groups move resources to the consumers using logistically organized task groups to exploit resources occurring in bulk. The quantities obtained are sufficient to permit, and even necessitate, processing for delayed consumption. Storage of processed resources is a necessity allowing the out-of-season use of those resources.

The collector-forager dichotomy characterizes resource acquisition patterns at the two extremes of the continuum and in environmentally extreme settings. In view of this and given that these strategies are not mutually exclusive, sometimes being used in variable mixes within the annual cycle of a single group, it is fair to question the utility of these constructs for modeling human adaptations. The answer to this is that the collectorforager dichotomy provides a useful conceptual starting point for asking questions about the causal factors behind different mobility patterns among prehistoric hunter-gatherers and for deriving expectations about the relationships between resource acquisition patterns, mobility strategies, site function, artifact assemblage composition, occupation length, group size, and regional settlement patterns. The remainder of this section is devoted to exploring these issues in greater detail.

Binford (1980) characterizes biotic production in different global environments by a measure termed "effective temperature" (ET). He argues that the structural properties of an environment and its resources can be described by the amount and yearly distribution of solar radiation (Bailey 1960). The lower the ET, the more seasonal the environment and the shorter the growing season. The higher the ET, the less seasonal the environment and the longer the growing season. For a human population exploiting natural resources, the number of critical resources increases as climatic severity increases and the length of the growing season decreases. In addition, the greater the seasonal variability in temperature, the greater the chances that spatial and temporal incongruence between critical resources will occur. From this perspective, it is the degree of incongruence between critical resources that conditions the manner in which resources are acquired (i.e., foraging or collecting). Typically, groups inhabiting temperate and colder settings solve the problem of seasonal scarcities of critical resources through increased logistical procurement/processing of key resources and increased storage of those resources. This promotes increased seasonal sedentism, thus further increasing the spatial incongruity between resources (Goland 1983). Binford finds a relatively good concordance in 31 ethnographic cases between dependence on storage (i.e., the reliance on collector-oriented strategies) and decreasing ET. Only groups in environments with an ET below $15{ }^{\circ} \mathrm{C}$ practice storage. In contrast, tropical rain forest groups maintain a relatively high degree of mobility in the exploitation of undifferentiated, homogeneous resource patches. Foraging for food is done on an encounter basis, and the exhaustion of resources within a foraging radius is followed by short-distance residential moves to new foraging areas.

This characterization of resource acquisition patterns is useful in that it points out the tendency for groups in high ET environments to operate as foragers, while those in low ET environments operate as collectors. Furthermore, it suggests that in warm temperate zones characterized by moderate ET values, resource acquisition patterns may be a complex mix, perhaps varying seasonally, of collecting and foraging strategies. 
Hayden (1986, 1987) addresses the factors that may generate logistically organized systems in temperate climates. He concurs that, in general, foraging strategies are adaptive to evenly distributed, scarce, and unpredictable resources in temperate areas and result in a land-use pattern characterized by high residential mobility. However, he also suggests that in some temperate regions logistical strategies may have been adopted once effective means for exploiting r-selected, small body sized, rapidly reproducing resources (e.g., grass seeds, acorns) were developed. While there is a strong technological component to this argument, the aspect that is significant for this discussion is the character of the resource base. Hayden (1986:86) suggests that reliability, richness, and seasonality are the critical factors conditioning how a resource can be used. Conaty (1987:60), based on analogies with predator optimal foraging strategies (Horn 1968), suggests that the critical variables are the availability and distribution (e.g., evenly distributed and stable versus highly clumped and transient) of a resource rather than its density (i.e., r-selected versus $\mathrm{K}$-selected). Foraging strategies appear to correlate with the exploitation of evenly distributed and relatively stable resources. Collecting strategies appear to be more commonly employed in the exploitation of clumped and transient resources.

Heffley (1981), based on a study of Northern Athapaskan settlement patterns and resource distribution, suggests the following classification of resources as an important determinant of settlement patterns: (1) evenly spaced and stable; (2) mobile, clumped, and unpredictable; and (3) clumped and predictable. Evenly spaced and stable resources appear to be exploited by small groups in a dispersed, relatively mobile settlement pattern. Mobile, clumped, and unpredictable resources are exploited by larger, relatively mobile groups, but the greater return for the energy invested generates storable surplus permitting some degree of seasonal sedentism. The highest degree of sedentism is found in the exploitation of clumped and predictable resources (e.g., salmon runs). This results in large villages occupied by large groups. Groups such as the Tanana (Heffley 1981:140-142), which exploit resources that are evenly spaced and stable as well as resources that are mobile, clumped, and unpredictable, practice a seasonally varying mix of logistical and residential mobility.

One approach that characterizes resource acquisition modes is provided by Kelly (1980, 1983). It offers a theoretically robust explanation derived from ecological principles to account for broad, global differences in resource acquisition patterns, particularly collector versus forager systems. He utilizes two primary factors, ET and rainfall, to examine variations in the structure of vegetative communities. Different regimes of temperature and rainfall produce environments differing in primary production and primary biomass, two elements that aid in defining the structure and accessibility of the resource base. Primary production (net primary production) refers to the amount of energy in vegetation remaining from the process of photosynthesis after respiration. Primary biomass is the total amount of standing plant material present in a region at a particular point in time.

Environments with relatively high ET values are high primary biomass settings (e.g., the tropics). However, primary biomass is inversely correlated with the accessibility of plant resources. Dividing primary production by primary biomass gives a rough estimate of the accessibility of primary production for both humans and large herbivores. Looking at resource structure from this perspective, it is clear that, while tropical rain forests are extremely high in primary biomass, the resources are largely inaccessible to human consumers. On the other hand, environments with lower ET values, such as the tundra or grasslands, have lower but highly accessible primary biomass. However, this highly accessible 
primary production is to a large extent available only in a form (i.e., grasses) that is inedible by humans. By dividing average secondary biomass by average primary biomass, an estimate of the accessibility of the fauna, the converters of the inedible primary production, for human consumers can be obtained. The relationship that emerges between ET and primary biomass and resource accessibility is that, holding ET constant, fauna decrease in body size and become more dispersed and less accessible as primary biomass increases. Holding primary biomass constant, fauna decrease in density but tend to increase in body size and to be more gregarious and more accessible as ET decreases. Resource monitoring is more important in environments with increasing seasonality because in such settings plants and animals are available only during a particular season of the year and animals tend to be migratory. In contrast, in high primary biomass areas monitoring costs are essentially the same as search costs (Kelly 1980:24).

Analyses of global patterns of primary production indicate that, in general, prairie or grassland vegetation communities have relatively low levels of primary production and primary biomass. Primary production levels suggested for such environments range from approximately 280-1,500 g/m²/year, with a mean of $600 \mathrm{~g} / \mathrm{m}^{2} /$ year (Rosenzweig 1968:69; Whittaker and Likens 1975:306; Kelly 1983:284). A somewhat more precise estimate of primary forage production for the short-grass and mixed-grass prairie of the Texas Panhandle, ranging from 180-582 $\mathrm{g} / \mathrm{m}^{2} /$ year, can be derived from Bamforth (1988:61). Finally, Owen and Schmidly (1986) calculate net above-ground primary productivity at Post (Garza County, Texas), located at the western edge of the Mesquite Savanna vegetation region, at 842 $\mathrm{g} / \mathrm{m}^{2} /$ year. The same statistic for Brownfield (Terry County, Texas), located in the Plains Grassland vegetation region, is $472 \mathrm{~g} / \mathrm{m}^{2} /$ year. The mean of the two values, $657 \mathrm{~g} / \mathrm{m}^{2} / \mathrm{year}$, is chosen to characterize the boundary between the two vegetation regions and the broader Justiceburg project area. The high end of the range provided by Bamforth (1988:61) and the mean value calculated from Owen and Schmidly (1986) are very close to the primary production figure $\left(600 \mathrm{~g} / \mathrm{m}^{2} /\right.$ year) used by Kelly $(1983: 284)$ for temperate grassland environments. Under these conditions of low primary production, primary and secondary biomass are also very low, 1,600 and $7 \mathrm{~g} / \mathrm{m}^{2} /$ year, respectively. On the other hand, the primary production is relatively accessible to humans and herbivores. Only lake/stream and swamp/marsh environments have higher accessibility indices. However, the high index for the grasslands reflects primarily the accessibility of the primary biomass to herbivores rather than humans. Many of the grasses and weedy species that flourish in such environments are not directly edible by human beings or become so only after extensive processing. On the other hand, the many grass species making up the short- and mixed-grass prairie communities are the primary native forage species for such ungulates as bison (Peden et al. 1974; Peden 1976). This aspect of the resource structure generates high faunal accessibility in grassland environments (Kelly 1983:284).

The second key statistic discussed above is ET. A calculation of ET for Post (Garza County, Texas) results in a figure of $14.4{ }^{\circ} \mathrm{C}\left(57.92^{\circ} \mathrm{F}\right)$, while Brownfield (Terry County, Texas) has an ET of $14.2{ }^{\circ} \mathrm{C}\left(57.56^{\circ} \mathrm{F}\right)$. A project area mean ET of $14.3^{\circ} \mathrm{C}\left(57.74{ }^{\circ} \mathrm{F}\right)$ is employed for the purposes of this research design. This figure is within the range of Binford's (1980) warm temperate environmental zone, in which seminomadic settlement patterns predominate. Thus, a certain degree of seasonal sedentism is practiced by some groups inhabiting such environments. The mean length of the growing season is 216 days (Natural Fibers Information Center 1987:191-192), which is similar to but slightly longer than the growing season that typifies environments in which ethnographic groups are characterized by an increased dependence on storage (Binford 1980:16). The Justiceburg Reservoir project area is within a region of mixed- and short-grass prairies (Carpenter 1940: 
665). It is a low primary biomass biome with a secondary biomass composed of medium to large herbivores (pronghorn, deer, and bison), relatively low species diversity, terrestrial (bison, pronghorn, deer, wapiti, and cottontail) and burrowing (prairie dog, ground squirrel, pocket gopher, and pocket mouse) primary mammalian habitat, and gregarious faunal distribution patterns (Shelford 1963). The resources can be grouped into two of the three categories defined by Heffley (1981): (1) evenly spaced and stable; and (2) mobile, clumped, and unpredictable.

The $14.3{ }^{\circ} \mathrm{C}$ ET value is not assumed to have been a constant during the prehistoric perlods discussed here. It is used as a base line representing the present environmental conditions and resource structure. It is almost certain that fluctuations in bison abundance and scarcity, the driving element of proposed shifts between collector and forager strategies, are due to climatological changes. The uncertainties lie in the relationship between relative moisture (i.e., dry versus wet) and bison populations. Here we follow Hall's (1988:210-211) suggestion that bison absence or scarcity, at least during the Late Prehistoric I Period, corresponds to a return to wetter conditions. Paralleling this shift would have been a change in ET which may not have been great but may have had profound effects nonetheless. For instance, the ET of the East Texas Oak-Hickory-Pine Forest vegetation region is $15.3{ }^{\circ} \mathrm{C}$ (Jacksonville, Cherokee County, Texas). Although it is an extremely different vegetational community compared to the Plains Grasslands, the ET difference between the two is only $0.9{ }^{\circ} \mathrm{C}$. On the other hand, the difference in mean annual precipitation between the two zones is $48.36 \mathrm{~cm}$ (19.04 inches). These patterns indicate that even small changes in ET accompanied by a substantial increase in mean annual precipitation may have been sufficient to alter the Southern Plains resource structure between 2000-1000 B.P. (Hall 1988:206-208). Such a shift in the structure of the resource base would have conditioned corresponding shifts in resource procurement systems.

Based on these aspects of effective temperature (ET) and its relationship to resource structure and relying upon the expectations derived from Binford (1980), Heffley (1981), and Kelly (1983), it seems likely that resource acquisition systems in the project region may have contained a substantial logistical component during periods of bison abundance and/or high spatio-temporal predictability (see Kelly 1983). During extended periods of bison scarcity in the region, all fauna, including bison, probably were distributed across the landscape in an even, but relatively less predictable, manner. Under such conditions, resource acquisition may have occurred most effectively within a foraging system, bison being only one of a number of resources exploited during the annual subsistence round.

The structure and spatio-temporal predictability of bison is conditioned by bison behavior and the nature of the bison populations found in the region. There are two schools of thought on bison behavior prior to European contact. One is that bison herds migrated long distances seasonally, while the other is that bison herd movements were relatively limited within a region. The presence of stable, local populations would have ensured the year-round availability of the resource. Ethnological data (Roe 1970; Moodie and Ray 1976; Morgan 1980; Hanson 1984; Chisholm et al. 1986; Bamforth 1987; Epp 1988) indicate, however, that even in regionally stable populations, the period of greatest herd aggregation is during the summer rut. It is the temporal predictability of these summer aggregations combined with the size of the herds that could have allowed for the bulk exploitation of bison under a logistically organized system. During the remainder of the year, the smaller herds could have been most efficiently exploited by individual hunters or small groups operating within a residentially mobile foraging system. The migratory herd alternative implies the absence of bison during the summer rut, assuming that populations 
moved south during the late fall, were present in the Lower Plains region during the mild winter, and moved back north during the late spring. While the available herds would have been relatively dispersed, the migratory pattern would have provided two periods of increased spatio-temporal predictability, late fall and late spring, which would have allowed the bulk exploitation of bison along well-defined migration routes. During the winter, the dispersed herds likely would have been exploited within a relatively mobile foraging system. This is the type of resource acquisition pattern that is observed among most ethnographic groups exploiting seasonally migratory fauna such as caribou (Binford 1979), elk (Heffley 1981), and bison (Fletcher and La Flesche 1972; Grinnell 1972).

Under either of these scenarios, the resource acquisition system would have been a seasonally varying combination of collecting and foraging. Under the regionally stable population alternative, the summer resource acquisition pattern would have been dominated by a strong logistical component, with the remainder of the year being characterized by a highly mobile foraging system. Under the migratory population alternative, logistical strategies would have prevailed during the late fall and late spring, and foraging strategies would have predominated during the remainder of the annual cycle. These two alternatives would have had a significant effect upon the organization of resource procurement activities and land-use patterns, and this should be reflected in the archeological record. Rather than generating two alternative models for each time period under concern, the discussion below focuses on the expected distinctions in site types, site structure and organization, lithic assemblage composition, and faunal and botanical records generated by collector (logistically organized) versus forager (residentially mobile) systems.

\section{Late Archaic Period}

The 4500-2000 B.P. period in the Lower Plains was characterized by a somewhat drier climate than that of today (Hall 1988:206) and correlates with a long period of suggested bison abundance, ca. 4450-1450 B.P. (Dillehey 1974:182). It is proposed here that human subsistence in the Justiceburg Reservoir area focused on exploiting bison during the late Archaic period and that local groups adopted a logistically organized collector strategy during seasons of bison abundance. As discussed above, it is likely that late Archaic peoples operated as foragers during other parts of the year.

Overall, the late Archaic land-use pattern should reflect a combination of logistically organized collector and residentially mobile forager strategies. The expected site types generated by a logistically organized collector strategy consist of residential base camps, field camps, locations, stations, and caches (Binford 1980). Residentially mobile foraging groups generate two types of sites, residential base camps and locations. Residential base camps are the primary loci of maintenance, processing, and manufacturing activities. Field camps represent camps occupied by task groups. Locations are procurement and processing loci, while stations are observation posts used in information gathering (e.g., hunting blinds). Caches are temporary storage facilities.

On a regional scale, residential base camps should exhibit a bimodal size distribution. Large residential base camps will reflect the large group sizes and extended sedentism allowed by bulk bison procurement under a logistically organized system. Features and facilities utilized in secondary processing (e.g., drying racks and butchering areas) and storage (e.g., storage pits) of bulk resources should be present. Such sites should have 
well-defined intrasite structure with archeologically identifiable activity areas (e.g., spatially segregated butchering, storage, secondary processing, living, and refuse disposal areas). Artifact assemblages should exhibit substantial diversity reflecting the utilization of a large number of specialized tools (Hayden 1986). Faunal assemblages should reflect the seasonal focus of subsistence activities on bison procurement, although smaller frequencies of other fauna secured on logistical trips should occur as well. The skeletal elements represented in bone assemblages will be determined by such factors as the size of the kill, distance from camp, size of the task group, and available mode of transportation (Fletcher and La Flesche 1972; Verbicky-Todd 1984:172-175; Hanson 1986). Botanical remains should consist of a wide variety of resources.

As the stored surpluses became exhausted, village residential groups likely fissioned into smaller nuclear or extended family foraging units; the residential base camps created by these smaller units should be smaller in size and exhibit shorter occupation spans because of the relatively rapid depletion of the resources within the foraging radius (Kelly 1983). Features and facilities in these camps should be fewer and less resource specific reflecting the broader resource base. Due to the more limited lengths of the occupations and the broader range of low-bulk activities carried out, site structure should be less differentiated exhibiting fewer archeologically visible activity areas. Artifact assemblages should be composed of generalized tool kits reflecting the lack of bulk resource procurement and processing, although some specialized tools may occur because of the exploitation of high-yield, r-selected resources. Faunal and botanical remains should reflect the exploitation of a broad range of resources, with perhaps some emphasis on r-selected resources procured in somewhat higher quantities.

Locations, the second site type generated under both resource acquisition systems, are different from residential base camps in that they represent loci of resource procurement and processing. Locations within logistical systems are the sites of high-bulk resource procurement and/or processing. Such sites should be relatively large and archeologically visible reflecting the large quantities of resources obtained. Features and facilities should be few and related to resource procurement (e.g., drive lines) or processing (e.g., drying racks and bone chip concentrations resulting from bone grease manufacture). The degree of intrasite structural definition (e.g., butchering areas and bone grease manufacturing areas) may be dependent on the duration and extent of field processing activities. Artifact assemblages should be characterized by specialized tool kits. Assemblages may contain significant numbers of worn, rejuvenated, and use-broken items discarded during retooling. Faunal and botanical remains should be well represented and should reflect the high specificity of the procurement activities. Locations generated by foragers should be smaller in size and archeologically less visible due to the low-bulk procurement and processing activities carried out there, although visibility may increase if a high degree of locational redundancy characterized foraging activities. Few features and facilities will be encountered due to the limited quantities of resources processed and the short-term use of such sites. Intrasite structural differentiation will be limited, and tool kits will be relatively generalized. Artifact assemblages may be composed primarily of expedient tools and/or tools with high transportation costs (e.g., hammerstones, anvils, and choppers). Locations within foraging systems should be characterized by a low degree of resource specificity. That is, relatively broad ranges of resources should have been exploited from foraging locations resulting in small but variable faunal and botanical samples. 
Field camps are generated only within logistically organized collector strategies and are the loci of group camping for the duration of resource procurement/processing tasks. They are distinct from residential base camps generated by collectors but may be somewhat similar to forager base camps. However, they should be distinguishable archeologically because of the short-term nature of the occupations and the small sizes of the occupying groups, which should result in extremely small site sizes. Features and facilities should be fewer than in forager residential base camps and should reflect primarily maintenance and manufacturing, rather than processing, activities. Site structure should be minimal reflecting the short occupations and lack of such maintenance activities as refuse disposal or the generation of specialized activity areas. Artifact assemblages should consist of task-specific artifacts discarded in the process of retooling (e.g., use-broken projectile point proximal fragments). It is possible that, under certain circumstances, a site may have served as both a field camp and a location. The frequency of this type of functional combination may depend on the nature of the exploited resource, the size of the kill, distance from the residential base camp, resource field processing requirements, and mode of transportation. Bison kill sites may be such a situation in which the field camp and location functions were combined.

Stations, another site type generated only by logistically organized collectors, are information gathering loci such as hunting stands. The small size of the task group utilizing them and the specialized, short-term use should result in very small sites with extremely low archeological visibility. Under conditions of high redundancy in site use (e.g., in the exploitation of highly predictable resources and in monitoring migration trails or water holes), archeological visibility may increase (Brooks and Yellen 1985). With the possible exception of features such as constructed blinds and small hearths, features and facilities will be few. Artifact assemblages will be extremely small, if deposited at all, and exhibit very low diversity. Perhaps occurring most commonly will be artifacts resulting from tool rejuvenation, particularly of hunting gear (e.g., resharpening flakes) (Binford 1979). Faunal and botanical remains will be few or absent.

Cache sites, or off-site storage features for foodstuffs, have extremely low archeological visibility. This site type has been identified most commonly among groups living in arctic environments where extended periods of below-freezing temperatures allow the preservation of perishable resources between field processing and return to residential camps. Given the relatively short periods of the year when temperatures in the Lower Plains stay below freezing, it is expected that this kind of site was not used frequently by collectors in the Justiceburg Reservoir area, although caching of foodstuffs may have been permitted by processing techniques such as sun drying.

Late Prehistoric I Period

The 2000-1000 B.P. period in the Lower Plains was characterized by a climate much wetter than that of today (Hall 1988:206-208); it partly corresponds with a suggested period of bison scarcity, ca. 1450 B.P. to 750 or 650 B.P. (Dillehay 1974:184-185). The model outlined here proposes that, in the absence of a stable and dependable bison population, human subsistence strategies focused on exploiting a variety of other plant and animal resources and that this could have been accomplished most effectively within a residentially mobile forager system. 
Late Prehistoric I sites should exhibit less intersite and intrasite variability than late Archaic sites. Only residential base camps and locations should occur. Residential base camps would have been moved often, although over short distances (Kelly 1983). The number and distance of the moves would have been conditioned by the productivity of the resource patch and the size of the foraging unit (Kelly 1983). Some variability in residential camp size conditioned by resource patch productivity may occur, with high-yield resource patches perhaps allowing some degree of seasonal group aggregation. Residential base camps used during seasons of low resource productivity or located in less-productive patches will be small reflecting group fissioning into smaller foraging units. Long-term storage of resources should not be evident. Given the relatively short term nature of the occupations at forager residential base camps and the limited need for bulk-resource processing, it is expected that features and facilities will be few and functionally nonspecific. This will likely limit the definition of intrasite structure (Binford 1985). Artifact assemblages will contain generalized tool kits reflecting the broad ranges and low quantities of resources utilized and the generalized processing techniques employed by foraging groups (Hayden 1986). Variability in assemblage size and composition may reflect differences in the sizes of the occupying groups and/or lengths of the occupations, as opposed to functional differences between residential base camps. The limited number of site types generated in foraging systems may result in the consistent occurrence of remains indicative of a broad range of lithic reduction activities at forager base camps, which contrasts with the greater potential intersite variability in lithic reduction under collector systems. Faunal and botanical remains should reflect the broad ranges of resources exploited. Botanical remains may be relatively good indicators of the season of occupation, since base camps were positioned across the landscape to take advantage of different resource harvesting schedules. Small fauna and age structure data on mediumsized mammals (e.g., antelope and deer) should provide similar information.

Late Prehistoric I locations should be small reflecting the smaller group sizes and the limited quantities of resources procured. While differences between locations could result from the procurement of different resources, these differences may be difficult to identify archeologically because of the use of generalized tool kits. The few facilities and features encountered should be related to the processing of small quantities of food consumed on daily foraging trips. Features used in the field processing of resources are not expected because processing would have taken place at the residential base camps. Site structure will be minimal due to the lack of site maintenance involved in such short-term occupations. Artifact assemblages will consist of generalized tools distributed in low densities. Expedient tools and tools with low curation values will make up the bulk of the collections. Tool maintenance and rejuvenation debris should not occur or should be low in frequency, while debitage from expedient tool manufacture may be found in higher frequencies. This relationship between rejuvenation and resharpening versus manufacturing debitage may be altered depending on raw material availability in the region, however. Faunal and botanical remains will exhibit low diversity, since they will represent the utilization of specific resource patches. These ecofacts will be strong indicators of the season of occupation.

Late Prehistoric II Period

The last 1,000 years in the Lower Plains has been characterized by a drying trend resulting in the modern climate (Hall 1988:208-209). Sometime during this period, probably 
ca. 700 years ago, the bison population in the Southern Plains increased dramatically (Dillehay 1974:184-185). It is proposed here that, as bison once again became abundant, human subsistence strategies shifted back to a bison-oriented economy, with Late Prehistoric II peoples adopting a logistically organized collector strategy to exploit bison during the seasons of abundance. During seasons of bison scarcity, resource procurement strategies likely shifted to a residentially mobile foraging system.

There are a number of important cultural factors (i.e., the development of extensive extraregional trade relationships) and technological changes (i.e., the introduction of ceramics, the bow and arrow, and the horse) that enter into modeling of Late Prehistoric II period adaptive strategies, as these factors may have made the operation of the seasonally alternating collector-forager resource procurement system more complex than that described for the late Archaic.

Extensive evidence of extraregional trade relationships (e.g., with Pueblo, Caddo, and Wichita villagers) suggests that the Late Prehistoric II inhabitants of the Lower Plains may have exercised some degree of territorial control over the region's bison herds and other resources such as lithic raw materials and salt. In particuilar, the interaction with Pueblo groups apparently was oriented toward exchanging surplus bison products for surplus agricultural products (Spielmann 1982, 1983). These exchange systems undoubtedly affected resource exploitation and land-use patterns, and in fact the Plains-Fueblo exchange system may be viewed as having been dependent on the logistical procurement of bison. In this sense, the extraregional trade relationships may have fostered the development of collector-oriented strategies in the Justiceburg Reservoir region.

Among the major technological changes during this period, the introduction of ceramics appears to have been the least important, and thus to have had the least effect on resource procurement strategies. This is based on the general scarcity of pottery in the project region and the lack of evidence that it was associated with a substantial increase in the ability to store foodstuffs. The introduction of the bow and arrow likely had a greater impact through increasing hunting efficiency. Such an increase in efficiency is important for the Late Prehistoric II period because it may have facilitated the procurement of large quantities of bison, thus promoting the adoption of collector-oriented strategies.

Of even greater importance in terms of its effect on land-use patterns was the introduction of the horse. For the purposes of this model, the first part of the Late Prehistoric II temporal unit, from 1000 to 300 B.P., is seen as predating any significant impact of the horse in the Lower Plains. Consequently, land-use patterns during this period are proposed to have been similar to those of the late Archaic period described above, and the archeological expectations for these two periods in the Justiceburg Reservoir area are the same. However, after about 300 B.P. (Newcomb 1961:87) the horse appears to have played a significant role in shaping regional settlement strategies and subsistence practices. Although no evidence of horse involvement has been found at any of the sites at Justiceburg Reservoir, several occupations date to this time and may contain information about changes in resource procurement patterns at the end of the Late Prehistoric II period.

While the effects of equestrian bison hunting on aboriginal cultures in the project region are difficult to estimate, Plains Village societies (e.g., Omaha and Cheyenne) provide a possible analogue. Among these groups, it is apparent that some pedestrian communal bison procurement practices were replaced due to the reduced search, pursuit, and commuting costs (Kelly 1983:290) allowed by horses (Oliver 1962; Hanson 1986). Specifically, the 
horse increased the distances logistical task groups traveled in search of game. Consequently, it may have increased the distance of kill sites from residential base camps. The reduced pursuit costs may have translated into an increase in the size of the kills and also may have reduced the extent of field processing needed prior to returning the meat to the base camp. The increased transportation capacity of horses over dogs may have increased the proportion of the kill returned to residential base camps, and the larger quantities of meat returned may have contributed to increased sedentism.

Hanson (1986:98) indicates that, among the Hidatsa, the more efficient mode of transportation offered by the horse reduced the need for part of the population to travel to kill locations to process meat. Instead, much of the primary and secondary processing was conducted at residential base camps. Such a change should produce at least two important effects that should be visible archeologically. Specifically, it should reduce the amount of camping residue associated with kill sites and increase the bone assemblage recovered from residential base camps.

However, increased mobility among some Plains Village groups appears to have characterized not only task groups but entire villages as well, as evidenced; by the summer and winter communal bison hunts of the Omaha (Fletcher and La Flesche 1972). This could generate field camps occupied by entire families rather than task groups. Such sites may appear similar to short-term forager residential base camps with the exception of more-numerous features and facilities, better-defined site structure, and larger quantities of faunal remains. This substitution of field camps occupied by entire family units for camps occupied by task groups could have led to a greater degree of functional specificity for locations in these settlement systems by limiting the instances in which a site was used both for procurement/processing and field camp activities. Additionally, the processing of kills in field camps would have reduced the quantity of skeletal materials returned to residential base camps. In a sense, the resource procurement pattern proposed here for the end of the Late Prehistoric II period is a hybrid of collector and forager strategies, which perhaps can be termed collector oriented with high residential mobility . As noted above, it is difficult to judge whether such a pattern is applicable to the Justiceburg Reservoir area; however, there is evidence suggesting that communal bison hunts following the patterns described above occurred among horticultural groups in the Lower Plains as far south and east as the Waco (Berlandier 1969:125).

Summary

The above discussion outlines a proposed series of shifts in land-use patterns in the Justiceburg Reservoir area conditioned by resource availability and distribution. Specifically, it builds a case for one resource, bison, conditioning changes between foragerand collector-oriented subsistence and settlement systems. It proposes that, during periods of bison abundance in the region, land-use patterns were composed of a seasonal mix of logistical and residential mobility. The logistical component was employed predominantIy as a response to the availability and bulk exploitation of the large-biomass resources represented by bison. Conversely, the residentially mobile, foraging component was a response to the scarcity of bison and the exploitation of a broader range of smaller, moredispersed fauna. The broad periods of bison abundance and scarcity proposed by Dillehay (1974) correlate roughly with the three temporal units represented in the project area. The late Archaic and Late Prehistoric II regional land-use patterns are seen as having been 
composed of a seasonal mix of logistical and residential mobility, while the Late Prehistoric I period is characterized by a residentially mobile foraging system. Differences between the late Archaic and Late Prehistoric II settlement systems are due to technological innovations and the increased complexity of interregional exchange networks. Overall, the proposed changes in regional settlement and subistence patterns between the late Archaic and Late Prehistoric II periods are viewed as representing broad technological and sociocultural adaptations conditioned by shifts in the regional resource base. It is within this broad perspective that the importance of the archeological sites at Justiceburg Reservoir must be viewed. Clearly, any site that can yield information allowing testing and refinement of the model should be considered to be of value. 



\section{CHAPTER 9}

\section{NATIONAL REGISTER ASSESSMENTS}

by Douglas K. Boyd and Ross C. Fields

This chapter discusses the eligibility of the 62 aboriginal sites investigated during this project for listing on the National Register of Historic Places. The intensive work at 34 first-priority sites provided sufficient data for full National Register assessments. The varying levels of work performed at the 28 second-priority sites, however, provided varying levels of information; as a consequence, many of the second-priority sites cannot be assessed fully in terms of National Register eligibility. In such cases, a recommendation of potentially eligible is made.

The 62 sites investigated constitute only 19\% of the 326 aboriginal sites documented at Justiceburg Reservoir. No additional data are available for sites that were not investigated during Phase II, and there is no basis for altering the i Phase I assessments presented in Boyd et al. (1989).

\section{Assessment Criteria}

Cultural resources are eligible for listing on the National Register of Historic Places, and thus worthy of avoidance, protection, or mitigation through data recovery, if they are significant in American history, architecture, engineering, or culture (U.S. Department of the Interior, National Park Service, National Register Division 1982:1). Significant properties are those that:

possess integrity of location, design, setting, materials, workmanship, feeling, and association, and:

A. that are associated with events that have made a significant contribution to the broad patterns of our history; or

B. that are associated with the lives of persons significant in our past; or

C. that embody the distinctive characteristics of a type, period, or method of construction, or that represent the works of a master, or that possess high artistic values, or that represent a significant and distinguishable entity whose component may lack individual distinction; or

D. that have yielded or may be likely to yield information important in prehistory or history. [U.S. Department of the Interior, National Park Service, National Register Division 1982:1]

The prehistoric sites and aboriginal rock art sites reported in this volume are evaluated under Criterion $D$ and thus must be capable of yielding important information to be 
considered eligible for listing on the National Register. Important information is defined as information relevant to the broad research goal, explained in Chapter 8, of understanding human adaptations and how they changed in response to changes in resource structure and abundance. To contribute important information concerning this topic, an archeological site must contain cultural materials that can be isolated into components or reasonably discrete periods of use, with little or no evidence of disturbance. In addition, a site must promise to yield data relevant to at least one of five broad problem domains that are the building blocks of the model of aboriginal adaptations presented in Chapter 8: chronology, environmental reconstruction, subsistence and resource exploitation, site function and settlement patterns, and cultural affiliation and intercultural relationships.

Temporal placement of archeological remains is especially critical for the Justiceburg Reservoir project area because previous archeological investigations in the Lower Plains have been limited, and thus the regional chronological framework remains ill defined. Over 10,000 years of human occupation are divided into a handful of cultural complexes/phases identified mainly from adjacent regions. These broad units form the basis for comparative analyses of material assemblages, but such analyses have proved problematical because of the sparse and mixed data. None of the other problem domains can be addressed adequately without better temporal controls. Even the Lower Plains projectile point sequence is extrapolated from other regions and is not based on dated archeological units. Until a regional chronological sequence can be established and supported by chronometric dating, advances toward understanding past lifeways will be minimal.

Late Pleistocene and Holocene climatic shifts postulated for the Southern Plains are based on limited data that are open to various interpretations. Climatic fluctuations and subsequent responses by plant and animal communities did have a profound impact on prehistoric populations and their adaptations, but only rudimentary correlations between cultural events and environmental conditions are currently possible. Paleoenvironmental evidence, such as pollen, phytoliths, and macrobotanical and faunal remains, is essential to reconstructing past environments, to understanding the nature and frequency of climatic shifts, and to documenting how these shifts affected biotic systems and human behavior.

A wide range of resources was available to prehistoric peoples in the Lower Plains, and many lines of archeological evidence can be used to infer subsistence strategies and document resource utilization. The current knowledge of prehistoric subsistence in the region is limited, however, and two steps are necessary for addressing this problem: first, to define the resource base; and second, to identify archeological evidence of specific resource utilization. Some resources, such as lithic materials, are relatively easy to define, and patterns of prehistoric exploitation can be documented. Many resources, particularly biological resources related to subsistence, are more difficult to identify in the archeological record. Archeological features and associated evidence, such as floral and faunal assemblages, are crucial elements in defining subsistence strategies and technologies.

Closely linked to studies of subsistence and resource exploitation are site function and settlement patterns. At present, few definitive statements can be made concerning the function of various kinds of prehistoric sites in the Lower Plains. Little data are available that can be used for defining regional settlement patterns. Broad site type categories, such as open campsite or lithic scatter, are not adequate to address these concerns. Unfortunately, the majority of the regional site data is survey-level information which is limited to such general classifications. Before substantive progress can be made 
concerning this problem domain, a larger data base of excavated sites and more synthetic treatment of the excavated data are needed.

The recognition of cultural affiliation and intercultural relationships for the project region is a long-term goal of archeological research in the Lower Plains. Archeological identification of cultural manifestations representing a particular group in time and space (i.e., a culture) is extremely difficult and requires that research go beyond the definition of complexes based solely on projectile points and pottery. Complete artifact assemblages must be considered in conjunction with all available chronological, environmental, and resource and subsistence data to address site function and settlement patterns. Armed with such data, however, ultimately it will be possible to address questions of group identity and how cultures interacted.

The aboriginal sites presented below are classified into seven categories: open campsites, lithic procurement sites, rockshelters, faunal localities, lithic scatters, isolated finds, and aboriginal rock art. While there is some overlap between campsite and lithic procurement activities, individual sites are classified based on the dominant activity represented.

Sites that have been shown through the work to date to have isolable components or periods of use and a high potential to contribute data relevant to at least one of the five problem domains are considered to be eligible for listing on the National Register of Historic Places. Conversely, sites that do not have isolable components/periods of use and have been shown to have a relatively low potential to contribute additional important information under all five problem domains are judged to be ineligible for listing on the National Register. All of the sites between these two extremes exhibit an unknown potential to address at least one problem domain, with this uncertainty being a function of the limited amount of work done. These sites, all of which are second-priority sites, are assessed as being potentially eligible for the National Register of Historic Places. Table 68 presents the site evaluations.

\section{Open Campsites}

Thirty-three open campsites were investigated. For discussion purposes, these are grouped into three categories based on their perceived research potential, i.e., low, unknown, and high. Ten sites (41GR286, 41GR287, 41GR323, 41GR359, 41GR374, 41GR376, 41GR378, 41GR456, 41GR515, and 41KT34) have a limited potential to yield important information. The primary characteristics displayed are a lack of discrete components, mixing of components, or evidence of severe disturbance. Sites that have been demonstrated to a reasonable degree to possess any of these characteristics are lacking in integrity. The interpretability of such sites is limited, and little or no data useful for addressing the problem domains can be recovered. As such, these sites are considered to be ineligible for listing on the National Register.

Fourteen sites (41GR207, 41GR239, 41GR302, 41GR380, 41GR393, 41GR467, 41GR471, 41GR474, 41GR483, 41GR566, 41GR569, 41KT47, 41KT148, and 41KT151) have an unknown potential to yield important information. All are second-priority sites and received only limited testing, as they were not the primary focus of the Phase II investigations. The data recovered from these sites are not adequate to demonstrate their research potential fully. 
TABLE 68

ASSESSMENTS OF RESEARCH POTENTIAL AND NATIONAL REGISTER ELIGIBILITY

\begin{tabular}{|c|c|c|c|c|c|c|}
\hline \multirow[b]{2}{*}{ Site } & \multicolumn{5}{|c|}{ Problem Domains } & \multirow[b]{2}{*}{$\begin{array}{l}\text { National } \\
\text { Register } \\
\text { Eligibility* }\end{array}$} \\
\hline & Chronology & $\begin{array}{l}\text { Environmental } \\
\text { Reconstruction }\end{array}$ & $\begin{array}{l}\text { Subsistence } \\
\text { and Resource } \\
\text { Exploitation }\end{array}$ & $\begin{array}{l}\text { Site Function } \\
\text { and Settlement } \\
\text { Patterns }\end{array}$ & $\begin{array}{l}\text { Cultural Affiliation } \\
\text { and Intercultural } \\
\text { Relationships }\end{array}$ & \\
\hline \multicolumn{7}{|c|}{ Prehistoric campsites: } \\
\hline 41GR207 & Moderate & $?$ & $?$ & ? & ? & $\mathrm{PE}$ \\
\hline 41GR239 & $?$ & $?$ & Low & ? & ? & $\mathrm{PE}$ \\
\hline 41GR286 & Low & Low & Low & Low & Low & $\mathrm{NE}$ \\
\hline $41 \mathrm{GR} 287$ & Low & Low & Low & Low & Low & $\mathrm{NE}$ \\
\hline 41GR291 & $\mathrm{High}$ & Moderate & High & High & $\mathrm{High}$ & $E$ \\
\hline 41GR302 & $?$ & $?$ & $?$ & $?$ & $?$ & $\mathrm{PE}$ \\
\hline 41GR303 & High & High & Moderate & Moderate & Moderate & $\mathrm{E}$ \\
\hline 41GR323 & Low & Low & Low & Low & Low & $\mathrm{NE}$ \\
\hline 41GR359 & Low & Low & Low & Low & Low & $\mathrm{NE}$ \\
\hline 41GR374 & Low & Low & Low & Low & Low & $\mathrm{NE}$ \\
\hline 41GR376 & Low & Low & Low & Low & Low & NE \\
\hline $41 \mathrm{GR} 378$ & Low & Low & Low & Low & Low & $\mathrm{NE}$ \\
\hline $41 \mathrm{GR} 380$ & $?$ & $?$ & $?$ & $?$ & $?$ & $\mathrm{PE}$ \\
\hline 41GR383 & $\mathrm{High}$ & ? & Moderate & High & Moderate & $\mathrm{E}$ \\
\hline $41 \mathrm{GR} 393$ & $?$ & $?$ & $?$ & $?$ & $?$ & $\mathrm{PE}$ \\
\hline $41 G R 456$ & Low & Low & Low & Low. & Low & $\mathrm{NE}$ \\
\hline $41 \mathrm{GR} 467$ & Moderate & $?$ & $?$ & $?$ & $?$ & $\mathrm{PE}$ \\
\hline 41GR471 & Moderate & ? & Moderate & Moderate & Moderate & $\mathrm{PE}$ \\
\hline 41GR4 74 & Moderate & ? & Mođerate & Moderate & $?$ & $\mathrm{PE}$ \\
\hline $41 \mathrm{GR} 483$ & $?$ & $?$ & $?$ & $?$ & $?$ & $\mathrm{PE}$ \\
\hline 41GR484 & High & Moderate & High & High & Moderate & $\mathrm{E}$ \\
\hline
\end{tabular}

$\star_{\mathrm{E}}=$ eligible; $\mathrm{PE}=$ potentially eligible; $\mathrm{NE}=$ not eligible. 
Table 68 , continued

Problem Domains

\begin{tabular}{lllll} 
& & Subsistence & Site Function & $\begin{array}{l}\text { Cultural Affiliation } \\
\text { and Intercultural } \\
\text { Site }\end{array}$ \\
Chronology & $\begin{array}{l}\text { Environmental } \\
\text { Reconstruction }\end{array}$ & $\begin{array}{l}\text { Register } \\
\text { Exploitation }\end{array}$ & Patterns & Relationships \\
\hline
\end{tabular}

\begin{tabular}{ll}
\hline & \\
41 GR515 & Low \\
41 GR566 & $?$ \\
41 GR569 & $?$ \\
41 KT33 & High \\
41 KT34 & Low \\
41 KT47 & $?$ \\
41 KT49 & High \\
41 KT51 & High \\
41 KT52 & Moderate \\
41 KT53 & High \\
41 KT148 & $?$ \\
41 KT151 & $?$
\end{tabular}

Lithic Procurement:

$\begin{array}{ll}41 \mathrm{GR} 327 & \text { Low } \\ 41 \mathrm{GR} 381 & \text { Low } \\ 41 \mathrm{KT} 35 & \text { Low } \\ 41 \mathrm{KT} 149 & \text { Low }\end{array}$

Rockshelters:

$\begin{array}{lll}\text { 41GR546 } & \text { High } & \text { High } \\ \text { 41GR559 } & \text { High } & \text { High }\end{array}$

Faunal Localities:

$\begin{array}{ll}41 G R 249 & \text { Low } \\ 41 G R 270 & \text { Low } \\ 41 G R 310 & \text { Low } \\ 41 G R 488 & \text { Low } \\ 41 \text { GR512 } & \text { Low }\end{array}$

Low
$?$
$?$
Moderate
Low
$?$
Moderate
Moderate
High
High
$?$
$?$

$\begin{array}{ll}\text { Low } & \text { Low } \\ \text { Low } & \text { Low } \\ \text { Low } & \text { Low } \\ \text { Low } & \text { Low }\end{array}$

High
High

Low
Low
Low
Low
Low

High
High

Low
Low
Low
Low
Low

Low
$?$
$?$
High
Low
$?$
High
High
Moderate
High
$?$
$?$

?

Low
$?$
$?$
High
Low
$?$
High
High
Moderate
High
$?$
$?$

Low
$?$
$?$
Moderate
Low
$?$
Moderate
High
Moderate
High
$?$
$?$

Low
Low
Low
Low

Low
Low
Low
Low

Moderate

Moderate

High
High

Low
Low
Low
Low
Low


Table 68 , continued

\section{Problem Domains}

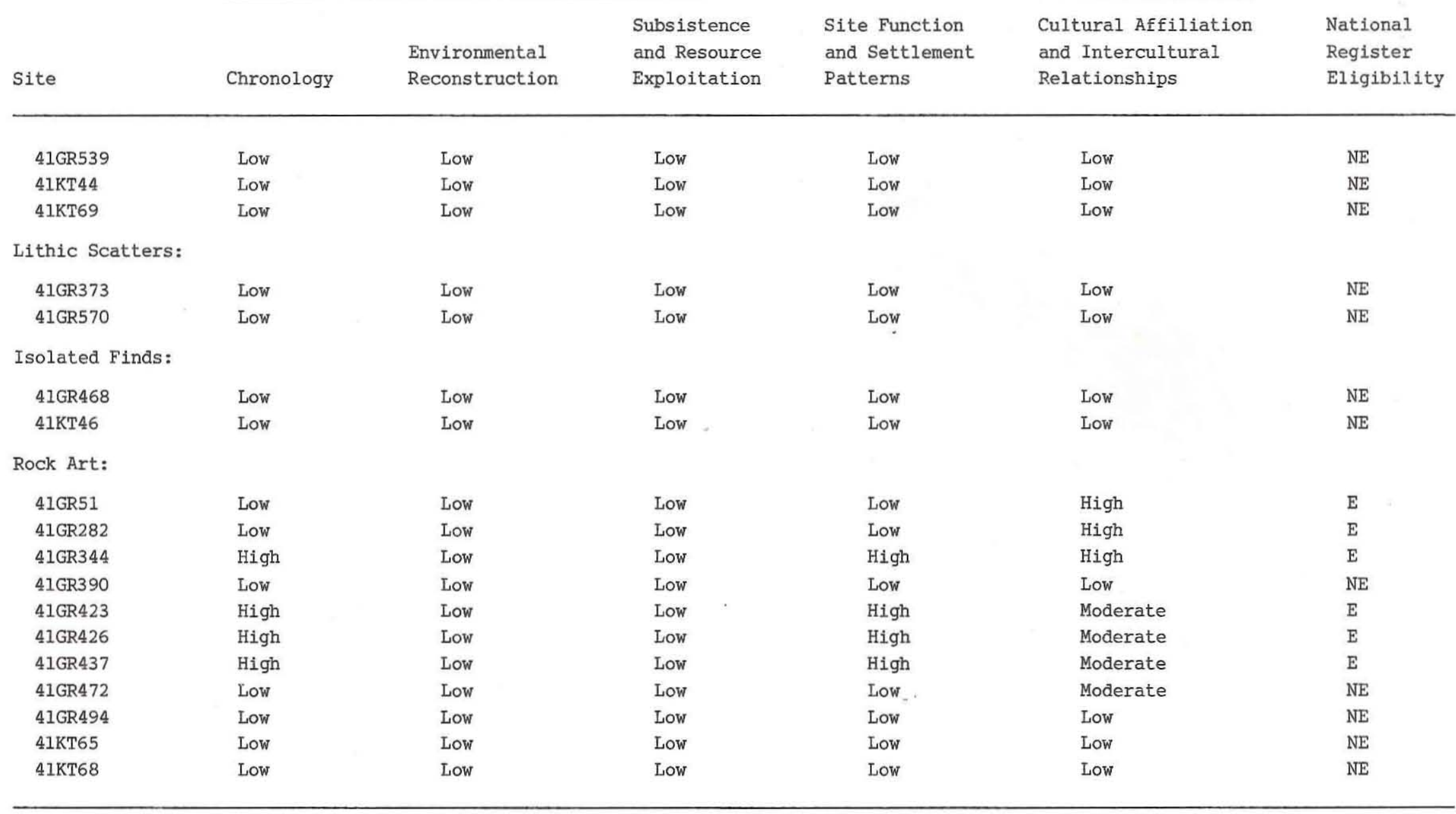


Although many are known from sparse material culture evidence, the depositional settings are such that the possiblility of discrete occupations cannot be ruled out. In the absence of more-definitive data, they are considered to be potentially eligible for listing on the National Register of Historic Places.

Nine sites (41GR291, 41GR303, 41GR383, 41GR484, 41KT33, 41KT49, 41KT51, 41KT52, and 41KT53) have a high research potential because they contain isolable components/periods of use and the appropriate types of physical evidence needed to address at least one problem domain. All of the sites have already yielded datable materials and/or temporally diagnostic artifacts necessary for addressing chronological research problems. These sites constitute a representative sample of the temporal periods evidenced in the archeological record at Justiceburg and of the topographic situations within the project area (Table 69). of the two cells in this matrix that contain more than one site, one (1ate Archaic--upland/ upland margin) consists of two sites in widely separated parts of the project area; $41 \mathrm{KT} 49$ lies east of Grape Creek at the downstream end of the reservoir, while 41 GR383 is west of Gobbler Creek near the upstream end. The other cell with multiple sites (Late Prehistoric I--upland/upland margin) consists of two resources that have substantially different kinds of archeological records and thus offer to yield complementary kinds of information; 41GR291 contains ceramics while $41 \mathrm{GR} 303$ is aceramic, and the latter has relatively thick stratified deposits while the former has thinner deposits that may be more discrete temporally. Establishing a cultural sequence and investigating patterns of local land use, i.e., settlement patterns within the project area, are particularly crucial research problems that can be addressed at these sites.

TABLE 69

CHRONOLOGICAL AND TOPOGRAPHIC DISTRIBUTION OF NATIONAL REGISTER-ELIGIBILE PREHISTORIC CAMPSITES

\begin{tabular}{|c|c|c|c|}
\hline \multirow[b]{2}{*}{ Topographic Setting } & \multicolumn{3}{|c|}{ Temporal Assignment* } \\
\hline & Late Archaic & Late Prehistoric I & Late Prehistoric II \\
\hline \multirow[t]{2}{*}{ Upland/upland margin } & 41GR383 & 41GR291 & -- \\
\hline & $41 \mathrm{KT} 49$ & 41GR303 & \\
\hline River terrace & $41 \mathrm{KT} 33$ & -- & 41GR484 \\
\hline Creek terrace & $41 \mathrm{KT} 52$ & -- & $41 \mathrm{KT} 53$ \\
\hline Levee & -- & -- & $41 K T 51$ \\
\hline
\end{tabular}


The types of physical evidence preserved in these nine sites, including archeological features and associated materials, stone tool assemblages, faunal and macrobotanical remains, pollen, phytoliths, and organic residues, are relevant to addressing the problems of environmental reconstruction, subsistence and resource exploitation, site function, and cultural affiliation and interaction. Subsurface features were discovered in all sites except 41KT51, which received only limited testing. The lithic tools and debitage recovered indicate that the frequencies of stone artifacts are adequate for a variety of analyses (e.g., assemblage variability, lithic technology, use-wear, etc.) at all sites except 41KT52. The paucity of lithics at this site could reflect the limited testing undertaken or perhaps a specialized site function. Evidence of intercultural relationships, in the form of exotic trade items, was recovered at three sites, 41GR291, 41KT51, and 41 KT53. Projectile points have been recovered from all but two sites, 41GR303 and 41KT52, and will be useful in defining cultural affiliations for the various occupations.

\section{Lithic Procurement Sites}

Investigations at two lithic procurement sites (41GR327 and 41GR381) recovered valuable data on the lithic raw materials available in the Quaternary Lingos gravels, but minimal information on the prehistoric utilization of these resources was obtained. Due to the multicomponent, surficial nature of these sites, they can contribute no data relevant to chronology, environmental reconstruction, or cultural affiliation, and only minimal information concerning resource exploitation, site function, and settlement patterns. Because discrete components or periods of use cannot be defined, they do not meet the minimum integrity standard and, as such, are judged to be ineligible for listing on the National Register of Historic Places.

Two additional lithic procurement sites received more-limited investigations. A single backhoe trench in $41 \mathrm{KT} 35$ yielded no new data, and site 41KT149 was discovered and recorded during Phase II investigations. Both are relatively small, sparsely utilized gravel outcrops that lack discrete components and are considered to have a low research potential. They are judged to be ineligible for listing on the National Register of Historic Places.

\section{$\underline{\text { Rockshelters }}$}

The two rockshelters investigated, 41 GR546 and 41GR559, contain stratified cultural deposits with associated features and artifacts; both have considerable potential to address all five of the problem domains. Isolable cultural occupations are evident, and although no diagnostic artifacts were recovered, the deposits are dated to the Late Prehistoric period. Stratified deposits and preserved organic remains are particularly crucial for establishing chronological relationships through radiocarbon dating. Additionally, the enhanced preservation of perishable materials that are not well preserved at other sites in the project area greatly increases the potential to address questions of subsistence, site function, and environmental reconstruction. Both rockshelters are judged to be eligible for listing on the National Register of Historic Places. 
Faunal Localities

The eight faunal localities investigated (41GR249, 41GR270, 41GR310, 41GR488, 41GR512, 41GR539, 41KT44, and 41KT69) all yielded important environmental information, and four contained possible cultural evidence as well. The testing apparently recovered all of the important information offered by these sites, however, and thus exhausted their potential to yield data relevant to the problem domains. As such, all eight faunal localities are judged to be ineligible for listing on the National Register of Historic Places.

\section{Lithic Scatters and Isolated Finds}

Minimal investigations were conducted at two lithic scatters and two isolated finds. One lithic scatter, 41GR570, was recorded during the Phase II investigations, and one exploratory trench in the other, 41GR373, yielded no cultural evidence. A backhoe trench adjacent to isolated find 41GR468 yielded a bone fragment, buti a subsequent test unit produced no cultural evidence. 'A backhoe trench adjacent to isolated find $41 \mathrm{KT} 46$ was also negative. Based on the paucity of cultural remains, these lithic scatters and isolated finds have little potential to contribute useful data beyond that already recorded. They are judged to be ineligible for listing on the National Register of Historic Places.

\section{$\underline{\text { Rock Art Sites }}$}

Distinctive aboriginal motifs are present at the 11 intensively investigated rock art sites. These sites represent an unusual, highly visible aspect of the region's archeological record. These sites have contributed significant information concerning chronology, site function, and cultural relationships, and several offer to yield additional important data related to these topics.

This additional information can be gained from more-detailed recording, the collection of pignent samples, and the testing of archeological deposits adjacent to, and perhaps associated with, the rock art panels. The four sites with the potential to yield additional information (41GR344, 41GR423, 41GR426, and 41GR437) are judged to be eligible for listing on the National Register of Historic Places. Additionally, one of these sites (4IGR344) and two others that have yielded valuable data but currently offer to yield no additional important information (41GR51 and 41GR282) are considered significant because they represent an historic aboriginal rock art complex that can be related to a defined style, i.e., the Plains Biographic Style, and thus have the potential to be associated with particular cultural groups. Such sites are not common in the Justiceburg Reservoir region. For these reasons, these three are judged to be eligible for listing on the National Register of Historic Places.

\section{Summary and Recommendations}

Of the 62 aboriginal sites investigated during the Justiceburg Reservoir Phase II study, 17 are assessed as being eligible for listing on the National Register of Historic 
Places. The integrity of these sites and the potential for addressing problem domains relevant to the study of aboriginal adaptations on the Southern Plains have been demonstrated. Fourteen sites are considered potentially eligible because the data obtained from the investigations are inadequate to support more-definitive assessments. The remaining 31 sites have a demonstrably low potential to yield useful information and are assessed as ineligible for listing on the National Register. These assessments are summarized in Table 70 .

TABLE 70

SUMMARY OF NATIONAL REGISTER ASSESSMENTS

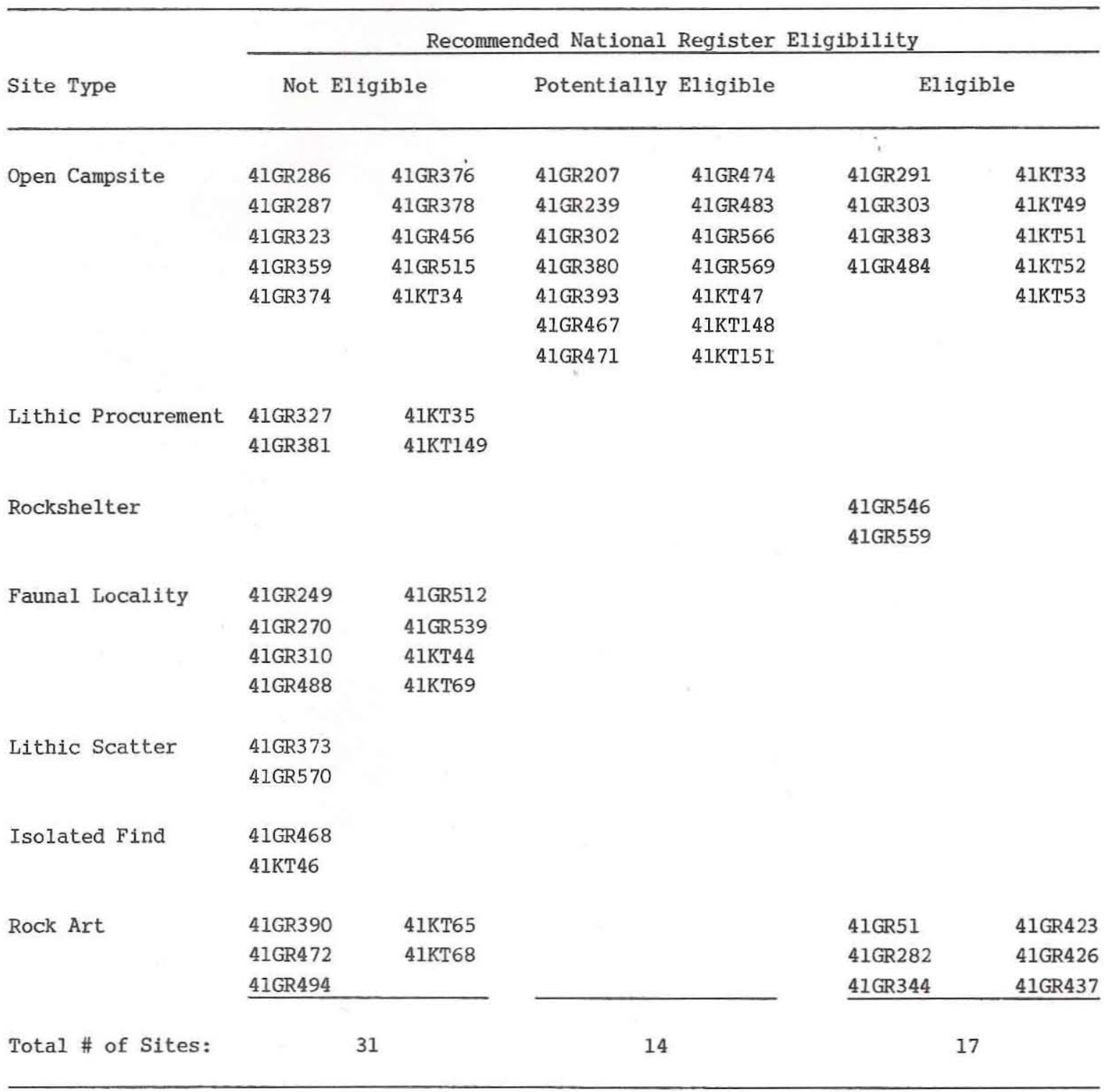


Future archeological investigations at Justiceburg Reservoir should concentrate on intensive site-specific data recovery at open campsites, rockshelters, and rock art sites. In addition to standard archeological field, laboratory, and analytical techniques, specialized technical studies should be undertaken to augment the recovery of important data. Continued geoarcheological investigations, particularly on a site-specific level, are critical to maximize the interpretive value of the archeological data. Magnetometer surveying was utilized successfully to locate buried cultural features at one site and can be a useful tool in locating and interpreting some kinds of cultural remains. The utility of several other specialized lines of investigation (flotation of feature and site sediments to recover macrobotanical remains, microscopic use-wear analysis of stone tools, palynological analysis, petrographic analysis of ceramic thin-sections) has been documented, and continued studies along these lines are warranted. Plant phytoliths and organic compound residues were found to be well preserved in the archeological record, and although the interpretation of these kinds of evidence can be problematical, critical and judicious use of the techniques, coupled with experimental studies, may provide unique and extremely important archeological data.

The sites selected for data recovery should be drawn chiefly from those investigated during Phase II since the research potential of these resources has been documented. It is noted, however, that the Phase II study, as directed by the regulatory agencies, investigated only sites in the primary impact zones, with the exception of rock art sites and rockshelters which are particularly susceptible to destruction from secondary impacts. Many uninvestigated sites remain in areas that will receive secondary impacts from reservoir construction, operation, and maintenance, and it is certain that a number of these sites contain information that could be used to address the research problem domains. The sites in these secondary impact zones constitute a valuable data base, the study of which would add greatly to an understanding of the cultural resources in the primary impact zones. Should these secondary-impact zone sites be threatened by reservoir-related activities or processes, it is hoped that they will be given due consideration so that important information concerning the archeology of the area will not be lost. 



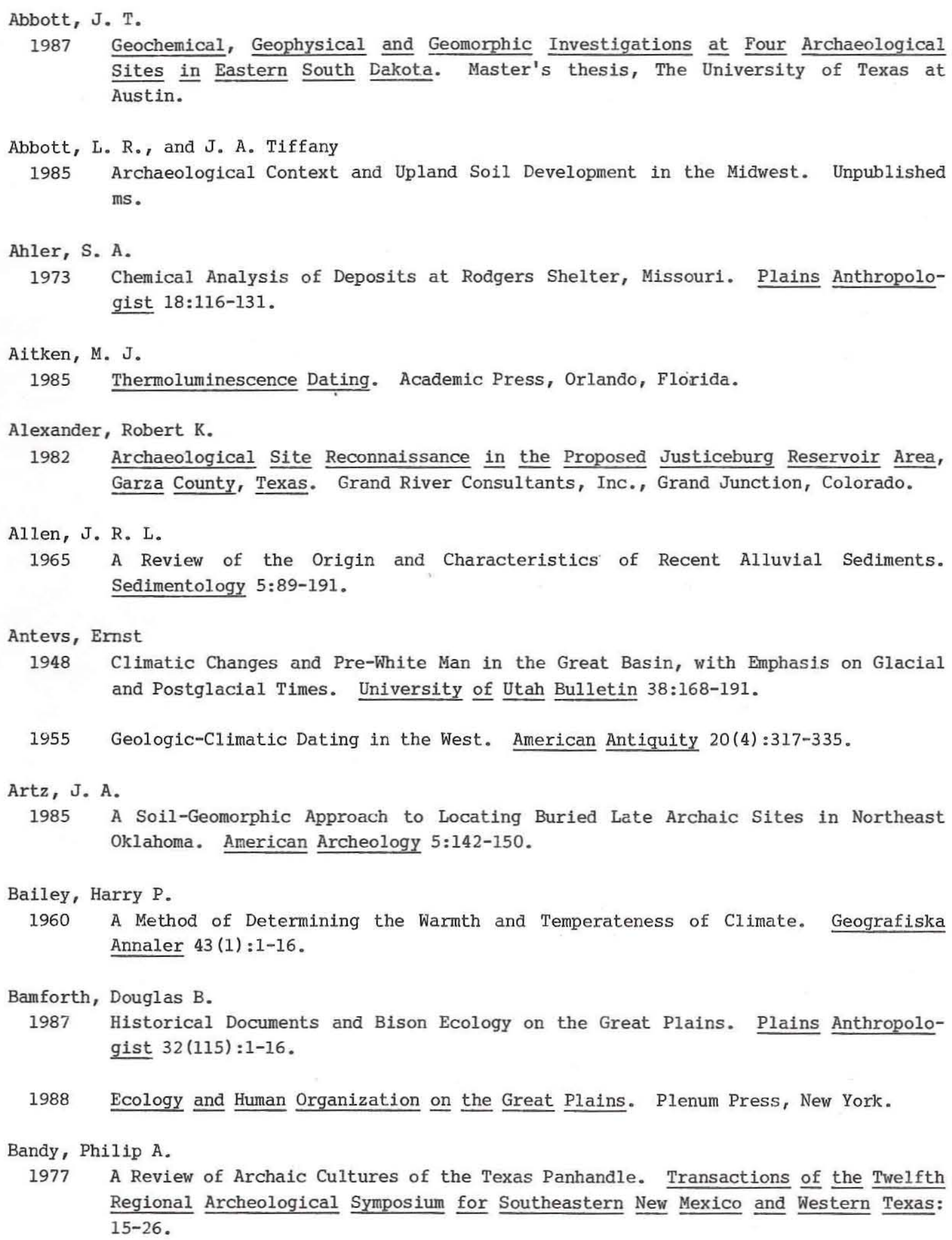
Sites in Eastern South Dakota. Master's thesis, The University of Texas at Austin.

1977 A Review of Archaic Cultures of the Texas Panhandle. Transactions of the Twelfth Regional Archeological Symposium for Southeastern New Mexico and Western Texas: 15-26. 


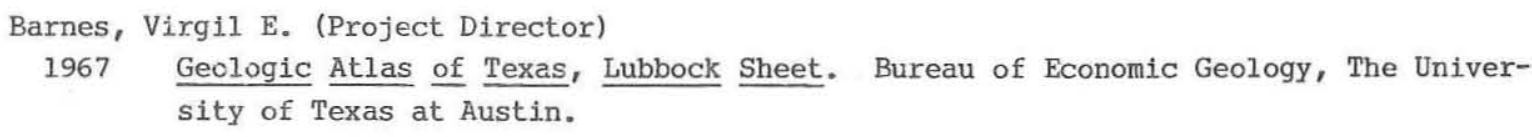

1974 Geologic Atlas of Texas, Big Spring Sheet. Bureau of Economic Geology, The University of Texas at Austin.

Baugh, Susan T.

1986 Late Prehistoric Bison Distributions in Oklahoma. Plains Anthropologist 31 (114, Part 2) :83-96.

Baugh, Timothy G.

1986 Culture History and Protohistoric Societies in the Southern Plains. Plains Anthropologist 31 (114, Part 2):167-187.

Berlandier, Jean Louis

1969 The Indians of Texas in 1830. Smithsonian Institution Press, Washington, D.C.

Binford, Lewis R.

1979 Organization and Formation Processes: Looking at Curated Technologies. Journal of Anthropological Research $35(3): 255-273$.

1980 Willow Smoke and Dogs" Tails: Hunter-Gatherer Settlement Systems and Archaeological Site Formation. American Antiquity 45(1):4-20.

1985 Researching Ambiguity: Frames of References and Site Structure. In Method and Theory for Activity Area Research: An Ethnoarchaeological Approach, edited by S. Kent, pp. 449-512. Columbia University Press, New York.

Birkeland, P. W.

1984 Soils and Geomorphology. Oxford University Press, New York.

Blair, W. Frank

1950 The Biotic Provinces of Texas. Texas Journal of Science 2(1):93-117.

Blissenbach, E.

1954 Geology of Alluvial Fans in Semiarid Regions. Geological Society of America Bulletin 65:175-190.

Blum, M. D.

1987 Late Quaternary Sedimentation in the Upper Federnales River, Texas. Master's thesis, The University of Texas at Austin.

1989 Geoarcheological Investigations. Chapter 7 in Phase I Cultural Resources Investigations at Justiceburg Reservoir on the Double Mountain Fork of the Brazos River, Garza and Kent Counties, Texas, by Douglas K. Boyd, Martha Doty Freeman, Michael D. Blum, Elton R. Prewitt, and J. Michael Quigg, pp. 81-106. Reports of Investigations No. 66, Volume I. Prewitt and Associates, Inc., Austin.

Blum, M. D., and S. Valasiro, Jr.

1989 Response of the Pedernales River of Central Texas to Late Holocene Climatic Change. Annals of the Association of American Geographers, in press. 
Bocek, B.

1986 Rodent Ecology and Burrowing Behavior: Predicted Effects on Archaeological Site Formation. American Antiquity 51:589-603.

Boyd, Douglas K.

1989a Environmental Setting. Chapter 2 in Phase I Cultural Resources Investigations at Justiceburg Reservoir on the Double Mountain Fork of the Brazos River, Garza and Kent Counties, Texas, by Douglas K. Boyd, Martha Doty Freeman, Michael D. Blum, Elton R. Prewitt, and J. Michael Quigg, pp. 7-21. Reports of Investigations No. 66, Volume I. Prewitt and Associates, Inc., Austin.

1989b Regional Archeological Background. Chapter 3 in Phase I Cultural Resources Investigations at Justiceburg Reservoir on the Double Mountain Fork of the Brazos River, Garza and Kent Counties, Texas, by Douglas K. Boyd, Martha Doty Freeman, Michael D. Blum, Elton R. Prewitt, and J. Michael Quigg, pp. 23-59. Reports of Investigations No. 66, Volume I. Prewitt and Associates, Inc., Austin.

1989c Prehistoric Resources in Justiceburg Reservoir. Chapter 8 in Phase I Cultural Resources Investigations at Justiceburg Reservoir on the Double Mountain Fork of the Brazos River, Garza and Kent Counties, Texas, by Douglas K. Boyd, Martha Doty Freeman, Michael D. Blum, Elton R. Prewitt, and J. Michael Quigg, pp. 107-131. Reports of Investigations No. 66, Volume I. Prewitt and Associates, Inc., Austin.

1989d Rock Art Resources. Chapter 10 in Phase I Cultural Resources Investigations at Justiceburg Reservoir on the Double Mountain Fork of the Brazos River, Garza and Kent Counties, Texas, by Douglas K. Boyd, Martha Doty Freeman, Michael D. Blum, Elton R. Prewitt, and J. Michael Quigg, pp. 157-194. Reports of Investigations No. 66, Volume I. Prewitt and Associates, Inc., Austin.

1989e Artifact Analysis. Appendix A in Phase I Cultural Resources Investigations at Justiceburg Reservoir on the Double Mountain Fork of the Brazos River, Garza and Kent Counties, Texas, by Douglas K. Boyd, Martha Doty Freeman, Michael D. Blum, Elton R. Prewitt, and J. Michael Quigg, pp. 291-364. Reports of Investigations No. 66, Volume I. Prewitt and Associates, Inc., Austin.

1990 Aboriginal Rock Art of Justiceburg Reservoir: A Regional Perspective for the Texas Panhandle-Plains. Submitted for publication to American Indian Rock Art. In press.

Boyd, Douglas K., Martha Doty Freeman, Michael D. Blum, Elton R. Prewitt, and J. Michael Quigg

1989 Phase I Cultural Resources Investigations at Justiceburg Reservoir on the Double Mountain Fork of the Brazos River, Garza and Kent Counties, Texas. Reports of Investigations No. 66. 2 volumes. Prewitt and Associates, Inc., Austin.

Brammer, $\mathrm{H}$.

1971 Coatings in Seasonally Flooded Soils. Geoderma 6:5-16.

Breiner, S.

1973 Applications Manual for Portable Magnetometers. Geometrics. Sunnyvale, California. 
Brooks, Alison S., and John E. Yellen

1985 The Preservation of Activity Areas in the Archaeological Record: Ethnoarchaeological and Archaeological Work in Northwest Ngamiland, Botswana. In Method and Theory for Activity Area Research: An Ethnoarchaeological Approach, edited by S. Kent, pp. 63-106. Columbia University Press, New York.

Brooks, Robert L., and Peggy Flynn

1988 34TX-71: A Late Prehistoric Bison Processing Station in the Oklahoma Panhandle. Plains Anthropologist $33(122): 467-487$.

Brown, Theodore M., Kay L. Killen, Helen Simons, and Virginia A. Wulfkuhle

1982 Resource Protection Planning Process for Texas. Texas Historical Commission, Austin.

Bryan, William A., Martha Doty Freeman, and Margaret Ann Howard

1989 Historic Site Descriptions. Appendix G in Phase I Cultural Resources Investigations at Justiceburg Reservoir on the Double Mountain Fork of the Brazos River, Garza and Kent Counties, Texas, by Douglas K. Boyd, Martha Doty Freeman, Michael D. Blum, Elton R. Prewitt, and J. Michael Quigg, pp. 577-643. Reports of Investigations No. 66, Volume II. Prewitt and Associates, Inc., Austin.

Bryan, William A., and Margaret Ann Howard

1989 Prehistoric Site Descriptions. Appendix F in Phase I Cultural Resources Investigations at Justiceburg Reservoir on the Double Mountain Fork of the Brazos River, Garza and Kent Counties, Texas, by Douglas K. Boyd, Martha Doty Freeman, Michael D. Blum, Elton R. Prewitt, and J. Michael Quigg, pp. 417-575. Reports of Investigations No. 66, Volume II. Prewitt and Associates, Inc., Austin.

Butzer, K. W.

1978 Changing Holocene Perspectives at the Koster Site: A Geo-Archaeological Perspective. American Antiquity 43:408-413.

1982 Archaeology as Human Ecology: Method and Theory for a Contextual Approach. Cambridge University Press, New York.

Campbel1, Robert G.

1975a An Archeological Survey of the South Plains Association of Governments Area. Transactions of the Tenth Regional Archeological Symposium for Southeastern New Mexico and Western Texas: 49-50.

1975b Archaeological Reconnaissance of Portions of the South Plains Region. Texas Tech University, Lubbock.

1976 Archaeological Survey in the S.P.A.G. Area. Transactions of the Eleventh Regional Archeological Symposium for Southeastern New Mexico and Western Texas: 93-97.

1977 Archaeological Reconnaissance of Portions of the South Plains Planning Region. Report No. 2: Corrections and Additions. Texas Tech University, Lubbock. 
Campbell, Robert G., and Sharon J. Judd

1977a Archaeological Reconnaissance of Portions of the South Plains Planning Region. Report No. 3: Tabulation of Archaeological Sites and Materials. Department of Anthropology, Texas Tech University, Lubbock.

1977b Archaeological Reconnaissance of Portions of the South Plains Planning Region. Report No. 4: Analysis of Archaeological Materials. Department of Anthropology, Texas Tech University, Lubbock.

Caran, S. Christopher, and Robert W. Baumgardner, Jr.

1988 The Lingos Formation, Western Rolling Plains of Texas. In Decade of North American Geology: Geological Society of America, South-Central Section, Centennial Field Guidebook 4:287-291. Edited by 0. T. Hayward.

Carpenter, Richard J.

1940 The Grassland Biome. Ecological Monographs 10:617-684.

Chisolm, B. J., S. Dube, and H. P. Schwarz

1986 Assessment of Prehistoric Bison Foraging and Movement Patterns Via Stable-Carbon Isotope Analysis. Plains Anthropologist 31(113):193-205.

Chorley, R. J., S. A. Schumm, and D. E. Sugden

1984 Geomorphology. Methuen, New York.

Cockrum, Dan E.

1963 A Multiple Burial from the Caprock Area. Bulletin of the South Plains Archeological Society 1:26-31.

Collins, Michael B.

1971 A Review of Llano Estacado Archaeology and Ethnohistory. Plains Anthropologist $16(52): 85-104$.

Conaty, Gerald T.

1987 Comments on Hayden's Resource Models of Inter-Assemblage Variability. Lithic Technology $16(2-3): 59-61$.

Connor, Stuart W., and Betty Lu Connor

1971 Rock Art of the Montana High Plains. The Art Galleries, University of California, Santa Barbara.

Couzzourt, Jim

1985 Preliminary Report: Testing at the Tascosa Creek Site, Oldham County, Texas. Transactions of the Twentieth Regional Archeological Symposium for Southeastern New Mexico and Western Texas:65-142.

Cruse, J. Brett

1989 Archeological Investigations at the Kent Creek Site (41HL66): Evidence of Mogollon Influence on the Southern Plains. Unpublished Master's thesis, Department of Anthropology, Texas A\&M University, College Station. 
De Niro, Michael J.

1987 Stable Isotopy and Archaeology. American Scientist 75:182-191.

Dillehay, Tom D.

1974 Late Quaternary Bison Population Changes on the Southern Plains. Plains Anthropologist 19(65): 180-196.

Dolliver, P. N., and V. T. Holliday

1988 Ogallala and Post-Ogallala Sediments of the Southern High Plains, Blanco Canyon and Mt. Blanco, Texas. Geological Society of America Centennial Field Guide-South-Central Section, pp. 299-304.

Eidt, R. C.

1977 Detection and Examination of Anthrosols by Phosphate Analysis. Science 197 (4311) :1327-1333.

1984 Advances in Abandoned Settlement Analysis: Application to Prehistoric Anthrosols in Colombia, South America. University of Wisconsin Press, Milwaukee.

Epp, Henry T.

1988 Way of the Migrating Herds: Dual Dispersion Strategy among Bison. Plains Anthropologist $33(121): 309-319$.

Etchieson, Gerald Meeks, Roberta D. Speer, and Jack T. Hughes

1979 Archeological Investigations in the Crowell Reservoir Area, Cottle, Foard, King and Knox Counties, Texas. Archeological Research Laboratory, Killgore Research Center, West Texas State University, Canyon.

Ewers, John C.

1976 Spanish Cattle in Plains Indian Art. Great Plains Journal 16(1):66-76.

Fletcher, Alice C., and Francis La Fleische

1972 The Omaha Tribe. Vol. I. The University of Nebraska Press, Lincoln.

Freeman, Martha Doty

1989a Regional Historical Background. Chapter 4 in Phase I Cultural Resources Investigations at Justiceburg Reservoir on the Double Mountain Fork of the Brazos River, Garza and Kent Counties, Texas, by Douglas K. Boyd, Martha Doty Freeman, Michael D. Blum, Elton R. Prewitt, and J. Michael Quigg, pp. 61-67. Reports of Investigations No. 66, Volume I. Prewitt and Associates, Inc., Austin.

1989b Historic Resources in Justiceburg Reservoir. Chapter 9 in Phase I Cultural Resources Investigations at Justiceburg Reservoir on the Double Mountain Fork of the Brazos River, Garza and Kent Counties, Texas, by Douglas K. Boyd, Martha Doty Freeman, Michael D. Blum, Elton R. Prewitt, and J. Michael Quigg, pp. 133-156. Reports of Investigations No. 66, Volume I. Prewitt and Associates, Inc., Austin.

Freeman, Martha Doty, and Douglas K. Boyd

1990 Phase II Historical Investigations at Justiceburg Reservoir, Garza and Kent Counties, Texas. Reports of Investigations No. 72. Prewitt and Associates, Inc., Austin. 


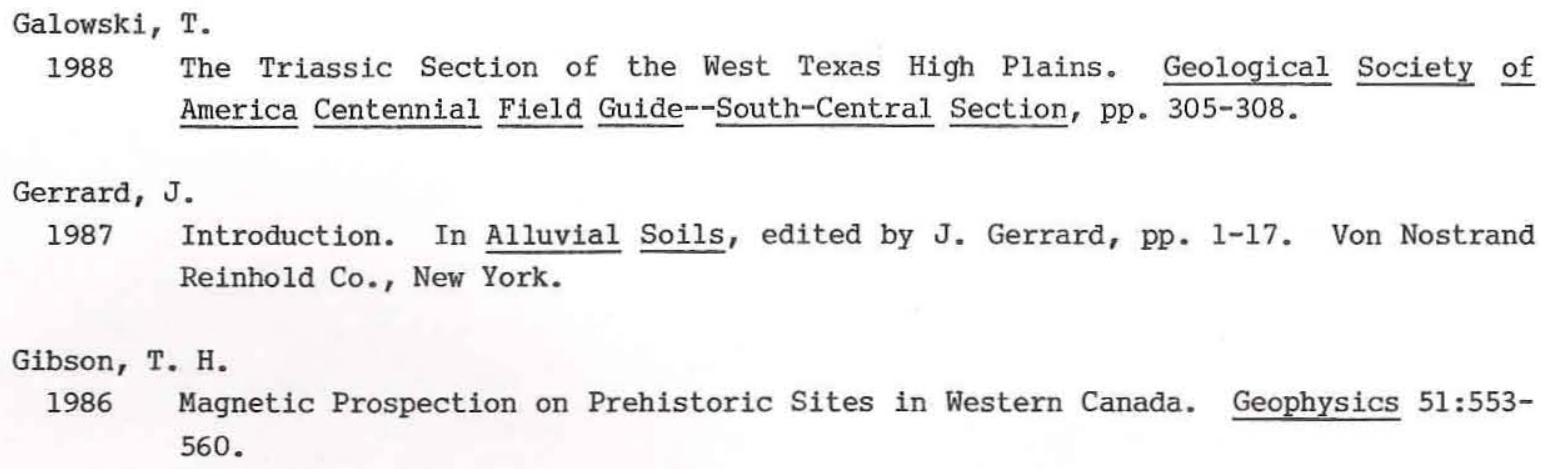

1979 The Desert Project Soil Monograph: Soils and Landscapes of a Desert Region Astride the Rio Grande Valley near Las Cruces, New Mexico. Publication of the U.S. Department of Agriculture, Soil Conservation Service. U.S. Government Printing Office, Washington, D.C..

Gladfelter, B. G.

1977 Geoarchaeology: The Geomorphologist and Archaeology. American Antiquity 42: 519-538.

Goland, Carol Ann

1983 The Ecological Context of Hunter-Gatherer Storage Strategies. Unpublished Master's thesis, Department of Anthropology, University of North Carolina, Chapel Hill.

Gregory, K. J., and D. E. Walling

1973 Drainage Basin Form and Process: $\underline{A}$ Geomorphological Approach. John Wiley and Sons, New York.

Grinnel1, George Bird

1910 Coup and Scalp among the Plains Indians. American Anthropologist 12:296-310.

1972 The Cheyenne Indians. Vol. I. University of Nebraska Press, Lincoln.

Gustavson, T. C. (editor)

1986 Geomorphology and Quaternary Stratigraphy of the Rolling Plains, Texas Panhandle. Bureau of Economic Geology Guidebook 22. The University of Texas at Austin.

Gustavson, Thomas C., and Robert J. Finley

1985 Late Cenozoic Geomorphic Evolution of the Texas Panhandle and Northeastern New Mexico: Case Studies of Structural Controls of Regional Drainage Development. Report of Investigations No. 148. Bureau of Economic Geology, The University of Texas at Austin.

Gustavson, T. C., R. J. Finley, and R. W. Baumgardner, Jr.

1981 Retreat of the Caprock Escarpment and Denudation of the Rolling Plains of the Texas Panhandle. Bulletin of the Association of Engineering Geologists 28(4): 413-422. 
Gustavson, Thomas C., and William W. Simpkins

1989 Geomorphic Processes and Rates of Retreat Affecting the Caprock Escarpment, Texas Panhandle. Reports of Investigations No. 180. Bureau of Economic Geology, The University of Texas at Austin.

Haas, Robert, Vance Holliday, and Robert Stuckenrath

1986 Dating of Holocene Stratigraphy with Soluble and Insoluble Organic Fractions at the Lubbock Lake Archaeological Site, Texas: An Ideal Case Study. Radiocarbon $28(2 A): 473-485$.

Habicht-Mauche, Judith A.

1987 Southwestern-style Culinary Ceramics on the Southern Plains: A Case Study of Technological Innovation and Cross-cultural Interaction. Plains Anthropologist $32(116): 175-189$.

Hall, Stephen A.

1977a Late Quaternary Sedimentation and Paleoecologic History of Chaco Canyon, New Mexico. Geological Society of America Bulletin 88:1593-1618.

1977b Geology: Palynology of Archaeological Sites and Associated Sediments. In The Prehistory of the Little Caney River, 1976 Field Season, edited by D. 0. Henry, pp. 13-41. Contributions in Archaeology 1, Laboratory of Archaeology, University of Tulsa, Tulsa, Oklahoma.

1982 Late Holocene Paleoecology of the Southern Plains. Quaternary Research 17:391407.

1985 Quaternary Pollen Analysis and Vegetational History of the Southwest. In Pollen Records of Late-Quaternary North American Sediments, edited by V. M. Bryant and R. G. Holloway, pp. 95-123. American Association of Stratigraphic Palynologists, Dallas.

1988 Environment and Archaeology of the Central Osage Plains. Plains Anthropologist $33(120): 203-218$.

Hammatt, Hallett $\mathrm{H}$.

1976 The Gore Pit Site: An Archaic Occupation in Southwestern Oklahoma and a Review of the Archaic Stage in the Southern Plains. Plains Anthropologist 21 (74):245277.

Hanson, Jeffery R.

1984 Bison Ecology in the Northern Plains and a Reconstruction of Bison Patterns for the North Dakota Region. Plains Anthropologist 29(104):93-114.

1986 Adjustment and Adaptation on the Northern Plains: The Case of Equestrianism among the Hidatsa. Plains Anthropologist 31(112):93-106.

Harrison, Billy R., and Kay L. Killen

1978 Lake Theo: A Stratified, Early Man Bison Butchering and Camp Site, Briscoe County, Texas: Archeological Investigations, Phase II. Panhandle-Plains Historical Museum, Canyon. 


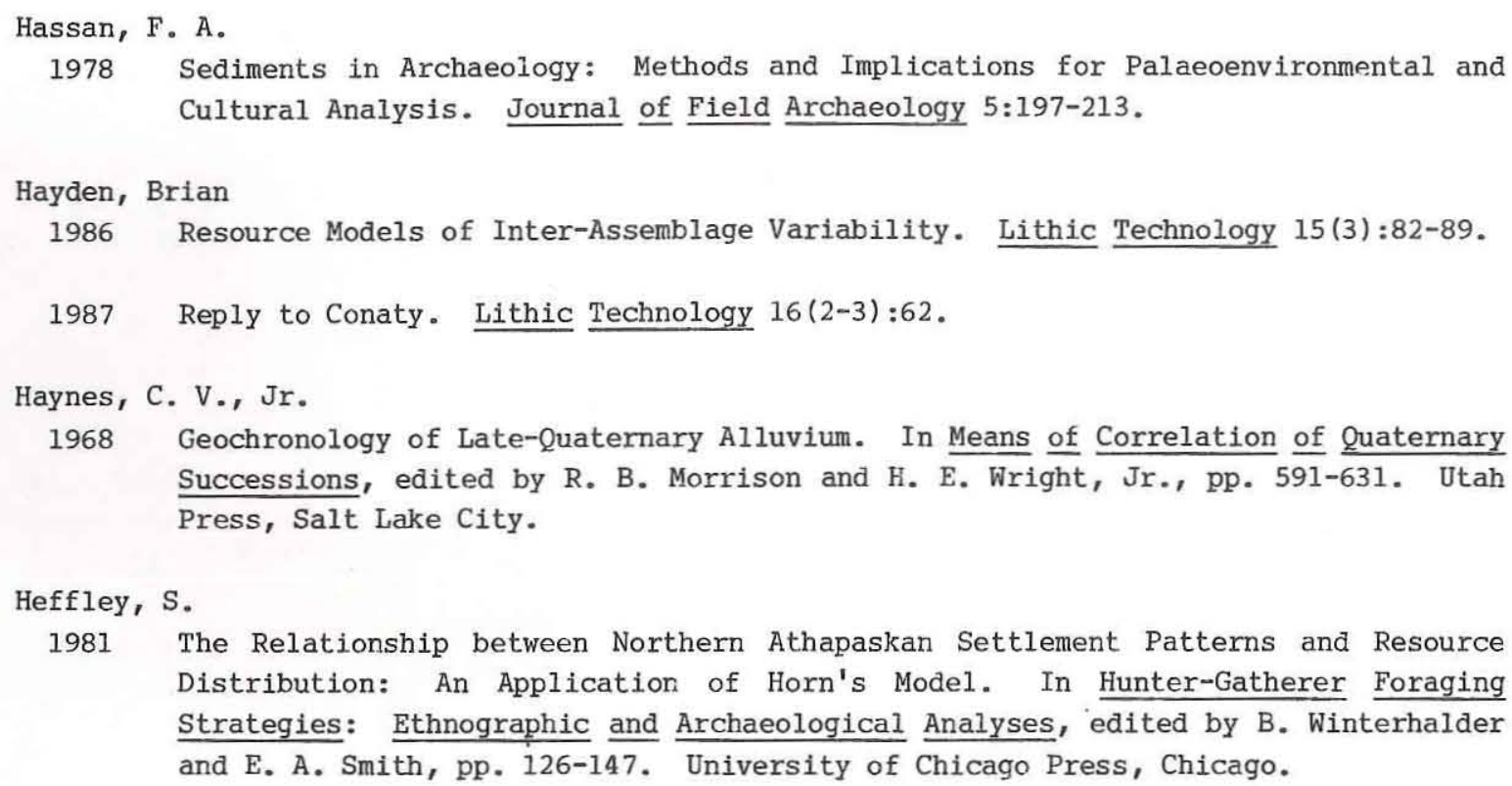

1979 River of Diamonds: An Alluvial History of the Lower Vaal Basin, South Africa. Research Paper 185. Department of Geography, University of Chicago.

Henry, D. 0.

1978 Big Hawk Shelter in Northeastern Oklahoma: Environmental, Economic, and Cultural Changes. Journal of Field Archaeology 5:269-287.

Hester, James J.

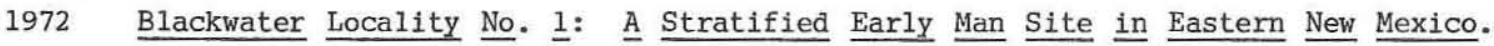
Fort Burgwin Research Center Publication No. 8. Southern Methodist University, Dallas.

Hester, Thomas Roy, Delbert Gilbow, and Alan D. Albee

1973 A Functional Analysis of "Clear Fork" Artifacts from the Rio Grande Plain, Texas. American Antiquity 38(1):90-96.

Hill, C. L., and D. J. Meltzer

1986 Late Quaternary Lithostratigraphy and Geochronology of the Mustang Springs Archaeological Site. Paper presented at the 1986 Annual Meeting, Geological Society of America, San Antonio, Texas.

Holliday, Vance T.

1985a Archaeological Geology of the Lubbock Lake Site, Southern High Plains of Texas. Geological Society of America Bulletin 96:1483-1492.

1985b Holocene Soil-geomorphological Relations in a Semi-arid Environment: The Southern High Plains of Texas. In Soils and quaternary Landscape Evolution, edited by J. Boardman, pp. 325-357. John Wiley and Sons, New York.

1985c New Data on the Stratigraphy and Pedology of the Clovis and Plainview Sites, Southern High Plains. Quaternary Research 23:388-402. 
1988 Late Pleistocene and Holocene Stratigraphy, Southern High Plains of Texas. Geological Society of America Centennial Field Guide-South-Central Section.

Hood, H. Charles

1978 Analysis of the Seymour Gravel. In Archeological Investigations in the Truscott Reservoir Area, King and Knox Counties, Texas, by Gerald Meeks Etchieson, Roberta D. Speer, and Jack T. Hughes, pp. 379-385. Archeological Research Laboratory, Killgore Research Center, West Texas State University, Canyon.

Hood, H. Charles, and Carrie A. Wright

1979 Analysis of the Seymour Gravel. In Archeological Investigations in the Crowell Reservoir Area, Cottle, Foard, King and Knox Counties, Texas, by Gerald Meeks Etchieson, Roberta D. Speer, and Jack T. Hughes, pp. 381-388. Archeological Research Laboratory, Killgore Research Center, West Texas State University, Canyon.

Hooke, R. LeB.

1967 Processes on Arid-Region Alluvial Fans. Journal of Geology 75:438-460.

Horn, H. S.

1968 The Adaptive Significance of Colonial Nesting in the Brewer's Blackbird (Euphagus cyanocephalus). Ecology 49:682-694.

Hughes, David T.

1977 Analysis of Certain Prehistoric Bison Kills in the Texas Panhandle and Adjacent Areas. Master's thesis, University of Arkansas, Fayetteville.

1984 The Foragers: Western Oklahoma. Chapter 6 in Prehistory of Oklahoma, edited by Robert E. Bell, pp. 104-117. Academic Press, New York.

Hughes, David T., and A. Alicia Hughes-Jones

1987 The Courson Archeological Projects, Final 1985 and Preliminary $\underline{1986 .}$ Innovative Publishing, Inc., Perryton, Texas.

Hughes, Jack T.

1955 Little Sunday: An Archaic Site in the Texas Panhandle. Bulletin of the Texas Archeological Society 26:55-74.

1962 Lake Creek: A Woodland Site in the Texas Panhandle. Bulletin of the Texas Archeological Society 32 (for 1961):65-84.

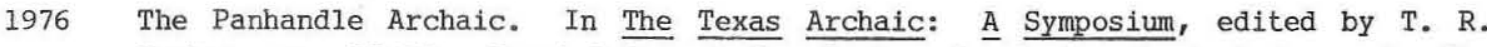
Hester, pp. 28-38. Special Report 2. Center for Archaeological Research, The University of Texas at San Antonio.

1978 Archeology of Palo Duro Canyon. Panhandle-Plains Historical Review 51:35-57.

n.d. Cultural Developments during the Archaic and NeoIndian Stages on the Texas High Plains. Unpublished ms. on file, Archeological Research Laboratory, Killgore Research Center, West Texas State University, Canyon. 
Hughes, Jack T., and Patrick S. Willey

1978 Archeology at Mackenzie Reservoir. Archeological Survey Report 24. Office of the State Archeologist, Texas Historical Commission, Austin.

Jackson, A. T.

1938 Picture-Writing of Texas Indians. University of Texas Publication No. 3809. Austin.

Jackson, Jack

1981 Floral and Faunal Remains. In Archeological Investigations at the George C. Davis Site, Cherokee County, Texas, edited by D. A. Story, pp. 347-360. Occasional Papers No. 1. Texas Archeological Research Laboratory, The University of Texas at Austin.

Jelinek, Arthur J.

1967 A Prehistoric Sequence in the Middle Pecos Valley, New Mexico. Anthropological Papers No. 31. Museum of Anthropology, University of Michigan, Ann Arbor.

Johnson, D. L., D. Watson-Stegner, D. N. Johnson, and R. A. Schaetzl

1987 Proisotropic and Proanisotropic Processes of Pedoturbation. Soil Science 143: 278-292.

Johnson, Eileen

1983 The Lubbock Lake Paleoindian Record. In Guidebook to the Central Llano Estacado, edited by Vance T. Holliday, pp. 81-105. Friends of the Pleistocene, SouthCentral Cell, 1982 Field Trip. The Museum, Texas Tech University, Lubbock.

1987 Lubbock Lake: Late Quaternary Studies on the Southern High Plains. Texas A\&M Press, College Station.

Johnson, Eileen, and Vance T. Holliday

1986 The Archaic Record at Lubbock Lake. Plains Anthropologist 31 (114, Part 2) :7-54.

Johnson, Eileen, Vance T. Holliday, Michael J. Kaczor, and Robert Stuckenrath

1977 The Garza Occupation at the Lubbock Lake Site. Bulletin of the Texas Archeological Society 48:83-110.

Jordan, T. G., J. L. Bean, Jr., and W. M. Holmes

1984 Texas: $\underline{A}$ Geography. Westview Press, Boulder, Colorado.

Judd, Sharon J.

1977 Prehistoric Cultural Resources in the Central Llano Estacado and Western Rolling Plains of Texas. Master's thesis, Department of Anthropology, Texas Tech University, Lubbock.

1978 Prehistoric Resources in the South Plains Association of Governments Area. Transactions of the Thirteenth Regional Archeological Symposium for Southeastern New Mexico and Western Texas:23-26.

Kelley, Jane Holden

1964 Comments on the Archeology of the Llano Estacado. Bulletin of the Texas Archeological Society 35:1-17. 
Kelly, Robert L.

1980 Hunter-Gatherer Settlement Systems. Unpublished Master's thesis, Department of Anthropology, University of New Mexico, Albuquerque.

1983 Hunter-Gatherer Mobility Strategies. Journal of Anthropological Research 39(3): 277-306.

Kenmotsu, Ray D.

1981 An Assessment and Overview of the Flora of the Brazos Natural Salt Pollution Control Project Area. Appendix VII in A Preliminary Assessment of the Cultural Resources in the Brazos Natural Salt Pollution Control Project, Kent, King, and Stonewall Counties, Texas, by J. Peter Thurmond, Martha Doty Freeman, and Susan L. Andrews, pp. 339-351. Reports of Investigations No. 18. Prewitt and Associates, Inc., Austin.

Keyser, James D.

1987 A Lexicon for Historic Plains Indian Rock Art: Increasing Interpretive Potential. Plains Anthropologist 32 (115):43-71.

Kirkland, Forrest, and W. W. Newcomb, Jr.

1967 The Rock Art of Texas Indians. University of Texas Press, Austin.

Kirkpatrick, Zoe

1978 A Preliminary Report on a Rare Form of Bedrock Mortar Holes in Garza County, Texas. Transactions of the Thirteenth Regional Archeological Symposium for Southeastern New Mexico and Western Texas:31-38.

Klassen, Michael A., and Martin P. R. Magne

1988 The Management and Conservation of Alberta Rock Art: Background and Preliminary Recommendations. In Archaeology in Alberta, 1987, compiled by Martin Magne, pp. 65-118. Archaeological Survey of Alberta, Occasional Paper No. 32. Alberta Culture and Multiculturalism, Edmonton.

Klein, G. D.

1980 Sandstone Depositional Models for Exploration for Fossil Fuels. 2nd edition. Burgess Publishing Company, Minneapolis.

Knox, J. C.

1983 Responses of River Systems to Holocene Climates. In Late quaternary Environments of the United States, Volume 2: The Holocene, edited by H. E. Wright, Jr., pp. 26-41. University of Minnesota Press, Minneapolis.

Leonhardy, Frank C.

1966 Test Excavations in the Mangum Reservoir Area of Southwestern Oklahoma. Contributions of the Museum of the Great Plains, No. 2. Lawton, Oklahoma.

Lew in, J.

1978 Floodplain Geomorphology. Processes in Physical Geography 2:408-437. 


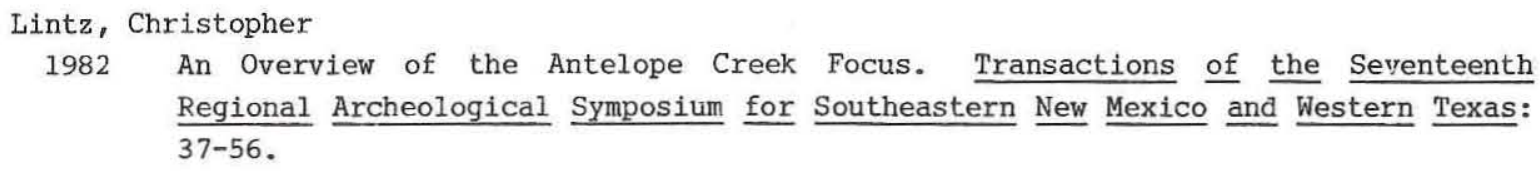
Regional Archeological Symposium for Southeastern New Mexico and Western Texas: 37-56.

1986 Architecture and Community Variability within the Antelope Creek Phase of the Texas Panhandle. Studies in Oklahoma's Past No. 14. Oklahoma Archeological Survey, Norman.

Lobeck, A. K.

1948 Physiographic Diagram of the United States. The Geographical Press, Maplewood, New Jersey.

Lowe, J. J., and M. J. C. Walker

1984 Reconstructing Quaternary Environments. Longman Press, New York.

Lynott, Mark

1979 Prehistoric Bison Populations of North Central Texas. Bulletin of the Texas Archeological Society 50:89-101.

Marchbanks, Michael Lee

1989 Lipid Analysis in Archaeology: An Initial Study of Ceramics and Subsistence at the George C. Davis Site. Master's thesis, Department of Anthropology, University of Texas at Austin.

Martin, P. S.

1963 The Last 10,000 Years: A Fossil Pollen Record of the American Southwest. University of Arizona Press, Tucson.

Mason Johnston and Associates, Inc.

n.d. Geotechnical Investigation, Justiceburg Dam, Kent/Garza Counties, Texas. Technical report presented to the City of Lubbock, Texas.

Meltzer, David J.

1986 The Archaeology and Paleoecology of Mustang Springs (41MT2), Southern Llano Estacado. Paper presented at the 57th Annual Meeting of the Texas Archeological Society, Laredo, Texas.

Meltzer, David J., and Michael B. Collins

1987 Prehistoric Water Wells on the Southern High Plains: Clues to Altithermal Climate. Journal of Field Archaeology 14:9-28.

Miall, A. D.

1977 A Review of the Braided River Depositional Environment. Earth Science Reviews 13:1-62.

Moodie, D. W., and A. J. Ray

1976 Buffalo Migrations on the Canadian Plains. Plains Anthropologist 21 (72):45-52. 


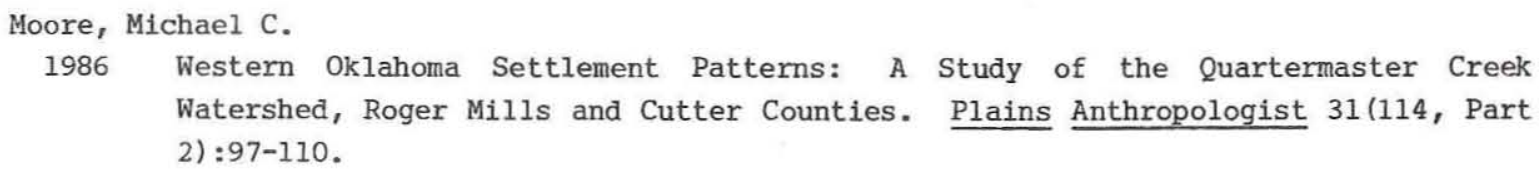

Natural Fibers Information Center

1987 The Climates of Texas Counties. Natural Fibers Information Center, in cooperation with the Office of the State Climatologist, Texas A\&M University, College Station.

Newcomb, W. W., Jr.

1961 The Indians of Texas: From Prehistoric to Modern Times. University of Texas Press, Austin.

Oliver, S. C.

1962 Ecology and Continuity as Contributing Factors in the Social Organization of Plains Indians. University of California Publications in American Archaeology and Ethnology No. 48 .

01son, G. W. (compiler)

1976 Criteria for Making and Interpreting a Soil Profile Description: A Compilation of the Official USDA Procedure and Nomenclature for Describing Soils. University of Kansas Publications, Lawrence.

Owen, James G., and David F. Schmidly

1986 Environmental Variables of Biological Importance in Texas. The Texas Journal of Science $38(2): 99-120$.

Parry, William J., and John D. Speth

1984 The Garnsey Spring Campsite: Late Prehistoric Occupation in Southeastern New Mexico. Technical Reports No. 15. Museum of Anthropology, University of Michigan, Ann Arbor.

Parsons, Mark L.

1987 Plains Indian Portable Art as a Key to Two Texas Historic Rock Art Sites. Plains Anthropologist 32 (117):257-274.

Pass, Fred

1981 Texas Almanac and State Industrial Guide, 1982-1983. A. H. Belo, Dallas.

Peden, Donald G.

1976 Botanical Composition of Bison Diets on Shortgrass Plains. The American Midland Naturalist $96(1): 225-229$.

Peden, D. G., G. M. Van Dyne, R. W. Rice, and R. M. Hansen

1974 The Trophic Ecology of Bison bison L. on Shortgrass Plains. Journal of Applied Ecology 11:489-498. 
Prewitt, Elton R.

1981 Cultural Chronology in Central Texas. Bulletin of the Texas Archeological Society 52:65-89.

1985 From Circleville to Toyah: Comments on Central Texas Chronology. Bulletin of the Texas Archeological Society 54 (for 1983):201-238.

Quinn, Jean, and Jane Holden

1949 Caves and Shelters in Dawson and Borden Counties. Bulletin of the Texas Archeological and Paleontological Society 20:115-131.

Reeves, C. C., Jr.

1970 Origin, Classification, and Geologic History of Caliche on the Southern High Plains, Texas and Eastern New Mexico. Journal of Geology 78:352-362.

Reineck, H. E., and I. B. Singh

1980 Depositional Sedimentary Environments, with Reference to Terrigenous Clastics. 2nd edition. Springer, Verlag, New York.

Richardson, W. E., and C. L. Girdner

1973 Scil Survey of Kent County, Texas. United States Department of Agriculture, Soil Conservation Service, in ccoperation with the Texas Agricultural Experiment Station.

Richardson, W. E., D. G. Grice, and L. A. Putnam

1975 Soil Survey of Garza County, Texas. United States Department of Agriculture, Soil Conservation Service, in cooperation with the Texas Agricultural Experiment Station.

Riggs, Aaron D., Jr.

1965 Petroglyphs of Garza County, Texas. Transactions of the First Regional Archeological Symposium for Southeastern New Mexico and Western Texas:9-14.

1966 The Reed Shelter: A Petroglyph Site in Garza County, Texas. Transactions of the Second Regional Archeological Symposium for Southeastern New Mexico and Western Texas: 44-58.

1969 Yellowhouse Crossing Mesa Fetroglyphs. Transactions of the Fifth Regional Archeological Symposium for Southeastern New Mexico and Western Texas:25-33.

Ritter, D. F.

1978 Process Geomorphology. Wm. C. Brown Co., Dubuque.

Roe, Frank G.

1970 The North American Buffalo: A Critical Study of the Species in its Wild State. University of Toronto Press, Toronto, Ontario, Canada.

Rosenzweig, Michael L.

1968 Net Primary Productivity of Terrestrial Communities: Prediction from Climatological Data. The American Naturalist 102(923):67-74. 
Runkles, Frank A.

1964 The Garza Site: A Neo-American Campsite Near Post, Texas. Bulletin of the Texas Archeological Society 35:101-125.

Runyan, John W., and John A. Hedrick

1987 Pottery Types of the Southwest Federation of Archeological Societies (SWFAS Area). The Artifact $25(4): 23-59$.

Rust, B. R.

1980 Facies Models 2: Coarse Alluvial Deposits. In Facies Models, edited by R. G. Walker, pp. 9-21. Geoscience Canada Reprint Series 1. Geological Association of Canada, Toronto.

Schaafsma, Polly

1985 Form, Content, and Function: Theory and Method in North American Rock Art Studies. In Advances in Archaeological Method and Theory, Vol. 8, edited by Michael B. Schiffer, pp. 237-277. Academic Press, Inc., New York.

Schiffer, M. B.

1983 Toward the Identification of Formation Processes. American Antiquity 48:675-705.

1987 Formation Processes of the Archaeological Record. University of New Mexico Press, Albuquerque.

Schuldenrein, J.

1985 Synthesis: The Geoarchaeology of Pinon Canyon. In Geomorphological Investigations at the U.S. Army Fort Carson-Pinon Canyon Maneuver Site, Las Animas County, Colorado. Gilbert Commonwealth, Inc., Jackson, Michigan.

Schultz, Gerald E., and Viola M. Rawn

1978 Faunal Remains from the Deadman's Shelter Site. In Archeology at Mackenzie Reservoir, edited by Jack T. Hughes and Patrick S. Willey, pp. 191-198. Archeological Survey Report 24. Texas Historical Commission, Austin.

Schumm, S. A.

1977 The Fluvial System. John Wiley and Sons, New York.

Sellards, E. H., W. S. Adkins, and F. B. Plummer

1932 The Geology of Texas, Volume I: Stratigraphy. Bureau of Economic Geology, Bulletin No. 3232. The University of Texas at Austin.

Seni, S. J.

1980 Sand-Body Geometry and Depositional Systems, Ogallala Formation, Texas. Report of Investigations No. 105. Bureau of Economic Geology, The University of Texas at Austin.

Shaeffer, James B.

1966 Salvage Archaeology in Oklahoma, Vol. II. Papers of the Oklahoma Archaeological Salvage Project, Nos. 18-21. Bulletin of the Oklahoma Anthropological Society 14:1-86. 
Shedd, Emmett

1968 A Probable Jornado Burial in Garza County, Texas. Transactions of the Third Regional Archeological Symposium for Southeastern New Mexico and Western Texas: 12-20.

Shelford, Victor E.

1963 Ecology of North America. University of Illinois Press, Urbana.

Simpkins, William W., and Thomas C. Gustavson

1987 Erosion Rates and Processes in Subhumid and Semiarid Climates, Texas Panhandle: Statistical Evaluation of Field Data. Reports of Investigations No. 162. Bureau of Economic Geology, The University of Texas at Austin.

Sjoberg, A.

1976 Phosphate Analysis of Anthropic Soils. Journal of Field Archaeology 3:447-454.

Soil Survey Staff

1951 Soil Survey Manual. U.S. Department of Agriculture, Handbook No. 18. U.S. Government Printing office, Washington, D.C..

Speth, John D.

1983 Bison Kills and Bone Counts: Decision Making by Ancient Hunters. Prehistoric Archeology and Ecology Series, edited by Karl W. Butzer and Leslie G. Freeman. University of Chicago Press, Chicago.

Spielmann, Katherine A.

1982 Inter-Societal Food Acquisition among Egalitarian Societies: An Ecological Analys is of Plains/Pueblo Interaction in the American Southwest. Ph.D. dissertation, Department of Anthropology, University of Michigan, University Microfilms, Ann Arbor.

1983 Late Prehistoric Exchange between the Southwest and Southern Plains. Plains Anthropologist 28(102, Part 1):257-272.

Stein, J. K.

1983 Earthworm Activity: A Source of Potential Disturbance of Archaeological Sediments. American Antiquity 48:277-289.

1985 Interpreting Sediments in Cultural Settings. In Archaeological Sediments in Context. Peopling of the Americas Edited Volume Series 1. Center for the Study of Early Man, Institute for Quaternary Studies, University of Maine, Orono.

Suhm, Dee Ann, and Edward B. Jelks

1962 Handbook of Texas Archeology: Type Descriptions. Texas Archeological Society Special Publication No. 1 and Texas Memorial Museum Bulletin No. 4. Austin.

Suhm, Dee Ann, Alex D. Krieger, and Edward B. Jelks

1954 An Introductory Handbook of Texas Archeology. Bulletin of the Texas Archeological Society 25 (entire volume). 


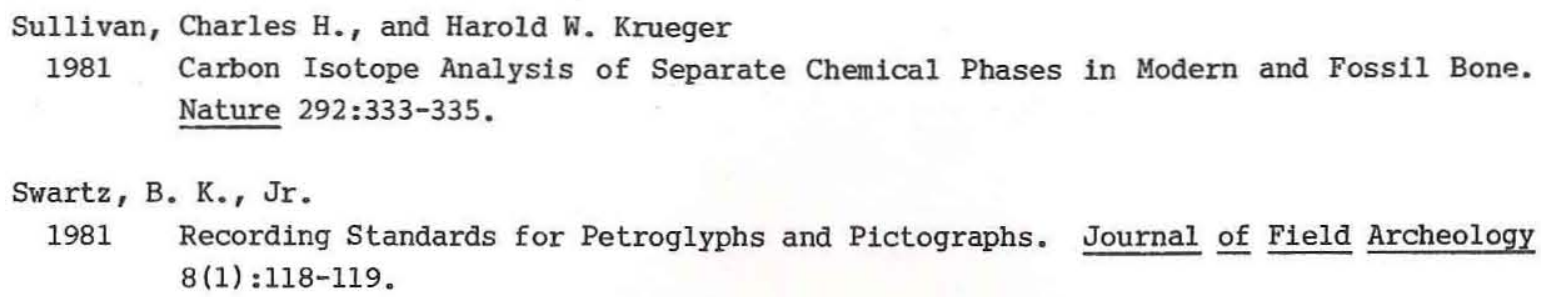
Adair-Steadman Site in Northwest Texas. Special Report 18. Office of the State Archeologist, Texas Historical Commission, Austin.

Tunnel1, Curtis D., and Jack T. Hughes,

1955 An Archaic Bison Kill in the Texas Panhandle. Panhandle-Plains Historical Review 28:63-70.

Turpin, Solveig A.

1987 Ethnohistoric Observations of Bison in the Lower Pecos River Region: Implications for Environmental Change. Plains Anthropologist 32 (118):424-429.

U.S. Department of the Interior, National Park Service, National Register Division 1982 How to Apply the National Register Criteria for Evaluation. National Park Service, Department of the Interior, Washington, D.C.

Van der Merwe, N. J.

1982 Carbon Isotopes, Photosynthesis, and Archaeology. American Scientist 70(6) :596606.

Vehik, Susan C.

1986 The Effectis of Trade on Resource Procurement Behavior: A Late Prehistoric Example from the Southern Plains. Plains Anthropologist 31 (114, Part 2):141-154.

Verbicky-Todd, Eleanor

1984 Communal Buffalo Hunting among the Plains Indians. Archaeological Survey of Alberta Occasional Paper No. 24.

Warren, A. H.

1987 Letter and notes on ceramic identification of sherds from Justiceburg Reservoir, June 30, 1987. On file, Prewitt and Associates, Inc., Austin.

Waters, M.

1985 Late Quaternary Alluvial Stratigraphy of Whitewater Draw, Arizona: Implications for Regional Correlation of Fluvial Deposits in the American Southwest. Geology 13: 705-708. 
Wedel, Waldo R.

1975 Chalk Hollow: Culture Sequence and Chronology in the Texas Panhandle. Actes del XLI Congreso Internacional de Americanistas 1:271-278. Mexico, D.F.

1986 Central Plains Prehistory: Holocene Environments and Culture Change in the Republican River Basin. University of Nebraska Press, Lincoln.

Weymouth, J. W., and R. Nickel

1977 A Magnetometer Survey of the Knife River Indian V1lages. Plains Anthropologist Memoir $13(78): 104-118$.

Weymouth, J. W., and R. Huggins

1985 Geophysical Surveying of Archaeological Sites. In Archaeological Geology, edited by G. Rapp, Jr. and J. A. Gifford, pp. 191-235. Yale University Press, New Haven.

Whittaker, Robert H., and Gene E. Likens

1975 The Biosphere and Man. In Primary Productivity of the Biosphere, edited by $H$. Lieth and R. W. Whittaker, pp. 305-328. Springer-Verlag, New York.

Willey, Patrick S., and Jack T. Hughes

1978 The Deadman's Shelter Site. In Archeology at Mackenzie Reservoir, edited by Jack T. Hughes and Patrick S. Willey, pp. 149-190. Archeological Survey Report No. 24. Texas Historical Commission, Austin.

Willey, Patrick S., Billy R. Harrison, and Jack T. Hughes

1978 The Rex Rodgers Site. In Archeology at Mackenzie Reservoir, edited by Jack T. Hughes and Patrick S. Willey, pp. 51-68. Archeological Survey Report No. 24. Texas Historical Commission, Austin.

Wolman, M. G., and L. B. Leopold

1957 River Flood Plains: Some Observations on Their Formation. USGS Professional Paper 282-C.

Wood, W. R., and D. L. Johnson

1978 A Survey of Disturbance Processes in Archaeological Site Formation. Chapter 9 in Advances in Archaeological Method and Theory, vol. 1, edited by M. B. Schiffer, pp. 315-381. Academic Press, New York.

Wulfkuhle, Virginia A.

1986 Investigations into the Prehistory of the Upper Clear Fork of the Brazos River, Fisher and Jones Counties, Texas. Master's thesis, The University of Texas at Austin. 